Marcos Catalan

\title{
A MORTE DA CULPA NA RESPONSABILIDADE CONTRATUAL
}

TESE DE DOUTORADo

Orientador: Prof. Titular Carlos Alberto Dabus Maluf

FaCuldade de Direito da UniVersidade de São Paulo

São Paulo 
Tese de Doutorado apresentada como requisito parcial no processo de obtenção do grau de Doutor na área de concentração de Direito Civil, sob a orientação do Prof. Titular Carlos Alberto Dabus Maluf.

Faculdade de Direito da Universidade de São Paulo

São Paulo 
BANCA EXAMINADORA 
Por me ensinar, a cada dia, que a felicidade se constrói na soma de cada momento vivido.

Por me fazer entender que, em cada nascer do sol, há um lindo a nossa espera. Por me apresentar a cada um dos mistérios da paixão. Por me permitir conhecer - e viver - o verdadeiro amor. A ti, cuja beleza angelical, sorriso sincero e abraço terno são fontes de energia, inspiração e serenidade.

A ti, Eliza, esposa amada, dedico cada linha desse trabalho. 
Escrever uma tese não é um trabalho solitário. Longe disso e, ao contrário do que muitos podem pensar, é um processo essencialmente dialógico. Antecipe-se que, por confiar plenamente que a memória nos trairá nesse instante, fica aqui nosso agradecimento a todos aqueles que de algum modo colaboraram para a realização desse sonho.

Em especial, minha eterna gratidão a meus amados pais, Margarida e Valter Catalan, pelo amor incondicional e constante apoio. Agradeço também. Ao professor Carlos Alberto Dabus Maluf, pela orientação, pelas valiosas lições acadêmicas e por todas as portas que ajudou a abrir. À professora Giselda Hironaka, pela oportunidade de convívio e, especialmente, por me fazer entender, que para transformar sonhos em realidade, era preciso antes acreditar em mim. Ao professor Lucas Barroso pela amizade verdadeira e pelo precioso auxílio com a revisão dos originais. Ao professor Pablo Malheiros, pelo apoio incondicional em todos os momentos desse trabalho. Aos amigos e professores Aldrey Azevedo, André Barros, André Franco, Antonio Babeto Spinelli, Bruno Miragem, Christiano

Cassetari, Cristiano Heineck Schmitt, Daniel Ustárroz, Darci Guimarães Ribeiro, Eduardo Bussatta, Eroulths Cortiano Junior, Fernanda Tartuce, Flávio Tartuce, Giselle Groeninga, Inácio Carvalho Neto, Inez Vedovatto, José Fernando Simão, Manuel David Masseno, Marcelo Zenckner, Mário Delgado, Maurício Bunazar, Paulo Nalin, Rodrigo Mazzei, Rodrigo Toscano de Brito, Rodrigo Xavier Leonardo, Sérgio Staut e Wladimir Alcibíades Marinho Falcão Cunha, pela amizade, companheirismo, diálogo constante e por cada momento de convívio. Obrigado também a meus novos amigos - professores da Unisinos -, que nos acolheram tão bem quando de nossa travessia de uma ponta a outra do Sul do Brasil. Enfim, a Zeno Veloso, fonte perene de inspiração. 


\section{RESUMO}

Esta pesquisa tem, por hipótese, a morte da culpa na responsabilidade contratual e, por objeto, aferir se o aludido elemento subjetivo pode (ou não) ser suprimido da arquitetura jurídica da responsabilidade contratual. Vale resgatar que, se é certo - não sem vozes em sentido oposto - que, em muitos momentos, o direito contratual não reservou papel algum à culpa, em outros tantos instantes, na visão da doutrina majoritária, ela continua a brilhar como em seus momentos de maior esplendor. A tese estrutura-se em quatro capítulos, metodologicamente alinhados às correntes pós-positivistas do Direito e projetados a partir de uma matriz teórica-crítica em busca da compreensão do fenômeno jurídico recortado para fins de investigação. Em um primeiro momento, explora-se a travessia da responsabilidade civil para o direito de danos. Nesse percurso, (a) analisa-se o contexto em que exsurgem as primeiras codificações; (b) identificam-se as balizas utilizadas pelo Estado Liberal na configuração do dever de reparar; e (c) demonstra-se que os mitos erigidos no Liberalismo perderam sua utilidade no processo de conformação da responsabilidade contratual contemporânea. O caminho conduziu também (d) à compreensão sobre o papel dos princípios constitucionais na intelecção do fenômeno obrigacional; (e) à percepção das razões pelas quais a Modernidade fora deixada para trás; (f) à identificação das principais características da contemporaneidade; e (g) à percepção das consequências mais visíveis da ruptura do paradigma Moderno na conformação da responsabilidade contratual. No capítulo subsequente, identifica-se que a existência de um contrato, a presença de uma conduta antijurídica e de um dano a ela atado por uma relação de causa e efeito são os pressupostos do dever de reparar. Nesse mesmo capítulo, a relação obrigacional é explorada tanto em perspectiva estática, como em perspectiva dinâmica. Em um terceiro momento, promove-se a análise da ascensão e declínio da culpa na conformação do dever de reparar. Demonstra-se ainda que a noção de culpa é uma só e que não há razão que justifique classificar as obrigações como de meio ou de resultado. No último capítulo, restando provado que a culpa perdeu sua razão de ser, demonstra-se por que seu lugar há de ser ocupado pela confiança. Demonstra-se, enfim, por que o contrato que hoje obriga é o contrato justo. A conclusão da morte da culpa na responsabilidade contratual encerra - mesmo que provisoriamente - esta tese de doutoramento.

Palavras-chave: culpa, confiança, contrato, responsabilidade contratual. 


\begin{abstract}
This research considers the hypothesis of guilt death within the contract responsibility and it aims at assessing if the mentioned subjective element may (or may not) be abolished from the legal architecture of the contract responsibility. It is worth rescuing that, if it is right - not without opposite voices - that, in many moments, the contract law did not reserve any role to guilt, upon several other moments, under the view of the majority doctrine, it continues to glow like in its moments of highest splendor. The thesis structure comprises four chapters. Grounded on a post-positivist theoretical matrix, at the first moment, one exploits the transition from civil responsibility onto the right to claim damages. Along this course, (a) one analyzes the context where the first code applications ex-surge; (b) one identifies the markers utilized by the Liberal State in the configuration of the repair duty; and (c) one demonstrates that the myths raised in the Liberalism have lost their utility within the conformation process of the contemporaneous contract responsibility. The path also led (d) to the understanding about the role of the constitution principles in the intellectual seizure of the duty phenomenon; (e) to the perception of the roots whereby Modernity has been left behind; (f) to the identification of the main features of contemporaneousness; and ( $\mathrm{g}$ ) to the perception of the most visible consequences deriving from the rupture of the Modern paradigm upon the conformation of the contract responsibility. In the subsequent chapter, one identifies that the existence of a contract as well as the presence of an anti-juridical conduct and of a damage attached to it by a causeeffect relation are the presuppositions of the repair duty. In this same chapter, the duty relation is exploited both under the static perspective and the dynamic one. At a third moment, one promotes the analysis of the guilt rise and decline upon the conformation of the repair duty. One evidences, yet, that the notion of guilt is just one. Thus, there is no reason that justifies classifying the duties into those of care and of outcome. Having proved that guilt has lost its rationale, in the last chapter, one demonstrates why its place ought to be taken by confidence. Finally, one demonstrates why the contract that nowadays obliges is the fair one. The conclusion drawn as to the guilt death in the contract responsibility closes - although provisionally - this $\mathrm{PhD}$ thesis.
\end{abstract}

Key words: guilt, confidence, contract, contract responsibility. 


\section{RESUMEN}

Esta pesquisa parte del hipótesis de la muerte de la culpa en la responsabilidad contractual y tiene, por objeto, evaluar si el aludido elemento subjetivo puede (o no) ser suprimido de la arquitectura jurídica de la responsabilidad contractual. Valle rescatar que, si es cierto no sin voces en sentido contrario - que, en muchos momentos, el derecho contractual no reservó papel alguno a la culpa, en otros tantos instantes, en la visión de la doctrina mayoritaria, ella sigue no obstante brillando como en sus momentos de mayor esplendor. La tesis, en su estructura, consiste en cuatro capítulos. A partir de una matriz teórica postpositivista, en un primer momento, se explora la travesía desde la responsabilidad civil al derecho de daños. En ese curso, (a) se analiza el contexto en que ex-surgen las primeras codificaciones; (b) se identifican las balizas utilizadas por el Estado Liberal en la configuración del deber de reparar; y, (c) se demuestra que los mitos erigidos en el Liberalismo perdieron su utilidad en el proceso de conformación de la responsabilidad contractual contemporánea. El camino condujo, también, (d) a la comprensión acerca del papel de los principios constitucionales en la intelección del fenómeno obligacional; (e) a la percepción de las razones por las cuales la Modernidad ha sido dejada para tras; (f) a la identificación de las principales características de la contemporaneidad; y, (g) a la percepción de las consecuencias más visibles de la ruptura del paradigma Moderno en la conformación de la responsabilidad contractual. En el capítulo subsecuente, se identifica que la existencia de un contracto así como la presencia de una conducta antijurídica y de un daño, a ella atado por una relación causa-efecto, son los presupuestos del deber de reparar. En ese mismo capítulo, la relación obligacional es explorada tanto en la perspectiva estática como en la dinámica. En un tercer momento, se promueve el análisis de la ascensión y de la declinación de la culpa en la conformación del deber de reparar. Se demuestra, aún, que la noción de culpa es sólo una. No hay, entonces, razón que justifique clasificar las obligaciones como de medio o de resultado. En el último capítulo, quedando probado que la culpa ha perdido su razón de ser, se demuestra por qué su lugar habrá de ser ocupado por la confianza. Se demuestra, por fin, por qué el contracto, que hoy día obliga, es el contracto justo. La conclusión acerca de la muerte de la culpa en la responsabilidad contractual encierra - aunque en carácter provisorio - esta tesis de doctoramiento.

Palabras-clave: culpa, confianza, contracto, responsabilidad contractual. 


\section{Abreviaturas e Siglas}

\begin{tabular}{|c|c|c|c|}
\hline a. & ano & jul. & Julho \\
\hline a.C. & antes de Cristo & jun. & Junho \\
\hline abr. & Abril & LAEL & Livraria do Advogado Editora \\
\hline ago. & Agosto & mai. & Maio \\
\hline $\mathrm{AgRg}$ & agravo regimental & mar. & Março \\
\hline Ap.Cív. & apelação cível & Min. & Ministro \\
\hline art. & artigo & $\mathrm{n}$. & número \\
\hline Atual. & atualização & nov. & Novembro \\
\hline $\mathrm{CC}$ & código civil & Org. & organização \\
\hline CCív. & câmara cível & out. & Outubro \\
\hline $\mathrm{Cf}$ & confira & p. & página \\
\hline $\mathrm{CF}$ & Constituição Federal & PR & Paraná \\
\hline $\begin{array}{l}\text { CJF } \\
\text { Federal }\end{array}$ & Conselho da Justiça & $\begin{array}{l}\text { PUC } \\
\text { Católica }\end{array}$ & Universidade \\
\hline Coord. & coordenação & Rel. & relator \\
\hline d.C. & depois de Cristo & REsp & recurso especial \\
\hline Dec. & Decreto & $\mathrm{RN}$ & Rio Grande do Norte \\
\hline Des. & Desembargador & $\mathrm{RS}$ & Rio Grande do Sul \\
\hline dez. & Dezembro & $\mathrm{RT}$ & Revista dos Tribunais \\
\hline DJ & Diário da justiça & set. & Setembro \\
\hline DJE & Diário da justiça eletrônico & STJ & Superior Tribunal de Justiça \\
\hline DJRS & Diário da justiça do Rio & $\mathrm{T}$. & turma \\
\hline \multicolumn{2}{|c|}{ Grande do Sul } & TJDFT & Tribunal de Justiça do Distrito \\
\hline ed. & edição & \multicolumn{2}{|c|}{ Federal e dos Territórios } \\
\hline EDcl & embargos de declaração & TJPR & Tribunal de Justiça do Paraná \\
\hline \multicolumn{2}{|c|}{ Direito de São Paulo } & \multicolumn{2}{|c|}{ Grande do Sul } \\
\hline fev. & Fevereiro & Trad. & tradução \\
\hline Ibid & igual ao anterior & $\mathrm{UC}$ & Universidade do Chile \\
\hline inc. & inciso & USP & Universidade de São Paulo \\
\hline j. & julgado em & $\mathrm{v}$. & volume \\
\hline jan. & Janeiro & $\S$ & parágrafo \\
\hline
\end{tabular}




\section{SUMÁRIO}

INTRODUÇÃO

1 A SUPERAÇÃO DA RESPONSABILIDADE CIVIL PELO DIREITO DE DANOS 15

1.1 A proteção patrimonial como fundamento da responsabilidade civil 15

1.2 Os paradigmas civis-constitucionais do atual modelo de responsabilidade civil 30

1.3 A personalização do dever de reparar 57

1.4 A incontrolabilidade dos danos na sociedade contemporânea

2 A ARQUITETURA JURÍDICA DA RESPONSABILIDADE CONTRATUAL 89

2.1 As atuais fronteiras da responsabilidade contratual

2.2 Os pressupostos conformadores da responsabilidade contratual 98

2.3 A violação de dever na configuração da responsabilidade contratual

2.4 A responsabilidade contratual na perspectiva da relação obrigacional como processo

3 ASCENSÃO E DECLÍNIO DA CULPA NA RESPONSABILIDADE 163 CONTRATUAL

3.1 A historiografia da culpa no direito das obrigações

3.2 Do equívoco existente na distinção entre culpa aquiliana e culpa contratual

3.3 A equiparação entre as obrigações de meio, de resultado e de garantia

3.4 Da culpa ao dano: a objetivação da responsabilidade contratual

4 FUNDAMENTOS DO DEVER DE REPARAR OS DANOS CONTRATUAIS NA 231 CIVILÍSTICA CONTEMPORÂNEA

4.1 Críticas à dogmática codificada em matéria de responsabilidade contratual 231

4.2 A confiança como fator de imputação do dever de reparar os danos contratuais

4.3 O dever de reparar e a efetivação da justiça contratual

4.4 A hermenêutica contratual hoje: o caso concreto como ponto de partida 


\section{INTRODUÇÃO}

O constante fluir do tempo transforma o futuro em presente e, nesse processo, enquanto cada momento vivido se afasta do tempo presente, é possível observar o avanço da técnica nos últimos dois séculos. Nesse mesmo quadro, se percebe, com alguma facilidade e concomitantemente, incomensuráveis benesses e efeitos deletérios de distintos matizes e intensidades.

E, apesar de a vida na contemporaneidade ser bastante distinta de qualquer modelo outrora conhecido, se insiste em buscar, em muitas hipóteses, em fórmulas pensadas em passado cada vez mais longínquo, a resposta para os conflitos que afetam a vida hodierna, ignorando uma miríade de mutações que saltam aos olhos de qualquer espectador minimamente atento.

Oportuno destacar que muitas das balizas pensadas para a solução dos problemas típicos de uma sociedade agrária e pré-industrial são hoje insuficientes para tutelar, adequadamente, as relações sociais vividas no presente. Insuficientes, dentre outros fatores, porque a contingência e a incerteza ocupam o lugar em que outrora reinavam as promessas de conhecimento e segurança. Insuficientes porque, em razão de distintas mutações sociais, não são aptas à distribuição de justiça na concretude dos fatos.

Ora, se a compreensão dos fenômenos que pululam nesse admirável mundo novo, em incomensuráveis hipóteses, não pode ser promovida a partir de estruturas e fórmulas concebidas outrora, como aceitar que molduras consumidas pelo tempo continuem a atuar ainda hoje, em um espaço que não reservou espaço algum para muitas delas?

Infira-se que, não obstante o domínio de técnicas como as que permitem (a) utilizar a energia nuclear, (b) manipular e produzir, em escala industrial, organismos geneticamente modificados, e, ainda, (c) trabalhar com elementos e partículas em escala nanométrica $\left(10^{-9} \mathrm{~m}\right)$ na fabricação de incontáveis produtos em circulação no mercado consumo, é comum perceber que o jurista continua buscando, em fórmulas criadas há mais de duzentos anos, a solução de males causados em um contexto bastante distinto daquele em que eclodiu o Liberalismo. 
Dentre outros aspectos, é possível antever, nesse quadro, em razão da complexidade dos conflitos instaurados no momento em que o futuro se transforma em presente e da contingência que permeia cada instante da vida, que o recurso à culpa é incapaz de pautar a solução das celeumas que afetam diuturnamente as relações sociais na contemporaneidade.

A inspiração que conduziu à realização desta pesquisa exsurge nesse contexto. Nasce da percepção de que não incumbe ao direito civil perseguir e punir pecadores. É fruto da constatação de que o recurso à culpa é um mecanismo deveras importante na arquitetura jurídica do Estado Liberal. E, muito embora múltiplas questões possam estar contidas nesse panorama, o corte metodológico formulado visa a identificar se a culpa possui alguma relevância no processo de conformação do dever de reparar os danos contratuais na realidade cotidiana.

Como a produção do saber exige uma indagação, essa se resume a identificar se a culpa possui alguma utilidade na compreensão do dever de reparar os danos causados durante o desvelar de uma relação jurídica obrigacional que tenha por fonte um contrato qualquer. Em outras palavras, a dúvida que inspirou a formulação de cada linha tecida ao longo desta tese deriva da necessidade de aferir se os fundamentos dogmáticos, sociológicos e filosóficos que justificaram e conduziram à mitificação da culpa - na seara contratual - se mantêm na contemporaneidade.

Tendo por hipótese a morte da culpa na arquitetura jurídica que conforma o dever de reparar os danos contratuais na atualidade, dela se extrai o principal objetivo desse estudo: comprovar a veracidade da assertiva anteriormente tecida. Outro objetivo a ser perseguido visa a identificar qual o fator de imputação do dever de reparar que deverá ocupar o lugar outrora reservado à culpa, até porque de nada adianta rasgar os mapas existentes se não for possível apontar o caminho a ser seguido.

A investigação ora apresentada foi dividida em quatro capítulos. As reflexões formuladas ao longo das próximas páginas, com apoio da fenomenologia, encontram-se ancoradas em construções teóricas desenvolvidas tanto por autores nacionais, como por juristas estrangeiros. E, completando as fontes utilizadas, julgados colhidos aleatoriamente em alguns tribunais brasileiros ajudam a ilustrar raciocínios e críticas ao longo de todo o trabalho. 
Cumpre informar que, em um primeiro momento, buscou-se compreender como se dá a travessia entre a responsabilidade civil e o direito de danos. Nesse percurso, foi analisado (a) o contexto em que exsurgem as primeiras codificações; (b) identificadas as balizas utilizadas pelo Estado Liberal na configuração do dever de reparar; e (c) demonstrado que os mitos erigidos no Liberalismo - dentre eles, a culpa - perderam a utilidade no processo de conformação da responsabilidade contratual contemporânea.

Investigou-se, ainda, (d) o papel dos princípios constitucionais na intelecção do fenômeno obrigacional; (f) as razões pelas quais a Modernidade fora deixada para trás; (g) as principais características da contemporaneidade; e (h) quais as consequências mais comuns da ruptura do paradigma Moderno na compreensão da responsabilidade contratual em toda a sua complexidade.

No segundo capítulo, revela-se a preocupação com a adequada formatação da arquitetura jurídica da responsabilidade contratual. Pode-se antecipar, aqui, que a compreensão dos pressupostos conformadores do dever de reparar os danos contratuais foi essencial não só para a escorreita intelecção do tema, como também para as conclusões tecidas ao final deste trabalho. Oportuno salientar que, nesse tópico da pesquisa, recorreuse à figura da violação de dever contratual, o que se justifica diante de sua capacidade de englobar as mais distintas patologias - a mora, o inadimplemento, o cumprimento inexato e a violação de dever geral de conduta - que podem surgir no curso do processo obrigacional.

O capítulo subsequente versa sobre a ascensão e declínio da culpa na aferição do dever de reparar os danos contratuais. Tendo como ponto de partida a Lex Aquilia de Damno, promoveu-se a análise das transformações - e, não foram poucas - provocadas pelo constante fluir do tempo na compreensão da figura em foco. E, uma vez constatado que o estudo da responsabilidade civil foi erigido a partir da necessidade de punir um culpado, buscou-se compreender se esses fundamentos sobreviveram às transformações ocorridas nos últimos séculos.

Esse capítulo questiona, ainda, a vigência da dicotomia que autoriza parte da doutrina a sustentar a existência de duas culpas - uma contratual, outra aquiliana -, bem como daquela que conduz à classificação obrigações de meio e de resultado, enquadramento, aliás, que ignora a existência das obrigações de garantia. 
Como a culpa - como indica o título da tese - não tem papel algum no processo de conformação do dever de reparar os danos contratuais na contemporaneidade, buscou-se apontar qual figura haverá de ocupar seu lugar. O capítulo quarto dedica-se a essa tarefa. Aliás, ainda no último capítulo, como o equilíbrio na relação negocial é uma constante exigida durante o desvelar de todo o processo obrigacional, esse aspecto é explorado, pois, tendo por premissa o fato de que o contrato que obriga é o contrato justo, parece inaceitável conceber a violação de um dever contratual de qualquer espécie, a partir de uma obrigação iníqua ou contrária à boa-fé.

Encerrando a pesquisa, promove-se um esboço de como haverá de se alcançar a adequada realização do Direito em cada hipótese concreta em que haja a violação de um dever contratual. Antecipe-se, nesse instante, que o recurso ao paradigma judicativodecisório foi fundamental para que essa tarefa - ainda que provisoriamente - pudesse ser cumprida.

E, embora as conclusões alcançadas neste estudo possam abarcar também as hipóteses em que a codificação exige a presença do dolo na conformação do dever de reparar, essa análise foi intencionalmente afastada, restringindo-se, reafirme-se, à aferição do papel da culpa na arquitetura jurídica da responsabilidade contratual. Na mesma esteira, apesar da violação de deveres surgidos de fontes negociais não contratuais estar balizada pelas mesmas premissas que informam este estudo, o tema não será explorado nesta pesquisa.

Enfim e em poucas palavras, esta tese é um convite à reflexão sobre o porquê da possibilidade de se afirmar que os fundamentos filosóficos, sociológicos e dogmáticos que atribuíram à culpa, ao longo do tempo, força mitológica, há algum tempo, perderam qualquer razão de existir. 


\section{A SUPERAÇÃO DA RESPONSABILIDADE CIVIL PELO DIREITO DE DANOS}

\subsection{A proteção patrimonial como fundamento da responsabilidade civil}

Compreender por que, por longa data, a tutela do ter foi o foco central das preocupações do direito civil exige, antes, entender os contornos que moldam o processo de surgimento dos primeiros códigos civis. Essa compreensão impõe, logicamente, olhar para o passado. Um quadro imaginário, retratando esse momento - que, de certo modo, está atado à Revolução deflagrada em 1789 -, muito provavelmente, descreveria a necessidade de afastar os desmandos do príncipe $^{1}$ e a disseminação da crença na garantia de que seria possível, a qualquer um e, ao mesmo tempo, a todos, comandar sua(s) vida(s). Também se mostra bastante factível - nesse processo de reconstrução do que teria ocorrido em um passado do qual o homem não pode se dissociar - aceitar por que o modelo que se instaura exige matizes distintos daqueles que coloriam o dia a dia das monarquias medievais.

As codificações não são fruto do acaso. As impressões provenientes do passado levam a crer que uma das estratégias que permeiam o surgimento da codificação francesa consistia na necessidade de manutenção da monarquia e da nobreza longe do poder. $\mathrm{E}$ como conquistar a confiança do povo era vital para o sucesso desse projeto, dissemina-se a promessa de que a igualdade de direitos e a propriedade seriam garantidas ${ }^{2}$ a todos os cidadãos. Nesse novo quadro, não haveria suseranos, nem vassalos.

Qualquer pessoa teria acesso aos bens, embora, talvez não fosse disseminado que o(s) interessado(s) deveria(m) pagar por eles. Às vésperas de 1804, soa um "grito de modernidade a favor das energias individuais" exigindo a criação e manutenção da ordem estritamente necessária à garantia plena do exercício da liberdade. ${ }^{3}$ E essa garantia parece estar contida na codificação que surge no início do século XIX.

\footnotetext{
${ }^{1}$ Nada obsta, entretanto, que, sob prisma distinto, se vislumbre o surgimento de outra espécie de principado.

${ }^{2}$ DIFINI, Luiz Felipe Silveira. Princípio do estado constitucional democrático de direito, Revista da Ajuris, Porto Alegre, v. 31, n. 95, p. 161-184, set. 2004. p. 162-163. Àquele tempo, vale destacar, considerada um direito praticamente intocável.

${ }^{3}$ CANOTILHO, José Joaquim Gomes. Estudos sobre direitos fundamentais. Coimbra: Coimbra, 2004. p. 30.
} 
É possível imaginar, também, que a burguesia tenha comemorado bastante o advento das primeiras codificações. Nada melhor, para o sucesso de seus negócios, que um ambiente seguro $^{4}$ e de simples compreensão. Vivia-se o império da liberdade ${ }^{5}$ e da razão. Os códigos da modernidade garantiriam - e garantiram, de fato - o êxito da atividade econômica por permitirem a identificação antecipada das consequências ligadas aos riscos da atividade. ${ }^{6}$ Em outras palavras, tais códigos não só almejavam, como foram capazes de promover a proteção do patrimônio.

Buscando blindar suas bases fundantes, as codificações oitocentistas consagraram a proteção da propriedade privada e do contrato. ${ }^{7}$ Esse, perceba-se, exsurge como um instrumento para a circulação daquela ${ }^{8}$ e de tantos outros bens passíveis de apreciação econômica. Outro fator que colabora com a supremacia da perspectiva patrimonial na análise das relações jurídicas ata-se à construção da noção do homo oeconomicus e sua alocação no lugar do homem real. Tal modelo alude a "uma espécie de estátua animada de sentidos", que almeja obter satisfação plena com o mínimo dispêndio de recursos. $\mathrm{O}(\mathrm{s})$ outro(s), agora, não passa(m) de mero(s) instrumento(s) de satisfação do egoísmo de um homem livre e racional. ${ }^{9}$

\footnotetext{
${ }^{4}$ VERDÚ, Pablo Lucas. O sentimento constitucional: aproximação ao estudo do sentir constitucional como modo de integração política. Trad. Agassiz Almeida Filho. Rio de Janeiro: Forense, 2004. p. 88. "O conceito de segurança jurídica não é algo exato. Não pode desvincular-se de sua origem e alcance ideológicos. Nesse sentido, a segurança jurídica é a formalização conceitual e positivada da ideologia burguesa liberal, tal como foi divulgado pela Revolução Francesa. A segurança jurídica liberal burguesa supõe estas identificações: lei $=$ liberdade $=$ propriedade privada $=$ segurança jurídica. $"$

${ }^{5}$ CORDEIRO, Eros Belin de Moura. A constituição da república de 1988 e as transformações na teoria contratual. In: CONRADO, Marcelo; PINHEIRO, Rosalice Fidalgo (Coord.). Direito privado e constituição: ensaios para uma recomposição valorativa da pessoa e do patrimônio. Curitiba: Juruá, 2009. p. 216. Consoante afirmado pelo autor, a liberdade é o principal alimento do sistema capitalista em construção.

${ }^{6}$ Nesse sentido: CAENEGEM, Raoul C. van. Uma introdução histórica ao direito privado. Trad. Carlos Eduardo Lima Machado. São Paulo: Martins Fontes, 2000. p. 8-13. DIEZ-PICAZO, Luis. Codificación, descodificación y recodificación, Anuario de Derecho Civil, Madrid, v. 45, n. 2, p. 473-484, abr./jun. 1992. p. 476. PINHEIRO, Rosalice Fidalgo. Contrato e direitos fundamentais. Curitiba: Juruá, 2009. p. 31. A última autora alude que a codificação estimula a atividade econômica ao afastar a insegurança reinante em razão do pluralismo das nascentes do direito.

${ }^{7} \mathrm{E}$, com isso, as sementes do sistema capitalista foram plantadas.

${ }^{8}$ GIORGIANNI, Michele. O direito privado e suas atuais fronteiras, Revista dos Tribunais, São Paulo, v. 87, n. 747 , p. 35-55, jan. 1998. p. 39-41.

${ }^{9}$ MARTÍNEZ, Pedro Soares. O homem e a economia, Revista da Faculdade de Direito da Universidade de Lisboa, Coimbra, v. 38, n. 1, p. 101-111, 1997. p. 103. Continua o autor ao salientar que: “[...] é de recear que o processo de desumanização da economia não tenha cessado pelo afastamento dos cânones economistas clássicos ou liberais [...] às construções econômicas que se lhes seguiram poderá ser assacada a crítica de esquecerem o homem real, através [sic] da abstração do homem socialista ou do não menos abstrato homem coorporativo."
} 
Escorados nos pilares da autonomia da vontade, da igualdade formal e da segurança jurídica ${ }^{10}$, o Code e outros que o seguiram se materializaram como perfeitas projeções do racionalismo. ${ }^{11}$ As codificações decimonônicas procuraram organizar as relações privadas de forma a assegurar o bom desenvolvimento do sistema econômico criado pela - e em favor - da classe econômica dominante. ${ }^{12}$ Os primeiros códigos civis são recheados de preocupações de ordem patrimonial, oriundas, provavelmente, da postura liberal - liberalismo econômico - que informa o pensamento dos idealizadores do movimento revolucionário. ${ }^{13}$

Esse Direito estava fundado na lei: as regras deviam ser claras, precisas em suas hipóteses de incidência, abstratas e universais. ${ }^{14}$ Nesse momento da História, Direito e lei identificavam-se. ${ }^{15}$ A fissão de ambos é algo impossível. Talvez por isso, à época, regras eram memorizadas e repetidas, legitimando socialmente a existência de respostas únicas. ${ }^{16}$ Justa seria a decisão pautada na literalidade da lei. Por essa razão, a atividade judicial limitava-se a encaixar os fatos em molduras normativas previamente codificadas. ${ }^{17}$

${ }^{10}$ DONNINI, Rogério. Revisão contratual sem imprevisão, Revista Brasileira de Direito Civil Constitucional e Relações de Consumo, Santo Amaro, n. 1, p. 245-259, jan./mar. 2009. p. 246. Consoante ensina o autor, o modelo liberal de contrato, consectário do preconizado no Code Napoléon, o "Código da Burguesia", inspirou-se no liberalismo do século XIX e na preocupação com a segurança das relações contratuais.

${ }^{11}$ BOLOGNA, Pablo Salvat. ¿Debe el derecho ser justo?, Persona y Sociedad, Santiago, v. 18, n. 2, p. 33-62, ago. 2004. p. 40-41. Segundo o autor, o processo de racionalização formal do direito o afasta das projeções almejadas pela racionalidade ética, o que redunda em diálogos muitas vezes nada amáveis entre o direito e a Justiça.

12 BENÍTEZ, Elsa. La revolución industrial y el derecho de daños: sus consecuencias. In: GHERSI, Carlos Alberto (Dir.). Responsabilidad objetiva: el artículo 1113 y la ley 24.999. Mendoza: Ediciones Jurídicas Cuyo, 1999. p. 30.

${ }^{13}$ COING, Helmut. Historia del derecho y dogmática jurídica, Revista Chilena de Derecho, Santiago, v. 9, n. 2, p. 245-257, mai./ago. 1982. p. 249.

14 JUNQUEIRA DE AZEVEDO, Antônio. O direito pós-moderno e a codificação, Revista de Direito do Consumidor, São Paulo, v. 9, n. 33, p. 123-129, jan./mar. 2000. p. 125. "Vindos dos traumas do absolutismo, os juristas de então viam, na lei, o direito. Para dar segurança, a norma devia ser clara, precisa nas suas hipóteses de incidência, abstrata, universal. Como garantia de impessoalidade, o papel do juiz, por isso mesmo, era visto como passivo; a sentença, um mero silogismo, cuja premissa maior era o imperativo hipotético do texto legal; a premissa menor o fato e a conclusão a decisão. A função do juiz era de um autômato [...]"

${ }^{15}$ BOBBIO, Norberto. O positivismo jurídico: lições de filosofia do direito. Trad. Márcio Pugliesi; Edson Bini; Carlos Rodrigues. São Paulo: Ícone, 1995. p. 83-89.

${ }^{16}$ MEDINA, Diego Eduardo López. Teoría impura del derecho: la transformación de la cultura jurídica latinoamericana. Bogotá: Legis, 2005. p. 2.

${ }^{17}$ ROCHA, Leonel Severo. Interpretação jurídica e racionalidade, Revista da Faculdade de Direito de Cruz Alta, Cruz Alta, v. 4, n. 4, p. 43-54, jan./jul. 1999. p. 44-45. "Para a dogmática jurídica tradicional os aplicadores da lei, principalmente, os juízes, encontrariam o sentido do direito na simples exegese dos textos legais [e] a interpretação da lei é considerada como uma operação lógica capaz de engendrar um silogismo no 
O Estado Liberal - como tantos outros modelos que o precederam, é imperioso perceber - exige a criação de entes mitológicos. E, dentre outros, o modelo escora-se no mito da legalidade: todo Direito emana do Estado e todos se sujeitam à incidência da lei, sem quaisquer distinções ou privilégios. ${ }^{18}$ Outra ficção que o sustenta implica aceitar que, como todos conhecem a lei, ninguém pode infringi-la alegando desconhecimento.

A escola da exegese ${ }^{19}$, orientando a aplicação de um Direito recentemente codificado, diante de seu rigor metodológico - rechaçava a liberdade hermenêutica parece se apresentar como mais uma reivindicação burguesa. ${ }^{20}$ Ao afastar a discricionariedade judicial, permite a consolidação das premissas liberais consagradas nas primeiras codificações e comungadas pelos detentores do poder econômico. É possível compreender porque a segurança no positivismo sempre foi a segurança do mais forte. ${ }^{21}$

qual cabe ao juiz (intérprete) adotar o suporte fático normativo ao conteúdo significativo pré-existente na moldura legal [...]." Essa postura hermenêutica foi superada a partir dos anos setenta do século XX.

${ }^{18}$ SILVA, José Afonso da. O estado democrático de direito, Revista dos Tribunais, São Paulo, v. 77, n. 635, p. 7-13, set. 1988. p. 7-8. Tal modelo "tinha como objetivo fundamental assegurar o princípio da legalidade, segundo o qual toda atividade estatal havia de submeter-se à lei” e suas características básicas foram: “a) submissão ao império da lei [sendo esta] considerada como ato emanado formalmente do Poder Legislativo [...]; b) divisão de poderes [e] c) enunciado e garantia dos direitos individuais."

${ }^{19}$ CAENEGEM, Raoul C. van. Uma introdução histórica ao direito privado. Trad. Carlos Eduardo Lima Machado. São Paulo: Martins Fontes, 2000. p. 211. "A crítica à Escola da Exegese avançou muito pouco antes do fim do século XIX. Nessa época, a crítica dirigia-se não apenas ao método seguido pela escola e a seu conceito positivista do direito, mas também a alguns dos princípios que informavam o código civil francês [dentre eles, o excessivo individualismo e a supervalorização da autonomia privada].

${ }^{20}$ FLACH, Norberto. O formalismo jurídico oitocentista: doença infantil do positivismo, Revista da Faculdade de Direito Ritter dos Reis, Porto Alegre, v. 3, p. 131-180, mar./jul. 2000. p. 171. Consoante o autor, "a postura exegética resultava do esgotamento político da revolução, tendente à estabilização das conquistas burguesas."

${ }^{21}$ OST, François. Tiempo y contrato: crítica del pacto fáustico, Doxa, Alicante, n. 25, p. 597-626, 2002. p. 625. "El tiempo positivista se concentra en los actos jurídicos, expresiones de la voluntad normativa de las personas privadas o de la soberanía del poder público. Tales actos, fruto de una especie de generación espontánea y a los que se ha prometido una vida eterna, se benefician instantáneamente -como hemos vistode la fuerza jurídica y permanecen en vigor hasta que otra norma, también "espontánea", los abroga o los sustituye. Tanto la teoría civilista del contrato como la teoría publicista de la ley tienen la marca de tal instantaneidad. Se deduce de esto un modelo sincopado del orden jurídico reducido a una sucesión de actos y de normas sin un vínculo inteligible. Este modelo está, en efecto, desprovisto de un pensamiento y de una deontología de la relación entre reglas; los principios de su formación permanecen fuera del campo jurídico, con la excepción de la regulación puramente procesal de su sucesión. Aislado de esta forma de los movimientos de opinión y de presión sociales que se ejercen sobre las reglas, sobre sus prácticas y sus interpretaciones, este modelo positivista se propone garantizar la seguridad jurídica. Pero, además, como se trata con frecuencia exclusivamente de la seguridad del más fuerte, esta seguridad tiene toda la vulnerabilidad del roble que resiste hasta el día en que, a falta de flexibilidad, se parte en dos. Este tiempo positivista cede progresivamente el paso hoy a una temporalidad más "metamórfica", queremos decir, un tiempo de la transformación progresiva, el tiempo de las identidades que saben convertirse en otras sin dejar por ello de ser ellas mismas. Estas entidades no se interpretan más exclusivamente como "actos", sino también como "instituciones", que son encadenamientos de actos, de procesos en curso, de procedimientos evolutivos. La dialéctica que ellas ponen en acción es, a partir de ahora, menos esa, discontinua, de la instantaneidad y de la intangibilidad, que la otra, mucho más continua, de lo instituido y el instituyente: las voluntades toman 
Outros dois mitos - abstração e igualdade perante a lei - foram, muito provavelmente, as melhores armas na grande batalha burguesa em busca da consolidação do seu poder: armas desinteressadas, e que foram utilizadas em benefício de todos somente em aparência. ${ }^{22} \mathrm{O}$ que não se percebe - ou propositalmente se despreza - é que, com a disseminação do mito da igualdade formal, surgiu um profundo abismo entre os homens, até porque, hodiernamente, é possível verificar que a prometida igualdade não teve forças para corrigir as desigualdades socioeconômicas que permeiam a vida. ${ }^{23}$

O individualismo é outro traço marcante nesse período. ${ }^{24}$ As relações negociais, conduzidas pelo império da autonomia da vontade, eram informadas por uma racionalidade prática que via no contrato a chave - e a porta - de acesso à ascensão social e política. ${ }^{25}$ A "liberdade de contratar significava livre possibilidade, para a burguesia empreendedora, de adquirir os bens das classes antigas, detentoras improdutivas da riqueza, e livre possibilidade de fazê-los frutificar com o comércio e a indústria." ${ }^{26} \mathrm{O}$ acesso às condições necessárias à acumulação de bens materiais - especialmente de imóveis - ocupam, nesse contexto de transição, o lugar outrora reservado aos títulos da nobreza no processo de distribuição do poder.

Perceba-se que esse mesmo individualismo exige como cenário a igualdade plena. Para o sucesso do modelo proposto, cria-se um palco no qual todos são considerados absolutamente iguais. Assim - e muito provavelmente, somente assim -, o sistema se legitima e se sustenta. Instaura-se um processo de alienação.

cuerpo en las formas instituidas que las fuerzas instituyentes transforman, sin embargo, a lo largo del tiempo. El modelo se enriquece de esta forma con una teoría y una deontología de las transformaciones normativas que dejan de hacer surgir únicamente reglas procesales. Lo hemos visto: al encuentro del estatismo de la convención-ley hoy se hace valer una regulación del momento que precede (negociación) y del que sigue al acuerdo (ejecución)."

${ }^{22}$ GROSSI, Paolo. Mitología jurídica de la modernidad. Trad. Manuel Martínez Neira. Madrid: Trotta, 2003. p. 82 .

${ }^{23}$ LIMA, Alvino. Da influência, no direito civil, do movimento socializador do direito, Revista Forense, Rio de Janeiro, v. 36, n. 80, p. 19-27, out./dez. 1939. p. 26.

${ }^{24}$ VILLEY, Michel. A formação do pensamento jurídico moderno. Trad. Claudia Berliner. São Paulo: Martins Fontes, 2005. p. 176-177.

${ }^{25}$ NERY, Rosa Maria Barreto Borriello de Andrade. Vínculo obrigacional: relação jurídica de razão (técnica e ciência de proporção). Tese (Livre-Docência) - Faculdade de Direito da PUC/SP, São Paulo, 2004. p. 133. Discorrendo sobre a influência do Code Napoléon e das Ordenações Filipinas no direito brasileiro, a autora destaca que "os vínculos jurídicos pessoais negociais [eram informados] por funcionalidade prática voltada, justamente, para o império da liberdade e da utilidade do contrato como mecanismo apto para permitir que a burguesia tivesse acesso a bens que poderiam fazê-la participar da vida política."

${ }^{26}$ ROPPO, Enzo. O contrato. Trad. Ana Coimbra; M. Januário C. Gomes. Coimbra: Almedina, 2009. p. 4546. 
Difunde-se que todos são absolutamente iguais e merecedores de idêntico tratamento por parte da lei. O discurso é repetido tantas vezes que passa a fazer parte do senso comum da sociedade. E como, talvez, nesse quadro da História, fosse mesmo melhor sentir-se igual ao outro, após tantos séculos de discriminação por não ter nascido em uma família nobre, o sonho da igualdade perpetuou-se por algum tempo.

Ocorre que, se todos são iguais, portanto, igualmente livres, que cada um decida por si próprio o que fazer com seu destino, até porque, como ser racional, é evidente que o homem sempre buscará o melhor para si. É possível visualizar, entretanto, que nesse modelo, cada pessoa é considerada como um ator representando papéis previamente descritos na codificação ${ }^{27}$, como se todos - e cada ser humano - não fossem nada mais que "átomos sociais idênticos.",28

As individualidades foram negadas com o advento da noção de "pessoa modulada." 29 O homem foi transformado em um ente abstrato ${ }^{30}$, quando, sob a égide da igualdade formal, passou a ser tratado pelo direito civil como um sujeito de direitos, igual, idêntico a todo e qualquer outro que necessite ocupar a posição jurídica de credor, devedor, contratante, terceiro, causador do dano, lesado, proprietário, não proprietário, chefe de família, filho, esposa, testador etc.

${ }^{27}$ RIBEIRO, Renato. Sujeito de direito, Revista de Direito Civil, Imobiliário, Agrário e Empresarial, São Paulo, v. 8, n. 29, p. 113-126, jul./set. 1984. p. 113-126.

${ }^{28}$ CASTRO, Torquato. Causalidade jurídica no direito romano: o título na linguagem jurídica dos romanos, Revista de Direito Civil, Imobiliário, Agrário e Empresarial, São Paulo, v. 8, n. 27, p. 7-47, jan./mar. 1984. p. 21.

${ }^{29}$ MARTINS-COSTA, Judith. Os danos à pessoa no direito brasileiro e a natureza de sua reparação. In: MARTINS-COSTA, Judith (Org.). A reconstrução do direito privado. São Paulo: RT, 2002. p. 410-411. "Submergida a idéia de "pessoa" na de "indivíduo" (ao senso "egoísta" do termo) e não-visualizada a de "personalidade" pela preeminência do conceito técnico de "capacidade", traçaram-se as tramas semânticas que acabaram por fundir o "ser pessoa" como "o ser capaz de adquirir direitos e contrair obrigações." Em outras palavras, instrumentalizou-se a personalidade humana, reproduziu-se, na sua conceituação, a lógica do mercado, o que conduziu à desvalorização existencial da idéia jurídica de pessoa, para torná-la mero instrumento da técnica do direito [...]"

${ }^{30}$ LISBOA, Wladimir Barreto. O direito, a moral e os limites da justiça: algumas dificuldades legadas pelos modernos. In: COPETTI, André; STRECK, Lenio Luiz; ROCHA, Leonel Severo (Org.). Constituição, sistemas sociais e hermenêutica: programa de pós-graduação em direito da unisinos. Porto Alegre: LAEL, 2006, v. 2. p. 289. "O direito natural moderno, ao hipostasiar a noção de sujeito, teria transformado o homem numa unidade abstrata cuja pretensão fundamental consistiria em buscar compreender a si próprio abstraindo sua própria subjetividade. Tal absolutização da noção abstrata e a-histórica do sujeito ter-se-ia construído sobre uma suposição de igualdade natural dos indivíduos cujo corolário no plano político seria a edificação de um pluralismo e horizontalização dos valores dignos de serem perseguidos pelos indivíduos na sociedade política. O desiderato do discurso moderno seria, portanto, a construção de um Estado assentado no princípio fundamental de ordem e segurança jurídicas." 
É possível inferir que as características pessoais forjadas ao longo do tempo e do espaço foram desprezadas quando a pessoa humana passa a ser concebida como um sujeito de direitos. Esse conceito operacional, é factível aceitar, privou o ser humano de sua alma.

Com os olhos ainda no passado, é possível imaginar porque, uma vez no poder, a burguesia passa a utilizar o Direito em seu favor. ${ }^{31}$ As poucas linhas tecidas até aqui permitem enxergar que o direito civil na modernidade foi erigido a partir dos anseios da classe dominante, embora essa, amparada no racionalismo, mascarara a ausência de legitimidade do Direito por ela imposto. ${ }^{32}$ Ao mesmo tempo em que os privilégios de uma aristocracia decadente foram suprimidos - mediante a elaboração de regras claras em um código informado pelo dogma da completude -, surgiram instrumentos para canalizar e impulsionar a ascensão econômica daqueles que estavam ligados às estruturas de poder $^{33}$, bem como daqueles que estavam por trás dessas personagens.

As imagens trazidas pelo tempo autorizam afirmar que o direito civil do século XIX, ditado por aquela mesma burguesia que havia recentemente assumido o poder político $^{34}$ - e por consequência o de legislar -, gravitou em torno de seus principais interesses: manutenção da liberdade e preservação da propriedade. ${ }^{35}$

\footnotetext{
${ }^{31}$ FREIRE, Ricardo Maurício. Tendências do pensamento jurídico contemporâneo. Salvador: Podivm, 2007. p. 21. "Ao encampar o poder político, a burguesia passou a utilizar a aparelhagem jurídica em conformidade com seus interesses, pois se a utopia jusnaturalista impulsionou a revolução, a ideologia legalista legitimou a preservação do statu quo pelo argumento de que o conjunto de leis corporifica o justo pleno, cristalizando formalmente os princípios perenes do direito natural."
}

${ }^{32}$ ALVES, Alaôr Caffé. A função ideológica do direito, Revista da Faculdade de Direito de São Bernardo do Campo, São Bernardo do Campo, v. 6, n. 8, p. 1-11, 2002. p. 1-6.

${ }^{33}$ RAMOS, Carmem Lucia Silveira. Os princípios gerais do direito civil, Revista da Faculdade de Direito, Curitiba, v. 22, n. 22, p. 272-284, 1985. p. 278. "É inconteste que os sistemas de direito, como os temos hoje, são frutos de uma reorganização do poder político, centrada contra os privilégios da aristocracia absolutista. Simultaneamente, porém, este processo de racionalização, que corresponde aos sistemas jurídicos da atualidade, trouxe consigo características correspondentes aos interesses econômicos da burguesia, no exercício de suas atividades financeiras, comerciais e industriais, e em detrimento das classes economicamente mais fracas."

${ }^{34}$ BORGES, Roxana Cardoso Brasileiro. Contrato: do clássico ao contemporâneo - a reconstrução do conceito, Revista do Programa de Pós-Graduação em Direito da Universidade Federal da Bahia, Salvador, v. 13 , p. 29-50, 2006. p. 30-31. "O modelo contratual liberal era um modelo que se justificava historicamente. A burguesia, que já era a elite econômica, passou, com a revolução francesa, a ser a nova elite política. Para garantir sua permanência nesta nova condição, para garantir a segurança jurídica desta nova ordem, e, ao mesmo tempo, para afastar a ordem jurídica absolutista, era necessário um Código [...] que consolidasse este novo quadro."

${ }^{35}$ ALVIM, Arruda. A função social dos contratos no novo código civil, Revista dos Tribunais, São Paulo, v. 92, n. 815, p. 11-31, set. 2003. p. 19-21. 
E, apesar da utilização de modelos formalmente distintos na elaboração das codificações desse período, pode-se constatar que, em cada uma delas, o contrato, a propriedade, a responsabilidade civil, a família e o direito das sucessões foram pensados a partir de uma lógica estritamente patrimonial. O valor atribuído à vontade na formação dos contratos, a intelecção dos limites imanentes ao princípio da força obrigatória dos contratos e o rechaço às teses revisionistas no século XIX e nas primeiras décadas do século XX, comprovam a assertiva formulada. Além disso, a compreensão do contrato como negócio que interessa exclusivamente às partes - sem que seja realçada, portanto, sua transcendência social ${ }^{36}$ - acaba ratificando a constatação promovida.

Nessa mesma esteira e naquilo que interessa mais de perto à tese em

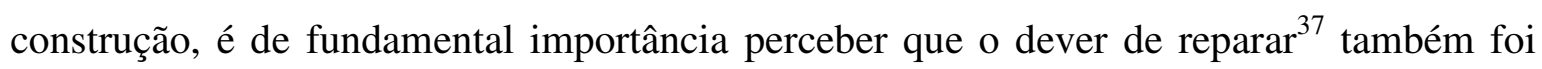
pensado como mecanismo - ainda que reflexo - de preservação da propriedade privada. ${ }^{38}$ Vale lembrar que, até bem pouco tempo atrás, a reparação do dano era a única via que poderia conduzir à tutela de distintos direitos. ${ }^{39}$ Medidas de cunho inibitório e (ou) preventivo eram ignoradas.

O recurso à culpa - o discurso coerente com as bases fundantes das primeiras codificações, isso é inegável - possui um viés profundamente individualista. Em apertada síntese, tal opção redunda na análise do problema - de modo maniqueísta - a partir de um de seus aspectos: o comportamento do causador do dano. ${ }^{40}$ A culpa atua, como é possível antever, como sanção a ser imposta em razão do mau uso da liberdade. ${ }^{41}$

${ }^{36}$ ITURRASPE, Jorge Mosset; PIEDECASAS, Miguel. Responsabilidad contractual. Santa Fé: RubinzalCulzoni, 2007. p. 34.

${ }^{37}$ GHERSI, Carlos Alberto. Teoría general de la reparación de daños. Buenos Aires: Astrea, 1997. p. 25-26. Prefere-se a expressão dever de reparar em lugar das já consagradas responsabilidade e indenização. Isso se justifica porque a noção de responsabilidade se constrói a partir de um juízo de reprovabilidade de uma conduta, ignorando a necessidade social de reparação dos danos injustos. Explica-se ainda, a nosso ver, porque muitos danos não têm como ser indenizados (tornar indene, sem lesão), apenas reparados. A recomposição do interesse jurídico violado in natura nem sempre será viável ou factível.

${ }^{38}$ HIRONAKA, Giselda Maria Fernandes Novaes. Responsabilidade pressuposta. Belo Horizonte: Del Rey, 2005. p. 95-96. Quando deveria, consoante acertadamente destaca a autora, atuar como instrumento "de fortalecimento da cidadania."

${ }^{39}$ MARINONI, Luiz Guilherme. Tutela específica: arts. 461, cpc e 84, cdc. 2 ed. São Paulo: RT, 2001. p. 21.

40 AMARAL, Francisco. Individualismo e universalismo no direito civil brasileiro: permanência ou superação de paradigmas romanos?, Revista Brasileira de Direito Comparado, Rio de Janeiro, n. 13, p. 6495, jul./dez. 1992. p. 90-91.

${ }^{41}$ SCHREIBER, Anderson. Novos paradigmas da responsabilidade civil: da erosão dos filtros da reparação à diluição dos danos. São Paulo: Atlas, 2007. p. 12. 
A visão parcial do fenômeno ignora, entretanto, a complexidade da questão atada à reparação dos danos. Perceba-se que a inspiração individualista - ao legitimar a alocação da culpa como figura central no universo do dever de $\operatorname{reparar}^{42}$ - atende aos anseios da classe dominante nos séculos XVIII e XIX. ${ }^{43}$ E isso, dentre outras possibilidades, porque o recurso ao subjetivismo conduz à acumulação de riqueza por atuar como um filtro ${ }^{44}$ das pretensões que merecerão (ou não) proteção estatal ${ }^{45}$, afastando, consequentemente, as possibilidades de distribuição de justiça social.

E mesmo que exista um viés moral permeando a compreensão da figura sob análise - viés esse intimamente atado à noção de livre arbítrio -, o papel da culpa para o projeto político e econômico ${ }^{46}$ da classe dominante é irrefutável. O valor atribuído a esse ente mitológico - desconstruído e deturpado ao longo da História ${ }^{47}$ - reverbera, ainda hoje, de tal modo que impede a escorreita compreensão da configuração do dever de reparar ${ }^{48}$, além de conduzir, em incontáveis situações, a decisões hialinamente teratológicas. ${ }^{49}$

${ }^{42}$ GHERSI, Carlos Alberto. Teoría general de la reparación de daños. Buenos Aires: Astrea, 1997. p. 4-5. No mesmo sentido: GOMES, Orlando. Culpa x risco, Revista Forense, Rio de Janeiro, v. 37, n. 83, p. 378384, set. 1940. p. 378.

${ }^{43}$ SCAVONE JUNIOR, Luiz Antonio. Do descumprimento das obrigações: conseqüências à luz do princípio da restituição integral: interpretação sistemática e teleológica. São Paulo: Juarez de Oliveira, 2007. p. 44.

${ }^{44}$ LORENZETTI, Ricardo Luis. Teoria da decisão judicial: fundamentos do direito. Trad. Bruno Miragem. São Paulo: RT, 2009. p. 239.

${ }^{45}$ Perceba-se que, em um grupo de uma centena de pessoas lesadas pela prática de um ilícito qualquer, nem todos têm uma prova sequer da culpa do devedor. Outros tantos não conseguiriam produzi-la. Existe ainda a possibilidade de que outros, mesmo provando a culpa do causador do dano, terão sua pretensão afastada porque o Judiciário entende que aquele comportamento não é uma conduta informada pela culpa.

${ }^{46}$ NORONHA, Fernando. Direito das obrigações. São Paulo: Saraiva, 2004, v. 1. p. 435.

${ }^{47} \mathrm{O}$ tema será tratado adequadamente no item 3.1 deste trabalho.

${ }^{48} \mathrm{O}$ tema será tratado adequadamente no capítulo 2 deste trabalho.

49 Alguns exemplos paradigmáticos podem ser extraídos do acervo de decisões do Superior Tribunal de Justiça: STJ. REsp 819789/RS. 1. T. Rel. Min. Francisco Falcão. j. 25.04.06. DJ 25.05.06. p. 191 (inserindo, indevidamente, a culpa como pressuposto do dever de reparar); STJ. REsp 955352/RN. 2. T. Rel. Min. Eliana Calmon. j. 18.06.09. DJE 29.06.09 (recorrendo à esdrúxula figura da "culpa objetiva" como fundamento de atribuição do dever de reparar); STJ. REsp 644984/RJ. 3. T. Rel. Min. Nancy Andrighi. j. 16.08.05. DJ 05.09.05. p. 402 (tratando como sinônimos culpa e inadimplemento, figuras manifestamente distintas), e enfim STJ. AgRg no REsp 1.155.827/SP. 1. T. Rel. Min. Hamilton Carvalhido. j. 22/6/10, cujo teor é aqui transcrito: "Cuida-se, na origem, de ação ordinária de restituição de tarifas relativas ao fornecimento de água e esgoto ajuizada pela ora agravante (Shopping) em razão de cobrança equivocada da companhia de saneamento no período de agosto de 1983 a dezembro de 1996, lapso em que vigente o Dec. estadual n. 21.123/1983. O tribunal a quo determinou a devolução do quantum pago indevidamente e afastou a repetição do indébito em dobro. A agravante sustenta ofensa ao art. 42, parágrafo único, do CDC, almejando a revisão do julgado quanto à devolução dos valores cobrados erroneamente a maior, que lhe seriam devidos em dobro. Dessa forma, a insurgência do Shopping está na restituição simples, pois o tribunal a quo afastou o pagamento em dobro, sob o fundamento de ser erro justificável por parte da concessionária de serviço público. Para o Min. Relator, não há como reexaminar a existência de culpa da concessionária. Entretanto, destacou que, mesmo se vencido esse óbice, era caso de se negar seguimento ao REsp, visto que somente se 
Insta ressaltar, ainda, que, ao focar a intelecção do dever de reparar na aferição de culpa na conduta do devedor - como o fizeram as primeiras codificações -, esse mesmo devedor acaba sendo injustificadamente protegido. E protegido, dentre outras razões, porque as contingências são desprezadas pelo sistema. $\mathrm{O}$ dano, nesse contexto - e talvez porque ele afligia, na normalidade dos casos, aquela parcela da população esquecida pelos detentores do poder político e econômico -, é compreendido em muitas hipóteses como um efeito colateral socialmente aceitável.

Mas, como os mitos não são vencidos facilmente, o processo de exaltação e enaltecimento de um indivíduo responsável ${ }^{50}$ acaba por agir como um véu de legitimação de um discurso que convence e apaixona. Por trás dessa homilia cativante, ao mesmo tempo em que se permite a acumulação de riqueza e o empreendedorismo, o dano é tratado como um simples - e aceitável - custo social. ${ }^{51}$

A responsabilidade civil vivia aqui seu primeiro modelo. Moldada a partir de premissas morais - e ainda que acobertada por um nevoeiro social, político e econômico -, a estruturação do dever de reparar era pensada a partir de código binário criado na dualidade do crime e castigo. ${ }^{52}$ A noção é tão arraigada que, ainda hoje, há quem defenda que o recurso à culpa visa a "castigar" o causador do dano. ${ }^{53}$

justifica a aplicação do parágrafo único do art. 42 da Lei n. 8.078/1990, quando ocorre erro injustificável do prestador de serviços, na cobrança dos débitos. No caso dos autos, não foi comprovada a ocorrência de erro injustificável do prestador do serviço público, uma vez que a questão referente ao enquadramento de imóveis comerciais do chamado "regime de economias" ensejou a aplicação de interpretações divergentes dos dispositivos do Dec. estadual n. 21.123/1983. [...]."

${ }^{50}$ GHERSI, Carlos Alberto. Teoría general de la reparación de daños. Buenos Aires: Astrea, 1997. p. 4-5. GHERSI, Carlos Alberto. De Velez a Borda un cambio ideológico transcendente, que no se complementó en el rápido acceso a la justicia. In: GHERSI, Carlos Alberto (Dir.). Responsabilidad: problemática moderna. Mendoza: Ediciones Jurídicas Cuyo, 1996. p. 22. "Para o individualismo o homem é dono de sua vontade o que envolve ser dono de suas ações e omissões. Por isso, a liberdade, como prolongamento do ser humano, carrega consigo sua própria essência e as únicas limitações que podem ser concebidas são aquelas impostas pelo poder constituído por meio da lei."

${ }^{51}$ LORENZETTI, Ricardo Luis. El sistema de la responsabilidad civil ¿una deuda de responsabilidad, un crédito de indemnización o una relación jurídica?, Revista da Ajuris, Porto Alegre, n. 63, p. 166-198, mar. 95. p. 171.

${ }^{52}$ SCHIPANI, Sándro. Análisis de La culpa en Justiniano 4,3. In: BUERES, Alberto Jesús; DE CARLUCCI, Aída Kemelmajer (Dir.). Responsabilidad por daños en el tercer milenio. Buenos Aires: Abeledo-Perrot, 1997. p. 127 e 136.

${ }^{53}$ PRADA, Maria González de; WAYAR, Ernesto. La mora, la demora y la crisis de la culpa. In: BUERES, Alberto Jesús (Dir.). Responsabilidad por daños. Buenos Aires: Abeledo-Perrot, 1997. p. 296. 
Erigida a único critério de imputação do dever de reparar - ainda que talvez possa ter servido às necessidades de uma sociedade agrária e mercantil ${ }^{54}$-, a alusão à essencialidade da culpa é uma das grandes responsáveis pelo processo de acumulação de riqueza nas sociedades capitalistas. Não há mais como negar que os caminhos eleitos pelo Estado Liberal priorizaram - em detrimento da promoção da cidadania - a tutela do capitalismo embrionário $^{55}$ do século XIX.

No Brasil, o código Beviláqua ${ }^{56}$ não destoa desse quadro. Reflete o pensamento capitalista do século XIX. Almeja a tranquilidade no tráfego jurídico em detrimento da justiça material. ${ }^{57}$ Com suas amarras atadas às codificações do século XIX ${ }^{58}$ - momento em que o arquétipo individualista ${ }^{59}$ baliza a construção do lastro jurídico que permitiria a ascensão do capitalismo ${ }^{60}$-, foi projetado para atender a interesses que não refletem os anseios das camadas menos favorecidas. Mais que isso. É um código forjado pelos anseios dos proprietários ${ }^{61}$ e que despreza as aspirações das outras camadas sociais existentes no início do século $\mathrm{XX} .^{62}$

${ }^{54}$ LA TORRE, Antonio. Il criterio d'imputazione della responsabilità civile, Roma e America: Diritto Romano Comune, Roma, n. 10, p. 96-114, 2000. p. 96. Até porque, destaca o autor, os danos tinham incidência individual circunscrita a espaços delimitados.

${ }^{55}$ Sobre o tema: SALVI, Cesare. La responsabilità civile. 2 ed. Milano: Giuffrè, 2005. p. 19. PONZANELLI, Giulio. La responsabilità civile: profili di diritto comparato. Bologna: Il Mulino, 1992. p. 52-53.

${ }^{56} \mathrm{E}$, parece hialino, também o direito civil.

${ }^{57}$ JUNQUEIRA DE AZEVEDO, Antonio. A boa-fé na formação dos contratos, Revista de Direito do Consumidor, São Paulo, n. 3, p. 78-87, set./dez. 1992. p. 78.

${ }^{58}$ AGUIAR JUNIOR, Ruy Rosado de. Projeto do código civil: as obrigações e os contratos, Revista de Direito Renovar, Rio de Janeiro, n. 15, p. 19-35, set./dez. 1999. p. 20. "O Código elaborado por Clóvis Beviláqua certamente [...] se distingue por sua feição nitidamente individualista, expressando a concepção político-filosófica vigorante depois da Revolução Francesa, sendo o homem o centro do mundo e capaz, com a sua vontade e a sua razão, de ordená-lo."

${ }^{59}$ TARTUCE, Flávio. Direito civil: lei de introdução e parte geral. 2 ed. São Paulo: Método, 2006, v. 1. p. 99. Ao versar sobre o Código revogado, o autor salienta que, no momento em que veio a lume, "a relação entre indivíduo e a propriedade era o centro do direito privado" e que a codificação vigente naquele momento "cumpria um papel de estatuto único e monopolizador das relações privadas, não sofrendo ingerência do Poder Público e a ele contrapondo-se", o que motivou a atribuição de "extremo valor à garantia do livre desenvolvimento da atividade econômica privada."

${ }^{60}$ GOMES, Orlando. Introdução ao direito civil. 11 ed. Atual. Humberto Theodoro Junior. Rio de Janeiro: Forense, 1995. p. 71. Versando sobre o individualismo, leciona ainda que este se alimenta da "idéia de que o homem possui direitos inseparáveis da condição humana, substancialmente intangíveis [e o direito] teria como finalidade assegurar ao indivíduo os meios para que expanda livremente sua atividade pelo exercício desses atributos [e regra alguma] poderia restringi-los, dificultá-los ou suprimi-los."

${ }^{61}$ TEPEDINO, Gustavo. Temas de direito civil. 3 ed. Rio de Janeiro: Renovar, 2004. p. 219.

${ }^{62}$ GOMES, Orlando. Raízes históricas e sociológicas do código civil brasileiro. São Paulo: Martins Fontes, 2003. p. 24-31. 
A codificação revogada compôs-se por preceitos manifestamente liberais. ${ }^{63} \mathrm{E}$ isso, especialmente porque a codificação francesa de 1804 influenciou diretamente sua configuração. ${ }^{64}$ Perceba-se que foram ignoradas peculiaridades inerentes ao sítio de produção $^{65}$ quando se ignora parte dos anseios que permeavam a realidade social brasileira existente nos primórdios do século passado. ${ }^{66}$

O código Beviláqua é fruto de seu tempo. ${ }^{67}$ De modo mais preciso, um produto imperfeito de sua época. ${ }^{68} \mathrm{E}$ isso porque surge atrasado, focando suas atenções em interesses agrários e desprezando a realidade de uma economia industrial ainda incipiente, mas certamente emergente. Era um "código patrimonial imobiliário." ${ }^{99}$ E, apesar da crítica, não se pode negar que foi importante - consoante o prisma utilizado nessa leitura - para o desenvolvimento do Brasil no século XIX e boa parte do século XX. ${ }^{70}$

\footnotetext{
${ }^{63}$ MONREAL, Eduardo Novoa. O direito como obstáculo à transformação social. Trad. Gérson Pereira dos Santos. Porto Alegre: SAFE, 1988. p. 16. "O importante, contudo, é fazer notar que esses grandes monumentos legislativos, cujo primado cabe ao Code Civil, respondem, todos, à ideologia política da Revolução Francesa, e servem para sancionar o triunfo da burguesia sobre os privilégios feudais. É esse último código o que afirma os princípios de igualdade pessoal, de respeito a um direito de propriedade privada, tido por sagrado e inviolável, à liberdade de contratar, ao amplo reconhecimento da autonomia da vontade e à preservação do direito de herança. Dito código e também os demais antes mencionados estão dominados, claramente, pelas idéias liberal-individualistas, consoante a concepção burguesa então imperante. Porém, ao serem cristalizadas, nos códigos fundamentais, essas idéias perdem a força pujante responsável pelo triunfo da Revolução francesa, e se convertem em garantia de uma nova forma de vida, quieta e segura."

${ }^{64}$ Vale lembrar que o modelo - forma - eleito tem por base o BGB alemão. Vale resgatar ainda que o direito contido nas Ordenações do Reino também influenciou a configuração do Código Beviláqua.

${ }^{65}$ MEDINA, Diego Eduardo López. Teoría impura del derecho: la transformación de la cultura jurídica latinoamericana. Bogotá: Legis, 2005. p. 22-69.

${ }^{66}$ MARTINS-COSTA, Judith; BRANCO, Gerson Luis Carlos. Diretrizes teóricas do novo código civil brasileiro. São Paulo: Saraiva, 2002. p. 166. Veja ainda: LÔBO, Paulo Luiz Netto. Constitucionalização do direito civil, Revista de Informação Legislativa, Brasília, v. 36, n. 141, p. 99-109, jan./mar. 1999. p. 101. "Os códigos civis tiveram como paradigma o cidadão dotado de patrimônio, vale dizer, o burguês livre do controle ou impedimentos públicos. Nesse sentido é que entenderam o homem comum, deixando a grande maioria fora de seu alcance. Para os iluministas, a plenitude da pessoa dava-se com o domínio sobre as coisas, com o ser proprietário."
}

${ }^{67}$ TOMASETTI JUNIOR, Alcides. Defesa do consumidor, concentração industrial, reserva de mercado: perplexidades de um civilista atento ao noticiário, Revista de Direito do Consumidor, São Paulo, n. 1, p. 1626, jan./abr. 1992. p. 25. "Aquele monumento legislativo é expressão de uma ideologia e de uma cosmovisão diversas daquelas caracterizantes da sociedade de hoje, menos homogênea, mais desigual e mais conflituosa."

${ }^{68}$ AMARAL, Francisco. A evolução do direito civil brasileiro, Revista da PGE, Porto Alegre, v. 13, n. 38, p. 65-83, 1983. p. 72. E isso porque, "elaborado a partir da realidade típica de uma sociedade colonial, traduzindo uma visão do mundo condicionado pela circunstância histórica, física e étnica em que se revela [ratifica a] cristalização axiológica das idéias dominantes no seu tempo, principalmente nas classes superiores [refletindo] as concepções filosóficas dos grupos dominantes, detentores do poder político e social da época."

${ }^{69}$ FACHIN. Luiz Edson. A reforma no direito brasileiro: novas notas sobre um velho debate no direito civil, Revista Brasileira de Direito Comparado, Rio de Janeiro, n. 16, p. 147-156, jan./jun. 1999. p. 148.

${ }^{70}$ LEWICKI, Bruno. Panorama da boa-fé objetiva. In: TEPEDINO, Gustavo (Coord.). Problemas de direito civil-constitucional. Rio de Janeiro: Renovar, 2000. p. 64. E isso "não só para fomentar o comércio (interno e externo), mas também para permitir a ampla liberdade na contratação [...] perpetuando a desumana 
Uma análise meticulosa da codificação recém-sepultada permite ainda afirmar que, com "retumbante silêncio sobre a vida e sobre o mundo", de um modo geral, nada mais fez que se limitar a especular "sobre os que têm" - esquecendo-se, a todo tempo, de uma imensa massa de despossuídos - e, nesse contexto, a instituir uma infinidade de regras tutelando os patrimônios desses sujeitos. ${ }^{71}$

O aludido diploma legislativo servia de cenário para que os papéis de proprietário, contratante, marido e testador pudessem ser desempenhados sem quaisquer óbices. ${ }^{72}$ É fácil perceber que a liberdade contratual e a igualdade formal auxiliavam na dissimulação da injustiça substancial existente nas relações negociais. ${ }^{73}$

É importante lembrar, enfim, que o código revogado, de forma consciente e salvo rara exceção, ignorou a existência dos princípios. Aliás, quando alude a eles, isso é feito a partir de perspectiva ideológica, visando à preservação da situação vigente. ${ }^{74}$ E esse fato ocorre mesmo com aqueles princípios consolidados na consciência ética e moral dos juristas. À medida que conclamavam a intervenção qualitativa do Judiciário na solução dos conflitos entre os privados - permitindo, por exemplo, a revisão dos negócios jurídicos -, os princípios, nessa quadra da História, foram relegados ao esquecimento. E como o direito civil recusava-se a dialogar com as Constituições, por mais que o inconstante trilhar do tempo trouxesse com ele alterações de distintos matizes, aquele continuou a atuar como se as mudanças sociais não lhe dissessem respeito. ${ }^{75}$

exploração dos trabalhadores, [fomentando] sobrevida à economia rural calcada no colonialismo [e consolidando] a ascendência social da burguesia emergente."

${ }^{71}$ FACHIN, Luiz Edson. Limites e possibilidades da nova teoria geral do direito civil, Revista da Faculdade de Direito, Curitiba, v. 27, n. 27, p. 49-60, 1992-1993. p. 53.

72 REALE, Miguel. Diretrizes da reforma do código civil, Revista do Advogado, São Paulo, n. 19, p. 5-12, out. 1985. p. 10-12.

${ }^{73}$ ROPPO, Enzo. O contrato. Trad. Ana Coimbra; M. Januário C. Gomes. Coimbra: Almedina, 2009. p. 3839.

${ }^{74}$ RAMOS, Carmem Lucia Silveira. Os princípios gerais do direito civil, Revista da Faculdade de Direito, Curitiba, v. 22, n. 22, p. 272-284, 1985. p. 280. Continua a autora destacando que a "análise crítica da aplicação dos princípios gerais do direito demonstra, desta sorte e à evidência, sua natureza ideológica [pois se apresentam como] representação imaginária dos valores da sociedade capitalista que se pretende preservar, que se quer permaneça como está, sem examinar se estes fatos econômicos, políticos e sociais que os princípios preservam correspondem efetivamente aos anseios da coletividade [...].” Ibid. p. 281.

${ }^{75}$ LÔBO, Paulo Luiz Netto. A constitucionalização do direito civil brasileiro, Revista Brasileira de Direito Civil Constitucional e Relações de Consumo, Santo Amaro, n. 1, p. 197-210, jan./mar. 2009. p. 205. "Manteve-se o paralelismo incomunicável entre Código e Constituição. Tal atitude resistente à mudança contaminou os civilistas e os tribunais, não se alterando nem mesmo quando importantes figuras do direito privado foram disciplinadas por leis especiais apesar dos microssistemas jurídicos serem caracterizados, exatamente, pela franca opção pelos princípios.” 
Curioso destacar que esse direito, surgido da Revolução Francesa, teimava em esquecer-se de um dos seus três pilares: a igualdade e a liberdade sempre são lembradas, a fraternidade - com exceção da proprietária ${ }^{76}$-, normalmente desprezada. Ignorada, talvez, porque impõe olhar para o outro, preocupação que parece inexistir no projeto liberal, especialmente, diante dos custos econômicos que tal postura representa.

Observe-se que, se, por um lado, as opções e estratégias do liberalismo concederam a alguns uma vida de sonhos - isso não se nega -, por outro, produzem um efeito colateral devastador: "a desintegração da condição humana" e o "esvaziamento ético" no cotidiano das relações sociais. ${ }^{77}$

Fato é que o direito civil brasileiro foi - e, pior, mantém-se - estruturado a partir de uma concepção histórica ${ }^{78}$ hialinamente ultrapassada. É facilmente perceptível que tanto o código revogado - e a boa parte de sua leitura -, como a codificação vigente ${ }^{79}$ - e a forma de atribuir vida as suas regras - estão contaminados. ${ }^{80}$

É ululante que esse Direito precisa ser repensado; embora, ainda hoje, exista quem defenda que, nos domínios do direito privado, deva "reinar a autonomia e a vontade soberana do indivíduo", pois só elas justificariam o respeito à "liberdade, sem a qual não se pode pensar em dignidade de homem algum." 81

\footnotetext{
${ }^{76}$ Em diálogo travado com o professor Lucas Abreu Barroso - por e:mail - durante o desenvolvimento desse item do trabalho, ele destaca que "a fraternidade foi substituída pela propriedade logo após a consolidação dos ideários da revolução" e que a igualdade não passou de uma promessa não realizada.

${ }^{77}$ FREIRE, Ricardo Maurício. Tendências do pensamento jurídico contemporâneo. Salvador: Podivm, 2007. p. 28. "Conquanto tenha desencadeado o progresso material da sociedade moderna, o racionalismo do ocidente acabou promovendo o cerceamento desintegrador da condição humana, a perda da liberdade individual, o esvaziamento ético e a formação de um sujeito egoísta, direcionado, precipuamente, ao ganho econômico. Os indivíduos foram convertidos a meros receptáculos de estratégias de produção, enquanto força de trabalho (alienação); de técnicas de consumo, enquanto consumidores (coisificação); e de mecanismos de dominação política, enquanto cidadãos da democracia de massas (massificação). A alienação, a coisificação e a massificação se tornaram patologias de uma modernidade em colapso.

${ }^{78}$ RAIZER, Ludwig. O futuro do direito privado, Revista da PGE, Porto Alegre, v. 9, n. 25, p. 11-30, 1979. p. 17. "A unidade do Direito Privado, uma vez codificado como fruto da pandectística dos fins do século XIX, permaneceu, finalmente, porém, fundada nas convicções éticas e políticas da camada social civil ainda relativamente unitária, que recebeu essa obra legislativa como ordenamento a ela adequada. Ela correspondeu a sua necessidade de liberdade, expansão e independência empresarial, a seu individualismo de posse [...]"

${ }^{79}$ Ainda que o problema ocorra de modo menos intenso que outrora.

${ }^{80} \mathrm{O}$ tema será abordado no item 4.1 deste trabalho.

81 THEODORO JUNIOR, Humberto. A onda reformista do direito positivo e suas implicações com o princípio da segurança jurídica, Revista da Escola Nacional da Magistratura, Brasília, v. 1, n. 1, p. 92-120, abr. 2006. p. 92.
} 
E, ao mesmo tempo em que o direito codificado perde sua importância - entre tantos outros problemas -, os danos multiplicam-se em quantidade e intensidade, embora, em boa parte das hipóteses, continue a ser tratado como algo sem muita importância. ${ }^{82}$ Eis um efeito pernóstico do viés patrimonial que informa a compreensão do tema: aspectos de ordem econômica normalmente prevalecem em detrimento da preocupação com a tutela da pessoa humana ${ }^{83}$ e da sociedade em toda sua complexidade. Curiosamente, e apesar de tantos problemas, "no centro de tantas mudanças e transformações, a nau encantada do direito civil [aparentemente cruza] tranquilamente um tempestuoso oceano de moribundos e cadáveres, parecendo não ressentir quaisquer influências dos novos tempos."84

Algumas vendas precisam ser retiradas. Para tanto, é oportuno resgatar que a ruptura simbolizada pelas codificações se destaca na História do direito civil. A partir daí, essa seara do Direito se torna estatal e burguesa, processo que se escora na concepção e sistematização do direito civil a partir dos anseios e interesses daqueles que detinham o poder político e econômico. Os códigos decimonônicos são um reflexo bastante evidente da ideologia da classe dominante.

Salvo rara exceção, ao longo dos últimos dois séculos, anseios e valores burgueses foram difundidos, ignorando não apenas os interesses, mas a própria existência das demais parcelas da sociedade. ${ }^{85}$ Tais dados, entretanto, raramente são apresentados, pois, no curso da História do Direito - e, portanto, da história de cada ser humano -, imagens e crenças são difundidas como valores universais - e isso quando não são canonizadas - com o intuito de pulverizar a compreensão de que a evolução do direito positivo está atada aos anseios das estruturas do poder. ${ }^{86}$

\footnotetext{
${ }^{82}$ VON THUR, Andreas. Tratado de las obligaciones. Trad. W. Roces. Madrid: Reus, 1934, t. 2. p. 101.

${ }^{83}$ GHERSI, Carlos Alberto. De Velez a Borda un cambio ideológico transcendente, que no se complementó en el rápido acceso a la justicia. In: GHERSI, Carlos Alberto (Dir.). Responsabilidad: problemática moderna. Mendoza: Ediciones Jurídicas Cuyo, 1996. p. 21.

${ }^{84}$ CIMBALI, Enrico. La nuova fase del diritto civile: nei rapporti economici e sociali. 4 ed. Torino: UTET, 1907. p. 3.

85 FACCHINI NETO, Eugênio. Reflexões histórico-evolutivas sobre a constitucionalização do direito privado. In: SARLET, Ingo Wolfgang (Org.). Constituição, direitos fundamentais e direito privado. 2 ed. Porto Alegre: LAEL, 2006. p. 19-20.

${ }^{86}$ WARAT, Luis Alberto. Introdução geral ao direito: interpretação da lei: temas para uma reformulação. Porto Alegre: SAFE, 1994, v. 1. p. 15.
} 
A partir dessas constatações, pulula a necessidade de assunção de uma nova ética. ${ }^{87}$ De uma ética cujo vértice seja a constante busca pela promoção e respeito da pessoa humana. É evidente que o patrimônio é merecedor de tutela jurídica. Em momento algum, essa premissa fora negada.

Ocorre que a ética que deve informar as condutas humanas somente poderá ser efetivamente encampada quando as estátuas do Liberalismo forem demolidas. Apenas assim, cada um de seus mitos será derradeiramente sepultado. É preciso entender que o Direito deve servir ao homem e à sociedade, e não, o contrário. Esse projeto exige, entretanto, que alguns grilhões sejam rompidos, dentre eles, os que atam o pensamento a um passado ${ }^{88}$ que não traz boas recordações à maior parte da sociedade brasileira.

\subsection{Os paradigmas civis-constitucionais do atual modelo de responsabilidade civil}

As primeiras codificações surgiram em um cenário no qual a ordem política do cidadão havia sido desconectada do palco em que se desenvolvem as relações privadas. São construídas em um momento no qual não havia diálogo entre direito público e direito privado. As constituições - destinadas a proteger o cidadão dos desmandos do Leviatã são compreendidas como cartas políticas distantes das relações - negociais ou não existentes entre as pessoas em seu cotidiano. Os códigos civis - construídos para prevenir, regrar e equacionar as relações interprivadas - assumem o status de constituição do homem comum. Tamanha a distância existente entre uma e outro que muitos autores afirmavam coexistirem duas constituições não comunicantes. ${ }^{89}$

${ }^{87}$ FAGÚNDEZ, Paulo Roney Ávila. O significado da modernidade. In: LEITE, José Rubens Morato; BELLO FILHO, Ney de Barros (Coord.). Direito ambiental contemporâneo. Barueri: Manole, 2004. p. 238. Parece não haver dúvida de que "a ética tradicional, moralista e preservacionista dos valores tradicionais precisa ser superada."

${ }^{88}$ HOLMES, Oliver Wendell. O caminho do direito, Revista da PGE, Porto Alegre, v. 13, n. 36, p. 13-31, 1983. p. 28. "Devemos nos precaver contra o perigo de cairmos em uma veneração cega do passado, e recordar que, para nossos propósitos, o único interesse que o passado pode oferecer, reside na luz que jorra no presente. Espero ansiosamente pelo dia no qual o papel desempenhado pela história na explicação dos dogmas for bem pequeno e, em vez de em pesquisas trabalhosas, gastemos nossas energias em um estudo sobre os objetivos a serem alcançados e as razões para os desejarmos." Vale destacar que estas frases foram proferidas há mais de cem anos.

${ }^{89}$ LÔBO, Paulo Luiz Netto. A constitucionalização do direito civil brasileiro, Revista Brasileira de Direito Civil Constitucional e Relações de Consumo, Santo Amaro, n. 1, p. 197-210, jan./mar. 2009. p. 198. Consoante o autor, o dualismo tanto seduz que persiste até hoje no senso comum do jurista. 
É patente que a proteção concedida pelas codificações liberais não foi capaz de solucionar uma infinidade de problemas. No modelo proposto pelo Estado Liberal, "a sociedade é madrasta no sentido dos contos infantis: têm favoritos e excluídos, filhos e enteados." ${ }^{90}$ Apesar de, perante a lei, todos serem considerados absolutamente iguais, a concretude dos fatos revelava constantemente a utopia contida em tal premissa. "Neste sistema [...], não havia lugar para a questão da intrínseca igualdade."91

O poder do mais forte lhe permitiu impor a seus parceiros a assunção de posições jurídicas pouco favoráveis. A leitura do cotidiano das relações sociais havidas em uma realidade que, há pouco, se foi permite visualizar também, em incontáveis situações, que os danos eram transferidos às vítimas, sendo tratados como efeitos colaterais socialmente aceitáveis.

A arquitetura projetada pelo liberalismo foi injusta com uma enorme parcela da população. Ela é responsável, em grande parte, pelo surgimento não só de uma gama de excluídos, mas também - e o que é bem mais preocupante - pelo advento de uma infinidade de esquecidos. ${ }^{92}$

E, dentre outras razões, diante do reconhecimento da vulnerabilidade de muitos daqueles que contratam diuturnamente e da situação peculiar das vítimas de danos cotidianos, o Direito gradativamente limita as ações em um espaço criado originalmente para o império da liberdade. Ao mesmo tempo em que essa é restringida, ampliam-se os deveres e as responsabilidades daqueles que integram uma relação jurídica qualquer. $\mathrm{O}$ direito civil sofre uma metamorfose. ${ }^{93}$

\footnotetext{
${ }^{90}$ ALTERINI, Atílio Aníbal. Estudios de derecho civil: conceptos, contratos, consumidor, derecho de daños. Buenos Aires: La Ley, 2007. p. 14.

${ }^{91}$ ROPPO, Enzo. O contrato. Trad. Ana Coimbra; M. Januário C. Gomes. Coimbra: Almedina, 2009. p. 4535.

${ }^{92}$ WARAT, Luis Alberto. A rua grita dionísio: direitos humanos da alteridade, surrealismo e cartografia. Trad. e Org. Vivian Alves de Assis; Júlio Cesar Marcellino Junior; Alexandre Morais da Rosa. Rio de Janeiro: Lumen Juris, 2010. p. 3-4.

${ }^{93}$ RAIZER, Ludwig. O futuro do direito privado, Revista da PGE, Porto Alegre, v. 9, n. 25, p. 11-30, 1979. p. 10. "[O direito privado] paralelamente, complementando e corrigindo [fez] valer, já desde a primeira guerra mundial, cada vez mais, o pensamento ético do enquadramento social do indivíduo e conseqüente responsabilidade social. Ele atua na ampliação do princípio de "fidelidade e fé" nas mais diversas aplicações sobre todos os institutos jurídicos, na integração da teoria da vontade através [sic] do princípio da proteção, da confiança e a extensão dos feitos contratuais sobre relações jurídicas sem completa união de vontades, no esforço em direção à justiça material contratual, na modificação da base do negócio [...] na ampliação da responsabilidade por dano contratual, delituosa ou objetiva - apenas para nomear os exemplos mais marcantes."
} 
Fruto dessa mutação, o Estado Social reduz o espaço outrora consagrado à liberdade por meio de um fenômeno que se convencionou denominar dirigismo contratual $^{94}$. A autonomia da vontade ${ }^{95}$, a liberdade individual e o direito de propriedade deixam de ser compreendidos a partir dos fundamentos teóricos e ideológicos que sustentam o Estado Liberal, passando a conviver com uma miríade de limitações. ${ }^{96}$

Nesse momento, ao mesmo tempo em que o individualismo gradativamente perdia sua sonoridade, soava o canto do universalismo. ${ }^{97} \mathrm{O}$ Estado Social fortalecia-se. Nele, proliferavam os microssistemas ${ }^{98}$ - recheados de comandos de ordem pública ${ }^{99}-$, dando regramento específico a um sem número de setores da vida em sociedade, nos quais o império da liberdade sufocava em vez de libertar. É importante salientar que variadas razões justificam a transição de modelos. Transformações econômicas, políticas e sociais estão entre os responsáveis pelo declínio do mito voluntarista. ${ }^{100}$

E, para que a substituição de modelos ocorresse, foi de extrema importância a percepção de que o papel da vontade na esfera negocial, em regra, não passava de uma fantasia. Ao chancelar - na concretude das relações - a prevalência dos anseios do mais

94 HIRONAKA, Giselda Maria Fernandes Novaes. A função social do contrato, Revista de Direito Civil, Imobiliário, Agrário e Empresarial, São Paulo, v. 12, n. 45, p. 141-152, jul./set. 1988. p. 146. “A intervenção do Estado [...] fez florescer um tempo novo, onde os malefícios do liberalismo jurídico foram mitigados pela proteção social [que] se estendeu ao mais fraco. As formas contratuais nas quais os direitos competiam todos a uma só das partes [...] foram repelidos [sic] severamente pelo que se convencionou chamar dirigismo contratual."

95 Atualmente, melhor será denominar o princípio como autonomia privada, já que à vontade quase não se reserva espaço no universo negocial contemporâneo.

96 Sobre limitações no direito de propriedade e no universo do direito dos contratos, respectivamente: MALUF, Carlos Alberto Dabus. Limitações ao direito de propriedade: de acordo com o código civil de 2002 e com o estatuto da cidade. São Paulo: RT, 2005. p. 15-49. SCHMITT, Cristiano Heineck. Cláusulas abusivas nas relações de consumo. 2 ed. São Paulo: RT, 2008. p. 43-186.

97 AMARAL, Francisco. Individualismo e universalismo no direito civil brasileiro: permanência ou superação de paradigmas romanos?, Revista de Direito Civil, Imobiliário, Agrário e Empresarial, São Paulo, v. 19, n. 71, p. 69-86, jan./mar. 1995. p. 75. "No século XX surge uma reação aos propósitos individualistas. A necessidade de mudança imposta pela revolução industrial que mostrava, cada vez mais, a diferença entre a igualdade formal, de todos perante a lei, e a desigualdade material, que afastava os menos favorecidos, transforma o Estado de direito liberal, burguês, em Estado social, intervencionista, que defende a prioridade da justiça social e a supremacia da segurança coletiva sobre a individual. O individualismo entra em crise, dando lugar aos valores sociais, à socialização do direito, à presença do Estado na economia. A autonomia privada limita-se pelos princípios de ordem pública. [...] O individualismo e o universalismo [...] harmonizam-se."

98 IRTI, Natalino. L'età della decodificazione, Revista de Direito Civil, Imobiliário, Agrário e Empresarial, São Paulo, v. 3, n. 10, p. 15-33, out./dez. 1979. p. 24-33.

${ }^{99}$ No Brasil, podem ser citados como exemplos o Estatuto da Terra, o Código Florestal e, mais recentemente, o Estatuto da Criança e do Adolescente e o Código de Defesa do Consumidor.

${ }^{100}$ GOMES, Orlando. Transformações gerais do direito das obrigações. São Paulo: RT, 1967. p. 10. 
forte - que, por esse motivo, acomodou-se nas sombras do liberalismo ${ }^{101}$-, o aludido princípio cobrou, e cobrou caro - especialmente daqueles que não podiam pagar - pelos poucos lugares vagos nesse contexto acolhedor.

É evidente que nem todos visualizam ou aceitam a mudança de modelos. O liberalismo é extremamente interessante para uma parcela considerável da sociedade capitalista. E, em que pese a resistência, o Estado Social solidifica-se, intervindo ainda mais com o advento das constituições do pós-guerra. ${ }^{102}$ Parece mesmo que essas constituições acabam por plantar as sementes do modelo que viria a ocupar, em pouco tempo, o lugar do Estado Social: o Estado Democrático de Direito. ${ }^{103}$

Nesse momento, ao mesmo tempo em que os textos constitucionais incorporam (ou reincorporam) as promessas feitas pela modernidade ${ }^{104}$, novos deveres são assumidos pelo Estado - pelo menos em perspectiva ideal -, dentre eles, encontrando-se os de “conformação, transformação e modernização" das relações sociais, visando a promover o acesso à igualdade, à justiça social ${ }^{105}$ e ao exercício pleno da cidadania.

No Estado Democrático de Direito, é do texto constitucional que emanam as luzes que permitirão que as respostas adequadas para cada caso concreto sejam alcançadas. Assim, cada momento de expressão do "poder normativo privado" deverá moldar-se à unidade constitucional, "unidade, não dogmática, mas jurídica; não totalitária, mas democrática; não absoluta, mas mediada por relações de preferência e compatibilidade entre os direitos fundamentais.",106

\footnotetext{
${ }^{101}$ BARRETO, Cunha. O dirigismo na vida dos contratos, Revista dos Tribunais, São Paulo, v. 28, n. 117, p. 455-462, jan. 1939. p. 460.

102 COSTA, Pedro Oliveira da. Apontamentos para uma visão abrangente da função social dos contratos. In: TEPEDINO, Gustavo (Coord.). Obrigações: estudos na perspectiva civil-constitucional. Rio de Janeiro: Renovar, 2005. p. 46.

${ }^{103}$ SOARES, Mário Lúcio Quintão; BARROSO, Lucas Abreu. A dimensão dialética do novo código civil em uma perspectiva principiológica. In: BARROSO, Lucas Abreu (Org.). Introdução crítica ao código civil. Rio de Janeiro: Forense, 2006. p. 1. "O paradigma Estado Democrático de Direito [tem] como arcabouços uma sociedade inclusiva e mecanismos institucionais para a emancipação do cidadão, pressupõe a vinculação dos atos estatais e do legislador ao texto constitucional."

${ }^{104}$ STRECK, Lenio Luiz. Quinze anos de constituição - análise crítica da jurisdição constitucional e das possibilidades hermenêuticas de concretização dos direitos fundamentais-sociais, Revista da Ajuris, Porto Alegre, v. 30, n. 92, p. 205-234, dez. 2003. p. 205.

105 CANOTILHO, José Joaquim Gomes. Direito constitucional e teoria da constituição. 7 ed. Coimbra: Almedina, 2003. p. 338.

${ }^{106}$ PERLINGIERI, Pietro. O direito civil na legalidade constitucional. Trad. Maria Cristina De Cicco. Rio de Janeiro: Renovar, 2008. p. 308-309.
} 
É nos princípios constitucionais que as respostas e soluções para boa parte das celeumas detectadas na seara das relações civis hão de ser encontradas. Isso permite priorizar a diversidade axiológica existente ${ }^{107}$ e abandonar os simplismos criados pelo Estado Liberal. Nessa esteira, considerando ser função de uma Constituição assegurar o respeito a valores fundamentais no desenvolvimento de uma sociedade em movimento ${ }^{108}$, cada hipótese que exija avaliação jurídica deverá passar pelo crivo daquela.

A Constituição condiciona e inspira o processo de concreção do direito civil ${ }^{109}$ ao ocupar o lugar de destaque outrora atribuído à codificação. ${ }^{110} \mathrm{E}$ essa postura, ao contrário do que alguns possam pensar, em vez de reduzir a importância do direito civil, o engrandece ao impor o constante repensar de suas estruturas fundantes, concedendo-lhe legitimidade e amplificando suas potencialidades na solução de problemas para os quais não fora originalmente pensado.

Aliás, um direito civil que não se permita conduzir pelos influxos constitucionais não é nem factível, nem juridicamente possível. E isso em razão dos vínculos e interações que o aquele deve ter com os preceitos constitucionais - sem os quais o processo de realização do Direito não poderá chegar a um resultado legítimo -; e da necessidade de ter na Constituição o eixo de centralidade hermenêutica. ${ }^{11}$

Destaque-se aqui que o viés apresentado, embora pareça o mais acertado, não é aceito pacificamente, havendo vozes que se insurgem contra a leitura proposta, sustentando, dentre outros argumentos, (a) que o código civil ainda é o "eixo interpretativo do direito privado"112; (b) que, "se uma lei ordinária não é inconstitucional, não deve

\footnotetext{
107 TEPEDINO, Gustavo. Temas de direito civil. Rio de Janeiro: Renovar, 2006, t. 2. p. 408.

108 TRABUCCHI, Alberto. Istituzioni di diritto civile. 37 ed. Padova: Cedam, 1997. p. 14.

109 SARMENTO, Daniel. Direitos fundamentais e relações privadas. 2 ed. Rio de Janeiro: Lumen Juris, 2006. p. 77-83. "Se é verdade que a Constituição converteu-se no centro de gravidade do Direito Privado, não é menos certo que ela não pretende desempenhar papel semelhante ao dos códigos do passado, disciplinando de forma exaustiva as condutas humanas em sociedade. Fica preservado o espaço de concretização do legislador, nos limites talhados pela ordem constitucional [...]."

${ }^{110}$ LOTUFO, Renan. Da oportunidade da codificação civil, Revista do Advogado, São Paulo, n. 68, p. 19-30, dez. 2002. p. 25.

111 VILLEGAS, Juan Jacobo Calderón. La constitucionalización de las controversias contractuales. In: ESPINOSA, Fabricio Mantilla; BARRIOS, Francisco Ternera (Dir.). Los contratos en el derecho privado. Bogotá: Legis, 2007. p. 765.

112 TIMM, Luciano Benetti. "Descodificação", constitucionalização e descentralização do direito privado: o código civil ainda é útil?, Revista de Direito Privado, São Paulo, v. 7, n. 27, p. 223-251, jul./set. 2006. p. 251.
} 


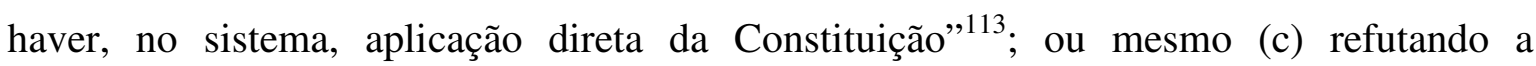
existência de um direito civil-constitucional. ${ }^{114}$ Apesar das aludidas críticas, não se olvida que o direito civil deva ser lido a partir das lentes fundidas no direito constitucional. E não poderia ser diferente, até porque o reencontro do público com o privado - dentre outros processos disparados pela leitura suscitada ${ }^{115}$ - é essencial para que as contingências da vida na contemporaneidade possam ser enfrentadas com alguma chance de sucesso.

É relevante destacar ainda que a Constituição aqui pensada é a Constituição moldura. ${ }^{116}$ Por isso, não se nega que exista um espaço reservado, com exclusividade, ao direito civil; o que não quer dizer que as luzes que emanam da Constituição possam ser apagadas. São elas as responsáveis pela indicação do caminho de acesso ao palco da cidadania. $^{117}$

113 JUNQUEIRA DE AZEVEDO, Antonio. Novos estudos e pareceres de direito privado. São Paulo: Saraiva, 2009. p. 603.

${ }^{114}$ SILVA, Virgílio Afonso da. A constitucionalização do direito: os direitos fundamentais nas relações entre particulares. São Paulo: Malheiros, 2008. p. 112-126. "Não são poucos os trabalhos que mencionam a existência de uma disciplina que, há poucas décadas, era desconhecida: o direito civil constitucional. Com essa denominação quer-se fazer referência, contudo, a uma variedade de idéias. Ora se fala em direito civil constitucional como as normas de direito civil consagradas na constituição, ora a menção é feita à influência do direito constitucional no direito civil. Na primeira hipótese, estamos claramente diante de um equívoco. Normas de direito civil não deixam de ser normas de direito civil pelo simples fatos de estarem consagradas pelo texto constitucional. O texto que as vincula é, neste ponto, irrelevante, pelo menos para justificar a criação de um direito civil constitucional. Na segunda hipótese, falar em direito civil constitucional pressupõe, a meu ver equivocadamente, que haja uma parte do direito civil completamente imune às influências dos princípios constitucionais e outra que seria por eles conformada. Se, ao contrário, é todo o direito civil que recebe essa influência e não apenas uma parte, a idéia de um direito civil constitucional perde ainda mais em sentido, a não ser que a expressão direito civil, sem qualificativos, seja abandonada, por deixar de fazer sentido."

115 LÔBO, Paulo Luiz Netto. Constitucionalização do direito civil, Revista de Informação Legislativa, Brasília, v. 36, n. 141, p. 99-109, jan./mar. 1999. p. 100. "Na atualidade, não se cuida de buscar a demarcação dos espaços distintos e até contrapostos. Antes havia a disjunção; hoje, a unidade hermenêutica, tendo a Constituição como ápice conformador da elaboração e aplicação da legislação civil. A mudança de atitude é substancial: deve o jurista interpretar o Código Civil segundo a Constituição e não a Constituição segundo o Código, como ocorria com frequência (e ainda ocorre). A mudança de atitude também envolve uma certa dose de humildade epistemológica. O direito civil sempre forneceu as categorias, os conceitos e classificações que serviram para a consolidação dos vários ramos do direito público, inclusive o constitucional, em virtude de sua mais antiga evolução (o constitucionalismo e os direitos públicos são mais recentes, não alcançando um décimo do tempo histórico do direito civil). Agora, ladeia os demais na mesma sujeição aos valores, princípios e normas consagrados na Constituição. Daí a necessidade que sentem os civilistas do manejo das categorias fundamentais da Constituição. Sem elas, a interpretação do Código e das leis civis desvia-se de seu correto significado."

${ }^{116}$ SILVA, Virgílio Afonso da. A constitucionalização do direito: os direitos fundamentais nas relações entre particulares. São Paulo: Malheiros, 2008. p. 112-126. Classificação aqui adotada, em oposição, consoante as definições apontadas pelo autor, à Constituição, denominada fundamento ou total.

${ }^{117}$ WARAT, Luis Alberto. Introdução geral ao direito: a epistemologia jurídica da modernidade. Porto Alegre: SAFE, 2002, v. 2. p. 356-357. 
Talvez seja mais fácil compreender a importância desse fenômeno quando se tem em mente que tanto o direito civil, como o direito constitucional passaram por profundas mutações. ${ }^{118}$ Ademais, somente a leitura do primeiro a partir dos vetores contidos no último permitirá a existência, em um futuro próximo, de uma sociedade mais justa e menos desigual.

A aceitação dessa acoplagem, ao mesmo tempo em que autoriza a incidência direta dos direitos fundamentais nas relações privadas ${ }^{119}$, reconhece a força jurígena contida nos princípios constitucionais. A efetividade da leitura proposta implica, entretanto, abandonar ao menos quatro preconceitos, sendo imperioso: (a) entender que a Constituição não é mera carta política; (b) aceitar que os princípios constitucionais têm força e hierarquia normativa; (c) compreender a fragilidade da subsunção como método e afastá-la definitivamente do processo de realização do Direito ${ }^{120}$; e, enfim, (d) ultrapassar a classificação dicotômica tradicional. ${ }^{121}$ Contemporaneamente, uma decisão pautada na legalidade não é aquela que é informada pela subserviência às regras pré-concebidas, mas a que respeita as escolhas constitucionais. ${ }^{122}$ ${ }^{118}$ FACHIN, Melina Girardi; PAULINI, Umberto. Problematizando a eficácia dos direitos fundamentais nas
relações entre particulares: ainda e sempre sobre a constitucionalização do direito civil. In: TEPEDINO,
Gustavo; FACHIN, Luiz Edson (Org.). Diálogos sobre direito civil. Rio de Janeiro: Renovar, 2008, v. 2. p.
197. "Mudou o direito civil, no qual a autonomia da vontade não é mais dogma [sic] e condição de validade.
Mudou o direito constitucional e sua ótica exclusivamente defensiva em face das ingerências estatais.
Ganharam, com isso, as duas searas, enriquecendo em problematização e complexidade."
119 Direitos fundamentais, aliás, que podem ser classificados consoante sua inserção em uma das cinco
dimensões - ou gerações - hodiernamente conhecidas.

${ }^{120}$ CASTANHEIRA NEVES, Antonio. O actual problema metodológico da interpretação jurídica. Coimbra: Coimbra, 2003, v. 1. p. 11-12. "O problema da interpretação jurídica está, com efeito, a sofrer uma radical mudança de perspectiva no actual contexto metodológico. Deixou de conceber-se tão só e estritamente como interpretação da lei, para se pensar como actus de realização do Direito. E isto significa, por um lado, que a realização do Direito não se identifica já com a interpretação da lei, nem nela se esgota; por outro lado, que não será em função da interpretação da lei, tomada abstractamente ou em si, que havemos de compreender a realização do Direito - em termos de se dizer que esta será o que for aquela -, antes é pela problemática autónoma e específica da realização do Direito, e como seu momento metodológico-normativo, que se haverá de entender o que persista dizer-se interpretação da lei. Com o que o próprio conceito de interpretação jurídica se altera: de interpretação da lei converte-se em interpretação do direito, de novo a interpretaria legis se confronta com a interpretatio iuris. É que, se intencional e normativamente o direito deixou de identificar-se com a lei, também metodologicamente a realização do Direito deixou de ser mera aplicação das normas legais e manifesta-se como o acto judicativamente decisório através [sic] do qual, pela mediação embora do critério jurídico possivelmente oferecido por essas normas, mas com ampla actividade normativamente constitutiva, se cumprem em concreto as intenções axiológicas e normativas do direito, enquanto tal. Dir-se-á que, nestes termos, o pensamento jurídico recuperou o concreto, que vai na essencial vocação do direito, depois que o positivismo legalista, com o seu normativismo analítico-dedutivo, o levara a refugiar-se no alienante abstracto."

${ }^{121}$ TEPEDINO, Gustavo. Temas de direito civil. 3 ed. Rio de Janeiro: Renovar, 2004. p. 18-19.

${ }^{122}$ PERLINGIERI, Pietro. O direito civil na legalidade constitucional. Trad. Maria Cristina De Cicco. Rio de Janeiro: Renovar, 2008. p. 24. 
Como não poderia ser diferente, "o Direito do estado constitucional democrático e de Direito leva a sério os princípios, [sendo mesmo] um Direito de princípios." ${ }^{123}$ Os princípios, agora constitucionalizados - e que reciprocamente se complementam e se restringem ${ }^{124}$-, são a chave do sistema jurídico. ${ }^{125}$ Vale lembrar que esses, por muito tempo, foram considerados tributários das leis: teriam aplicação supletiva, só autorizada quando da inexistência de solução previamente legislada e após a tentativa de uma solução analógica coerente. Os papéis se inverteram. Os princípios são considerados o fundamento mais importante em qualquer processo de realização do Direito. ${ }^{126}$ Aliás, é preciso aceitar que os princípios balizam a solução de todos os problemas concretos, e não apenas daquelas hipóteses que não se enquadram em arquétipos pré-concebidos para atuarem a partir do recurso à técnica da subsunção. ${ }^{127}$ Os princípios assumem posição de destaque $^{128}$ no processo de realização do Direito.

${ }^{123}$ CANOTILHO, José Joaquim Gomes. A "principialização" da jurisprudência através da constituição, Revista de Processo, São Paulo, v. 25, n. 98, p. 83-89, abr./jun. 2000. p. 84.

${ }^{124}$ CANARIS, Claus-Wilhelm. Pensamento sistemático e conceito de sistema na ciência do direito. 3 ed. Trad. Antônio Manuel da Rocha e Menezes Cordeiro. Lisboa: Fundação Calouste Gulbenkian, 2002. p. 9293.

${ }^{125}$ BONAVIDES, Paulo. Curso de direito constitucional. 9 ed. São Paulo: Malheiros, 2000. p. 228-266.

${ }^{126}$ Ibid. p. 263-265. "Em resumo, a teoria dos princípios chega à presente fase do pós-positivismo com os seguintes resultados já consolidados: a passagem dos princípios da especulação metafísica e abstrata para o campo concreto e positivo do Direito, com baixíssimo teor de densidade normativa; a transição crucial da ordem jusprivatista (sua antiga inserção nos Códigos) para a órbita juspublicística (seu ingresso nas Constituições); a suspensão da distinção clássica entre princípios e normas; o deslocamento dos princípios da esfera da jusfilosofia para o domínio da Ciência Jurídica; a proclamação de sua normatividade; a perda de seu caráter de normas programáticas; o reconhecimento definitivo de sua positividade e concretude por obra sobretudo das Constituições; a distinção entre regras e princípios, como espécies diversificadas do gênero norma, e, finalmente, por expressão máxima de todo esse desdobramento doutrinário, o mais significativo de seus efeitos: a total hegemonia e preeminência dos princípios. Fazem eles a congruência, o equilíbrio e a essencialidade de um sistema jurídico legítimo. Postos no ápice da pirâmide normativa, elevam-se, portanto, ao grau de norma das normas, de fonte das fontes. São qualitativamente a viga-mestra do sistema, o esteio da legitimidade constitucional, o penhor da constitucionalidade das regras de uma Constituição."

${ }^{127}$ Para compreensão de aspectos relevantes dos problemas causados pela subsunção: STRECK, Lenio Luiz. Decisionismo e discricionariedade judicial em tempos pós-positivistas: o solipsismo hermenêutico e os obstáculos à concretização da constituição no Brasil. In: AVELÃS NUNES, António José; COUTINHO, Jacinto Nelson Miranda (Coord.). O direito e o futuro: o futuro do direito. Almedina: Coimbra, 2008. p. 101105. "Se as concepções metafísicas sobre o direito estão sustentadas na atribuição de sentidos in abstracto - e por isso sustentam a possibilidade da existência de múltiplas respostas - é porque a interpretação ocorre em etapas, cindindo interpretação e aplicação. Ora, é exatamente neste ponto que reside o diferencial entre a hermenêutica e as diversas teorias discursivo-procedurais. Em outras palavras, é a incindibilidade entre interpretar e aplicar que irá representar a ruptura com o paradigma representacional-metodológico. E é o círculo hermenêutico que vai se constituir em condição de ruptura do esquema (metafísico) sujeito-objeto, nele introduzindo o mundo prático (faticidade), que serve para cimentar essa travessia, até então ficcionada na e pela epistemologia. Não há como isolar a pré-compreensão."

${ }^{128}$ MAIA, Antonio Cavalcanti. O direito constitucional do limiar do século XXI: princípios jurídicos e póspositivismo. In: MORAES, Guilherme Peña de. Readequação constitucional do estado moderno. Rio de Janeiro: Lumen Juris, 2006. p. XXVI. Veja ainda: BONAVIDES, Paulo. Curso de direito constitucional. 9 
Sua escorreita compreensão permite identificar quais condutas deverão (ou não) ser observadas - e quais hão de ser sancionadas - na concretude dos fatos. ${ }^{129}$ É imperioso ainda, nesse momento, aceitar ser factível a existência de uma única resposta adequada para cada caso, resposta essa que irá informar - mas em momento algum amalgamar - a solução de hipóteses semelhantes, até ser eventualmente substituída por outra que se mostre como opção mais viável. É evidente que o Direito precisa de estabilidade, e em momento algum o recurso aos princípios pode ser visto como a legitimação da arbitrariedade ou do exercício de uma discricionariedade existente apenas em aparência.

E se de um lado, o processo de realização do Direito passa a ser balizado por nova perspectiva metodológica, que considera o caso como o ponto de partida, os princípios como seu fundamento e o desenvolvimento do raciocínio jurídico como razão prática $^{130}$, de outro, a valorização do aspecto problemático nesse processo não implica ignorar a dogmática ou rechaçar todo o direito positivo vigente; mas sim, alocá-los em seus lugares. É que a dogmática só tem sentido enquanto tradução da experiência jurídica e o direito posto, por sua vez, enquanto instrumento regulatório ${ }^{131}$ só tem efetivo valor depois de ser sopesado pelos princípios que hão de dirigir a ponderação das intersubjetividades inerentes a cada situação concretamente estabelecida; valendo lembrar que o direito legislado não é um simples "repositório normativo."132

ed. São Paulo: Malheiros, 2000. p. 259. Segundo o autor, o atual estado da arte passa pela "demonstração do reconhecimento da superioridade e hegemonia dos princípios na pirâmide normativa; supremacia que não é unicamente formal, mas, sobretudo material, e apenas possível na medida em que os princípios são compreendidos e equiparados e até mesmo confundidos com os valores [refletindo] a expressão mais alta da normatividade que fundamenta a organização do poder."

129 ÁVILA, Humberto. Teoria dos princípios: da definição à aplicação dos princípios jurídicos. 4 ed. São Paulo: Malheiros, 2004. p. 87-127. Veja ainda: CORRAL, Alfonso de Cossio y. Instituciones de derecho civil: parte general, obligaciones y contratos. 2 ed. Madrid: Civitas, 1991, t. 1. p. 116.

${ }^{130}$ AMARAL, Francisco. Uma carta de princípios para um direito como ordem prática. In: TEPEDINO, Gustavo; FACHIN, Luiz Edson (Coord.). O direito e o tempo: embates jurídicos e utopias contemporâneas. Rio de Janeiro: Renovar, 2008. p. 137-139. "Segue-se aqui, como referencial teórico, uma nova perspectiva metodológica que vê o direito como expressão de uma racionalidade prática, em que é determinante a atividade judicial, pelo que se denomina o jurisprudencialismo, segundo a qual o direito é sempre um processo de concreção, que se realiza por meio da decisão jurídica a partir de princípios jurídicos. Situandose em pólo diametralmente oposto ao pensamento positivista da modernidade, representa um retorno ou a reabilitação da filosofia prática de matriz aristotélica."

${ }^{131}$ MOZOS, Jose Luis de los. Metodologia y ciencia en el derecho privado moderno. Madrid: Editoriales de Derecho Reunidas, 1977. p. 41.

132 TEPEDINO, Gustavo. Normas constitucionais e direito civil na construção unitária do ordenamento. In: CONRADO, Marcelo; PINHEIRO, Rosalice Fidalgo (Coord.). Direito privado e constituição: ensaios para uma recomposição valorativa da pessoa e do patrimônio. Curitiba: Juruá, 2009. p. 39. 
Esse processo permitirá apreender o que se encontra por trás dos textos, leitura essa que não pode ser feita sem ter em conta a realidade social. ${ }^{133}$ "O Direito não é um dado que se encontre previamente estabelecido, mas um processo, uma atividade específica de composição de conflitos, por meio de um poder que a sociedade legitima e institucionaliza."134 Não se propõe aqui uma revolta contra o direito institucionalizado, mas apenas uma demonstração da essencialidade do seu constante repensar a partir da realidade social vigente e dos objetivos consagrados pelo Estado Democrático de Direito.

Importa saber, nesse novo modelo, o Direito que está por vir, aquele que há de ser construído a partir dos princípios que informam cada situação surgida na concretude dos fatos e, portanto, despido de arbitrariedades. ${ }^{135}$ Somente com respeito aos direitos fundamentais, será possível assegurar o exercício da cidadania social. ${ }^{136}$

Por tudo isso, a imposição (ou não) do dever de reparar não pode ser promovida apenas pela comprovação da legalidade de uma decisão oriunda do preenchimento das regras infraconstitucionais. Solidariedade social, isonomia substancial e dignidade da pessoa humana entram em cena, assumindo importância ímpar no processo de gênese da norma jurídica, expressão aqui compreendida no sentido que lhe é dado por Eros Grau. ${ }^{137}$

${ }^{133}$ GRAU, Eros Roberto. Técnica legislativa e hermenêutica contemporânea. In: TEPEDINO, Gustavo (Org.). Direito civil contemporâneo: novos paradigmas à luz da legalidade constitucional. São Paulo: Atlas, 2008. p. 282-286.

${ }^{134}$ AMARAL, Francisco. Uma carta de princípios para um direito como ordem prática. In: TEPEDINO, Gustavo; FACHIN, Luiz Edson (Coord.). O direito e o tempo: embates jurídicos e utopias contemporâneas. Rio de Janeiro: Renovar, 2008. p. 140.

${ }^{135}$ STRECK, Lenio Luiz. Da interpretação de textos à concretização de direitos: a incindibilidade, entre interpretar e aplicar - contributo a partir da hermenêutica filosófica, Revista da Faculdade de Direito da Universidade de Lisboa, Coimbra, v. 46, n. 2, p. 911-954, 2005. p. 912-931.

${ }^{136}$ SOARES, Mário Lúcio Quintão; BARROSO, Lucas Abreu. A concretização do devido processo legal pelo Supremo Tribunal Federal. In: ROSSI, Alexandre Luiz Bernardi; MESQUITA, Gil Ferreira (Org.). Maioridade constitucional: estudo em comemoração aos 18 anos da Constituição Federal. São Paulo: Lemos \& Cruz, 2008. p. 354.

${ }^{137}$ GRAU, Eros Roberto. Técnica legislativa e hermenêutica contemporânea. In: TEPEDINO, Gustavo (Org.). Direito civil contemporâneo: novos paradigmas à luz da legalidade constitucional. São Paulo: Atlas, 2008. p. 283. Veja ainda: GRAU, Eros Roberto. Pareceres, juristas e apedeutas, Revista da Faculdade de Direito da UFRGS, Porto Alegre, v. 18, p. 93-96, 2000. p. 94. "“...] sustento ser o texto (preceito, enunciado normativo) alográfico. Não se completa no sentido nele impresso pelo legislador. A "completude" do texto somente é realizada quando o sentido por ele expressado é produzido, como nova forma de expressão, pelo intérprete. Mas "o sentido expressado pelo texto" já é algo novo, distinto do texto: é a norma." 


\section{A solidariedade social}

A reciprocidade assume importante papel na estruturação das relações sociais. Pode-se mesmo afirmar que esse valor fundamenta a própria existência em sociedade ${ }^{138}$, e isso, especialmente, porque a preocupação com o outro conduz à tutela da continuidade e da adequação das condutas que sustentam a estrutura social. ${ }^{139}$ Por isso, parece irrefutável que à solidariedade deva ser atribuído valor jurídico ${ }^{140}$, permitindo-lhe atuar como uma via hábil na solução de uma infinidade de conflitos, mormente por impor que o olhar de cada indivíduo seja direcionado para o outro, para aquele que se encontra além do eu, combatendo o isolamento - destruidor - para o qual se encaminha a humanidade. ${ }^{141}$

Ademais, a tutela da solidariedade parece ser tão importante quanto a promoção da dignidade na fundação da arquitetura jurídica contemporânea. ${ }^{142}$ Ora, se "a base de toda a ética [se encontra] no senso de responsabilidade" é patente porque incumbe a cada um - mesmo quando a sociedade se furta a cumprir seus deveres -, como integrante dessa mesma sociedade, atuar para retirá-la da inércia. ${ }^{143}$ Aliás, parece impossível pensar uma democracia sem que cada pessoa tenha efetiva consciência de suas responsabilidades perante o outro, especialmente porque "a solidariedade exprime a cooperação e a igualdade na afirmação dos direitos fundamentais de todos." 144

${ }^{138}$ HELLERN, Victor; NOTAKER, Henry; GAARDER, Jostein. O livro das religiões. Trad. Isa Mara Lando. São Paulo: Companhia das Letras, 2000. p. 269.

${ }^{139}$ MALINOWSKI, Bronislaw. Crimen y costumbre en la sociedad salvaje. Trad. J. y M. T. Alier. Barcelona: Planeta-Agostini, 1985. p. 39.

${ }^{140}$ FACHIN, Luiz Edson. Estatuto jurídico do patrimônio mínimo. Rio de Janeiro: Renovar, 2001. p. 50. "A solidariedade adquire valor jurídico. A preocupação do jurista não se dirige apenas ao indivíduo, mas à pessoa tomada em relação, inserida no contexto social. A pessoa humana, como bem supremo do Direito, não é um elemento abstrato, isolado, dotado de plenos poderes, com direito absolutos e ilimitados. A coexistencialidade implica que se assegure não só o pleno desenvolvimento da pessoa individual, mas, simultaneamente, que as demais pessoas com as quais o indivíduo está em relação também possam ter esse desenvolvimento, de forma solidária. A pessoa tem o dever social de colaborar com o bem do qual também participa, ou seja, deve colaborar com a realização dos demais integrantes da comunidade."

${ }^{141}$ BAUMAN, Zygmunt. Modernidade e ambivalência. Trad. Marcus Penchel. Rio de Janeiro: Zahar, 1999. p. 271-288.

${ }^{142}$ HIRONAKA, Giselda Maria Fernandes Novaes. Direito das obrigações: o caráter de permanência de seus institutos, as alterações produzidas pela lei civil brasileira de 2002 e a tutela das gerações futuras. In: HIRONAKA, Giselda Maria Fernandes Novaes (Coord.). Novo código civil: interfaces no ordenamento jurídico brasileiro. Belo Horizonte: Del Rey, 2004. p. 53.

${ }^{143}$ HELLERN, Victor; NOTAKER, Henry; GAARDER, Jostein. O livro das religiões. Trad. Isa Mara Lando. São Paulo: Companhia das Letras, 2000. p. 270.

${ }^{144}$ PERLINGIERI, Pietro. O direito civil na legalidade constitucional. Trad. Maria Cristina De Cicco. Rio de Janeiro: Renovar, 2008. p. 462. 
Oportuno resgatar que "a palavra solidariedade descreve um conceito [ligado à] responsabilidade mútua." ${ }^{145}$ Daí que, ao recepcionar as necessidades sociais, produz direitos e deveres ${ }^{146}$, distribuindo-os em nível individual e coletivo. Também por conta disso, hodiernamente, é possível sustentar que a solidariedade social aloca uma série de mecanismos direcionados a garantir dignidade a todos - e a cada um - e induz à criação de uma sociedade sem marginalizados ou excluídos, prenhe de liberdade e justiça social. ${ }^{147}$

Apesar de ser um princípio cuja carga axiológica baliza o desenvolvimento humano, integrando a todos na busca do bem comum $^{148}$, parece encontrar seu principal opositor no próprio homem, que ignora - às vezes, é melhor não saber ${ }^{149}$ - a realidade e os pontos de vista alheios. Na verdade, nada muito distante do Admirável Mundo Novo, imaginado por Aldous Huxley. ${ }^{150}$ Bastante próximo, ainda, do pensamento abissal do homem ocidental - dividindo a realidade social em dois hemisférios -, que faz desaparecer o que está do outro lado de um marco divisório imaginário, tratando quem ou o que não está ao alcance dos olhos como irrelevante ou inexistente. ${ }^{151}$

145 HELLERN, Victor; NOTAKER, Henry; GAARDER, Jostein. O livro das religiões. Trad. Isa Mara Lando. São Paulo: Companhia das Letras, 2000. p. 271. "Quando nos juntamos aos outros, compartilhamos a responsabilidade, a unidade e a afinidade mental - unindo o nosso destino ao das pessoas que estão em dificuldade."

146 LÔBO, Paulo Luiz Netto. Direito civil: parte geral. São Paulo: Saraiva, 2009. p. 81. Como os de cooperação, assistência, amparo, auxílio e proteção ao próximo.

${ }^{147}$ MORAES, Maria Celina Bodin de. Danos à pessoa humana: uma leitura civil-constitucional dos danos morais. Rio de Janeiro: Renovar, 2003. p. 114.

${ }^{148}$ MONREAL, Eduardo Novoa. O direito como obstáculo à transformação social. Trad. Gérson Pereira dos Santos. Porto Alegre: SAFE, 1988. p. 154. "Esse espírito é necessário em toda sociedade organicamente estruturada e que queira ser algo mais do que uma mera justaposição, ou soma de indivíduos, e que tenha clara consciência de que é a união coletiva, organizada politicamente e ordenada juridicamente, a que permitirá, ao conjunto de seus membros, o desenvolvimento humano, que é a meta do homem, como ser racional. Isso permitirá integrar a todos os indivíduos em uma tarefa comum, conscientemente procurada e harmonicamente realizada, abandonando autonomias pessoais, ou isolamentos, e concentrando todos os esforços no bem de todos. Tem sua origem na tendência social do homem, mas requer um enobrecimento espiritual para que encontre campo propício de desenvolvimento. No fundo, é expressão do sentido de fraternidade, com a qual todo homem, não dominado por egoísmos ou cobiças, se identifica com os demais."

149 BONFIM, Vinícius Silva. A responsabilidade de ter "olhos": o direito na perspectiva do imaginário literário, Revista CEJ, Brasília, v. 14, n. 48, p. 101-109, jan./mar. 2010. p. 104. "Mas o ponto é que, às vezes, é melhor não saber. É-se mais feliz, ou pelo menos contente, sem ter consciência dos problemas. De um lado, porque a consciência mostra a realidade mais dura e cruel do que imaginávamos antes; de outro, porque geralmente, é difícil descobrir uma situação que julgamos incorreta e não nos sentirmos, pelo menos em parte, responsáveis pela sua solução. Não saber é melhor porque se acredita que o mundo é melhor - de acordo com seus valores - do que é verdadeiramente. Não saber é melhor porque não se sente responsável por fazer alguma coisa."

${ }^{150}$ HUXLEY, Aldous. Admirável mundo novo. Trad. Lino Vallandro; Vidal Serrano. Rio de Janeiro: Globo, 2009.

${ }^{151}$ SOUZA SANTOS, Boaventura de. Para além do pensamento abissal: das linhas globais a uma ecologia de saberes, Revista Crítica de Ciências Sociais, Coimbra, v. 78, p. 3-46, out. 2007. p. 3-12. Continua o autor, ao 
Encarada, entretanto, com seriedade - até porque o Direito não pode ignorar a dimensão política da juridicidade ${ }^{152}$-, a solidariedade se mostra como opção que permitirá "sair do narcisismo, aceitando que o outro existe." ${ }^{153} \mathrm{E}$ à medida que os pilares do individualismo forem derrubados um a um, a solidariedade estimulará, ainda que de modo gradual, a humanização do próprio Direito. ${ }^{154}$

É importante perceber que a solidariedade, ao mesmo tempo em que garante a existência de todos em nível pessoal e comunitário, atua de modo a inibir a marginalização do homem ao promover a reversão do processo de exclusão social. ${ }^{155} \mathrm{E}$ isso porque impõe a assunção de responsabilidades no que pertine à existência e à coesão da sociedade, bem como pelo bem-estar de cada ser humano. ${ }^{156}$ Nela, o Direito encontra o substrato necessário para reciclar sua força integradora. ${ }^{157}$

Nesse contexto, aceitando-se sua incidência de forma direta ${ }^{158}$ - ou mediante recurso às cláusulas gerais ${ }^{159}$-, é inegável que a solidariedade é um valor a ser observado quando da análise do surgimento de todo e qualquer dano injusto. Esse papel, entretanto,

frisar que a lógica deste pensamento só se sustenta quando se desconsidera a existência de qualquer elemento do outro lado desta linha invisível. As linhas se movimentam incluindo e excluindo realidades com as quais não se quer conviver, mas sempre existem e são fortemente protegidas.

${ }^{152}$ LEGAZ Y LACAMBRA, Luís. Direito e política, Revista Forense, Rio de Janeiro, v. 48, n. 136, p. 5-17, jul./ago. 1951. p. 17.

${ }^{153}$ WARAT, Luis Alberto. Introdução geral ao direito: o direito não estudado pela teoria jurídica moderna. Porto Alegre: SAFE, 1997, v. 3. p. 61.

${ }^{154}$ CUNHA, Abelmar Ribeiro da. Tendência socializadora do direito civil, Revista Forense, Rio de Janeiro, v. 48, n. 134, p. 21-39, mar./abr. 1951. p. 26.

155 MORAES, Maria Celina Bodin de. O conceito de dignidade humana: substrato axiológico e conteúdo normativo. In: SARLET, Ingo Wolfgang (Org.). Constituição, direitos fundamentais e direito privado. 2 ed. Porto Alegre: LAEL, 2006. p. 142.

156 WIEACKER, Franz. História do direito privado moderno. 3 ed. Trad. António Manuel Botelho Hespanha. Lisboa: Fundação Calouste Gulbenkian, 2004. p. 718.

${ }^{157}$ SOARES, Mário Lúcio Quintão. Teoria do estado: introdução. 2 ed. Belo Horizonte: Del Rey, 2004. p. 27.

${ }^{158}$ Visão que nos parece mais acertada e que permite a incidência direta e imediata (horizontal) desse e dos demais princípios constitucionais às relações pactuadas entre particulares, existindo, no Brasil e no exterior, farta bibliografia sobre o tema.

${ }^{159}$ MARTINS-COSTA, Judith. A boa-fé como modelo (notas para a compreensão da boa-fé obrigacional como modelo doutrinário e jurisprudencial no direito brasileiro), Roma e America: Diritto Romano Comune, Roma, n. 13, p. 71-97, 2002. p. 93. Consoante a autora, "a boa-fé objetiva é a via para a concretização, no domínio das relações obrigacionais, notadamente as contratuais, dos deveres que defluem da diretriz constitucional da solidariedade social." 
não é aceito de forma pacífica, havendo quem afaste de sua órbita a possibilidade de servir de fundamento do dever de reparar. ${ }^{160}$

A ética da solidariedade - ou da responsabilidade - parece ocupar o lugar outrora reservado à ética da liberdade. ${ }^{161}$ A compreensão dessa premissa permite entender por que a objetivação do dever de reparar não se dá apenas em razão da imposição dos riscos da atividade ou diante de expressa previsão legal. Essa nova ética revela sua importância quando desperta a necessidade de garantir a reparação dos danos suportados pela vítima a partir de uma perspectiva solidária ${ }^{162}$, essencial diante do modo de vida eleito pela sociedade, do qual cada pessoa - empresária (ou não) - não consegue e nem deseja se desvencilhar. Fixa-se aqui um dos pilares da tese em construção.

A vida na sociedade contemporânea - e também nas sociedades primitivas ${ }^{163}$ é responsável pela gênese de um “dever inderrogável de solidariedade”, operando como critério hermenêutico que impõe um olhar atento à vítima do dano. Tendo por ponto fulcral de análise a preocupação com o outro, a diretriz da solidariedade há de sobrepor-se a considerações de ordem meramente econômica e mesmo a eventual juízo lastreado exclusivamente na reprovação da conduta lesiva, redundando, ratifique-se, na opção pelo fator de imputação objetiva do dever de reparar. ${ }^{164}$

Ademais, considerando a força que possui para afastar da culpa ${ }^{165}$ a qualidade de pressuposto do dever de reparar, assume inquestionável potencialidade na intelecção da injustiça do dano ${ }^{166}$, mormente no universo contratual, e isso porque a lesão a ser reparada nem sempre derivará do desrespeito a um dever de prestação ou de proteção claramente delimitado pela lei ou pela autonomia privada.

\footnotetext{
${ }^{160}$ RIPERT, Georges. A regra moral nas obrigações civis. Trad. Osório de Oliveira. Campinas: Bookseller, 2002. p. 218-220.

161 MORAES, Maria Celina Bodin de. Constituição e direito civil: tendências, Revista dos Tribunais, São Paulo, v. 89, n. 779, p. 47-63, set. 2000. p. 57.

162 SCHREIBER, Anderson. Novos paradigmas da responsabilidade civil: da erosão dos filtros da reparação à diluição dos danos. São Paulo: Atlas, 2007. p. 29.

${ }^{163}$ Sobre o tema: MALINOWSKI, Bronislaw. Crimen y costumbre en la sociedad salvaje. Trad. J. y M. T. Alier. Barcelona: Planeta-Agostini, 1985.

${ }^{164}$ SALVI, Cesare. La responsabilità civile. 2 ed. Milano: Giuffrè, 2005. p. 38-39.

${ }^{165}$ HIRONAKA, Giselda Maria Fernandes Novaes. Responsabilidade pressuposta. Belo Horizonte: Del Rey, 2005. p. 351.

${ }^{166}$ SALVI, Cesare. La responsabilità civile. 2 ed. Milano: Giuffrè, 2005. p. 31-32.
} 
Nas relações negociais, a solidariedade social atua ao afastar a premissa individualista - que leva à competição e ao antagonismo -, inserido, em seu lugar, o paradigma solidarista - que conduz ao diálogo e à convergência dos interesses dos parceiros negociais -, o que ocorre quando impõe, na análise de cada problema surgido na concretude dos fatos, o dever de preocupar-se com o valor do alter. ${ }^{167}$

É preciso admitir que a visão solidarista do processo obrigacional, longe de alijar as partes de sua liberdade, conduz a conformação do exercício das distintas posições jurídicas à dimensão social ${ }^{168}$ que lhes é inerente, postura exigida pelas balizas existentes no Estado Democrático de Direito. A solidariedade social possibilita, nesse contexto, compreender como é possível promover a substituição de um modelo obrigacional encampado por antagonistas, por outro, cujos protagonistas agem em simbiose, cooperando, de modo recíproco, em busca do adimplemento. É possível antever, ademais, que esse princípio molda a garantia de reparação dos danos injustamente causados ao parceiro contratual em razão da inobservância de um dever.

O princípio constitucional da solidariedade implica ainda, é plausível destacar, a promoção do equilíbrio da relação jurídica obrigacional durante todo seu desvelar ${ }^{169}$, afastando a prevalência dos interesses do mais forte, mais experiente e(ou) melhor informado. Em síntese, nesse contexto, atua de modo a balizar o exercício da autonomia privada.

Enfim, a solidariedade constitucional impõe que cada pessoa deva ter em conta, além da relevância do negócio, os interesses do outro, sujeitando-se aos sacrifícios necessários à conclusão, permanência, cumprimento ${ }^{170}$ e reparação dos danos contratuais, promovendo, portanto, a justiça social. É passada a hora de afastar a expiação e o sofrimento inerentes à culpa e alocar, em seu lugar, a ética da responsabilidade perante o outro.

\footnotetext{
${ }^{167}$ ROSENVALD, Nelson. Dignidade humana e boa-fé no código civil. São Paulo: Saraiva, 2005. p. 175.

168 NANNI, Giovanni Ettore. O dever de cooperação nas relações obrigacionais à luz do princípio constitucional da solidariedade. In: NANNI, Giovanni Ettore (Coord.). Temas relevantes do direito civil contemporâneo: reflexões sobre os cinco anos do código civil. São Paulo: Atlas, 2008. p. 297.

${ }^{169}$ LÔBO, Paulo Luiz Netto. Direito civil: parte geral. São Paulo: Saraiva, 2009. p. $48-49$.

${ }^{170}$ OST, François. Tiempo y contrato: crítica del pacto fáustico, Doxa, Alicante, n. 25, p. 597-626, 2002. p. 612.
} 


\section{A igualdade material}

Apesar de a igualdade ter atuado como uma das escoras mais importantes do liberalismo, é relevante resgatar que, nesse período, se esgotava em sua dimensão formal de igualdade perante a lei. ${ }^{171}$ Essa igualdade, aliás, limitava-se a lastrear juízos negativos de valor ao propagar a inexistência de diferenças entre os homens. ${ }^{172}$ Nesse viés, ao mesmo tempo em que tal discurso disseminava a necessidade de idêntico tratamento a qualquer pessoa que se enquadrasse em situação semelhante a do outro - vedando distinções não justificadas ${ }^{173}$ pela lei -, fazia com que a injustiça social atingisse mais e mais pessoas.

As promessas de igualdade não foram cumpridas. Grande parte da população acabou sendo abandonada à própria sorte, no mais das vezes - mas não exclusivamente -, aquelas que não possuíam nenhuma condição material ou cultural de exercitar seus direitos. Essas últimas, em especial, diante da necessidade de contratar, eram levadas pelos discursos - e das condições gerais de contratação - ditados pelas classes dominantes ${ }^{174}$, problema que se acentuou - e, de certo modo, pode ser percebido até hoje - em razão de fenômenos como o êxodo rural e a especialização do empresariado.

171 Sobre o tema: FACHIN, Luiz Edson; RUZYK, Carlos Eduardo Pianovski. Direitos fundamentais, dignidade da pessoa humana e o novo código civil: uma análise crítica. In: SARLET, Ingo Wolfgang (Org.). Constituição, direitos fundamentais e direito privado. 2 ed. Porto Alegre: LAEL, 2006. p. 90-93. Vide ainda: ROPPO, Enzo. O contrato. Trad. Ana Coimbra; M. Januário C. Gomes. Coimbra: Almedina, 2009. p. 7-63.

${ }^{172}$ CAFFERA, Gerardo. Autonomía privada: los cambios y las tensiones del presente. In: FERNÁNDEZ, Carlos López; CAUMONT, Arturo; CAFFERA, Gerardo (Coord.). Estudios de derecho civil en homenaje al profesor Jorge Gamarra. Montevideo: FCU, 2001. p. 88-89. Consoante o autor, é justificável que, no contexto do início do século XIX, o argumento abolicionista tenha sido suficiente para escorar a ideia de liberdade e, na verdade, a transcendência dessa formulação não deixa de ser historicamente enorme considerando-se o rompimento das barragens sociais até então erguidas e a possibilidade de ascensão social.

173 GALDOS, Jorge Mario. El principio favor debilis en materia contractual, Derecho del consumidor, Rosario, n. 8, p. 37-47, 1997. p. 37.

${ }^{174}$ BORGES, Roxana Cardoso Brasileiro. Reconstrução do conceito de contrato: do clássico ao atual. In: HIRONAKA, Giselda Maria Fernandes Novaes; TARTUCE, Flávio (Coord.). Direito contratual: temas atuais. São Paulo: Método, 2008. p. 29. "Percebeu-se rapidamente a armadilha do discurso da igualdade formal que deixava os indivíduos à própria sorte, considerados livres para assumirem qualquer vínculo contratual, ainda que, em alguns momentos, esses indivíduos se movessem preponderantemente não por liberdade verdadeira, mas por necessidade. Guiados pela necessidade, levados ao contrato, não tinham nenhum poder nem condição material de exercer a liberdade contratual, que se refere à determinação do conteúdo do contrato. $\mathrm{O}$ que a parte mais poderosa naquele contexto impusesse como conteúdo do contrato era aceito pela parte necessitada ou desinformada, levando os contratos, em certas situações, a serem vistos como vínculos de abuso e exploração. O problema residia na liberdade apenas pressuposta, mas não real, em que as partes eram pela lei consideradas como iguais, mas na verdade não eram. Da soma das duas premissas falsas, o resultado era o vínculo desequilibrado que a ideologia jurídica liberal e individualista produzia." 
Assim, ao mesmo tempo em que o mito da igualdade formal legitimava a manutenção das desigualdades ${ }^{175}$, a igualdade a ser efetivamente alcançada - de natureza substancial - continuava sendo desprezada pelas grandes codificações ${ }^{176}$ e por boa parte das escolas de pensamento que se propunham a compreendê-las.

Ocorre que, a partir do momento em que se constata que as pessoas não são idênticas, o mito da igualdade formal desmorona. ${ }^{177}$ Como as pessoas não são iguais, a noção de isonomia, longe de ser lida como mera proibição de diferenciações ${ }^{178}$, passa a exigir a valorização das desigualdades para tornar simétricas as relações de poder ${ }^{179}$, incluindo-se aqui o poder negocial.

E, ao usar as vestes tecidas na vigência do Estado Democrático de Direito, encontra-se apta a promover a equalização dos interesses das pessoas que integram uma relação jurídica de qualquer natureza - aqui inserido, por razões evidentes, o processo obrigacional -, sendo desrespeitada não só quando, sem fundamento relevante, pessoas na mesma situação são tratadas de modo distinto, mas também quando, em situações díspares, são destinatárias de idêntico tratamento jurídico. ${ }^{180}$

Talvez mais que isso. Entre as possibilidades contidas na isonomia, encontra-se a que permite conduzir ao estímulo da análise das características inerentes a cada ser humano durante o desvelar das relações jurídicas - aqui inserido, uma vez mais, o processo obrigacional -, potencializando a possibilidade de transformação do indivíduo sitiado pelo - ou, ao menos, durante ${ }^{181}$ - Estado Liberal em uma pessoa situada a partir de sua história de vida.

\footnotetext{
${ }^{175}$ HESPANHA, António Manuel. O caleidoscópio do direito: o direito e a justiça nos dias e no mundo de hoje. Coimbra: Almedina, 2007. p. 143.

${ }^{176}$ LÔBO, Paulo Luiz Netto. Direito civil: parte geral. São Paulo: Saraiva, 2009. p. 86. No mesmo sentido: LORENZETTI, Ricardo Luis. Teoria da decisão judicial: fundamentos do direito. Trad. Bruno Miragem. São Paulo: RT, 2009. p. 53.

177 ALTHEIM, Roberto. Direito de danos: pressupostos contemporâneos do dever de indenizar. Curitiba: Juruá, 2008. p. 41-43. Consoante o autor, claro reflexo deste fenômeno encontra-se nos instrumentos de tutela coletiva.

${ }^{178}$ FACHIN, Luiz Edson. Teoria crítica do direito civil. Rio de Janeiro: Renovar, 2000. p. 294.

${ }^{179}$ BENJAMIN, Antônio Herman de Vasconcellos e; MARQUES, Cláudia Lima; BESSA, Leonardo Roscoe. Manual de direito do consumidor. São Paulo: RT, 2007. p. 33.

${ }^{180}$ PERLINGIERI, Pietro. Perfis do direito civil: introdução ao direito civil constitucional. 2 ed. Trad. Maria Cristina De Cicco. Rio de Janeiro: Renovar, 2002. p. 48.

${ }^{181}$ MATA-MACHADO, Edgar de Godoi. Contribuição ao personalismo jurídico. Belo Horizonte: Del Rey, 2000. p. 31-51.
} 
Em verdade, a aceitação do pluralismo social - com a percepção das incontáveis diferenças e peculiaridades existentes em cada indivíduo e entre as distintas pessoas e grupos sociais ${ }^{182}$ - é uma das pontes de acesso à promoção da pessoa humana em suas relações surgidas na concretude de cada momento da vida. ${ }^{183}$

É inegável que o princípio sob análise mantém algo de sua base original, autorizando, por meio da comparação, a generalização de hipóteses, fator indispensável à justiça das decisões. ${ }^{184}$ Aliás, parece mesmo que só se pode trabalhar a igualdade mediante juízos e raciocínios comparativos. Ser igual implica ser igual a algo ou estar na mesma condição de alguém. Há de se ter em mente, entretanto, que a principal referência nesse processo é um ser humano ${ }^{185}$, composto de alma, carne e osso - opção que permite a constante valorização do "ser" e do "humano" em cada indivíduo -, e não um conceito abstrato e meramente operacional como o são os de contratante, credor ou devedor.

O aludido princípio impõe, assim, que cada situação da vida seja analisada de forma pontual e minudentemente, exigindo a identificação das características de cada pessoa na relação jurídica, em vez de limitar-se, como outrora, a trabalhar com juízos hipotéticos e comparações abstratas.

182 WARAT, Luis Alberto. Introdução geral ao direito: a epistemologia jurídica da modernidade. Porto Alegre: SAFE, 2002, v. 2. p. 363-364. "Na lei e no saber do Direito encontramos o mito de uma sociedade sem fraturas. Certamente, desse modo se simboliza a petrificação das relações sociais e a dissolução juridicista dos conflitos. O mito de uma sociedade coesa permite, através [sic] do Direito, a supressão simbólica da autonomia dos sujeitos, construindo-se um imaginário coercitivo que coloca o político como uma instância do universal. Necessita-se então [de] um trabalho de interrogação sobre o discurso jurídico, utilizando-se a lei e o saber do Direito contra eles mesmos, fazendo deles um lugar vazio, onde o homem autônomo não seja um grande transgressor, mas o protagonista que assegura a invenção que legitima a democracia."

${ }^{183}$ MORAES, Maria Celina Bodin de. Danos à pessoa humana: uma leitura civil-constitucional dos danos morais. Rio de Janeiro: Renovar, 2003. p. 91.

${ }^{184}$ AGUIAR JUNIOR, Ruy Rosado. O princípio da igualdade e o direito das obrigações. In: TEPEDINO, Gustavo; FACHIN, Luiz Edson (Coord.). O direito e o tempo: embates jurídicos e utopias contemporâneas. Rio de Janeiro: Renovar, 2008. p. 534-535.

${ }^{185}$ MARQUES, Mário Reis. Grandes linhas de evolução do pensamento e da filosofia jurídicas. In: CUNHA, Paulo Ferreira da (Org.). Instituições de direito: filosofia e metodologia do direito. Coimbra: Almedina, 1998, v. 1. p. 284-285. "Sempre que o direito positivo [e por que não, cada comando judicial] está em contradição ou em desarmonia com esses valores, sempre que viola os direitos fundamentais, que se impõe como fundamento de todo o direito e como justificação da submissão a todas as regras jurídicas, estamos perante prescrições ilegítimas que deverão ser denunciadas. [...] O Estado social e democrático de direito constrói-se em estrita vinculação às leis justas e ao verdadeiro direito e só tem sentido se tiver como projeto o aperfeiçoamento das condições do reconhecimento da dignidade humana e o aumento da justiça material; em suma, se tiver como projeto a promoção do livre desenvolvimento da personalidade de cada cidadão. É que num sistema de democracia representativa os direitos humanos não estão subordinados à vontade da maioria. A não ser assim cairíamos numa concepção puramente formal do direito e na justificação universal de todas as "ordens." A problemática dos direitos do homem é um tema central do jurista post-moderno." 
Esse ser situado - a partir de sua realidade individual e social - passa a ocupar contemporaneamente o lugar antes destinado ao sujeito de direito. Acredita-se que o aludido viés de análise é de extrema valia quando se tem em mente uma realidade na qual a vida se tornou fluida, o contrato fragmentou-se ${ }^{186}$, as relações pessoais são cada vez mais impessoais e a ética encontra-se desacoplada de muitos momentos que não deveriam existir sem sua presença.

É preciso ir além. Assim, a partir da constatação de que "a igualdade constitui o signo fundamental da democracia" $" 187$, é possível compreender que a aludida baliza constitucional não pode ser lida como um mero "princípio estático", refratário à eliminação de desigualdades sociais. Além de valor importante no Estado Democrático de Direito, a isonomia é um princípio de justiça social ${ }^{188} \mathrm{e}$, como tal, há de auxiliar a promoção dos objetivos fundamentais consagrados constitucionalmente. ${ }^{189}$

Ao lado da solidariedade social, o princípio da igualdade material é uma importante ponte de acesso à promoção do desenvolvimento da pessoa humana. ${ }^{190}$ Cumpre bem esse papel, por exemplo, ao auxiliar o preenchimento da noção de liberdade ${ }^{191}$, até porque só pode livremente exercer a autonomia privada quem está diante de iguais condições e possui as mesmas oportunidades que o outro. ${ }^{192}$

${ }^{186}$ Sobre essa última questão: NEGREIROS, Teresa. Teoria do contrato: novos paradigmas. Rio de Janeiro: Renovar, 2002. p. 500. Veja ainda: ZANETTI; Cristiano de Souza. Direito contratual contemporâneo: a liberdade contratual e sua fragmentação. São Paulo: Método, 2008. p. 191-278.

${ }^{187}$ SILVA, José Afonso da. Curso de direito constitucional positivo. 19 ed. São Paulo: Malheiros, 2001. p. 214. "Por isso é que a burguesia, cônscia de seu privilégio de classe, jamais postulou um regime de igualdade tanto quanto reivindicara o de liberdade. É que um regime de igualdade contraria seus interesses e dá à liberdade sentido material que não se harmoniza com o domínio de classe em que assenta a democracia liberal burguesa."

${ }^{188}$ CANOTILHO, José Joaquim Gomes. Direito constitucional e teoria da constituição. 7 ed. Coimbra: Almedina, 2003. p. 350 e 430.

189 “CF. Art. $3^{\circ}$ Constituem objetivos fundamentais da República Federativa do Brasil: I - construir uma sociedade livre, justa e solidária; II - garantir o desenvolvimento nacional; III - erradicar a pobreza e a marginalização e reduzir as desigualdades sociais e regionais; IV - promover o bem de todos, sem preconceitos de origem, raça, sexo, cor, idade e quaisquer outras formas de discriminação."

${ }^{190}$ PERLINGIERI, Pietro. Perfis do direito civil: introdução ao direito civil constitucional. 2 ed. Trad. Maria Cristina De Cicco. Rio de Janeiro: Renovar, 2002. p. 46.

191 SARMENTO, Daniel. Direitos fundamentais e relações privadas. 2 ed. Rio de Janeiro: Lumen Juris, 2006. p. 93. Veja ainda: PRATA, Ana. A tutela constitucional da autonomia privada. Coimbra: Almedina, 1982. p. 56-58.

192 MONREAL, Eduardo Novoa. O direito como obstáculo à transformação social. Trad. Gérson Pereira dos Santos. Porto Alegre: SAFE, 1988. p. 90-91. 
É por isso que o exercício da autonomia privada - em maior ou menor medida - deve passar por um constante controle de qualidade - controle esse a ser instrumentalizado por meio da análise das intersubjetividades de cada relação concretamente situada -, mormente porque aquela, somente pode ser eficazmente exercida por uma pessoa que tenha efetiva compreensão da complexidade das relações nas quais se encontra imersa, realidade que certamente é a de boa parte das pessoas que compõem a população brasileira.

Infere-se ainda que reflexões que sustentam que o Estado não se deve imiscuir na autonomia privada ${ }^{193}$ - quase sempre trazidas da Europa para o Brasil sem a necessária contextualização - normalmente ignoram que, quando não há igualdade, não pode existir verdadeira liberdade. É por isso que a isonomia substancial deve trabalhar visando a eliminar os obstáculos que dificultem ou impeçam a remoção das desigualdades fáticas que permeiam as relações sociais ${ }^{194}$, alterando o curso de uma História na qual as diferenças entre os homens foram tratadas como desígnios do destino. ${ }^{195}$

E, apesar de estar longe de ser plenamente realizada no Brasil ${ }^{196}$, a isonomia tem plenas condições de atuar como uma preciosa ferramenta de análise e compreensão do fenômeno obrigacional em toda sua complexidade. E isso especialmente - mas não exclusivamente - por considerar ilegítimo o recurso às abstrações, aos conceitos vazios e ao universalismo que, por tanto tempo, serviram a um direito que interessava a poucos e que excluía muitos.

193 CANARIS, Claus-Wilhelm. A liberdade e a justiça contratual na "sociedade de direito privado". In: MONTEIRO, António Pinto (Coord.). Contratos: actualidade e evolução. Porto: Universidade Católica Portuguesa, 1997. p. 51-60. O autor defende que "o Estado, na sociedade de direito privado, exige aos seus cidadãos, em princípio, que cuidem de si próprios [...]” e por isso sustenta, lastreando suas reflexões nas bases que informam a concepção de justiça comutativa, a primazia da liberdade ao contrapô-la ao controle existente nos modelos totalitários.

${ }^{194}$ PRATA, Ana. A tutela constitucional da autonomia privada. Coimbra: Almedina, 1982. p. 94.

${ }^{195}$ RIPERT, Georges. A regra moral nas obrigações civis. Trad. Osório de Oliveira. Campinas: Bookseller, 2002. p. 89. "Mas essa igualdade não se encontra nunca, mesmo quando é aparente; ela pode não existir entre dois seres que têm um pensamento, uma vontade e um fim diferentes. Enquanto a superioridade depender da formação intelectual e moral da pessoa humana, da moderação dos seus desejos, da compreensão dos seus interesses, da precisão dos acontecimentos, a moral aprova que ela se afirme pela vantagem contratual, ainda que com prejuízo de outrem. É uma falsa concepção de igualdade nos contratos que inspira esse brado muitas vezes ouvido contra a superioridade de um dos contratantes. A desigualdade é fatal, e é justo que as qualidades manifestadas no negócio jurídico sejam motivo de vantagem."

${ }^{196}$ COELHO, Luiz Fernando. Saudade do futuro. 2 ed. Curitiba: Juruá, 2007. p. 196. 
Fundamento de legitimidade do Direito ${ }^{197}$, a igualdade material é uma poderosa arma contra o "fascismo contratual" - mecanismo que impõe a aceitação, normalmente por alguém vulnerável, das condições predispostas pela parte mais forte na relação jurídica -, problema que se acentua, dentre outra razões, por conta: (a) da privatização de serviços essenciais ${ }^{198}$; (b) da crescente concentração do capital nas mãos de minúscula parcela do empresariado; e, ainda, (c) da publicidade cada vez mais agressiva.

Naquilo que interessa mais de perto à tese ora erigida, a isonomia assume incomum valia. Primeiro, por ser um importantíssimo pressuposto do justo. Hodiernamente, antes de aferir se houve (ou não) qualquer patologia no curso do processo obrigacional, deve ser verificado se o contrato - e isso nos planos genético e funcional trouxe à vida direitos e deveres que possam ser qualificados como equânimes, e isso somente é possível mediante a identificação - concreta - dos interesses em questão.

Em um segundo momento, ganha relevo por lhe incumbir iluminar cada momento de aferição das situações invocadas a título de causa externa e não imputável. Perceba-se que, nesses casos, é seu papel chamar a atenção - mormente diante dos incontáveis pluralismos vigentes, bem como porque o homem não pode ser desconectado de sua realidade histórica e social -, para que as práticas sociais existentes sejam consideradas no processo de realização do direito. Ao possibilitar a comparação de condutas consideradas imputáveis (ou não), atuará como baliza hábil na distribuição de justiça social, conduzindo a esse valor a ser constantemente perseguido pelo Direito.

Como terceiro ponto a ser destacado, assume relevância o papel que há de exercitar no processo de quantificação dos danos - patrimoniais e(ou) extrapatrimoniais oriundos da violação de um dever contratual. Aqui, por auxiliar no processo de composição da prestação - pecuniária, ou não - que exsurge da violação de um dever contratual. É por meio dela que características como (a) o patrimônio de devedor, (b) do

197 GALUPPO, Marcelo Campos; BASILE, Rafael Faria. O princípio jurídico da igualdade e a ação afirmativa étnico-racial no estado democrático de direito: o problema das cotas, Revista de Informação Legislativa, Brasília, v. 43, n. 171, p. 99-108, out./dez. 2006. p. 102. "Uma vez que a igualdade é condição formal e material da realização daquilo que confere legitimidade ao direito moderno, a saber, dos discursos de justificação e de aplicação, ela é tida como pressuposto em geral da própria legitimidade do direito, ou seja, a igualdade é fundamento da legitimidade do discurso jurídico."

${ }^{198}$ SOUZA SANTOS, Boaventura de. Para além do pensamento abissal: das linhas globais a uma ecologia de saberes, Revista Crítica de Ciências Sociais, Coimbra, v. 78, p. 3-46, out. 2007. p. 16. 
credor, (c) a extensão do dano, (d) a concorrência de causas, (e) o estado da técnica, dentre outros aspectos, serão valoradas (ou não) em cada situação concretamente estabelecida. ${ }^{199}$

\section{A dignidade da pessoa humana}

Compreender toda a extensão da noção de dignidade da pessoa humana é um trabalho bastante complexo, especialmente porque o Direito não lhe empresta conteúdo. ${ }^{200}$ Sua intelecção - como a de tantas outras figuras e instrumentos utilizados pelo Direito deve, então, ser construída. Nesse processo, pelo menos três momentos são importantes para a adequada formatação de sua carga axiológica: (a) a valorização do homem pelo cristianismo; (b) os imperativos categóricos kantianos e a supremacia da razão; e (c) o desprezo pela noção de humanidade durante as duas grandes guerras do século $\mathrm{XX}{ }^{201} \mathrm{~A}$ apreensão da essência da humanidade nos dois primeiros momentos, e os males a ela infligidos no último momento invocado embasam reflexões sobre o valor da pessoa humana e auxiliam na compreensão do princípio sob análise.

Os elementos históricos delineados, bem como os percalços ${ }^{202}$ havidos entre um e outro, ao lado de indagações filosóficas ${ }^{203}$, permitem afirmar que a dignidade da pessoa humana alude à essência da humanidade. ${ }^{204}$ Mera retórica? Parece que não.

${ }^{199}$ O tema é tentador. Comporta, sem dúvida, análise minuciosa, que foge, entretanto, aos objetivos deste trabalho, sendo deixado de lado propositalmente por ultrapassar os objetivos da tese em construção.

${ }^{200}$ Um conceito bastante interessante pode ser encontrado em: SARLET, Ingo Wolfgang. As dimensões da dignidade da pessoa humana: construindo a compreensão jurídico-constitucional necessária e possível. In: SARLET, Ingo Wolfgang (Org.). Dimensões da dignidade: ensaios de filosofia do direito e do direito constitucional. 2 ed. Porto Alegre: Livraria do Advogado, 2009. p. 37. "Tem-se por dignidade da pessoa humana a qualidade intrínseca e distintiva reconhecida em cada ser humano que o faz merecedor do mesmo respeito e consideração por parte do Estado e da comunidade, implicando, neste sentido, um complexo de direitos e deveres fundamentais que assegurem a pessoa tanto contra todo e qualquer ato degradante $e$ desumano, como venham a lhe garantir as condições existenciais mínimas para uma vida saudável, além de propiciar e promover sua participação ativa e co-responsável nos destinos da própria existência e da vida em comunhão com os demais seres humanos."

${ }^{201}$ ROSENVALD, Nelson. Dignidade humana e boa-fé no código civil. São Paulo: Saraiva, 2005. p. 1-7. Segundo o autor, "o processo de despersonalização do ser humano começa com a fragmentação da família, a eliminação de suas vestes e documentos, a substituição de seu nome por um número marcado no braço, tal qual gado [daí] a perda da identidade, aliada à fome, à dor e à doença, retira do ser humano o seu vestígio de racionalidade, pois apenas subsiste o instinto de luta pela vida, nada mais."

${ }^{202}$ SESSAREGO, Carlos Fernández. ¿Qué es ser "persona” para el derecho?. In: GESUALDI, Dora Mariana (Coord.). Derecho privado. Buenos Aires: Hammurabi, 2001. p. 130. "A pessoa, contrariamente ao que acontecia em séculos anteriores, quando a proteção da propriedade era a principal preocupação do Direito, é atualmente considerada como o eixo e o centro do Direito. Esta realidade se construiu penosamente através do tempo dentro da disciplina jurídica. Para que tal ocorresse, fez-se necessário superar tendências e 
A dignidade é um valor intrínseco, inerente ao ser humano ${ }^{205}$ e apenas a ele. A dignidade é atributo de todos os seres humanos - diga-se uma vez mais - pelo simples fato de serem humanos; até porque, distanciando-se de eventuais fundamentações transcendentais, esse valor deve ser compreendido a partir de uma percepção com viés imanentista. ${ }^{206} \mathrm{O}$ conteúdo do princípio em foco, portanto, há de ser esquadrinhado tendo por lastro a essência e as peculiaridades de cada ser humano. ${ }^{207}$

É imperioso ratificar: a dignidade da pessoa humana alude a todas as pessoas em razão da característica comum que as une: serem humanas -, e ao mesmo tempo, a cada ser individualmente considerado. Em síntese preciosa: "a dignidade nos faz únicos e ao mesmo tempo iguais." ${ }^{208}$ Assim, o princípio em tela possibilita afirmar que "não há duas biografias similares." ${ }^{209}$ Em outras palavras: os humanos são seres idênticos e ao mesmo tempo únicos e insubstituíveis. A lógica é paradoxal, mas também encantadoramente compreensível.

correntes unidimensionais ou que faziam o Direito gravitar em torno de valores como a justiça, ou que atuavam redutivamente ao redor da norma jurídica, que é apenas, como é sabido, uma estrutura formal do pensamento humano. A vida humana e os valores foram mesmo considerados como metajurídicos por setor doutrinário dominante. Mais difícil ainda tem sido superar a concepção individualista-patrimonial" que gravita ao redor do que é ser pessoa para o Direito.

${ }^{203}$ MORAES, Maria Celina Bodin de. Danos à pessoa humana: uma leitura civil-constitucional dos danos morais. Rio de Janeiro: Renovar, 2003. p. 76-85. A autora entende que "o substrato material da dignidade [...] pode ser desdobrado em quatro postulados: i) o sujeito moral (ético) reconhece a existência dos outros como sujeitos iguais a ele; ii) merecedores do mesmo respeito à integridade psicofísica de que é titular; iii) é dotado de vontade livre, de autodeterminação; iv) é parte do grupo social, em relação ao qual tem o direito de não vir a ser marginalizado."

${ }^{204}$ Para uma visão aprofundada do tema em perspectiva histórica e filosófica, reportamo-nos às belíssimas construções formuladas por: HIRONAKA, Giselda Maria Fernandes Novaes. Responsabilidade pressuposta. Belo Horizonte: Del Rey, 2005. p. 158-224.

${ }^{205}$ SILVA, José Afonso da. A dignidade da pessoa humana como valor supremo da democracia, Revista de Direito Administrativo, Rio de Janeiro, v. 212, p. 89-94, abr./jun. 1998. p. 91. Assinala o autor que "a dignidade é um atributo intrínseco, da essência, da pessoa humana, único ser que compreende um valor interno, superior a qualquer preço, que não admite substituição equivalente [e desse modo] a dignidade entranha e se confunde com a própria natureza do homem."

${ }^{206}$ MAURER, Béatrice. Notas sobre o respeito da dignidade da pessoa humana ... ou uma pequena fuga incompleta em torno de um tema central. In: SARLET, Ingo Wolfgang (Org.). Dimensões da dignidade: ensaios de filosofia do direito e do direito constitucional. 2 ed. Porto Alegre: Livraria do Advogado, 2009. p. 125-128.

${ }^{207}$ BORGES, Roxana Cardoso Brasileiro. Direitos da personalidade e dignidade: da responsabilidade civil para a responsabilidade constitucional. In: DELGADO, Mário Luiz; ALVES, Jones Figueiredo (Coord.). Questões controvertidas: responsabilidade civil. São Paulo: Método, 2006, v. 5. p. 559.

${ }^{208}$ LÔBO, Paulo Luiz Netto. Direito civil: parte geral. São Paulo: Saraiva, 2009. p. 78-80. "A dignidade relaciona-se tanto com a liberdade e valores do espírito quanto com as condições materiais da existência [representando] a superação da intolerância, da discriminação, da exclusão social, da violência, da incapacidade de aceitar o outro ou o diferente, na plenitude de sua liberdade de ser, pensar e criar."

${ }^{209}$ SESSAREGO, Carlos Fernández. Protección a la persona humana, Ajuris, Porto Alegre, v. 56, n. 19, p. 87-142, nov. 1992. p. 91. 
No afã de preencher seu conteúdo e reconhecendo a dificuldade de compor o substrato material do princípio em tela, Antonio Junqueira de Azevedo salienta que uma análise antropológica do tema deve sobrepor-se às teses insulares que veem o homem apenas como um ser dotado de razão e vontade, sem situá-lo histórica e socialmente. O homem não é só razão, autoconsciência, nem é apenas ação; é bem mais que isso: um ser capaz de reconhecer-se no outro, de dialogar e de amar, um ser que somente poderá ser reconhecido a partir de suas ligações com a natureza. ${ }^{210}$ Essa mesma trilha é seguida por Ingo Sarlet, ao sustentar que o princípio da dignidade da pessoa humana pode ser compreendido a partir da sobreposição das distintas dimensões que o compõem: (a) a ontológica - diante da qualidade intrínseca e indissociável do ser humano; (b) a social - ao revelar-se no seio das intersubjetividades; e (c) a histórico-cultural - por se tratar não de algo dado, mas de um constante e eterno vir a ser. ${ }^{211}$

Infira-se que, na construção dessa "via sem fim"212, o princípio sob análise longe de atuar como uma "arma de argumentação [ou] tábua de salvação para a complementação de interpretações possíveis de normas postas" ${ }^{213}$ - permite compreender a pessoa como valor-fonte do Direito. ${ }^{214}$ Por isso, imanta a atividade do intérprete ${ }^{215}$ ao atuar como vetor conformador ${ }^{216}$ na solução de problemas cotidianos.

${ }^{210}$ JUNQUEIRA DE AZEVEDO, Antonio. Caracterização jurídica da dignidade da pessoa humana, Revista dos Tribunais, São Paulo, v. 91, n. 797, p. 11-26, mar. 2002. p. 12-13. Continua o autor afirmando que "o racionalismo iluminista, que deu origem à concepção insular, corresponde visualmente à figura do homem europeu: o terno que veste deixa-lhe à mostra somente a cabeça e as mãos (= razão + ação ou vontade); o resto do corpo é a parte oculta do iceberg - a natureza física, cuja essência, no homem, aquela filosofia ignora."

211 SARLET, Ingo Wolfgang. As dimensões da dignidade da pessoa humana: construindo a compreensão jurídico-constitucional necessária e possível. In: SARLET, Ingo Wolfgang (Org.). Dimensões da dignidade: ensaios de filosofia do direito e do direito constitucional. 2 ed. Porto Alegre: Livraria do Advogado, 2009. p. 20-30.

${ }^{212}$ MAURER, Béatrice. Notas sobre o respeito da dignidade da pessoa humana ... ou uma pequena fuga incompleta em torno de um tema central. In: SARLET, Ingo Wolfgang (Org.). Dimensões da dignidade: ensaios de filosofia do direito e do direito constitucional. 2 ed. Porto Alegre: Livraria do Advogado, 2009. p. 131.

${ }^{213}$ NERY, Rosa Maria Barreto Borriello de Andrade. Introdução ao pensamento jurídico e à teoria geral do direito privado. São Paulo: RT, 2008. p. 235.

${ }^{214}$ MARTINS-COSTA, Judith. Os danos à pessoa no direito brasileiro e a natureza da sua reparação, Revista dos Tribunais, São Paulo, v. 90, n. 789, p. 21-47, jul. 2001. p. 25.

${ }^{215}$ RUZYK, Carlos Eduardo Pianovski. A responsabilidade civil por danos produzidos no curso de atividade econômica e a tutela da dignidade da pessoa humana: o critério do dano ineficiente. In: RAMOS, Carmem Lucia Silveira et all (Org.). Diálogos sobre direito civil: construindo a racionalidade contemporânea. Rio de Janeiro: Renovar, 2002. p. 131.

216 BORGES, Roxana Cardoso Brasileiro. Direitos da personalidade e dignidade: da responsabilidade civil para a responsabilidade constitucional. In: DELGADO, Mário Luiz; ALVES, Jones Figueiredo (Coord.). 
Há de se ter em conta, ademais, que como o eu se reconhece no outro, o fato de o desprezar implica - em última análise - o desprezo a si próprio. ${ }^{217} \mathrm{E}$ é por isso que somente respeita a diretriz da dignidade da pessoa humana a leitura capaz de promover cada pessoa pelo que ela é - e não mais a partir do que ela tem, ou possa ter -, até porque não há "pecúnia nem patrimônio" que a mensurem. ${ }^{218}$

A dignidade da pessoa humana nutre e atravessa toda uma gama de direitos fundamentais que, de modo mais ou menos intenso, devem ser considerados como suas exteriorizações. $^{219}$ É um valor que influencia a materialização do conteúdo daqueles ${ }^{220}$, impondo uma postura promocional ativa, e não meramente abstencionista como pretendido por alguns. ${ }^{221}$ Infira-se aqui, nesse contexto, a importância que o tema assume na esfera dos danos contratuais - e da tese ora erigida -, mormente quando esses violem valores de ordem extrapatrimonial.

É possível antever ainda que a dignidade se constrói a partir da consagração de liberdade e respeito ${ }^{222}$, e não apenas de respeito à liberdade. Esse caminho pressupõe compreender que o outro é tão importante e digno quanto o eu, ainda que existam incontáveis diferenças entre os que compõem o nós, característica indelével da sociedade hodierna $^{223}$ em razão dos incontáveis pluralismos que a informam. Nesse ponto, ao lado da isonomia, atua como pressuposto do justo em cada relação obrigacional.

Questões controvertidas: responsabilidade civil. São Paulo: Método, 2006, v. 5. p. 566. "A dignidade do ser humano é, dessa forma, um novo valor conformador e está presente em todo o direito, seja nas relações econômicas entre particulares [...] seja nas relações existenciais [...] seja nas relações entre o indivíduo e o Estado. [...] A pessoa é resgatada como valor supremo do ordenamento.”

217 SILVA, José Afonso da. A dignidade da pessoa humana como valor supremo da democracia, Revista de Direito Administrativo, Rio de Janeiro, v. 212, p. 89-94, abr./jun. 1998. p. 90-91.

${ }^{218}$ FACHIN, Luiz Edson. Estatuto jurídico do patrimônio mínimo. Rio de Janeiro: Renovar, 2001. p. 311.

219 SARMENTO, Daniel. Direitos fundamentais e relações privadas. 2 ed. Rio de Janeiro: Lumen Juris, 2006. p. 89.

${ }^{220}$ SILVA, José Afonso da. Curso de direito constitucional positivo. 19 ed. São Paulo: Malheiros, 2001. p. 109.

${ }^{221}$ Com visão restritiva sobre o assunto: POPP, Carlyle. Liberdade negocial e dignidade da pessoa humana: aspectos relevantes. In: NALIN, Paulo; VIANNA, Guilherme Borba (Coord.). Direito em movimento. Curitiba: Juruá, 2007. p. 64-65.

${ }^{222}$ MAURER, Béatrice. Notas sobre o respeito da dignidade da pessoa humana ... ou uma pequena fuga incompleta em torno de um tema central. In: SARLET, Ingo Wolfgang (Org.). Dimensões da dignidade: ensaios de filosofia do direito e do direito constitucional. 2 ed. Porto Alegre: Livraria do Advogado, 2009. p. 132-143.

${ }^{223}$ MORAES, Maria Celina Bodin de. O conceito de dignidade humana: substrato axiológico e conteúdo normativo. In: SARLET, Ingo Wolfgang (Org.). Constituição, direitos fundamentais e direito privado. 2 ed. Porto Alegre: LAEL, 2006. p. 119-124. 
A importância do princípio em foco se amplia com a detecção do discurso que apregoa o retorno ao individualismo e a supervalorização da autonomia privada, propostas que ignoram as diferenças existentes em um espaço social no qual impera a distinção funcional. ${ }^{224}$ Como se denota, a dignidade da pessoa humana - resgatando aqui sua força normativa - assume papel ímpar na solução de problemas cotidianos que afligem milhões de brasileiros. $^{225}$

E, em que pese as assertivas destacando que a dignidade da pessoa humana se manifesta hierarquicamente a partir da proteção da vida, segurança, propriedade, liberdade e igualdade ${ }^{226}$, aparentemente não é possível formular juízos prévios solucionando as múltiplas possibilidades de conflitos entre os valores acima descritos. ${ }^{227}$ Impõe-se, em cada caso, o recurso à ponderação, caminho que permitirá aferir a melhor solução em cada hipótese concretamente estabelecida. ${ }^{228}$

Outro caminho que pode conduzir ao preenchimento da carga axiológica do princípio em foco está na identificação de quais valores são capazes de revelar a humanidade das pessoas. Essa compreensão afasta o reducionismo que identificava a pessoa com seu patrimônio quando impõe a necessidade de antever que o ser humano "anima e justifica a própria existência do ordenamento jurídico."229

${ }^{224}$ LOVECE, Graciela. El riesgo de la víctima y la eximición de responsabilidad, Revista de Responsabilidad Civil y Seguros, Buenos Aires, n. 6 extra, p. 1-6, jun. 2007. p. 3.

${ }^{225}$ Para uma melhor compreensão da ideia: FACHIN, Luiz Edson. Aspectos da racionalidade históricocultural do arquétipo inserido no código civil brasileiro de 2002, Revista do Advogado, São Paulo, n. 98, p. 143-150, jul. 2008. p. 149. Consoante o autor, "a dignidade da pessoa é dado concreto, aferível no atendimento das necessidades que propiciam ao sujeito se desenvolver com efetiva liberdade - que não se apresenta apenas em um âmbito formal, mas se baseia, também, na efetiva presença de condições materiais de existência que assegurem a viabilidade real do exercício de liberdade."

226 JUNQUEIRA DE AZEVEDO, Antonio. Caracterização jurídica da dignidade da pessoa humana, Revista dos Tribunais, São Paulo, v. 91, n. 797, p. 11-26, mar. 2002. p. 19-25. Saliente-se que, quando o autor insere a proteção da propriedade como corolário do princípio constitucional sob análise, o faz a partir de perspectivas semelhantes às que embasam as ideias de mínimo existencial e da necessidade de proteção do patrimônio mínimo.

227 Ademais, parece-nos que, se a redução da pobreza e a diminuição das desigualdades estão entre os objetivos constitucionais, em princípio, se houver eventual choque entre o direito de propriedade e direitos de liberdade ou de igualdade, aquele não terá primazia. Essa resposta, entretanto, somente poderá ser encontrada na intersubjetividade da relação jurídica concretamente estabelecida.

${ }^{228}$ MORAES, Maria Celina Bodin de. Constituição e direito civil: tendências, Revista dos Tribunais, São Paulo, v. 89, n. 779, p. 47-63, set. 2000. p. 59. Defende a autora que dignidade da pessoa humana, em cada hipótese, deve atuar de modo a promover a ponderação adequada entre dois outros valores em princípio contraditórios: liberdade e solidariedade.

${ }^{229}$ MARTINS-COSTA, Judith. Os danos à pessoa no direito brasileiro e a natureza de sua reparação. In: MARTINS-COSTA, Judith (Org.). A reconstrução do direito privado. São Paulo: RT, 2002. p. 413. 
A consagração da dignidade da pessoa humana como um valor a ser perseguido, redunda, ainda, no processo de personalização ${ }^{230}$ do direito civil. Quando se aceita que a pessoa humana hodiernamente ocupa o centro gravitacional das preocupações do Direito ${ }^{231}$ e que "indivíduo e pessoa são duas dimensões indissociáveis e incindíveis do mesmo ser"232, compreende-se por que o exercício da democracia pressupõe sua constante e plena realização. ${ }^{233}$

Das acoplagens possíveis entre os objetivos almejados nessa tese e o princípio sob análise, além das preocupações com a preservação do mínimo existencial ${ }^{234}$-, três fenômenos parecem se destacar. Antecipe-se, apenas, que todos eles são provas hialinas da ampliação da órbita de preocupações do Direito e da valorização da qualidade da tutela destinada à pessoa humana. A (a) expansão dos danos indenizáveis, (b) a objetivação dos fatores de atribuição do dever de reparar, e (c) a coletivização dos prejuízos ${ }^{235}$, além de

230 MEIRELLES, Jussara Maria Leal de. Repersonalização, transindividualidade, relativização: a subjetividade revista em prol de um desenvolvimento juridicamente sustentável. In: CONRADO, Marcelo; PINHEIRO, Rosalice Fidalgo (Coord.). Direito privado e constituição: ensaios para uma recomposição valorativa da pessoa e do patrimônio. Curitiba: Juruá, 2009. p. 49. "Reconstruir a noção jurídica de pessoa. Reconhecer a pessoa humana como valor pré-normativo. Respeitar a sua dinâmica de ser humano que, por essa condição, apresenta dimensões não categorizáveis estaticamente. Apreender a dignidade humana no seu significado essencial. Todas essas inclinações e atividades parecem traduzir o significado do verbo repersonalizar."

231 FACCHINI NETO, Eugênio. Reflexões histórico-evolutivas sobre a constitucionalização do direito privado. In: SARLET, Ingo Wolfgang (Org.). Constituição, direitos fundamentais e direito privado. 2 ed. Porto Alegre: LAEL, 2006. p. 34. Lembra o autor que "o patrimônio deixa de estar no centro das preocupações privatistas (recordem-se que o modelo dos códigos civis modernos, o Code Napoléon, dedica mais de $80 \%$ de seus artigos à disciplina jurídica da propriedade e suas relações), sendo substituído pela consideração com a pessoa humana.

232 AFONSO, Elza Maria Miranda. Prefácio. In: MATA-MACHADO, Edgar de Godoi. Contribuição ao personalismo jurídico. Belo Horizonte: Del Rey, 2000. p. 22.

${ }^{233}$ WARAT, Luis Alberto. Introdução geral ao direito: o direito não estudado pela teoria jurídica moderna. Porto Alegre: SAFE, 1997, v. 3. p. 60.

${ }^{234}$ SARLET, Ingo Wolfgang. Direitos fundamentais sociais e proibição do retrocesso: algumas notas sobre o desafio da sobrevivência dos direitos sociais num contexto de crise, Revista da Ajuris, Porto Alegre, v. 31, n. 95, p. 103-135, set. 2004. p. 129-130. Consoante ensina o autor, "a noção de mínimo existencial, compreendida, por sua vez, como abrangendo o conjunto de prestações materiais que asseguram a cada indivíduo uma vida com dignidade, que necessariamente só poderá ser uma vida saudável, [não pode ser restringida] à noção de um mínimo vital ou a uma noção estritamente liberal de um mínimo suficiente para assegurar o exercício das liberdades fundamentais."

235 NORONHA, Fernando. Desenvolvimentos contemporâneos da responsabilidade civil, Revista dos Tribunais, São Paulo, n. 761, p. 31-44, mar. 1999. p. 35. "O fenômeno da ampliação dos danos suscetíveis de reparação traduz-se na extensão da obrigação de indenizar os danos extrapatrimoniais, ou morais, e na tutela dos danos transindividuais, correspondendo os dois aspectos à aspiração da sociedade atual no sentido de que a reparação proporcionada às pessoas seja a mais abrangente possível. O fenômeno da objetivação, talvez a principal consequiência da revolução industrial no âmbito da responsabilidade civil, consiste no progressivo distanciamento desta com relação ao princípio segundo o qual não poderia haver responsabilidade sem culpa. O fenômeno da coletivização traduz o declínio da responsabilidade individual perante o desenvolvimento de processos comunitários para indenização de diversos danos, especialmente os que atingem a integridade 
claramente refletirem maior preocupação com a promoção da pessoa humana, apresentamse como características marcantes do processo de superação da responsabilidade civil pelo direito de danos. Os dois primeiros pontos merecem um pouco mais de atenção.

Inicialmente, cabe ponderar que, se um sistema de reparação de danos encontra justificativa na necessidade de proteção - e de promoção, mormente quando se acentua a função preventiva inexoravelmente conectada àquele - da pessoa humana ${ }^{236}$, se torna factível aceitar porque a ampliação da tutela de seus interesses - dos mais distintos matizes e formas - se legitima. ${ }^{237}$ A recepção pelo direito brasileiro da reparação de danos de ordem patrimonial é uma prova contundente do fenômeno descrito. A seu turno, no que pertine à objetivação do reparar, vale lembrar que a necessidade de promover a tutela do lesado $^{238}$ detém irrefutável prioridade quando (e se) comparada às preocupações do Direito com a sanção de um comportamento reprovável. A objetivação do dever de reparar dentre outras conquistas - promove não só a tutela da vítima, mas da sociedade como um todo. Com isso, atua de modo a disseminar múltiplas possibilidades latentes na premissa constitucional ora explorada, atendendo, ao mesmo tempo, ao clamor de reivindicações históricas raramente ouvidas.

\subsection{A personalização do dever de reparar}

A relação jurídica, consoante os moldes forjados pelas primeiras codificações, tinha como um de seus elementos estruturantes um sujeito concebido em razão da necessidade de se atribuir um titular a um patrimônio. ${ }^{239}$ Os códigos - segundo essa lógica

física ou psíquica das pessoas; tais danos são posto a cargo de todo grupo social, ou mesmo de toda a sociedade."

${ }^{236}$ HIDALGO, Carmen Domínguez. La concepción dualista de la responsabilidad civil en Chile: panorama general, Revista Anales Derecho UC, Santiago, v. 3, p. 73-89, mar. 2008. p. 89.

${ }^{237}$ REIS, Clayton. El daño a la persona en el derecho brasileño. In: GESUALDI, Dora Mariana (Coord.). Derecho privado. Buenos Aires: Hammurabi, 2001. p. 1168.

${ }^{238}$ VASCONCELOS, Ábner de. Responsabilidade civil objetiva, Revista Forense, Rio de Janeiro, v. 53, n. 163, p. 22-33, jan./fev. 1953. p. 23.

${ }^{239}$ CORTIANO JUNIOR, Eroulths; MEIRELLES, Jussara Maria Leal de; PAULINI, Umberto. Um estudo sobre o ofuscamento jurídico da realidade: a impossibilidade de proteção de novos valores e fatos a partir de velhos institutos. In: CORTIANO JUNIOR, Eroulths; MEIRELLES, Jussara Maria Leal de; FACHIN, Luiz Edson; NALIN, Paulo (Coord.). Apontamentos críticos para o direito civil brasileiro contemporâneo. Curitiba: Juruá, 2007. p. 25-36. 
- criaram personagens a serem fielmente desempenhadas por pessoas absolutamente iguais, dentre elas, o contratante, o testador, o proprietário, o pai de família etc. ${ }^{240}$

Nesse quadro, a relação jurídica no Estado Liberal "exprime menos um meio técnico para desenhar uma exposição e mais uma ordenação conceitual para dar conta de um modo de ver a vida e sua circunstância. Em suas vestes, está menos o Direito em movimento, coletivamente considerado, e mais um Direito que se afirma no confronto e na negação do outro" 241 , ignorando a existência do diferente ${ }^{242}$ e que, "sob a capa neutral de sujeitos de direito, se confrontam entes morfologicamente diversos."

Indivíduo e sujeito de direitos ${ }^{244}$, nesse contexto, são expressões sinônimas. No modelo criado pelas primeiras codificações, não há razão para qualquer preocupação com a pessoa humana. Se todos são considerados iguais perante a lei, todos têm as mesmas condições, por meio de seus esforços, de contratar e acumular riqueza. ${ }^{245}$ A noção de pessoa, nesse contexto, é apenas uma abstração ${ }^{246}$ que ignora, ou propositalmente despreza, que "conceitos são só conceitos.",247

${ }^{240}$ ALTHEIM, Roberto. Direito de danos: pressupostos contemporâneos do dever de indenizar. Curitiba: Juruá, 2008. p. 68.

${ }^{241}$ FACHIN, Luiz Edson. Teoria crítica do direito civil. Rio de Janeiro: Renovar, 2000. p. 26. Leciona o autor que a noção de sujeito de direito "é um conceito superado por sua própria insuficiência, denunciada pelas tentativas de captar, atemporalmente, pessoas, nexos e liames."

${ }^{242}$ WARAT, Luis Alberto. Introdução geral ao direito: a epistemologia jurídica da modernidade. Porto Alegre: SAFE, 2002, v. 2. p. 97.

${ }^{243}$ RIBEIRO, Joaquim de Souza. Direito dos contratos: estudos. Coimbra: Coimbra, 2007. p. 41.

${ }^{244}$ WARAT, Luis Alberto. A rua grita dionísio: direitos humanos da alteridade, surrealismo e cartografia. Trad. e Org. Vivian Alves de Assis; Júlio Cesar Marcellino Junior; Alexandre Morais da Rosa. Rio de Janeiro: Lumen Juris, 2010. p. 92. Como destaca o autor, "o sujeito da modernidade foi uma construção do imaginário social que nos impregnou de uma sensação de unidade que terminou sendo contraproducente em relação à nossa busca de emancipação e em termos de nossa necessidade de nos construir em alteridade."

${ }^{245}$ CORTIANO JUNIOR, Eroulths. O discurso jurídico da propriedade e suas rupturas: uma análise do ensino do direito de propriedade. Rio de Janeiro: Renovar, 2002. p. 55.

${ }^{246}$ RODRIGUES, Rafael Garcia. A pessoa e o ser humano no novo código civil. In: TEPEDINO, Gustavo (Coord.). A parte geral do novo código civil: estudos na perspectiva civil-constitucional. Rio de Janeiro: Renovar, 2002. p. 29. "Essa Pessoa figura como elemento central de nossos Códigos somente de forma retórica; trata-se tão somente de um conceito, desprovido de valor, construído de forma hermética com base no rigorismo científico, a fim de possibilitar sua incorporação nos pólos da relação jurídica que, por sua vez, de forma idealizada, representa as conflituosas relações sociais no mundo jurídico."

${ }^{247}$ HESPANHA, António Manuel. O caleidoscópio do direito: o direito e a justiça nos dias e no mundo de hoje. Coimbra: Almedina, 2007. p. 369. 
Esse sujeito "tão abstrato e sem vida quanto a sua figura estrutural" ${ }^{248}$, esse sujeito anônimo ${ }^{249}$, transformado em um ser codificado, podia ser identificado a partir da “insularidade, abstração, atemporalidade e ausência de historicidade." 250 O ser humano, nesse universo, não passa de uma noção formal, que só possui utilidade quando representa algum papel. ${ }^{251} \mathrm{O}$ aspecto humano de cada pessoa foi esmagado pela análise tecnicista. ${ }^{252}$ Muito além de mera "submissão ou proletarização" de certa classe social, a repetição desse discurso levou à desumanização ${ }^{253}$ e ao genocídio das subjetividades. ${ }^{254}$

248 MEIRELLES, Jussara Maria Leal de. Repersonalização, transindividualidade, relativização: a subjetividade revista em prol de um desenvolvimento juridicamente sustentável. In: CONRADO, Marcelo; PINHEIRO, Rosalice Fidalgo (Coord.). Direito privado e constituição: ensaios para uma recomposição valorativa da pessoa e do patrimônio. Curitiba: Juruá, 2009. p. 50.

${ }^{249}$ ALVES, Alaôr Caffé. A função ideológica do direito, Revista da Faculdade de Direito de São Bernardo do Campo, São Bernardo do Campo, v. 6, n. 8, p. 1-11, 2002. p. 5. "Sob o enfoque da formalidade dogmática e abstrata do direito, o que se revela mediante um sistema axiomatizado, constituído de normas formais, abstratas e gerais, a singularidade pessoal e concreta de cada indivíduo e sua condição existencial específica como membro de uma determinada classe social não são particularmente consideradas. O que se leva em conta é o indivíduo como titular de um papel ou de uma função generalizada, como algo tipificado, anônimo e genérico [...] como indivíduo abstrato, intercambiável e substituível. Neste mundo, a unificação de múltiplas figuras sob a categoria homogênea de "sujeito de direito" se torna necessária para operar as relações de liberdade e igualdade formais indispensáveis aos pactos recorrentes da reprodução econômica capitalista. [E é] sob a ficção jurídica e operacional da igualdade e liberdade abstrata dos cidadãos [que] oculta-se a realidade concreta das classes sociais profundamente diferenciadas e, não raro, antagônicas em seus interesses."

${ }^{250}$ CORTIANO JUNIOR, Eroulths. O discurso jurídico da propriedade e suas rupturas: uma análise do ensino do direito de propriedade. Rio de Janeiro: Renovar, 2002. p. 168-170.

${ }^{251}$ FACHIN, Luiz Edson; RUZYK, Carlos Eduardo Pianovski. Direitos fundamentais, dignidade da pessoa humana e o novo código civil: uma análise crítica. In: SARLET, Ingo Wolfgang (Org.). Constituição, direitos fundamentais e direito privado. 2 ed. Porto Alegre: LAEL, 2006. p. 97. "O sujeito, assim, só tem relevância como elemento da relação jurídica. Trata-se de hábil instrumento ideológico que atende à manutenção de uma dimensão patrimonialista do Direito Civil: se o sujeito, ainda que abstrato, é o elemento unificador do sistema, mais cedo ou mais tarde a sua abstração implicaria uma crise de legitimação de um direito que embora discursivamente centrado do sujeito, afasta-se da realidade concreta, sem ter olhos para as desigualdades concretas e para a exclusão daqueles que não se inserem no modelo jurídico de proprietários."

${ }^{252}$ CUNHA, Alexandre dos Santos. A teoria das pessoas de Teixeira de Freitas: entre individualismo e humanismo, Revista da Faculdade de Direito da UFRGS, Porto Alegre, v. 18, p. 15-23, 2000. p. 17.

${ }^{253}$ LORENZETTI, Ricardo Luis. Teoria da decisão judicial: fundamentos do direito. Trad. Bruno Miragem. São Paulo: RT, 2009. p. 328.

${ }^{254}$ WARAT, Luis Alberto. A rua grita dionísio: direitos humanos da alteridade, surrealismo e cartografia. Trad. e Org. Vivian Alves de Assis; Júlio Cesar Marcellino Junior; Alexandre Morais da Rosa. Rio de Janeiro: Lumen Juris, 2010. p. 46. "Isto é muito importante por que [sic]: primeiro instala a ideia de que o genocídio é uma prática cotidiana constante; segundo que não é uma ação irracional de um grupo de monstros humanos; terceiro, estamos reintroduzindo uma dimensão simbólica, o genocídio entendido não só como atos de guerra senão também semiocídio, o extermínio das subjetividades, as marcas de um sistema de crenças que nos penetram como se fossem balas que produzem a morte de quem é contaminado por elas. $\mathrm{O}$ genocídio que nos obriga unicamente a escutar as crenças que previamente organizaram nossa consciência como instância robotizada. Existem campos de concentração para as ideias, e fornos onde se crema a memória. Não só as pessoas desaparecem nos estados de terror e nas mafiocracias, também existem ideias desaparecidas." 
Tal construção, apesar de compreensível em razão das balizas fixadas pelo Estado Liberal $^{255}$, não resiste à leitura crítica, até porque a manutenção do tratamento dos sujeitos de direito como entes abstratos só interessa à classe dominante. ${ }^{256}$ Considerando a essencialidade da tarefa de resgatar as identidades esmagadas pelos detentores do poder $^{257}$, parece imperioso denunciar que a visão patrimonialista que imperou nessa quadra da História - e que ainda informa muitos discursos na contemporaneidade - é recheada de vícios $^{258}$, em especial, o de ignorar aqueles que nada têm. ${ }^{259}$ É imprescindível lembrar que a concepção formal da pessoa humana é algo inaceitável nos dias atuais, sendo essencial reconhecer "o valor ontológico da vida.",260

O tratamento dos sujeitos de direito como entes abstratos é fonte de efeitos extremamente nocivos em nível individual e social. No universo contratual, uma de suas consequências mais graves encontra-se na valoração da vontade como produtora de efeitos, bastando para isso que seja externada sem defeitos e que preencha os demais moldes que recepcionam o negócio entabulado. Esse quadro dá prevalência à forma em detrimento do conteúdo; ignora aspectos existenciais que permeiam a relação; despreza a relevância do objeto e as intersubjetividades; além de não se importar com o equilíbrio entre as prestações inerentes à relação concretamente estabelecida.

${ }^{255}$ LIMA, Ruy Cirne. O sujeito de direitos no código civil, Revista da Faculdade de Direito de Porto Alegre, v. 5 , n. 1 , p. $13-17,1971$. p. 13-17.

${ }^{256}$ ALVES, Alaôr Caffé. Estado e direito: estrutura, formas e ilusões da sociedade real, Revista da Ordem dos Advogados do Brasil, São Paulo, v. 18, n. 43/48, p. 57-74, 1988. p. 65-74.

${ }^{257}$ WARAT, Luis Alberto. A rua grita dionísio: direitos humanos da alteridade, surrealismo e cartografia. Trad. e Org. Vivian Alves de Assis; Júlio Cesar Marcellino Junior; Alexandre Morais da Rosa. Rio de Janeiro: Lumen Juris, 2010. p. 19.

${ }^{258}$ SESSAREGO, Carlos Fernández. Protección a la persona humana, Ajuris, Porto Alegre, v. 56, n. 19, p. 87-142, nov. 1992. p. 91. Segundo o autor, o patrimonialismo apresenta ao menos dois graves erros: a) ignorar a qualidade existencial inerente à pessoa humana, distinta, portanto, das coisas e objetos que integram seu acervo patrimonial; b) desprezar que a pessoa humana constitui, por si, um valor que não possui significação econômica.

${ }^{259}$ FLAH, Lily; SMAYEVSKY, Miriam. El llamado valor de la vida humana. In: GESUALDI, Dora Mariana (Coord.). Derecho privado. Buenos Aires: Hammurabi, 2001. p. 1196. "No cabe duda de que el derecho a la vida dentro de la supremacía de los derechos constitucionales es absoluto, pero, en materia de danos, cuantificar su pérdida obliga a recurrir a una mirada distinta. El criterio de la producción y de los resultados económicos de un trabajo se queda con la parte más sórdida del valor de la vida que, por cierto, tiene otros ámbitos, otras expresiones y otras expansiones valorables patrimonialmente, pero que no se ajustan al quantum de una entrada lucrativa. De lo contrario, una persona sin patrimonio no tendría vida valorable y, por ello, se descartaría todo lo que puede hacer, dar y ofrecer con sus energías, tanto en su vida privada como en lo social y productivo." Exemplo manifesto do aludido problema é notado, no Brasil, nos primeiros julgamentos versando sobre reparação de danos em razão da morte de filho menor de idade que não possuía renda própria.

260 JUNQUEIRA DE AZEVEDO, Antonio. Novos estudos e pareceres de direito privado. São Paulo: Saraiva, 2009. p. 12. 
Como se percebe, a compreensão da pessoa humana como sujeito de direitos pautado na análise estrutural e bipolar da relação jurídica ignora aspectos existenciais e condicionamentos individuais importantes, a classe social a que ele pertence - a justiça não pertence aos oprimidos, que não têm recursos para pagar por ela -, e a realidade histórica de cada indivíduo. No Direito construído pela burguesia, "não há espaço para a cidadania concreta" ${ }^{261}$, nem preocupação com o avanço do processo de exclusão social. ${ }^{262}$

Os problemas denunciados são apreendidos pelo Estado Social que lentamente derruba um dos mitos do liberalismo ao reconhecer que as pessoas não são iguais umas as outras. ${ }^{263}$ Esse momento histórico é responsável pelo surgimento das primeiras trilhas que permitirão, no porvir - as possibilidades existem -, a libertação de um homem aprisionado pelo individualismo. A análise mais atenta dessa questão permite vislumbrar o caráter ideológico encoberto pela aparente univocidade do Direito e autoriza a formulação de críticas ao modelo vigente, até porque não se pode fazer ciência social na ausência de compromisso com as condições materiais da sociedade ${ }^{264}$ e sem que haja prevalência da pessoa humana sobre a noção abstrata de sujeito de direito.

Consoante o constante fluir do tempo, a pessoa gradativamente deixa de ser um conceito meramente operacional ${ }^{265}$ e começa a ser pensada a partir de sua realidade complexa. Tal tendência parece crescente, mas, certamente, ainda é incipiente ${ }^{266}$, até

261 AGUIAR, Roberto. O imaginário dos juristas, Revista de Direito Alternativo, São Paulo, n. 2, p. 18-27, 1993. p. 20-21.

${ }^{262}$ LOPES, Mônica Sette. Os sujeitos jurídicos: concepções tangenciadoras do novo código civil, Revista da Faculdade de Direito, Belo Horizonte, v. 42, p. 191-217, 2002/2003. p. 194. "O risco do grotesco e, algumas vezes, do cruel estampa-se a partir da existência das diferenças de substância, da polarização dos interesses. As máscaras que cobrem os seres humanos com a versão conceitual de sua personalidade jurídica não são suficientes para afastar as possibilidades de uso destes instrumentos de exclusão impostos pela realidade social $[\ldots] "$

${ }^{263}$ ALBUQUERQUE, Fabíola Santos. O princípio da informação à luz do código civil e do código de defesa do consumidor. In: BARROSO, Lucas Abreu (Org.). Introdução crítica ao código civil. Rio de Janeiro: Forense, 2006. p. 100-102.

${ }^{264}$ WARAT, Luis Alberto. O direito e sua linguagem. 2 versão. 2 ed. Porto Alegre: SAFE, 1995. p. 45-48.

265 SILVA FILHO, José Carlos Moreira da. Pessoa humana e boa-fé objetiva nas relações contratuais: a alteridade que emerge da ipseidade. In: SILVA FILHO, José Carlos Moreira da; PEZZELLA, Maria Cristina Cereser (Coord.). Mitos e rupturas no direito civil contemporâneo. Rio de Janeiro: Lumen Juris, 2008. p. 317-318. Justificando o fenômeno, o autor destaca que, "de um lado, tem-se a ênfase constitucional na dignidade da pessoa humana, de outro, tem-se a análise da própria complexidade das relações contratuais, que tendem, cada vez mais, a se prolongar no tempo e a indicar a necessidade de maior interação entre as partes [...]."

${ }^{266}$ FARIA, José Eduardo. A justiça e a formação da magistratura, Nomos, Fortaleza, v. 7/8, n. 2, p. 65-75, jan./dez. 1988/1989. p. 66. Em estudo que investiga a formação dos atores jurídicos, o autor busca aferir se estes continuam sendo educados a partir de uma visão dogmática que valoriza aspectos formais da relação jurídica ou se o ensino se preocupa em ressaltar uma missão prática e crítica que permita visualizar aspectos 
porque a mudança em curso é muito mais complexa do que possa parecer. ${ }^{267} \mathrm{O}$ caminho foi e é cercado de obstáculos. Apesar da existência do discurso acerca da personalização do direito $^{268}$, o homem continua a ser tratado como mercadoria ${ }^{269}$, o que é inaceitável, seja por conta do valor inerente à pessoa humana ou porque a propriedade, ontologicamente, não possui valor algum. ${ }^{270}$

Problemas à parte, fato é que a pessoa humana certamente não é mais aquele sujeito de direitos modelado, "descarnado", "sempre-igual", concebido outrora para preencher um lugar na relação jurídica. Ao contrário, é uma pessoa real, concreta, com suas peculiaridades ${ }^{271}$; enfim, uma pessoa situada em sua ambiência histórica e social. Já é hora de deixar de apreciar as sombras dos conceitos como se essas fossem a essência do Direito. $^{272}$

como a desigualdade econômica e estimular a assunção de compromissos que alterem a realidade vigente, concluindo que a primeira perspectiva tem sido a regra.

${ }^{267}$ BAUMAN, Zygmunt. Vida líquida. Trad. Carlos Alberto Medeiros. Rio de Janeiro: Zahar, 2007. p. 37. Dentre os problemas vislumbrados, um é de ordem sociológica. Transcreve-se uma passagem do pensamento do autor que, a nosso ver, bem identifica a questão: "as balsas que trafegam entre a margem do "indivíduo de iure" e a do "indivíduo de facto" cobram caro pelos bilhetes, além do dinheiro necessário para reservar um espaço e acampar na outra margem. [...] Ser um indivíduo numa sociedade de indivíduos custa dinheiro, muito dinheiro. A corrida pela individualização tem acesso restrito e concentra os que têm credenciais para participar. Como nos sucessivos capítulos do programa Big Brother, as fileiras dos eliminados tendem a engrossar a cada rodada."

${ }^{268}$ AFONSO, Elza Maria Miranda. Prefácio. In: MATA-MACHADO, Edgar de Godoi. Contribuição ao personalismo jurídico. Belo Horizonte: Del Rey, 2000. p. 17. "Foi [...] a partir da Segunda Guerra Mundial, que o termo personalismo passou a designar uma corrente de pensamento de caráter ético-político, que se opõe ao individualismo e ao coletivismo, na sua concepção de pessoa."

269 MOREIRA, Lenice Silveira. Ciência jurídica e complexidade: reflexões sobre as mudanças epistemiológicas [sic] necessárias à compreensão do direito no século XXI, Revista da FARN, Natal, v. 5, n. $1 / 2$, p. 27-50, 2006. p. 34. "A fé tecnológica mantém seu ardor apesar das contestações crescentes. [...] A referida dominação mecanicista extrapola para o universo da ciência da vida, da biomédica e da biotecnologia. Toda nova descoberta e contribuição nesta área torna-se objeto de lutas para apropriação intelectual das patentes sobre a "coisa viva recombinada." O ser vivo manipulado passa também a constituirse mercadoria, sujeito a grandes investimentos de capital, o que banaliza o comércio da vida progressivamente."

${ }^{270}$ PROUDHON, Pierre Joseph. A propriedade é um roubo e outros escritos anarquistas. Trad. Suely Bastos. Porto Alegre: L\&PM, 1998. p. 35. "Os proprietários me desejam mal de morte por haver dito que a propriedade, sozinha e por si mesma, é um roubo; como se a propriedade não tirasse todo seu valor (sua renda) da circulação dos produtos e, por conseguinte, não revelasse de um fato superior a ela, a força coletiva, a solidariedade do trabalho."

${ }^{271}$ MARTINS-COSTA, Judith. Os direitos fundamentais e a opção culturalista do novo código civil. In: SARLET, Ingo Wolfgang (Org.). Constituição, direitos fundamentais e direito privado. 2 ed. Porto Alegre: LAEL, 2006. p. 70-74. "O Direito é construção de significados. Dos novos fatos sociais, das novas concepções, resulta a relevância que tem adquirido, para a ciência jurídica privatista, um significado de pessoa humana que se define não apenas por sua abstrata liberdade de firmar vínculos jurídicos, mas por sua concreta e multidimensional vivência [no] espaço."

${ }^{272}$ RIBEIRO, Darci Guimarães. Da tutela jurisdicional às formas de tutela. Porto Alegre: LAEL, 2010. p. 227. 
A pessoa agora é concebida pelo Direito como um fim em si mesmo. Assim, somente poderão ser recepcionadas construções que favoreçam a realização daquela. ${ }^{273} \mathrm{O}$ sujeito de direito, abstratamente concebido e pensado pela dogmática, não se confunde com o ser humano concreto e hodiernamente tutelado pelo Direito: apenas esse tem necessidades de plúrimas ordens, desejos e sentimentos. ${ }^{274}$

O Direito acompanha as mudanças da vida. ${ }^{275}$ Aquele direito civil forjado na tripla dominação burguesa - a econômica, a intelectual e a política - não serve mais para solucionar os problemas surgidos nos novos tempos. Recupera-se a noção de pessoa: um ser que possui dimensão existencial, que tem paixões, fome e desejos ${ }^{276}$; mesmo porque "uma sociedade democrática encontra-se fundamentalmente comprometida com a necessidade de prover as condições de possibilidade de um desenvolvimento pleno, autônomo e de todos os membros da sociedade."277

É possível inferir que a opção personalista - essa conquista de todos os brasileiros - se apresenta hialina no texto constitucional e que impõe o abandono do viés patrimonialista legado ao direito civil brasileiro pelas codificações europeias. ${ }^{278}$

${ }^{273}$ BARZOTTO, Luis Fernando. Os direitos humanos como direitos subjetivos: da dogmática jurídica à ética, Revista da PGE, Porto Alegre, v. 28, n. 59, p. 137-175, jun. 2004. p. 141.

${ }^{274}$ FACHIN, Luiz Edson. Aspectos da racionalidade histórico-cultural do arquétipo inserido no código civil brasileiro de 2002, Revista do Advogado, São Paulo, n. 98, p. 143-150, jul. 2008. p. 144.

${ }^{275}$ HIRONAKA, Giselda Maria Fernandes Novaes. Tendências do direito civil no século XXI. In: FIUZA, César; SÁ, Maria de Fátima Freire de; NAVES, Bruno Torquato de Oliveira (Coord.). Direito civil: atualidades. Belo Horizonte: Del Rey, 2003. p. 95. "A história da civilização humana, em cada um de seus infindáveis momentos, influi, portanto, a conformação e a estrutura do direito privado como um todo, e do Direito Civil, em especial. O atual estágio desta história, quer dizer, o momento histórico que agora vivenciamos, é um estágio que tem imposto ao Direito Civil uma releitura importantíssima, a implicar em extraordinárias transformações. Creio, como professora e estudiosa deste segmento da ciência jurídica, que é justamente esta dinâmica que formatam o encanto maior do Direito Civil, já que não admite, a quem a ele se dedica, nem mesmo um minuto de tranqüilidade, de repouso, de qualquer certeza acerca da imutabilidade de seus institutos e de suas categorias. A sua organização estrutural e a moldura de sua essência estão - e devem estar, mesmo - umbilicalmente relacionados às mudanças na vida dos homens, mudanças estas derivadas do progresso das ciências, do avanço das tecnologias e do comportamento das pessoas em face destas todas alterações."

${ }^{276}$ CORTIANO JUNIOR, Eroulths. As quatro fundações do direito civil: ensaio preliminar, Revista da Faculdade de Direito, Curitiba, v. 45, p. 99-102, 2006. p. 101-102.

277 WARAT, Luis Alberto. Introdução geral ao direito: a epistemologia jurídica da modernidade. Porto Alegre: SAFE, 2002, v. 2. p. 358.

${ }^{278}$ FACHIN, Luiz Edson. Aspectos da racionalidade histórico-cultural do arquétipo inserido no código civil brasileiro de 2002, Revista do Advogado, São Paulo, n. 98, p. 143-150, jul. 2008. p. 144. Nesse sentido: PERLINGIERI, Pietro. O direito civil na legalidade constitucional. Trad. Maria Cristina De Cicco. Rio de Janeiro: Renovar, 2008. p. 10. 
A assertiva pode ser comprovada (a) na alusão constitucional à necessidade de proteção da pessoa humana; (b) na exigência de valoração das distintas situações jurídicas a partir de uma perspectiva isonômica em nível substancial; e, ainda, (c) diante do comando que visa a promover a redução das desigualdades sociais e a redistribuição da riqueza, premissas que buscam satisfazer as necessidades básicas individuais e sociais de cada ser humano que habita o território brasileiro, e que não podem mais ser lidas como meras recomendações dirigidas ao legislador.

Nessa onda, é importante salientar que a despatrimonialização do Direito não implica a redução do papel do direito civil no universo das relações econômicas, mas, sim, no reconhecimento de que bens e direitos de índole patrimonial não podem ser vistos como fins em si mesmos, mas como meios para a realização de uma pessoa histórica e socialmente situada. ${ }^{279}$ Como antecipado ${ }^{280}$, é preciso aceitar que, a luzes hão de incidir sobre "a pessoa humana valorada por si só, pelo exclusivo fato de ser pessoa."

É perfeitamente factível aceitar que o personalismo retira do patrimônio as luzes do Direito e as redireciona para o ser humano. ${ }^{282}$ Aclare-se, uma vez mais, que a perspectiva que impõe a primazia do valor da pessoa humana não priva de tutela qualquer direito de ordem patrimonial. Ao contrário, protege-se o patrimônio como meio de realização daquela ${ }^{283}$ e da sociedade como um todo.

\footnotetext{
279 SARMENTO, Daniel. Direitos fundamentais e relações privadas. 2 ed. Rio de Janeiro: Lumen Juris, 2006. p. 90-91.

${ }^{280}$ Vide item 1.2.

${ }^{281}$ MARTINS-COSTA, Judith; BRANCO, Gerson Luis Carlos. Diretrizes teóricas do novo código civil brasileiro. São Paulo: Saraiva, 2002. p. 132. “O conteúdo do direito privado, bem por isso, está muito proximamente ligado ao valor que historicamente é dado à pessoa e às suas relações com os demais bens da vida, patrimoniais ou existenciais, com as esferas do ser, do ter e do agir. Se o mais relevante for a relação entre a pessoa e os bens patrimoniais, economicamente avaliáveis, crescem em importância as regras jurídicas atinentes à tutela do patrimônio. As normas do direito privado restam aí reduzidas a meios de tutela dos bens patrimoniais. obscurecendo-se a civilidade, dimensão social da existência, e a própria dimensão social do "ser civil" no individualismo egoísta. Contudo, se em primeiro plano está a pessoa humana valorada por si só, pelo exclusivo fato de ser pessoa - isto é, a pessoa em sua irredutível subjetividade e dignidade, dotada de personalidade singular e por isso mesmo titular de atributos e de interesses não mensuráveis economicamente -, passa o Direito a construir princípios e regras que visam a tutelar essa dimensão existencial, na qual, mais do que tudo, ressalta a dimensão ética das normas jurídicas. Então o direito civil reassume a sua direção etimológica e do direito dos indivíduos passa a ser considerado o direito dos civis, dos que portam em si os valores da civilidade."

${ }^{282}$ FACHIN, Luiz Edson. Estatuto jurídico do patrimônio mínimo. Rio de Janeiro: Renovar, 2001. p. 49.

${ }^{283}$ CORTIANO JUNIOR, Eroulths. Para além das coisas (breve ensaio sobre o direito, a pessoa e o patrimônio mínimo). In: RAMOS, Carmem Lucia Silveira et all (Org.). Diálogos sobre direito civil: construindo a racionalidade contemporânea. Rio de Janeiro: Renovar, 2002. p. 156.
} 
Não se pode esquecer, em momento algum, que os bens têm como finalidade precípua permitir a realização do ser humano. ${ }^{284}$ Atuam como suporte hábil a favorecer esse processo, especialmente nas economias capitalistas. O personalismo liberta um indivíduo aprisionado no tempo e no espaço, permitindo - ao abrir as portas de acesso ao palco - que esse exerça sua cidadania.

Ademais, como o nível de proteção da pessoa humana serve para avaliar o potencial de desenvolvimento de uma sociedade ${ }^{285}$, o processo de personalização encontra mais uma razão fundante, mostrando-se como opção impostergável à superação do viés de análise patrimonial das relações jurídicas. ${ }^{286}$

O desafio aqui consiste - repita-se uma vez mais - em conseguir ver a pessoa em sua máxima amplitude, e não somente em razão dos bens que possui, até porque aquela é bem mais que simples detentora de titularidades. A realocação da pessoa humana em um lugar de destaque é a condição inicial de adequação do direito civil à Constituição. ${ }^{287}$ Assim, o processo de personalização do Direito é uma via propícia ao resgate do homem em toda sua plenitude. ${ }^{288}$

${ }^{284}$ RODRIGUES, Rafael Garcia. A pessoa e o ser humano no novo código civil. In: TEPEDINO, Gustavo (Coord.). A parte geral do novo código civil: estudos na perspectiva civil-constitucional. Rio de Janeiro: Renovar, 2002. p. 34.

${ }^{285}$ PEZZELLA, Maria Cristina Cereser. Código civil em perspectiva histórica. In: SARLET, Ingo Wolfgang (Org.). O novo código civil e a constituição. 2 ed. Porto Alegre: LAEL, 2006. p. 65. "Uma sociedade que não perquire, não discute e não confere possibilidades para uma ampliada discussão social e jurídica da importância da pessoa em sua plenitude, e, por assim dizer, integral na perspectiva física e psíquica, deixa de cumprir o seu principal papel: o desenvolvimento integral da pessoa."

${ }^{286}$ HIRONAKA, Giselda Maria Fernandes Novaes. Tendências do direito civil no século XXI. In: FIUZA, César; SÁ, Maria de Fátima Freire de; NAVES, Bruno Torquato de Oliveira (Coord.). Direito civil: atualidades. Belo Horizonte: Del Rey, 2003. p. 114. "A tendência marcante, a partir deste repensar das matrizes fundantes e dos matizes axiológicos do direito na pós-modernidade, marcar-se-á, por certo, na consecução e completude de um direito mais ético, mais composto com o sentir do que com a razão, mais digno, mais socializado, mais corajoso e fiel, mais despojado de arcabouços meramente patrimoniais [...]."

${ }^{287}$ LÔBO, Paulo Luiz Netto. Constitucionalização do direito civil, Revista de Informação Legislativa, Brasília, v. 36, n. 141, p. 99-109, jan./mar. 1999. p. 103. "É certo que as relações civis têm um forte cunho patrimonializante, bastando recordar que seus principais institutos são a propriedade e o contrato (modo de circulação da propriedade). Todavia, a prevalência do patrimônio, como valor individual a ser tutelado nos códigos, submergiu a pessoa humana, que passou a figurar como pólo de relação jurídica, como sujeito abstraído de sua dimensão real. A patrimonialização das relações civis, que persiste nos códigos, é incompatível com os valores fundados na dignidade da pessoa humana, adotado pelas constituições modernas, inclusive pela brasileira (artigo $1^{\circ}$, III). A repersonalização reencontra a trajetória da longa história da emancipação humana, no sentido de repor a pessoa humana como centro do direito civil, passando o patrimônio ao papel de coadjuvante, nem sempre necessário."

${ }^{288}$ CORTIANO JUNIOR, Eroulths. O discurso jurídico da propriedade e suas rupturas: uma análise do ensino do direito de propriedade. Rio de Janeiro: Renovar, 2002. p. 163-165. 
O ser humano - repita-se - há de ser compreendido em toda a sua complexidade. Em cada análise, devem ser consideradas sua dignidade individual ${ }^{289}$ e coexistencial $^{290}$, o que permite a abertura do Direito aos influxos inerentes aos fatos da vida real e multifacetada ${ }^{291}$, mesmo porque a pessoa humana, ao contrário do sujeito de direitos, é um ser em constante evolução. A reflexividade é inerente a sua condição pessoal e social. $^{292}$

Repercussão imediata do aludido fenômeno - e que importa diretamente na construção das bases da tese em desenvolvimento - está em que a destinação e a função dos atos e negócios jurídicos assumem hodiernamente papel preponderante quando comparadas àquelas de ordem meramente estrutural.

O exercício das posições jurídicas no desvelar do processo obrigacional há de ser funcionalizado. ${ }^{293}$ Tal leitura permite ultrapassar o diagrama meramente estrutural de análise da relação obrigacional. Nessa esteira, a liberdade econômica exercida por meio do contrato deve ser equalizada pelos princípios promotores da pessoa humana ${ }^{294}$, e, portanto, em qualquer situação, impõe-se refletir sobre aspectos como "para que serve e a quem serve o Direito., 295

${ }^{289}$ AMARAL, Francisco. O direito civil na pós-modernidade. In: FIUZA, César; SÁ, Maria de Fátima Freire de; NAVES, Bruno Torquato de Oliveira (Coord.). Direito civil: atualidades. Belo Horizonte: Del Rey, 2003. p. 76. A ideia redunda no reconhecimento "da crescente importância da vida e da dignidade da pessoa humana, elevados à categoria de direitos e de princípio fundamental da Constituição."

${ }^{290}$ FACHIN, Luiz Edson. Estatuto jurídico do patrimônio mínimo. Rio de Janeiro: Renovar, 2001. p. 49.

${ }^{291}$ FACHIN, Luiz Edson; RUZYK, Carlos Eduardo Pianovski. Direitos fundamentais, dignidade da pessoa humana e o novo código civil: uma análise crítica. In: SARLET, Ingo Wolfgang (Org.). Constituição, direitos fundamentais e direito privado. 2 ed. Porto Alegre: LAEL, 2006. p. 99.

${ }^{292}$ GHERSI, Carlos Alberto. La pobreza jurídica y el ejercicio de los derechos fundamentales: el valor de las libertades negativas, Revista de Direito do Consumidor, São Paulo, v. 11, n. 43, p. 11-20, jul./set. 2002. p. 14.

${ }^{293}$ BOBBIO, Norberto. Da estrutura à função: novos estudos de teoria do direito. Trad. Daniela Beccaccia Versiani. Barueri: Manole, 2007. p. 40. Como discorre o autor, "o direito não é um sistema de regras já postas e transmitidas, mas um conjunto de regras em movimento, a serem postas e repropostas continuamente, o objeto da ciência jurídica deve ser não tanto as regras, isto é, as valorações dos fatos sociais nas quais as regras consistem, mas os próprios fatos sociais dos quais as regras jurídicas são valorações." Veja ainda: STEINMETZ, Wilson. Direitos fundamentais e função social do (e no) direito, Revista da Ajuris, Porto Alegre, v. 34, n. 107, p. 285-291, set. 2007. p. 290. Salienta o autor que, enquanto a noção de função perpassa pela pergunta: "para que serve", a de funcionalização implica a aferição dos motivos determinantes do exercício de determinada posição jurídica.

${ }^{294}$ PERLINGIERI, Pietro. A doutrina do direito civil na legalidade constitucional. In: TEPEDINO, Gustavo (Org.). Direito civil contemporâneo: novos paradigmas à luz da legalidade constitucional. São Paulo: Atlas, 2008. p. 3.

${ }^{295}$ FACHIN, Luiz Edson. A construção do direito privado contemporâneo na experiência crítico-doutrinária brasileira a partir do catálogo mínimo para o direito civil-constitucional no Brasil. In: TEPEDINO, Gustavo 
O contrato - como fonte da relação obrigacional - deve seguir a mesma lógica: priorizar os interesses da pessoa humana e ser lido funcionalmente. Importante destacar que o contrato aqui pensado não é aquele imaginado pelos autores clássicos, mas, sim, o construído a partir da análise de seu conceito "pós-moderno." ${ }^{296}$ Um contrato não pode ser concebido meramente como um acordo com gênese na conjunção de vontades de duas ou mais pessoas. Essa leitura é extremamente pobre por simplificar ao extremo toda a complexidade do fenômeno contratual na contemporaneidade.

Esse mesmo contrato nasce, ao contrário, de necessidades das mais distintas ordens $^{297}$, peculiaridades que devem ser observadas no processo de realização do Direito. Pondere-se, ainda, que analisá-lo a partir de seu viés existencial não trará prejuízos em sede hermenêutica quando tenha escopo essencialmente material, o que ocorreria se as premissas fossem invertidas. A distinção básica em um e outro caso será, em princípio, a intensidade da carga eficacial - os efeitos oriundos do(s) princípio(s) no caso concreto por ocasião do processo de realização do Direito.

A personalização das relações civis permite compreender, como observa o leitor atento, que a pessoa humana não pode - se é que um dia essa possibilidade existiu, ainda que tais leituras fossem promovidas diuturnamente - ser considerada como um simples elemento da relação obrigacional. ${ }^{298}$ Recupere-se que a abstração promove a indiferença que legitima o processo de exclusão social. ${ }^{299}$

(Org.). Direito civil contemporâneo: novos paradigmas à luz da legalidade constitucional. São Paulo: Atlas, 2008. p. 17.

${ }^{296}$ NALIN, Paulo. Do contrato: conceito pós-moderno em busca de sua formulação na perspectiva civilconstitucional. Curitiba: Juruá, 2001. p. 253. O contrato, nessa esteira, consiste na "relação jurídica subjetiva, nucleada na solidariedade constitucional, destinada à produção de efeitos jurídicos existenciais e patrimoniais, não só entre os titulares subjetivos da relação, como também perante terceiros."

${ }^{297}$ FIUZA, César. Por uma redefinição da contratualidade, Revista da Faculdade Mineira de Direito, Belo Horizonte, v. 9, n. 18, p. 33-41, jul./dez. 2006. p. 33-41.

${ }^{298}$ Opta-se por utilizar a expressão relação obrigacional em lugar da terminologia usual - obrigação. Isso se dá diante da capacidade que a primeira possui de abarcar adequadamente a complexidade do tema, a pluralidade de direitos e deveres, direitos formativos etc, bem como as transformações de ordem subjetiva e objetiva pelas quais pode ela passar.

${ }^{299}$ FACHIN, Luiz Edson. Teoria crítica do direito civil. Rio de Janeiro: Renovar, 2000. p. 42-43. "Os contratos pressupõem um modelo de obrigação, e quando se fala em modelo de obrigação está-se falando em relação jurídica, porque a obrigação não se confunde com o seu objeto, pois, se assim o fosse, ao desaparecer o objeto[,] desapareceria a obrigação. Eis bem tipificado esse modelo de obrigação, uma relação jurídica de caráter transitório em que seu objeto é um comportamento que se converte na noção de prestação, que poderá, por sua vez, mediatamente ter por objeto uma determinada coisa. Apreende-se juridicamente, nas ações ou omissões, com fatos positivos (fazer) ou negativos (abstenções), a conduta humana que se quer juridicamente apreender, não sendo, por isso, indiferente a esse padrão de emolduramento nem mesmo o 
Mas é preciso ir além. Assim, atando, de modo mais pontual, o momento explorado ao objeto da investigação, é possível identificar que a leitura da responsabilidade contratual sob a perspectiva de lesão ao crédito pode ser atribuída ao processo de personalização das relações privadas. Por meio dessa leitura, não se promove um juízo de aprovação (ou não) do comportamento do devedor, mas busca-se aferir se houve (ou não) a satisfação dos legítimos interesses do credor. ${ }^{300}$

É imperioso perceber que essa forma de compreender a questão deixa de lado a preocupação com a sanção do causador do dano. O direito civil é um direito de acessos. $\mathrm{O}$ papel de punir não lhe foi atribuído. Os holofotes são deslocados para a reparação do lesado. ${ }^{301}$ Tutela-se, assim, a vítima de um dano injusto. ${ }^{302}$ Tutela-se, por consequência, toda a sociedade. ${ }^{303}$

A compreensão do raciocínio aqui tecido exige que se aceite que a atribuição do dever de reparar os danos contratuais não interessa apenas como forma de responsabilizar o devedor que de algum modo violou a obrigação a qual se obrigara, mormente porque o binômio crime e castigo há de ser definitivamente superado quando da análise dessas questões. Longe disso, e como frisado, o estudo do tema deve ter por foco a reparação do dano suportado pelo lesado ${ }^{304}$ e a repercussão social causada por essa lesão.

É fundamental identificar que o dever de reparar - dever que se encontra atado a um momento patológico no curso do processo obrigacional e que se manifesta tendo por suporte uma relação de causa e efeito existente entre uma conduta contrária ao Direito e um dano ${ }^{305}$ - é uma garantia em favor do credor. ${ }^{306}$

comportamento que lhe é, de fato (e de direito), indiferente. A indiferença se torna, assim, um conceito jurídico operado por exclusão proposital. Excluídas podem estar pessoas, condutas e coisas.”

300 LORENZETTI, Ricardo Luis. Esquema de una teoría sistémica del contrato, Revista de Direito do Consumidor, São Paulo, v. 9, n. 33, p. 51-77, jan./mar. 2000. p. 65-66. No mesmo sentido: LORENZETTI, Ricardo Luis. Tratado de los contratos: parte general. Buenos Aires: Rubinzal Culzoni, 2004. p. 584. As consequências são bastante distintas das alcançadas pela leitura anteriormente promovida. Agora: a) a análise da violação de dever contratual será promovida de modo objetivo e a imputabilidade (a partir de critérios subjetivos ou objetivos será feita em momento posterior); b) a impossibilidade superveniente não imputável é o limite da responsabilidade; c) em regra, o devedor só se exime diante de causa estranha não imputável.

301 SEGUÍ, Adela Maria. Aspectos relevantes de la responsabilidad civil moderna, Revista de Direito do Consumidor, São Paulo, v. 13, n. 52, p. 267-318, out./dez. 2004. p. 278-279.

${ }^{302}$ A questão será explorada no item 2.2 deste trabalho.

${ }^{303}$ A questão será explorada no item 3.4 deste trabalho.

${ }^{304}$ HINESTROSA, Fernando. Devenir del derecho de daños, Roma e America: Diritto Romano Comune, Roma, n. 10, p. 17-36, 2000. p. 21.

${ }^{305} \mathrm{O}$ tema será tratado pormenorizadamente no capítulo 2 deste trabalho. 
Essencial perceber também que é uma garantia da própria sociedade, compreendida aqui em toda sua complexidade, até porque, por menor que seja, cada lesão suportada pelo parceiro negocial em razão do não cumprimento do contrato repercute além do universo delimitador do negócio jurídico violado.

Um Direito personalizado busca reequilibrar a relação jurídica a partir da reparação da lesão causada à vítima ${ }^{307}$ - tutelando assim a pessoa humana - em vez de ter por base fundante a necessidade de repreender uma conduta inadequada. A imposição do dever de reparar não pode ser pensada como sanção repressora de um comportamento prenhe de culpa - essa "espécie de pecado jurídico"308 ou castigo moral. ${ }^{309}$ Deve sim, concentrar as energias existentes no dano a ser reparado. ${ }^{310}$

A tutela dos valores existenciais ${ }^{311}$ é outra premissa relevante na compreensão do processo de personalização do direito civil. É essencial para entender o próprio Direito na contemporaneidade. Tal viés reforça a necessidade de mudança no epicentro do dever de reparar, fenômeno percebido há quase setenta anos por David Campista Filho ${ }^{312}$ e que atualmente informa as reflexões de César Fiuza ${ }^{313}$, Eugênio Facchini Neto ${ }^{314}$, Judith Martins-Costa $^{315}$ e Maria Celina Bodin de Moraes. ${ }^{316}$

\footnotetext{
306 TRIMARCHI, Pietro. Istituzioni di diritto privato. 11 ed. Milano: Giuffré, 1996. p. 348.

${ }^{307}$ SALLES, Raquel Bellini de Oliveira. A justiça social e a solidariedade como fundamentos ético-jurídicos da responsabilidade civil objetiva, Revista Trimestral de Direito Civil, Rio de Janeiro, n. 18, p. 109-133, abr./jun. 2004. p. 132. Veja ainda: BUSNELLI, Francesco Donato. L'illecito civile nella stagione europea delle riforme del diritto delle obbligazioni, Rivista de Diritto Civile, Padova, anno 52, n. 6, p. 439-457, nov./dez. 2006. p. 447-449. O último autor, ao analisar o direito francês e alemão, percebe crescente preocupação com os danos causados à pessoa humana.
}

308 JOSSERAND, Louis. Evolução da responsabilidade civil, Revista Forense, Rio de Janeiro, n. 86, p. 5263, jun. 1941. p. 61.

${ }^{309}$ ROSAS, Cristian Patricio. Daños derivados de actividades riesgosas. In: GHERSI, Carlos Alberto (Dir.). Responsabilidad: problemática moderna. Mendoza: Ediciones Jurídicas Cuyo, 1996. p. 40. Consoante o autor, a responsabilidade subjetiva está lastreada na ideia de reprovação de uma conduta moralmente adotada por indivíduo livre.

${ }^{310}$ CAORSI, Juan Benítez. Reflexiones en torno a la noción de ilicitud, Revista de Direito Privado, São Paulo, n. 21, p. 287-294, jan./mar. 2005. p. 293-294.

${ }^{311}$ MORAES, Maria Celina Bodin de. A caminho de um direito civil constitucional, Revista de Direito Civil Imobiliário, Agrário e Empresarial, São Paulo, v. 17, n. 65, p. 21-32, jul./set. 1993. p. 25. “A transformação não é de pequena monta. Ao invés [sic] da lógica proprietária, da lógica produtivista, empresarial (em uma palavra, patrimonial), são os valores existenciais que, porque privilegiados pela Constituição, se tornam prioritários no âmbito do direito civil."

312 CAMPISTA FILHO, David. Responsabilidade civil e a ação liberatória do seguro, Revista dos Tribunais, São Paulo, v. 31, n. 137, p. 16-25, mai. 1942. p. 20.

${ }^{313}$ FIUZA, César. Para uma releitura da teoria geral da responsabilidade civil, Revista da Faculdade Mineira de Direito, Belo Horizonte, v. 7, n. 13/14, p. 9-15, 2004. p. 14-15. “Afinal, ninguém poderia, em tese, sofrer 
E aqui é oportuno apontar que a responsabilidade objetiva é uma das respostas encontradas para os problemas criados pela sociedade contemporânea. ${ }^{317}$ Como demonstrado outrora, nela "o epicentro [das preocupações] é o respeito pelo homem." ${ }^{318} \mathrm{E}$, se a reparação dos danos se encontra, hodiernamente, ancorada em premissas que visam ao contínuo desenvolvimento de cada - e também de todas - pessoa humana, considerada aqui em sua mais ampla dimensão ${ }^{319}$, não há como ignorar que é hora de enterrar os fantasmas - e aqui se encontra incluída a culpa - que teimam em negar essa realidade.

Aceitar essa metamorfose é tarefa bastante complexa. Isso não se nega. É difícil compreender como referenciais utilizados por longa data pelos seres humanos podem desaparecer. ${ }^{320}$ É inegável, entretanto, que o fundamento ético-jurídico do dever de reparar se encontra informado por fatores objetivos de imputabilidade. Hodiernamente, a proteção consagrada no Direito atingirá quem quer que seja injustamente lesado ${ }^{321}$, independentemente da presença de culpados.

Outra importante consequência do processo de personalização do direito civil cinge-se à despatrimonialização do dano. É factível pensar que, em vez da reparação em

danos injustamente e não ter direito à reparação, a não ser que o dano não possa ser imputável à conduta de alguém."

314 FACCHINI NETO, Eugênio. Prefácio. In: VAZ, Caroline. Funções da responsabilidade civil: da reparação à punição ou dissuasão: os punitive damages no direito comparado e brasileiro. Porto Alegre: LAEL, 2009. p. 8.

315 MARTINS-COSTA, Judith. Um aspecto na obrigação de indenizar: notas para uma sistematização dos deveres pré-negociais de proteção no direito civil brasileiro, Revista dos Tribunais, São Paulo, v. 97, n. 867, p. 11-51, jan. 2008. p. 13. "Há uma revolução copernicana de enfoque na responsabilidade civil que reverbera nos seus pressupostos e perpassa a sua técnica: para o bem ou para o mal, agora se privilegia o olhar sobre a vítima, rompendo-se a equação moral que, centrada no exame da conduta do agente, causador do dano, alicerçou por séculos o instituto."

${ }^{316}$ MORAES, Maria Celina Bodin de. A caminho de um direito civil constitucional, Revista de Direito Civil Imobiliário, Agrário e Empresarial, São Paulo, v. 17, n. 65, p. 21-32, jul./set. 1993. p. 23. "Os objetivos constitucionais de construção de uma sociedade livre, justa e solidária e de erradicação da pobreza colocaram a pessoa humana - isto é, os valores existenciais - no vértice do ordenamento jurídico brasileiro, de modo que tal é o valor que conforma todos os ramos do Direito."

317 AGOGLIA, María Martha; BORAGINA, Juan Carlos; MEZA, Jorge Alfredo. Responsabilidad por incumplimiento contractual. Buenos Aires: Hammurabi, 2003. p. 99.

${ }^{318}$ WEINGARTEN, Celia. La equidad como principio de seguridad económica para los contratantes, Revista de Direito do Consumidor, São Paulo, v. 10, n. 39, p. 32-40, jul./set. 2001. p. 40.

${ }^{319}$ HIRONAKA, Giselda Maria Fernandes Novaes. Responsabilidade pressuposta. Belo Horizonte: Del Rey, 2005. p. 111.

${ }^{320}$ COELHO, Luiz Fernando. Saudade do futuro. 2 ed. Curitiba: Juruá, 2007. p. 60-63.

321 MORAES, Maria Celina Bodin de. Risco, solidariedade e responsabilidade objetiva, Revista dos Tribunais, São Paulo, v. 95, n. 854, p. 11-37, dez. 2006. p. 26. 
pecúnia, sanções como a retratação pública ${ }^{322}$ ou outras formas de tutela específica ${ }^{323}$ devam ser pensadas quando se pondera acerca dessas questões. Soluções, aliás, em princípio, ontologicamente preferíveis quando comparadas à tutela reparatória.

Enfim, talvez seja possível afirmar que as luzes identificadas até aqui estão a indicar a existência de possibilidades. Se elas existem, deve-se ir em frente, pois, como apregoado por Luiz Edson Fachin, é preciso continuar a "reconstruir o sujeito, [esse] ser coletivo." 324 Esse caminho existe, embora não esteja demarcado. Nele, sem dúvida, os atalhos que aludem à culpa são extremamente perigosos.

\subsection{A incontrolabilidade dos danos na sociedade contemporânea}

Quando a Idade Média foi deixada para trás - com o advento da Modernidade $^{325}$-, projetou-se um futuro no qual o bem-estar de todos seria alcançado. Triunfa a razão, projetada em todos os saberes e setores da vida humana. ${ }^{326}$

A ciência - única forma válida do conhecimento - permitiria, em um futuro próximo, controlar as forças da natureza, auxiliando o homem a construir seu destino. ${ }^{327}$ Os cientistas da modernidade pretendiam ser "os bibliotecários de Babel." 328

${ }^{322}$ SCHREIBER, Anderson. Novas tendências da responsabilidade civil brasileira, Revista Trimestral de Direito Civil, Rio de Janeiro, n. 22, p. 45-70, abr./jun. 2005. p. 64-66.

${ }^{323}$ Sobre o tema: RIBEIRO, Darci Guimarães. Da tutela jurisdicional às formas de tutela. Porto Alegre: LAEL, 2010. p. 187-189.

${ }^{324}$ FACHIN, Luiz Edson. Teoria crítica do direito civil. Rio de Janeiro: Renovar, 2000. p. 13-14.

${ }^{325}$ BAUMAN, Zygmunt. Modernidade líquida. Trad. Plínio Dentzien. Rio de Janeiro: Zahar, 2001. p. 15. “A modernidade começa quando o espaço e o tempo são separados da prática da vida e entre si, e assim podem ser teorizados como categorias distintas e mutuamente independentes da estratégia e da ação; quando deixam de ser, como eram ao longo dos séculos pré-modernos, aspectos entrelaçados e dificilmente distinguíveis da experiência vivida, presos numa estável e aparentemente invulnerável correspondência biunívoca."

${ }^{326}$ TOURAINE, Alain. Um novo paradigma: para compreender o mundo de hoje. 3 ed. Trad. Gentil Avelino Titton. Petrópolis: Vozes, 2007. p. 86-87. Segundo o autor, a modernidade tem como paradigmas principais a "crença na razão e na ação racional" e o "reconhecimento dos direitos do indivíduo, ou seja, a afirmação de um universalismo que concede a todos os indivíduos os mesmos direitos, sejam quais forem seus atributos econômicos, sociais ou políticos." Veja ainda: COELHO, Luiz Fernando. Saudade do futuro. 2 ed. Curitiba: Juruá, 2007. p. 29. "No plano filosófico, a modernidade representa o triunfo do racionalismo sobre as formas de pensamento dominadas pelo dogmatismo teológico, conduzindo ao Iluminismo do século XVIII."

${ }^{327}$ FREIRE, Ricardo Maurício. Tendências do pensamento jurídico contemporâneo. Salvador: Podivm, 2007. p. 14-16. Em "suas conotações mais positivas, o conceito de modernidade indica uma formação social que multiplicava sua capacidade produtiva, pelo aproveitamento mais eficaz dos recursos humanos e materiais, graças ao desenvolvimento técnico e científico, de modo que as necessidades sociais pudessem ser respondidas, com o uso mais rigoroso e sistemático da razão. A modernidade caracterizava-se também pela 
Na sociedade agrária da Modernidade - e mesmo quando esse modelo passa a coexistir com as novas perspectivas e técnicas a ele acopladas pela Revolução Industrial ${ }^{329}$ -, talvez fosse possível que um projeto de tamanha amplitude pudesse ser concebido como algo viável. Nesse momento da História, os riscos, expressão que remonta originalmente ao desconhecido - a "aquilo que não se encontra nas cartas de navegação" -, derivavam de eventos naturais, afastando-se de sua noção quaisquer situações com gênese na ação humana. ${ }^{330}$

Especificamente no que alude ao não cumprimento do contrato - que se apresenta a partir de tipos legalmente previstos -, parece importante salientar aqui, em especial por conta dos poucos tipos contratuais existentes, que os problemas nessa ambiência poderiam ser antevistos, sendo raras as contingências ligadas ao tema. Sob esse aspecto, durante o século XIX, também nessa seara, foi possível gerir as incertezas mediante a adoção de condutas previdentes em nível individual.

forma participativa das tomadas de decisões na vida social, valorizando o método democrático e as liberdades individuais. O objetivo da sociedade moderna era oferecer uma vida digna, na qual cada um possa realizar sua personalidade, abandonando as constrições de autoridades externas e ingressando na plenitude expressiva da própria subjetividade. [...] A idéia de modernidade denotava, assim, o triunfo de uma razão redentora, que se projetaria nos diversos setores da atividade humana. Esta razão deflagaria a secularização do conhecimento, conforme os arquétipos da física, geometria e matemática. Viabilizaria a racionalidade cognitivo-instrumental da ciência, concebida como a única forma válida de saber. Potencializaria, através [sic, leia-se por meio] do desenvolvimento científico, o controle das forças adversas da natureza, retirando o ser humano do reino das necessidades. Permitiria ao homem construir o seu destino, livre do jugo da tradição, da tirania, da autoridade e da sanção religiosa."

${ }^{328}$ WARAT, Luis Alberto. A rua grita dionísio: direitos humanos da alteridade, surrealismo e cartografia. Trad. e Org. Vivian Alves de Assis; Júlio Cesar Marcellino Junior; Alexandre Morais da Rosa. Rio de Janeiro: Lumen Juris, 2010. p. 7.

329 PINHEIRO PEDRO. Antônio Fernando. Aspectos ideológicos do meio ambiente. In: SILVA, Bruno Campos (Org.). Direito ambiental: enfoques variados. São Paulo: Lemos \& Cruz, 2004. p. 19. “A Revolução Industrial, de início, libertou seus agentes econômicos dos valores éticos agrários, feudais, estamentais e religiosos que reduziam o indivíduo comum à perspectiva transcendental da subordinação, humildade e desapego dos bens materiais (postos na Terra para desfrute dos senhores do antigo regime). [...] O arcabouço de direito dessa primeira geração de demandas, portanto, buscou atender à liberalização de consumo e produção para o consumo em escala, instituindo a possibilidade de ter-se propriedade de bens e liberdade de contratar, como tradução da liberdade individual."

${ }^{330}$ MENDES, Felismina. Risco: um conceito do passado que colonizou o presente, Revista Portuguesa de Saúde Pública, Lisboa, v. 20, n. 2, p. 53-62, jul./dez. 2002. p. 54. “A noção de risco adquiriu expressão durante os séculos XVI e XVII e começou por ser usada pelos exploradores ocidentais quando partiam para as viagens que os levavam a todas as partes do mundo. A palavra risco parece ter chegado ao inglês através [sic] do espanhol ou do português, línguas em que era utilizada para caracterizar a navegação em mares desconhecidos, ainda não descritos nas cartas de navegação. [...] Nesse tempo, o risco designava a possibilidade de um perigo objectivo, um acto de Deus, uma força maior ou uma tempestade que pudesse comprometer a viagem e que não pudesse ser imputado a uma conduta humana errada. Este conceito de risco excluía a idéia de falha ou de responsabilidade humana. O risco era percebido como um evento natural e, como tal, os humanos pouco mais podiam fazer do que tentarem estimar quando estes acontecimentos iriam surgir e actuarem no sentido de reduzirem o seu impacto." 
Talvez seja possível entender por que a culpa se encaixa, com peculiar precisão, nesse modelo: a conduta será sancionada apenas se não forem tomadas as cautelas necessárias para evitar um dano previsível. Por outro lado, a solução para os problemas que não têm origem em uma falha ou desvio de conduta é abandonada aos desígnios do destino ${ }^{331}$ ou colocada nas de Deus. ${ }^{332}$

A Modernidade - marcada pela promessa de deleite a ser alcançado universalmente a partir do desenvolvimento científico e tecnológico - vê o risco como algo passível de sistematização e controle. ${ }^{333}$ É indubitável que a evolução científica, o crescimento industrial e o incremento da produtividade agropecuária, dentre outros frutos dessa era, possibilitaram mais qualidade de vida e melhores condições de saúde e de educação para certa parcela da população. ${ }^{334}$

As vantagens prometidas pela Modernidade, entretanto, não permitem a visualização de seus aspectos negativos ${ }^{335}$, os quais cresceram em assustadora progressão. Ou talvez os homens os tenham ignorado propositalmente. Em que pese o aviltamento dos problemas, colabora com a manutenção do modelo vigente o fato de que riscos nessa quadra do tempo recaem - ao menos, de forma mais acentuada -, nas camadas menos favorecidas da população. ${ }^{336}$

O homem moderno - e, especialmente aquele que compõe a classe dominante - foi transformado, nesse contexto, em um ser isolado. Em vez de colaborar, passa a

331 ESPINOLA, Eduardo. Systema do direito civil brasileiro: theoria geral das relações jurídicas de obrigação. Rio de Janeiro: Porto, 1912, v. 2, t. 1. p. 359. "Sob o ponto de vista do direito, o acaso se apresenta como um acontecimento estranho à vontade do devedor."

${ }^{332}$ HAMMERSCHMIDT, Denise. O risco na sociedade contemporânea e o princípio da precaução no direito ambiental, Revista Seqüência, Florianópolis, n. 45, p. 97-122, dez. de 2002. p. 99. A assertiva da autora permite identificar (ao buscar uma solução metafísica para questões que ainda não têm lastro seguro na razão) uma característica relevante na análise evolutiva de uma sociedade: o novo não substitui o antigo; ao menos, não necessariamente.

333 LÓPEZ, Andrés Mariño. Los fundamentos de la responsabilidad contractual. Montevideo: Carlos Alvarez, 2005. p. 34.

334 Nesse sentido: LANFREDI, Geraldo Ferreira. Política ambiental: busca de efetividade de seus instrumentos. São Paulo: RT, 2002. p. 17. "A formidável transformação histórica desencadeada pela Revolução Industrial ocorrida no séc. XIX, que resultou na introdução de máquinas no processo produtivo, conduziu a relevantes reflexos econômicos e políticos, além dos sociais, no Ocidente."

${ }^{335}$ BARRIOS, Luis. El conflicto de la celulosa. Estado de derecho. Montevideo, p. 12, dez. 2007.

${ }^{336}$ CARVALHO, Délton Winter de. Dano ambiental futuro: a responsabilização pelo risco ambiental. Rio de Janeiro: Forense Universitária, 2008. p. 57. 
concorrer com os outros ${ }^{337}$ em busca de um dos poucos lugares reservados aos vencedores. Esse mesmo homem torna-se tão dependente da técnica que passa a evitar, no mais das vezes, a necessidade de avaliar racionalmente as consequências negativas provocadas pelo desenvolvimento científico e tecnológico. ${ }^{338}$ Abandonar as benesses da técnica é uma alternativa irreal.

A Modernidade, consoante trilha o tempo, fragmenta a vida ${ }^{339}$, impedindo a adequada compreensão de muitas das relações existentes. ${ }^{340} \mathrm{O}$ pensamento torna-se abissal. $^{341}$ Quase tudo é analisado atomisticamente e, nessa esteira, os raciocínios formulados a partir dos pilares de uma ciência redentora, normalmente, são bastante reducionistas. $^{342}$

Mas nem todos se permitem serem seduzidos pelo brilho do ouro. Como exemplo, vale lembrar que, há quase um século, Louis Josserand, percebendo a aproximação de um horizonte assustador, denunciava que o homem se serve de forças cuja essência íntima desconhece. ${ }^{343}$ Mal sabia o autor o que estava no porvir.

${ }^{337}$ CORTIANO JUNIOR, Eroulths. O discurso jurídico da propriedade e suas rupturas: uma análise do ensino do direito de propriedade. Rio de Janeiro: Renovar, 2002. p. 49-50.

${ }^{338}$ ROSAS, Cristian Patricio. Daños derivados de actividades riesgosas. In: GHERSI, Carlos Alberto (Dir.). Responsabilidad: problemática moderna. Mendoza: Ediciones Jurídicas Cuyo, 1996. p. 40.

${ }^{339}$ LORENZETTI, Ricardo Luis. A era da desordem e o fenômeno da descodificação, Revista de Direito do Consumidor, São Paulo, v. 17, n. 68, p. 212-241, out./dez. 2008. p. 224-225. "O tempo virtual, igualmente ao espaço, se separou das categorias comunitárias e naturais que configuram o tempo real. $\mathrm{O}$ dia e a noite definiram o tempo para o trabalho e o descanso, mas agora se trabalha em lugares fechados diante de computadores, sem prestar atenção ao dia e à noite. Não interessa a natureza e tampouco a comunidade; se antes havia horários reservados para determinadas atividades, agora desapareceram: na família, por exemplo, um trabalha, outro se diverte, outro passeia, outro compra, no mesmo horário, porque tudo pode ser feito a qualquer tempo."

${ }^{340}$ FAGÚNDEZ, Paulo Roney Ávila. O significado da modernidade. In: LEITE, José Rubens Morato; BELLO FILHO, Ney de Barros (Coord.). Direito ambiental contemporâneo. Barueri: Manole, 2004. p. 225228.

${ }^{341}$ SOUZA SANTOS, Boaventura de. Para além do pensamento abissal: das linhas globais a uma ecologia de saberes, Revista Crítica de Ciências Sociais, Coimbra, v. 78, p. 3-46, out. 2007. p. 3-12.

342 CAPRA, Fritjof. O ponto de mutação: a ciência, a sociedade e a cultura emergente. São Paulo: Cultrix, 1997. p. 54-55. Como ensina o autor, "o método de Descartes é analítico. Consiste em decompor pensamentos e problemas em suas partes componentes e em dispô-las em sua ordem lógica. Esse método analítico de raciocínio é provavelmente a maior contribuição de Descartes à ciência. Tornou-se uma característica essencial do moderno pensamento científico e provou ser extremamente útil no desenvolvimento de teorias científicas e na concretização de complexos projetos tecnológicos. Foi o método de Descartes que tornou possível à NASA levar o homem à Lua. Por outro lado, a excessiva ênfase dada ao método cartesiano levou à fragmentação característica do nosso pensamento em geral e das nossas disciplinas acadêmicas, e levou à atitude generalizada de reducionismo na ciência - a crença em que todos os aspectos dos fenômenos complexos podem ser compreendidos se reduzidos às suas partes constituintes."

343 JOSSERAND, Louis. Evolução da responsabilidade civil, Revista Forense, Rio de Janeiro, n. 86, p. 5263, jun. 1941. p. 53. Apesar da relativa extensão da passagem, impossível não transcrevê-la neste momento, 
A modernidade entra em crise. ${ }^{344} \mathrm{O}$ modelo precisa ser substituído e, de fato, está em vias de sê-lo. Para alguns, a transição iniciou-se há algo em torno de quatro décadas $^{345}$; outros frisam que o processo tem seu marco inicial fincado um pouco antes, cerca de seis décadas atrás. ${ }^{346}$

São tantas as dúvidas que ainda não existe sequer uma denominação precisa para esse momento de metamorfose vivido em nível global: alta modernidade ${ }^{347}$,

diante da beleza quase melódica que brota da construção formulada pelo autor e traduzida para o português por Raul Lima: “Antes, ao tempo dos nossos antepassados, o acidente era raro, ou, pelo menos, apresentavase sob uma feição tal que não era absolutamente gerador de responsabilidades; as guerras, o assassinato, as epidemias, a fome, faziam muitas vítimas, mas se suportava então, sem recurso, o que se chamou de riscos da humanidade, pois não se podia cogitar de pedir contas de sua desgraça a quem quer que fosse. Numa época em que reinava só a pequena indústria, quando o operário manejava individualmente utensílios inofensivos, quando as viagens, mesmo consideráveis, eram feitas a pé ou em veículos a tração animal, os fatos suscetíveis de importar em responsabilidade delitual, puramente civil, eram pouco freqüentes, e o homem se sentia em segurança, na rua como na oficina ou na loja. Que mudanças depois dessa idade de ouro que era também a da imobilidade! Ao homem sedentário sucedeu um ser que parece pertencer a uma raça diferente, que se movimenta sem cessar, para seus negócios, para seu prazer, para vir fazer conferências diante de vós, e que recorre, para esse fim, a engenhos maravilhosos e rápidos, mas suscetíveis de causar catástrofes medonhas; a artérias das grandes cidades, onde a erva outrora crescia discretamente, são cortadas em todos os sentidos por veículos rápidos e diversos, que se cruzam e se chocam, por vezes não sem brutalidade; ao trabalho individual, a domicílio, sucedeu o labor coletivo nas oficinas, nas usinas, que ocupam centenas, milhares, dezenas de milhares de operários; os instrumentos inofensivos de antanho foram substituídos por máquinas cujo poder é terrível; o homem captou e utiliza as forças das quais ele não penetra sempre a essência íntima: a eletricidade, os raios X, o radium; multiplicam-se os acidentes, muitos permanecem anônimos e sua causa verdadeira fica desconhecida; os acidentes de locomoção alimentam a crônica dos jornais e fazem cada dia, na Europa, milhares de vítimas; a segurança na via pública, mesmo nas calçadas, onde os automóveis se arriscam às vezes em desagradáveis incursões, não é perfeita; e será menos ainda, quando reinar praticamente a aviação, quando veículos aéreos circularem incessantemente acima das nossas cabeças, deixando cair sobre nosso planeta objetos de pesos e de dimensões variadas; então, o homem da rua [...], ocupará uma posição subordinada que não será de repouso. O século do caminho de ferro, do automóvel, do avião, da grande indústria e do maquinismo, o século do transporte e da mecanização universal, não será precisamente o século da segurança material."

${ }^{344}$ MASI, Domenico de. A sociedade pós-industrial. In: MASI, Domenico de. A sociedade pós-industrial. 4 ed. Trad. Anna Maria Capovilla et all. São Paulo: Senac, 2003. p. 30. "Na realidade, a sensação de crise é uma crise de modelos interpretativos, é uma resistência às mudanças causada [sic] pelo fosso cultural, fazendo com que nossas atitudes e nossos comportamentos derivem de categorias sedimentadas no decorrer dos séculos rurais e industriais, profundamente arraigadas em nossa personalidade e dificilmente substituíveis a curto prazo. Aliás, dificuldades análogas ocorreram também na transição da sociedade rural para a industrial, com uma diferença fundamental: o elemento estrutural sobre o qual se baseara a sociedade industrial - isto é, a fábrica - difundiu-se com uma lentidão intrínseca; por isso, ainda hoje, dois séculos depois de seu aparecimento, permanecem vastas zonas do planeta que ainda não foram alcançadas pelos complexos industriais e até mesmo por seus produtos."

${ }^{345}$ COELHO, Luiz Fernando. Saudade do futuro. 2 ed. Curitiba: Juruá, 2007. p. 30-36.

346 GUERRA FILHO, Willis Santiago. Pós-modernismo, pós-positivismo e a filosofia do direito, Nomos, Fortaleza, v. 15, n. 1/2, p. 13-17, jan./dez. 1996. p. 15. Veja ainda: MASI, Domenico de. A sociedade pósindustrial. In: MASI, Domenico de. A sociedade pós-industrial. 4 ed. Trad. Anna Maria Capovilla et all. São Paulo: Senac, 2003. p. 66-67. Segundo o autor, "se devemos privilegiar um ponto como início claro [...] pretendemos identificá-lo no ato cruel e onipotente com o qual, no dia 6 de agosto de 1945, alguém, por ordem de outrem, realizava um gesto programado por outras pessoas em seus mínimos detalhes [...]”

347 GIDDENS, Anthony. As conseqüências da modernidade. Trad. Raul Fiker. São Paulo: Unesp, 1991. passim. $\mathrm{O}$ autor não aceita que o momento atual possa ser denominado pós-modernidade por acreditar que as 
modernidade reflexiva ${ }^{348}$, sociedade pós-industrial ${ }^{349}$, sociedade de risco ${ }^{350}$, transmodernidade ${ }^{351}$ e pós-modernidade ${ }^{352}$ estão entre as expressões mais comuns. ${ }^{353}$ Uma das poucas certezas nesse universo é que todas elas se propõem a rotular uma sociedade marcada inegavelmente pelo "tecnocentrismo.",354

A transição vivida hodiernamente, por outro lado, não implica necessariamente uma revolução ${ }^{355}$, até porque os aspectos centrais do modelo anterior continuarão

balizas que delimitam a modernidade não foram ultrapassadas especialmente em razão da falta de opções possíveis.

${ }^{348}$ BECK, Ulrich. Viviendo en la sociedad del riesgo mundial. Trad. María Ángeles Sabiote González; Yago Mellado López. Barcelona: CIDOB, 2007. p. 19. "La teoría de la sociedad del riesgo mundial aborda la comprensión de la ubicuidad irreprimible de la incertidumbre radical en el mundo moderno. Las instituciones básicas, los actores de la primera modernidad - la ciencia y los sistemas especializados, el Estado, el comercio y el sistema internacional, incluyendo el militar - responsables del cálculo y del control de las incertidumbres fabricadas están socavados por una conciencia creciente acerca de su ineficiencia, e incluso de las consecuencias contraproducentes de sus acciones. Esto no ocurre de cualquier manera sino sistemáticamente. La radicalización de la modernidad genera esta ironía fundamental del riesgo: la ciencia, el Estado y el ejército se están convirtiendo en parte de un problema que supuestamente deberían resolver. Esto es lo que significa la "modernidad reflexiva": no vivimos en un mundo postmoderno, sino en un mundo másmoderno. No es la crisis, sino la victoria de la modernidad, a través de la cual la lógica de los efectos secundarios desconocidos e involuntarios socava las instituciones básicas de la primera modernidad."

${ }^{349}$ MASI, Domenico de. A sociedade pós-industrial. In: MASI, Domenico de. A sociedade pós-industrial. 4 ed. Trad. Anna Maria Capovilla et all. São Paulo: Senac, 2003. p. 18.

${ }^{350}$ GIDDENS, Anthony; BECK, Ulrich; LASH, Scott. Modernização reflexiva: política, tradição e estética na ordem social moderna. Trad. Magda Lopes. São Paulo: Unesp, 1997. p. 15-17. A expressão sociedade de risco reflete um momento no desenvolvimento da sociedade hodierna no qual "os riscos sociais, políticos, econômicos e individuais tendem cada vez mais a escapar das instituições para o controle e a proteção da sociedade industrial [...] designa um estágio da modernidade em que começam a tomar corpo as ameaças produzidas até então no caminho da sociedade industrial."

${ }^{351}$ COELHO, Luiz Fernando. Saudade do futuro. 2 ed. Curitiba: Juruá, 2007. p. 30. A “transmodernidade [...] se distingue da modernidade e da pós-modernidade na medida em que alude a uma fase de transição para um futuro ainda não definido, mas que, desde logo, envolvem [sic] aspectos que levam a uma superação dos velhos paradigmas de comportamento individual e coletivo e dos modelos de saber já consolidados como algo produzido pela modernidade. Ela passa a ser compreendida como antecipação de um futuro que, antes vivenciado na ficção, nas profecias, conjecturas e utopias, já se apresenta como definitivo, ao catalisar as energias da humanidade."

${ }^{352}$ COELHO, Luiz Fernando. Saudade do futuro. 2 ed. Curitiba: Juruá, 2007. p. 30. "Embora em geral se fale em modernidade para aludir às grandes transformações ocorridas no passado século, as ciências humanas caracterizam a contemporaneidade como pós-modernidade."

${ }^{353}$ MASI, Domenico de. A sociedade pós-industrial. In: MASI, Domenico de. A sociedade pós-industrial. 4 ed. Trad. Anna Maria Capovilla et all. São Paulo: Senac, 2003. p. 33. Segundo o autor, seriam mais de trezentas denominações utilizadas em mais de mil títulos publicados. Isso forneceria "motivos suficientes para não aceitar nenhuma delas."

${ }^{354}$ BARROSO, Lucas Abreu. A obrigação de indenizar e a determinação da responsabilidade civil por dano ambiental. Rio de Janeiro: Forense, 2006. p. 16. Consoante o autor, o tecnocentrismo representa a "doutrina que preleva a técnica como elemento cêntrico da reflexão ao redor da qual orbita toda aproximação à realidade."

${ }^{355}$ BAUMAN, Zygmunt. Modernidade e ambivalência. Trad. Marcus Penchel. Rio de Janeiro: Zahar, 1999. p. 288. “A pós-modernidade não significa necessariamente o fim, o descrédito ou a rejeição da modernidade. Não é mais (nem menos) que a mente moderna a examinar-se longa, atenta e sobriamente, a examinar sua condição e suas obras passadas, sem gostar muito do que vê e percebendo a necessidade de mudança. A pós- 
presentes $^{356}$, ainda que em nível periférico. Enquanto a sociedade clássica se assemelhava "a um castelo de pedra", a atual pode ser comparada a uma "paisagem em movimento",357 ou a um reality show, construído a cada dia, sem roteiro prévio.

Em verdade, a humanidade parece encontrar-se sobre uma esteira em constante movimento. E, para tornar a situação ainda mais complexa - e mais próxima do momento vivido -, não há controle algum sobre quando ou onde irá parar. Sem dúvida, quando e se for permitido aos homens descer dessa esteira, as paisagens serão, no mínimo, vistas sob ângulos distintos, o que implica - na hipótese - novas formas de compreensão de uma realidade que continuará intrinsecamente a mesma.

Parece importante, então, compreender esse momento vivido pela humanidade $^{358}$ e suas principais características. Consoante a lição de Cláudia Lima Marques, a cultura pós-moderna seria marcada por quatro elementos: o pluralismo, a comunicação, a narração e o retorno dos sentimentos. ${ }^{359}$ Tais premissas são fundamentais para a compreensão - e operacionalização - adequada do Direito na contemporaneidade.

modernidade é a modernidade que atinge a maioridade, a modernidade olhando-se a distância e não de dentro, fazendo um inventário completo de ganhos e perdas, psicanalizando-se [...] chegando a um acordo com sua própria impossibilidade, uma modernidade que se automonitora, que conscientemente descarta o que outrora fazia inconscientemente."

${ }^{356}$ MASI, Domenico de. A sociedade pós-industrial. In: MASI, Domenico de. A sociedade pós-industrial. 4 ed. Trad. Anna Maria Capovilla et all. São Paulo: Senac, 2003. p. 31. Consoante o autor, "a passagem de uma fase para a outra não significa uma substituição radical da primeira pela segunda, significa apenas que um elemento se torna central em lugar de outro, o qual perde a própria hegemonia, mas não sua presença e influência."

${ }^{357}$ TOURAINE, Alain. Um novo paradigma: para compreender o mundo de hoje. 3 ed. Trad. Gentil Avelino Titton. Petrópolis: Vozes, 2007. p. 110.

${ }^{358}$ LIMA, Hermes. Introdução à ciência do direito. 33 ed. Rio de Janeiro: Freitas Bastos, 2002. p. 12-13. "A sociedade, complexo de pessoas e coisas, exige necessariamente uma organização, que, orientando a vida coletiva, discipline a atividade dos indivíduos e assegure a distribuição dos bens. [...] Seria impossível entender os sistemas sociais sem referi-los fundamentalmente às relações que o modo de produzir de uma dada época condiciona e torna plausíveis. [...] Mas o espírito humano não vive no vazio nem retira de si mesmo as idéias e planos, como se obrasse independente da realidade social. [...] A consciência não retira das próprias entranhas nenhum conhecimento próprio e idôneo para dirigir e modelar autonomamente a realidade. [...] A matéria social está nas relações que se nucleiam em torno do modo pelo qual se produzem os bens."

${ }^{359}$ MARQUES, Cláudia Lima. Direito na pós-modernidade e a teoria de Erik Jayme. In: OLIVEIRA JUNIOR, José Alcebíades (Org.). Faces do multiculturalismo: teoria, política, direito. Santo Ângelo: Ediuri, 2007. p. 28-29. "Pluralismo de fontes legislativas a regular o fato, pluralismo de sujeitos a proteger, por vezes difusos, como o grupo de consumidores ou os que se beneficiam da proteção do meio ambiente, pluralidade de agentes ativos, em relações extremamente despersonalizadas, múltiplas, multifacetadas. Pluralismo na Filosofia aceita, onde o diálogo é que legitima o consenso, onde os valores e princípios têm sempre uma dupla função, o "double coding" e onde os valores são, muitas vezes, antinômicos. O pluralismo de fontes legislativas é hoje total, a ponto do diálogo das fontes nacionais e internacionais (mesmo soft law) nascer o novo direito. A comunicação é um valor máximo da pós-modernidade, associado à valorização extrema do tempo, do direito como instrumento de comunicação, de informação, como valorização do passar 
Em nível social, dentre os traços mais marcantes do momento vivido estão a primazia do conhecimento teórico no planejamento da vida - em suas multifacetadas manifestações individuais e coletivas -; a concentração de material humano no setor terciário da economia; a valorização do lazer e da busca por qualidade de vida; além da fluidez dos conflitos - "a luta saiu da fábrica e invadiu a sociedade" ${ }^{360}$-, premissa essa que dificulta saber quem são os mocinhos e os vilões da atualidade.

Importante salientar ainda que outra marca expressiva do período atravessado pela humanidade é a velocidade na qual se desenrolam as transformações das tecnologias. Esse processo, por sua vez, acelera o curso da própria História. ${ }^{361}$ A reflexividade é, ao mesmo tempo, produto e característica indelével da sociedade contemporânea, induzindo à modificação constante, contínua e cada vez mais veloz da vida social. ${ }^{362}$

Nesse contexto, surgem novas formas contratuais - contratos, muitas vezes, vestidos de forma atípica e (ou) inominada, o que amplia bastante os efeitos das contingências -, e uma miríade de danos absolutamente imprevisíveis passam a ser contabilizados.

do tempo nas relações humanas, valorização do eterno e do transitório, do congelar momentos e ações para garantir a proteção dos mais fracos e dos grupos que a lei quer privilegiar. A comunicação é o método de legitimação [...]. O consentimento legitimador, alerta o mestre, é só aquele informado e esclarecido. [...] A narração é a conseqüência desse impulso de comunicação, de informação que invade a Filosofia do Direito e as próprias normas legais. Haveria um novo método de elaborar normas legais, não normas para regular condutas, mas normas que narram seus objetivos, seus princípios, suas finalidades, positivando os objetivos do legislador no sistema de forma a auxiliar na interpretação teleológica e no efeito útil das normas. Um belo exemplo são essas novas normas do Direito contemporâneo, que Erik Jayme denominou "normas narrativas." Com tal fluidez e narratividade, o papel do intérprete e aplicador da lei se multiplica. Essas transformações na interpretação das leis e na Filosofia do Direito se fariam sentir também no aparecimento de movimentos contestatórios da dogmática tradicional, uma forte Jurisprudência de valores, estudos críticos e direito alternativo, em uma geral flexibilização, fragmentação e mesmo descaracterização do dogma ou crença no sistema geral de direito, mas também - positivamente - na grande influência representada pelos direitos fundamentais no direito privado. Por fim, a quarta característica da cultura pós-moderna a afetar a ciência do direito é o que Jayme denomina "retour des sentiments." Seria, de um lado, a volta de uma certa "emocionalidade" no discurso jurídico, de outro lado, é o imponderável, a procura de novos elementos sociais, ideológicos, religiosos e/ou fora do sistema, que passam a incluir a argumentação e as decisões jurídicas, criando forte insegurança e imprevisibilidade quanto à solução a ser efetivamente encontrada."

${ }^{360}$ MASI, Domenico de. A sociedade pós-industrial. In: MASI, Domenico de. A sociedade pós-industrial. 4 ed. Trad. Anna Maria Capovilla et all. São Paulo: Senac, 2003. p. 50 e 78.

${ }^{361}$ COELHO, Luiz Fernando. Saudade do futuro. 2 ed. Curitiba: Juruá, 2007. p. 58-59.

362 GIDDENS, Anthony. As conseqüências da modernidade. Trad. Raul Fiker. São Paulo: Unesp, 1991. p. 45. "A reflexidade da vida social moderna consiste no fato de que as práticas sociais são constantemente examinadas e reformadas à luz de informação renovada sobre essas próprias práticas, alterando assim constitutivamente seu caráter." 
Não há como estabelecer qual o comportamento a ser adotado. A insegurança permeia todos os momentos da vida. ${ }^{363}$ Acoplem-se à problemática os bens e serviços surgidos ou aperfeiçoados nas últimas décadas em razão da evolução tecnológica ${ }^{364}$, dentre os quais, podem ser lembrados: os organismos geneticamente modificados e os bens de consumo que os utilizam; as nanotecnologias; a multiplicação dos produtos farmacológicos, das cirurgias e das técnicas, almejando transformações estéticas e físicas; a poluição eletromagnética, oriunda das tecnologias de transmissão de dados e o estímulo a um consumismo absurdamente inconsequente.

Fica fácil perceber por que a culpa perdeu seu espaço nesse admirável mundo novo. É hialino que a ela não foi reservado nenhum lugar na contemporaneidade. Cumpriu o papel que lhe fora reservado na sociedade pré-industrial. Protegeu o patrimônio e permitiu sua acumulação ao balizar a solução de conflitos de cunho individual, com atores conhecidos $^{365}$ e que desempenhavam os mesmos papéis em novelas quase sempre muito parecidas.

E isso porque, como denunciado, as contingências da contemporaneidade afastam a possibilidade de juízos de previsibilidade. ${ }^{366}$ A humanidade caminha diuturnamente sobre solo instável, movediço. Antigos portos seguros transformaram-se em produtores de riscos. ${ }^{367}$

${ }^{363}$ BAUMAN, Zygmunt. Modernidade líquida. Trad. Plínio Dentzien. Rio de Janeiro: Zahar, 2001. p. 70-71. "Os passageiros do avião "Capitalismo Leve" [da contemporaneidade] descobrem horrorizados que a cabine do piloto está vazia e que não há meio de extrair da "caixa preta" chamada piloto automático qualquer informação sobre para onde vai o avião, onde aterrissará, quem escolherá o aeroporto e sobre se existem regras que permitam que os passageiros contribuam para a segurança da chegada."

${ }^{364}$ BARROSO, Lucas Abreu. A obrigação de indenizar e a determinação da responsabilidade civil por dano ambiental. Rio de Janeiro: Forense, 2006. p. 19-20.

${ }^{365}$ VISINTINI, Giovanna. Tratado de la responsabilidad civil: la culpa como criterio de imputación de la responsabilidad. Trad. Aída Kemelmajer de Carlucci. Buenos Aires: Astrea, 1999, v. 1. p. 9-10.

${ }^{366}$ MORELLO, Augusto Mario. El principio de la buena fe en la sociedad del riesgo. In: CÓRDOBA, Marcos (Dir.). Tratado de la buena fe en el derecho: doctrina nacional. Buenos Aires: La Ley, 2004, v. 1. p. 37. "Essa paisagem, tão colorida e de tantas tonalidades foi afetada por novas modalidades - riscos, perigos [...] consistência débil, precariedade e carências - de situações às quais estavam acostumadas a se amoldar regras fundadas na previsibilidade e permanência, diante do surgimento de alterações em um arco de notável dinamismo e mutabilidade."

${ }^{367}$ BECK, Ulrich. Viviendo en la sociedad del riesgo mundial. Trad. María Ángeles Sabiote González; Yago Mellado López. Barcelona: CIDOB, 2007. p. 16. "De la confianza a la sospecha: Los riesgos globales son la expresión de una forma nueva de interdependencia global que no puede ser abordada adecuadamente mediante políticas nacionales, ni por las formas disponibles de cooperación internacional. Todas las experiencias prácticas pasadas y presentes de los seres humanos en su lucha contra la incertidumbre conviven actualmente sin ofrecer una solución disponible para los problemas resultantes. No sólo eso: las instituciones clave de la modernidad como la ciencia, la empresa y la política que, supuestamente, son las garantes de la racionalidad y de la seguridad, se ven enfrentadas a situaciones en las que sus aparatos no tienen valor y en 
As promessas da modernidade ficaram para trás, estão cada vez mais distantes. A insegurança que nasce da liquidez das relações sociais é fonte imediata de incontáveis patologias e, nesse contexto, viver tornou-se mais complicado. Alguns segundos de desatenção podem destruir um projeto de vida ${ }^{368}$ - e mesmo a própria vida.

É importante perceber que um dos elementos mais importantes - ou ao menos o mais facilmente identificável -que informa a sociedade contemporânea são os riscos. ${ }^{369}$ Inicialmente circunscritos a fatores naturais, assumem hoje nova configuração.

Os riscos, na atual quadra do tempo, têm características peculiares que os diferenciam dos inerentes à Modernidade. Seus efeitos ultrapassam a esfera do indivíduo: não estão mais conectados a sujeitos, lugares ou períodos determinados. Projetam-se difusamente no tempo e no espaço, afetando os seres vivos de modo indiscriminado. Agora, os riscos não têm como ser concebidos ou identificados a partir de uma leitura superficial, como ameaças simplistas à integridade psicofísica ou patrimonial. ${ }^{370}$ Suas causas são as mais distintas ${ }^{371}$, seus efeitos, mais cruéis que os de outrora. Antevê-los é

las que los principios básicos de la modernidad no se aguantan. Es más, la percepción acerca de su posición cambia, de la confianza a la sospecha. Estas instituciones ya no son vistas únicamente como instrumentos de gestión de riesgos, sino también como fuentes de riesgo."

${ }^{368}$ BAUMAN, Zygmunt. Vida líquida. Trad. Carlos Alberto Medeiros. Rio de Janeiro: Zahar, 2007. p. 91. "Em vez de grandes expectativas e doces sonhos, o "progresso" evoca uma insônia repleta de pesadelos "de ser deixado para trás", perder o trem ou cair da janela de um veículo em rápida aceleração."

${ }^{369}$ PARDO, José Esteve. El derecho del medio ambiente como derecho de decisión y gestión de riesgos, Revista Electrónica del Departamento de Derecho de la Universidad de La Rioja, Logroño, n. 4, p. 7-16, dez. 2006. p. 8. "El concepto de riesgo se adscribe inequívocamente a la técnica. Los riesgos - al menos tal y como están yo creo que ya definitivamente perfilados en su concepto -, tienen un origen siempre tecnológico. Aquí está la diferencia un tanto convencional, si se quiere, pero útil a nuestros efectos, entre riesgo y peligro. El peligro tiene un origen natural, son peligros naturales. No hay intervención humana en la generación de los peligros, mientras que el riesgo tiene un origen tecnológico. Detrás de un riesgo siempre hay, ineludiblemente, una tecnología, y detrás de una tecnología siempre hay un conjunto de decisiones humanas."

${ }^{370}$ HAMMERSCHMIDT, Denise. O risco na sociedade contemporânea e o princípio da precaução no direito ambiental, Revista Seqüência, Florianópolis, n. 45, p. 97-122, dez. de 2002. p. 102.

${ }^{371}$ CAUBET, Christian Guy. O escopo do risco no mundo real e no mundo jurídico. In: VARELLA, Marcelo Dias (Org.). Governo dos riscos: rede latino-americana-européia sobre governo dos riscos. Brasília: Pallotti, 2005. p. 46-49. Transcreve-se o ponto mais significativo: “A noção de risco que está em análise não possui o sentido trivial de algo indesejável, suscetível de produzir-se e de acarretar alguns dissabores ou conseqüências desagradáveis para uma pessoa ou um pequeno grupo. A noção de sociedade de risco refere-se a consequiências tão amplamente catastróficas, que não se vê como indenizar as vítimas ou voltar ao statu quo ante. Os danos provocados são imensos, difusos e cumulativos. Em função de cinco tipos principais de causas, os riscos podem ser ditos: 1) tecnológicos; 2) industriais; 3) sanitários; 4) naturais ambientais; 5) políticos; ou seja: 1) novas tecnologias industriais aplicadas em ampla escala geográfica e social; 2) conseqüências, especialmente ambientais, do uso de novas tecnologias; e todas as realizações humanas com amplo impacto ambiental; 3) contextos sanitários específicos (novos riscos para a saúde; novas doenças ou afecções) ou globais: epidemias e pandemias; 4) ocorrências naturais com amplo impacto social: inundações; tufões; secas; chamadas de catástrofes naturais; 5) incidência de fenômenos ligados ao terrorismo político." 
impossível. ${ }^{372}$ A possibilidade de cálculo prévio cede lugar à constante presença de lesões indetectáveis, assolando os pilares erigidos pelo prognóstico da segurança. ${ }^{373}$

Criados pela atividade humana - e não mais pelas forças da natureza ${ }^{374}-$, justificam-se a partir dos proveitos de ordem pessoal, sendo aceitos socialmente, ora por conta de certas necessidades, ora em razão de um meio de vida ao qual a sociedade não pretende renunciar. $^{375}$

Como se percebe, o modelo de organização eleito pela sociedade contemporânea, lastreado no risco, compromete o mundo de hoje e do amanhã. ${ }^{376} \mathrm{E}$ a partir dessa constatação, aqui, cabe perguntar: qual a legitimidade da classe social autorizada a fazer essas escolhas, mormente quando se tem em conta a necessidade de respeito às minorias e de tutela dos vulneráveis? A resposta para essa indagação deve partir da premissa segundo a qual o Estado Democrático de Direito tem por características uma sociedade plural e um regime de participação democrática marcado pela descentralização do poder e pelo respeito ao dissenso e à diferença. ${ }^{377}$ Nesse modelo, impera ainda a preocupação constante com a realização da pessoa humana.

$\mathrm{Na}$ ausência de alternativas, é preciso aceitar que os riscos são uma consequência inevitável da tomada de decisões. Ao se optar por um caminho no presente, antecipa-se o futuro esperado ${ }^{378}$, mas não necessariamente certo. Tamanha é a

\footnotetext{
372 BAUMAN, Zygmunt. Medo líquido. Trad. Carlos Alberto Medeiros. Rio de Janeiro: Zahar, 2008. p. 85. "No final de uma longa viagem de descoberta (não intencional) empreendida na esperança de que ela [a razão] colocaria a humanidade a uma distância segura da natureza cruel, já que insensível e empedernida, a humanidade se vê enfrentando males produzidos pelo homem que são tão cruéis, insensíveis, empedernidos, aleatórios e impossíveis de prever (muito menos cortar pela raiz) quanto o foram o terremoto, o incêndio e o maremoto de Lisboa."

373 BERGEL, Salvador Darío. Introducción del principio precautorio en la responsabilidad civil. In: GESUALDI, Dora Mariana (Coord.). Derecho privado. Buenos Aires: Hammurabi, 2001. p. 1011-1012.

${ }^{374}$ HESPANHA, António Manuel. O caleidoscópio do direito: o direito e a justiça nos dias e no mundo de hoje. Coimbra: Almedina, 2007. p. 174. Consoante o autor, os riscos derivam hodiernamente da manipulação da natureza pelo homem.

375 LA TORRE, Antonio. Il criterio d'imputazione della responsabilità civile, Roma e America: Diritto Romano Comune, Roma, n. 10, p. 96-114, 2000. p. 98-99.

${ }^{376}$ BARROSO, Lucas Abreu. A obrigação de indenizar e a determinação da responsabilidade civil por dano ambiental. Rio de Janeiro: Forense, 2006. p. 135.

${ }^{377}$ LORENZETTI, Ricardo Luis. Teoria da decisão judicial: fundamentos do direito. Trad. Bruno Miragem. São Paulo: RT, 2009. p. 322-339.

378 LUHMANN, Niklas. Observaciones de la modernidad: racionalidad y contingencia en la sociedad moderna. Trad. Carlos Fortea Gil. Barcelona: Paidós, 1997. p. 132-138.
} 
complexidade do assunto que não tomar decisões também é arriscado. ${ }^{379}$ Afere-se, assim, que o risco, compreendido aqui como probabilidade de dano - e a insegurança por ele causada - ocupa posição de destaque na sociedade contemporânea. ${ }^{380}$

Marcados pela invisibilidade, imprevisibilidade e difusão em nível global ${ }^{381}$, pela seriedade, complexidade e ambiguidade ${ }^{382}$, com consequências irreparáveis e incalculáveis ${ }^{383}$, parece ser impossível ignorá-los em qualquer análise científica.

Como se percebe, muitos dos riscos inerentes à vida em sociedade, ao contrário daqueles ligados à Modernidade, não agridem “o nariz e os olhos”, nem são passíveis de prévia demarcação geográfica. Atuando em perspectiva territorial macroscópica, paradoxalmente, são invisíveis mesmo a olhares atentos ${ }^{384}$, tendo, certas vezes, escalas nanométricas. ${ }^{385} \mathrm{O}$ risco, na contemporaneidade, se liquefaz. ${ }^{386} \mathrm{E}$, nessa esteira, fugindo à percepção sensorial, excedem a imaginação dos homens ${ }^{387}$ sem perder sua força destrutiva.

${ }^{379}$ GIDDENS, Anthony. As conseqüencias da modernidade. Trad. Raul Fiker. São Paulo: Unesp, 1991. p. 40.

${ }^{380}$ LÓPEZ, Andrés Mariño. Los fundamentos de la responsabilidad contractual. Montevideo: Carlos Alvarez, 2005. p. 33-35.

${ }^{381}$ CARVALHO, Délton Winter de. Dano ambiental futuro: a responsabilização pelo risco ambiental. Rio de Janeiro: Forense Universitária, 2008. p. 59. "Desde meados do século XX pode ser constatado que as aquisições evolutivas e as instituições sociais da sociedade industrial enfrentam a possibilidade, sem precedentes históricos, da destruição da vida no planeta [e] esta, a sociedade passa a ter de encarar e lidar com os riscos que ela mesma produz [salientando-se que] a sociedade de risco demarca a passagem de uma primeira modernidade [...] para uma modernidade reflexiva [não mais] fundada em uma racionalidade cientificista, [...] na previsibilidade [...] dos riscos, [mas sim na] autoconfrontação da sociedade industrial com suas próprias conseqüências: o surgimento de riscos globais, imprevisíveis, incalculáveis, invisíveis, transtemporais, transnacionais [...]"

382 RENN, Ortwin; STIRLING Andrew; MÜLLER-HEROLD, Ulrich. The precautionary principle: a new paradigm for risk management and participation, Idées pour le Débat, Paris, n. 3, p. 1-19, 2004. p. 3-4.

${ }^{383}$ BECK, Ulrich. Viviendo en la sociedad del riesgo mundial. Trad. María Ángeles Sabiote González; Yago Mellado López. Barcelona: CIDOB, 2007. p. 12. "La teoría de la sociedad del riesgo mundial sostiene, sin embargo, que las sociedades modernas están configuradas por nuevos tipos de riesgos; que sus fundamentos están siendo socavados por la anticipación global de catástrofes globales. Estas percepciones del riesgo global estás caracterizadas por tres rasgos: 1. Deslocalización: Sus causas y consecuencias no están limitadas a un lugar o espacio geográfico; son en principio omnipresentes. 2. Incalculabilidad: Sus consecuencias son en principio incalculables. En el fondo es una cuestión de riesgos hipotéticos que están basados sobre todo en el no-conocimiento inducido por la ciencia y en el disenso normativo. 3. No compensabilidad: El sueño de la seguridad de la primera modernidad estaba basado en la utopía científica de hacer aún más controlables las inseguras consecuencias y los peligros de las decisiones. Los accidentes podían ocurrir, en tanto que y porque eran considerados compensables. Si el clima ha cambiado de forma irreversible, si el progreso en la genética hace posible las intervenciones irreversibles en la existencia humana, si los grupos terroristas ya tienen a su disposición armas de destrucción masiva, entonces es demasiado tarde."

${ }^{384}$ BECK, Ulrich. La sociedad del riesgo: hacia una nueva modernidad. Trad. Jorge Navarro. Barcelona: Paidós, 1998. p. 26-30.

${ }^{385}$ Sobre o tema: ENGELMANN, Wilson. Os direitos humanos e as nanotecnologias: em busca de marcos regulatórios, Cadernos IHU Idéias, São Leopoldo, v. 7, n. 123, p. 3-24, 2009. 
As promessas da modernidade se esvaem como fumaça. A segurança e a transparência prometidas pela ciência distanciam-se do imaginário dos homens. ${ }^{388} \mathrm{O}$ imponderável se transforma em realidade; preocupante realidade. E, mesmo que as verdades da ciência não sejam mais tão confiáveis quanto outrora ${ }^{389}$, é possível afirmar que, por estarem conectados à incerteza ${ }^{390}$, os riscos podem ser evitados. ${ }^{391}$

\section{Consoante o prisma eleito para análise da questão, será mesmo possível afirmar} que viver, mormente em grandes cidades, tornou-se um risco. ${ }^{392}$ Elm muitas situações, em

${ }^{386}$ BECK, Ulrich. Viviendo en la sociedad del riesgo mundial. Trad. María Ángeles Sabiote González; Yago Mellado López. Barcelona: CIDOB, 2007. p. 24. "Es la liquidez" (Bauman), esto es, la permanente transformación, acumulación y multiplicidad de riesgos distintos y a menudo espurios - ecológicos, biomédicos, sociales, económicos, financieros, simbólicos e informacionales - que caracterizan la ambivalencia y la incalculabilidad de la sociedad del riesgo mundial."

${ }^{387}$ GIDDENS, Anthony; BECK, Ulrich; LASH, Scott. Modernização reflexiva: política, tradição e estética na ordem social moderna. Trad. Magda Lopes. São Paulo: Unesp, 1997. p. 13.

${ }^{388}$ BAUMAN, Zygmunt. Modernidade e ambivalência. Trad. Marcus Penchel. Rio de Janeiro: Zahar, 1999. p. 244-251.

${ }^{389}$ MENDES, Felismina. Risco: um conceito do passado que colonizou o presente, Revista Portuguesa de Saúde Pública, Lisboa, v. 20, n. 2, p. 53-62, jul./dez. 2002. p. 56. "Se durante dois séculos a ciência funcionou como uma espécie de tradição nas sociedades ocidentais, em que os leigos pediam opinião aos especialistas e peritos, nos dias de hoje torna-se cada vez mais difícil aceitar as descobertas dos cientistas, por serem cada vez mais freqüentes os desacordos entre eles, especialmente quando se trata da análise dos riscos provocados pelo homem. O carácter mutável da ciência é outra das características cuja visibilidade emergiu nas sociedades modernas."

${ }^{390}$ BECK, Ulrich. Viviendo en la sociedad del riesgo mundial. Trad. María Ángeles Sabiote González; Yago Mellado López. Barcelona: CIDOB, 2007. p. 10. "Riesgo no significa catástrofe. El riesgo significa la anticipación de la catástrofe. Los riesgos existen en un estado permanente de virtualidad y sólo se convierten en concretos en el momento en que son anticipados. Los riesgos no son reales, se están convirtiendo en reales (Joost van Loon). En el momento en el que los riesgos se convierten en reales (por ejemplo, en el caso de un atentado terrorista) dejan de ser riesgos para convertirse en catástrofes. Los riesgos se han trasladado a otra parte: a la anticipación de más ataques, inflación, nuevos mercados, guerras o la reducción de las libertades civiles. Los riesgos son siempre acontecimientos amenazantes. Sin técnicas de visualización, sin formas simbólicas, sin medios de comunicación, etc. los riesgos no son nada. En otras palabras, el riesgo es irrelevante si vivimos en un mundo que es, de hecho o en cierta manera, objetivamente más seguro que otros mundos; si la destrucción y los desastres son anticipados, entonces se produce un apremio para actuar."

${ }^{391}$ Ibid. p. 5-6. "La narrativa del riesgo es una narrativa de la ironía. Esta narrativa trata de la sátira involuntaria, de la futilidad optimista con la que las instituciones más desarrolladas de la sociedad moderna ciencias, Estado, negocios y sector militar- tratan de anticiparse a aquello que no puede ser anticipado. [...] La ironía del riesgo consiste en este caso en que la racionalidad o, lo que es lo mismo, la experiencia del pasado fomenta la anticipación del tipo de riesgo equivocado, aquél que creemos poder calcular y controlar, mientras que el desastre surge de aquello que no conocemos y que no podemos calcular."

392 BAUMAN, Zygmunt. Vida líquida. Trad. Carlos Alberto Medeiros. Rio de Janeiro: Zahar, 2007. p. 102. "Desde o início, as cidades têm sido lugares em que estranhos convivem em estrita proximidade, embora permanecendo estranhos. A companhia de estranhos é sempre assustadora (ainda que nem sempre temida), já que faz parte da natureza dos estranhos, diferentemente tanto dos amigos como dos inimigos, que suas intenções, maneiras de pensar e reações a condições comuns sejam desconhecidas ou não conhecidas o suficiente para que se possa calcular as probabilidades de sua conduta. Uma reunião de estranhos é um lócus de imprevisibilidade endêmica e incurável. Pode-se dizer isso de outra forma: os estranhos incorporam o risco. Não há risco sem pelo menos algum resquício de medo de um dano ou perda, mas sem risco também não há chance de ganho ou triunfo. [...] Os ambientes repletos de risco simultaneamente atraem e repelem, e 
nome do desenvolvimento da sociedade, esse risco é imposto pela adoção de uma postura de indiferença quanto a seus potenciais destinatários; situação que se agrava diante da distribuição desigual de riqueza entre os membros dos mais diversos núcleos sociais ${ }^{393}$, em especial, entre os menos favorecidos.

A problemática é ampliada quando se constata que o risco se encontra "no centro do funcionamento da atividade industrializada" 394 e torna-se ainda mais complexa quando se afere que certa "cegueira ética" permeia o mundo, permitindo a ocorrência de danos que poderiam ser evitados. ${ }^{395}$

Nessa corrida, interesses econômicos sobrepõem-se aos sociais. Decisões políticas continuam a dar primazia aos desejos do mercado que, por sua vez, subjuga a sociedade e suas instituições. ${ }^{396}$ Aliás, é importante lembrar que as profundas alterações vivenciadas pela sociedade são consequências do triunfo, e não da crise do modelo econômico atualmente vigente. ${ }^{397}$

Fato é que, como os efeitos potenciais do desenvolvimento industrial de alta tecnologia pouco têm a ver com os problemas clássicos da Modernidade, na qual os danos podiam ser calculados a partir de dados estatísticos ${ }^{398}$ e, em razão disso, tutelados

o ponto em que uma reação se transforma no seu oposto é eminentemente variável e mutante, virtualmente impossível de apontar com segurança, que dirá de fixar."

393 LA TORRE, Antonio. Il criterio d'imputazione della responsabilità civile, Roma e America: Diritto Romano Comune, Roma, n. 10, p. 96-114, 2000. p. 98-99.

394 MORAES, Maria Celina Bodin de. Risco, solidariedade e responsabilidade objetiva, Revista dos Tribunais, São Paulo, v. 95, n. 854, p. 11-37, dez. 2006. p. 17. “O acidente, como emerge da sociedade industrial, tem características que impedem de interpretá-lo nos significados anteriores de acaso ou providência. $\mathrm{O}$ conceito obedece a um tipo de objetividade específica e decorre do curso natural das atividades coletivas, e não de acontecimentos excepcionais ou extraordinários. O evento danoso deixa, pois, de ser considerado uma fatalidade e passa a ser tido como um fenômeno "normal", estatisticamente calculável."

395 BAUMAN, Zygmunt. Vida para o consumo: a transformação das pessoas em mercadorias. Trad. Carlos Alberto Medeiros. Rio de Janeiro: Zahar, 2008. p. 150. "A questão controversa é se "imprevisto" significa necessariamente "impossível de prever" e, para ser mais específico, se "não-intencional" quer dizer "impossível de calcular" e, portanto "impossível de evitar intencionalmente", ou apenas a indiferença e a frieza de quem fez os cálculos e não se preocupou muito em evitar. Uma vez que se faça essa pergunta de maneira explícita, torna-se claro que, independentemente da resposta que a investigação de determinado caso possa apontar, há boas razões para suspeitar que invocar o argumento da "falta de intencionalidade" tem o objetivo de negar ou isentar a cegueira ética, condicionada ou deliberada. [...] Quando elefantes lutam, coitada da grama; mas os elefantes serão os últimos a ter pena dela."

${ }^{396}$ HAMMERSCHMIDT, Denise. O risco na sociedade contemporânea e o princípio da precaução no direito ambiental, Revista Seqüência, Florianópolis, n. 45, p. 97-122, dez. de 2002. p. 101.

${ }^{397}$ GIDDENS, Anthony; BECK, Ulrich; LASH, Scott. Modernização reflexiva: política, tradição e estética na ordem social moderna. Trad. Magda Lopes. São Paulo: Unesp, 1997. p. 13.

${ }^{398}$ BAUMAN, Zygmunt. Medo líquido. Trad. Carlos Alberto Medeiros. Rio de Janeiro: Zahar, 2008. p. 129130. "Em outras palavras, o conceito de "riscos" só faz sentido em um mundo rotinizado, monótono e 
previamente, ainda que por meio de seguros ${ }^{399}$, se observa um fenômeno estarrecedor: os danos tornaram-se incontroláveis. $\mathrm{O}$ aumento em progressão geométrica da complexidade das relações cotidianas, difundida em nível planetário ${ }^{400}$, dispara esse fenômeno.

Essa realidade - e, por consequência, os danos por ela causados - infligem à vida cotidiana tanto sofrimento que há quem sustente que o mito de Prometeu diuturnamente se renova. ${ }^{401}$

É inegável que os danos na contemporaneidade crescem em número e intensidade. ${ }^{402}$ A sociedade colhe os frutos das sementes que plantou. Diante da expansão dos danos nos tempos atuais, muitos deixam de ser tutelados ${ }^{403}$, sendo suportados

repetitivo, no qual as seqüências causais reapareçam com freqüência e de modo suficientemente comum para que os custos e benefícios das ações pretendidas e suas chances de sucesso e fracasso sejam passíveis de tratamento estatístico e avaliados em relação aos precedentes. [...] Mas o mundo "negativamente globalizado" não é assim. [...] O que torna nosso mundo vulnerável são principalmente os perigos da probabilidade não-calculável, um fenômeno profundamente diferente daqueles aos quais o conceito de "risco" comumente se refere. Perigos não-calculáveis aparecem, em princípio, em um ambiente que é, em princípio, irregular, onde as sequiências interrompidas e a não-repetição das seqüências se tornam a regra, e a anormalidade a norma. A incerteza sob um nome diferente."

${ }^{399}$ BARRIOS, Luis. El conflicto de la celulosa. Estado de derecho. Montevideo, p. 12, dez. 2007. Continua o autor ao frisar que "la crónica reciente de los nuevos riesgos transformados en daños al ambiente, a las personas físicas y a sus bienes, abunda en episodios trágicos de menor o mayor entidad en Estados Unidos, en Italia, en España, en Chile, en Argentina y en Brasil, por mencionar solamente casos muy conocidos."

${ }^{400}$ GONZÁLEZ, Sérgio Pérez. El derecho en la sociedad global del riesgo, Revista Electrónica del Departamento de Derecho de la Universidad de La Rioja, Logroño, n. 6, p. 95-107, dez. 2008. p. 96. "Esta imagen abarca prácticamente todos los ámbitos de actividad y desarrollo sociales, de manera que puede ser abordada desde muy diferentes puntos de vista: el medioambiente, la economía, la política, el derecho, etc. sin embargo, para todos esos ámbitos, tiene validez un factor común: la globalización. [...]”

${ }^{401}$ DINIZ, Arthur José Almeida. Humanismo de tecnologia, Revista da Faculdade de Direito, Belo Horizonte, n. 31, p. 121-136, 1987/1988. p. 122. "Por que Prometeu? Prometeu, o titã, filho de Jopestos e Clymene, irmão de Atlas e de Epimeteu, teve a audácia de roubar o fogo do Olimpo, ajudado pela deusa da sabedoria, Pallas-Atenas, e doá-lo aos homens. A vingança de Zeus é terrível. Vai aprisionar Prometeu num rochedo no Cáucaso onde este terá seu fígado vorazmente comido por um abutre. Este, o mito. Se quebrarmos as castanha do mito veremos que no fundo estamos vivendo hoje o castigo de Prometeu que, na versão moderna, nos concedeu o fogo ... atômico. E, curiosamente, os efeitos das radiações se localizam instantaneamente no fígado, destroçando o equilíbrio somático das vítimas. A lista de horrores é grande: Hiroshima, Nagasaki e, modernamente, outro dia, Chernobyl. E depois?"

${ }^{402}$ BARROSO, Lucas Abreu. A obrigação de indenizar e a determinação da responsabilidade civil por dano ambiental. Rio de Janeiro: Forense, 2006. p. 26. Ao discorrer sobre "o aumento, a agravação e a universalidade" do dano ambiental e os diversos fatores responsáveis por esses fenômenos, afirma o autor que "é tranqüila a constatação de que esse fatores outros são ínsitos ou derivam de uma sociedade e/ou modelo econômico que lhes servem de apanágio e sustentação." A reflexão se encaixa, com perfeição, na análise da expansão dos danos no universo negocial.

${ }^{403}$ GHERSI, Carlos Alberto. El ser humano y la dañosidad como inevitable contingencia social. In: GHERSI, Carlos Alberto (Dir.). Responsabilidad: problemática moderna. Mendoza: Ediciones Jurídicas Cuyo, 1996. p. 30-37. "A nova realidade do capitalismo selvagem só vê nas relações de produção, circulação, distribuição e comercialização de bens e serviços formas econômicas de acumulação de riquezas e de maneira alguma contempla processos sociais de integração humana consoante o ideário de justiça, ética e eqüidade de onde pode derivar o dano. O discurso sobre o dano suportável (o necessário para a sobrevivência humana) e, portanto não ressarcível, se apresenta de modo cada vez mais intenso e amplia suas fronteiras avançando 
normalmente pelas camadas menos favorecidas da sociedade civil ${ }^{404}$, de forma individual ou difusa. Outros tantos escapam ao direito civil, sendo transplantados para o universo da seguridade social ${ }^{405}$ : uma luz, sem dúvida, em meio a tantas trevas.

A insuficiência de soluções para a expansão dos danos é um dado real. O avanço tecnológico torna as pessoas mais vulneráveis, o que autoriza a objetivação do dever de reparar. ${ }^{406}$ Se o Direito existe visando à promoção da pessoa humana, nada mais adequado que um sistema que, de fato, possibilite atingir essa meta. A justificativa é mais que legítima.

Nesse admirável mundo novo, o esquema clássico da responsabilidade subjetiva, lastreado no livre-arbítrio, só subsiste como instrumento de dominação ideológica: a objetivação do dever de reparar é inimiga do sistema liberal, do livremercado, do capitalismo ocidental e do cristianismo. ${ }^{407}$

Curioso é que, ainda hoje, quando alguém se depara com um acidente de trânsito, a primeira inquietude leva a buscar saber quem foi o culpado; quando, em verdade, havendo vítimas, a maior preocupação deveria ser a de aferir se essas necessitam de cuidados médicos ou de recursos durante o período de convalescença. Em termos de análise econômica, jurídica, política ou social, é primordial saber como evitar que a vítima de um dano injusto tenha que suportar suas consequências. ${ }^{408}$

É importante ratificar que nenhum espaço resta à culpa na realidade hodierna. É imperioso, ainda, definir um sistema de ressarcimento que, a cada dia, deixe um menor

sobre o dano ressarcível de tal forma que este será minimizado, colocado em situação de controle, passando a ser um dado a mais qualificado pela economia."

${ }^{404}$ GHERSI, Carlos Alberto. La independencia de poderes y el acceso a la reparación de daños. In: GHERSI, Carlos Alberto (Dir.). Responsabilidad: problemática moderna. Mendoza: Ediciones Jurídicas Cuyo, 1996. p. 102-103. "O dano social é aquele causado em razão de fatos que vulneram a confiança e a credibilidade das pessoas no mercado."

${ }^{405}$ MASSIMO BIANCA, Cesare. La colpa come elemento costitutivo della fatispecie dell'illecito, Roma $e$ America: Diritto Romano Comune, Roma, n. 3, p. 201-204, 1997. p. 202.

${ }^{406}$ CHINELATO, Silmara Juny. Tendências da responsabilidade civil no direito contemporâneo: reflexos no código de 2002. In: DELGADO, Mário Luiz; ALVES, Jones Figueiredo (Coord.). Questões controvertidas: responsabilidade civil. São Paulo: Método, 2006, v. 5. p. 588.

${ }^{407}$ GHERSI, Carlos Alberto. De Velez a Borda un cambio ideológico trascendente, que no se complementó en el rápido acceso a la justicia. In: GHERSI, Carlos Alberto (Dir.). Responsabilidad: problemática moderna. Mendoza: Ediciones Jurídicas Cuyo, 1996. p. 20.

${ }^{408}$ HINESTROSA, Fernando. Devenir del derecho de daños, Roma e America: Diritto Romano Comune, Roma, n. 10, p. 17-36, 2000. p. 22. 
número de vítimas sem reparação. ${ }^{409} \mathrm{O}$ ser humano, cada vez mais isolado, necessita de proteção $^{410}$, e o recurso a fatores objetivos de imputação do dever de reparar é um dos caminhos que levam a esse destino.

A criação de marcos visando a (re)definição dos contornos que informam o dever de reparar na sociedade contemporânea é essencial para a redução dos danos e(ou) das consequências infligidas a quem tenha que os suportar injustamente, até porque impedi-los parece impossível. Esse processo deve priorizar a proteção da pessoa humana. Quando essa é adequadamente tutelada, por consequência, promove-se a redução de custos sociais. ${ }^{411}$ Finca-se aqui outra estaca de sustentação da tese em construção: a objetivação do dever de reparar é uma necessidade na sociedade contemporânea.

A crise vivida destrói antigas certezas e valores dos mais diversos. ${ }^{412}$ No que pertine aos referenciais, aos moldes de compreensão do mundo, certo é que o velho não serve mais, e o novo há de ser construído. Nesse quadro, entre a possibilidade de adoção de

\footnotetext{
${ }^{409}$ HIRONAKA, Giselda Maria Fernandes Novaes. Responsabilidade pressuposta: evolução de fundamentos e de paradigmas na responsabilidade civil na contemporaneidade, Revista da Faculdade de Direito da UFG, Goiânia, v. 31, p. 33-59, jan./jun. 2007. p. 34.

${ }^{410}$ BECK, Ulrich. Viviendo en la sociedad del riesgo mundial. Trad. María Ángeles Sabiote González; Yago Mellado López. Barcelona: CIDOB, 2007. p. "La individualización trágica: La vida cotidiana en la sociedad del riesgo mundial se caracteriza, a consecuencia de lo expuesto, por una nueva variante de la individualización. El individuo debe hacer frente por sí mismo a la incertidumbre del mundo global. En este caso la individualización es un resultado por defecto del fracaso de los sistemas especializados de gestión de riesgos. Ni la ciencia, ni los políticos en el poder, ni los medios de comunicación, ni las empresas, ni el derecho, ni tan siquiera el ejército, están en buena posición para definir o controlar racionalmente los riesgos. El individuo se ve obligado a desconfiar de las promesas de racionalidad de estas instituciones clave. La gente debe depender de sí misma, es alienada de los sistemas expertos, pero tampoco tiene otra alternativa. Desvinculación sin vinculación, ésta es la fórmula irónico-trágica para esta dimensión de la individualización en la sociedad del riesgo mundial. Por ejemplo, la responsabilidad de una decisión acerca de los alimentos genéticamente modificados y de sus consecuencias a largo plazo inimaginables y desconocidas se traslada, en última instancia, al tan denominado "consumidor responsable" (rige la decisión del consumidor). La llamada a la "responsabilidad" es el cinismo con el que las instituciones intentan encubrir su propio fracaso. Sin embargo -y esto también forma parte de la trágica ironía de este proceso de individualización- el individuo, cuyos sentidos le fallan frente a las incomprensibles amenazas a la civilización, y que es forzado a depender de sí mismo, es ciego ante los peligros y al mismo tiempo es incapaz de zafarse del poder de definición de los sistemas especializados en cuyo criterio no puede pero debe confiar. Mantener un yo individual con integridad en la sociedad del riesgo mundial es realmente algo trágico."
}

${ }^{411}$ HIRONAKA, Giselda Maria Fernandes Novaes. Responsabilidade pressuposta: evolução de fundamentos e de paradigmas na responsabilidade civil na contemporaneidade, Revista da Faculdade de Direito da UFG, Goiânia, v. 31, p. 33-59, jan./jun. 2007. p. 54-55.

${ }^{412}$ MARQUES, Cláudia Lima. Direito na pós-modernidade e a teoria de Erik Jayme. In: OLIVEIRA JUNIOR, José Alcebíades (Org.). Faces do multiculturalismo: teoria, política, direito. Santo Ângelo: Ediuri, 2007. p. 34. 
uma postura defensiva ou de um comportamento acolhedor, o último parece ser preferível, pois os "olhos pós-modernos" veem "a diferença com alegria e prazer."413

As reflexões tecidas não ignoram ser evidente que, enquanto houver "homens não reconhecidos como tal por outros homens, o mundo continuará a ser a arena do extermínio potencial e o campo da exploração legal de uns pelos outros." ${ }^{\text {,14 }}$ Não se despreza a realidade, especialmente porque uma das vantagens da democracia está na "possibilidade de tomada de decisões sempre diferentes."

E é por isso, especialmente por conta das possibilidades contidas no porvir, que se afirma que à culpa não foi reservado lugar algum na contemporaneidade. As complexidades e contingências inerentes ao atual momento vivido não permitem promover juízos prévios de causa e efeito. Se os pecados só são conhecidos depois de cometidos, não há razão para manter viva uma figura concebida para que esses fossem evitados.

${ }^{413}$ BAUMAN, Zygmunt. Modernidade e ambivalência. Trad. Marcus Penchel. Rio de Janeiro: Zahar, 1999. p. 268. "A diferença é bela e não menos boa por isso."

${ }^{414}$ COMPARATO, Fábio Konder. Os problemas fundamentais da sociedade brasileira e os direitos humanos, Revista da Ordem dos Advogados do Brasil, São Paulo, v. 19, n. 51, p. 7-18, 1989. p. 9.

${ }^{415}$ ROCHA, Leonel Severo. Novas perspectivas da teoria do direito, Revista da Ajuris, Porto Alegre, v. 26, n. 77, p. 248-255, mar. 2000. p. 255. 


\section{A ARQUITETURA JURÍDICA DA RESPONSABILIDADE CONTRATUAL}

\subsection{As atuais fronteiras da responsabilidade contratual}

A responsabilidade civil há de ser compreendida como o conjunto de princípios e regras conformadores do dever de reparar os danos causados a outrem, em razão de uma conduta antijurídica, atribuível a alguém ${ }^{416}$, a partir de um fator de imputabilidade previamente eleito pelo Direito. Diante dessa premissa, a responsabilidade contratual pode ser delimitada como o campo do saber que tem por escopo reparar as lesões oriundas do desrespeito a um dever contratual. Nessa esteira, mais que simples fragmento da responsabilidade civil, supostamente construída a fim de tutelar as lesões oriundas do "incumprimento imputável de uma obrigação pré-existente",417, a responsabilidade contratual é a seara hábil à solução das celeumas provocadas pela violação de deveres jurídicos que emanam de um contrato. ${ }^{418}$

Em outras palavras, tem por escopo dirimir os conflitos nascidos da violação de um dever que exsurge da relação singular e pré-existente entre dois [ou mais] sujeitos. ${ }^{419}$ Estando atada à existência de um contrato ${ }^{420}$, almeja, primordialmente, garantir a cooperação entre os contratantes, conduzindo-os à satisfação de seus anseios. É possível afirmar, ainda, contemporaneamente, que para além de simplesmente ter por escopo "restabelecer o equilíbrio econômico-jurídico alterado pelo dano"421, está ancorada na necessidade de promoção do ser humano, atuando de modo a corrigir as distorções provocadas por lesões detectadas no desvelar da relação contratual concretamente estabelecida.

\footnotetext{
${ }^{416}$ ITURRASPE, Jorge Mosset. Contratos. Buenos Aires: Rubinzal-Culzioni, 2007. p. 398.

${ }^{417}$ LORENZETTI, Ricardo Luis. Tratado de los contratos: parte general. Buenos Aires: Rubinzal Culzoni, 2004. p. 582.

${ }^{418}$ DE CARLUCCI, Aída Kemelmajer. El sistema dualista de responsabilidad contractual y extracontractual en Argentina. Reflexiones sobre la inconveniencia de su supervivencia, Revista Anales Derecho UC, Santiago, v. 3, p. 29-69, mar. 2008. p. 30.

${ }^{419}$ SALVI, Cesare. La responsabilità civile. 2 ed. Milano: Giuffrè, 2005. p. 14.

${ }^{420}$ Os negócios jurídicos unilaterais não são objeto da pesquisa.

${ }^{421}$ AGUIAR DIAS, José de. Da responsabilidade civil. 10 ed. Rio de Janeiro: Forense, 1995, v. 1. p. 42.
} 
Oportuno salientar, desde cedo, que a mera ausência de adimplemento não basta à configuração do dever de reparar. Na concretude das relações cotidianas, poderá haver atraso ou impossibilidade de desempenho da prestação, sem que isso obrigue o devedor a ressarcir os danos suportados pelo parceiro contratual. Assevere-se, noutro vértice, que, mesmo diante do desempenho da prestação, é importante aferir se o credor teve suas expectativas satisfeitas. Tal análise, a ser promovida em cada hipótese a partir dos influxos emanados pela pontualidade, integralidade, correspondência, boa-fé objetiva e concretude $^{422}$, permitirá identificar a conformação (ou não) da conduta desempenhada pelo devedor ao programa obrigacional concretamente estabelecido e, por consequência, se houve (ou não) adimplemento. É imperioso, enfim, identificar se a multiplicidade latente de deveres gerais de conduta ${ }^{423}$ inerentes a cada relação contratual, projetada pelas partes com o escopo de antecipar o tempo, fora observada ou não.

O que se pretende destacar, nesse momento, é que, se de um lado, a simples constatação de ausência de pagamento nem sempre haverá de disparar o dever de reparar os danos provocados no curso de um contrato, de outro, o mero desempenho da prestação prometida, nem sempre, conduzirá à redenção do devedor.

Assim, ainda que outras consequências possam decorrer do desrespeito a um dever contratual, caso não sejam imputáveis à conduta do devedor - ou do credor -, não dão azo ao dever de reparar. A assertiva pode ser facilmente compreendida quando se visualiza uma situação em que o retardo no cumprimento da prestação é atribuível a uma causa estranha e não imputável ao devedor. Infira-se que, na hipótese projetada, mesmo não existindo mora, é possível inferir que, desaparecendo o impedimento temporal, o adimplemento continua a ser devido e, uma vez realizado a contento, redundará na extinção da relação obrigacional sem que surja qualquer traço de responsabilidade contratual. E isso ocorre porque o dever de reparar, além de depender, em princípio, da existência de um dano, exige, em sua configuração, que esse tenha sido disparado pela violação de um dever contratual imputável à conduta de uma das partes, o que não ocorre na situação imaginada.

\footnotetext{
${ }^{422}$ BUSSATTA, Eduardo Luiz. Resolução dos contratos e teoria do adimplemento substancial. São Paulo: Saraiva, 2007. p. 21.

${ }^{423}$ Prefere-se essa expressão a deveres laterais por demonstrar, com maior exatidão, o universo de deveres que se propõe a abarcar. O tema é explorado adequadamente no item 2.3 deste trabalho.
} 
Importante salientar, também - visando à escorreita compreensão do fenômeno em sua integralidade e às críticas que serão formuladas no momento adequado -, que a arquitetura jurídica da responsabilidade contratual foi construída e sistematizada tendo por premissa a diferença existente entre as noções de impossibilidade e inadimplemento. ${ }^{424} \mathrm{Em}$ outras palavras, erigiu-se a partir da noção de impossibilidade de desempenho da prestação $^{425}$, ignorando a manifesta complexidade do problema e a múltiplas possibilidades em que se pode identificar a violação de um dever contratual.

Em termos gerais, afirmava-se que, se a impossibilidade de adimplemento fosse atribuída à conduta do devedor, haveria inadimplemento ${ }^{426} \mathrm{e}$, por consequência, nasceria o dever de reparar. Caso contrário e sem desejar ser redundante, a simples impossibilidade não seria hábil a produzir qualquer reflexo na seara da responsabilidade contratual. Relevante destacar que a impossibilidade à que se alude deveria ser qualificada como absoluta e objetiva, pois, ausentes tais características, o devedor permaneceria obrigado a adimplir ou a reparar o prejuízo suportado pelo credor.

Reafirme-se que, consoante as premissas criadas pelo objetivismo ${ }^{427}$, o recurso à impossibilidade de desempenho da prestação somente exoneraria o devedor se pudesse ser classificada como objetiva e absoluta. Acentue-se que a primeira deve ser compreendida a partir da prestação considerada em si mesma, em oposição à impossibilidade subjetiva que tem por base uma situação pessoal do devedor como motivo do não cumprimento, manifestando-se, por exemplo, diante da insolvência. A noção de impossibilidade objetiva, portanto, estava atada à própria prestação prometida, e não, às condições particulares do devedor. ${ }^{428}$

${ }^{424}$ BARBERO, Domenico. Sistema del derecho privado: obligaciones. Trad. Santiago Sentis Melendo. Buenos Aires: EJEA, 1967, v. 3. p. 68-77. Nesse sentido: LÔBO, Paulo Luiz Netto. Teoria geral das obrigações. São Paulo: Saraiva, 2005. p. 276. Consoante o autor, no primeiro caso, tendo origem em fato imputável ao devedor, o que não ocorre na segunda das hipóteses.

${ }^{425}$ OSTI, Giuseppe. Revisione critica della teoria sulla impossibilità della prestazione (continuazione), Rivista di Diritto Civile, Milano, v. 10, n. 4, p. 313-360, jul./ago. 1918. p. 336.

${ }^{426}$ SILVA, Rafael Peteffi da. Teoria do adimplemento e modalidade de inadimplemento, atualizado pelo novo código civil, Revista do Advogado, São Paulo, n. 68, p. 135-153, dez. 2002. p. 145-147.

${ }^{427}$ Para uma visão detalhada da construção das bases da responsabilidade contratual pelas correntes objetivistas: VITA NETO, José Virgílio. A atribuição da responsabilidade contratual. Tese (Doutorado) Faculdade de Direito da USP, São Paulo, 2007. p. 10-37.

${ }^{428}$ PICASSO, Sebastián. El incumplimiento en las obligaciones contractuales: el problema de la ausencia de culpa y de la imposibilidad sobrevenida de la prestación - obligaciones de medios y de resultado. In: GESUALDI, Dora Mariana (Coord.). Derecho privado. Buenos Aires: Hammurabi, 2001. p. 1110. 
Em apertada síntese, é possível afirmar que a caracterização da impossibilidade objetiva exigia, nesse contexto, que a prestação não pudesse ser desempenhada por quem quer que fosse; o que não ocorria na impossibilidade subjetiva, na qual o devedor, por conta de circunstâncias de ordem pessoal, é quem não possuía condições de adimplir. ${ }^{429}$

A seu turno, a distinção entre impossibilidade absoluta e relativa - construída tendo por lastro a intensidade do não cumprimento ${ }^{430}$ - está ligada aos sacrifícios exigíveis junto ao devedor. De um modo geral, sustenta-se que a primeira se manifesta quando não pode ser vencida pelas forças humanas ${ }^{431}$, enquanto a segunda se faz presente diante de dificuldades que poderiam ser superadas pelo homem. Daí que, nos casos de impossibilidade relativa, ao menos em princípio, o devedor continuaria obrigado a prestar, mesmo quando aquela estivesse atada a uma causa estranha e a ele não imputável.

E, isso porque, em regra, essa última modalidade de impossibilidade tem forças apenas para promover a suspensão do dever de prestar. ${ }^{432}$ Assim, se a impossibilidade é passageira, o devedor não se libera dos vínculos obrigacionais, embora, enquanto persistir o impedimento, não possa ser obrigado a desempenhar a prestação prometida. ${ }^{433}$

Observe-se que isso somente ocorrerá quando o retardo tenha origem em um fato não imputável à conduta do devedor. Somente nesses casos, o dever de prestar permanecerá suspenso até que cesse a causa impeditiva do pagamento - possibilitando o cumprimento da prestação prometida, sem produzir a pretensão à reparação das perdas e danos - ou até que o credor demonstre ter perdido o interesse no adimplemento ${ }^{434}$, até porque parece razoável sustentar que o exercício desse direito prescinda da mora do devedor. Destaque-se, por outro lado, que, se o retardo for imputável ao devedor, haverá mora e, consequentemente, estará configurado o dever de reparar.

${ }^{429}$ OSTI, Giuseppe. Revisione critica della teoria sulla impossibilità della prestazione, Rivista di Diritto Civile, Milano, v. 10, n. 3, p. 209-249, mai./jun. 1918. p. 216-221 e 228-230.

${ }^{430}$ Ibid. p. 216-221.

${ }^{431}$ BUERES, Alberto Jesus. Derecho de daños. Buenos Aires: Hammurabi, 2001. p. 433-437.

${ }^{432}$ LARROUMET, Christian. La causa estraña. In: ESPINOSA, Fabricio Mantilla; BARRIOS, Francisco Ternera (Dir.). Los contratos en el derecho privado. Bogotá: Legis, 2007. p. 306.

433 ENNECCERUS, Ludwig. Derecho de obligaciones: doctrina general. Trad. Blas Pérez Gonzales; José Alguer. Barcelona: Bosch, 1944, v. 1. p. 241.

${ }^{434}$ Nesse sentido, o enunciado 162, aprovado na III Jornada de Estudos de Direito Civil, sob a coordenação do Conselho da Justiça Federal, dispondo que "a inutilidade da prestação que autoriza a recusa da prestação por parte do credor deverá ser aferida objetivamente, consoante o princípio da boa-fé e a manutenção do sinalagma, e não de acordo com o mero interesse subjetivo do credor." 
E, apesar de a doutrina clássica ignorar outras formas de violação de deveres contratuais, aparentemente os raciocínios tecidos são úteis na solução de situações em que houver cumprimento inexato da prestação. Nesses casos, se a patologia não decorrer da conduta do devedor, é impossível sustentar o nascimento do dever de reparar, embora seja inegável que o defeito contido na prestação desempenhada haverá de ser corrigido, evitando-se, assim, a frustração das expectativas depositadas pelo parceiro contratual na prestação prometida. Tal reflexão tem por lastro a necessidade de manter a harmonia durante todo o desvelar do processo obrigacional e ainda o respeito à confiança depositada pelo parceiro negocial na conduta que lhe foi prometida anteriormente. Saliente-se, dentre outras soluções, que tais celeumas podem ser corrigidas mediante readequação do preço, correção do vício que dificulta o uso da coisa, nova execução do serviço, complementação da área entregue etc.

Infira-se que o dever de promover a adequação da prestação desempenhada com imperfeições tem forte assento nos princípios da pontualidade ${ }^{435}$ - também denominado da correspondência - e da equivalência das prestações. Identifique-se que, nas situações em que o defeito contido na prestação está conectado a um evento alheio à conduta do devedor, ainda que não haja dever de reparar, a distorção há de ser corrigida, evitando, assim, a frustração das legítimas expectativas do credor. ${ }^{436}$

Enfim, antecipe-se que a violação de um dever geral de conduta também há de ser acrescido às hipóteses ensejadoras de responsabilidade contratual. Esses deveres, de caráter manifestamente multifacetário, se manifestam por todo o processo obrigacional, obrigando ambas as partes, e não, apenas o devedor. Assevere-se que sua adequada compreensão exige a superação das premissas liberais e individualistas que, por longa data, informaram a relação obrigacional e a aceitação dos influxos que emanam dos princípios constitucionais e dos princípios contratuais sociais. ${ }^{437}$

Apontadas as formas pelas quais é possível identificar o desrespeito a um dever contratual, em termos gerais, parece possível concluir que haverá dever de reparar um dano contratual quando sua violação puder ser imputada a uma das partes.

\footnotetext{
435 CUNHA DE SÁ, Fernando Augusto. Direito ao cumprimento e direito a cumprir. Coimbra: Almedina, 1997. p. 8. A pontualidade implica que somente haverá adimplemento se a prestação for efetuada "ponto por ponto" considerando-se todas as condições que permeiam a relação obrigacional.

${ }^{436}$ Desde que seja pré-existente à tradição e que não tenha sido provocado pelo próprio credor.

${ }^{437}$ Essas questões serão aprofundadas no item 2.3 .
} 
Em um esforço sintetizador, talvez seja possível afirmar que a responsabilidade contratual estará configurada quando detectada a desconformidade entre a conduta adotada e aquela que deveria ter sido observada no programa obrigacional concretamente estabelecido. ${ }^{438}$ É evidente, entretanto, que, contemporaneamente, a importância e a extensão do dever violado devem ser ponderadas no processo que visa à identificação do surgimento do dever de reparar. A lesão ao interesse juridicamente protegido precisa revestir-se de gravidade e, por isso, são afastados, desse universo, todos os detalhes sem maior importância ${ }^{439}$ e as questiúnculas que visem apenas à satisfação dos caprichos de uma das partes.

Há outro ponto relevante na caracterização da responsabilidade contratual que precisa ser explorado. Tendo sido explicitados seu conteúdo e as hipóteses conformadoras do dever de reparar, cabe aferir agora se esse dever possui autonomia (ou não) em relação aos deveres desrespeitados no desvelar de uma relação contratual.

Ao analisar o tema, parte da doutrina afirma que o dever de reparar tem caráter substitutivo. Consoante essas linhas, a violação de dever contratual seria responsável por promover a mutação do dever de prestar em dever de reparar. No Brasil, a tese é defendida, por exemplo, por Pontes de Miranda ${ }^{440}$ e Ruy Rosado de Aguiar Junior. ${ }^{441}$ No exterior, por Eugene Gaudemet ${ }^{442}$, Mário Júlio de Almeida $\operatorname{Costa}^{443}$ e Von Thur. ${ }^{444}$ Em termos gerais, essa corrente doutrinária defende que a ausência de pagamento seria responsável pela transformação da prestação prometida em outra distinta da ajustada.

\footnotetext{
${ }^{438}$ LLAMBÍAS, Jorge Joaquín. Estudio sobre la mora en las obligaciones. Buenos Aires: Perrot, 1965. p. 7.

${ }^{439}$ ITURRASPE, Jorge Mosset; PIEDECASAS, Miguel. Responsabilidad contractual. Santa Fé: RubinzalCulzoni, 2007. p. 289.

${ }^{440}$ PONTES DE MIRANDA, Francisco Cavalcanti. Tratado de direito privado: parte especial. 2 ed. Rio de Janeiro: Borsoi, 1958, t. 23. p. 192. O autor é um dos expoentes desse pensamento no Brasil.

441 AGUIAR JUNIOR, Ruy Rosado de. Os contratos nos códigos civis francês e brasileiro, Revista CEJ, Brasília, v. 9, n. 28, p. 5-14, jan./mar. 2005. p. 10. Discorrendo sobre a proximidade e o distanciamento entre os direitos francês e brasileiro, salienta o autor, que, "enquanto o fato ilícito absoluto faz surgir uma nova relação que é a indenizatória prevista no art. 927, o ilícito contratual leva à extensão da mesma relação obrigacional, que se substitui ou se acrescenta pela indenização, em razão do inadimplemento."

${ }^{442}$ GAUDEMET, Eugene. Teoría general de las obligaciones. Trad. Pablo Macedo. México: Editorial Porúa, 1974. p. 403.

${ }^{443}$ COSTA, Mário Júlio de Almeida. Direito das obrigações. 6 ed. Coimbra: Almedina, 1994. p. 59.

${ }^{444}$ VON THUR, Andreas. Tratado de las obrigaciones. Trad. W. Roces. Madrid: Reus, 1934, t. 2. p. 87.
} 
Sustenta-se que, alocando-se no lugar do dever de prestar, o dever de reparar almeja a reparação do dano surgido no curso do processo obrigacional. ${ }^{445}$ Aqui, a violação de dever imputável a uma das partes não é fonte de nova relação obrigacional. ${ }^{446} \mathrm{O}$ dever de reparar, portanto, não possui autonomia, sendo nada mais que mero prolongamento da obrigação pré-existente. Noutras palavras, a violação de dever promoveria a alteração do conteúdo da prestação ${ }^{447}$, sem, contudo, quebrar a identidade da relação jurídica. ${ }^{448}$

Tal leitura promove o enquadramento do tema em perspectiva equivocada. $\mathrm{O}$ dever de reparar não é mero substitutivo do dever de prestar - ou de outra natureza, desde que inerente ao contrato - desrespeitado por uma das partes.

Infira-se que a autonomia do dever de reparar permite visualizar, com bastante clareza, a função preventiva e a reparatória ${ }^{449}$, que lhe são inerentes. A leitura criticada dificulta, ainda, a compreensão da violação de deveres não prestacionais, os quais podem se manifestar independentemente de existir qualquer patologia ligada ao adimplemento prometido ou desempenhado.

Por tudo isso, sustenta-se a existência de um dever de reparar dotado de autonomia. ${ }^{450}$ Esse dever não é mero efeito da violação de um dever contratual. Nasce da contrariedade ao Direito ${ }^{451}$ e precisa ser compreendido como fonte da qual emana uma situação jurídica nova. $^{452}$

${ }^{445}$ CRUZ, Gaston Fernandez. Los supuestos dogmaticos de la responsabilidad contractual: la division de sistemas y la previsibilidad, Revista de Direito Privado, São Paulo, v. 5, n. 19, p. 289-318, jul./set. 2004. p. 296-303.

${ }^{446}$ MOREIRA ALVES, José Carlos. Direito romano: instituições de direito romano. 6 ed. Rio de Janeiro: Forense, 2000, v. 2. p. 36.

447 MAZEAUD, Denis. Responsabilidad contractual y responsabilidad extracontractual: el futuro de la distinción en el derecho francés, Revista Anales Derecho UC, Santiago, v. 3, p. 13-25, mar. 2008. p. 13-14.

${ }^{448}$ PONTES DE MIRANDA, Francisco Cavalcanti. Tratado de direito privado: parte especial. 2 ed. Rio de Janeiro: Borsoi, 1958, t. 23. p. 61-64.

449 LÓPEZ, Andrés Mariño. Los fundamentos de la responsabilidad contractual. Montevideo: Carlos Alvarez, 2005. p. 23-24.

${ }^{450}$ ASSIS, Araken de. Resolução do contrato por inadimplemento. 3 ed. São Paulo: RT, 1999. p. 132.

451 LÓPEZ, Andrés Mariño. Los fundamentos de la responsabilidad contractual. Montevideo: Carlos Alvarez, 2005. p. 25.

${ }^{452}$ COSTA JUNIOR, Olímpio. A relação jurídica obrigacional: situação, relação e obrigação em direito. São Paulo: Saraiva, 1994. p. 7. O autor continua sua reflexão explicitando que os efeitos do inadimplemento são produzidos no âmbito do direito processual, raciocínio esse com o qual absolutamente não se concorda. Basta lembrar que o devedor, diante da impossibilidade de adimplemento a ele imputável, liberta-se do vínculo obrigacional consignando (em caso de recusa do credor em receber a prestação que lhe é devida) o valor ajustado a título de cláusula penal compensatória. 
É evidente que nem sempre, extinguirá a prestação primitiva. ${ }^{453}$ A violação de um dever contratual produz um novo dever jurídico. Aquela atua como fonte - as fontes das obrigações são os fatos jurídicos - desse dever, obrigando o devedor a responder pelos prejuízos que causou. Isso fica ainda mais claro quando se tem em mente que as perdas e danos são consequência de uma conduta contrária ao direito, e não, mero efeito do desrespeito aos deveres que emanam da relação obrigacional. ${ }^{454}$

É por isso que, havendo a violação de um dever contratual, se buscará, em regra, não apenas a satisfação dos interesses do credor, mas, sobretudo, a equalização do equilíbrio contratual e social afetado pela violação de dever. Esse é um ponto relevante na compreensão do tema e que permite ultrapassar os limites construídos pela doutrina clássica no seu tratamento. Antecipe-se, aqui, que cada lesão concretamente produzida não recai apenas sobre aquele que a suportou, mas, de modo mais ou menos intenso, sobre toda a coletividade.

Oportuno destacar que, ao se tratar a violação de dever contratual como fonte do dever de reparar - dever autônomo, como demonstrado ${ }^{455}$-, se promove a aproximação de muitas das construções teóricas formuladas nos universos da responsabilidade contratual e aquiliana, ampliando, assim, a gama de direitos protegidos na primeira das searas, perspectiva que se coaduna com as premissas que informam o direito de danos, dentre elas, a que ressalta a função preventiva e a necessidade de reparação dos danos injustos.

\footnotetext{
${ }^{453}$ GAMARRA, Jorge. Tratado de derecho civil uruguayo. 2 ed. Montevideo: FCU, 2003, v. 2, t. 20. p. 48. Até porque os deveres de prestar e de reparar podem ser cumulados.

${ }^{454}$ GAMARRA, Jorge. Responsabilidad contractual: el incumplimiento. Montevideo: FCU, 2004. p. 16-24. Destaca o autor que "o ato ilícito caracteriza-se no incumprimento e a responsabilidade o sanciona, sendo que a natureza ilícita do incumprimento se aprecia a partir de duplo aspecto: enquanto comportamento antijurídico do devedor (violação de um dever) e pela consequência que acarreta ao mesmo (a obrigação de ressarcir)."

${ }^{455}$ VITA NETO, José Virgílio. A atribuição da responsabilidade contratual. Tese (Doutorado) - Faculdade de Direito da USP, São Paulo, 2007. p. 72. "É preciso compreender que no universo contratual existe uma terceira classe de deveres contratuais, cuja autonomia não é tradicionalmente reconhecida pela dogmática. Trata-se dos deveres cujo conteúdo é a obrigação do sujeito passivo de restaurar as consequiências da violação contratual com a reparação integral dos prejuízos causados. Decorrentes da violação de deveres de prestação ou de deveres ulteriores de conduta, não visam à realização das atribuições econômicas programadas, nem tampouco à proteção da pessoa e do patrimônio da outra parte. Sua função é tão somente a indenização dos prejuízos causados pela violação contratual."
} 
Vale destacar que, no Brasil, comungam desse entendimento Anelise Becker $^{456}$, Arnoldo Wald ${ }^{457}$, Carlos Alberto Dabus Maluf ${ }^{458}$, José de Aguiar Dias ${ }^{459}$ e Silvio Rodrigues. ${ }^{460}$ No exterior, a mesma perspectiva de compreensão informa as reflexões de Álvaro Pérez Vives ${ }^{461}$, Jorge Mosset Iturraspe ${ }^{462}$, Michele Giorgianni ${ }^{463}$, Roberto Antonio Vázquez Ferreyra ${ }^{464}$ e Roberto de Ruggiero. ${ }^{465}$

Enfim, parece possível concluir, neste instante, mesmo que suportando os riscos da imperfeição, que a responsabilidade contratual consiste na atribuição do dever de reparar os danos provocados pela violação, imputável a uma das partes, de um direito de titularidade do parceiro contratual. ${ }^{466}$

${ }^{456}$ BECKER, Anelise. Elementos para uma teoria unitária da responsabilidade civil, Revista de Direito do Consumidor, São Paulo, n. 13, p. 42-55, jan./mar. 1995. p. 45. "Se o contrato é uma fonte de obrigações, a sua inexecução, i. é, a responsabilidade contratual, é outra."

${ }^{457}$ WALD, Arnoldo. Da responsabilidade civil contratual e delitual, Revista Forense, Rio de Janeiro, v. 72, n. 256, p. 107-123, out./dez. 1976. p. 114.

${ }^{458}$ MONTEIRO, Washington de Barros; MALUF, Carlos Alberto Dabus. Curso de direito civil: direito das obrigações. 35 ed. São Paulo: Saraiva, 2010, v. 4. p. 82.

${ }^{459}$ AGUIAR DIAS, José de. Da responsabilidade civil. 10 ed. Rio de Janeiro: Forense, 1995, v. 1. p. 126. "Por outro lado, não se pode encarar a responsabilidade contratual como simples problema de efeito das obrigações. Se o contrato é uma fonte de obrigações, a sua inexecução também o é. Quando ocorre a inexecução, não é a obrigação contratual que movimenta o mundo da responsabilidade. O que se estabelece é uma obrigação nova que se substitui à obrigação preexistente no todo ou em parte: a obrigação de reparar o prejuízo conseqüente à inexecução da obrigação assumida. Essa verdade se afirmará com mais vigor se observarmos que a primeira obrigação (contratual) tem origem na vontade comum das partes, ao passo que a obrigação que a substitui por efeito de inexecução, isto é, a obrigação de reparar o prejuízo, advém, muito ao contrário, contra a vontade do devedor: este não quis a obrigação nova, estabelecida com a inexecução da obrigação que contratualmente consentira. Em suma: a obrigação nascida do contrato é diferente da que nasce de sua inexecução. Assim sendo, a responsabilidade contratual é também fonte de obrigações, como a responsabilidade delitual."

${ }^{460}$ RODRIGUES, Silvio. Direito civil: responsabilidade civil. 19 ed. São Paulo: Saraiva, 2002, v. 4. p. 8.

${ }^{461}$ VIVES, Álvaro Pérez. Teoría general de las obligaciones: de las fuentes de las obligaciones. 2 ed. Bogotá: Temis, 1954, v. 2, t. 1. p. 13.

${ }^{462}$ ITURRASPE, Jorge Mosset; PIEDECASAS, Miguel. Responsabilidad contractual. Santa Fé: RubinzalCulzoni, 2007. p. 21.

${ }^{463}$ GIORGIANNI, Michele. L'obbligazione: la parte generale delle obbligazioni. Milano: Giuffrè, 1968, v. 1. p. 163.

${ }^{464}$ FERREYRA, Roberto Antonio Vázquez. El acto ilícito: significado, estrutura y evolución. In: GESUALDI, Dora Mariana (Coord.). Derecho privado. Buenos Aires: Hammurabi, 2001. p. 1003-1005. Consoante o autor, a antijuridicidade supõe uma contradição com alguma das fontes do Direito e não apenas a contrariedade às regras previamente insertas em textos codificados.

${ }^{465}$ RUGGIERO, Roberto de. Instituições de direito civil: direito das obrigações, direito hereditário. Trad. Paolo Capitanio. Campinas: Bookseller, 1999, v. 3. p. 158-159.

${ }^{466}$ Informe-se que aspectos inerentes ao universo externo de atuação do princípio da função social dos contratos não foram explorados neste trabalho e, por isso, são excluídos da noção formulada. 
É possível afirmar, ainda, que, uma vez configurada, deve ser concebida como fonte obrigacional, ao produzir um dever que tem por escopo reparar a lesão suportada pelo parceiro contratual, embora nada impeça a cumulação do dever de reparar com o dever de prestar.

\subsection{Os pressupostos conformadores da responsabilidade contratual}

O ressarcimento dos danos surgidos no desvelar de um processo obrigacional disparado pela relação contratual existente entre as partes exige a observância de alguns pressupostos. Identificá-los é tarefa de extrema importância, pois, somente assim, aferir-seá, com segurança, quando (ou não) terá gênese o dever de reparar.

Antecipe-se que, em linhas gerais, tem-se afirmado que são essenciais à caracterização da responsabilidade contratual: (a) a existência e a validade de um contrato, (b) o não cumprimento da prestação exigível, (c) um dano passível de ressarcimento, ligado à conduta do devedor por meio de (d) um liame de causalidade ${ }^{467}$; (e) havendo, ainda, quem acrescente, aqui, a figura da culpa. ${ }^{468}$

Saliente-se, ademais, que construções mais recentes sustentam que são essenciais à caracterização do dever de reparar, além da pré-existência do contrato: (a) um fato jurídico - que, no universo contratual, se manifesta mediante a violação de dever, (b) um dano certo, atual e passível de reparação, (c) imputável a uma das partes por meio de um fator eleito pelo Direito, desde que a lesão ao interesse juridicamente protegido esteja ligada à violação do dever contratual (d) por uma relação causal denominada nexo de causalidade. $^{469}$

Delimitar quais são os pressupostos do dever de reparar na realidade contemporânea e compreender qual a essência e extensão de cada um deles é a missão ora assumida. A investigação dos pressupostos da responsabilidade contratual é de extrema importância para que se possa aferir quando (ou não) surgirá o dever de reparar.

\footnotetext{
${ }^{467}$ SAVI, Sérgio. Inadimplemento das obrigações, mora e perdas e danos. In: TEPEDINO, Gustavo (Coord.). Obrigações: estudos na perspectiva civil-constitucional. Rio de Janeiro: Renovar, 2005. p. 478.

${ }^{468}$ LEITÃO, Luís Manuel Teles de Menezes. Direito das obrigações: transmissão e extinção das obrigações, não cumprimento e garantias do crédito. 3 ed. Coimbra: Almedina, 2005, v. 2. p. 243-244.

${ }^{469}$ FROTA, Pablo Malheiros da Cunha. Danos morais e a pessoa jurídica. São Paulo: Método, 2008. p. 162171.
} 
O surgimento do dever de reparar os danos oriundos da violação de um dever contratual pressupõe a existência de um contrato. ${ }^{470}$ Além dessa configuração, tem-se sustentado, clássica e contemporaneamente, que a responsabilidade contratual exige um contrato válido ${ }^{471}$, pensamento predominante na América Latina, como se observa nas linhas tecidas por Jorge Bustamante Alsina ${ }^{472}$, Jorge Mosset Iturraspe ${ }^{473}$, Lorenzo de la Maza Rivadeneira ${ }^{474}$ e Rafael Durán Trujillo. ${ }^{475}$

Essa assertiva, entretanto, apesar de senso comum em sede doutrinária, precisa ser repensada. Em verdade, apenas a existência do contrato é pressuposto do dever de reparar os danos contratuais. A validade do contrato, embora permeie a maior parte das situações concretamente estabelecidas, é circunstância meramente acidental. Ratifique-se que apenas a existência do contrato é pressuposto e que, nesse contexto, eventuais defeitos contidos na gênese do contrato não têm força suficiente para afastar a incidência da responsabilidade contratual.

Prova disso é que, no universo dos contratos anuláveis, podem ser visualizadas as hipóteses em que uma das partes, podendo buscar a desconstituição do negócio, opta por não o fazer. E isso pode ocorrer tanto quando permite que a decadência fulmine o direito de desconstituir o contrato viciado, como quando cumpre a prestação prometida. Aqui, podem ser enquadradas, ainda, as situações em que uma das partes - com idade entre 16 e 18 anos -, se afirma maior de idade ou esconde dolosamente sua menoridade e, enfim, a hipótese na qual, uma vez demandada, não postula a anulação do ajuste.

\footnotetext{
${ }^{470}$ DINIZ, Maria Helena. Curso de direito civil brasileiro: responsabilidade civil. 22 ed. São Paulo: Saraiva, 2008, v. 7. p. 274. "É imprescindível, para sua configuração, a existência de um vínculo contratual entre credor e devedor, isto é, entre a vítima e o autor do dano, pois somente se houver contrato o credor estará autorizado a exigir do devedor o cumprimento da prestação."

${ }^{471}$ AGUIAR DIAS, José de. Da responsabilidade civil. 10 ed. Rio de Janeiro: Forense, 1995, v. 1. p. 132.

472 BUSTAMANTE ALSINA, Jorge. Teoria general de la responsabilidad civil. 3 ed. Buenos Aires: Abeledo-Perrot, 1980. p. 95.

${ }^{473}$ ITURRASPE, Jorge Mosset. Contratos. Buenos Aires: Rubinzal-Culzioni, 2007. p. 418-419.

474 RIVADENEIRA, Lorenzo de la Maza. Responsabilidad contractual, Revista Chilena de Derecho, Santiago, v. 16, n. 3, p. 619-634, set./dez. 1989. p. 619.

475 TRUJILLO, Rafael Durán. Nociones de responsabilidad civil: contractual y delictuosa. Bogotá: Temis, 1957. p. 31-54.
} 
A seu turno, no que diz respeito aos contratos nulos, embora sejam mais raras as ocasiões em que possa surgir o dever de reparar, também é possível antevê-las. Um primeiro exemplo decorre dos contratos que, embora nulos, possam passar pelo processo de conversão substancial. Nessa mesma esteira de reflexão, outra situação é vislumbrada por Luis Edson Fachin, ao destacar que, nos contratos nulos, a inobservância do princípio da função social pode ensejar a reparação de interesses positivos. ${ }^{476}$ Pode-se pensar, ainda, nos contratos nulos em razão da inobservância de aspectos formais e nas relações contratuais de fato, tema que deixa de ser explorado por extrapolar os limites da tese em construção.

Noutro vértice, afirma-se, ainda, que o dever de reparar os danos contratuais exige um contrato eficaz. ${ }^{477}$ E eficaz ${ }^{478}$ porque, somente assim, seria possível pensar na ausência de cumprimento. Tais reflexões, embora não sejam totalmente equivocadas, pecam por serem imprecisas. E pecam, inicialmente, porque os deveres contratuais que exsurgem da relação concretamente estabelecida, como se sabe, vão além dos deveres de prestação.

É sempre oportuno resgatar a existência de deveres distintos daquele que impõe ao devedor adimplir o que prometera - tratados neste trabalho como deveres gerais de conduta. Aqui, facilmente se percebe que, mesmo que a prestação prometida pelo devedor ainda não seja exigível - por ter sido projetada para um momento futuro no tempo ou por estar subordinada a uma condição -, o credor ou devedor poderão ser lesados. O dano pode ocorrer porque, por exemplo, não foram adequadamente informados acerca do uso do objeto da prestação, por quebra de sigilo, ou porque não lhes foi assegurada a devida proteção.

\footnotetext{
${ }^{476}$ FACHIN, Luiz Edson. Responsabilidade por dano de cumprimento diante do desaproveitamento da função social do contrato. In: NERY, Rosa Maria Barreto Borriello de Andrade; DONNINI, Rogério (Coord.). Responsabilidade civil: estudos em homenagem ao professor Rui Geraldo Camargo Viana. São Paulo: RT, 2009. p. 315-319. "Em suma, é o caso de violação do interesse positivo, emergindo danos do não cumprimento do contrato pela não observância ou desaproveitamento da função social; o mesmo será, em juízo de proporcionalidade, diante do seu cumprimento defeituoso ou tardio. O desaproveitamento da função social configura a violação de dever jurídico específico, independentemente de afetar as respectivas prestações típicas ou principais."

477 AGOGLIA, María Martha; BORAGINA, Juan Carlos; MEZA, Jorge Alfredo. Responsabilidad por incumplimiento contractual. Buenos Aires: Hammurabi, 2003. p. 188.

${ }^{478}$ PONTES DE MIRANDA, Francisco Cavalcanti. Tratado de direito privado: parte especial. 2 ed. Rio de Janeiro: Borsoi, 1958, t. 23. p. 134.
} 
Identifique-se, ainda, que a figura da quebra antecipada do contrato ${ }^{479}$ permite compreender que o devedor poderá ser compelido a reparar os prejuízos suportados pelo credor antes do vencimento da prestação. Não há dúvida, nesse contexto, de que é factível defender a possibilidade do não cumprimento antecipado dos deveres de prestação ${ }^{480}$, apto não só a autorizar a resolução do contrato, mas também, presentes os demais pressupostos, a configurar o dever de reparar.

\section{A lesão a um interesse juridicamente protegido}

É afirmação recorrente que o dano é elemento essencial a qualquer espécie de responsabilidade civil. ${ }^{481}$ A assertiva, por pecar pela imprecisão, precisa ser revista. E revista porque o dever de reparar pode se manifestar sem dano ${ }^{482}$, mas não, saliente-se desde cedo, sem a existência de lesão a um interesse juridicamente protegido.

A afirmação pode ser comprovada quando se vislumbram os juros moratórios e a cláusula penal, consectários exigíveis - ainda que a última possa ser reduzida ou mesmo afastada em algumas ocasiões -, mesmo sem a existência de qualquer prejuízo de ordem material suportado pelo parceiro contratual. Não se trata de simples dispensa de prova do dano, mesmo porque, na última das hipóteses, pode ocorrer que o titular da aludida posição jurídica - credor de cláusula penal violada - não sofra prejuízo algum. Ademais, parece irrefutável aceitar a existência de hipóteses de responsabilidade por dano futuro. ${ }^{483}$ Por tudo isso, o dano não pode ser tratado como pressuposto do dever de reparar. Seu lugar é ocupado, contemporaneamente, pela ideia de lesão a interesse juridicamente protegido.

\footnotetext{
${ }^{479} \mathrm{O}$ tema é trabalhado, dentre outros por: ASSIS, Araken de. Resolução do contrato por inadimplemento. 3 ed. São Paulo: RT, 1999. p. 95-98. USTÁRROZ, Daniel. Temas atuais de direito contratual: a boa-fé objetiva, a responsabilidade pré-contratual e o inadimplemento antecipado. Sapucaia do Sul: Notadez, 2010. p. 89-112.

${ }^{480}$ TENENBAUM, Michael. Efficient breach of contract: perspectives from american courts at the dawn of the $21^{\text {st }}$ century. In: ESPINOSA, Fabricio Mantilla; BARRIOS, Francisco Ternera (Dir.). Los contratos en el derecho privado. Bogotá: Legis, 2007. p. 339-349. Veja ainda: GAMARRA, Jorge. Responsabilidad contractual: el incumplimiento. Montevideo: FCU, 2004. p. 149-157.

${ }^{481}$ COELHO, Fábio Ulhoa. Curso de direito civil. São Paulo: Saraiva, 2004, v. 2. p. 286.

482 SAGARNA, Fernando Alfredo. La relación de causalidad: ¿es prescindible como presupuesto de la responsabilidad civil?. In: GESUALDI, Dora Mariana (Coord.). Derecho privado. Buenos Aires: Hammurabi, 2001. p. 1271.

${ }^{483}$ Reconhecido em acórdão do Tribunal de Justiça Catarinense: TJSC. AI 2004.031762-2. 2. CCív. Rel. Des. Newton Janke. j. 09.06.08.
} 
Considerando-se, entretanto, que a aludida conclusão não afasta a importância do tema, em linhas gerais, é relevante destacar, excluídas aqui situações excepcionais, que não há maiores discussões sobre a necessidade de demonstração da concretude do dano sofrido, ônus que, em regra, pertence ao lesado. ${ }^{484}$ Além disso, a quantificação da reparação não pode ser arbitrariamente fixada. ${ }^{485}$ Enfim, embora se afirme que a lesão passível de reparação é aquela que se mostra certa, atual ${ }^{486}$ e contrária ao Direito ${ }^{487}$, aparentemente, nem sempre os dois últimos aspectos precisarão ser observados.

Aliás, é oportuno destacar que várias são as correntes de pensamento que se entrechocam ao debater acerca do que é dano ${ }^{488}$ ressarcível. Afirma-se que o dano consistiria na diminuição direta ou indireta do patrimônio. ${ }^{489}$ Defende-se, noutra esteira, que esse se manifestaria em razão da "diminuição ou subtração de um bem jurídico"490 , ou ainda, que deve ser concebido como a desvantagem suportada por esse bem. ${ }^{491}$

Tais concepções não têm espaço na contemporaneidade. O principal problema na primeira das correntes está atrelado à tutela de aspectos exclusivamente materiais, visão inaceitável à luz do estado da arte. A segunda construção, por sua vez, peca, especialmente, por ignorar que os seres humanos e os direitos da personalidade não podem ser classificados como bens, embora sejam obviamente merecedores de tutela jurídica.

\footnotetext{
${ }^{484}$ LARROUMET, Christian. La defensa de la responsabilidad contractual en derecho frances, Revista Trimestral de Direito Civil, Rio de Janeiro, n. 8, p. 151-163, out./dez. 2001. p. 153.

485 PEREIRA, Caio Mário da Silva. Instituições de direito civil: teoria geral das obrigações. 20 ed. Atual. Luis Roldão de Freitas Gomes. Rio de Janeiro: Forense, 2004, v. 2. p. 337.

${ }^{486}$ FROTA, Pablo Malheiros da Cunha. Danos morais e a pessoa jurídica. São Paulo: Método, 2008. p. $167-$ 168.

${ }^{487}$ DE CUPIS, Adriano. El daño: teoria general de la responsabilidad civil. Trad. Ángel Martínez Sarrión. Barcelona: Bosch, 1975. p. 86-92. "Quando o ato humano é não apenas juridicamente relevante, mas se apresenta como antijurídico, essa nota de antijuridicidade se estende ao dano produzido [e no] que se refere à íntima essência da antijuridicidade, deve destacar-se que essa significa contrariedade ao direito."

${ }^{488}$ Optou-se por utilizar os termos contidos nos textos pesquisados.

${ }^{489}$ BUSTAMANTE, Lino Rodriguez-Arias. Derecho de obligaciones. Madrid: Editorial Revista de Derecho Privado, 1965. p. 229.

${ }^{490}$ FIUZA, César. Por uma nova teoria do ilícito civil, Revista da Faculdade Mineira de Direito, Belo Horizonte, v. 6, n. 11/12, p. 29-48, 2003. p. 35.

491 ENNECCERUS, Ludwig. Derecho de obligaciones: doctrina general. Trad. Blas Pérez Gonzales; José Alguer. Barcelona: Bosch, 1944, v. 1. p. 61. Dentre tais bens, o autor insere "o patrimônio, o corpo, a vida, a saúde, a honra, o crédito, o bem-estar, a capacidade de aquisição etc."
} 
Uma terceira concepção vê o dano como a lesão de ordem patrimonial ou extrapatrimonial a um interesse juridicamente protegido e passível de reparação. ${ }^{492}$ Talvez, a principal virtude dessa linha de pensamento esteja na ampliação do universo de bens e valores que se encontram por ela albergados.

Aliás, mister destacar que se observa, contemporaneamente, uma tendência em compreender o dano passível de reparação como o dano injusto ${ }^{493}$, noção que permite depurar quais, dentre os danos suportados, são merecedores de reparação. ${ }^{494} \mathrm{O}$ dano injusto é assim classificado por derivar de um comportamento contrário ao Direito ${ }^{495}$, ou seja, aquele que foi causado sem direito - sem justificação - e, ao mesmo tempo, contra o direito. $^{496}$

A injustiça do dano será buscada no juízo de ponderação ${ }^{497}$ a ser processado tendo em conta a conduta e a lesão por ela provocada no caso concreto. ${ }^{498} \mathrm{Um}$ dano injusto parece ter dupla face, sendo assim classificado porque foi injustamente causado e (ou) por ser injusto que aquele que o sofreu suporte sozinho (ou não) suas consequências. ${ }^{499}$ A perspectiva é relevante, mormente por conduzir a que a análise do dano deixe de perquirir se esse foi produzido (ou não) ilicitamente e passe a identificar se a lesão deriva (ou não) do exercício de um direito ou interesse digno de tutela. ${ }^{500}$

\footnotetext{
${ }^{492}$ ALPA, Guido. Responsabilità civile e danno: lineamenti e questioni. Imola: Il Mulino, 1991. p. 463. No mesmo sentido: BORAGINA, Juan Carlos. El daño. In: GESUALDI, Dora Mariana (Coord.). Derecho privado. Buenos Aires: Hammurabi, 2001. p. 1140-1141.

${ }^{493}$ GOMES, Orlando. Tendências modernas na teoria da responsabilidade civil. In: DI FRANCESCO, José Roberto. Estudos em homenagem ao professor Silvio Rodrigues. São Paulo: Saraiva, 1989. p. 293. O autor alude ao "giro conceitual do ato ilícito para o dano injusto."

${ }^{494}$ VISINTINI, Giovanna. Tratado de la responsabilidad civil: el daño, otros criterios de imputación. Trad. Aída Kemelmajer de Carlucci. Buenos Aires: Astrea, 1999, v. 2. p. 17-21.

${ }^{495}$ ITURRASPE, Jorge Mosset. Contratos. Buenos Aires: Rubinzal-Culzioni, 2007. p. 410-411. No mesmo sentido: ALTERINI, Atílio Aníbal. Estudios de derecho civil: conceptos, contratos, consumidor, derecho de daños. Buenos Aires: La Ley, 2007. p. 330.

${ }^{496}$ SALVI, Cesare. La responsabilità civile. 2 ed. Milano: Giuffrè, 2005. p. 87.

${ }^{497}$ É por isso que os danos suportados pelo credor no quadro emoldurado pela parte final do art. 399 do Código Civil não são passíveis de reparação civil. O legislador, nesse caso, em que pese a incidência da perpetuatio obligationis, afasta a possibilidade de incidência do dever de reparar.

${ }^{498}$ RUSCELLO, Francesco. Istituzioni di diritto privato: le obbligazioni. 2 ed. Milano: Giuffrè, 2006, v. 2. p. 177.

${ }^{499}$ BENÍTEZ, Elsa. La revolución industrial y el derecho de daños: sus consecuencias. In: GHERSI, Carlos Alberto (Dir.). Responsabilidad objetiva: el artículo 1113 y la ley 24.999. Mendoza: Ediciones Jurídicas Cuyo, 1999. p. 37-38.

${ }^{500}$ SEGUí, Adela Maria. Aspectos relevantes de la responsabilidad civil moderna, Revista de Direito do Consumidor, São Paulo, v. 13, n. 52, p. 267-318, out./dez. 2004. p. 281.
} 
Infira-se que a noção do dano injusto passa pela aferição do interesse juridicamente protegido. ${ }^{501} \mathrm{~A}$ análise proposta permite, com alguma facilidade, afirmar que lesões irrisórias não são dignas de reparação civil. ${ }^{502} \mathrm{O}$ dano passível de ressarcimento, nesse contexto, há de ser relevante ${ }^{503}$, análise a ser promovida tendo em conta as intersubjetividades existentes na relação contratual concretamente estabelecida.

O dano pode, ainda, ser classificado como patrimonial ou extrapatrimonial. ${ }^{504}$ Prefere-se a expressão dano extrapatrimonial ${ }^{505}$ em lugar da terminologia consagrada ${ }^{506}$ por retratar com maior precisão o fenômeno que se propõe a descrever. E, mesmo que, por longa data, tenha se defendido que o dano extrapatrimonial não teria vez no universo contratual $^{507}$, atualmente, além de ser inquestionável que os danos extrapatrimoniais são tutelados também nessa seara, estudos sobre o tema identificaram que aqueles comportam várias "classes", destacando-se, aqui, a título exemplificativo, o dano corporal, o psíquico, o fisiológico, o biológico ${ }^{508}$, o estético, o causado à esfera sexual, o dano às condições de

${ }^{501}$ MORAES, Maria Celina Bodin de. Danos à pessoa humana: uma leitura civil-constitucional dos danos morais. Rio de Janeiro: Renovar, 2003. p. 181.

502 JORGE, Fernando Pessoa. Ensaio sobre os pressupostos da responsabilidade civil. Coimbra: Almedina, 1999. p. 387.

${ }^{503}$ AGUIAR DIAS, José de. Da responsabilidade civil, Revista do Advogado, São Paulo, n. 19, p. 33-39, out. 1985. p. 34-35.

${ }^{504}$ DE CORES, Carlos. Acerca de las funciones de la responsabilidad civil. In: FERNÁNDEZ, Carlos López; CAUMONT, Arturo; CAFFERA, Gerardo (Coord.). Estudios de derecho civil en homenaje al profesor Jorge Gamarra. Montevideo: FCU, 2001. p. 114. Esclarece o autor que haverá dano extrapatrimonial quando houver uma lesão a um direito fundamental da personalidade e, ainda, que a tese que o embasa na dor ou sofrimento se encontra superada.

505 BORGES, Roxana Cardoso Brasileiro. Direitos da personalidade e dignidade: da responsabilidade civil para a responsabilidade constitucional. In: DELGADO, Mário Luiz; ALVES, Jones Figueiredo (Coord.). Questões controvertidas: responsabilidade civil. São Paulo: Método, 2006, v. 5. p. 567. Destaca a autora que “convém abandonar a expressão "dano moral" e adotar "dano extrapatrimonial”, reforçando a idéia de que basta a violação do direito de personalidade para que caracterize o dano [...] abandonando-se a idéia de sofrimento e de demonstração da intensidade da dor sofrida."

${ }^{506}$ No Brasil, quase unanimemente, recorre-se à expressão dano moral.

${ }^{507}$ DE CUPIS, Adriano. El daño: teoria general de la responsabilidad civil. Trad. Ángel Martínez Sarrión. Barcelona: Bosch, 1975. p. 173-181.

${ }^{508}$ LA TORRE, Antonio. I criterio d'imputazione della responsabilità civile, Roma e America: Diritto Romano Comune, Roma, n. 10, p. 96-114, 2000. p. 104. O dano biológico, segundo o autor, é aquele que se percebe a partir de "uma diminuição da integridade psicofísica da pessoa, atingindo o valor humano e todas as concretas expressões inerentes ao seu modo de ser e agir no ambiente no qual a vida se desenvolve, envolvendo relações sociais, culturais, recreativas, etc." 
existência, dentre outras. ${ }^{509}$ Em verdade, é impossível antever como hão de se manifestar. ${ }^{510}$

Seja permitido destacar ainda a existência dos denominados danos sociais ${ }^{511}$, perspectiva que se coaduna com as diretrizes constitucionais informadoras da temática sob análise e cujo estudo pode enriquecer a seara da responsabilidade contratual ${ }^{512}$, mormente por conta da função preventiva que deve cumprir.

É importante, enfim e em apertada conclusão, salientar que a ideia de interesse passível de reparação sintetiza-se nas consequências pessoais e (ou) patrimoniais - dignos de tutela - oriundas da violação, imputável à conduta de uma das partes, de um dever de prestação (ou não), não se limitando à ofensa a um direito creditício ou a mera violação de um dever contratual. ${ }^{513}$

\section{A antijuridicidade}

A antijuridicidade também se apresenta como pressuposto do dever de reparar. Ela há de qualificar a conduta do devedor - ou do credor -, adjetivando-a como consoante

${ }^{509}$ HINESTROSA, Fernando. Devenir del derecho de daños, Roma e America: Diritto Romano Comune, Roma, n. 10, p. 17-36, 2000. p. 34.

510 MORAES, Maria Celina Bodin de. Prefácio. In: SCHREIBER, Anderson. Novos paradigmas da responsabilidade civil: da erosão dos filtros da reparação à diluição dos danos. São Paulo: Atlas, 2007. p. XIV. "Dano à vida de relação, dano pela perda de concorrencialidade, dano pela redução de capacidade laboral genérica, dano sexual, dano hedonístico, dano consistente no custo de manutenção de filho indesejado, dano consistente na perturbação das atividades normais do indivíduo e da serenidade pessoal, dano de férias arruinadas, dano de mobbing, dano de mass media, dano de processo lento, dano de brincadeiras cruéis, dano decorrente do rompimento de noivado, da separação após a notícia de gravidez, do descumprimento de deveres conjugais, do abandono afetivo de filho menor, dano-morte (inclusive de animal doméstico)."

511 JUNQUEIRA DE AZEVEDO, Antonio. Por uma nova categoria de dano na responsabilidade civil: o dano social. In: FILOMENO, José Geraldo Brito; WAGNER JUNIOR, Luiz Guilherme da Costa; GONÇALVES, Renato Afonso (Coord.). O código civil e sua interdisciplinaridade: os reflexos do código civil nos demais ramos do direito. Belo Horizonte: Del Rey, 2004. p. 370-377. Veja ainda: TARTUCE, Flávio. Reflexões sobre o dano social, Revista Trimestral de Direito Civil, Rio de Janeiro, v. 34, p. 179-201, abr./jun. 2008. p. 179-201.

${ }^{512}$ Por ultrapassar os objetivos desta tese, o tema, apesar de extremamente interessante, não será explorado.

${ }^{513}$ CASTILlA, Gustavo Ordoqui. Diez reglas para la avaluación del daño contractual, Revista de Derecho de la Universidad Católica del Uruguay, Montevideo, v. 2, p. 75-125, 2001. p. 80-81. 
ou contrária ao Direito. Antijurídica é a atribuição que deve ser dada a qualquer conduta não tolerada pelo Direito. ${ }^{514}$

É essencial compreender que o processo de aferição da antijuridicidade da conduta daquele a quem se pretende atribuir o dever de reparar há de ser promovida a partir de parâmetros objetivos, portanto, com absoluta independência da formulação de qualquer juízo de culpabilidade.

Ato contínuo, importante salientar que, no universo do direito contratual, a antijuridicidade exsurge da violação de um dever - independentemente das vestes que usa $^{515}$ - desrespeitado no curso do processo obrigacional. ${ }^{516}$ Reafirme-se ser irrelevante, para sua caracterização, a presença (ou ausência) de culpa ${ }^{517}$ ou de qualquer outro fator de atribuição do dever de reparar.

Considerando-se que a antijuridicidade qualifica a conduta concretamente adotada por aquele a quem se pretende imputar o dever de reparar, torna-se imperioso compreender no que ela consiste. Em apertada síntese, por conduta, deve ser compreendida a possibilidade de domínio das circunstâncias de fato, ou "todo comportamento por meio do qual o sujeito dominava, ou podia ter dominado, o resultado da cadeia causal de acontecimentos, de modo a poder, se assim se decidisse, modificá-la."

514 BUSTAMANTE ALSINA, Jorge. El perfil de la responsabilidad civil al finalizar el siglo XX. In: BUERES, Alberto Jesús; DE CARLUCCI, Aída Kemelmajer (Dir.). Responsabilidad por daños en el tercer milenio. Buenos Aires: Abeledo-Perrot, 1997. p. 19. Veja ainda: ITURRASPE, Jorge Mosset. Contratos. Buenos Aires: Rubinzal-Culzioni, 2007. p. 401-403. Ensina o autor que "a responsabilidade contratual nasce do incumprimento, entendido em sentido amplo, do dever jurídico qualificado de dar, fazer ou não fazer. [O incumprimento] qualifica como antijurídico o comportamento daquele."

${ }^{515}$ LORENZETTI, Ricardo Luis. Tratado de los contratos: parte general. Buenos Aires: Rubinzal Culzoni, 2004. p. 595-596.

${ }^{516}$ BUSTAMANTE, Lino Rodriguez-Arias. Derecho de obligaciones. Madrid: Editorial Revista de Derecho Privado, 1965. p. 193-195.

${ }^{517}$ SAVAUX, Eric. O fim da responsabilidade contratual?, Revista Justitia, São Paulo, n. 194, p. 130-152, abr./jun. 2001. p. 145. "Em matéria contratual, a noção de culpa deve ser abandonada em proveito da de inexecução da obrigação. Sendo as perdas e danos contratuais destinadas a fornecer ao credor uma satisfação por equivalência, e não a indenizá-lo de um dano, basta que se pergunte se ele recebeu a prestação prometida. $\mathrm{Na}$ negativa, tem ele direito a perdas e danos sem que seja necessário indagar se o comportamento do devedor é ou não culposo. Como na common law, onde só se leva em conta o breach of contract, o direito do credor deve se fundar unicamente na inexecução da obrigação."

${ }^{518}$ VITA NETO, José Virgílio. A atribuição da responsabilidade contratual. Tese (Doutorado) - Faculdade de Direito da USP, São Paulo, 2007. p. 100. "Conduta será então todo o [sic] comportamento pelo qual o sujeito atue sobre o mundo externo. A transformação do mundo externo, a apropriação das circunstâncias que levam a esse ou àquele resultado, constitui a expressão máxima da personalidade de um sujeito de direito. Quando o sujeito não pode influenciar o ambiente, não pode determinar as circunstâncias do fato, as conseqüências verificadas não serão expressão de sua personalidade, mas do mero acaso, ou decorrência de 
Infira-se que, a partir dessa ideia, é fácil compreender como age a antijuricidade, atribuindo à conduta o papel de fonte da injustiça do dano ao desvalorá-la, seu resultado ou, concomitantemente, ambos. ${ }^{519}$

Saliente-se que diversos são os autores que, em vez de recorrer à expressão antijuridicidade, desenvolvem seus estudos exigindo a ilicitude da conduta do causador do dano como pressuposto do dever de reparar. Em termos gerais, defendem que a ilicitude atua como um filtro, determinando objetivamente quais danos serão (ou não) ressarcidos ${ }^{520}$ em cada situação em que a violação de um dever contratual provocar a lesão a um interesse juridicamente tutelado.

Aliás, é possível afirmar que não existe problema algum na alusão à ilicitude. A substituição da expressão antijuridicidade pela ilicitude é viável ${ }^{521}$ desde que, por ilícita, se compreenda a conduta que se distancia do Direito ${ }^{522}$, ou seja, aquela que é contrária ao Direito $^{523}$, reafirme-se, análise promovida independentemente da presença (ou não) da culpa do causador do dano. ${ }^{524}$

Opta-se, entretanto, pela utilização da expressão antijuridicidade em razão da associação comumente feita da ilicitude com a culpa, problema percebido em autores que afirmam que a culpa é todo ilícito prejudicial ao direito alheio ${ }^{525}$ e que também pode ser identificada em concepções que tratam a culpa como inobservância de dever de conduta. ${ }^{526}$

condutas alheias. Submeter o sujeito às conseqüências desse evento significa negar sua individualidade, fazêlo instrumento de outros propósitos."

${ }^{519}$ GESUALDI, Dora Mariana. De la antijuridicidad a las causas de justificación. In: BUERES, Alberto Jesús; DE CARLUCCI, Aída Kemelmajer (Dir.). Responsabilidad por daños en el tercer milenio. Buenos Aires: Abeledo-Perrot, 1997. p. 148.

520 BARBOSA, Mafalda Miranda. Liberdade vs. responsabilidade: a precaução como fundamento da imputação delitual?. Coimbra: Almedina, 2006. p. 213. Compreenda-se ilicitude como ato contrário ao direito.

${ }^{521}$ BRAGA NETTO, Felipe Peixoto. Teoria dos ilícitos civis. Belo Horizonte: Del Rey, 2003. p. 78. "Em nosso juízo existem ilícitos cuja fonte normativa não é um texto expresso, mas paradigmas semânticos evidenciados pela atividade hermenêutica, à luz dos valores, princípios e normas existentes num dado contexto histórico."

${ }^{522}$ CASTILHA, Gustavo Ordoqui. Buena fe contractual. Montevideo: Del Foro, 2005. p. 211.

${ }^{523}$ BUSSATTA, Eduardo Luiz. Resolução dos contratos e teoria do adimplemento substancial. São Paulo: Saraiva, 2007. p. 84-91. Dispensa, portanto, de seu suporte fático, as figuras da culpa e do dano.

${ }^{524}$ Consoante disposto no artigo 186 do Código Civil.

${ }^{525}$ AMÉZAGA, Juan José. Culpa aquiliana: leciones del curso de derecho civil. Montevideo: s/e, 1914. p. 3.

526 GRAMSTRUP, Erik Frederico. Responsabilidade objetiva na cláusula geral codificada e nos microssistemas. In: DELGADO, Mário Luiz; ALVES, Jones Figueirêdo (Coord.). Questões controvertidas: responsabilidade civil. São Paulo: Método, 2006, v. 5. p. 127-128. Confundindo, salvo melhor juízo, a culpa com o ato ilícito. 
Outra razão que informa essa reflexão busca evitar a compreensão de que a responsabilidade objetiva decorre necessariamente de comportamentos lícitos ${ }^{527}$, assertiva que não é verdadeira. Finalmente, a objeção à expressão ilicitude ampara-se no fato de que comportamentos lícitos podem ensejar o dever de reparar.

Retomando a trilha aberta, é importante ratificar que a antijuridicidade se liquefaz em atos contrários ao Direito e independe de quaisquer considerações inerentes à esfera subjetiva na conduta do causador do dano. ${ }^{528}$ Por isso, é perfeitamente possível identificar-se uma conduta que seja, ao mesmo tempo, contrária ao Direito e despida de culpa. $^{529}$ É fundamental deixar claro que a culpa não faz parte da noção de antijuridicidade. ${ }^{530}$ Essa, como antecipado, consiste na "contrariedade ao Direito entendido como ordenamento composto por princípios e regras e [concorde-se ou não com a ideia] polarizado por uma precisa finalidade, qual seja, ordenar a coexistência de liberdades.. ${ }^{251}$

Outro equívoco comum é detectado na exigência da presença do dano para a caracterização de um ato contrário ao Direito. ${ }^{532}$ Afirma-se, com alguma frequência, que a antijuridicidade exige, além de um comportamento reprovável, a presença de um dano ${ }^{533}$; problema que se agrava quando se percebe o retrocesso da codificação vigente no que pertine a esse aspecto. ${ }^{534}$

\footnotetext{
${ }^{527}$ MORAES, Maria Celina Bodin de. Danos à pessoa humana: uma leitura civil-constitucional dos danos morais. Rio de Janeiro: Renovar, 2003. p. 176. A autora afirma que as hipóteses de responsabilidade objetiva derivam de atos lícitos que causam danos injustos.

${ }^{528}$ SEGUí, Adela Maria. Aspectos relevantes de la responsabilidad civil moderna, Revista de Direito do Consumidor, São Paulo, v. 13, n. 52, p. 267-318, out./dez. 2004. p. 278. No mesmo sentido: LIMA, Alvino, Culpa e risco. 2 ed. São Paulo: RT, 1999. p. 52-53.

529 MIRAGEM, Bruno. Abuso de direito: ilicitude objetiva no direito privado brasileiro, Revista dos Tribunais, São Paulo, v. 94, n. 842, p. 11-44, dez. 2005. p. 18-22.

${ }^{530}$ LIMA NETO, Francisco Vieira. Ato antijurídico e responsabilidade civil aquiliana - crítica à luz do novo código civil. In: BARROSO, Lucas Abreu (Org.). Introdução crítica ao código civil. Rio de Janeiro: Forense, 2006. p. 256-261. No mesmo sentido: AGOGLIA, María Martha. ¿Es la antijuridicidad un presupuesto de la responsabilidad civil?. In: GESUALDI, Dora Mariana (Coord.). Derecho privado. Buenos Aires: Hammurabi, 2001. p. 1036-1038.

${ }^{531}$ MARTINS-COSTA, Judith. Os avatares do abuso de direito e o rumo indicado pela boa-fé. In: TEPEDINO, Gustavo (Org.). Direito civil contemporâneo: novos paradigmas à luz da legalidade constitucional. São Paulo: Atlas, 2008. p. 69.

${ }^{532}$ TOLOMEI, Carlos Young. A noção de ato ilícito e a teoria do risco na perspectiva do novo código civil. In: TEPEDINO, Gustavo (Coord.). A parte geral do novo código civil: estudos na perspectiva civilconstitucional. Rio de Janeiro: Renovar, 2002. p. 360.

${ }^{533}$ FERNANDES, Adaucto. Das obrigações no direito brasileiro. Rio de Janeiro: A. Coelho Branco $\mathrm{F}^{\mathrm{o}}$ Editor, 1951, v. 2. p. 531.

${ }^{534} \mathrm{O}$ artigo 186 do código vigente dispõe que "aquele que, por ação ou omissão voluntária, negligência ou imprudência, violar direito e causar dano a outrem, ainda que exclusivamente moral, comete ato ilícito."
} 
É fundamental perceber que o dano é uma circunstância meramente acidental na seara da antijuridicidade. ${ }^{535}$ Não fosse assim, seria impossível sustentar a existência, dentre outras figuras, (a) das tutelas inibitórias, (b) das tutelas de remoção do ilícito, (c) da responsabilidade sem dano e, ainda, (d) da função preventiva incorporada pelo direito de danos.

\section{O nexo de causalidade}

A caracterização do dever de reparar exige um liame imaterial atando a conduta contrária ao Direito à lesão suportada pelo parceiro contratual. Aliás, não parece ser possível conceber a conformação do dever de reparar sem a presença do nexo de causalidade. ${ }^{536}$ A figura é tão importante a ponto de afirmar-se que somente o nexo causal é indispensável à caracterização do dever de reparar. ${ }^{537}$

E parece mesmo verdade que a imposição do dever de reparar exige uma relação de causa e efeito ate a conduta antijurídica à lesão a um interesse juridicamente tutelado. ${ }^{538} \mathrm{E}$, se essa assertiva é verdadeira, o nexo causal é, de fato, pressuposto do dever de reparar os danos contratuais. ${ }^{539}$

Há de se destacar, entretanto, que a situação é controversa, não sendo admitida pacificamente. Dentre outros autores, Fernando Alfredo Sagarna salienta que o nexo causal não é pressuposto do dever de reparar, e isso porque existem hipóteses nas quais se impõe esse dever sem a presença do nexo de causalidade. ${ }^{540}$

\footnotetext{
${ }^{535}$ MARINONI, Luiz Guilherme. Tutela específica: arts. 461, cpc e 84, cdc. 2 ed. São Paulo: RT, 2001, p. 20-27.

${ }^{536}$ LARROUMET, Christian. La causa estraña. In: ESPINOSA, Fabricio Mantilla; BARRIOS, Francisco Ternera (Dir.). Los contratos en el derecho privado. Bogotá: Legis, 2007. p. 293.

537 ALVIM, Agostinho. Do enriquecimento sem causa, Revista dos Tribunais, São Paulo, n. 259, p. 3-36, 1957. p. 18. O lastro da afirmação está em que a ação pode não ser culposa, e o dano inexistir.

${ }^{538}$ MIRANDA, Custódio da Piedade Ubaldino. A responsabilidade civil no âmbito do código de defesa do consumidor, Revista do Advogado, São Paulo, n. 33, p. 49-56, dez. 1990. p. 54.

539 CRUZ, Gisela Sampaio da. O problema do nexo causal na responsabilidade civil. Rio de Janeiro: Renovar, 2005. p. 347.

540 SAGARNA, Fernando Alfredo. La relación de causalidad: ¿es prescindible como presupuesto de la responsabilidad civil?. In: GESUALDI, Dora Mariana (Coord.). Derecho privado. Buenos Aires: Hammurabi, 2001. p. 1272-1273.
} 
Apesar do esforço, assertivas como a destacada não se sustentam, inexistindo, salvo melhor juízo, uma situação sequer, ao menos no universo contratual, em que o dever de reparar não decorra da conexão havida entre a lesão a um interesse juridicamente protegido e uma conduta qualificada pela antijuridicidade. Por isso, até prova em contrário, o nexo de causalidade é, sim, pressuposto na configuração do dever de reparar.

Superada essa questão, destaque-se que são diversas as construções teóricas versando sobre a figura sob análise. ${ }^{541}$ No Brasil, há intenso debate tentando identificar qual teoria teria sido recepcionada pelo direito civil. Dentre inúmeras variáveis, as mais citadas são a causalidade adequada e a teoria do dano direto e imediato.

Em termos gerais, afirma-se que, por causa adequada, deve ser compreendida a causa extraída de um fato antecedente considerado como necessário e adequado à produção da lesão a um interesse digno de tutela. ${ }^{542}$ Afirma-se que a teoria da causalidade adequada seria a que melhor permite trabalhar com as regras codificadas inerentes ao tema. ${ }^{543}$

A seu turno, consoante a teoria do dano direto e imediato ${ }^{544}$, da causalidade direta e imediata ou teoria da interrupção do nexo causal, exige-se uma "relação de causa e efeito, direta e imediata" entre conduta contrária ao Direito e a lesão suportada pelo parceiro contratual. ${ }^{545}$

Para os fins almejados neste trabalho, independentemente da opção por um ou outro caminho, é essencial compreender que o nexo causal serve para aferir se a lesão juridicamente tutelada decorre (ou não) da conduta. Nesse condão, se a lesão não puder ser atribuída à conduta do devedor - ou do credor -, não haverá dever de reparar.

\footnotetext{
${ }^{541}$ Como a questão extrapola os limites desta pesquisa, serão promovidos apenas os comentários essenciais à sua compreensão. Sobre o tema, no Brasil: CRUZ, Gisela Sampaio da. O problema do nexo causal na responsabilidade civil. Rio de Janeiro: Renovar, 2005. p. 33-122. MULHOLLAND, Caitlin Sampaio. A responsabilidade civil por presunção de causalidade. Rio de Janeiro: GZ, 2009. p. 135-194. HIRONAKA, Giselda Maria Fernandes Novaes Direito civil: estudos. Belo Horizonte: Del Rey, 2000. p. 293-316. No exterior, dentre outros: GHERSI, Carlos Alberto. Teoría general de la reparación de daños. Buenos Aires: Astrea, 1997. p. 75-84. ITURRASPE, Jorge Mosset. Contratos. Buenos Aires: Rubinzal-Culzioni, 2007. p. 412-417. SAGARNA, Fernando Alfredo. La relación de causalidad: ¿es prescindible como presupuesto de la responsabilidad civil?. In: GESUALDI, Dora Mariana (Coord.). Derecho privado. Buenos Aires: Hammurabi, 2001. p. 1246-1273.

542 BARROS, Raimundo Gomes de. Relação de causalidade e o dever de indenizar, Revista de Direito do Consumidor, São Paulo, n. 27, p. 32-41, jul./set. 1998. p. 39.

${ }^{543}$ NORONHA, Fernando. Direito das obrigações. São Paulo: Saraiva, 2004, v. 1. p. 609-610.

544 CRUZ, Gisela Sampaio da. O problema do nexo causal na responsabilidade civil. Rio de Janeiro: Renovar, 2005. p. 33-122.

${ }^{545}$ SAVI, Sérgio. Inadimplemento das obrigações, mora e perdas e danos. In: TEPEDINO, Gustavo (Coord.). Obrigações: estudos na perspectiva civil-constitucional. Rio de Janeiro: Renovar, 2005. p. 485.
} 
É de fundamental importância perceber, entretanto, que isso ocorre, não pela ausência de culpa ${ }^{546}$, como comumente afirmado ${ }^{547}$, mas por não se detectar, na situação concretamente estabelecida, a presença de um liame atando conduta e lesão suportada pelo parceiro negocial.

A afirmação recorrente de que quaisquer das hipóteses que se encaixem na noção de caso fortuito ou de força maior excluem a culpa é incorreta. É passada a hora de compreender que as hipóteses que afastam a culpa e aquelas que implodem o nexo de causalidade são distintas. ${ }^{548}$ Devem ser vistas como duas dimensões paralelas. É hora de enxergar que a análise do nexo causal precede o juízo de atribuição do dever de reparar. ${ }^{549}$

É evidente que o trato negocial impõe o dever de agir de modo prudente e diligente. Mas isso não basta. Impõe-se ao devedor, em cada situação concreta, superar impedimentos ou obstáculos apostos entre a conduta prometida e aquela que deve ser concretamente desempenhada, incluídos aqui os não previstos no momento da formação do contrato, só podendo ceder, em princípio, a eventos irresistíveis. ${ }^{550}$

\footnotetext{
${ }^{546}$ NORONHA, Fernando. Direito das obrigações. São Paulo: Saraiva, 2004, v. 1. p. 636-637. "Se o dano não é atribuível ao indigitado responsável, mas a fato do lesado, ou de terceiro, ou a caso fortuito ou de força maior, não teria sentido dizer-se que se aquele não responde é porque não agiu com culpa. Se não foi o fato dele que causou o dano, não se justifica discutir uma sua eventual atuação, ainda que culposa; tal discussão, não dizendo respeito ao fato que efetivamente causou o dano, seria irrelevante."
}

${ }^{547}$ GAZALLE, Gustavo Kratz. O conceito de mora no código civil de 2002. Porto Alegre: SAFE, 2008. p. 31. "Nas obrigações contratuais, as excludentes de nexo causal e de culpa seriam rigorosamente as mesmas."

${ }^{548}$ LARROUMET, Christian. La causa estraña. In: ESPINOSA, Fabricio Mantilla; BARRIOS, Francisco Ternera (Dir.). Los contratos en el derecho privado. Bogotá: Legis, 2007. p. 294.

${ }^{549}$ NORONHA, Fernando. Direito das obrigações. São Paulo: Saraiva, 2004, v. 1. p. 521-522 e 634-637. "Todos os fatos que caibam na noção de caso fortuito ou de força maior em sentido amplo, abrangendo o próprio fato do lesado e ainda o de terceiro, excluem o nexo causal entre o fato atribuído ao indigitado responsável e o dano ocorrido. Excluem a causalidade, não a culpa. A invocação do caso fortuito ou de força maior significa afirmar que o dano se ficou devendo a algo que por definição é independente da atuação, culposa ou não, da pessoa a quem em princípio ele era atribuído. Não é correta a afirmação, muito corrente, de que a ocorrência de caso fortuito ou de força maior exclui a culpa. A existência ou ausência de culpa diz respeito a um requisito da responsabilidade civil, o nexo de imputação (que aponta a pessoa a quem pode ser ligado um determinado fato gerador de danos, seja a título de culpa ou de risco), ao passo que a ocorrência ou não de caso fortuito ou de força maior, fato de terceiro ou fato do próprio lesado, diz respeito a outro requisito, o nexo de causalidade (que indica quais são os danos que podem ser considerados consequiência do fato que esteja em questão). Aliás, em termos lógicos, a apuração do nexo de causalidade precede o juízo de imputação. Verificado um determinado dano, primeiro é preciso apurar qual foi a sua causa. Só depois de determinado o fato causador, levanta-se a questão de saber se este pode ser imputado a alguém. [...] Dizer que o caso fortuito ou de força maior eliminaria a culpabilidade, significaria o mesmo que afirmar que ninguém é culpado por evento que não causou."

550 OLIVARES, Álvaro Vidal. Cumplimiento e incumplimiento contractual en el codigo civil: una perspectiva más realista, Revista Chilena de Derecho, Santiago, v. 34, n. 1, p. 41-59, jan./abr. 2007. p. 46-48. Vale destacar com o autor que, se o impedimento for meramente temporário, o adimplemento tardio é devido desde que a prestação ainda interesse ao credor. 
Comungando desse ponto de vista e, depois de demonstrar a insuficiência da diligência como fator de atribuição do dever de reparar os danos contratuais, Emílio Betti afirma que é possível concluir que a imputabilidade do não cumprimento da prestação está coligada ao aspecto objetivo do não cumprimento. Assevera o autor que o aludido dever somente será afastado diante da impossibilidade superveniente e não imputável ao obrigado. $^{551}$

A diligência exigida do devedor, portanto, impõe-lhe evitar a impossibilidade da prestação, mas apenas o perecimento não imputável exclui o dever de reparar. ${ }^{552} \mathrm{O}$ que ainda não foi percebido é que essa configuração acaba tornando a necessidade de um comportamento diligente uma noção supérflua, mormente porque, para eximir-se do dever de reparar, a parte deverá demonstrar que a patologia surgida no curso do processo obrigacional foi causada por causa estranha e a ela, não imputável.

É evidente, portanto, que não é a ausência de culpa do devedor que irá obstaculizar a pretensão reparatória do credor, mas o fato de a violação de dever não ser imputável ao primeiro. ${ }^{553}$ Em outras palavras, a demonstração da ausência de culpa, por si só, não possui valor algum.

Perceba-se que as hipóteses enquadradas pela moldura de causa estranha e não imputável rompem o nexo de causalidade, embora, como frisado, sejam frequentes as passagens destacando que as excludentes de causalidade ${ }^{554}$ afastariam a culpa, pecado notado em Álvaro Villaça Azevedo ${ }^{555}$, Arnaldo Rizzardo ${ }^{556}$, Fábio Ulhoa Coelho ${ }^{557}$ e

${ }^{551}$ BETTI, Emílio. Teoria generale delle obbligazioni: prolegomeni: funzione economico-sociale dei rapporti
d’obbligazione. Milano: Giuffrè, 1953, v. 1. p. 110-131. Ensina ainda, que a fattispecie da inexecução da
prestação possui um elemento objetivo e outro de ordem subjetiva: o primeiro consiste no inadimplemento,
no cumprimento inexato ou na violação do pontual cumprimento da prestação, que ao devedor se impõe por
força da relação obrigacional; o segundo, na ausência, por parte do obrigado, do esforço devido, da falta de
cooperação com o interesse do credor exigido para o caso, estando presente, e esse ponto é relevante, quando
ausente a prova de que a prestação restou impossibilitada por causa estranha a sua esfera de controle. ${ }^{552}$ GIORGIANNI, Michele. L`inadempimento. Milano: Giuffrè, 1975. p. 208-209.

${ }^{553}$ GAMARRA, Jorge. Responsabilidad contractual: el incumplimiento. Montevideo: FCU, 2004. p. 166. Consoante o autor, "a falta de relação de causalidade entre o comportamento do devedor e a insatisfação do credor" é que obstaculiza a pretensão do credor ao ressarcimento.

${ }^{554}$ GONZÁLEZ, Jorge Baraona. El retraso en el cumplimiento de las obligaciones. Madrid: Dykinson S. L., 1998. p. 78.

555 AZEVEDO, Álvaro Villaça. Inexecução culposa e cláusula penal compensatória, Revista dos Tribunais, São Paulo, n. 791, p. 121-132, set. 2001. p. 125-126.

${ }^{556}$ RIZZARDO, Arnaldo. Direito das obrigações. Forense: Rio de Janeiro, 2000. p. 502. O autor destaca que a culpa estaria presente quando ocorre o não cumprimento de uma obrigação. 
Pablo Stolze Gagliano ${ }^{558}$, ao confundirem ausência de culpa com inexistência de nexo causal entre conduta e dano.

Esclarecida essa questão, vale lembrar que a expressão causa estranha não imputável é aqui utilizada tendo em conta a totalidade de fenômenos não atribuíveis ao devedor - ou ao credor, em algumas hipóteses -, que impedem ou dificultam excessivamente o adimplemento ou a fiel observância a outros deveres contratuais.

Por causa não imputável, deve-se compreender o conjunto de fenômenos alheios à esfera de controle do obrigado, circunstâncias essas que são responsáveis pela impossibilidade ${ }^{559}$, pelo atraso do adimplemento ou pela imperfeição que o vicia.

$\mathrm{E}$, embora haja controvérsias ${ }^{560}$, as situações aqui emolduradas não precisam derivar de causa natural. É importante destacar que a concepção de causa estranha e não imputável pode assumir distintas feições. ${ }^{561} \mathrm{O}$ caso fortuito, a força maior, o fato de terceiro e o fato do credor $^{562}$ - ou do devedor nas situações de violação de dever geral de conduta - estão contidos, dentre outras causas legítimas de não cumprimento ${ }^{563}$, no interior das balizas que delimitam a figura sob análise. É uma noção porosa, que, consoante a concreta relação negocial, será construída tendo por raias os princípios que balizam o processo de realização do Direito.

\footnotetext{
${ }^{557}$ COELHO, Fábio Ulhoa. Curso de direito civil. São Paulo: Saraiva, 2004, v. 2. p. 167. "O inadimplemento verifica-se sempre que a obrigação não é cumprida no vencimento. Ele também é referido pela expressão inexecução, e pode ser voluntário (decorrente da vontade do sujeito obrigado) ou involuntário (causado por fatos estranhos a esta vontade) [...] Qualquer fato jurídico escapado ao controle das partes pode dar ensejo à inexecução involuntária: atos de terceiros, eventos naturais, impedimento legal superveniente e outros." Mais à frente, leciona o autor que, "quando o inadimplemento não deriva de culpa de sujeito obrigado, a hipótese é, em termos técnicos, de caso fortuito ou de força maior." Ibid. p. 202.

${ }^{558}$ GAGLIANO, Pablo Stolze; PAMPLONA FILHO, Rodolfo. Novo curso de direito civil: obrigações. 8 ed. São Paulo: Saraiva, 2007, v. 2. p. 269. "O descumprimento da obrigação também pode decorrer de fato não imputável ao devedor. Diz-se, nesse caso, ter havido inadimplemento fortuito da obrigação, ou seja, não resultante de atuação dolosa ou culposa do devedor, que, por isso, não estará obrigado a indenizar."

559 VISINTINI, Giovanna. Tratado de la responsabilidad civil: la culpa como criterio de imputación de la responsabilidad. Trad. Aída Kemelmajer de Carlucci. Buenos Aires: Astrea, 1999, v. 1. p. 189-201.

${ }^{560}$ CARVALHO NETO, Inácio de. Curso de direito civil brasileiro: teoria geral das obrigações. Curitiba: Juruá, 2009, v. 2. p. 363.

${ }^{561}$ VISINTINI, Giovanna. Il codice civile: commentario. inadempimento e mora del debitore. 2 ed. Milano: Giuffrè, 2006. p. 349-413.

562 PONTES DE MIRANDA, Francisco Cavalcanti. Tratado de direito privado: parte especial. Rio de Janeiro: Borsoi, 1959, t. 26. p. 7. No mesmo sentido: LÔBO, Paulo Luiz Netto. Teoria geral das obrigações. São Paulo: Saraiva, 2005. p. 277.

${ }^{563}$ MOREIRA, Guilherme Alves. Instituições do direito civil português: das obrigações. Coimbra: Coimbra, 1925 , v. 2. p. 115-120. Podem aqui ser lembrados o direito de retenção, a exceção do contrato não cumprido, a compensação e a recusa do credor em entregar a quitação.
} 
E, apesar de ser discutível se a conformação dessa figura exige três elementos a exterioridade, a imprevisibilidade e a irresistibilidade ${ }^{564}$ - ou apenas dois deles -

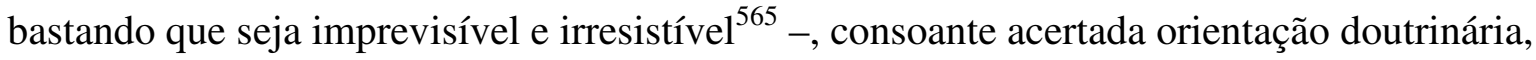
somente o último é essencial a sua caracterização. ${ }^{566}$

A doença não é um elemento exterior e não seria concebível imputar ao devedor os efeitos do não cumprimento da prestação motivado exclusivamente por ela. ${ }^{567}$ A seu turno, em muitas situações, o evento que impossibilitou o desempenho da prestação ou que motivou a violação de um dever contratual pôde ser antevisto, sem que fosse possível evitá-lo.

Afirma-se, ainda, que a causa estranha não imputável deve impossibilitar o adimplemento, e não, apenas dificultá-10 ${ }^{568}$, perspectiva que tem suas raízes na compreensão clássica do tema. Como visto outrora, a responsabilidade do devedor teria seus limites na impossibilidade objetiva e superveniente da prestação. ${ }^{569}$

Tal visão, atualmente criticada ${ }^{570}$, peca pela ausência de precisão, ao desprezar construções teóricas com forte conotação social - como a que versa sobre o limite do sacrifício -, o processo de personalização do direito civil e a leitura da relação obrigacional como um processo. Ignora, ademais, o balizamento realizado pelos princípios constitucionais e contratuais sociais no processo de realização do Direito.

564 LÓPEZ, Andrés Mariño. Los fundamentos de la responsabilidad contractual. Montevideo: Carlos Alvarez, 2005. p. 214-217 e 226-233.

${ }^{565}$ LIMA, Alvino. Responsabilidade do depositário no caso fortuito ou de força maior, Revista Forense, Rio de Janeiro, v. 42, n. 103, p. 447-448, jul./set. 1945. p. 448.

566 LÔBO, Paulo Luiz Netto. Teoria geral das obrigações. São Paulo: Saraiva, 2005. p. 267. No mesmo sentido: LARROUMET, Christian. La causa estraña. In: ESPINOSA, Fabricio Mantilla; BARRIOS, Francisco Ternera (Dir.). Los contratos en el derecho privado. Bogotá: Legis, 2007. p. 296-300.

${ }^{567}$ LARROUMET, Christian. La causa estraña. In: ESPINOSA, Fabricio Mantilla; BARRIOS, Francisco Ternera (Dir.). Los contratos en el derecho privado. Bogotá: Legis, 2007. p. 301.

${ }^{568}$ GIORGI, Jorge. Teoria de las obligaciones en el derecho moderno. Madrid: Reus, 1977, v. 2. p. 45.

569 OSTI, Giuseppe. Revisione critica della teoria sulla impossibilità della prestazione, Rivista di Diritto Civile, Milano, v. 10, n. 3, p. 209-249, mai./jun. 1918. p. 209.

${ }^{570}$ Para compreensão dos problemas de ordem sistêmica: VITA NETO, José Virgílio. A atribuição da responsabilidade contratual. Tese (Doutorado) - Faculdade de Direito da USP, São Paulo, 2007. p. 10-37. 
Um bom exemplo da reconfiguração da ideia de causa estranha e não imputável pode ser percebido no esforço doutrinário realizado para atenuar a noção de impossibilidade por meio do recurso ao princípio da boa-fé objetiva. ${ }^{571}$

A caracterização da causa estranha não imputável, contemporaneamente, haverá de ser modulada, em cada caso concreto. Não mais se exige uma catástrofe a sua configuração, bastando a impraticabilidade da conduta - em razão de um evento irresistível - motivada por fato alheio à esfera de atuação do devedor. ${ }^{572}$

Apesar de, em regra, a relação obrigacional apenas se extinguir quando do advento de uma impossibilidade absoluta e superveniente ${ }^{573}$, casos que dificultem muito o adimplemento poderão ser equiparados aos de impossibilidade. E isso, dentre outras razões, porque a cooperação permeia a relação obrigacional, atua no conteúdo dos direitos formativos e coíbe comportamentos desfuncionalizados. ${ }^{574}$

A mesma reflexão deve ser dilatada a ponto de justificar o atraso, o cumprimento inexato e a violação de outros deveres contratuais. E isso porque, agora, “impossível já não é unicamente o inconcebível, o irrealizável pelas forças humanas, mas tudo aquilo cuja realização não seja razoável, que fuja das expectativas do tráfico jurídicoeconômico."

Daí que, apesar de historicamente defender-se que razões de ordem pessoal não podem ser invocadas para excluir a responsabilidade do devedor ${ }^{576}$, parece inegável que, em algumas circunstâncias, a impossibilidade relativa deverá ser equiparada à absoluta,

\footnotetext{
${ }^{571}$ VISINTINI, Giovanna. Tratado de la responsabilidad civil: la culpa como criterio de imputación de la responsabilidad. Trad. Aída Kemelmajer de Carlucci. Buenos Aires: Astrea, 1999, v. 1. p. 183. O exemplo da autora de impossibilidade relativa cinge-se a doenças que retardem ou impeçam o adimplemento da prestação.

572 ALTERINI, Atílio Aníbal. Estudios de derecho civil: conceptos, contratos, consumidor, derecho de daños. Buenos Aires: La Ley, 2007. p. 190.

573 ANTUNES VARELA, João de Matos. Das obrigações em geral. 7 ed. Coimbra: Almedina, 1997, v. 2. p. 68-71. Sustenta o autor que "a doutrina do limite do sacrifício [...] não é geralmente aceita noutros países, nem é perfilhada pela doutrina de longe dominante na literatura e jurisprudência alemãs, pela perigosa incerteza e pelos inevitáveis arbítrios a que daria lugar a sua aplicação na prática.”

${ }^{574}$ FROTA, Pablo Malheiros da Cunha. Os deveres contratuais gerais nas relações civis e de consumo. Dissertação (Mestrado) - Faculdade Autônoma de Direito de São Paulo, São Paulo, 2008. p. 169. “Destroemse as idéias de denuncia vazia em contrato de locação, dispensa de trabalhador sem justa causa, cláusulas de inalienabilidade, impenhorabilidade e incomunicabilidade sem justa causa em contratos e em testamentos (CC/02, art. 1848)."

575 VITA NETO, José Virgílio. A atribuição da responsabilidade contratual. Tese (Doutorado) - Faculdade de Direito da USP, São Paulo, 2007. p. 31.

${ }^{576}$ RIPERT, Georges; BOULANGER, Jean. Tratado de derecho civil: las obligaciones. Trad. Delia García Daireaux. Buenos Aires: La Ley, 1964, v. 1, t. 4. p. 475-479.
} 
libertando o devedor dos vínculos obrigacionais quando o não cumprimento não possa ser imputado a ele.

Essa aproximação pode ser promovida, por exemplo, quando a prestação for considerada infungível $^{577}$ ou quando possa levar o devedor - pessoa natural - à bancarrota, sempre que essas hipóteses possam ser chanceladas com recurso ao critério hermenêutico da boa-fé. ${ }^{578}$

Resgate-se que a distinção entre impossibilidade absoluta e relativa tem ligação com os sacrifícios exigíveis. A primeira se manifesta quando não pode ser vencida pelas forças humanas. A última estará configurada quando o devedor não tenha condições de adimplir.

É oportuno apontar que, ao discorrer sobre as hipóteses que isentam a responsabilidade do devedor pela ausência de cumprimento na reforma do código civil alemão, Canaris dá mostras claras do estado da arte no tratamento do tema. Em sua visão, (a) uma primeira situação versa sobre as ocasiões em que o nível de sacrifício exigido para o desempenho da prestação seja grosseiramente desproporcional se comparado ao interesse do credor; e um segundo momento (b) autoriza o devedor de prestação personalíssima a se recusar ao adimplemento quando haja um impedimento razoável. Em ambos os casos, o não cumprimento da prestação prometida equivale ao não cumprimento inimputável em razão da "impossibilidade de execução." ${ }^{, 579}$ Perceba-se que, em perspectiva de ordem exclusivamente material, o adimplemento permanece sendo possível nos dois casos.

Importante aclarar, ainda, que é bastante comum a utilização das expressões caso fortuito e força maior em detrimento da categoria que denota o conjunto de situações aptas à exclusão do nexo de causalidade. Prova disso é a alusão de que o caso fortuito consiste em "qualquer evento estranho à esfera de atividade do devedor.",580

\footnotetext{
${ }^{577}$ FARIA, Jorge Leite Areias Ribeiro de. Direito das obrigações. Coimbra: Almedina, 1990, v. 2. p. 356357.

${ }^{578}$ BUERES, Alberto Jesus. Derecho de daños. Buenos Aires: Hammurabi, 2001. p. 434-437. O exemplo do autor é o da morte de parente próximo do ator às vésperas da apresentação. No caso, o não comparecimento seria hipótese de incumprimento não imputável diante da justificativa lastreada em razões humanitárias.

579 CANARIS, Claus-Wilhelm. O novo direito das obrigações na alemanha, Revista Brasileira de Direito Comparado, Rio de Janeiro, n. 25, p. 3-26, jul./dez. 2003. p. 10-13.

${ }^{580}$ BIONDI, Biondo. Istituzioni di diritto romano. 2 ed. Milano: Giuffrè, 1952. p. 335.
} 
Por isso, parece adequado recorrer à noção de causa estranha e não imputável como figura hábil a polarizar e albergar todas as hipóteses aptas a romper o nexo causal que, aparentemente, informa cada relação concretamente estabelecida.

As noções de caso fortuito e força maior ${ }^{581}$, mesmo que não sejam de todo incorretas, além de não conglobarem todas as hipóteses de exclusão de causalidade, permitem a perpetuação de uma discussão inócua visando a distinguir uma e outra. ${ }^{582}$

A tentativa de diferenciar as figuras, além de ser um trabalho despido de qualquer interesse prático, no plano teórico, encontra difícil solução por conta da ausência de um critério seguro de diferenciação. ${ }^{583}$ Aliás, se essa discussão possui uma vantagem, é a que conduz a lembrar os doces versos de Cecília Meireles. ${ }^{584}$

No universo contratual, parece inquestionável que a prova da ausência de nexo causal pertença ao devedor ${ }^{585}$, pensamento sustentado, dentre outros, por Josserand ${ }^{586}$, Pontes de Miranda ${ }^{587}$, Pothier ${ }^{588}$ e Carlos Alberto Dabus Maluf. ${ }^{589}$

581 Sobre o tema: FONSECA, Arnoldo Medeiros da. Caso fortuito e teoria da imprevisão. 3 ed. Rio de Janeiro: Revista Forense, 1958. p. 27-193. E ainda: ALVIM, Agostinho. Da inexecução das obrigações e suas conseqüências. 4 ed. São Paulo: Saraiva, 1972. p. 325-337.

582 PONTES DE MIRANDA, Francisco Cavalcanti. Tratado de direito privado: parte especial. 2 ed. Rio de Janeiro: Borsoi, 1958, t. 23. p. 79. “A distinção entre força maior e caso fortuito só teria de ser feita, só seria importante, se as regras jurídicas a respeito daquela e desse fossem diferentes. [...] Não ocorrendo tal necessidade, é escusado estarem os juristas a atribuir significados que não têm base histórica, nem segurança em doutrina. Lamentável é que, em vez de se fixarem conceitos, se perca tempo em critérios ao sabor pessoal dos escritores."

${ }^{583}$ NORONHA, Fernando. Direito das obrigações. São Paulo: Saraiva, 2004, v. 1. p. 630.

${ }^{584}$ A alusão aqui é feita ao poema intitulado "Ou isto ou aquilo", cuja transcrição nos permitimos:

Ou se tem chuva e não se tem sol, ou se tem sol e não se tem chuva!

Ou se calça a luva e não se põe o anel, ou se põe o anel e não se calça a luva!

Quem sobe nos ares não fica no chão, quem fica no chão não sobe nos ares.

É uma grande pena que não se possa estar ao mesmo tempo em dois lugares!

Ou guardo o dinheiro e não compro o doce, ou compro o doce e gasto o dinheiro.

Ou isto ou aquilo: ou isto ou aquilo ... e vivo escolhendo o dia inteiro!

Não sei se brinco, não sei se estudo, se saio correndo ou fico tranqüilo.

Mas não consegui entender ainda qual é melhor: se é isto ou aquilo.

585 SZAFIR, Dora; VENTURINI, Beatriz. Nuevamente sobre el nexo causal en la responsabilidad contractual. In: FERNÁNDEZ, Carlos López; CAUMONT, Arturo; CAFFERA, Gerardo (Coord.). Estudios de derecho civil en homenaje al profesor Jorge Gamarra. Montevideo: FCU, 2001. p. 409. No mesmo sentido: AGUIAR JUNIOR, Ruy Rosado de. Responsabilidade civil do médico, Revista dos Tribunais, São Paulo, v. 84, n. 718, p. 33-53, ago. 1995. p. 35.

586 JOSSERAND, Louis. Derecho civil: teoría general de las obligaciones. Trad. Santiago Cunchillos y Manterola. Buenos Aires: Bosch Editores, 1950, v. 1, t. 2. p. 739. 
Uma vez reconhecido que os deveres gerais de conduta obrigam também o credor, talvez seja possível defender que a prova da ausência de nexo causal deva ser feita por aquele a quem se imputa o dano, reflexão lastreada na necessidade de tratar a temática de modo isonômico.

Enfim e independentemente dessa questão, a materialização dessa prova exigirá a demonstração de que: (a) o evento ocorreu sem que pudesse ser evitado; (b) que esse mesmo evento não foi causado pelo devedor, pelo credor nas hipóteses de violação de dever geral de conduta, ou por alguém sob a responsabilidade de qualquer um deles; e, ainda, (c) que o evento inevitável tenha provocado a impossibilidade do adimplemento 590 ou o desrespeito ao dever contratual violado.

\section{A culpa}

Impossível não perceber quão imenso é o rol de autores sustentando que a culpa é pressuposto da responsabilidade contratual. Dentre eles, podem ser destacados Agostinho Oli Koppe Pereira ${ }^{591}$, Arnaldo Rizzardo ${ }^{592}$, Arnoldo Wald ${ }^{593}$, Caio Mário da Silva Pereira ${ }^{594}$, Carlos Roberto Gonçalves ${ }^{595}$, Fábio Ulhoa Coelho ${ }^{596}$ e Flávio Tartuce. ${ }^{597}$

${ }^{587}$ PONTES DE MIRANDA, Francisco Cavalcanti. Tratado de direito privado: parte especial. 2 ed. Rio de Janeiro: Borsoi, 1958, t. 23. p. 172-180.

${ }^{588}$ POTHIER, Robert Joseph. Tratado das obrigações. Trad. Adrian Sotero De Witt Batista; Douglas Dias Ferreira. Campinas: Servanda, 2002. p. 583.

${ }^{589}$ MALUF, Carlos Alberto Dabus. Do caso fortuito e da força maior excludentes de culpabilidade no código civil de 2002. In: DELGADO, Mário Luiz; ALVES, Jones Figueiredo (Coord.). Questões controvertidas: responsabilidade civil. São Paulo: Método, 2006, v. 5. p. 59-60. "Nós mesmos somos taxativos em responder: ao devedor é que cabe o ônus da prova de havê-la [a prestação] cumprido ou de que teve recusa legítima e relevante para não o fazer. [...] Logo, quem se pretende liberar alegando o caso fortuito, como causa de exoneração de responsabilidade, deve prová-lo. Não basta, porém, a prova do fato material invocado, é preciso mais; é necessário que se demonstre ter sido ele a causa verdadeira do prejuízo, ou da impossibilidade de executar a prestação prometida."

${ }^{590}$ MELLO, Baptista de. Do caso fortuito e da força maior nos contractos civis, Revista dos Tribunais, São Paulo, v. 25, n. 101, p. 15-28, mai. 1936. p. 27.

${ }^{591}$ PEREIRA, Agostinho Oli Koppe. A culpa e a responsabilidade civil no direito brasileiro, Revista da Faculdade de Direito, Caxias do Sul, n. 6, p. 116-132, mar. 1997. p. 117. Curioso, no pensamento do autor, é que, após afirmar que "a culpa é um dos pressupostos da responsabilidade civil", salienta que esta não está adstrita àquela. Interessante, ainda, é aferir o ponto de partida utilizado pelo autor, que, ao frisar que, "embora novas teorias venham a se somar à culpa, esta é, na busca da reparação do dano, indiscutivelmente, o elemento que maior atenção requer do jurista", demonstrando ignorar - ou intencionalmente afastar -, do centro da discussão, o dano suportado pela vítima.

${ }^{592}$ RIZZARDO, Arnaldo. Direito das obrigações. Forense: Rio de Janeiro, 2000. p. 504-506. Curioso destacar que, apesar de lastrear sua reflexão na necessidade da presença da culpa para que se consubstancie a 
Aliás, é relevante destacar, apesar de mais de dois séculos separarem a realidade contemporânea da primeira grande codificação, que, ainda hoje, há quem sustente que a culpa é o único fator de imputabilidade do dever de reparar existente no direito, construções que se escoram na pas de responsabilité sans faute, ou seja, em que não pode haver responsabilidade sem culpa. ${ }^{598}$

Diversos são os fatores que permitem inferir que essa percepção não se apresenta como a mais acertada. E, assim, é possível, sem maior esforço, implodir tais construções. De antemão, é preciso compreender que, se existem hipóteses nas quais o dever de reparar é disparado por um fator de imputabilidade objetivo, não se pode afirmar que a culpa seja um pressuposto do dever de reparar. Pensar de modo contrário conduz à inaceitável incoerência lógica e sistêmica.

Perceba-se que essa única constatação é mais que suficiente para demonstrar cientificamente que a culpa não pode ser qualificada como pressuposto do dever de reparar. E não pode ser assim tratada porque, se é possível imputar a alguém o dever de reparar os danos contratuais por ele provocados, sem que a culpa esteja elencada entre os elementos que hão de conformar tal dever, não há formas de qualificá-la como pressuposto.

A repetição acrítica da inverdade denunciada impõe, entretanto, explorar um pouco mais o tema, destacando que os moldes clássicos da responsabilidade civil cooperam na propagação da visão distorcida antes denunciada. Não só por ocasião das

inexecução em sentido amplo, o autor leciona que é "suficiente a mera inadimplência para detectar sua presença [sendo irrelevante] que o sujeito passivo seja negligente, imprudente, imperito, ou revele outras falhas, para [que possam ser exigidas] as perdas e danos [bastando] o mero inadimplemento [salvo se oriundo] de caso fortuito ou força maior, dentre outras situações, como a alteração substancial da base do negócio." Ibid. p. 506.

${ }^{593}$ WALD, Arnoldo. Curso de direito civil brasileiro: obrigações e contratos. 14 ed. São Paulo: RT, 2000 , v. 2. p. 138. "O inadimplemento culposo ou doloso é fonte de responsabilidade, enquanto a inexecução justificada por força maior ou caso fortuito implica em [sic] extinção da obrigação, sem dever de compor as eventuais perdas e danos."

${ }^{594}$ PEREIRA, Caio Mário da Silva. Instituições de direito civil: teoria geral das obrigações. 20 ed. Atual. Luis Roldão de Freitas Gomes. Rio de Janeiro: Forense, 2004, v. 2. p. 334.

${ }^{595}$ GONÇALVES, Carlos Roberto. Direito civil brasileiro: responsabilidade civil. 3 ed. São Paulo: Saraiva, 2008, v. 4. p. 35.

${ }^{596}$ COELHO, Fábio Ulhoa. Curso de direito civil. São Paulo: Saraiva, 2004, v. 2. p. 165-174.

597 TARTUCE, Flávio. Direito civil: direito das obrigações e responsabilidade civil. 2 ed. São Paulo: Método, 2006, v. 2. p. 192-205.

598 MOISÁ, Benjamin. La culpa como unico fundamento de la responsabilidad civil, Revista de Responsabilidad Civil y Seguros, Buenos Aires, n. 12, p. 349-358, dez. 2006. p. 349-358. 
primeiras codificações, mas, ainda hoje, culpa e causa estanha não imputável são concebidas como regiões fronteiriças, tratamento que conduz a afirmações de que, para afastar sua culpa, se impõe ao devedor o ônus de provar o caso fortuito ou a força maior. ${ }^{599}$

É possível identificar que outro fator que colabora com a manutenção da distorção apontada se encontra afeito à ausência de rigor no tratamento científico do tema, fenômeno que pode ser percebido em passagens como a que aduz que, "quando se diz que um homem incorreu em culpa, todos sabem o que isso quer dizer." 600

Aliás, a ausência de um conceito claro do fenômeno sob análise talvez seja o principal responsável pela repetição incorreta, acrítica e irrefletida de que a culpa é pressuposto do dever de reparar.

A pesquisa conduziu à identificação de incontáveis tentativas de conceituação da culpa. Dentre elas, são bastante comuns as concepções de culpa a partir de suas modalidades. ${ }^{601}$ Com a mesma frequência, afirma-se que essa figura consiste na violação de um dever jurídico. ${ }^{602}$

Outros tantos autores sustentam que a culpa se sintetiza em um erro de conduta. A culpa seria, nesse último viés, "o desvio de conduta que não praticaria o homem diligente e competente" ${ }^{\text {,603; }}$ o "erro de conduta, imputável ao agente, consistente em não adotar o cuidado que teria sido adotado pelo ser humano prudente nas circunstâncias do caso concreto"604; ou, ainda, e para não ser enfadonho, enfim, "um erro

\footnotetext{
599 MARQUES, Henrique Paulo Azevedo. Da responsabilidade civil em face dos acidentes de trânsito, Revista dos Tribunais, São Paulo, v. 38, n. 181, p. 510-517, set. 1949. p. 513.

600 COLIN, Ambrosio; CAPITANT, Henry. Curso elemental de derecho civil: teoria general de las obligaciones. 2 ed. Trad. Demofilo de Buen. Madrid: Instituto Editorial Reus, 1943, t. 3. p. 824.

${ }^{601}$ FIUZA, César. Por uma nova teoria do ilícito civil, Revista da Faculdade Mineira de Direito, Belo Horizonte, v. 6, n. 11/12, p. 29-48, 2003. p. 33. Consoante o autor, "culpa é ação ou omissão negligente, imprudente ou imperita."

602 PEREIRA, Agostinho Oli Koppe. A culpa e a responsabilidade civil no direito brasileiro, Revista da Faculdade de Direito, Caxias do Sul, n. 6, p. 116-132, mar. 1997. p. 117-118. No mesmo sentido: LIMA NETO, Francisco Vieira. Ato antijurídico e responsabilidade civil aquiliana - crítica à luz do novo código civil. In: BARROSO, Lucas Abreu (Org.). Introdução crítica ao código civil. Rio de Janeiro: Forense, 2006. p. 243.

${ }^{603}$ BERTI, Silma Mendes. Considerações sobre a responsabilidade civil do médico, Revista de Direito Comparado, Belo Horizonte, v. 2, n. 2, p. 121-129, mar. 1998. p. 123.

${ }^{604}$ CALIXTO, Marcelo Junqueira. A culpa na responsabilidade civil: estrutura e função. Rio de Janeiro: Renovar, 2008. p. 31.
} 
de conduta, moralmente imputável ao agente e que não seria cometido por uma pessoa avisada, em iguais circunstâncias de fato.",605

Cada uma das leituras apontadas conduzem, como facilmente se percebe, à intelecção da culpa como algo atado à "reprovabilidade ou censurabilidade da conduta do agente."

Sustenta-se, ainda, que uma conduta culposa deve estar necessariamente ligada à produção de danos. A "culpa é o ato imprudente manifestado em forma de ação ou abstenção que causa um prejuízo."607

E, enfim, em outras ocasiões, somam-se vários dos vícios apontados na tentativa conceitual. Prova disso é a afirmação de que culpa consiste no "erro de conduta, cometido pelo agente que, procedendo contra [o] direito, causa dano a outrem, sem a intenção de prejudicar, e sem a consciência de que seu comportamento poderia causálo., 608

As compreensões apontadas podem ser desconstruídas com alguma facilidade. As definições que confundem a noção de culpa com suas modalidades são descartadas de plano. ${ }^{609}$ E isso porque não é possível definir um gênero por meio de referências as suas formas de manifestação. A segunda perspectiva - que vê na culpa a violação de um dever jurídico - produz um problema no universo contratual, pois, salvo melhor juízo, confunde culpa com antijuridicidade. ${ }^{610}$

\footnotetext{
${ }^{605}$ LIMA, Alvino, Culpa e risco. 2 ed. São Paulo: RT, 1999. p. 69.

606 ANTUNES VARELA, João de Matos. Direito das obrigações: conceito, estrutura e função da relação obrigacional, fontes das obrigações, modalidades das obrigações. Rio de Janeiro: Forense, 1977, v. 1. p. 219.

607 COLIN, Ambrosio; CAPITANT, Henry. Curso elemental de derecho civil: teoria general de las obligaciones. 2 ed. Trad. Demofilo de Buen. Madrid: Instituto Editorial Reus, 1943, t. 3. p. 130. "A culpa contratual pressupõe: a) um dano; b) incumprimento; c) que o incumprimento seja imputável ao devedor; d) que o incumprimento seja a causa do dano." Veja ainda: TRUJILLO, Rafael Durán. Nociones de responsabilidad civil: contractual y delictuosa. Bogotá: Temis, 1957. p. 66.

${ }^{608}$ PEREIRA, Caio Mário da Silva. Responsabilidade civil: de acordo com a constituição federal de 1988.8 ed. Rio de Janeiro: Forense, 1997. p. 69.

${ }^{609}$ Entre outros: COELHO, Fábio Ulhoa. Curso de direito civil. São Paulo: Saraiva, 2004, v. 2. p. 308. "Culposo é o ato negligente, imprudente, imperito ou intencionalmente destinado a prejudicar alguém." RODRIGUES, Silvio. Direito civil: parte geral. 32 ed. São Paulo: Saraiva, 2002, v. 1. p. 311. "Atua culposamente aquele que causa prejuízo a terceiro em virtude de sua imprudência, imperícia ou negligência."

${ }^{610}$ COLIN, Ambrosio; CAPITANT, Henry. Curso elemental de derecho civil: teoria general de las obligaciones. 2 ed. Trad. Demofilo de Buen. Madrid: Instituto Editorial Reus, 1943, t. 3. p. 22. No mesmo sentido: RIPERT, Georges; BOULANGER, Jean. Tratado de derecho civil: las obligaciones. Trad. Delia García Daireaux. Buenos Aires: La Ley, 1964, v. 1, t. 4. p. 466-468. Consoante os autores, "a culpa do devedor consiste em não haver cumprido sua obrigação."
} 
A seu turno, as concepções normativas - aquelas que conceituam a culpa como um erro de conduta - devem ser afastadas por confundirem-na com a antijuridicidade. Destaque-se, por sua vez, que a exigência do dano retira a autonomia da culpa e não permite visualizar a possibilidade de condutas culposas sem a existência de lesão a um interesse juridicamente protegido. Antijuridicidade e dano são figuras distintas e autônomas, como outrora delineado.

Em verdade, a culpa deve ser compreendida como um erro de percepção, de julgamento ou de processamento de informação no processo que orienta - ou antecede - a adoção de uma dada conduta.

É impossível objetivar o fenômeno aqui explorado, mesmo porque, consoante é possível identificar em estudos no campo da psicanálise, a culpa atua, concomitantemente, nos níveis do consciente e do inconsciente. ${ }^{611}$

A percepção da importância da interdisciplinaridade para a escorreita compreensão do conteúdo da culpa é algo fundamental. Ela informa algumas tentativas de conceituação da culpa, embora nenhuma delas reflita o fenômeno com precisão - missão que, muito provavelmente, também não foi alcançada neste trabalho.

Retomando o caminho iniciado, a pesquisa identificou que a culpa consistiria na ação ou omissão voluntária e desprovida de malícia que impede o desempenho da prestação prometida ${ }^{612}$ ou que se apresenta como uma falha motivada pela "omissão de diligências." $" 613$

E, apesar de a discussão sobre o conceito de culpa continuar aberta, diversos autores conseguem visualizar, com alguma facilidade, que a culpa não é pressuposto do dever de reparar os danos contratuais, pensamento que informa as reflexões de Maria

${ }^{611}$ GROENINGA, Giselle Câmara. Sem mais desculpas - é tempo de responsabilidade. In: DIAS, Maria Berenice (Org.). Direito das famílias: contributo do ibdfam em homenagem a Rodrigo da Cunha Pereira. São Paulo: RT, 2009. p. 147-166.

${ }^{612}$ BUSTAMANTE, Lino Rodriguez-Arias. Derecho de obligaciones. Madrid: Editorial Revista de Derecho Privado, 1965. p. 213. Resta patente que o autor trabalha a partir da dicotomia culpa contratual e aquiliana e que o conceito restringe-se à primeira. Em sentido semelhante: ESPINOLA, Eduardo. Systema do direito civil brasileiro: theoria geral das relações jurídicas de obrigação. Rio de Janeiro: Porto, 1912, v. 2, t. 1. p. 413. A culpa consiste na "omissão voluntária do cuidado requerido para se evitar a lesão dos direitos."

${ }^{613}$ GHERSI, Carlos Alberto. De Velez a Borda un cambio ideológico trascendente, que no se complementó en el rápido acceso a la justicia. In: GHERSI, Carlos Alberto (Dir.). Responsabilidad: problemática moderna. Mendoza: Ediciones Jurídicas Cuyo, 1996. p. 23. 
Helena Diniz ${ }^{614}$, Paulo Luiz Netto Lôbo ${ }^{615}$, Pablo Stolze Gagliano e Rodolfo Pamplona Filho $^{616}$, dentre outros.

Consoante a percepção da vanguarda doutrinária, a culpa nada mais é que um potencial fator de atribuição ${ }^{617}$ do dever de reparar. Aliás, consoante o estado da arte, com atuação bastante restrita. ${ }^{618}$ Ao seu lado, a doutrina aponta a existência de outros tantos fatores de imputação do aludido dever, dentre eles, o risco criado, a garantia, o abuso de direito. ${ }^{619}$ Além deles, poderão ser encontrados, ainda, no comércio de produtos e tecnologias utilizados pela humanidade, nas atividades desenvolvidas nos mercados em geral, nos lucros auferidos, na presença de deveres de garantia e de equidade ${ }^{620}$ etc. Saliente-se, ademais - e isso é importante -, crescer, a cada dia, a aceitação de que o dever de reparar é atribuído em razão de um fator de imputabilidade ${ }^{621}$ que pode ser a culpa ou não.

${ }^{614}$ DINIZ, Maria Helena. Curso de direito civil brasileiro: responsabilidade civil. 22 ed. São Paulo: Saraiva, 2008, v. 7. p. 37. Dentre os pressupostos da responsabilidade civil, estaria a "existência de uma ação, comissiva ou omissiva, qualificada juridicamente, isto é, que se apresenta como um ilícito ou lícito, pois, ao lado da culpa, como fundamento da responsabilidade, temos o risco."

${ }^{615}$ LÔBO, Paulo Luiz Netto. Teoria geral das obrigações. São Paulo: Saraiva, 2005. p. 265.

${ }^{616}$ GAGLIANO, Pablo Stolze; PAMPLONA FILHO, Rodolfo. Novo curso de direito civil: responsabilidade civil. 5 ed. São Paulo: Saraiva, 2007, v. 3. p. 25. "A culpa, portanto, não é um elemento essencial, mas sim acidental, pelo qual reiteramos nosso entendimento de que os elementos básicos ou pressupostos gerais da responsabilidade civil são apenas três: a conduta humana (positiva ou negativa), o dano ou prejuízo e o nexo de causalidade."

${ }^{617}$ LA TORRE, Antonio. I criterio d'imputazione della responsabilità civile, Roma e America: Diritto Romano Comune, Roma, n. 10, p. 96-114, 2000. p. 96. Segundo o autor, falar-se em critérios de imputação do dever de reparar na primeira metade dos novecentos, época em que culpa e responsabilidade eram conceitos inseparáveis, seria algo quase incompreensível.

${ }^{618} \mathrm{O}$ tema será retomado no cap. III.

${ }^{619}$ LORENZETTI, Ricardo Luis. El sistema de la responsabilidad civil ¿una deuda de responsabilidad, un crédito de indemnización o una relación jurídica?, Revista da Ajuris, Porto Alegre, n. 63, p. 166-198, mar. 95. p. 175. No mesmo sentido: GHERSI, Carlos Alberto. De Velez a Borda un cambio ideológico trascendente, que no se complementó en el rápido acceso a la justicia. In: GHERSI, Carlos Alberto (Dir.). Responsabilidad: problemática moderna. Mendoza: Ediciones Jurídicas Cuyo, 1996. p. 24.

${ }^{620}$ PAPAYANNIS, Diego Martín. En torno de la teoría del derecho de daños, Revista de Responsabilidad Civil y Seguros, Buenos Aires, n. 8, p. 23-34, ago. 2007. p. 24.

${ }^{621}$ LEONARDO, Rodrigo Xavier. Responsabilidade civil contratual e extracontratual: primeiras anotações em face do novo código civil brasileiro, Revista de Direito Privado, São Paulo, v. 5, n. 19, p. 260-269, jul./set. 2004. p. 265. "Destaca-se, cada vez mais, a compreensão de que o dever de indenizar é proveniente de uma imputação, que pode ter por fundamento a culpa, o risco, a repartição dos custos das externalidades provenientes do desenvolvimento de uma atividade econômica, ou, ainda, uma outra escolha política que, em maior ou menor medida, pressupõe um sopesar de valores entre os interesses de proteção dos potenciais lesados e os incentivos ou a repressão à determinada conduta ou atividade." 
E como "imputar não é inculpar, não é atribuir culpa [como comumente afirmado $\left.^{622}\right]$, mas sim, atribuir responsabilidade"623, não é a culpa que impõe o dever de reparar, mas o recurso, desde que presentes os pressupostos apontados - existência do contrato, conduta antijurídica, nexo de causalidade e lesão a um interesse digno de tutela a um fator de atribuição do dever de reparar. ${ }^{624}$

É importante repisar que a noção de imputabilidade não alude ao sujeito nem constitui uma qualidade que lhe pertença ${ }^{625}$, denotando, ao contrário, uma relação existente entre a violação de um dever e a imposição (ou não) do dever de reparar ao causador do dano. $^{626}$

Infira-se que, quando se enxerga que o dever de reparar é imputado a alguém em razão de distintos fatores, também se compreende por que a culpa não é fonte de responsabilidade, ao contrário do que pretendem autores como Carlos Young Tolomei. ${ }^{627}$

A culpa, como se pode perceber, há de ser compreendida apenas como potencial fator de atribuição do dever de reparar, embora não tenha utilidade alguma na conformação do dever de reparar os danos contratuais, como será demonstrado ao longo da tese ainda em construção. A culpa não é, repita-se, uma vez mais, pressuposto do dever de reparar os danos contratuais, afixando-se, desse modo, mais um pilar na sustentação da tese em construção.

${ }^{622}$ ENNECCERUS, Ludwig. Derecho de obligaciones: doctrina general. Trad. Blas Pérez Gonzales; José Alguer. Barcelona: Bosch, 1944, v. 1. p. 222-224.

${ }^{623}$ SAVI, Sérgio. Inadimplemento das obrigações, mora e perdas e danos. In: TEPEDINO, Gustavo (Coord.). Obrigações: estudos na perspectiva civil-constitucional. Rio de Janeiro: Renovar, 2005. p. 466. No mesmo sentido: MARTINS-COSTA, Judith. Comentários ao novo código civil: do inadimplemento das obrigações. Rio de Janeiro: Forense, 2003, v. 5, t. 2. p. 84-89.

${ }^{624}$ FONTES, André. Os fatores de atribuição na responsabilidade por danos, Revista Brasileira de Direito Comparado, Rio de Janeiro, n. 16, p. 177-189, jan./jun. 1999. p. 186. O autor elenca como potenciais fatores objetivos de atribuição de responsabilidade, entendendo-se como fator de atribuição "o fundamento da reparação", os seguintes: "a) a solidariedade; b) a seguridade social; c) o risco criado; d) a eqüidade; e) a garantia e tutela especial do crédito; f) igualdade dos ônus públicos; g) seguro; h) critérios econômicos." No mesmo sentido: ALTHEIM, Roberto. Direito de danos: pressupostos contemporâneos do dever de indenizar. Curitiba: Juruá, 2008. p. 170. Dentre outros, o autor aduz como exemplos: "a culpa, o dolo, a solidariedade social, a seguridade social, o risco criado, a equiidade, a garantia, a tutela especial do crédito, a igualdade dos ônus públicos, o seguro, os critérios econômicos, o abuso de direito, a boa-fé objetiva [...]."

${ }^{625}$ LÔBO, Paulo Luiz Netto. Direito civil: parte geral. São Paulo: Saraiva, 2009. p. 326. "Imputável é o que deu causa ao dano ou o que o direito qualifica como responsável, ainda que não tenha tido culpa ou mesmo participação no evento."

${ }^{626}$ DEVOTO, Luigi. L'imputabilità e le sue forme nel diritto civile. Milano: Giuffrè, 1964. p. 238.

${ }^{627}$ TOLOMEI, Carlos Young. A noção de ato ilícito e a teoria do risco na perspectiva do novo código civil. In: TEPEDINO, Gustavo (Coord.). A parte geral do novo código civil: estudos na perspectiva civilconstitucional. Rio de Janeiro: Renovar, 2002. p. 354. 


\subsection{A violação de dever na configuração da responsabilidade contratual}

A análise das distintas patologias no curso do processo obrigacional pode ser unificada com o recurso à ideia nuclear de "violação de um dever" ${ }^{\text {"628 }}$; supraconceito ${ }^{629}$, o qual, aliás, foi recentemente consagrado pela reforma do código civil alemão. ${ }^{630}$

Além da precisão conceitual - essencial quando se pretende fazer ciência -, a escorreita compreensão do que seja a violação de dever permite vislumbrar questões desprezadas e (ou), por vezes, incompreendidas pela doutrina brasileira, especialmente por que essa, em regra, pauta o estudo das patologias no processo obrigacional a partir da dicotomia mora e inadimplemento.

Ademais, considerando-se que a relação contratual é modelada por uma multiplicidade de deveres, por mais esse motivo, surge a necessidade de dar unicidade ao processo de formatação do dever de reparar os danos contratuais, o que conduz, por outra via, à noção de violação de dever, figura que permite sistematizar o tratamento dos problemas inerentes à inobservância de deveres contratuais de qualquer natureza. ${ }^{631}$

Almejando melhor compreender o assunto, faz-se necessário recordar que a expressão pacare, proveniente de pax, "significa pacificar, apaziguar e também libertar.",632 A alusão à etimologia do adimplemento é fundamental por permitir compreendê-lo em toda a sua complexidade.

\footnotetext{
${ }^{628}$ MENEZES CORDEIRO, António Manuel da Rocha e. Da modernização do direito civil: aspectos gerais. Coimbra: Almedina, 2004, v. 1. p. 103. A proposta é formulada pelo autor com amparo na reforma alemã de 2001/2002. Seu cerne parece estar alocado no § 280 (1) do BGB: "Quando o devedor viole [sic] um dever proveniente de uma relação jurídica, pode o credor exigir a indenização do dano daí resultante. Essa regra não se aplica quando a violação do dever não seja imputável ao devedor."

${ }^{629}$ DOHRMANN, Klaus Jochen Albiez. Um nuevo derecho de obligaciones. la reforma 2002 del bgb, Anuario de Derecho Civil, Madrid, v. 55, n. 3, p. 1133-1227, jul./set. 2002. p. 1164.

${ }^{630}$ Sobre o tema: CANARIS, Claus-Wilhelm. La riforma del diritto tedesco delle obbligazioni: contenuti fondamentali e profili sistematici del Gesetz zur Modernisierung des Schuldrechts. Trad. Marcello Farneti; Sonja Haberl. Padova: CEDAM, 2003. p. 7-96. NORDMEIER, Carl Friedrich. O novo direito das obrigações no código civil alemão - a reforma de 2002. In: MARQUES, Cláudia Lima (Coord.). A nova crise do contrato: estudos sobre a nova teoria contratual. São Paulo: RT, 2007. p. 146-159.

${ }^{631}$ VITA NETO, José Virgílio. A atribuição da responsabilidade contratual. Tese (Doutorado) - Faculdade de Direito da USP, São Paulo, 2007. p. 58.

${ }^{632}$ AZEVEDO JUNIOR, José Osório de. Breves anotações sobre o pagamento e o ato jurídico não negocial. In: NANNI, Giovanni Ettore (Coord.). Temas relevantes do direito civil contemporâneo: reflexões sobre os cinco anos do código civil. São Paulo: Atlas, 2008. p. 353.
} 
Desse modo, se o pagamento consiste na "realização, pelas partes e conforme seus deveres específicos, de todos os interesses envolvidos na relação obrigacional"633, somente haverá pagamento se as legítimas expectativas do credor, depositadas na conduta prometida pelo devedor, forem efetivamente satisfeitas. ${ }^{634}$ Infira-se que, nesse contexto, toda projeção almejando simplificar a caracterização do pagamento como simples ato de entrega de uma prestação há de ser afastada.

O cumprimento (ou não) da obrigação - vista aqui como "organismo e totalidade" ${ }^{\text {, }} 35$, reafirme-se, somente poderá ser identificado diante do confronto entre o comportamento concretamente externado e aquele que foi prometido por ocasião do ajuste negocial, ou seja, aquele que pré-estabeleceu o programa obrigacional ${ }^{636}$ a ser observado pelos contratantes.

Em termos gerais, é possível afirmar que a caracterização da violação de dever será informada pela não realização dos interesses - de quaisquer das partes - delineados no programa obrigacional concretamente estabelecido, manifestando-se no desrespeito a um dever de prestação ou de deveres que assumam outra feição, cujo principal escopo é a proteção da integridade psicofísica de ambas as partes e de seu patrimônio.

O desrespeito aos deveres de prestação se manifesta sob três formas: o inadimplemento, a mora e o cumprimento inexato, também conhecido por cumprimento imperfeito, adimplemento ruim, dentre outras expressões que o caracterizam. ${ }^{637}$ Acrescente-se a elas - na composição da noção de violação de dever - o desrespeito aos deveres gerais de conduta.

\footnotetext{
${ }^{633}$ SILVA, Jorge Cesa Ferreira da. A boa-fé e a violação positiva do contrato. Rio de Janeiro: Renovar, 2007. p. 123.

${ }^{634}$ CASIELLO, Juan José. El pago: concepto y esencia jurídica. In: GESUALDI, Dora Mariana (Coord.). Derecho privado. Buenos Aires: Hammurabi, 2001. p. 922.

${ }^{635}$ MARTINS-COSTA, Judith. Comentários ao novo código civil: do direito das obrigações - do adimplemento e da extinção das obrigações. Rio de Janeiro: Forense, 2005, v. 5, t. 1. p. 76-80. "Nesta perspectiva, a relação obrigacional, mormente a relação contratual, é sempre complexa, pois estruturada não apenas na obrigação principal (dever de prestação), mas, igualmente, por deveres de prestação secundários e deveres instrumentais, assim reconhecidos pela ordem jurídica porque visam garantir, otimamente, a consecução da finalidade à qual se dirigem a relação e a proteção dos legítimos interesses do alter."

${ }^{636}$ DIEZ-PICAZO, Luis. Fundamentos del derecho civil patrimonial: las relaciones obligatorias. 5 ed. Madrid: Civitas, 1996, v. 2. p. 567-569.

${ }^{637}$ PICASSO, Sebastián. El incumplimiento en las obligaciones contractuales: el problema de la ausencia de culpa y de la imposibilidad sobrevenida de la prestación - obligaciones de medios y de resultado. In: GESUALDI, Dora Mariana (Coord.). Derecho privado. Buenos Aires: Hammurabi, 2001. p. 1105.
} 


\section{O inadimplemento}

O inadimplemento é um das patologias que podem atingir a prestação. Em linhas gerais, a figura restará caracterizada diante da situação objetiva de não desempenho da prestação prometida ${ }^{638}$, revelando-se, assim, quando "a obrigação não foi cumprida, nem poderá sê-lo."639 Em outras palavras, haverá inadimplemento "sempre que a prestação se torna impossível ou sempre que, por não ter sido efetuada no momento devido, a prestação se torna inútil para o credor e este a recusa." 640

Em síntese preciosa, ao discorrer sobre o tema, Judith Martins-Costa aponta que o inadimplemento consiste na "não-realização, imputável, da prestação devida, enquanto devida" ${ }^{\prime 641}$, construção que tem, dentre outros, o mérito de apontar a necessidade de que o não cumprimento seja imputável.

Apreenda-se, como traço comum nas ideias transcritas, que a identificação do inadimplemento é promovida de modo objetivo, dispensando a alusão a qualquer circunstância de ordem subjetiva ${ }^{642}$, perspectiva que carrega a vantagem de afastar a afirmação de que a relação obrigacional se limita a um dever de esforço. ${ }^{643}$ A questão, entretanto, não é pacífica, existindo viva controvérsia. ${ }^{644}$

${ }^{638}$ ANTUNES VARELA, João de Matos. Das obrigações em geral. 7 ed. Coimbra: Almedina, 1997, v. 2. p. 60.

${ }^{639}$ ALVIM, Agostinho. Da inexecução das obrigações e suas conseqüências. 4 ed. São Paulo: Saraiva, 1972. p. 7.

${ }^{640}$ ANTUNES VARELA, João de Matos. Direito das obrigações. Rio de Janeiro: Forense, 1978, v. 2. p. 57.

${ }^{641}$ MARTINS-COSTA, Judith. Comentários ao novo código civil: do inadimplemento das obrigações. Rio de Janeiro: Forense, 2003, v. 5, t. 2. p. 84. No mesmo sentido: MENEZES CORDEIRO, Antônio Manuel da Rocha e. Direito das obrigações. Lisboa: Associação Acadêmica da Faculdade de Direito de Lisboa, 1986, v. 2. p. $456-457$.

642 Nesse sentido: NALIN, Paulo. Responsabilidade civil: descumprimento do contrato e dano extrapatrimonial. Curitiba: Juruá, 1996. p. 149-152. ESPINOSA, Fabricio Mantilla; BARRIOS, Francisco Ternera. La resolución. In: ESPINOSA, Fabricio Mantilla; BARRIOS, Francisco Ternera (Dir.). Los contratos en el derecho privado. Bogotá: Legis, 2007. p. 252. PACCHIONI, Giovanni. Obbligazioni e contratti: succinto commento al libro quarto del codice civile. Padova: CEDAM, 1950. p. 18-19. Saliente-se que esse último autor afasta a necessidade da culpa como pressuposto da obrigação que nasce do inadimplemento, segundo ele, consoante se extrai do art. 1218 do Codice Civile.

643 DIEZ-PICAZO, Luis. Fundamentos del derecho civil patrimonial: las relaciones obligatorias. 5 ed. Madrid: Civitas, 1996, v. 2. p. 578.

${ }^{644}$ Sobre o tema: MARTINS-COSTA, Judith. Comentários ao novo código civil: do inadimplemento das obrigações. Rio de Janeiro: Forense, 2003, v. 5, t. 2. p. 84-92. 
Por outro lado, é de fundamental importância a compreensão de que a inexecução de uma prestação pode ser imputável ao devedor, ao credor ou a evento estranho a(s) sua(s) esfera(s) de atuação. ${ }^{645}$

E relevante porque, somente quando imputável à conduta do devedor, será possível conceber que houve inadimplemento e, portanto, apenas nesses casos, estará caracterizada a violação de dever.

E se, por imputável, deve ser compreendida a consequência atribuída ao devedor, em razão de uma conduta contrária ao direito ${ }^{646}$, por não imputável deve ser concebido o não cumprimento oriundo do fortuito ${ }^{647} \mathrm{ou}$, de modo mais preciso, provocado por uma causa estranha à conduta daquele e, ainda, o que deriva do exercício de um direito existente na concretude da relação negocial.

A adequada formatação da figura explorada exige, ainda, a presença da impossibilidade de desempenho da prestação ou o desaparecimento do interesse do credor no adimplemento não realizado no momento oportuno, hipótese conhecida como caráter transformista da mora. ${ }^{648}$

Aliás, acerca do caráter transformista da mora, é relevante destacar que o desaparecimento do interesse do credor deve ser aferido objetivamente ${ }^{649}$, até porque, dentre outras razões, o processo obrigacional não admite comportamentos mesquinhos ou desfuncionalizados.

${ }^{645}$ JORGE, Fernando Pessoa. Ensaio sobre os pressupostos da responsabilidade civil. Coimbra: Almedina, 1999. p. 27.

${ }^{646}$ SILVA, Jorge Cesa Ferreira da. Inadimplemento das obrigações: mora, perdas e danos, juros legais, cláusula penal, arras ou sinal. São Paulo: RT, 2007. p. 56-58. "O fator de imputação responde à pergunta sobre a razão pela qual é imputado a alguém o dever de indenizar [...] imputar é atribuir dever."

${ }^{647}$ MARTINEZ, Pedro Romano. Cumprimento defeituoso: em especial na compra e venda e na empreitada. Almedina: Coimbra, 2001. p. 275-282.

${ }^{648}$ ASSIS, Araken de. Resolução do contrato por inadimplemento. 3 ed. São Paulo: RT, 1999. p. 110. "Em outros termos, a viabilidade do cumprimento, porque útil ao credor a prestação tardia, completada pelas perdas e danos, constitui um pressuposto da mora; perdido o interesse, ou desaparecida a possibilidade, quando a prestação se torna irrealizável, surge a figura do não cumprimento definitivo da obrigação [...] é o que se chama caráter transformista da mora."

${ }^{649}$ Nesse sentido: MARTINS-COSTA, Judith. Comentários ao novo código civil: do inadimplemento das obrigações. Rio de Janeiro: Forense, 2003, v. 5, t. 2. p. 250-263. GOMES, Orlando. Questões de direito civil. São Paulo: Saraiva, 1976. p. 76-77. ASSIS, Araken de. Resolução do contrato por inadimplemento. 3 ed. São Paulo: RT, 1999. p. 111. Saliente-se, ainda, que, consoante informado noutro momento (item 2.1), nesse sentido, o enunciado 162, aprovado na III Jornada de Estudos de Direito Civil sob a coordenação do Conselho da Justiça Federal. 
A primeira das situações exige melhor análise. E, isso porque, apesar de ser comum identificar afirmações destacando que a impossibilidade exoneratória deve ser qualificada como superveniente ${ }^{650}$ e objetiva $^{651}$, é possível perceber que a doutrina tem buscado abrandar os pressupostos clássicos da impossibilidade liberatória. Tanto que, nessa quadra, são identificadas teses defendendo que a impossibilidade que atinge exclusivamente a pessoa do devedor deverá ser equiparada à impossibilidade objetiva ${ }^{652}$, solução de grande utilidade na equalização das celeumas nas obrigações intuito personae.

Sob outro prisma, se a consagração do paradigma da essencialidade indiscutivelmente permite a mitigação dos efeitos do inadimplemento da prestação ${ }^{653}$, aparentemente, também pode ser utilizado no processo de reconfiguração da noção de impossibilidade exoneratória. E, com esse mesmo escopo, há de se dedicar especial atenção às circunstâncias concretas e aos influxos que emanam da boa-fé objetiva ${ }^{654}$, eixo gravitacional das reflexões para a solução dos problemas concretamente identificados no desvelar de cada processo obrigacional. ${ }^{655}$

Outras tantas razões impõem a necessidade de ampliação das cercanias que delimitam a noção de impossibilidade objetiva. Em um primeiro momento, saliente-se que aquela deve ser compreendida em perspectiva sociocultural, e não, mediante o recurso à paradigmas físicos ou naturalísticos. ${ }^{656}$

\footnotetext{
${ }^{650}$ No direito brasileiro, a impossibilidade anterior ou concomitante à formação do negócio jurídico é tratada como hipótese de nulidade consoante dispõe o art. 166, II do CC: "É nulo o negócio jurídico quando: [...] II for ilícito, impossível ou indeterminável o seu objeto."

${ }^{651}$ SILVA, Jorge Cesa Ferreira da. A boa-fé e a violação positiva do contrato. Rio de Janeiro: Renovar, 2007. p. 130-134.

652 OSTI, Giuseppe. Revisione critica della teoria sulla impossibilità della prestazione, Rivista di Diritto Civile, Milano, v. 10, n. 3, p. 209-249, mai./jun. 1918. p. 216-221.

${ }^{653}$ NEGREIROS, Teresa. Teoria do contrato: novos paradigmas. Rio de Janeiro: Renovar, 2002. p. 470.

${ }^{654}$ CASTILHA, Gustavo Ordoqui. Buena fe contractual. Montevideo: Del Foro, 2005. p. 213. “Assim como a boa-fé amplia as obrigações do credor impondo a esse informar e não criar riscos (de danos) para o parceiro negocial, também permeia a noção de impossibilidade", autorizando a reconfiguração da última.

${ }^{655}$ PICASSO, Sebastián. El incumplimiento en las obligaciones contractuales: el problema de la ausencia de culpa y de la imposibilidad sobrevenida de la prestación - obligaciones de medios y de resultado. In: GESUALDI, Dora Mariana (Coord.). Derecho privado. Buenos Aires: Hammurabi, 2001. p. 1110-1113.

${ }^{656}$ MENEZES CORDEIRO, António Manuel da Rocha e. Da modernização do direito civil: aspectos gerais. Coimbra: Almedina, 2004, v. 1. p. 110. A questão alude especialmente à recepção da denominada impossibilidade fática ou prática que se encontra no cerne da construção da teoria do limite do sacrifício. No mesmo sentido: BERDAGUER, Jaime. Las obligaciones de resultado: situación actual y perspectivas futuras. In: FERNÁNDEZ, Carlos López; CAUMONT, Arturo; CAFFERA, Gerardo (Coord.). Estudios de derecho civil en homenaje al profesor Jorge Gamarra. Montevideo: FCU, 2001. p. 34-35. GIORGIANNI, Michele. L'inadempimento. Milano: Giuffrè, 1975. p. 210-211.
} 
De fato, parece hialino que a configuração do que seja impossibilidade exoneratória deve ter em conta elementos culturais. Esses serão utilizados pelo Direito no preenchimento da carga axiológica dos princípios que informam o direito obrigacional, mesmo porque o que é o Direito senão uma prática social discursiva. Infira-se, ainda, que a noção naturalista do fenômeno "sacrifica excessivamente" o devedor e não se coaduna com uma visão equilibrada da relação obrigacional. ${ }^{657}$

A postura sugerida tempera o rigor do tema em sua originalidade com a carga axiológica emanada de princípios como a solidariedade constitucional ${ }^{658}$ e a outrora citada boa-fé objetiva.

É preciso reconhecer, também, que perspectivas de ordem subjetiva possam ser invocadas como hipóteses de exclusão do dever de reparar. ${ }^{659}$ Prova disso encontra-se na reforma do código civil alemão, equiparando as situações de impossibilidade objetiva e subjetiva quando alude à impossibilidade fática. ${ }^{660}$ Assim, mesmo que a prestação não seja impossível, "pode ser impossível para um determinado devedor", diante do contexto fático em que se encontra envolto. ${ }^{661}$

Destaque-se, enfim e em homenagem à constante busca por justiça contratual, que a projeção antes apontada permite sustentar que o aumento dos custos da prestação poderá integrar a hipótese de impossibilidade superveniente, desde que seja manifestamente desproporcional quando comparado ao resultado projetado no momento do ajuste negocial. ${ }^{662}$

\footnotetext{
${ }^{657}$ MASSIMO BIANCA, Cesare. Diritto civile: 1'obbligazione. Milano: Giuffrè, 2006, v. 4. p. 531.

${ }^{658}$ RUSCELLO, Francesco. Istituzioni di diritto privato: le obbligazioni. 2 ed. Milano: Giuffrè, 2006, v. 2. p. 51-53.

${ }^{659}$ OSTI, Giuseppe. Revisione critica della teoria sulla impossibilità della prestazione, Rivista di Diritto Civile, Milano, v. 10, n. 3, p. 209-249, mai./jun. 1918. p. 225-226.

${ }^{660}$ CANARIS, Claus-Wilhelm. La riforma del diritto tedesco delle obbligazioni: contenuti fondamentali e profili sistematici del Gesetz zur Modernisierung des Schuldrechts. Trad. Marcello Farneti; Sonja Haberl. Padova: CEDAM, 2003. p. 13.

${ }^{661}$ DOHRMANN, Klaus Jochen Albiez. Um nuevo derecho de obligaciones. la reforma 2002 del bgb, Anuario de Derecho Civil, Madrid, v. 55, n. 3, p. 1133-1227, jul./set. 2002. p. 1166.

${ }^{662}$ MASSIMO BIANCA, Cesare. Diritto civile: 1'obbligazione. Milano: Giuffrè, 2006, v. 4. p. 529.
} 
Etimologicamente ligada à memor ${ }^{663}$ - falha na memória -, a mora se apresenta diante do atraso de prestação ainda possível, motivado em um fato imputável ao devedor ou ao credor. Apreenda-se que mora não é mero atraso, mas demora qualificada. ${ }^{664}$ Assim, haverá mora quando um fato imputável à conduta do devedor - ou do credor - impedir o adimplemento no tempo, e apenas no tempo, de uma prestação ainda possível e útil.

É relevante destacar que, ao contrário do que ocorre nas situações de impossibilidade definitiva, a impossibilidade temporária não exonera o devedor, que continuará obrigado ao adimplemento, somando-se a esse dever o de reparar, nos casos de mora debitoris.

Noutro vértice, não haverá a imposição do dever de reparar, quando a mora estiver atada a um fato imputável ao credor - mora creditoris - ou a uma causa estranha e não imputável. ${ }^{665}$ Aqui, embora haja atraso, não é possível sustentar a presença da mora do devedor. Também não será possível sustentar a gênese do dever de reparar - por não haver mora - quando o adimplemento não foi realizado em razão do exercício legítimo de uma posição jurídica, como ocorre quando o devedor recorre ao direito de retenção ou às exceções do contrato não cumprido, de inseguridade ou de compensação.

A perfeita compreensão do tema exige, ainda, aceitar que, no Brasil, promoveu-se o alargamento - indevido, frise-se, desde cedo - da noção de mora. A regra codificada $^{666}$ - repetindo o conteúdo do artigo equivalente no código Beviláqua ${ }^{667}$ - é diretamente responsável pela ampliação das cercanias de um conceito construído

\footnotetext{
${ }^{663}$ PONTES DE MIRANDA, Francisco Cavalcanti. Tratado de direito privado: parte especial. 2 ed. Rio de Janeiro: Borsoi, 1958, t. 23. p. 117. Expressão que, segundo o autor, remete a "lembrar, recordar, tal como "memória." Originariamente, assistir pensando."

${ }^{664}$ RUSCELLO, Francesco. Istituzioni di diritto privato: le obbligazioni. 2 ed. Milano: Giuffrè, 2006, v. 2. p. 41.

${ }^{665}$ Nesse sentido, dispõe o código civil brasileiro: "Art. 396. Não havendo fato ou omissão imputável ao devedor, não incorre este em mora."

${ }^{666}$ Dispõe o código civil brasileiro: “Art. 394. Considera-se em mora o devedor que não efetuar o pagamento e o credor que não quiser recebê-lo no tempo, lugar e forma que a lei ou a convenção estabelecer."

${ }^{667}$ Trata-se do artigo 955 do código civil de 1916.
} 
historicamente, impondo sua utilização nos casos de desobediência a fatores como lugar e modo de desempenho da prestação. ${ }^{668}$

Ocorre que tal opção, mesmo sendo aceita por autores como Jorge Cesa Ferreira da Silva ${ }^{669}$, Luciano de Camargo Penteado ${ }^{670}$ e Paulo Jorge Scartezzini Guimarães $^{671}$, dentre outros ${ }^{672}$, ultrapassa limites intransponíveis, dentre eles, as bases etimológicas ${ }^{673}$ nas quais o conceito encontra porto seguro e o tratamento dado ao tema por um sem número de codificações estrangeiras ${ }^{674}$, dificultando, assim, o diálogo internacional.

E, como a onipotência está longe de ser uma qualidade atribuída ao legislador, embora o conceito alargado de mora tenha sido consagrado no direito pátrio há, pelo menos, quase um século, uma vez desrespeitados aspectos como lugar ou forma de desempenho da prestação, não haverá mora, mas patologia distinta. ${ }^{675}$

Superada essa questão, vale lembrar que, como antecipado, a mora pode ser atribuída ao credor - mora creditoris - ou ao devedor - mora debitoris. A dicotomia é relevante, pois, consoante o enquadramento formulado, produzirá efeitos distintos. No primeiro caso, será imputável ao credor cuja conduta retardou o adimplemento no

\footnotetext{
${ }^{668}$ ALVIM, Agostinho. Da inexecução das obrigações e suas conseqüências. 4 ed. São Paulo: Saraiva, 1972. p. $11-12$.

669 SILVA, Jorge Cesa Ferreira da. Inadimplemento das obrigações: mora, perdas e danos, juros legais, cláusula penal, arras ou sinal. São Paulo: RT, 2007. p. 44. Discorre o autor que, "ao contrário da maioria dos ordenamentos da família romano-germânica, o nosso conceito de mora não se limita ao mero atraso da prestação em si, mas abarca todas as situações que possam atrasar a satisfação dos interesses do credor na prestação."
}

${ }^{670}$ PENTEADO, Luciano de Camargo. Efeitos contratuais perante terceiros. São Paulo: Quarter Latin, 2006. p. 183-184. Salienta o autor que "a categoria da violação positiva do contrato, entretanto, é dispensável no sistema brasileiro, para o qual existe, uma noção peculiar de mora.”

${ }^{671}$ GUIMARÃES, Paulo Jorge Scartezzini. Vícios do produto e do serviço por qualidade, quantidade $e$ insegurança: cumprimento imperfeito do contrato. São Paulo: RT, 2004. p. 173. Destacando o autor que, "como vimos no início deste trabalho, o cumprimento imperfeito nada mais é do que a mora."

${ }^{672}$ GAZALLE, Gustavo Kratz. O conceito de mora no código civil de 2002. Porto Alegre: SAFE, 2008. p. 21-59.

${ }^{673}$ MARTINS-COSTA, Judith. Comentários ao novo código civil: do inadimplemento das obrigações. Rio de Janeiro: Forense, 2003, v. 5, t. 2. p. 224-225. "Os mais arcanos significados etimológicos indicam ser a mora um "esquecimento" que gera a memória do que devia ser prestado (ou recebido), e não o foi. Nas mais diversas legislações, este "não o foi" diz respeito ao retardo da prestação: o que devia ser prestado (ou recebido) não o foi no tempo devido."

${ }^{674}$ Como se extrai, por exemplo, do regramento do tema no código civil espanhol (Art. 1100), no português (Art. 804) e no argentino (Art. 509).

${ }^{675}$ A ser explorada na sequência dessas reflexões. 
transcorrer do processo obrigacional. Algo impediu que o credor cooperasse visando a sua própria satisfação. ${ }^{676}$

E, naquilo que importa mais diretamente à tese em desenvolvimento, embora exista quem defenda que a culpa é necessária à caracterização da mora creditoris $^{677}$, essa é preterida na configuração da figura analisada. ${ }^{678}$ A culpa não é requisito da mora do credor, sendo possível afastar o elemento subjetivo por diversas razões: (a) ante o direito do devedor de adimplir, buscando liberar-se das amarras que o atam ao credor $^{679}$; (b) por conta da extensão temporal da responsabilidade do devedor quanto à guarda e conservação da coisa nas obrigações de dar - entregar e restituir -; (c) em razão da existência de um dever de cooperação imposto aos parceiros negociais ${ }^{680}$; e ainda, diante da (d) constatação de que a mora creditoris não pode agravar a situação do devedor. ${ }^{681}$

A seu turno, a mora do devedor ${ }^{622}$ caracteriza-se pelo atraso no desempenho da prestação prometida, em razão de um fato imputável ao devedor. É importante salientar que, ao contrário do que ocorre no inadimplemento, a mora poderá ser purgada mediante desempenho da prestação não desempenhada, cumulada com os consectários legais e/ou contratuais inerentes à situação concreta. E aqui, no que tange à culpa, é interessante destacar que boa parte da doutrina pátria a defende na composição da mora debitoris, visão mantida, dentre outras razões, diante da (a) equivocada compreensão da culpa como

\footnotetext{
${ }^{676} \mathrm{E}$ os principais efeitos, nesse caso, consistem na subtração da responsabilidade do devedor - salvo conduta dolosa - na conservação da coisa e no surgimento de um dever, imposto ao credor, de ressarcir as despesas na conservação do objeto da prestação.

${ }^{677}$ SERPA LOPES, Miguel Maria de. Curso de direito civil: obrigações em geral. Atual. José Serpa Santa Maria. Rio de Janeiro: Freitas Bastos, 1989, v. 2. p. 354-359.

${ }^{678}$ ALVIM, Agostinho. Da inexecução das obrigações e suas conseqüências. 4 ed. São Paulo: Saraiva, 1972. p. 22-36. O autor exemplifica seu raciocínio com a afirmação de que há mora, mesmo quando o credor deixa de receber obrigação quesível em razão de ter adoecido, não obstante tal fato não ter sido por ele causado. No mesmo sentido: WESTERMANN, Harm Peter. Código civil alemão: direito das obrigações - parte geral. Trad. Armindo Edgar Laux. Porto Alegre: SAFE, 1983. p. 97. Lecionando que o código civil alemão não tem como pressuposto o elemento culpa na aferição da mora do credor, bastando uma oferta concreta e possível de realizar-se.

${ }^{679}$ ALVIM, Agostinho. Da inexecução das obrigações e suas conseqüências. 4 ed. São Paulo: Saraiva, 1972. p. 29.

${ }^{680}$ NALIN, Paulo. Do contrato: conceito pós-moderno em busca de sua formulação na perspectiva civilconstitucional. Curitiba: Juruá, 2001. p. 196-197.

${ }^{681}$ CUNHA DE SÁ, Fernando Augusto. Direito ao cumprimento e direito a cumprir. Coimbra: Almedina, 1997. p. 99.

${ }^{682}$ Cujos principais efeitos são (a) a perpetuatio obligationis e, caso haja danos, (b) a gênese do dever de reparar.
} 
violação de dever de conduta e, (b) do desconhecimento da existência de fatores de atribuição na configuração do dever de reparar. ${ }^{683}$

É importante perceber que, para sua conformação, basta que o atraso decorra da conduta do devedor. Em outras palavras, que o devedor não possa se escorar em um motivo legítimo para justificar o retardo ${ }^{684}$ no desempenho de prestação por ele assumida. Como não poderia ser diferente, especialmente por conta da compreensão turva do fenômeno da culpa, essa questão não é pacífica, e, talvez também por isso, não são poucos os autores que sustentam que a mora é "qualquer atraso culposo"685 ou o "retardamento culposo no cumprimento da obrigação."686

Apesar de farta bibliografia em sentido contrário, a mora se configura diante do transcurso da data limite para o adimplemento e da possibilidade de atribuição do atraso à conduta do devedor. Nesses termos, será moldada a partir do critério cronológico ${ }^{687}$ e da possibilidade de atribuição do não pagamento à conduta do devedor. A culpa, portanto, não é elemento da mora debitoris.

Em outras palavras, há de se indagar apenas se a demora - o retardo, o atraso, o esquecimento -, pode ser atribuída (ou não) a uma causa estranha e não imputável à conduta do devedor. Se for possível promover esse enquadramento, haverá mero atraso; caso contrário, a mora estará configurada.

É extremamente importante perceber que sustentar a necessidade de culpa na conformação da mora do devedor implica, dentre outras possibilidades, manifesta ofensa às diretrizes que informam o direito civil contemporâneo, permeado, dentre outros

\footnotetext{
${ }^{683}$ Nesse sentido: RIZZARDO, Arnaldo. Direito das obrigações. Rio de Janeiro: Forense, 2000. p. 502. "Incide em culpa quando viola explicitamente dispositivos de lei, ou quando se dá o não cumprimento da obrigação, ou deixando de cumpri-la pelo modo e no tempo devidos" AZEVEDO, Álvaro Villaça. Teoria geral das obrigações. 10 ed. São Paulo: Atlas, 2004. p. 223. Para o autor, a culpa contratual equivale à inobservância dos deveres entabulados pelas partes. GOMES, Orlando. Obrigações. 9 ed. Atual. Humberto Theodoro Junior. Rio de Janeiro: Forense, 1994. p. 167. Consoante o autor, retardamento culposo é aquele que não decorre de caso fortuito ou força maior.

${ }^{684}$ PONTES DE MIRANDA, Francisco Cavalcanti. Tratado de direito privado: parte especial. 2 ed. Rio de Janeiro: Borsoi, 1958, t. 23. p. 122-127.

${ }^{685}$ RUGGIERO, Roberto de. Instituições de direito civil: direito das obrigações e direito hereditário. Trad. Paolo Capitanio. Campinas: Bookseller, 1999, v. 3. p. 176-177.

${ }^{686}$ WALD, Arnoldo. Curso de direito civil brasileiro: obrigações e contratos. 14 ed. São Paulo: RT, 2000, v. 2. p. 98.

${ }^{687}$ BORGES, Nelson. A teoria da imprevisão no direito civil e no processo civil. São Paulo: Malheiros, 2002. p. 315 .
} 
princípios, pela boa-fé objetiva, traduzida aqui como fonte das legítimas expectativas de cada uma das partes quanto à conduta a ser seguida pela outra.

Ora, se a boa-fé informa o processo obrigacional em toda a sua complexidade, impondo às partes deveres de lealdade e de cooperação e se a aferição de respeito (ou não) a tais deveres há de ser promovida objetivamente - a partir das intersubjetividades inerentes à situação concretamente estabelecida -, a necessidade de perquirição do elemento subjetivo - para a caracterização da mora - torna-se supérflua.

Ademais, no universo da dogmática codificada, o tratamento do tema, em momento algum, exige a culpa. O conceito de mora insculpido na codificação não alude a ela. ${ }^{688}$ A regra que versa sobre o dever de reparar os danos causados ao parceiro contratual durante a mora também não. ${ }^{689} \mathrm{E}$, na mesma esteira, a regra que trabalha a possibilidade de afastar a incidência da mora labora com a atribuição (ou não) do atraso à conduta do devedor. $^{690}$

É imperioso distinguir, assim, se a prestação deixou de ser efetuada por conta de um fato atribuível à conduta do devedor, do credor ${ }^{691}$, de causa externa e não imputável ou em razão do exercício de um direito pré-existente. E isso porque, apenas na primeira das hipóteses, o atraso poderá ser considerado imputável ao devedor e, somente aqui, haverá mora. ${ }^{692}$

Também não se sustenta a ideia de que a culpa do devedor é presumida no atraso. Pensar desse modo autorizaria o devedor impontual a demonstrar que agiu de modo diligente, ou seja, que não agiu com culpa - quando o que afasta a configuração da mora é a demonstração de que o atraso não decorre de sua conduta - e, ainda assim, não pôde adimplir a prestação prometida no prazo devido, eximindo-se do dever de reparar e impondo, ao mesmo tempo, ao credor o ônus de suportar os danos oriundos da mora.

\footnotetext{
688 “Art. 394. Considera-se em mora o devedor que não efetuar o pagamento e o credor que não quiser recebê-lo no tempo, lugar e forma que a lei ou a convenção estabelecer."

689 “Art. 395. Responde o devedor pelos prejuízos a que sua mora der causa, mais juros, atualização dos valores monetários segundo índices oficiais regularmente estabelecidos, e honorários de advogado."

690 “Art. 396. Não havendo fato ou omissão imputável ao devedor, não incorre este em mora.”

${ }^{691}$ O que é ratificado pelo seguinte julgado: STJ. REsp 713329/RS. 2. S. Rel. Min. Carlos Alberto Menezes Direito. j. 23.08.06. DJ 07.12.06. p. 270. “[...] 1. Caracterizada a cobrança, pela instituição financeira, de parcela abusiva, somente restam autorizados os efeitos da mora depois de apurado o valor exato do débito, afastada, no caso, a multa moratória."

${ }^{692}$ COSTA, Mário Júlio de Almeida. Direito das obrigações. 6 ed. Coimbra: Almedina, 1994. p. 908.
} 
Perceba-se que a confusão entre os fenômenos da culpa presumida e da responsabilidade objetiva estimula assertivas nesse sentido.

Aqui, assevere-se, por fim, é imperioso visualizar que, quando a codificação exige que o devedor demonstre que a impossibilidade decorre de causa estranha e a ele não imputável, trabalha a questão no plano do nexo de causalidade, e não, no plano da culpabilidade ${ }^{693}$. Basta, portanto, que o retardo derive da conduta do devedor -, e não, necessariamente, em sua conduta culposa - para que a mora se manifeste.

\section{O cumprimento inexato da prestação}

O cumprimento imperfeito ${ }^{694}$, cumprimento inexato ${ }^{695}$, adimplemento ruim ${ }^{696}$ ou adimplemento insatisfatório ${ }^{697}$ - as expressões são sinônimas - se apresenta como uma forma de violação de dever ${ }^{698}$ dotada de autonomia e peculiar importância. ${ }^{699}$

${ }^{693}$ A tese encontra respaldo em julgados como se verifica em: TJSP. AI 1151815007. 30. Câmara de Direito Privado. Rel. Des. Andrade Neto. j. 14.05.08. Do voto extrai-se que "basta à [sic] existência de imputabilidade para a caracterização do estado moratório, ausente a necessidade de perquirição de culpa [e nesse contexto,] disputas judiciais entre sócios controladores da empresa devedora não se qualificam como causa capaz de elidir a mora no cumprimento de obrigações contratuais com terceiros, sendo inviável entrever na eventual situação prejudicial derivada destas disputas a caracterização de caso fortuito ou força maior."

${ }^{694}$ ANTUNES VARELA, João de Matos. Das obrigações em geral. 7 ed. Coimbra: Almedina, 1997, v. 2. p. 65.

695 MENEZES CORDEIRO, António Manuel da Rocha e. Direito das obrigações. Lisboa: Associação Acadêmica da Faculdade de Direito de Lisboa, 1986, v. 2. p. 440.

696 PONTES DE MIRANDA, Francisco Cavalcanti. Tratado de direito privado. Rio de Janeiro: Borsoi, 1959, t. 26. p. 15.

${ }^{697}$ LÔBO, Paulo Luiz Netto. Teoria geral das obrigações. São Paulo: Saraiva, 2005. p. 260.

${ }^{698}$ POTHIER, Robert Joseph. Tratado das obrigações. Trad. Adrian Sotero De Witt Batista; Douglas Dias Ferreira. Campinas: Servanda, 2002. p. 142-144. O autor traz como exemplos o caso de alienação de madeira a ser utilizada para escorar uma casa, cujas vigas, por estarem podres, não alcançaram o fim almejado pelo comprador, que acabou vendo o prédio desabar a sua frente; e o relato da situação de um imóvel que, logo depois de construído e entregue ao dono, veio a desmoronar por fato imputável ao construtor que não executou a obra adequadamente. Veja ainda: ANTUNES VARELA, João de Matos. Direito das obrigações. Rio de Janeiro: Forense, 1978, v. 2. p. 61. Imagine, com o autor, a hipótese de uma empresa açucareira que entrega, na data aprazada, a cana prometida à refinaria, entretanto, tendo enviado o produto fermentado, o açúcar que é fruto de sua transformação, não tem a qualidade esperada, especialmente porque, ante a confiança existente entre as partes, o adquirente não checou previamente o vício contido na carga adquirida, ou, ainda, a situação do fazendeiro que entregou ao adquirente, no prazo estipulado, as crias que vendera, animais estes que, por estarem doentes, contaminaram todo o rebanho do comprador, causando a morte de significativa parcela deste.

699 Além da figura dos vícios do produto ou serviço (CDC, Art. 18 e ss), o direito brasileiro permite enquadrar na sistematização proposta os vícios redibitórios (CC Arts. 441 a 446). O tratamento do tema como cumprimento inexato, por exemplo, teria o condão de inverter a regra do artigo 443, que dita que, se o 
A partir da premissa de que a mora consiste no atraso qualificado e que o inadimplemento, na impossibilidade, imputável ao devedor, de desempenho da prestação, pode-se tentar delimitar, por exclusão, o âmbito de atuação das hipóteses de cumprimento inexato, via hábil a abarcar os casos em que a prestação tenha sido desempenhada com imperfeição. $^{700}$

Em termos gerais, o ponto de sustentação do cumprimento imperfeito consiste no adimplemento que afronta o princípio da pontualidade ${ }^{701}$, também conhecido como princípio da correspondência $^{702}$ ou da identidade. E, nessa esteira, quaisquer hipóteses em que o adimplemento, aferido em sua concretude, não foi suficiente para satisfazer os interesses do credor $^{703}$, por conta da incoincidência entre a prestação prometida - aquela que o credor confiava receber - e a efetivamente desepenhada, preenchem o conteúdo da noção ora apontada.

Talvez, por isso, seja possível afirmar que se estará diante de uma situação de cumprimento defeituoso sempre que o devedor, tendo realizado uma prestação, não o faz como deveria e que, por essa razão, não permite a satisfação dos interesses do credor. ${ }^{704}$ Ao analisar o tema sob outras luzes, Luis Diez-Picazo leciona que haverá cumprimento

alienante conhecia o vício ou defeito da coisa, restituirá o que recebeu com perdas e danos, não estando obrigado, se desconhecê-lo, solução ofensiva ao sistema, em especial diante das diretrizes impostas pela boafé, fonte de deveres gerais de conduta - dentre eles, o de cooperação - e pelo princípio constitucional da solidariedade social. Nesse contexto, não se impondo ao alienante o dever de reparar os danos suportados pelo adquirente na hipótese de aquele desconhecer o vício, automaticamente, inverte-se toda a construção teórica que sustenta a responsabilidade contratual na contemporaneidade, pois, ainda que desconheça o defeito, o fato lhe é imputável.

${ }^{700}$ MENEZES CORDEIRO, António Manuel da Rocha e. Direito das obrigações. Lisboa: Associação Acadêmica da Faculdade de Direito de Lisboa, 1986, v. 2. p. 440. "Há cumprimento ou prestação inexata sempre que, chegado o prazo para a sua execução, esta seja efetivada em termos que não correspondam à conduta devida. A não correspondência pode advir de algum dos vários fatores acima referidos, como seja, a insuficiência, a má qualidade, etc, do comportamento tomado, face à atitude devida."

${ }^{701}$ BUSSATTA, Eduardo Luiz. Resolução dos contratos e teoria do adimplemento substancial. São Paulo: Saraiva, 2006. p. 19. Ensina o autor que "quadra asseverar que não se pode entender a pontualidade como, simplesmente, o cumprimento da obrigação no momento ajustado [situação que muito embora esteja englobada pelo princípio, não o limita, cumprindo ainda ao devedor] observar todos os pontos, as exigências, os requisitos, as formalidades previstas no contrato ao realizar o pagamento, seja em relação à qualidade dos bens, seja em relação às suas características, dentre outras possíveis exigências contidas no termo da obrigação."

702 MENEZES CORDEIRO, António Manuel da Rocha e. Direito das obrigações. Lisboa: Associação Acadêmica da Faculdade de Direito de Lisboa, 1986, v. 2. p. 187. "Chamamos princípio da correspondência à proposição segundo a qual o comportamento deve reproduzir, qualitativamente, o figurino abstrato de comportamento humano dado pelo binômio direito à prestação - dever de prestar."

703 TEPEDINO, Gustavo; BARBOZA, Heloísa Helena; MORAES, Maria Celina Bodin. Código civil interpretado: conforme a constituição da república. Rio de Janeiro: Renovar, 2004, v. 1. p. 693.

${ }^{704}$ LEITÃO, Luís Manuel Teles de Menezes. Direito das obrigações: transmissão e extinção das obrigações, não cumprimento e garantias do crédito. 3 ed. Coimbra: Almedina, 2005, v. 2. p. 265. 
inexato ou defeituoso quando o comportamento levado a cabo pelo solvens não se ajuste aos pressupostos reclamados pelo pagamento para a produção do efeito satisfativo. ${ }^{705}$

Acrescente-se que parte da doutrina exige, ainda, como elemento que permite individualizar a figura sob análise, o advento de danos típicos, ou seja, aqueles que não seriam causados nas hipóteses de inadimplemento ou de mora. ${ }^{706}$ Aparentemente, os danos típicos não são necessários à caracterização do cumprimento inexato, até porque os danos devem ser encarados como pressuposto do dever de reparar.

O traço que diferencia a patologia apontada consiste na presença de deficiências ou defeitos na prestação desempenhada. $\mathrm{O}$ adimplemento deixou de observar a forma ajustada $^{707}$ e, por consequência, não atende às expectativas do credor. Haverá, assim, o cumprimento inexato, quando o devedor adimplir em desconformidade com os princípios da boa-fé e da correspondência. Em feliz assertiva, Eduardo Bussatta afirma que, nesses casos, o devedor cumpre, mas não o faz adequadamente ao deixar de observar, ponto por ponto, o programa obrigacional existente na concretude dos fatos. ${ }^{708}$

É oportuno salientar que, apesar de sustentar-se que a inexatidão pode ser "qualitativa ou quantitativa",709, caso a violação seja meramente quantitativa - ao menos em princípio -, se estará diante de mora parcial, e não, de cumprimento inexato, até porque nada impede que o credor se sujeite a receber parcialmente. ${ }^{710}$

Também é importante evidenciar, noutro prisma, que, existindo como aproveitar a prestação desempenhada, o devedor deverá corrigir o defeito ${ }^{711}$, solução que se coaduna com o princípio da conservação dos contratos - favor negotti - e orienta-se pela funcionalização no exercício das posições jurídicas, respeitando, portanto, os valores

705 DIEZ-PICAZO, Luis. Fundamentos del derecho civil patrimonial: las relaciones obligatorias. 5 ed. Madrid: Civitas, 1996, v. 2. p. 666.

706 COSTA, Mário Júlio de Almeida. Direito das obrigações. 6 ed. Coimbra: Almedina, 1994. p. 928. No mesmo sentido: LEITÃo, Luís Manuel Teles de Menezes. Direito das obrigações: transmissão e extinção das obrigações, não cumprimento e garantias do crédito. 3 ed. Coimbra: Almedina, 2005, v. 2. p. 265.

${ }^{707}$ NALIN, Paulo. Responsabilidade civil: descumprimento do contrato e dano extrapatrimonial. Curitiba: Juruá, 1996. p. 158.

${ }^{708}$ BUSSATTA, Eduardo Luiz. Resolução dos contratos e teoria do adimplemento substancial. São Paulo: Saraiva, 2006. p. 25.

${ }^{709}$ GIORGIANNI, Michele. L'inadempimento. Milano: Guiffrè, 1975. p. 40-46.

${ }^{710}$ Vale lembrar a existência de hipóteses nas quais o credor não pode recusar receber pagamento parcial, servindo como exemplos os artigos $902, \S 1^{\circ}$ do CC e 745-A do CPC.

711 DIEZ-PICAZO, Luis. Fundamentos del derecho civil patrimonial: las relaciones obligatorias. 5 ed Madrid: Civitas, 1996, v. 2. p. 670. 
sociais vigentes. ${ }^{712}$ Ainda, nessa esteira, caso o cumprimento imperfeito seja imputável ao devedor, ao credor é facultado postular as perdas e danos decorrentes do mesmo. ${ }^{713}$

Cumpre destacar, enfim, acerca do tema, que, para que se possa imputar o dever de reparar os danos provocados pelo cumprimento inexato ao solvens, consoante os mesmos moldes erigidos para balizar as hipóteses de mora e de inadimplemento, a culpa não precisa informar a conduta daquele que cumpre mal. ${ }^{714}$ Ratificando a ideia, pode ser destacada a abalizada posição de Pontes de Miranda, ao afirmar que a culpa não compõe o suporte fático ensejador da imposição do dever de reparar os danos provenientes do adimplemento insatisfatório da prestação. ${ }^{715}$

E, como a autoridade do argumento tem mais valor que o argumento da autoridade, parece ser importante destacar, ainda, entre outros argumentos, que a culpa se esvai diante da necessidade de tratamento sistematizado das patologias abarcadas pela violação de dever.

Assim e se como antecipado, a culpa é uma circunstância supérflua à configuração da mora e do inadimplemento, não há como sustentar sua utilidade na formatação da patologia sob análise. Pensar de modo contrário subverte todo o lastro teórico que sustenta o dever de reparar os danos contratuais na contemporaneidade, mormente porque, mesmo que solvens desconheça o defeito que afeta a prestação desempenhada, é irrefutável que aquele se encontra contido nesta, frustrando, em maior ou menor grau, consoante cada hipótese concreta, as legítimas expectativas do accipiens.

\footnotetext{
${ }^{712}$ PERLINGIERI, Pietro. Perfis do direito civil: introdução ao direito civil constitucional. 2 ed. Trad. Maria Cristina De Cicco. Rio de Janeiro: Renovar, 2002. p. 120-121. Consoante ensina o autor, "o perfil mais significativo é constituído pela obrigação, ou dever, do sujeito titular do direito de exercê-lo de modo a não provocar danos excepcionais a outros sujeitos, em harmonia com o princípio da solidariedade política, econômica e social [o que] incide de tal modo sobre o direito subjetivo [e também sobre o direito potestativo] que, em vez de resultar como poder arbitrário, acaba por funcionalizá-lo e por socializá-lo.”
}

713 CASSETTARI, Christiano. Multa contratual: teoria e prática. São Paulo: RT, 2009. p. 111-122. Questiona o autor se "seria possível exigir a cláusula penal em caso de inadimplemento parcial da obrigação. [Responde que] a questão merece reflexão, pois entendemos que o inadimplemento parcial pode estar incluído no inadimplemento total ou na mora [ou no] cumprimento inexato da obrigação. Imaginemos uma obrigação de fazer reforma na cozinha de uma casa. Se o devedor fizer esta reforma de forma diversa da requisitada pelo credor, podemos dizer que a obrigação de prestação de serviço foi cumprida (construção de algo), mas não a contento, motivo pelo qual a cláusula penal, caso exista, poderá ser exigida no referido caso."

${ }^{714}$ SILVA, Jorge Cesa Ferreira da. A boa-fé e a violação positiva do contrato. Rio de Janeiro: Renovar, 2002. p. 273. A matéria não é pacífica consoante pode se aferir da posição adotada pelo autor ao destacar que a violação positiva do contrato consistiria no "inadimplemento decorrente do descumprimento culposo de dever lateral, quando este dever não tenha uma vinculação direta com os interesses do credor na prestação."

${ }^{715}$ PONTES DE MIRANDA, Francisco Cavalcanti. Tratado de direito privado: parte especial. 2 ed. Rio de Janeiro: Borsoi, 1958, t. 23. p. 165-167. 
Além do inadimplemento, da mora e do cumprimento inexato da prestação, males que afetam - cada um a seu modo - o dever de prestar, existem outros deveres que exsurgem no desvelar de cada processo obrigacional concretamente estabelecido, deveres que são de importância ímpar para que o tempo antecipado por meio do contrato seja, de fato, alcançado.

Como pôde se perceber, a principal função dos aludidos deveres consiste em garantir que o programa contratual se desenvolva, em cada um de seus momentos, da forma mais eficiente possível, de modo que possa culminar com a satisfação das expectativas de todos os interessados. ${ }^{716}$

Tais deveres são concebidos, tendo por preocupação principal a proteção dos contratantes, do seu patrimônio ${ }^{717}$ e dos terceiros. E, mesmo que um equilíbrio perfeito só exista em visões românticas ${ }^{718}$, transparência e mútuo respeito parecem essenciais no desvelar de cada relação obrigacional. ${ }^{719}$

É preciso aclarar ainda que tais deveres não decorrem diretamente da autonomia privada. Ao menos em regra, não derivam do clausulado eleito pelos parceiros negociais. Também, em regra e paradoxalmente, são inafastáveis por meio do recurso ao poder jurígeno que lhes é consagrado pelo Direito. ${ }^{720}$

Ademais, apesar de ser recorrente a afirmação de que derivam do princípio da boa-fé objetiva - que, sem dúvida, pode ser considerado sua fonte mais estudada e conhecida $^{721}$-, em verdade, os aludidos deveres emanam não apenas do aludido princípio,

\footnotetext{
${ }^{716}$ LORENZETTI, Ricardo Luis. Esquema de una teoría sistémica del contrato. In: FERNÁNDEZ, Carlos López; CAUMONT, Arturo; CAFFERA, Gerardo (Coord.). Estudios de derecho civil en homenaje al profesor Jorge Gamarra. Montevideo: FCU, 2001. p. 246.

${ }^{717}$ GHERSI, Carlos Alberto. Teoría general de la reparación de daños. Buenos Aires: Astrea, 1997. p. 206207.

${ }^{718}$ Nesse sentido: FROTA, Pablo Malheiros da Cunha. Os deveres contratuais gerais nas relações civis e de consumo. Dissertação (Mestrado) - Faculdade Autônoma de Direito de São Paulo, São Paulo, 2008. p. 189.

${ }^{719}$ RIBEIRO, Joaquim de Souza. Direito dos contratos: estudos. Coimbra: Coimbra, 2007. p. 78-84.

${ }^{720}$ FRADERA, Véra Maria Jacob de. A boa-fé objetiva, uma noção presente no conceito alemão, brasileiro e japonês de contrato, Revista Brasileira de Direito Comparado, Rio de Janeiro, n. 24, p. 127-157, jan./jun. 2003. p. 154.

${ }^{721}$ STIGLITZ, Rubén. El principio de buena fe. In: GESUALDI, Dora Mariana (Coord.). Derecho privado. Buenos Aires: Hammurabi, 2001. p. 512-513.
} 
mas de todos aqueles que possam ser considerados aptos, incluídos aqui os princípios constitucionalmente consagrados e, entendida a questão em toda sua complexidade, à promoção da justiça contratual.

De modo mais pragmático, pode ser afirmado que o contrato - fonte, como fato jurídico, do fenômeno obrigacional - é responsável pelo nascimento de deveres que ultrapassam aqueles que foram expressamente ajustados pelas partes. ${ }^{722}$

Por isso, só poderão ser identificados - na relação contratual - consoante as circunstâncias peculiares que envolvem cada processo obrigacional apreciado em sua concretude. $^{723}$

Ao contrário dos deveres de prestação - que, em regra, subordinam seus efeitos aos princípios que informam a autonomia privada -, os deveres aqui tratados produzirão efeitos independentemente de explícita previsão contratual $^{724}$ e, mais que isso, independentemente da validade do contrato. Os deveres sob análise, saliente-se, ainda, não se confundem com aqueles que são classificados como secundários. ${ }^{725}$

Como "quem contrata não mais contrata tão só o que contrata"726, ainda que ignorados pelos contratantes, os deveres sob análise podem assumir dimensão negativa, impedindo a invasão arbitrária da intimidade, ou positiva, ao facilitar, por exemplo, o adimplemento. $^{727}$

\footnotetext{
${ }^{722}$ COLLURA, Giorgio. Importanza dell 'inadempimento e teoria del contratto. Milano: Giuffrè, 1992. p. 5.

${ }^{723}$ SILVA, Jorge Cesa Ferreira da. A boa-fé e a violação positiva do contrato. Rio de Janeiro: Renovar, 2007. p. 90. Mais à frente, o autor discorre que, "quando se afirma que os deveres laterais possuem fontes normativas e fáticas diversas dos deveres de prestação, tem-se uma decorrência desta distinção [pois, como visto] os deveres laterais fundam-se preponderantemente no princípio da boa-fé, especialmente no vetor confiança, quando este não se destina a impor uma dada prestação, mas a impedir que danos venham a ser provocados à pessoa ou aos bens da outra parte, ou a determinar que o adimplemento se dê da forma qualitativa e objetivamente mais satisfativa aos interesses do credor e de forma menos onerosa para ao devedor." Ibid. p. 95.
}

${ }^{724}$ VENOSA, Sílvio de Salvo. A cláusula de "melhores esforços" nos contratos. In: HIRONAKA, Giselda Maria Fernandes Novaes (Coord.). Novo código civil: interfaces no ordenamento jurídico brasileiro. Belo Horizonte: Del Rey, 2004. p. 222.

${ }^{725}$ Sobre o tema: COUTO E SILVA, Clóvis Veríssimo do. A obrigação como processo. São Paulo: Bushatsky, 1976. p. 111-114.

${ }^{726}$ FACHIN, Luiz Edson. Contratos na ordem pública do direito contemporâneo. In: TEPEDINO, Gustavo; FACHIN, Luiz Edson (Coord.). O direito e o tempo: embates jurídicos e utopias contemporâneas. Rio de Janeiro: Renovar, 2008. p. 458.

${ }^{727}$ LORENZETTI, Ricardo Luis. Esquema de una teoría sistémica del contrato, Revista de Direito do Consumidor, São Paulo, v. 9, n. 33, p. 51-77, jan./mar. 2000. p. 57. 
E, em razão de sua natureza multifacetária, só serão identificados na análise da relação negocial concretamente estabelecida, estimulando e exigindo, ao mesmo tempo, a utilização do paradigma judicativo-decisório ${ }^{728}$ e a perquirição das intersubjetividades do caso, provas vivas de que, do "formalismo e da rigidez dos pactos", as titularidades na contemporaneidade passam a ser informadas pelos "ares da funcionalização" e da "justificação social.",729

Impressiona a quantidade de expressões qualificando os deveres sob análise. Entre as mais usuais, estão deveres laterais ${ }^{730}$, acessórios ${ }^{731}$, anexos ${ }^{732}$, colaterais ${ }^{733}$, regras secundárias de conduta ${ }^{734}$, deveres instrumentais ${ }^{735}$, deveres fiduciários ${ }^{736} \mathrm{e}$, enfim, deveres gerais de respeito e de diligência. ${ }^{737}$

${ }_{728}$ FROTA, Pablo Malheiros da Cunha. Os deveres contratuais gerais nas relações civis e de consumo.
Dissertação (Mestrado) - Faculdade Autônoma de Direito de São Paulo, São Paulo, 2008. p. 165-166.
${ }^{729}$ FACHIN. Luiz Edson. A reforma no direito brasileiro: novas notas sobre um velho debate no direito civil,
Revista Brasileira de Direito Comparado, Rio de Janeiro, n. 16, p. 147-156, jan./jun. 1999. p. 151-152.
730 OLIVEIRA, Ubirajara Mach de. A harmonização formal do direito da venda internacional de mercadorias
no âmbito da Convenção de Viena de 1980 e o standard da boa-fé, Revista da Faculdade de Direito Ritter
dos Reis, Porto Alegre, v. 4, p. $97-124$, mar./jul. 2001. passim. No mesmo sentido: NANNI, Giovanni Ettore.
O dever de cooperação nas relações obrigacionais à luz do princípio constitucional da solidariedade. In:
NANNI, Giovanni Ettore (Coord.). Temas relevantes do direito civil contemporâneo: reflexões sobre os
cinco anos do código civil. São Paulo: Atlas, 2008. p. 311 . "Evidentemente, o dever de cooperação, pela sua
própria essência de dever lateral, não integra a prestação principal objeto da prestação nem também pode ser
tão largamente reclamado a tal ponto de deixar de ser um racional ato de colaboração solidária obrigacional
entre as partes para se transformar em um ato de altruísmo.". ${ }^{731}$ ANTUNES VARELA, João de Matos. Das obrigações em geral. 7 ed. Coimbra: Almedina, 1997, v. 2. p. 130.

${ }^{732}$ Utilizando a terminologia apontada, por exemplo: SILVA, Jorge Cesa Ferreira da. A boa-fé e a violação positiva do contrato. Rio de Janeiro: Renovar, 2007. p. 75. Para o autor, "os deveres laterais podem ser definidos, a título aproximativo, como todos aqueles deveres decorrentes do fato jurígeno obrigacional cujo escopo não seja, diretamente, a realização ou a substituição da prestação." Veja ainda: TEPEDINO, Gustavo. Temas de direito civil. Rio de Janeiro: Renovar, t. 2. 2006.

${ }^{733}$ TOMASETTI JUNIOR, Alcides. As relações de consumo em sentido amplo na dogmática das obrigações e dos contratos, Revista de Direito do Consumidor, São Paulo, n. 13, p. 12-17, jan./mar. 1995. p. 16-17.

${ }^{734}$ STIGLITZ, Rubén. El principio de buena fe. In: GESUALDI, Dora Mariana (Coord.). Derecho privado. Buenos Aires: Hammurabi, 2001. p. 503-516.

${ }^{735}$ SAVI, Sérgio. Inadimplemento das obrigações, mora e perdas e danos. In: TEPEDINO, Gustavo (Coord.). Obrigações: estudos na perspectiva civil-constitucional. Rio de Janeiro: Renovar, 2005. p. 476.

${ }^{736}$ NORONHA, Fernando. Direito das obrigações. São Paulo: Saraiva, 2004, v. 1. p. 79-81. Opta-se por essa denominação porque é a que "aponta diretamente para o fato de eles serem exigidos pelo dever de agir de acordo com a boa-fé, tendo como fundamento a confiança gerada na outra parte."

${ }^{737}$ JORGE, Fernando Pessoa. Ensaio sobre os pressupostos da responsabilidade civil. Coimbra: Almedina, 1999. p. 71-102. 
Tais denominações podem ser criticadas. E, isso porque não representam, com exatidão, a extensão e complexidade inerente a deveres que pululam no desvelar de um processo obrigacional, compreendido, aqui, em sua totalidade.

A expressão deveres laterais é criticada porque eles não estão ao lado do dever de prestar, como se possuíssem menor importância que este. Consoante a situação concreta, a violação de tais deveres pode se manifestar de modo mais grave que no inadimplemento. A mesma constatação serve para refutar a terminologia deveres acessórios ou anexos, com uma agravante no primeiro dos casos.

Esses deveres não podem ser tratados como acessórios - gravitando ao redor da prestação $^{738}$ - porque sua transgressão implica, no mais das vezes, ofensa a garantias constitucionais. ${ }^{739}$ Ademais, o acessório depende do principal, e essa conclusão seria equivocada no tratamento dos deveres ora analisados. A utilização de dever colateral e de regra secundária de conduta carregam consigo, uma vez mais, a diminuição da importância dos deveres em questão ao subordiná-los a algo. Acrescente-se à primeira das expressões o problema de compreendê-los como algo não desejado, com caráter prejudicial - podendo haver confusão com efeitos colaterais - e, a segunda, a desnecessidade de que tenham sido ajustadas entre os parceiros negociais. A alusão a deveres instrumentais permite entender que são meros instrumentos, meios para algo, quando, como demonstrado, possuem autonomia e importância próprias. A patologia no uso da locução deveres fiduciários encontra-se na restrição do conceito à confiança. Enfim, a última das expressões merece ser rechaçada por ser extremamente restritiva, bem como, diante da constatação de que, já que nem sempre são conhecidos antecipadamente, restaria inviabilizada qualquer análise subjetiva da questão.

Importante perceber que os aludidos deveres, vinculados diretamente aos princípios, ultrapassam a função estrutural de auxiliares do adimplemento. Irradiam efeitos sobre devedor, credor e perante terceiros - reverberando em nível contratual e paracontratual $^{740}$ - por todo o processo obrigacional. Ao mesmo tempo, atuam como fonte

\footnotetext{
738 ANTUNES VARELA, João de Matos. Direito das obrigações: conceito, estrutura e função da relação obrigacional, fontes das obrigações, modalidades das obrigações. Rio de Janeiro: Forense, 1977, v. 1. p. 63.

739 RINESSI, Antônio. La extensión del resarcimiento y la infracción al deber de seguridad, Revista de Responsabilidad Civil y Seguros, Buenos Aires, n. 2, p. 1-8, fev. 2007. p. 1.

${ }^{740}$ LEONARDO, Rodrigo Xavier. A teoria das redes contratuais e a função social dos contratos: reflexões a partir de uma recente decisão do superior tribunal de justiça, Revista dos Tribunais, São Paulo, v. 94, n. 832, p. 100-111, fev. 2005. p. 104-105.
} 
e baliza de conformação no exercício de distintas posições jurídicas. Por isso, devem ser tratados como "deveres gerais de conduta"741, expressão que representa, com maior fidelidade, a importância da figura sob análise.

A construção dogmática dos deveres gerais de conduta é relativamente recente, e a colaboração doutrinária e jurisprudencial ${ }^{742}$ para sua compreensão é de importância ímpar. Na Itália, dois momentos relevantes no processo de formatação desses deveres - por lá, denominados deveres de proteção - estão no reconhecimento judicial da necessidade de proteção da integridade psicofísica (a) dos passageiros nos contratos de transporte e (b) das vítimas de acidentes de trabalho. ${ }^{743}$

Em termos gerais, é possível apontar que, consoante o pensamento vigente nas primeiras décadas do século XX, o patrão deveria proteger seus empregados, agindo como um segurador ${ }^{744}$; o transportador, conduzir seus passageiros e(ou) sua carga incólumes ao destino. Com o tempo, esses deveres se estendem a distintos contratos, dentre eles, os de apresentação de espetáculos públicos. ${ }^{745}$ Infira-se, ainda, que a escola francesa seguiu essa mesma trilha. ${ }^{746}$

O que parece inegável é que tais deveres se transformaram ao longo do tempo em uma espécie de garantia de garantia, o que se dá pela necessidade de salvaguardar os

${ }^{741}$ LÔBO, Paulo Luiz Netto. Deveres gerais de conduta nas obrigações civis. In: DELGADO, Mário Luiz; ALVES, Jones Figueirêdo (Coord.). Questões controvertidas: no direito das obrigações e dos contratos. São Paulo: Método, 2005, v. 4. p. 76-78. "Os deveres gerais de conduta, ainda que incidam diretamente nas relações obrigacionais, independentemente da manifestação de vontade dos participantes, necessitam de concreção de seu conteúdo em cada relação, considerados o ambiente social e as dimensões do tempo e do espaço de sua observância ou aplicação."

${ }^{742} \mathrm{O}$ tema é conhecido nas cortes brasileiras, servindo com exemplo o seguinte julgado: STJ. AgRg no Ag 47901/SP. 4. T. Rel. Min. Ruy Rosado de Aguiar. j. 12.09.94. DJ 31.10.94. p. 29505. "Responsabilidade civil. Estacionamento. Relação contratual de fato. Dever de proteção derivado da boa-fé. Furto de veiculo. O estabelecimento bancário que põe a disposição dos seus clientes uma área para estacionamento dos veículos assume o dever, derivado do principio da boa-fé objetiva, de proteger os bens e a pessoa do usuário. $\mathrm{O}$ vinculo tem sua fonte na relação contratual de fato assim estabelecida, que serve de fundamento a responsabilidade civil pelo dano decorrente do descumprimento do dever."

${ }^{743}$ VISINTINI, Giovanna. Il codice civile: commentario. inadempimento e mora del debitore. 2 ed. Milano: Giuffrè, 2006. p. 297-321.

${ }^{744}$ COELHO, José Gabriel Pinto. A responsabilidade civil baseada no conceito da culpa. Coimbra: Imprensa da Universidade, 1906. p. 52.

${ }^{745}$ VINEY, Geneviève. As tendências atuais do direito da responsabilidade civil. In: TEPEDINO, Gustavo (Org.). Direito civil contemporâneo: novos paradigmas à luz da legalidade constitucional. São Paulo: Atlas, 2008. p. 49. Utilizando, entretanto, a expressão obrigação de segurança.

746 JUNQUEIRA DE AZEVEDO, Antonio. Estudos e pareceres de direito privado. São Paulo: Saraiva, 2004. p. 17-18. 
interesses do parceiro negocial ${ }^{747}$ e, por que não, também de terceiros. O dever de evitar e, não sendo isso possível, de reparar os danos causados pela violação de um dever geral de conduta adquire autonomia quando se percebe a necessidade de ampliação da tutela até então destinada à pessoa humana. ${ }^{748}$

Talvez seja relevante salientar, ainda, que, sob outras luzes, sustenta-se que os deveres aqui sob análise podem ser classificados, conforme a função que assumem na concretude das relações, em deveres de proteção, de lealdade e de esclarecimento. ${ }^{749} \mathrm{~A}$ aludida proposta - e tantas outras no mesmo sentido - não se justifica. E isso porque, ao impor às partes os deveres de esclarecimento e de lealdade, o que se busca é a proteção do alter, viabilizando, assim, a satisfação de ambas as partes em cada hipótese surgida na concretude das relações cotidianas. Aqui, o dever de proteção absorve os demais.

Em verdade e como antecipado, tamanha é a heterogeneidade assumida pelos deveres gerais de conduta e tantas são as formas por meio das quais eles podem se apresentar que, por consequência, as possibilidades de sua configuração se tornam praticamente incomensuráveis, de modo que qualquer ensaio de sistematização nascerá comprometido.

É preciso avançar. E tendo aqui, por premissa, a constatação de que a doutrina desenvolve o estudo do tema, de forma praticamente uníssona, mediante recurso à boa-fé objetiva - quando as vestes por meio das quais os deveres sob análise podem ser violados, são bem mais variadas -, opta-se por desenvolver as próximas reflexões apenas sob esse viés. Com isso, não se quer afirmar que ela poderá ser desprezada em qualquer estudo sobre o assunto, mas, tão somente salientar que os deveres gerais de conduta podem ter por fonte outras nascentes. ${ }^{750}$

\footnotetext{
${ }^{747}$ VISINTINI, Giovanna. Tratado de la responsabilidad civil: la culpa como criterio de imputación de la responsabilidad. Trad. Aída Kemelmajer de Carlucci. Buenos Aires: Astrea, 1999, v. 1. p. 115-126. A análise da autora pauta-se pelo estudo da ampliação havida ao longo do tempo da responsabilidade do empregador e do transportador.

748 JUNQUEIRA DE AZEVEDO, Antonio. Caracterização jurídica da dignidade da pessoa humana, Revista dos Tribunais, São Paulo, v. 91, n. 797, p. 11-26, mar. 2002. p. 22.

${ }^{749}$ ROSENVALD, Nelson. Dignidade humana e boa-fé no código civil. São Paulo: Saraiva, 2005. p. 104110.

${ }^{750}$ Nesse sentido, a Declaração de Interpretação n. 11 da Academia Brasileira de Direito Civil, consoante a qual "o desatendimento da função social contratual configura violação de dever jurídico específico, independentemente de afetar as respectivas prestações típicas ou principais, e à luz do sentido do art. 421 do Código Civil, esse descumprimento da função social pode corresponder a uma forma de inadimplemento ou inexecução do contrato." Veja ainda, acerca do tema: FROTA, Pablo Malheiros da Cunha. Os deveres contratuais gerais nas relações civis e de consumo. Dissertação (Mestrado) - Faculdade Autônoma de
} 
Dessarte e retomando o caminho iniciado, vale lembrar, uma vez mais, que a boa-fé atravessa toda a intersubjetividade do processo obrigacional, emoldurando uma infinidade de condutas ${ }^{751}$ em cada hipótese concretamente estabelecida. Ela implica um modelo valorativo do comportamento humano, servindo de instrumento hábil a considerálo adequado (ou não) ao exigido no caso concreto, mediante o recurso a valores como a probidade, a solidariedade, a lealdade e a cooperação. ${ }^{752}$

E, sendo ululante seu caráter normativo ${ }^{753}$, é possível perceber que a boa-fé se densifica, impondo às partes o dever de preservar os interesses do alter no desvelar do processo obrigacional, mesmo porque "é sempre um pensar no outro, um pensar reflexivo." ${ }^{, 754}$ Por isso, ao mesmo tempo em que atribui as mais distintas titularidades, encontra limites no interesse do sujeito em desfavor de quem são produzidos esses mesmos direitos $^{755}$, equalizando os interesses reciprocamente existentes.

A extensão e a intensidade desses deveres deverão ser calibradas por meio da ponderação a ser promovida entre o que se pode e aquilo que - até que ponto - se pode exigir do outro. Dito de outro modo, a adequada modulação dos deveres de conduta na realidade dos fatos será encontrada quando se tem em mente que só é possível exigir do outro o esforço que poderia ser exigido do próprio eu.

Via de mão dupla, enquanto a primeira das pistas, longe de ser mero mecanismo de avaliação do "estado de ânimo de uma dada pessoa"756, exige, na

Direito de São Paulo, São Paulo, 2008. p. 165-206. O autor defende a existência de tantos outros deveres como os lastreados na justiça, na informação e na função social do contrato.

751 ASCENSÃO, José de Oliveira. Cláusulas contratuais gerais, cláusulas abusivas e o novo código civil, Revista da Faculdade de Direito da Universidade Federal do Paraná, Porto Alegre, n. 39, p. 5-22, 2003. p. 17.

${ }^{752}$ MARTINS-COSTA, Judith. A boa-fé objetiva e o adimplemento das obrigações, Revista Brasileira de Direito Comparado, Rio de Janeiro, n. 25, p. 229-282, jul./dez. 2003. p. 233.

${ }^{753}$ NEGREIROS, Teresa. O princípio da boa-fé contratual. In: MORAES, Maria Celina Bodin de (Coord.). Princípios do direito civil contemporâneo. Rio de Janeiro: Renovar, 2006. p. 226-252.

${ }^{754}$ MARQUES, Cláudia Lima. Direitos básicos do consumidor na sociedade pós-moderna de serviços: o aparecimento de um sujeito novo e a realização de seus direitos, Revista de Direito do Consumidor, São Paulo, v. 9, n. 35, p. 61-96, jul./set. 2000. p. 62. Da mesma autora e no mesmo sentido: MARQUES, Cláudia Lima. Contratos no código de defesa do consumidor: o novo regime das relações contratuais. 5 ed. São Paulo: RT, 2006. p. 216.

755 MASSIMO BIANCA, Cesare. La nozione di buona fede quale regola di comportamento contrattuale, Rivista di Diritto Civile, Padova, anno 29, n. 3, p. 205-216, mai./jun. 1983. p. 209. Continua o autor, destacando que não se pode obrigar o sujeito, em razão do dever de agir a partir das diretrizes que emanam da boa-fé, a assumir apreciável sacrifício pessoal ou econômico.

${ }^{756}$ SILVA, Jorge Cesa Ferreira da. O direito das obrigações no novo código civil: apontamentos para a defesa do estado, Revista da PGE, Porto Alegre, v. 27, n. 57, p. 135-156, 2004. p. 143. 
concretude da relação, "cooperação e respeito"757 recíprocos daqueles de quem se espera uma conduta prenhe de honestidade de fato ${ }^{758}$; a outra impõe limites às titularidades por ela geradas, funcionalizando, assim, o exercício das mesmas posições jurídicas que permitiu nascer.

Ademais, diante da possibilidade de violação dos deveres gerais de conduta, existem ainda duas questões a exigir reflexão. A primeira versa sobre o papel reservado à culpa nesse universo. Ao considerar-se que o deslinde do problema poderá servir como pilar de sustentação da tese em desenvolvimento - ou abalar-lhe irremediavelmente a estrutura -, é preciso enfrentá-lo.

Em linhas gerais, é possível afirmar os autores que sustentam a necessidade de culpa para que se impute o dever de reparar àquele que violou um dever geral de conduta $^{759}$ têm como principal argumento o fato de que, como tais deveres são normalmente ignorados pelas partes, a conduta culposa seria de fundamental importância para evitar a injusta atribuição da reparação civil. ${ }^{760}$

Existem, ainda, teses intermediárias defendendo que as consequências reparatórias decorrentes da inobservância dos deveres gerais de conduta serão imputadas, ora a partir de parâmetros subjetivos, ora com recurso a critérios objetivos, identificáveis a partir da análise do caso concreto. ${ }^{761}$ Tais teses, mesmo salientando que a culpa informará o dever de reparar em algumas situações, destacam que, em princípio, o desrespeito aos

\footnotetext{
757 MARQUES, Cláudia Lima. A boa-fé nos serviços bancários, financeiros, de crédito e securitários e o código de defesa do consumidor: informação, cooperação e renegociação?, Revista de Direito do Consumidor, São Paulo, v. 11, n. 43, p. 215-257, jul./set. 2002. p. 219.

${ }^{758}$ FRIED, Charles. Contrato como promessa: uma teoria da obrigação contratual. Trad. Sérgio Duarte. Rio de Janeiro: Elsevier, 2008. p. 99. "Um homem honesto pode ser um negociador duro, mas o faz de maneira aberta, sincera. [...] A quintessência da honestidade é o cavalheiro vitoriano, que embora rígido e talvez nada generoso, além de duro negociador, mantém a palavra dada e não mente. A honestidade assegura, em primeiro lugar, que a pessoa não enganará a outra quanto aos fatos a fim de aproveitar uma decisão malinformada de parte dessa outra. Também assegura que os compromissos assumidos serão honrados. A boa-fé, no sentido de honestidade, pode ser vista como manifestação da crença liberal na objetividade dos fatos, na autonomia individual e na importância de manter a palavra dada."

${ }^{759}$ Dentre outros: NORONHA, Fernando. Direito das obrigações. São Paulo: Saraiva, 2004, v. 1. p. 458-460. SILVA, Jorge Cesa Ferreira da. A boa-fé e a violação positiva do contrato. Rio de Janeiro: Renovar, 2007. p. 106. DOHRMANN, Klaus Jochen Albiez. Um nuevo derecho de obligaciones. la reforma $2002 \mathrm{del} \mathrm{bgb,}$ Anuario de Derecho Civil, Madrid, v. 55, n. 3, p. 1133-1227, jul./set. 2002. p. 1173-1174.

${ }^{760}$ LARENZ, Karl. Derecho justo: fundamentos de etica juridica. Trad. Luis Díez-Picazo. Madrid: Civitas, 1993. p. 118.

${ }^{761}$ LAMBOIS, Susuna Elena. La obligación de seguridad. In: GESUALDI, Dora Mariana (Coord.). Derecho privado. Buenos Aires: Hammurabi, 2001. p. 1119-1126.
} 
deveres de proteção será, em regra, aferido objetivamente ${ }^{762}$ e, nesse contexto, a culpa seria uma exceção com utilidade apenas quando expressamente consagrada. ${ }^{763}$

A preponderância do recurso aos fatores objetivos de atribuição do dever de reparar nas hipóteses de violação de deveres gerais de conduta parece derivar do valor que assume a necessidade de proteção da vida ${ }^{764}$, valor que, ao lado da integridade psicofísica, justifica a existência dos deveres sob análise.

Uma terceira corrente pauta seus estudos objetivando a imputação do dever de reparar os danos nascidos da violação de um dever geral de conduta. ${ }^{765}$ Além das razões anteriormente destacadas, suas principais justificativas estão polarizadas (a) na necessidade de promover a satisfação dos legítimos interesses do credor, (b) na valorização da confiança depositada na conduta prometida pelo devedor ${ }^{766}$, (c) no fato de que "a obrigação de segurança" impõe a obtenção de um resultado - o que afasta a culpa de seu

\footnotetext{
${ }^{762}$ AGOGLIA, María Martha; BORAGINA, Juan Carlos; MEZA, Jorge Alfredo. La buena fe y la obligación de seguridad. In: CÓRDOBA, Marcos (Dir.). Tratado de la buena fe en el derecho: doctrina nacional. Buenos Aires: La Ley, 2004, v. 1. p. 260. Consoante os autores - que aparentam escorar a existência de exceções apenas por conta de eventual dicção legal -, "em nossa opinião, a natureza desse dever é substancialmente de resultado, pois sua finalidade seria menosprezada se não fossem exigidas condutas que assegurem indenidade, o que afasta a discussão do âmbito dos fatores subjetivos, [entretanto] a questão passa ainda pela análise das regras contidas na lei para cada tipo de contrato celebrado."
}

${ }^{763}$ JUNQUEIRA DE AZEVEDO, Antonio. Estudos e pareceres de direito privado. São Paulo: Saraiva, 2004. p. 18. "A obrigação de segurança hoje se "autonomizou"; existe independentemente de contrato - pode não haver contrato nem muito menos importa se o contrato é gratuito ou oneroso (transporte pago ou não, hospedagem, serviços em geral, etc.). A obrigação de segurança existe sempre; os danos à pessoa devem ser indenizados. É importante dizer: em matéria de danos à pessoa, a regra é hoje a responsabilidade objetiva. A responsabilidade subjetiva, nesse campo, é atualmente a exceção. A responsabilidade objetiva, na obrigação de segurança, surge agora diretamente da Constituição (não é da lei ou da jurisprudência); somente haverá responsabilidade subjetiva quando houver lei expressa (p. ex., na responsabilidade médica - na qual, assim mesmo, há inversão do ônus da prova, porque a prova deve ser feita por quem tem melhores condições para fazê-la)."

764 JUNQUEIRA DE AZEVEDO, Antonio. Caracterização jurídica da dignidade da pessoa humana, Revista dos Tribunais, São Paulo, v. 91, n. 797, p. 11-26, mar. 2002. p. 22.

${ }^{765}$ GAMARRA, Jorge. Tratado de derecho civil uruguayo. 2 ed. Montevideo: FCU, 2003, v. 2, t. 20. p. 48. Sustenta o autor, entretanto, que os deveres de segurança devam incidir apenas nas hipóteses em que a relação contratual implique riscos ínsitos e inevitáveis à outra parte; justificando seu raciocínio no rigor que o tratamento da matéria impõe àquele que desrespeita tais deveres.

766 BALLESTEROS, Jorge Santos. La responsabilidad civil contractual aplicada a la actividad del empresario. In: ESPINOSA, Fabricio Mantilla; BARRIOS, Francisco Ternera (Dir.). Los contratos en el derecho privado. Bogotá: Legis, 2007. p. 934-935. Ao discorrer sobre os deveres de proteção, destaca o autor que "seu campo de aplicação propício é o da responsabilidade por cumprimento defeituoso do contrato e seu fundamento estriba-se na hialina violação da confiança e expectativa depositadas pelo credor de receber a prestação de uma coisa livre de vícios que possam afetar seu uso e gozo [...] trata-se de responsabilidade objetiva fundada na não obtenção do resultado desejado pelo credor ou na ausência de satisfação plena do mesmo conforme a expectativa cimentada na relação obrigacional." 
interior - e que (d) essa opção se coaduna com as premissas que informam o direito de danos. $^{767}$

Tomando posição, parece inquestionável que a opção pela terceira teoria ${ }^{768}$ é o único caminho que pode ser trilhado. Ora, se, como demonstrado, a violação dos deveres de prestação prescinde da culpa na conformação do dever de reparar, seria contraditório defender aqui tese contrária, diante de uma postura que busca também coerência sistêmica.

Ademais, parece, no mínimo, curioso defender que a culpa é essencial à imputação do dever de reparar a partir do argumento atado ao desconhecimento dos deveres que permeiam a relação concreta. Tal tese, a não ser por conta dos influxos de ordem liberal e individualista que a informam, soa ontologicamente contraditória. Em sua essência, leva a transitar pelo problema de saber como evitar, agindo de modo diligente e zeloso, efeitos que não se pode antecipar. Aqui surge o problema de saber, como será possível agir de modo diligente no cumprimento de deveres que, no mais das vezes, são completamente desconhecidos.

É importante deixar claro que a boa-fé, ontologicamente, não se apresenta como preceito protetivo, impondo a ambos os parceiros negociais o dever de agir com lealdade e cooperar reciprocamente uns com os outros ${ }^{769}$, deveres que, ao lado de tantos outros, uma vez presentes, poderão variar apenas em intensidade, mormente porque, os princípios irradiam cargas eficaciais distintas consoante as intersubjetividades ${ }^{770}$ inerentes à relação concretamente estabelecida.

\footnotetext{
${ }^{767}$ AGOGLIA, María Martha; BORAGINA, Juan Carlos; MEZA, Jorge Alfredo. Responsabilidad por incumplimiento contractual. Buenos Aires: Hammurabi, 2003. p. 135-141. Dando primazia à tutela da vítima em detrimento da necessidade de sancionar um responsável.

${ }^{768}$ A essa conclusão também chegou o Conselho da Justiça Federal por meio do Enunciado 24, aprovado por ocasião da I Jornada de Direito Civil realizada no Superior Tribunal de Justiça, dispondo que, "em virtude do princípio da boa-fé, positivado no art. 422 do novo Código Civil, a violação dos deveres anexos constitui espécie de inadimplemento, independentemente de culpa", e ainda, do enunciado 363, aprovado recentemente por ocasião da IV Jornada de Direito Civil, que prescreve que "os princípios da probidade e da confiança são de ordem pública, estando a parte lesada somente obrigada a demonstrar a existência da violação."

${ }^{769}$ TEPEDINO, Gustavo; SCHREIBER, Anderson. A boa-fé objetiva no código de defesa do consumidor e no novo código civil. In: TEPEDINO, Gustavo (Coord.). Obrigações: estudos na perspectiva civilconstitucional. Rio de Janeiro: Renovar, 2005. p. 33.

770 NANNI, Giovanni Ettore. O dever de cooperação nas relações obrigacionais à luz do princípio constitucional da solidariedade. In: NANNI, Giovanni Ettore (Coord.). Temas relevantes do direito civil contemporâneo: reflexões sobre os cinco anos do código civil. São Paulo: Atlas, 2008. p. 311. Ao discorrer sobre o dever de cooperação. o autor, salienta que "não é, por conseguinte, uma regra imóvel de comportamento, tendo em vista que se trata de uma cláusula geral, suscetível de adaptação à situação de fato [podendo] variar de intensidade dependendo do caso, sendo, por exemplo, praticamente imperceptível em um e absolutamente essencial em outro."
} 
Há de se destacar também que as premissas constitucionais que informam o tema atuam de modo a fortalecer a defesa da postura assumida. Ao se considerar a importância da tutela das vítimas de um dano injusto e o fato de que essa preocupação promove a proteção da própria sociedade - mediante a adoção de comportamentos informados pela solidariedade -, o fato de o dever violado ser ou não conhecido com antecipação se mostra absolutamente irrelevante na aferição do fator de atribuição do dever de reparar mais adequado ao caso concreto.

E, uma vez constatado, considerando-se o estado da arte, que os deveres gerais de conduta podem ser classificados como obrigações de resultado ${ }^{771}$, resta patente a objetivação do dever de reparar ${ }^{772}$, também por esse motivo.

Ademais, diante da percepção de que a origem dos deveres gerais de conduta está atada à necessidade de tutela da incolumidade do alter em contratos como o de transporte $^{773}$ e de apresentações teatrais, realidades nas quais o dever de reparar é atribuído objetivamente, também por essa razão, a configuração do destacado dever prescinde da culpa de um dos parceiros contratuais. Ora, se o foco das preocupações do Direito é o mesmo, tanto no caso dos contratos destacados, como na fundação dos deveres sob análise - a proteção da integridade psicofísica e patrimonial do outro -, não há como aceitar que se recorra a fatores de imputação distintos.

Enfim, no que pertine às possibilidades contidas na noção de violação de dever, destaque-se que, por ser despida de unidade, a figura da violação positiva ${ }^{774}$, também

\footnotetext{
${ }^{771}$ TOURNEAU, Philippe le. La responsabilidad civil. Trad. Javier Tamayo Jaramillo. Bogotá: Legis, 2004. p. 107-108. Reconhece o autor a existência de vozes em sentido contrário e sustenta que qualquer lesão à integridade psicofísica deverá ser objeto de reparação "objetiva e automática."

${ }^{772}$ A matéria é tratada no item 3.3 deste trabalho.

${ }^{773}$ AGUIAR DIAS, José de. Da responsabilidade civil. 10 ed. Rio de Janeiro: Forense, 1995, v. 1. p. 188 190.

${ }^{774}$ SAVI, Sérgio. Inadimplemento das obrigações, mora e perdas e danos. In: TEPEDINO, Gustavo (Coord.). Obrigações: estudos na perspectiva civil-constitucional. Rio de Janeiro: Renovar, 2005. p. 475-477. Veja ainda: MARTINEZ, Pedro Romano. Cumprimento defeituoso: em especial na compra e venda e na empreitada. Almedina: Coimbra, 2001. p. 60-64. Segundo o autor português, Staub, em seus estudos, teria observado que, além das duas conhecidas modalidades de patologia no desempenho da prestação, havia ainda outros sete grupos de casos que mereceriam tratamento legislativo, sendo eles: a violação de deveres de omissão; o desrespeito aos deveres de cuidado e proteção; a ofensa a deveres laterais como os de informação, conselho e segredo; a situação ocorrida em um contrato de fornecimento sucessivo, quando é desrespeitado apenas um dever de entrega; a hipótese em que o devedor declara, categoricamente, que não irá cumprir a prestação; os casos de responsabilidade pós-contratual, e por fim, os casos de cumprimento defeituoso.
} 
denominada quebra positiva do contrato ${ }^{775}$, por mostrar-se supérflua ${ }^{776}$ e frágil, apesar de sua importância histórica, é aqui afastada.

E frágil porque as hipóteses de (a) violação de dever de omissão, (b) de mau cumprimento da prestação, (c) de risco criado em uma relação duradoura, (d) da ausência de pagamento de apenas uma das prestações nas relações obrigacionais de trato sucessivo e, ainda, (e) de recusa de cumprimento da prestação pelo devedor antes do vencimento, em verdade, nada mais são que casos de mora ou de inadimplemento - ainda que antecipado -, o que se percebe com facilidade, quando se identifica a existência de que todos os casos acima destacados implicam a violação de um dever de prestação. ${ }^{777}$

Além disso, como é patente a possibilidade de fusão das hipóteses de violação de deveres de omissão, cuidado, proteção, informação, conselho e segredo em um único grupo de casos, tratando-os como deveres gerais de conduta ${ }^{778}$, parece mais adequado recorrer a essa última figura do que a uma estrutura manifestamente instável.

\subsection{A responsabilidade contratual na perspectiva da relação obrigacional como processo}

Superada a ideia de que a pessoa do devedor se encontra ligada aos interesses do credor $^{779}$, ainda hoje parece existir dúvida se o objeto de uma relação obrigacional consiste no comportamento prometido pelo devedor ou se ele se concentra no resultado útil esperado pelo credor. Os debates acerca do assunto - informados por essa dicotomia -, em um primeiro momento, conduziram à elaboração de duas construções teóricas aparentemente conflitantes. Surgem as correntes personalistas e as realistas.

\footnotetext{
775 OLIVEIRA, Ubirajara Mach de. Quebra positiva do contrato, Revista de Direito do Consumidor, São Paulo, n. 25, p. 39-56, jan./mar. 1998. p. 39-56.

776 MARTINEZ, Pedro Romano. Cumprimento defeituoso: em especial na compra e venda e na empreitada. Almedina: Coimbra, 2001. p. 65-66.

777 MENEZES CORDEIRO, Antônio Manuel da Rocha e. Da boa fé no direito civil. Coimbra: Almedina, 1984, v. 1. p. 596-598. "O escrito de Staub teve uma repercussão larga e imediata na doutrina e na jurisprudência. A esta última servia, muito particularmente, a elasticidade e a imprecisão da tese [...] A doutrina, pelo contrário, [detectou que] à designação unitária de violação positiva do contrato se abrigavam, na realidade, fenômenos diferentes."

${ }^{778}$ MARTINS-COSTA, Judith. A boa-fé no direito privado. São Paulo: RT, 2000. p. 437-454.

779 DIEZ-PICAZO, Luis. Fundamentos del derecho civil patrimonial: las relaciones obligatorias. 5 ed. Madrid: Civitas, 1996, v. 2. p. 50-51.
} 
A primeira das correntes parte do pressuposto de que a relação obrigacional consiste no vínculo em razão do qual o devedor deverá desempenhar uma prestação em favor do credor $^{780}$, atribuindo a esse o direito sobre o comportamento prometido por aquele. $^{781}$

As doutrinas personalistas se identificam por vislumbrarem a "obrigação como um direito a uma atividade humana." ${ }^{, 782}$ Em apertada síntese, pode ser afirmado que essas correntes atentam contra direitos da personalidade e excluem, do universo de análise do tema, a sanção para as hipóteses de violação de dever contratual. ${ }^{783}$

Fato é que, com o passar do tempo, as críticas formuladas em desfavor das correntes personalistas - promessa de atuação e atribuição ao credor de direito sobre o comportamento a ser desempenhado - induzem ao surgimento das teorias patrimonialistas. Essas advêm da noção de que o patrimônio do devedor garante a satisfação dos débitos por ele contraídos. Eram comuns afirmações como a que destaca que o credor goza de mera expectativa de adimplemento ${ }^{784}$, ou que salienta que seu direito de crédito se manifestaria apenas se fosse necessário agredir o patrimônio do devedor. ${ }^{785}$ Afirmou-se, também, que a relação obrigacional não passa de uma relação entre dois patrimônios. ${ }^{786}$

${ }^{780}$ JUSTO, Antônio Santos. Direito privado romano: direito das obrigações. 2 ed. Coimbra: Coimbra, 2006, v. 2. p. 11.

${ }^{781}$ KONDER, Carlos Nelson; RENTERÍA, Pablo. A funcionalização das relações obrigacionais: interesse do credor e patrimonialidade da prestação. In: TEPEDINO, Gustavo; FACHIN, Luiz Edson. Diálogos sobre direito civil. Rio de Janeiro: Renovar, 2008, v. 2. p. 269.

782 MENEZES CORDEIRO, António Manuel da Rocha e. Direito das obrigações. Lisboa: Associação Acadêmica da Faculdade de Direito de Lisboa, 1986, v. 1. p. 173.

783 ANTUNES VARELA, João de Matos. Direito das obrigações. Rio de Janeiro: Forense, 1978, v. 2. p. 405-407.

${ }^{784}$ MENEZES CORDEIRO, António Manuel da Rocha e. Direito das obrigações. Lisboa: Associação Acadêmica da Faculdade de Direito de Lisboa, 1986, v. 1. p. 183. "O devedor, por seu turno, não se encontraria adstrito a nenhum dever propriamente dito, mas, apenas, a um dever livre. Ele acataria a obrigação caso pretendesse evitar a investida do credor contra o seu patrimônio [...]."

785 ANTUNES VARELA, João de Matos. Direito das obrigações. Rio de Janeiro: Forense, 1978, v. 2. p. 408-412.

${ }^{786}$ GAUDEMET, Eugene. Teoría general de las obligaciones. Trad. Pablo Macedo. México: Editorial Porúa, 1974. p. 29. Sustentando que "ahora, por el contrario, la personalidad del acreedor o la del deudor, son elementos secundarios en la obligación. En efecto: el acreedor no tiene ya ningún derecho sobre la persona física del deudor y tiene siempre un derecho de prenda general que, en caso de ejecución, pone a su disposición todo el sistema de embargos del Código de procedimientos. El crédito se ha convertido en un valor o una afectación de los bienes. En este sentido ha podido decirse que la deuda y el crédito modernos son relación entre dos patrimonios, al mismo tiempo y con mayor razón que entre dos personas; así como el deudor y el acreedor ya no son sino representantes jurídicos de sus bienes. No quiere esto decir que la obligación deje de ser relación entre personas, sino sencillamente, que la individualidad de esas personas resulta indiferente a la existencia de la relación y que el acreedor o el deudor pueden cambiar, sin que el crédito o la deuda se extingan o modifiquen." 
As críticas a essas percepções não são poucas. Primeiro, por ser inaceitável a supremacia do momento patológico em prejuízo do deslinde naturalmente esperado da prestação prometida, quando da análise do fenômeno obrigacional. Depois, porque a atividade do devedor é desprezada em uma relação cuja essência é a cooperação. ${ }^{787}$ Enfim, por conta da dificuldade de compreensão de uma relação entre patrimônios, quando o Direito regra os laços jurídicos que se estabelecem entre pessoas. ${ }^{788}$

Ocorre que as discussões travadas entre personalistas e realistas conduzem à concepção de uma corrente intermediária que tenta conciliar a dissidência entre as teorias destacadas, aproveitando o que cada uma delas possui de mais interessante.

Surgem as teorias dualistas. ${ }^{789}$ A relação obrigacional agora é concebida como uma relação jurídica que atribuiu ao credor o direito subjetivo de exigir o desempenho da prestação destinada a atender a seu interesse, desde que lícito e digno de tutela, sendo-lhe facultado utilizar a força - mediante a intervenção (ou não) do Poder Judiciário - caso não haja adimplemento espontâneo. ${ }^{790}$

A doutrina brasileira, seguindo essa trilha, em linhas gerais, trabalha a relação obrigacional a partir das estruturas dualistas, compreendendo-a consoante o código binário dívida e responsabilidade. A primeira das noções alude ao dever de prestar, assumido pelo devedor e a segunda, à possibilidade de agredir o patrimônio do devedor que não adimpliu. ${ }^{791}$ Essa concepção também não escapa as críticas ${ }^{792}$, especialmente porque dívida e responsabilidade se apresentam como ingredientes de um mesmo fenômeno. ${ }^{793}$

\footnotetext{
${ }^{787}$ KONDER, Carlos Nelson; RENTERÍA, Pablo. A funcionalização das relações obrigacionais: interesse do credor e patrimonialidade da prestação. In: TEPEDINO, Gustavo; FACHIN, Luiz Edson. Diálogos sobre direito civil. Rio de Janeiro: Renovar, 2008, v. 2. p. 272-274.

${ }^{788}$ RIPERT, Georges. A regra moral nas obrigações civis. Trad. Osório de Oliveira. Campinas: Bookseller, 2002. p. 384. Salientando o autor que a obrigação, longe de ser mera relação entre patrimônios, sempre se apresentou a partir da submissão de um homem ao outro.

789 Sobre o tema: LARENZ, Karl. Derecho de obligaciones. Trad. Jaime Santos Briz. Madrid: Editorial Revista de Derecho Privado, 1958, t. 1. p. 31-37. Veja, ainda: para uma compreensão detalhada das teorias dualistas: MENEZES CORDEIRO, António Manuel da Rocha e. Direito das obrigações. Lisboa: Associação Acadêmica da Faculdade de Direito de Lisboa, 1986, v. 1. p. 189-215.

790 AGOGLIA, María Martha; BORAGINA, Juan Carlos; MEZA, Jorge Alfredo. Responsabilidad por incumplimiento contractual. Buenos Aires: Hammurabi, 2003. p. 31.

${ }^{791}$ CALIXTO, Marcelo Junqueira. Reflexões em torno do conceito de obrigação, seus elementos e fontes. In: TEPEDINO, Gustavo (Coord.). Obrigações: estudos na perspectiva civil-constitucional. Rio de Janeiro: Renovar, 2005. p. 3-5. Concordamos com a crítica formulada pelo autor, ao destacar, como um dos problemas da aludida construção teórica a subordinação imposta ao devedor na qualidade de único responsável pelo adimplemento da obrigação assumida.
} 
Independentemente dos defeitos apontados nos aludidos modelos teóricos, o que parece ser inegável é que todas as linhas de pensamento analisadas se embasam em um pensar meramente descritivo, ignorando tempo e espaço na análise do fenômeno obrigacional. ${ }^{794}$ Todos os modelos apontados conduzem a percepções absolutamente estáticas, o que dificulta a compreensão de toda complexidade inerente ao fenômeno obrigacional.

Talvez, mais que isso. A relação obrigacional, por longa data, foi concebida como uma relação prenhe de interesses antagônicos, recheada por tanta tensão que despertava a necessidade cotidiana de vigilância, estimulando a desconfiança dos parceiros negociais. ${ }^{795}$ Por conta desses problemas, há quem diga que o modelo estático de análise da relação obrigacional se encontra superado. ${ }^{796}$

Apesar da leitura estática não ser de todo incorreta, não restam dúvidas de que a identificação da relação obrigacional, como um vínculo que impõe ao devedor prestar algo em favor credor, dificulta a explicação de distintos fenômenos, e isso ocorre mesmo nas obrigações de execução instantânea. É preciso aceitar que o viés clássico de análise do fenômeno obrigacional é, no mínimo, reducionista ${ }^{797}$ e, só por essa razão, imperfeito.

\footnotetext{
${ }^{792}$ NORONHA, Fernando. Direito das obrigações. São Paulo: Saraiva, 2004, v. 1. p. 139-142. Em síntese, o autor sustenta que a construção da teoria dualista é artificial. Após explicar as razões do seu surgimento, discorre sobre a dificuldade de a doutrina aceitar que a tutela seria um elemento externo à relação jurídica, já que não desempenhada a prestação prometida, o patrimônio do devedor garantiria o adimplemento ou a satisfação dos prejuízos suportados pelo credor. Defende não ser possível aceitar a existência de dívida sem responsabilidade (porque essas relações não seriam jurídicas), bem como a existência de responsabilidade sem dívida (ainda que essa pertença à pessoa distinta do responsável pelo adimplemento). Veja ainda: ANTUNES VARELA, João de Matos. Direito das obrigações. Rio de Janeiro: Forense, 1978, v. 2. p. 415420.

793 DIEZ-PICAZO, Luis. Fundamentos del derecho civil patrimonial: las relaciones obligatorias. 5 ed. Madrid: Civitas, 1996, v. 2. p. 59-82.

${ }^{794}$ SILVA, Carlos Augusto. A obrigação como totalidade e processo, Revista da Ajuris, Porto Alegre, v. 31, n. 95 , p. 55-69, set. 2004. p. 60-61.

${ }^{795}$ CANCINO, Emilssen González de. La protección del deudor en la tradición romanística: una búsqueda de soluciones, Revista Brasileira de Direito Comparado, Rio de Janeiro, n. 10, p. 120-141, jan./jun. 1991. p. 120.

${ }^{796}$ BECKER, Anelise. Elementos para uma teoria unitária da responsabilidade civil, Revista de Direito do Consumidor, São Paulo, n. 13, p. 42-55, jan./mar. 1995. p. 50.

${ }^{797}$ BUSSATTA, Eduardo Luiz. Resolução dos contratos e teoria do adimplemento substancial. São Paulo: Saraiva, 2007. p. 11. Deixando, como sustenta o autor, "à margem uma série de questões umbilicalmente ligadas a necessidades econômicas e práticas, as quais o jurista não pode olvidar.”
} 
E, ainda que não seja equivocado definir a relação obrigacional como o vínculo jurídico que permite ao credor exigir do devedor o desempenho de uma prestação ${ }^{798}$, essa, com toda certeza, não é a melhor forma de entender toda a complexidade do fenômeno obrigacional, que, há algum tempo, se despiu da simplicidade de outrora.

Atualmente, a relação obrigacional, longe de identificar-se com os direitos do credor, apresenta-se como uma estrutura complexa que exige, constantemente, recíproca cooperação.

E, se inicialmente, a doutrina dualista foi responsável por identificar os diversos momentos contidos na relação obrigacional, pouco tempo após, percebeu-se que cada um desses momentos se encontram intimamente conectados ao anterior ${ }^{799}$, viés dinâmico que "processualiza a conduta das partes", vinculando-as ao adimplemento, clímax aguardado, com ansiedade e confiança, em todo e qualquer processo obrigacional. ${ }^{800}$

Infira-se que, se, de um lado, é inegável que a relação obrigacional tem por finalidade viabilizar a satisfação dos legítimos interesses do credor, de outro, haverá de ser equalizada pela necessidade de respeito à pessoa humana e pelos efeitos que emanam do princípio da solidariedade social.

Diante dos múltiplos influxos que atualmente permeiam o processo obrigacional, é possível afirmar que o estado de tensão beligerante inerente às relações jurídicas fundadas nas premissas que informavam o individualismo foi substituído pela

\footnotetext{
${ }^{798}$ Nesse sentido, por exemplo: LIRA, Ricardo Pereira. Obrigação de meios e obrigação de resultado a pretexto da responsabilidade médica: análise dogmática, Revista de Direito Renovar, Rio de Janeiro, n. 6, p. 75-82, set./dez. 1996. p. 75.

799 MARTINS-COSTA, Judith. Comentários ao novo código civil: do direito das obrigações - do adimplemento e da extinção das obrigações. Rio de Janeiro: Forense, 2005, v. 5, t. 1. p. 27.

${ }^{800}$ LEONARDO, Rodrigo Xavier. Direito das obrigações: em busca de elementos caracterizadores para compreensão do livro I da parte especial do código civil. In: CANEZIN, Claudete Carvalho. Arte jurídica: biblioteca científica do programa de pós-graduação em direito civil e processo civil da universidade estadual de londrina. Curitiba: Juruá, 2005, v. 1. p. 288-289.
} 
cooperação $^{801}$, dever que imanta a conduta a ser desempenhada aos legítimos interesses do parceiro negocial. $^{802}$

Além disso, é relevante destacar que a relação obrigacional abrange não apenas direitos subjetivos atribuídos ao credor e os deveres jurídicos a eles ligados. A esses, indubitavelmente, somam-se direitos formativos e os estados de sujeição a eles conectados, ônus e expectativas jurídicas ${ }^{803}$ etc. A relação obrigacional, longe de caracterizar-se por uma estrutura simplista, compõe-se, na atual conjuntura, por uma infinidade de direitos e deveres de distintas nuanças, intensidades e formas.

É conveniente, ainda, situar a relação obrigacional em seu campo de operação - o plano da eficácia -, em especial diante do contexto dinâmico e das mais diversas alterações em seu conteúdo, mutações essas que são promovidas pelas marés da realidade fática que a envolve. ${ }^{804}$ Alteram-se sujeitos, objetos, garantias, direitos subjetivos e formativos, tudo isso sem que a relação obrigacional deixe de existir ou perca sua essência. Por tudo isso, a relação obrigacional, contemporaneamente, deve ser concebida e tratada como um ente orgânico, que "nasce, vive e morre." 805

Distante do pensamento analítico, o feixe de relações obrigacionais há de ser analisado como um todo, e não, como simples soma de cada uma de suas partes ${ }^{806}$, pois o todo, aqui inserido no tempo e no espaço, é mais importante que a simples união de cada um de seus distintos momentos. No decorrer do tempo, o adimplemento, a observância de

\footnotetext{
${ }^{801}$ VILLELA, João Baptista. Por uma nova teoria dos contratos, Revista Forense, Rio de Janeiro, v. 74, n. 261, p. 27-35, jan./mar. 1978. p. 32. No mesmo sentido: PERLINGIERI, Pietro. Perfis do direito civil: introdução ao direito civil constitucional. 2 ed. Trad. Maria Cristina De Cicco. Rio de Janeiro: Renovar, 2002. p. 212. Como ensina o autor, a relação obrigacional, portanto, longe de identificar-se com os interesses do credor, como sustentado por longa data, cada vez mais, apresenta-se como uma relação de colaboração.

802 MARTINS-COSTA, Judith. Comentários ao novo código civil: do direito das obrigações - do adimplemento e da extinção das obrigações. Rio de Janeiro: Forense, 2005, v. 5, t. 1. p. 33.

${ }^{803}$ NORONHA, Fernando. Direito das obrigações. São Paulo: Saraiva, 2004, v. 1. p. 77. No mesmo sentido: MARTINS-COSTA, Judith. Comentários ao novo código civil: do direito das obrigações - do adimplemento e da extinção das obrigações. Rio de Janeiro: Forense, 2005, v. 5, t. 1. p. 29.

${ }^{804}$ COSTA JUNIOR, Olímpio. A relação jurídica obrigacional: situação, relação e obrigação em direito. São Paulo: Saraiva, 1994. p. 56.

${ }^{805}$ MARQUES, Cláudia Lima. Contratos no código de defesa do consumidor: o novo regime das relações contratuais. 5 ed. São Paulo: RT, 2006. p. 217.

806 PONTES DE MIRANDA, Francisco Cavalcanti. Tratado de direito privado: parte especial. Rio de Janeiro: Borsoi, 1959, t. 26. p. 283.
} 
determinados deveres e mesmo a extinção de direitos pelo não uso não implicarão, necessariamente, a extinção da relação obrigacional. ${ }^{807}$

A partir das premissas apontadas, resta claro por que a relação obrigacional não pode ser explicada de modo suficientemente claro e convincente mediante o recurso a sua concepção simplificada. Some-se a elas o fato de que a análise dogmática e estática da relação obrigacional é, ao mesmo tempo, fruto e fonte do processo que redunda na manutenção de uma visão distorcida, atemporal e atomística do assunto.

Ao considerá-la "sempre igual a si mesma", ignora as intersubjetividades inerentes a cada situação concreta. Aspectos importantes são desprezados pela visão aqui criticada, dentre eles: (a) as particularidades das pessoas sobre as quais irradia seus efeitos, (b) a importância do objeto da prestação e, (c) quais os interesses preponderantes no caso concreto $^{808}$; questões importantes mormente quando as patologias se manifestam.

Nesse cenário, a relação obrigacional deixa de ser representada por uma fotografia revelada a partir de uma imagem registrada em um negativo, passando a ser narrada em forma de filme, o que permite constante e intensa interatividade. O processo obrigacional - oriundo de um fato jurídico que pode se manifestar, dentre outras formas, por meio de um contrato, de uma declaração unilateral de vontade ou do contato social não nasce pronto, precisando ser escrito ${ }^{809}$, dia após dia.

${ }^{807}$ LARENZ, Karl. Derecho de obligaciones. Trad. Jaime Santos Briz. Madrid: Editorial Revista de Derecho Privado, 1958, t. 1. p. 37-41. E isso porque, consoante ensina o autor, "a relação obrigacional como um todo se extingue quando seu fim tenha sido totalmente alcançado, é dizer, quando o interesse do credor no desempenho da prestação tenha sido satisfeito."

${ }^{808}$ PERLINGIERI, Pietro. Perfis do direito civil: introdução ao direito civil constitucional. 2 ed. Trad. Maria Cristina De Cicco. Rio de Janeiro: Renovar, 2002. p. 206-212.

${ }^{809}$ OST, François. Tiempo y contrato: crítica del pacto fáustico, Doxa, Alicante, n. 25, p. 597-626, 2002. p. 611. "Para la concepción clásica, el contrato hacía surgir instantaneidad de su conclusión e inmutabilidad de su ejecución: la intangibilidad de la letra acompañaba la espontaneidad casi mágica de su escritura. De hecho, un contrato así se situaba "fuera del tiempo". Los desarrollos contemporáneos, restituyendo al contrato la duración de la vida concreta, han hecho que éste reencuentre el hilo del tiempo y esto es así tanto antes como después de su conclusión. La inmutabilidad de la letra hace así lugar a la progresividad del espíritu: el contrato es un vínculo con vida que va escribiéndose a lo largo de sus distintas etapas de elaboración. Del contrato tal y como fue expresado al contrato querido o deliberado, y del contrato concluido al contrato ejecutado, se producen una buena cantidad de metamorfosis en el curso de las cuales se ejerce la fuerza consolidativa (pero a veces también destructiva) del tiempo: es el pasaje progresivo de lo posible a lo real, de lo indeterminado a lo determinado, de lo informe a lo formado y de la potencia al acto. Pero el acto jurídico que resulta no puede pretender su perfección el día de su conclusión formal. La teoría clásica veía perfecto este acto a partir del simple hecho de la concordancia de las voluntades del que era resultado. Su "intemporalidad" era el tiempo ficticio y abstracto del perfecto que presenta al acto o a la acción en un estado (siempre ya) alcanzado, como si el dominio que la voluntad ejerce sobre el tiempo fuera tal que ella, desde el principio, detuviera por completo los avatares. Podríamos decir, por otro lado, que el tiempo contractual que se manifiesta hoy a través de sus transformaciones jurisprudenciales y legislativas es más bien el tiempo del imperfecto -tiempo que dura y que es iterativo, que presenta la acción siempre desenvolviéndose y cuyo 
A relação obrigacional, uma vez percebida essa gama de questões, passa a ser examinada a partir de seu caráter dinâmico, como processo ${ }^{810}$ que se desenvolve no tempo e no espaço. Como se percebe, a expressão processo significa aqui a série de atos interdependentes e inter-relacionados que são necessários para atingir um objetivo. ${ }^{811}$

A relação obrigacional se apresenta, então, nesse novo cenário, como uma série concatenada de comportamentos direcionados ao fim naturalmente esperado - o adimplemento - e exige recíproca cooperação dos parceiros negociais ${ }^{812}$ durante cada uma de suas fases.

Em outras palavras, a relação jurídica obrigacional passa a ser representada como processo hábil a conduzir à satisfação dos interesses do credor, sendo organizada em busca desse fim ${ }^{813}$, sem deixar de olhar para o devedor, pois, ao se desenvolver dinamicamente, exige a cooperação das partes para que possa atingir seu momento máximo. $^{814}$

A compreensão do fenômeno obrigacional como ente dinâmico, dentre outros aspectos, permite abandonar os modelos estáticos outrora utilizados para o tratamento das vicissitudes e patologias que cotidianamente afetam o curso dos processos obrigacionais concretamente situados.

Essa perspectiva de análise tem ainda o mérito de facilitar a visualização de figuras como as que autorizam a transmissão de posições jurídicas e as que delineiam os deveres gerais de conduta. E, considerando que o tempo se faz cada vez mais duradouro

comienzo y final no son identificables con precisión. Lejos de traducir la imperfección del contrato, este imperfecto da testimonio más bien de su mayor capacidad de supervivencia al satisfacer mejor que ayer las exigencias de justicia y de utilidad económica. Claro que esta transformación del tiempo contractual no es ajena a la modificación de la concepción acerca de los fundamentos."

${ }^{810}$ COUTO E SILVA, Clóvis Veríssimo do. A obrigação como processo. São Paulo: Bushatsky, 1976. p. 10. "Com a expressão obrigação como processo tenciona-se sublinhar o ser dinâmico da obrigação, as várias fases que surgem no desenvolvimento da relação obrigacional e que entre si se ligam com interdependência."

${ }^{811}$ AMARAL, Francisco. Direito civil: introdução. 7 ed. Rio de Janeiro: Renovar, 2008. p. 204.

${ }^{812}$ MARTINS-COSTA, Judith. Adimplemento e inadimplemento. In: EMERJ DEBATE O NOVO CÓDIGO CIVIL. Rio de Janeiro: EMERJ, 2002, parte 01. p. 95-113.

${ }^{813}$ CUNHA DE SÁ, Fernando Augusto. Direito ao cumprimento e direito a cumprir. Coimbra: Almedina, 1997. p. 80 .

${ }^{814}$ SILVA, Jorge Cesa Ferreira. O direito das obrigações no novo código civil: apontamentos para a defesa do estado, Revista da PGE, Porto Alegre, v. 27, n. 57, p. 135-156, 2004. p. 139. 
nas relações negociais ${ }^{815}$, facilita a intelecção e o enquadramento de uma série de vicissitudes que podem ocorrer no curso do processo obrigacional.

Diga-se, ainda, que a análise da relação obrigacional como processo não é mero refinamento teórico. Reflete, mormente quando se promove sua releitura, a partir dos influxos que atravessam a realidade contemporânea, um novo modelo de compreensão do direito obrigacional, facilitando a compreensão de toda complexidade inerente a cada um dos fatos da vida e, viabilizando, por consequência, soluções pautadas na justiça obrigacional. ${ }^{816}$

A apreensão do tema em perspectiva dinâmica permite afastar o apego excessivo à forma, dando primazia à busca pela produção de um resultado útil ${ }^{817}$, funcionalizando, portanto, a compreensão do fenômeno obrigacional.

Se existe um plano, um programa obrigacional a ser observado pelas partes, no qual se busca a satisfação dos interesses do credor, não se pode negar que os resultados esperados por ele hão de ser alcançados ${ }^{818}$ - salvo o advento de impossibilidade não imputável.

E, ainda que, quando de sua formulação teórica ${ }^{819}$, as aludidas preocupações não estivessem na pauta do dia, a compreensão contemporânea do fenômeno obrigacional como um processo autoriza, sem dúvida alguma, o influxo dos valores que emanam do Estado Democrático de Direito. Aliás, como se tocou no assunto, nunca é demais lembrar quão importante é a recorrente busca por justiça contratual, o respeito à isonomia substancial e a valorização da solidariedade social.

\footnotetext{
${ }^{815}$ LORENZETTI, Ricardo Luis. Esquema de una teoría sistémica del contrato, Revista de Direito do Consumidor, São Paulo, v. 9, n. 33, p. 51-77, jan./mar. 2000. p. 67.

${ }^{816}$ NALIN, Paulo; XAVIER, Luciana Pedroso; XAVIER, Marília Pedroso. A obrigação como processo: breve releitura trinta anos após. In: TEPEDINO, Gustavo; FACHIN, Luiz Edson. Diálogos sobre direito civil. Rio de Janeiro: Renovar, 2008, v. 2. p. 322.

${ }^{817}$ KONDER, Carlos Nelson; RENTERÍA, Pablo. A funcionalização das relações obrigacionais: interesse do credor e patrimonialidade da prestação. In: TEPEDINO, Gustavo; FACHIN, Luiz Edson. Diálogos sobre direito civil. Rio de Janeiro: Renovar, 2008, v. 2. p. 297.

${ }^{818}$ ITURRASPE, Jorge Mosset; PIEDECASAS, Miguel. Responsabilidad contractual. Santa Fé: RubinzalCulzoni, 2007. p. 227.

${ }^{819}$ Sobre o tema e por todos: COUTO E SILVA, Clóvis Veríssimo do. A obrigação como processo. São Paulo: Bushatsky, 1976. p. 5-215.
} 
Reafirme-se: cada relação obrigacional - em razão do acoplamento proposto há de ser permeada pela justiça social, pela igualdade substancial e pela solidariedade ${ }^{820}$, valores que singram todo o processo obrigacional, afastando reducionismos que ignoram a importância de olhar para outro ${ }^{821}$ e que desprezam as intersubjetividades inerentes a cada hipótese concretamente estabelecida. ${ }^{822}$

Parece mesmo que não só a relação obrigacional, mas o próprio contrato devem ser vistos como processo ${ }^{823}$, afastando-se, com essa percepção, seu caráter estático e aprisionador. Tamanhas são as complexidades na ordem do dia, que a ideia de contrato não mais se coaduna a uma representação puramente linear. ${ }^{824}$

E, como esse contrato - essa relação intersubjetiva informada por uma incomensurável complexidade - passa a ser alimentado por distintos subsistemas de modo recíproco e ininterrupto, resta evidente por que deixa de ser uma simples situação jurídica $^{825}$ como aquelas normalmente descritas nos manuais sobre o tema.

Por isso, pode-se afirmar que as molduras dentro das quais ser inserem os contratos são infinitas e, dentro delas, telas incompletas esperam pelo colorido das tintas. É impossível enxergar antecipadamente a feição definitiva do contrato em razão de seu feitio dinâmico e mutável. ${ }^{826}$

\footnotetext{
${ }^{820}$ NANNI, Giovanni Ettore. O dever de cooperação nas relações obrigacionais à luz do princípio constitucional da solidariedade. In: NANNI, Giovanni Ettore (Coord.). Temas relevantes do direito civil contemporâneo: reflexões sobre os cinco anos do código civil. São Paulo: Atlas, 2008. p. 291.

${ }^{821}$ NALIN, Paulo. Do contrato: conceito pós-moderno em busca de sua formulação na perspectiva civilconstitucional. Curitiba: Juruá, 2001. p. 201.

${ }^{822}$ COLLURA, Giorgio. Importanza dell ínadempimento e teoria del contratto. Milano: Giuffrè, 1992. p. 3236.

${ }^{823}$ LORENZETTI, Ricardo Luis. Esquema de una teoría sistémica del contrato. In: FERNÁNDEZ, Carlos López; CAUMONT, Arturo; CAFFERA, Gerardo (Coord.). Estudios de derecho civil en homenaje al profesor Jorge Gamarra. Montevideo: FCU, 2001. p. 256-257.

${ }^{824}$ NORONHA, Fernando. O ato ilícito nos contratos e fora deles, Revista de Direito Civil, Imobiliário, Agrário e Empresarial, São Paulo, v. 9, n. 34, p. 34-35, out./dez. 1985. p. 39.

${ }^{825}$ WEINGARTEN, Celia. La equidad como principio de seguridad económica para los contratantes, Revista de Direito do Consumidor, São Paulo, v. 10, n. 39, p. 32-40, jul./set. 2001. p. 39.

${ }^{826}$ KONDER, Carlos Nelson; RENTERÍA, Pablo. A funcionalização das relações obrigacionais: interesse do credor e patrimonialidade da prestação. In: TEPEDINO, Gustavo; FACHIN, Luiz Edson. Diálogos sobre direito civil. Rio de Janeiro: Renovar, 2008, v. 2. p. 268.
} 
Nunca é demais lembrar que, no interior de cada contrato, há distintos conteúdos atuando com intensidade variável. ${ }^{827} \mathrm{E}$, também por isso, talvez seja possível afirmar que, apenas quando os contratantes estiverem satisfeitos e o tempo se encarregar de secar a beleza das cores sobre a tela, será possível afirmar que o negócio cumpriu satisfatoriamente suas funções.

Sob outro ângulo, esse mesmo contrato, ao permitir antever e antecipar as contingências contidas no porvir, reduz drasticamente a "imponderabilidade e a contingência. $"{ }^{828} \mathrm{Na}$ qualidade de mecanismo de dominação do futuro, o contrato viabiliza a diminuição das incertezas contidas no porvir ${ }^{829}$, cooperando, de forma eficaz, para a manutenção das bases da vida em sociedade.

Na qualidade de instrumento que permite aos homens "comprometer o futuro", deve ser utilizado - em cada hipótese que o exija - de modo a distribuir, de forma equilibrada, os riscos que lhe são inerentes. ${ }^{830} \mathrm{E}$ isso porque, o contrato que obriga é o contrato justo.

E, embora, paradoxalmente, a realidade demonstre ser quase impossível antever todos os riscos que cada contrato contém ${ }^{831}$, essa é uma função importante que não pode ser desprezada no processo de realização do direito, razão pela qual os deveres jurídicos multifacetados nele contidos hão de ser balizados pelos princípios constitucionais e pelos princípios contratuais sociais, homenageando-se, assim, a todo tempo e o tempo todo, o justo contratual.

\footnotetext{
${ }^{827}$ FARO, Frederico Kastrup de. Boa-fé objetiva e dever de cooperação: uma análise sob as óticas do exercício da autonomia privada e da execução do contrato, Revista Trimestral de Direito Civil, Rio de Janeiro, n. 38, p. 3-39, abr./jun. 2009. p. 31-32.

${ }^{828}$ LEONARDO, Rodrigo Xavier. Responsabilidade civil contratual e extracontratual: primeiras anotações em face do novo código civil brasileiro, Revista de Direito Privado, São Paulo, v. 5, n. 19, p. 260-269, jul./set. 2004. p. 266.

${ }^{829}$ OST, François. Tiempo y contrato: crítica del pacto fáustico, Doxa, Alicante, n. 25, p. 597-626, 2002. p. 605. "En efecto, cuando reclamamos una temporalidad más evolutiva del vínculo contractual es preciso subrayar que el contrato es, antes que ninguna otra cosa, un instrumento de dominación del futuro, un instrumento de previsión destinado a reducir el componente azaroso del porvenir, los cambios de las circunstancias y las debilidades de la voluntad."

${ }^{830}$ FRIED, Charles. Contrato como promessa: uma teoria da obrigação contratual. Trad. Sérgio Duarte. Rio de Janeiro: Elsevier, 2008. p. 145.

${ }^{831}$ CRUZ, Gaston Fernandez. Los supuestos dogmaticos de la responsabilidad contractual: la division de sistemas y la previsibilidad, Revista de Direito Privado, São Paulo, v. 5, n. 19, p. 289-318, jul./set. 2004. p. 305-318.
} 
Enfim, não se pode olvidar que, se, de um lado, o contrato permite antecipar o futuro, de outro, raramente afastará a tensão que permeia o processo obrigacional. Por mais que se garanta ao credor o exercício de distintas pretensões e direitos, ele somente terá certeza do adimplemento ${ }^{832}$ com o desempenho da prestação prometida por seu parceiro.

E, enquanto o tempo exige a espera do momento em que o futuro se transformará em presente, ao mesmo tempo em que não há como evitar a dúvida, pulula a importância da cooperação imposta a ambos os contratantes. Assim, longe de ser vista como algo exclusivamente negativo, a incerteza que reina no universo contratual atua de modo a amplificar a necessidade de respeito a um sem-número de deveres éticos, conduzindo, ainda, a uma perspectiva socializante na compreensão do fenômeno contratual, visto aqui, uma vez mais, a partir de toda a sua complexidade. ${ }^{833}$

Mais um pilar escora a tese que se erige. $\mathrm{O}$ atomismo e a compreensão estática da relação obrigacional não permitem a visualização de uma série de fenômenos no curso do processo obrigacional. A partir da compreensão do fenômeno obrigacional como um processo - e de toda sua complexidade, intrínseca e extrínseca -, as vicissitudes e patologias dos mais distintos matizes encontrarão soluções não apenas dogmaticamente aceitáveis, mas constitucionalmente irrepreensíveis e socialmente justas.

\footnotetext{
${ }^{832}$ AZEVEDO JUNIOR, José Osório de. Breves anotações sobre o pagamento e o ato jurídico não negocial. In: NANNI, Giovanni Ettore (Coord.). Temas relevantes do direito civil contemporâneo: reflexões sobre os cinco anos do código civil. São Paulo: Atlas, 2008. p. 353.

${ }^{833}$ HIRONAKA, Giselda Maria Fernandes Novaes. Contrato: estrutura milenar de fundação do direito privado - superando a crise e renovando princípios, no início do vigésimo primeiro século, ao tempo da transição legislativa brasileira. In: BARROSO, Lucas Abreu (Org.). Introdução crítica ao código civil. Rio de Janeiro: Forense, 2006. p. 125.
} 


\section{ASCENSÃO E DECLÍNIO DA CULPA NA RESPONSABILIDADE CONTRATUAL}

\subsection{A historiografia da culpa no direito das obrigações}

A percepção de que o Direito - suas figuras e seus institutos - não pode ser pensado como algo alheio a sua historicidade justifica ${ }^{834}$ a tentativa, aqui empreendida, de compreensão do processo de ascensão e queda da culpa no direito obrigacional. Nessa viagem ao passado e rumo a instantes que jamais serão alcançados, todos os momentos anteriores aos havidos no direito romano foram afastados por conta da aparente distância entre esses períodos - que remontam a estágios como a vingança privada ${ }^{835}$ - e a contemporaneidade. Não se ignora que essa premissa pode permear também o marco temporal eleito, entretanto, como o direito romano ${ }^{836}$ - essa linha que se estende por treze séculos $^{837}$ - informa relevante parcela do pensamento jurídico hodierno, fixa-se nele o início do passeio que agora tem início.

\footnotetext{
${ }^{834}$ Sobre o tema: MADEIRA, Hélcio Maciel França. À história do direito, Revista da Faculdade de Direito de São Bernardo do Campo, São Bernardo do Campo, v. 8, n. 10, p. 149-154, 2004. p. 151-152.

835 POSNER, Richard Allen. The economics of justice. Cambrige, 1996. p. 192 apud HINESTROSA, Fernando. Devenir del derecho de daños, Roma e America: Diritto Romano Comune, Roma, n. 10, p. 17-36, 2000. p. 19. "Desde el punto de vista de la sociedad como un todo, la compensación es una solución más económica que la venganza, porque simplemente implica la entrega de un pago en vez de la destrucción de una persona o de su propiedad. Transición de la retaliación a la compensación, atribuible, no a un avance de la racionalidad o a la disminución de la sed de sangre, o a otras factores que presuponen diferencias fundamentales de inteligencia o de gustos entre el hombre primitivo y el moderno, sino, simplemente, al incremento de la riqueza. Un sistema de compensación no funciona, a menos que los agresores y su gens tengan una provisión suficiente de bienes en exceso sobre lo necesario para su subsistencia, que les permita pagar la compensación por los daños que inflijan a otros. La idea de que la única sanción por una injuria personal o una muerte ha de ser el pago de danos en dinero es coherente con la teoría económica. El análisis económico del delito recomienda mayor confianza en la multa frente a la prisión y otros castigos no pecuniarios en que se funda el sistema penal moderno, sobre la base de que la multa es un castigo menor desde el punto de vista social."

${ }^{836}$ FRANÇA, Rubens Limongi. Recepção do direito romano no direito brasileiro, Revista de Direito Civil, Imobiliário, Agrário e Empresarial, São Paulo, v. 3, n. 7, p. 181-196, jan./mar. 1979. p. 181-183. Analisado externamente, o direito romano é dividido em quatro períodos: a) Régio - que vai da fundação de Roma (754 a.C.) a expulsão dos reis (510 a.C.); b) República - que quase alcança o início da era cristã (27 a.C.); c) Principado - inicia-se com a coroação de Otaviano Augusto e finda com a morte de Alexandre Severo (235 d.C.); d) Monarquia - que começa com Diocleciano (284 d.C.) e termina com a invasão dos Godos (565 d.C.). Internamente, entretanto, divide-se em três momentos: a) Jus Civile - que se encerra com a Lei das XII Tábuas (410 a.C.); b) Jus Gentium - que abrange todo o restante da República, o Principado, e se encerra com o início da Monarquia; c) Pós-Clássico.
}

${ }^{837}$ VELASCO, Ignácio Maria Poveda. História externa e interna do direito romano, Revista de Direito Civil, Imobiliário, Agrário e Empresarial, São Paulo, v. 13, n. 49, p. 74-89, jul./set. 1989. p. 74. "O direito romano não é um ponto, é uma linha" com treze séculos carregados de informações. 
Explicado o porquê e em que momento se inicia esse passeio através do tempo - de importância fundamental, aliás, para a compreensão do hoje -, pode-se dizer que é bastante provável que, até o advento da Lex Aquilia de Damno ${ }^{838}$, o dever de reparar pressupunha tão somente a existência de uma relação de causalidade entre a conduta e a lesão dela decorrente.

E isso porque inexistem provas contundentes de que, nas primeiras fases do direito romano, o dever de reparar esteve lastreado na culpa ${ }^{839}$ Longe disso, parece que, como frisado, ao menos, em seus primeiros momentos, além do dano, a Lex Aquilia exigia apenas que esse estivesse conectado à conduta do agente, desprezando a culpa nas situações por ela regradas. ${ }^{840}$

As leituras sobre o tema permitem deduzir que a Lex Aquilia de Damno não aludia à culpa ${ }^{841} \mathrm{O}$ fator de atribuição do dever de reparar por ela eleito é a iniuria, figura cuja aferição deveria ser promovida de forma objetiva.

Nesse condão, a destacada lei aparentemente impunha o dever de reparar os danos provocados por um comportamento considerado contrário ao direito, embora não necessariamente culposo ${ }^{842}$, ou seja, a reparação dos danos causados a outrem era imputada àquele que os causasse a partir de fator de atribuição a ser aferido em perspectiva de ordem objetiva. $^{843}$

\footnotetext{
${ }^{838}$ Cuja origem remonta ao Século III a.C.

${ }^{839}$ BARRETTO, Vicente de Paulo. Responsabilidade e teoria da justiça contemporânea. In: SILVA FILHO, José Carlos Moreira da; PEZZELLA, Maria Cristina Cereser (Coord.). Mitos e rupturas no direito civil contemporâneo. Rio de Janeiro: Lumen Juris, 2008. p. 59. "A etimologia da palavra "responsabilidade" mostra como se considerava "responsável" todo indivíduo que pudesse ser convocado pelos tribunais em virtude de sobre ele pesar certa "obrigação", dívida procedente ou não de um ato de vontade livre. [...] Tratava-se, portanto, de uma obrigação determinada pela lei e que seria finalmente resolvida nos tribunais, caracterizando-se assim a responsabilidade como referida ao futuro tendo em vista uma ação do passado."

${ }^{840}$ BRAVO, Adolfo. O conceito de responsabilidade no código civil portuguez, Revista dos Tribunais, São Paulo, v. 25, n. 104, p. 361-376, nov. 1936. p. 364.

${ }^{841}$ Nesse sentido: SCHIPANI, Sándro. Análisis de la culpa en Justiniano 4,3. In: BUERES, Alberto Jesús; DE CARLUCCI, Aída Kemelmajer (Dir.). Responsabilidad por daños en el tercer milenio. Buenos Aires: Abeledo-Perrot, 1997. p. 134.

${ }^{842}$ LA TORRE, Antonio. Genesi e metamorfosi della responsabilità civile, Roma e America: Diritto Romano Comune, Roma, n. 8, p. 61-115, 1999. p. 75-76.

${ }^{843}$ CALIXTO, Marcelo Junqueira. A culpa na responsabilidade civil: estrutura e função. Rio de Janeiro: Renovar, 2008. p. 129.
} 
A expressão iniuria, reafirme-se, aludia a um comportamento injustificado. ${ }^{844}$ Sua aferição não exigia a análise de quaisquer subjetividades. Para que estivesse configurada, impunha-se, apenas, que houvesse ofensa à integridade material ou imaterial de uma pessoa ${ }^{845}$, comportamento que, longe de ser traduzido como prenhe de culpa, estava muito mais próximo do que hoje pode ser descrito como contrário ao Direito.

Ratificando assertivas pretéritas, parece ser possível afirmar, também, que os romanos, apesar de seu admirável pragmatismo, não conseguiram delinear a culpa. Prova disso está na análise realizada por Mário Talamanca, ao relatar que, nesse período da História, à expressão investigada eram atribuídos, pelo menos, três significados ao ser tratada como: (a) ato ilícito, (b) atribuição do dever de reparar ou, ainda, (c) negligência em sentido genérico. ${ }^{846}$

É possível, nesse contexto, afirmar que a culpa é um conceito que pode ser traduzido como lesão a direito alheio ${ }^{847}$ sem justificativa plausível. O pragmatismo que supostamente balizava o pensamento romano se apresenta como mais uma razão a autorizar a defesa da tese de que culpa era uma figura desconhecida quando do advento da Lex Aquilia de Damno. Aliás, o fato de essa ter suas raízes na Lei de Talião e a percepção de que continha explícita menção à necessidade de sanção do devedor nas hipóteses de incumprimento não fortuito $^{848}$ reforçam a argumentação. Informe-se, entretanto, que a questão não é pacífica ${ }^{849}$, mesmo porque, além das dificuldades inerentes a quaisquer projetos que almejam estudar o passado, qualquer tentativa de compreensão do tema dependerá do significado a ser dado pelo interlocutor à culpa.

${ }^{844}$ SCHIPANI, Sándro. Análisis de la culpa en Justiniano 4,3. In: BUERES, Alberto Jesús; DE CARLUCCI, Aída Kemelmajer (Dir.). Responsabilidad por daños en el tercer milenio. Buenos Aires: Abeledo-Perrot, 1997. p. 127-134.

${ }^{845}$ BIONDI, Biondo. Istituzioni di diritto romano. 2 ed. Milano: Giuffrè, 1952. p. 508.

${ }^{846}$ TALAMANCA, Mario. Colpa. In: Enciclopedia del diritto. Milano: Giuffrè, 1960, v. 7. p. 518.

${ }^{847}$ VISINTINI, Giovanna. Tratado de la responsabilidad civil: el daño, otros criterios de imputación. Trad. Aída Kemelmajer de Carlucci. Buenos Aires: Astrea, 1999, v. 2. p. 4.

${ }^{848}$ D’ALMEIDA, Luiz Duarte. A culpa em Roma e o direito penal: notas de reflexão para uma oral de melhoria de direito romano, Revista da Faculdade de Direito da Universidade de Lisboa, Coimbra, v. 40, n. 1/2, p. 317-321, 1999. p. 317-318.

849 AMARAL, Francisco. Individualismo e universalismo no direito civil brasileiro: permanência ou superação de paradigmas romanos?, Revista Brasileira de Direito Comparado, Rio de Janeiro, n. 13, p. 6495, jul./dez. 1992. p. 91. O autor defende que a culpa era pressuposto na Lex Aquilia. Veja ainda: KASER, Max. Direito privado romano. Trad. Samuel Rodrigues; Ferdinand Hämmerle. Lisboa: Fundação Calouste Gulbenkian, 1999. p. 213. Afirma o autor que a iniuria deve ser compreendida como "violação consciente do direito alheio." 
Independentemente de a Lex Aquilia versar ou não acerca do elemento subjetivo em questão, fato é que os argumentos apontados, no mínimo, revelam a impossibilidade de afirmar-se, com razoável certeza, se a culpa informou (ou não) as primeiras fases do direito romano no deslinde de problemas na seara do dever de reparar.

O que também se mostra aceitável é que, consoante o fluir do tempo, o viés subjetivo, pouco a pouco, foi introduzido na formulação do juízo de reprovabilidade da conduta. A reconfiguração do conceito de iniuria foi aparentemente disparada pela conversão do Imperador Constantino ${ }^{850}$ ao Cristianismo. Por isso, parece possível afirmar que a culpa não é herança do direito romano clássico, mas inovação do direito bizantino. ${ }^{851}$ E, assim, a intelecção da iniuria, a partir de bases subjetivas, dia após dia, foi difundida pelo trabalho dos intérpretes do período pós-clássico. ${ }^{852}$

Apesar de a mutação denunciada não ser aceita unanimemente como fator positivo $^{853}$, há defensores apaixonados afirmando que a espiritualização do Direito mostra avanço em relação ao pensamento jurídico simplista dos povos primitivos. ${ }^{854}$

\footnotetext{
${ }^{850}$ Constantino entrou para a História como o primeiro imperador romano a professar o cristianismo, tendo governado Roma de 307 até 337 d.C. Sob seu comando houve a publicação do Édito de Milão (313), por meio do qual Roma se declarou neutra em relação à religião professada por seus cidadãos.
}

${ }^{851}$ AMARAL, Francisco. Individualismo e universalismo no direito civil brasileiro: permanência ou superação de paradigmas romanos?, Revista de Direito Civil, Imobiliário, Agrário e Empresarial, São Paulo, v. 19, n. 71, p. 69-86, jan./mar. 1995. p. 84-85. No mesmo sentido, HIRONAKA. Giselda Maria Fernandes Novaes. Tendências atuais da responsabilidade civil: marcos teóricos para o direito do século XXI, Revista Brasileira de Direito Comparado, Rio de Janeiro, n. 19, p. 189-206, jul./dez. 2000. p. 194. BAÍA, Jacinto Américo Guimarães. A evolução da responsabilidade civil e a reparação do dano nuclear, Revista de Direito Civil, Imobiliário, Agrário e Empresarial, São Paulo, v. 2, n. 4, p. 49-68, abr./jun. 1978. p. 52. E, ainda, AZEVEDO, Vicente de Paulo Vicente de. O fundamento da responsabilidade civil extracontratual, Revista de Direito Privado, São Paulo, v. 1, n. 1, p. 151-165, jan./mar. 2000. p. 157-158. Consoante ensina o autor, a culpa ocupa lugar na aferição da responsabilidade civil por ocasião da compilação de Justiniano.

${ }^{852}$ GIMÉNEZ-CANDELA, Teresa. Una perspectiva historica de la responsabilidad objetiva, Roma $e$ America: Diritto Romano Comune, Roma, n. 8, p. 117-129, 1999. p. 128. No mesmo sentido: LA TORRE, Antonio. Genesi e metamorfosi della responsabilità civile, Roma e America: Diritto Romano Comune, Roma, n. 8, p. 61-115, 1999. p. 78-87.

${ }^{853}$ HINESTROSA, Fernando. Devenir del derecho de daños, Roma e America: Diritto Romano Comune, Roma, n. 10, p. 17-36, 2000. p. 22. "En las primeras lecciones del curso de obligaciones se suele ensenar que en materia de responsabilidad, la humanidad dio penosamente un paso adelante al abandonar la responsabilidad subjetiva, estricta, para vincular solamente a quien hubiera obrado intencionalmente o a lo menos, con negligencia o imprudencia. Claramente se advierte allí la influencia de la concepción penalista de la responsabilidad. Ciertamente hay que ver las cosas así pensando sólo o más que todo, en la arbitrariedad con que habitualmente se aplicaron las penas por los distintos poderes a toda clase de faltas y en la crueldad de aquéllas, delante de lo cual la exigencia de culpa y la individualización de la responsabilidad constituían, sin más, un progreso: la espiritualización de la responsabilidad, fundada en la culpabilidad y corroborada con la presunción de inocencia. Sin embargo, el tratamiento del derecho de daños con ese criterio, sin fundamento plausible, desprotege a las víctimas, abrumadas por la múltiple carga probatoria, especialmente la del error de conducta del autor del daño, ocurrido la más de las veces de manera inopinada." 
O que se mostra como inegável - independentemente da tomada de posição nesse momento -, é que o direito romano conhecia hipóteses de responsabilidade objetiva $^{855}$ mesmo após o advento e reformulação da compreensão da expressão iniuria, contida na Lex Aquilia de Damno. Prova dessa assertiva está em que, no período clássico, o responsável pela custódia da coisa respondia objetivamente por seu perecimento. ${ }^{856}$

É preciso bater às portas da Idade Média ${ }^{857}$, informando, inicialmente, que por ocasião de seus primeiros seis séculos - Alta Idade Média -, a organização da Europa - e de suas instituições - era bastante precária. Nesse período, as estruturas de poder e a organização cultural da sociedade podem ser qualificadas como dispersas. ${ }^{858}$ O Direito, por sua vez, pode ser descrito como "primitivo, consuetudinário e provinciano." 859 Também, por isso, talvez possa se afirmar que esse pedaço da História não teve importância alguma para o desenvolvimento do objeto sob investigação.

Todavia, durante a Baixa Idade Média, a culpa parece encontrar ambiente propício a sua expansão. A compreensão da transformação em curso tem por lastro, não só a disseminação do Cristianismo pela Europa ${ }^{860}$, mas também o resgate e o acoplamento do direito romano às premissas filosóficas e metodológicas do canonismo ${ }^{861}$ e o crescimento cultural disparado pelas primeiras universidades. ${ }^{862}$ É oportuno salientar que, durante a Idade Média, todas as universidades eram eclesiásticas. ${ }^{863}$

${ }^{854}$ NONATO, Orosimbo. Aspectos do modernismo jurídico e o elemento moral na culpa objectiva, Revista Forense, Rio de Janeiro, n. 56, p. 5-26, jan./jun. 1931. p. 20-21.

${ }^{855}$ JUSTO, Antônio Santos. Direito privado romano: direito das obrigações. 2 ed. Coimbra: Coimbra, 2006, v. 2. p. 205. "É possível que a responsabilidade por custódia do devedor assente no seu compromisso de guardar a res, que lhe foi confiada com diligência e cuidado, isto é, preservando-a da perda e deterioração. Por isso, se perece, é danificada ou roubada, o depositário responderá independentemente de culpa [...]"

${ }^{856}$ MARCHI, Eduardo César Silveira Vita. Dos riscos pela perda fortuita da coisa vendida no direito romano, Revista da Faculdade de Direito, São Paulo, v. 96, p. 45-73, jan./dez. 1996. p. 58-59. A época, sustenta o autor, que sequer a prova de furto ou incêndio exonerariam a responsabilidade do devedor, situação que, atualmente, poderia ser enquadrada, ao que parece, à responsabilidade por risco integral.

${ }^{857}$ Período que se estende de 476 a 1453.

${ }^{858}$ BERMAN, Harold. Direito e revolução: a formação da tradição jurídica ocidental. Trad. Eduardo Takemi Kataoka. São Leopoldo: Unisinos, 2006. p. 375-381.

${ }^{859}$ FIUZA, César. Direito civil: curso completo. 11 ed. Belo Horizonte: Del Rey, 2008. p. 64-67.

${ }^{860}$ SURGIK, Aloísio. O cristianismo e a formação do direito medieval, Revista de Direito Civil, Imobiliário, Agrário e Empresarial, São Paulo, v. 7, n. 26, p. 156-167, out./dez. 1983. p. 157-165.

861 AMARAL, Francisco. Individualismo e universalismo no direito civil brasileiro: permanência ou superação de paradigmas romanos?, Revista de Direito Civil, Imobiliário, Agrário e Empresarial, São Paulo, v. 19, n. 71, p. 69-86, jan./mar. 1995. p. 84.

${ }^{862}$ FIUZA, César. Direito civil: curso completo. 11 ed. Belo Horizonte: Del Rey, 2008. p. 67-68.

${ }^{863}$ CARRILHO, Cristiano. Manual de história dos sistemas jurídicos. Rio de Janeiro: Elsevier, 2009. p. 134. 
Nesse recorte temporal, vale recordar que a Igreja Católica além de ser a mais importante e sólida instituição europeia ${ }^{864}$, era o principal centro produtor de conhecimento daquele continente. Por isso, talvez seja possível sustentar, com alguma certeza, que os valores humanistas que informam a doutrina cristã e o desenvolvimento da dogmática como método de difusão daquele pensamento ${ }^{865}$ - estão entre os grandes responsáveis pela ascensão da culpa no universo do dever de reparar.

Outra conexão que se mostra viável, nesse passeio pelo tempo, é a que induz a enxergar que o recurso à culpa - e, talvez, a gênese de seu matiz subjetivo -, no universo do direito obrigacional, se encontra intimamente conectado à inserção da Igreja Católica no lugar outrora ocupado pelo Império Romano - como instituição que produz e dissemina o pensamento dominante. ${ }^{866}$ É por isso que o saber jurídico, em boa parte do território europeu, se desenvolveu como prolongamento do sistema moral ${ }^{867}$ que informava o catolicismo, saber erigido, nesse período da História, sobre bases teológicas. ${ }^{868}$ Tanto é que, as noções de livre-arbítrio, pecado, expiação e punição informaram não apenas os discursos dos sacerdotes, mas também as letras daqueles que se propunham a pensar e escrever sobre o Direito.

As balizas da responsabilidade civil, nessa quadra da História, confundem-se com os critérios ético-comportamentais prevalentes no direito canônico. A partir dessa premissa, é possível entender por que o dever de reparar foi sistematizado como uma exceção indesejada, sendo assim pensado, ao menos, nesse recorte biográfico da humanidade.

864 WIEACKER, Franz. História do direito privado moderno. 3 ed. Trad. António Manuel Botelho Hespanha. Lisboa: Fundação Calouste Gulbenkian, 2004. p. 67. "A Igreja era a força espiritual de longe mais importante; era, ao mesmo tempo, a mais coerente e a mais extensa organização social da Idade Média; finalmente, a sua ordem jurídica interna era a mais poderosa da Idade Média em termos gerais.”

${ }^{865}$ SANTOS, Rogério Dultra dos. A institucionalização da dogmática jurídico-canônica medieval. In: WOLKMER, Antonio Carlos (Org.). Fundamentos da história do direito. 4 ed. Belo Horizonte: Del Rey, 2007. p. 214. "A institucionalização canônica da dogmática [atuou como forte] elemento de construção, manutenção e manipulação da verdade, fundamentadora de uma política autoritária imposta pela Igreja Católica durante o desenrolar da Idade Média, legitimando a lógica de um discurso que irradia sua influência até os dias atuais: o próprio discurso jurídico-dogmático."

${ }^{866}$ CARVALHO, Délton Winter de. Dano ambiental futuro: a responsabilização pelo risco ambiental. Rio de Janeiro: Forense Universitária, 2008. p. 54.

${ }^{867}$ BARRETTO, Vicente de Paulo. Responsabilidade e teoria da justiça contemporânea. In: SILVA FILHO, José Carlos Moreira da; PEZZELLA, Maria Cristina Cereser (Coord.). Mitos e rupturas no direito civil contemporâneo. Rio de Janeiro: Lumen Juris, 2008. p. 59-61.

${ }^{868}$ SALDANHA, Nelson. Da teologia à metodologia: secularização e crise do pensamento jurídico. Belo Horizonte, Del Rey, 2005. p. 26-38. 
Outro discurso bastante comum nesse período afirmava que, "pela experiência, a infinidade de casos singulares se reduz a alguns casos finitos que acontecem mais geralmente, e o conhecimento destes é suficiente para a prudência humana." 869

Infira-se que a complexidade social reinante à época autorizava, àquele tempo, reflexões nesse sentido. Assim, embora hodiernamente seja claro que a culpa aprisiona o homem $^{870}$, demonstra-se como a Idade Média foi favorável à sacralização da culpa.

É oportuno resgatar, nesse momento, que tanto a força obrigatória dos $\operatorname{contratos}^{871}$ - premissa elevada, alguns séculos mais tarde, ao status de princípio jurídico , como o dever de reparar parecem ter sido construídos tendo, por fundamento basilar e comum, a noção de pecado. ${ }^{872}$ Imprudência e negligência são falhas graves, afirma Tomás de Aquino $^{873}$ e, por isso, devem ser combatidas a todo custo.

Assim, aquele que se permite influenciar por falhas que poderiam ser evitadas deve ser sancionado, e sanção aqui quer dizer punição, sofrimento, expiação, agonia. Nesse contexto, a culpa atua como o fundamento do castigo infligido ao responsável pelos danos causados a outrem ${ }^{874}$ e, não, como deveria ocorrer, enquanto critério capaz de distribuir justiça em cada situação concretamente estabelecida.

Caso fosse possível a alguém regressar no tempo, talvez trouxesse do passado a informação de que a constante alusão à culpa induzia o devedor a lembrar-se, todo o tempo e o tempo todo, que, caso não cumprisse o que prometera, mereceria ser punido. Arderia, portanto, pela eternidade, no fogo alimentado por Hades.

\footnotetext{
${ }^{869}$ TOMÁS DE AQUINO. A prudência: a virtude da decisão certa. Trad. Jean Lauand. São Paulo: Martins Fontes, 2005. p. 6-7.

${ }^{870}$ GUEDES, Paulo Sergio Rosa; WALZ, Julio Cesar. O sentimento de culpa. 2 ed. Porto Alegre: ed. do autor, 2009. p. 19-65. Vide ainda: GROENINGA, Giselle Câmara. Uma análise interdisciplinar da (in)operabilidade do conceito de culpa no direito de família. Dissertação (Mestrado) - Faculdade de Direito da USP, São Paulo, 2007. p. 25. "A culpa, na realidade, tem o efeito de diminuir a responsabilidade."

${ }^{871}$ DÍEZ-PICAZO, Luiz. Fundamentos del derecho civil patrimonial: introduccion, teoria del contrato. 5 ed. Madrid: Civitas, 1996, v. 1. p. 120.

${ }^{872}$ COSTA, Álvaro Ferreira da. Responsabilidade sem culpa, Revista da Faculdade de Direito, Curitiba, v. 4, n. 4, p. 234-250, dez. 1956. p. 238.

${ }^{873}$ TOMÁS DE AQUINO. A prudência: a virtude da decisão certa. Trad. Jean Lauand. São Paulo: Martins Fontes, 2005. p. 76-88.

${ }^{874}$ BUERES, Alberto Jesus. Derecho de daños. Buenos Aires: Hammurabi, 2001. p. 13.
} 
Nessa viagem, talvez se comprovasse, ainda, que a atividade dos glosadores e dos pós-glosadores influenciou a universalização da culpa ${ }^{875}$ na responsabilidade contratual. E, isso porque seu labor - informado, vale recordar, pela ética metafísica - se cingia à promoção de comentários sobre as possibilidades contidas em cada palavra explorada ${ }^{876}$ e sobre as relações existentes entre essas palavras.

A natureza do trabalho desenvolvido explica por que o labor desses estudiosos coopera com a atomização do estudo do Direito, com a manutenção de uma perspectiva de reprodução acrítica do conhecimento e com a universalização dos conceitos. Ao realizar suas análises de modo fragmentado, afastavam-se do viés sistêmico na leitura do Direito. Ademais, é bastante provável que tenham sido influenciados por influxos metafísicos; afinal, Deus era o centro de todas as coisas, e Sua vontade, a explicação para tudo o que acontecia.

A soma dos argumentos acima apontados dificulta e/ou impede, no que interessa a esta tese, a compreensão adequada da violação de dever como momento patológico na seara obrigacional. Mesmo na Baixa Idade Média, a literalidade das fontes prevalecia sobre a análise sistêmica ou teleológica dos distintos momentos havidos no desvelar da relação obrigacional. A visão atomística que informava o pensamento da época conduziu, ainda - é razoável aceitar -, ao surgimento da tripartição - classificando-a como grave, leve e levíssima - da culpa ${ }^{877}$, fragmentação pautada, diga-se de passagem, em paradigma de complexa aplicação concreta. ${ }^{878}$

${ }^{875}$ CAENEGEM, Raoul C. van. Uma introdução histórica ao direito privado. Trad. Carlos Eduardo Lima Machado. São Paulo: Martins Fontes, 2000. p. 71. Curioso notar que os glosadores não tinham como questionar "a doutrina do Corpus iuris, pois esse expressava a ratio scripta [e] qualquer atentado aos textos era, portanto, algo destituído de razão e sentido [até porque não era visto] como o produto de uma civilização determinada; longe de considerá-lo um documento histórico, elevavam-no à categoria de modelo universal e eterno, de revelação."

${ }^{876}$ BRITO, Alejandro Guzmán. La penetración del derecho romano en américa, Revista Chilena de Derecho, Santiago, v. 18, n. 2, p. 203-211, mai./ago. 1991. p. 207.

${ }^{877}$ TALAMANCA, Mario. Colpa. In: Enciclopedia del diritto. Milano: Giuffrè, 1960, v. 7. p. 523.

${ }^{878}$ POTHIER, Robert Joseph. Tratado das obrigações. Trad. Adrian Sotero De Witt Batista; Douglas Dias Ferreira. Campinas: Servanda, 2002. p. 128. "Quando o contrato corresponda tão somente ao simples benefício daquele a quem a coisa deve ser dada ou restituída, o devedor que está obrigado a dá-la ou restituíla está obrigado apenas a dispor de boa-fé na conservação da coisa, e, por conseguinte, só é responsável por causa de uma falta tão grande que, por sua extensão, repute-se que tenha existido dolo [...] Por exemplo, um depositário não está obrigado a dedicar mais que sua boa-fé na conservação do depósito que lhe foi confiado, e que se obrigou a restituir, uma vez que o contrato de depósito se faz apenas para o benefício daquele que confiou a coisa, a quem o depositário se obriga a devolvê-la. Se ao contrato concerne ao benefício comum dos dois contratantes, o devedor está obrigado a prestar à conservação da coisa devida o cuidado que de ordinário as pessoas prudentes têm em seus negócios, e, por conseguinte, é responsável pela mais leve falta. Por exemplo: o vendedor está obrigado por essa falta para com aquele com quem se obrigou a entregar a 
É possível compreender, nesse contexto, porque, durante a Baixa Idade Média, o Direito se preocupou mais com a tutela do agente causador do dano ${ }^{879}$ do que com a reparação das vítimas de danos injustos. E, nessa esteira, uma apertada síntese do ocorrido nessa quadra do tempo permite afirmar que a História conduziu à substituição da causalidade externa - premissa que, como visto, informou o dever de reparar antes dos influxos do cristianismo - por "uma causalidade interna", informada exclusivamente pela culpa. ${ }^{880}$

O advento da Idade Moderna traz consigo tendências como o racionalismo, o humanismo e o mercantilismo, aspectos que colaboram com o fortalecimento dos direitos nacionais. E, talvez, aqui, seja possível conectar tais aspectos com a atribuição à culpa do papel de princípio geral informativo do dever de reparar, especialmente quando são considerados os influxos jusracionalistas no processo de universalização da culpa. ${ }^{881}$

Durante o transcorrer da Idade Moderna, é que a imposição do dever de reparar foi definitivamente ligada à noção de "delito civil." Consoante o pensamento reinante à época, essa lógica exsurge como a mais perfeita expressão de um juízo de reprovação ética do comportamento do causador do dano. ${ }^{882}$

E, enquanto os anseios sociais começavam a ser transplantados para o Direito, isso ocorreu, em boa parte, diante da necessidade de manutenção do poder econômico e/ou

coisa vendida; o credor é responsável por essa falta em relação à coisa recebida em amortização, por cuja restituição se obrigou; isso porque os contratos de venda e amortização são feitos para o respectivo benefício dos contratantes. Se o contrato é feito apenas para que seja útil ao devedor, por exemplo, como quando se trata de um contrato de empréstimo, está obrigado a ter em relação à conservação da coisa não somente um cuidado comum, mas todo o cuidado possível, e, em decorrência disso, é responsável pela mais leve falta."

${ }^{879}$ BAUMAN, Zygmunt. Medo líquido. Trad. Carlos Alberto Medeiros. Rio de Janeiro: Zahar, 2008. p. 76. "Com o pecado e a punição sendo os principais instrumentos do pensamento na caixa de ferramentas da razão, a contrição e a expiação constituíam as rotinas naturais e seguras a empregar na busca de imunidade em relação ao mal e na luta para expulsá-lo do mundo dos humanos."

${ }^{880}$ COELHO, José Gabriel Pinto. A responsabilidade civil baseada no conceito da culpa. Coimbra: Imprensa da Universidade, 1906. p. 15-16.

881 NORONHA, Fernando. Desenvolvimentos contemporâneos da responsabilidade civil, Revista dos Tribunais, São Paulo, n. 761, p. 31-44, mar. 1999. p. 32-33. Nesse sentido, veja ainda: NORONHA, Fernando. $\mathrm{O}$ ato ilícito nos contratos e fora deles, Revista de Direito Civil, Imobiliário, Agrário e Empresarial, São Paulo, v. 9, n. 34, p. 34-35, out./dez. 1985. p. 41-42. LA TORRE, Antonio. Genesi e metamorfosi della responsabilità civile, Roma e America: Diritto Romano Comune, Roma, n. 8, p. 61-115, 1999. p. 97-100.

${ }^{882}$ SALVI, Cesare. La responsabilità civile. 2 ed. Milano: Giuffrè, 2005. p. 17. 
político. ${ }^{883}$ A metamorfose denunciada, longe de ter ocorrido de forma espontânea, ou de ter sido provocada por movimentos sociais, foi estimulada ideologicamente.

Tanto a Igreja Católica, em um primeiro momento, como a burguesia em ascensão, ocupando o lugar daquela na condução dos destinos da Europa, utilizaram a culpa - e com maestria - como mecanismo de disseminação dos valores que apregoavam, almejando a manutenção das estruturas de poder. Para tanto, escondiam suas reais intenções, de forma hábil e sorrateira, atrás de um discurso cativante e tentador.

O papel atribuído à culpa pelas primeiras codificações comprova tais assertivas. E, a partir daí, tal qual um dogma, passa a ser cultuada por gerações de juristas. ${ }^{884}$ Tamanho o valor a ela atribuído que, no início do século XIX, se apresenta como o único fundamento legal na atribuição do dever de reparar. ${ }^{885}$

É oportuno destacar também que, nesse momento, a culpa era compreendida em perspectiva manifestamente subjetivista. Era um elemento de natureza "pessoal e psíquica." ${ }^{, 866}$

Inspirando-se no direito justinianeo e nos ideais cristãos, se, de um lado, o recurso à culpa impedia que a mera causalidade física conduzisse à responsabilização de alguém, obtemperando, assim, o dever de reparar ${ }^{887}$, por outro, mostrava-se inaceitável a formulação de qualquer juízo que deixasse de aferir a conduta do causador do dano. ${ }^{888}$

\footnotetext{
${ }^{883}$ CÁRCOVA, Carlos María. Las teorias jurídicas post positivistas. 2. ed. Buenos Aires: Abeledo Perrot, 2009. p. 193-224.

${ }^{884}$ JOSSERAND, Louis. Evolução da responsabilidade civil, Revista Forense, Rio de Janeiro, n. 86, p. 5263, jun. 1941. p. 55. "Toda a teoria tradicional da responsabilidade repousava sobre a velha idéia de culpa: não há responsabilidade sem culpa provada; era um dogma milenário, herdado do direito romano, uma verdade primária que as gerações de juristas transmitiam de século em século, e que resistia a tudo, mesmo às transformações políticas mais violentas, às revoluções, às mudanças de legislação e às codificações."

${ }^{885}$ GIORGIANNI, Michele. L`inadempimento. Milano: Giuffrè, 1975. p. 324.

${ }^{886}$ LORENZETTI, Ricardo Luis. El sistema de la responsabilidad civil ¿una deuda de responsabilidad, un crédito de indemnización o una relación jurídica?, Revista da Ajuris, Porto Alegre, n. 63, p. 166-198, mar. 95. p. 168-170.

${ }^{887}$ CORSARO, Luigi. Colpa e responsabilità civile, Rassegna di Diritto Civile, Napoli, n. 2, p. 270-310, 2000. p. 275.

${ }^{888}$ GAMARRA, Jorge. Responsabilidad contractual objetiva. In: BUERES, Alberto Jesús; DE CARLUCCI, Aída Kemelmajer (Dir.). Responsabilidad por daños en el tercer milenio. Buenos Aires: Abeledo-Perrot, 1997. p. 114.
} 
O viés subjetivista que informava a compreensão da culpa pode ser justificado. Estando ela vinculada, por razões históricas, à concepção de pecado ${ }^{889}$ - noção da qual não conseguira separar-se, até esse momento do tempo -, era comumente equiparada a uma falta moral associada a impulsos anímicos do agente. ${ }^{890}$

Esse conceito aparentemente tão caro ao Direito era compreendido, por outras palavras, como um defeito - uma falha no âmbito da vontade de alguém ${ }^{891}$ - que impedia e/ou dificultava o desempenho de um comportamento necessário ao fiel cumprimento do programa obrigacional projetado pelas partes. Consistia, diga-se, uma vez mais, no nexo de atribuição psicológica do ato ao agente, pressupondo sempre um ato - falho, é evidente de vontade. ${ }^{892}$

Nessa esteira, De Cupis destacava ser inquestionável que a culpa estaria presente em um estado anímico passível de repreensão ${ }^{893}$, enquanto José Gabriel Pinto Coelho salientava que a culpa consistia em um especial momento psicológico, um particular estado d'alma. ${ }^{894} \mathrm{E}$, pouco tempo após Chironi aludir à culpa como um estado de ânimo informador do comportamento lesivo ${ }^{895}$, Barassi escreveu que ela poderia ser

889 HERKENHOFF, Henrique Geaquinto. Responsabilidade pressuposta. In: TARTUCE, Flávio; CASTILHO, Ricardo (Coord.). Direito civil: direito patrimonial, direito existencial. São Paulo: Método, 2006. p. 400. "Ao tempo em que o Império Romano se tornou um império cristão, abandonando o caráter laico até então preservado, passou a predominar a concepção de culpa como decorrência de uma conduta decaída, contrária à moral religiosa, associando o ilícito à idéia de pecado. Em consequiência, a obrigação de reparar o dano se concebe como apenas mais uma das muitas formas de expiação da culpa moral cristã, até certo ponto interessando antes ao próprio pecador, que ao lesado ou ao Estado. Esta concepção em que a culpa implica o desvalor do agente prevaleceu, mesmo após a queda do Império, enquanto perdurou a influência da Igreja e do Direito Canônico, determinando todo o direito cristão medieval, em cujo desenvolvimento cada vez mais freqüentemente a culpa dispensa ou substitui a causalidade, [...] uma vez que a simples intenção já era reprovável, medindo-se a indenização não tanto pela extensão do dano como pela gravidade da infração, isto é, do pecado a expiar."

${ }^{890}$ ESMEIN, Paul. La faute et sa place dans responsabilité civile, Revue Trimestrielle de Droit Civil, Paris, $\mathrm{n}$. 47, p. 481-490, 1949. p. 481-483. No mesmo sentido: HIRONAKA, Giselda Maria Fernandes Novaes. Responsabilidade pressuposta. Belo Horizonte: Del Rey, 2005. p. 37.

${ }^{891}$ CORSARO, Luigi. Colpa e responsabilità civile, Rassegna di Diritto Civile, Napoli, n. 2, p. 270-310, 2000. p. 277-279.

892 JORGE, Fernando Pessoa. Ensaio sobre os pressupostos da responsabilidade civil. Coimbra: Almedina, 1999. p. 321-330.

${ }^{893}$ DE CUPIS, Adriano. El daño: teoria general de la responsabilidad civil. Trad. Ángel Martínez Sarrión. Barcelona: Bosch, 1975. p. 185-187.

${ }^{894}$ COELHO, José Gabriel Pinto. A responsabilidade civil baseada no conceito da culpa. Coimbra: Imprensa da Universidade, 1906. p. 1-3.

${ }^{895}$ CHIRONI, Giampietro. La colpa nel diritto civile odierno: colpa contrattuale. 2 ed. Torino: Fratelli Bocca Editori, 1897. p. 6-7. 
identificada na imputabilidade moral de uma conduta que pressupõe inteligência e vontade. ${ }^{896}$

A perspectiva subjetivista de compreensão da culpa influenciou autores brasileiros, destacando-se, dentre eles, Pontes de Miranda, para quem ela seria um "defeito que se pode apontar na vontade" 897 de alguém.

Afastando, aqui, quaisquer pleonasmos, parece ser possível afirmar que, nesse momento do tempo, o subjetivismo - conformador do dever de reparar - era informado, metodologicamente, por outro subjetivismo, esse último, atuando na identificação do que poderia - e do que não poderia - ser considerado como um comportamento prenhe de culpa.

E, isso porque, sendo a culpa um "juízo de censura de que o devedor é passível” ${ }^{, 898}$, uma falha psíquica ${ }^{899}$ no agir sem a necessária prudência ${ }^{900}$ ou, ainda, uma conduta despida de diligência ${ }^{901}$, resta claro que sua perquirição só pode ser promovida a partir do comportamento analisado em si mesmo. ${ }^{902}$

A identificação da culpa, nessa realidade, é promovida a partir da aferição da situação concretamente estabelecida. Comparava-se o comportamento do causador do dano com aquele que poderia ser esperado dele próprio. ${ }^{903}$ A culpa, enquanto juízo de reprovabilidade de uma conduta - a partir da prudência e diligência exigidas do sujeito em seu atuar -, era analisada tendo por moldura as circunstâncias que envolviam a conduta

\footnotetext{
${ }^{896}$ BARASI, Lodovico. La teoria generale delle obbligazioni: 1'attuazione. Milano: Giuffrè, 1946, v. 3. p. 1054. No mesmo sentido: COELHO, José Gabriel Pinto. A responsabilidade civil baseada no conceito da culpa. Coimbra: Imprensa da Universidade, 1906. p. X.

${ }^{897}$ PONTES DE MIRANDA, Francisco Cavalcanti. Tratado de direito privado: parte especial. 2 ed. Rio de Janeiro: Borsoi, 1958, t. 23. p. 71. Continua o autor, ao frisar que se "que o agente, no que quis, passou o limite em que a sua atividade ou a sua omissão seriam sem defeito."

${ }^{898}$ FARIA, Jorge Leite Areias Ribeiro de. Direito das obrigações. Coimbra: Almedina, 1990, v. 2. p. 402.

${ }^{899}$ VON THUR, Andreas. Tratado de las obligaciones. Trad. W. Roces. Madrid: Reus, 1934, t. 2. p. 97.

900 ÁGUILA, Ramón Domínguez. La culpa en el derecho civil chileno - aspectos generales, Revista Anales Derecho UC, Santiago, v. 3, p. 107-138, mar. 2008. p. 116-117.

901 TALAMANCA, Mario. Colpa. In: Enciclopedia del diritto. Milano: Giuffrè, 1960, v. 7. p. 519.

902 MOREIRA, Guilherme Alves. Instituições do direito civil português: das obrigações. Coimbra: Coimbra, 1925, v. 2. p. 114. "É, portanto necessário, para que se dê a imputação de responsabilidade, não só que o devedor seja susceptível de culpa em abstrato, isto é, em relação à diligência de que usa um homem normal ou um bom chefe de família, mas que seja susceptível dum grau de diligência tal, que pudesse prever e evitar o dano que causou ao credor em virtude do não cumprimento da obrigação."

${ }^{903}$ LIMA, Alvino. Responsabilidade do depositário no caso fortuito ou de força maior, Revista Forense, Rio de Janeiro, v. 42, n. 103, p. 447-448, jul./set. 1945. p. 448.
} 
concretamente desempenhada, o tempo e o lugar em que fora praticada ${ }^{904}$ e, ainda, as características pessoais do causador do dano.

Se a culpa exprime a voluntariedade de um comportamento, é mais que evidente que deva ser apreciada em concreto ${ }^{905}$, considerando, dentre outros aspectos, as características delineadoras da relação obrigacional e as circunstâncias pessoais, temporais e geográficas ${ }^{906}$ que compunham a realidade fática na qual o dano teve gênese.

Em síntese, a moldura subjetiva exige a análise da aptidão do devedor para antever que a lesão havida poderia derivar do seu comportamento ${ }^{907}$ e, consoante o modelo proposto, a culpa precisaria ser individualizada. ${ }^{908}$ Embora tenha se afirmado que a análise da culpa, em concreto, importaria no agravamento da situação do devedor ${ }^{909}$, não parece que essa consequência possa ser considerada regra. E, isso porque um dos motivos que conduzem ao próximo passo na evolução do tema exsurge das críticas dirigidas à função de filtro - atuando em nível subliminar (ou não), pré-processual ou jurisdicional - exercida pelo matiz subjetivo da culpa.

Apesar da afinidade entre o modelo subjetivo de compreensão do fenômeno sob análise e a perspectiva concreta de apreciação da culpa na identificação do dever de reparar, em cada situação que o exija, é bastante comum encontrar autores subjetivistas defendendo a necessidade de aferição da conduta culposa a partir de modelos abstratos ${ }^{910}$;

${ }^{904}$ GHERSI, Carlos Alberto. Teoría general de la reparación de daños. Buenos Aires: Astrea, 1997. p. 108118.

905 JORGE, Fernando Pessoa. Ensaio sobre os pressupostos da responsabilidade civil. Coimbra: Almedina, 1999. p. 336.

${ }^{906}$ BUERES, Alberto Jesus. Derecho de daños. Buenos Aires: Hammurabi, 2001. p. 346.

907 AGOGLIA, María Martha; BORAGINA, Juan Carlos; MEZA, Jorge Alfredo. Responsabilidad por incumplimiento contractual. Buenos Aires: Hammurabi, 2003. p. 83-86. Veja ainda: GOMES, Orlando. Obrigações. 9 ed. Atual. Humberto Theodoro Junior. Rio de Janeiro: Forense, 1994. p. 268. "No rigor da lógica, a concepção subjetiva conduz à individualização da culpa, visto que, se alguém somente deve ser considerado responsável quando o ato que praticou lhe pode ser moralmente imputável, não se compreende que se desprezem ou se ignorem suas condições pessoais."

${ }^{908}$ GOMES, Orlando. Culpa x risco, Revista Forense, Rio de Janeiro, v. 37, n. 83, p. 378-384, set. 1940. p. 382. "A culpa, como elemento psicológico determinante da responsabilidade, somente pode ser estimada levando-se em consideração as condições subjetivas do agente. Numa palavra, o subjetivismo pressupõe necessariamente a individualização da culpa. Em cada oportunidade onde deve ela ser investigada, mister se faz um exame da individualidade do agente para se verificar se o ato pode ser considerado gerador de responsabilidade. Se alguém somente pode ser considerado responsável quando o ato que praticou the pode ser moralmente imputado, é preciso levar em conta, sobretudo, seu complexo individual."

${ }^{909}$ BIONDI, Biondo. Istituzioni di diritto romano. 2 ed. Milano: Giuffrè, 1952. p. 338.

${ }^{910}$ CHIRONI, Giampietro. La colpa nel diritto civile odierno: colpa contrattuale. 2 ed. Torino: Fratelli Bocca Editori, 1897. p. 51-60. No mesmo sentido: MAZEAUD, Henri; MAZEAUD, Léon; TUNC, André. Tratado 
método pautado na comparação da realidade fática - da conduta, externalizada por alguém, concretamente situado - com uma imagem previamente formulada, sob uma tela imaginária, retratando a pitoresca figura do bom pai de família.

$\mathrm{E}$, em que pese sua coerência interna, o modelo subjetivo não escapa às críticas. A primeira se expressa na dificuldade em se aferir, com segurança, se houve ou não falta de habilidade ou aptidão do devedor para antever as consequências da postura que informou sua conduta. Infira-se que investigações pautadas em paradigmas subjetivos são sempre deveras complexas.

A segunda, na complexidade de identificação de quais - e quantas - seriam as balizas que permitiriam afirmar como culposa (ou não) uma dada conduta ${ }^{911}$, problema que se amplifica na atualidade, diante da constatação de que a solidez das relações se liquefez.

Uma terceira questão está ligada a como saber a quem será dado o poder de eleger as balizas regulatórias que permitam aferir o que é (ou não) uma conduta culposa. As críticas tecidas são suficientes para revelar que o modelo subjetivo é responsável pela produção de manifesta instabilidade no universo do dever de reparar.

Tudo isso autoriza afirmar que são patentes as impropriedades inerentes à perquirição psicológica da culpa e ao processo de demarcação de seus contornos. A problemática é ampliada em sociedades plurais, nas quais coexistem modos de vida completamente distintos e desconectados. Agrava-se em países nos quais, concomitantemente, certas comunidades vivem como se a Revolução Industrial não tivesse ocorrido, e outras fruem os benefícios provocados pelos avanços tecnológicos.

E se, de um lado, é inconteste que são muitas as realidades sociais existentes dentro da vastidão de países como o Brasil, de outro, é preciso sempre salientar que o Direito não pode fechar seus olhos para essa constatação, especialmente porque, há muito tempo, aquele sujeito de direitos concebido pelas grandes codificações não habita mais entre nós.

teórico y práctico de la responsabilidad civil delictual y contractual. Trad. Luis Alcalá Zamora y Castillo. Buenos Aires: Ediciones Jurídicas Europa-América, 1962, v. 2, t. 1. p. 423.

${ }^{911}$ LIMA, Alvino, Culpa e risco. 2 ed. São Paulo: RT, 1999. p. 57. "Temos uma obrigação legal de agir com prudência e diligência em todos os atos de nossas atividades; seria impossível fixar os princípios ou regras desta conduta, ou determiná-los para cada indivíduo particularmente [...] tal sistema subjetivo de responsabilidade, além de insustentável e deficiente, traria dificuldades práticas insuperáveis.” 
Afirme-se aqui, entretanto, que, independentemente do viés de aferição abstrato ou concreto - e apesar dos diversos problemas que a análise subjetiva da culpa acarreta, é inegável ser esse o seu melhor retrato. A culpa possui profundo substrato subjetivo. $^{912}$ É, assim, portanto, que deve ser compreendida. Não é possível aceitar sua intelecção, senão a partir de considerações de ordem subjetiva. ${ }^{913} \mathrm{E}$, se essa culpa não se amolda à realidade da sociedade contemporânea, deverá ser substituída por outro vetor mais adequado à satisfação das necessidades sociais hodiernas.

Apesar da transparência da constatação formulada, em vez de se promover a substituição da culpa por outro fator de valoração do dever de reparar mais adequado aos problemas contemporâneos, optou-se por sua reconfiguração.

$\mathrm{Na}$ contemporaneidade, a análise subjetiva que, até então, permeava a compreensão da culpa foi gradativamente afastada. ${ }^{914}$ É possível, de modo cada vez mais transparente, apreender o fenômeno em perspectiva objetiva. Optou-se por vestir e maquiar - talvez disfarçar - a culpa de tal modo que, enxergar sua essência é quase impossível.

Não se nega que a compreensão da culpa em perspectiva subjetiva se mostrou incapaz de solucionar os conflitos surgidos nas relações cotidianas a partir do fim da era industrial. O que não se aceita - como será adiante explicitado - é a objetivação de uma figura que, ontologicamente, se encontra atada às subjetividades que formam e informam as condutas de sujeitos concretamente situados.

É relevante resgatar o fato de que outros problemas paralelos, como a dificuldade de explicar satisfatoriamente a figura da culpa inconsciente (?) ou culpa sem

\footnotetext{
912 PEREIRA, Alexandre Pimenta Batista. Os confins da responsabilidade objetiva nos horizontes da sociologia do risco: almejando a permanente certeza na contingência das improbabilidades, Revista de Informação Legislativa, Brasília, v. 43, n. 170, p. 181-189, abr./jun. 2006. p. 184. "Produto do século XVII, a culpa designava a idéia de censura moral do dano, enfatizada na reprovação da consciência; alicerçava, ainda, o dever de justiça, consubstanciando os adágios suum cuique tribuere e neminem laedere." Nesse sentido: GAMARRA, Jorge. Incidencia del problema de la carga de la prueba en la fundamentación de la responsabilidad civil, Revista de la Facultad de Derecho y Ciencias Sociales, Montevideo, v. 2, n. 3, p. 639665, 1951. p. 655.

913 GUEDES, Paulo Sergio Rosa; WALZ, Julio Cesar. O sentimento de culpa. 2 ed. Porto Alegre: ed. do autor, 2009. p. 19-118. GROENINGA, Giselle Câmara. Uma análise interdisciplinar da (in)operabilidade do conceito de culpa no direito de família. Dissertação (Mestrado) - Faculdade de Direito da USP, São Paulo, 2007. p. 13-14. "As contribuições da Psicanálise visam [sic] demonstrar que a culpa tem qualidades permeadas por aspectos inconscientes, com manifestações e conseqüências que, embora sejam verificáveis na realidade das relações, trazem impedimentos na utilização do conceito enquanto categoria jurídica."

${ }^{914}$ BUSSANI, Mauro. As peculiaridades da noção de culpa: um estudo de direito comparado. Trad. Helena Saldanha. Porto Alegre: LAEL, 2000. p. 47-62.
} 
previsão $^{915}$ (?) e, ainda, a culpa dos incapazes (?) - teses apegadas a um passado que provavelmente não retornará - cooperam com a releitura de um conceito lentamente construído através do tempo. Consoante avança o século XX, aquela culpa forjada por aproximadamente 1500 anos torna-se cada vez menos útil e, como denunciado, passa por uma metamorfose.

Nesse processo de transformação ${ }^{916}$, em um primeiro momento, apesar de ser lida a partir de parâmetros subjetivos - tendo em conta quem é a parte e quais são suas características pessoais -, sua aferição se afasta das subjetividades do causador do dano. O modelo abstrato de verificação da culpa passa de exceção à regra, o que implica ignorar boa parte das peculiaridades do caso concreto.

Ao se propor a identificação da culpa a partir da comparação de condutas - a do caso concreto, com a do modelo abstrato -, basta que aquela destoe desta para que a conduta reprimida pelo Direito se caracterize. A culpa passou a ser compreendida como um critério psiconormativo-social desprovido de qualquer influência moral ou religiosa. ${ }^{917}$

Em verdade, o que o constante passar do tempo demonstrou é que a culpa é mais sócionormativa do que psíquica. Isso pode ser percebido quando aquela é tratada como um "erro de conduta", cuja aferição será promovida abstratamente ${ }^{918}$, mediante

915 AGOGliA, María Martha; BORAGINA, Juan Carlos; MEZA, Jorge Alfredo. Responsabilidad por incumplimiento contractual. Buenos Aires: Hammurabi, 2003. p. 70-71.

916 TRIMARCHI, Pietro. Istituzioni di diritto privato. 11 ed. Milano: Giuffré, 1996. p. 347. No mesmo sentido: RESCIGNO, Pietro. Danno ingiusto e ruolo della colpa: un profilo storico, Rivista de Diritto Civile, Padova, anno 36, n. 2, p. 133-155, mar./abr. 1990. p. 149. O autor, ao lecionar sobre a concepção de culpa, destaca que, "para alguns, é critério de valoração de comportamento, considerada, a partir daí, como ausência de diligência; para outros é sinônimo de lesão a direito protegido, o que não impede sua leitura também como critério de valoração de comportamento, entretanto, agora, centrado sobre os efeitos [do comportamento concretamente aferido]."

917 AGOGLIA, María Martha; BORAGINA, Juan Carlos; MEZA, Jorge Alfredo. Responsabilidad por incumplimiento contractual. Buenos Aires: Hammurabi, 2003. p. 73-76.

918 ÁGUILA, Ramón Domínguez. La culpa en el derecho civil chileno - aspectos generales, Revista Anales Derecho UC, Santiago, v. 3, p. 107-138, mar. 2008. p. 127. "De esta forma, llevada la idea e apreciación en abstracto a su pureza ideal, ella implica objetivar la noción de culpa, puesto que significa, en otros términos, establecer verdaderos padrones o medidas de conducta a los que ha de ajustarse el deudor o el sujeto en su actuar, de modo que cada vez que no alcanza la conducta del estándar, se concluirá en que hay culpa, con prescindencia de todo reproche moral que pueda merecer o no su acto o su omisión y con independencia de los factores subjetivos que le hayan impulsado a obrar como lo hizo. Los criterios de normalidad y de previsibilidad pasan a ser así esenciales, de forma que todo individuo en su actuar, deberá ajustarse a una verdadera malla de deberes y reacciones impuestos por el actuar del modelo con que ha de compararse la conducta del deudor o del demandado." No mesmo sentido: LÓPEZ, Andrés Mariño. Los fundamentos de la responsabilidad contractual. Montevideo: Carlos Alvarez, 2005. p. 113. "Para determinar a responsabilidade a partir de um fator de atribuição subjetivo, se compara a conduta desempenhada pelo devedor com o parâmetro objetivo e abstrato de ação exigido pela norma aplicável ao caso. Se a conduta do devedor não coincidir com o modelo de conduta devido haverá culpa, e como consequência, ser-lhe-á imputada a 
recurso a parâmetros objetivos de identificação. ${ }^{919}$ Exige-se a comparação da conduta desempenhada com aquela que deveria ser adotada pelo bom pai de família, bom profissional etc. ${ }^{920}$

O problema é que essa percepção do fenômeno ignora aspectos que permitem contextualizar a solução da celeuma tendo em conta quem é o causador do dano ${ }^{921}$, ou seja, o modelo prevalente despreza boa parte das intersubjetividades inerentes à situação que clama ao Direito por respostas. O modelo abstrato, quando não impede, dificulta a análise de uma série de questões ligadas ao cenário do dano. ${ }^{922}$

Ignorando, entretanto, esse problema, agora, não mais se questiona acerca da capacidade de o devedor cumprir a prestação, mas tão somente se seu comportamento se externalizou consoante o padrão socialmente esperado. ${ }^{923}$ A percepção da culpa exige, nesse contexto, a comparação da realidade fática com modelos pré-definidos de conduta. ${ }^{924}$

responsabilidade contratual." Veja ainda: IPPÓLITO, Rita Maria. Culpa e risco: fundamentos ou critérios de responsabilização?, Revista da Escola de Direito, Pelotas, v. 3, n. 1, p. 77-103, jan./dez. 2002. p. 81. A autora assume tal posição após afirmar, de forma retórica, que "a apreciação da culpa in concreto não pode fornecer um critério aceitável, em face dos princípios jurídicos."

919 BECKER, Anelise. Elementos para uma teoria unitária da responsabilidade civil, Revista de Direito do Consumidor, São Paulo, n. 13, p. 42-55, jan./mar. 1995. p. 43-44.

${ }^{920}$ GHERSI, Carlos Alberto. Teoría general de la reparación de daños. Buenos Aires: Astrea, 1997. p. 117.

${ }^{921}$ WILSON, Carlos Pizarro. La responsabildad contractual en el derecho chileno. In: ESPINOSA, Fabricio Mantilla; BARRIOS, Francisco Ternera (Dir.). Los contratos en el derecho privado. Bogotá: Legis, 2007. p. 218-220.

922 SCHREIBER, Anderson. Novos paradigmas da responsabilidade civil: da erosão dos filtros da reparação à diluição dos danos. São Paulo: Atlas, 2007. p. 39. "A transposição do modelo, fundado na percepção judicial, a certos contextos mostra-se mesmo impossível diante da absoluta disparidade de antecedentes culturais subjacentes ao próprio cenário em que determinados tipos de conflitos emergem [bem como a existência de] desigualdades sociais, como também a crescente complexidade da vida contemporânea, a especialização dos setores econômicos e o avanço desconcertante das novas tecnologias resultam em que, muitas vezes, o juiz se vê diante de situações às quais não se pode transportar."

923 VITA NETO, José Virgílio. A atribuição da responsabilidade contratual. Tese (Doutorado) - Faculdade de Direito da USP, São Paulo, 2007. p. 62-63. Consoante o autor, "a desconsideração dos parâmetros subjetivos de cuidado aparta, de forma radical, o critério da culpa de seu tradicional conteúdo moral, transformando-o em um conceito inteiramente diferente. A "culpa objetiva" tem em comum com o tradicional critério da culpa apenas a denominação, e rompe a unidade do conceito de culpa no ordenamento jurídico. Dentro no âmbito do direito civil, e mais especificamente no âmbito do direito contratual, o critério da culpa ganha formulação própria. É, por exemplo, bastante diversa da formulação típica do direito penal, para a qual é irrenunciável a necessidade de reprovação moral do comportamento como fundamento da pena. Criam-se, assim, diferentes definições de culpa, cada uma construída de acordo com o âmbito dogmático ao qual será aplicada. A distância entre as diferentes formulações do critério da culpa é tão acentuada que impede que se reconduzam a um princípio valorativo único, de modo a prejudicar a unidade sistemática."

${ }^{924}$ CORTÉS, Édgar. Breve nota sobre la culpa contractual y la extracontractual en el derecho colombiano, Revista Anales Derecho UC, Santiago, v. 3, p. 93-104, mar. 2008. p. 99. 
A culpa tem nova essência. Aliás, não só foi modificada, mas reconstruída. $\mathrm{E}$ reconfigurada a partir da depuração dos parâmetros éticoindividuais que orientavam o processo que visava a sua identificação.

Ocorre que, ao alargar-se a noção de culpa - com a equivocada atrofia de seu viés psicológico -, ela foi privada de sua característica mais importante ${ }^{925}$ : o viés subjetivo $^{926}$ do qual não poderia, nunca, ser alijada.

Ignorando, entretanto, tal aspecto, a aferição da culpa passou a ser promovida mediante a utilização de parâmetros objetivos. Na transição apontada, balizas sociais ${ }^{927}$ servem como moldes na identificação (ou não) de uma conduta culposa.

A afirmação de que a culpa consiste no "desvio de um padrão esperado de conduta de alguém que age de boa-fé e diligentemente" 928 torna-se discurso comum, embora não se aponte que parâmetro é esse. Isso impõe obediência a regras de conduta construídas por um legislador que acredita ser onipotente e despreza, ao mesmo tempo, o sujeito concretamente situado e as intersubjetividades inerentes às relações jurídicas obrigacionais cotidianamente pactuadas. Tal processo ignora, ainda, as dificuldades inerentes à verificação do modelo de conduta a ser seguido em cada situação.

Exsurge o conceito normativo de culpa. Ela passa a ser identificada em razão de exigências normativas. A atribuição do dever de reparar, mormente no âmbito contratual, dispensa o elemento de ordem espiritual. ${ }^{929}$

A culpa passa a ser descrita como o erro de conduta que uma pessoa diligente e cuidadosa não cometeria, se inserida em circunstâncias semelhantes às daquela a quem se

${ }^{925}$ GOMES, Orlando. Culpa x risco, Revista Forense, Rio de Janeiro, v. 37, n. 83, p. 378-384, set. 1940. p. 381.

${ }^{926}$ GUEDES, Paulo Sergio Rosa; WALZ, Julio Cesar. O sentimento de culpa. 2 ed. Porto Alegre: ed. do autor, 2009. p. 19 e 34. "Ao contrário do que se pensa, o sentimento de culpa não nos torna responsáveis. Absolutamente. E, portanto, não nos ajuda de nenhuma forma. É danoso e prejudicial à vida [mesmo porque é falsa a impressão] da possibilidade de repetição das coisas. O passado pode tornar-se presente, até por um ato de pensamento. Por outro lado, permanece aprisionado como se o tempo não tivesse a sua sequência natural." Os autores destacam, ainda, que "o sentimento de culpa não ensina nada acerca de nós mesmos, especialmente em nossas possibilidades criativas. Ele não permite que aprendamos e nos desenvolvamos."

${ }^{927}$ SALVI, Cesare. La responsabilità civile. 2 ed. Milano: Giuffrè, 2005. p. 18-19.

${ }^{928}$ MULHOLLAND, Caitlin Sampaio. A responsabilidade civil por presunção de causalidade. Rio de Janeiro: GZ, 2009. p. 43.

${ }^{929}$ CORSARO, Luigi. Colpa e responsabilità civile, Rassegna di Diritto Civile, Napoli, n. 2, p. 270-310, 2000. p. 289-299. 
atribuiu um comportamento recheado de culpa. ${ }^{930}$ Infira-se que dessa percepção derivam, pelo menos, quatro problemas: (a) identificar qual o modelo a ser utilizado; (b) descobrir se há mais de uma moldura e, nesse caso, quais os valores que permitirão optar por uma ou outra; (c) saber quem será legitimado para fincar as cercanias que separam uma conduta informada (ou não) pela culpa em cada hipótese que o exija; e, enfim, (d) saber quais deveres devem ser respeitados em cada hipótese havida no dia a dia das relações sociais. ${ }^{931}$

Ao se trabalhar a culpa como "noção social" - a partir de uma perspectiva abstrata -, é patente a dificuldade de eleição do parâmetro adequado ao qual será comparada a conduta concretamente desempenhada. E isso é um problema também porque não permite aferir que certas pessoas se encontram abaixo - ou acima - do padrão mediano de comportamento, ignorando, portanto, o matiz isonômico ${ }^{932}$ que deve permear todo o processo de realização do Direito.

Por outro lado, é extremamente complexo compreender o que seja comportamento médio em sociedades plurais. Havendo vários modelos, surge o problema de como encaixar, com serenidade e exatidão, a situação concreta na moldura adequada, sem correr o risco, uma vez mais, de afronta à isonomia constitucional.

Ademais, ao se conceber a culpa como "erro de conduta", seria possível - ao menos em tese - afastá-la mediante demonstração do erro. ${ }^{933}$ Nesse caso, entretanto, a vítima suportaria o dano injusto, o que não se coaduna com a evolução do tema, clara prova da involução na transição dos significados atribuídos à culpa.

Talvez seja possível, ainda, inferir que as construções que apregoam que a culpa consiste na violação de um dever pré-existente carregam o problema de impor o dever de reparar apenas quando se estiver diante de expressa e prévia previsão legal - ou

\footnotetext{
${ }^{930}$ HINESTROSA, Fernando. Notas sobre la responsabilidad por incumplimiento de las obligaciones. In: GESUALDI, Dora Mariana (Coord.). Derecho privado. Buenos Aires: Hammurabi, 2001. p. 1095.

931 CALIXTO, Marcelo Junqueira. A culpa na responsabilidade civil: estrutura e função. Rio de Janeiro: Renovar, 2008. p. 10.

932 BUSSANI, Mauro. As peculiaridades da noção de culpa: um estudo de direito comparado. Trad. Helena Saldanha. Porto Alegre: LAEL, 2000. p. 37-45.

${ }^{933}$ BUERES, Alberto Jesus. Derecho de daños. Buenos Aires: Hammurabi, 2001. p. 319-320. Saliente-se que o autor trabalha com a perspectiva da escusabilidade do erro, premissa essa que parece ter sido superada no direito brasileiro.
} 
contratual $^{934}$-, o que seria absolutamente insustentável, quer parecer, na realidade contemporânea. $^{935}$

E, embora se reconheça que reflexões como a apontada não se sustentam, quando o pensamento tem por lastro aspectos como o pluralismo jurídico e a força normativa dos princípios - premissas, salvo melhor juízo, desconhecidas quando nasceu à concepção normativa de culpa -, a crítica existe e, por isso, não pode ser desprezada.

Os problemas não cessam por aqui. Vale lembrar, ainda, que a avaliação da culpa em perspectiva objetiva ignora as peculiaridades inerentes ao indivíduo ${ }^{936}$, consoante apontado em outro momento desse estudo. Sem dúvida alguma, esse olhar despido de sensibilidade - exigido pelo normativismo - impede a visão detalhada das intersubjetividades inerentes ao caso concreto, afrontando os valores que devem permear todo o processo obrigacional.

Críticas à parte e informando que a dogmática codificada será analisada em momento oportuno ${ }^{937}$, fato é que, na transição do modelo subjetivo para o normativo, a culpa passa a ser vista como transgressão, "ainda que não intencional, de um dever, estabelecido especificamente por um contrato ou genericamente pela lei." $" 938$

Nesse processo, afirma-se, com acentuada frequência, que ela consiste na "violação do dever jurídico" ${ }^{939}$ ou que nasce da inobservância de uma regra de conduta. ${ }^{940}$ E, apesar da existência de autores sustentando que a culpa não pode ser concebida como sinônimo de responsabilidade ${ }^{941}$, a concepção normativa ganha destaque ${ }^{942}$, proclamando-

934 BUSTAMANTE ALSINA, Jorge. Teoria general de la responsabilidad civil. 3 ed. Buenos Aires: Abeledo-Perrot, 1980. p. 96. A culpa consiste no desrespeito a um dever de conduta ajustado no contrato.

${ }^{935}$ MAYO, Jorge. El ámbito de la culpa en el derecho de las obligaciones. In: GESUALDI, Dora Mariana (Coord.). Derecho privado. Buenos Aires: Hammurabi, 2001. p. 1287.

${ }^{936}$ BUSSANI, Mauro. As peculiaridades da noção de culpa: um estudo de direito comparado. Trad. Helena Saldanha. Porto Alegre: LAEL, 2000. p. 12-13.

937 O tema será tratado, com o rigor necessário, no item 4.1.

938 PONDÉ, Lafayette. Responsabilidade civil dos médicos, Revista Forense, Rio de Janeiro, v. 57, n. 191, p. 30-36, set./out. 1960. p. 30.

${ }^{939}$ GIORGI, Jorge. Teoria de las obligaciones en el derecho moderno. Madrid: Reus, 1977, v. 2. p. 52. No mesmo sentido: MELLO, Baptista de. Do caso fortuito e da força maior nos contractos civis, Revista dos Tribunais, São Paulo, v. 25, n. 101, p. 15-28, mai. 1936. p. 16.

940 SCAVONE JUNIOR, Luiz Antonio. Do descumprimento das obrigações: conseqüências à luz do princípio da restituição integral: interpretação sistemática e teleológica. São Paulo: Juarez de Oliveira, 2007. p. 45.

${ }^{941}$ FRANÇA, Rubens Limongi. Responsabilidade civil e abuso de direito, Revista do Advogado, São Paulo, n. 19 , p. 40-45, out. 1985. p. 40. 
se que aquela consiste na conduta que se desvia do modelo exigido pelo Direito ${ }^{943}$ ou na conduta que não alcança o objeto perseguido em razão do programa normativo. ${ }^{944}$

Curioso é que parece passar despercebido aos autores que, ao confundirem ou fundirem - a culpa com a antijuridicidade, desaparece por completo sua utilidade. Se o Direito é uma ciência prescritiva - e não meramente descritiva -, é inegável que os comportamentos que destoem de seus comandos hão de ser vistos como antijurídicos, embora não sejam necessariamente culposos. Ao mesmo tempo em que fundem as noções de culpa e de antijuridicidade - equiparando aquela à violação de um dever de conduta -, brindam à morte da culpa.

A culpa foi transformada em um conceito retórico, um adorno sem qualquer utilidade; embora, ignorando essa constatação - talvez em razão do apego à tradição e/ou da comodidade provocada por esse comportamento -, normativistas continuem a aprovar e/ou reprovar condutas a partir de parâmetros abstratamente concebidos. ${ }^{945}$

Apesar de todos os problemas apontados, muitos vêem a culpa como um erro de conduta. Dentre eles, no Brasil, podem ser apontados, Caio Mário da Silva Pereira ${ }^{946}$,

942 CORSARO, Luigi. Colpa e responsabilità civile, Rassegna di Diritto Civile, Napoli, n. 2, p. 270-310, 2000. p. 300-308. Consoante leciona o autor, "para preencher a noção de culpa [lato sensu] ingressa o dolo, a negligência, a imprudência, a imperícia, a inobservância da lei, regulamentos, ordens; isto é, a culpa consiste na violação de regras de conduta que visam à proteção de direito alheio. No mesmo sentido, SCHREIBER, Anderson. Novos paradigmas da responsabilidade civil: da erosão dos filtros da reparação à diluição dos danos. São Paulo: Atlas, 2007. p. 33-37. E, ainda: MASSIMO BIANCA, Cesare. Supervivencia de la teoría de la culpa. In: BUERES, Alberto Jesús; DE CARLUCCI, Aída Kemelmajer (Dir.). Responsabilidad por daños en el tercer milenio. Buenos Aires: Abeledo-Perrot, 1997. p. 142.

943 LORENZETTI, Ricardo Luis. Tratado de los contratos: parte general. Buenos Aires: Rubinzal Culzoni, 2004. p. 603.

${ }^{944}$ BUERES, Alberto Jesus. Derecho de daños. Buenos Aires: Hammurabi, 2001. p. 322.

945 AgOGLIA, María Martha; BORAGINA, Juan Carlos; MEZA, Jorge Alfredo. Responsabilidad por incumplimiento contractual. Buenos Aires: Hammurabi, 2003. p. 71-72.

946 PEREIRA, Caio Mário da Silva. Instituições de direito civil: teoria geral das obrigações. 20 ed. Atual. Luis Roldão de Freitas Gomes. Rio de Janeiro: Forense, 2004, v. 2. p. 330. "Moralmente (e a idéia de culpa, antes de ser jurídica já é moral), como juridicamente, há de haver uma predeterminação de conduta. O agente é adstrito a um certo procedimento. Partindo-se da idéia de que a sua conduta é predeterminada pela lei ou pela convenção, o primeiro pressuposto ressalta e fica estabelecido. O segundo é a ação voluntária do agente em contravenção a essa conduta e em contradição com aquela norma. Ele desviou-se da normação, transgrediu a regra predeterminante. Devendo seguir um rumo condizente com a norma, afastou-se dela, ainda que sem a consciência de violentá-la. Cometeu um desvio ou erro de conduta, por negligência, por desatenção, por imprudência, por omissão da observância de regras - não importa a causa. Podendo evitar ou prevenir, desviou-se da conduta imposta pela norma. E com isso causou um mal ao bem jurídico alheio. Sem a pretensão de definir, fixamos a noção de culpa com esse caráter, em que predomina um sentido objetivo de aferição." 
Carlos Roberto Gonçalves ${ }^{947}$, Fernando Noronha ${ }^{948}$, Flávio Tartuce ${ }^{949}$, Marcelo Junqueira Calixto $^{950}$, Ney da Fontoura Boccanera ${ }^{951}$, Pablo Stolze Gagliano, Rodolfo Pamplona Filho $^{952}$ e Sílvio Venosa ${ }^{953}$.

Véra Fradera, ao sustentar que a culpa consiste em uma conduta, e não, naquilo que motivou o comportamento aferido concreta e individualmente ${ }^{954}$, aparentemente, também encampa essa vertente de pensamento.

É oportuno destacar que se alude, ainda, à culpa social - "há culpa quando o autor do dano se desvia de uma norma de conduta social" $" 955$-, e que a culpa pode, nessa esteira, ser objetiva ${ }^{956}$, portanto, despida de culpabilidade. ${ }^{957}$ Apesar de não ser pacífica a

${ }^{947}$ GONÇALVES, Carlos Roberto. Direito civil brasileiro: responsabilidade civil. 3 ed. São Paulo: Saraiva, 2008 , v. 4. p. 296. "Para que haja obrigação de indenizar, não basta que o autor do fato danoso tenha procedido ilicitamente, violando um direito de outrem ou infringindo uma norma jurídica tuteladora de interesses particulares. A obrigação de indenizar não existe, em regra, só porque o agente causador do dano procedeu objetivamente mal. É essencial que ele tenha agido com culpa [e] agir com culpa significa atuar o agente em termos de, pessoalmente, merecer a censura ou reprovação do direito."

${ }_{948}$ NORONHA, Fernando. O ato ilícito nos contratos e fora deles, Revista de Direito Civil, Imobiliário, Agrário e Empresarial, São Paulo, v. 9, n. 34, p. 34-35, out./dez. 1985. p. 37.

${ }^{949}$ TARTUCE, Flávio. Direito civil: direito das obrigações e responsabilidade civil. 2 ed. São Paulo: Método, 2006, v. 2. p. 305. "A culpa pode ser conceituada como sendo o desrespeito a um dever preexistente, não havendo intenção de violar o dever jurídico, que acaba sendo violado por outro tipo de conduta."

${ }^{950}$ CALIXTO, Marcelo Junqueira. A culpa na responsabilidade civil: estrutura e função. Rio de Janeiro: Renovar, 2008. p. 359. "Inicialmente recorda-se a opção por um conceito mais próximo da chamada concepção objetiva ou normativa da culpa por ser aquela que prescinde da análise de aspectos estritamente subjetivos do agente, além de dispensar a perquirição dos graus de culpa em razão da maior ou menor reprovação da conduta desviante. Prefere-se, de fato, ver na culpa o desvio de certo padrão de conduta, padrão este fixado pela referência ao ser humano prudente nas circunstâncias do caso concreto."

951 BOCCANERA, Ney da Fontoura. Culpa aquiliana, Revista de Direito Civil, Imobiliário, Agrário e Empresarial, São Paulo, v. 7, n. 24, p. 106-108, abr.jun. 1983. p. 108. Culpa é um "erro de conduta" ou a "infração de norma preexistente."

${ }^{952}$ GAGLIANO, Pablo Stolze; PAMPLONA FILHO, Rodolfo. Novo curso de direito civil: responsabilidade civil. 5 ed. São Paulo: Saraiva, 2007, v. 3. p. 123. Segundo os autores, "a culpa (em sentido amplo) deriva da inobservância de um dever de conduta, previamente imposto pela ordem jurídica, em atenção à paz social."

${ }^{953}$ VENOSA, Sílvio de Salvo. Direito civil: responsabilidade civil. 3 ed. São Paulo: Atlas, 2003, v. 4. p. 23. "Em sentido amplo, culpa é a inobservância de um dever que o agente devia conhecer e observar."

${ }^{954}$ FRADERA, Véra Maria Jacob de. Conceito de culpa, Revista dos Tribunais, São Paulo, n. 770, p. 117122, dez. 1999. p. 119. Continua a autora ao destacar, a partir da análise do Corpus Júris Secundum, que a culpa "é uma conduta desacompanhada da atenção que tem um homem normalmente prudente, em determinadas circunstâncias, e também conduta desacompanhada de certas considerações relacionadas às consequências, a que chamamos cuidado."

${ }^{955}$ DUPICHOT, Jacques. Derecho de las obligaciones. Trad. Rosangela Calle. Bogotá: Temis, 1984. p. 64.

${ }^{956}$ SEGUí, Adela Maria. Aspectos relevantes de la responsabilidad civil moderna, Revista de Direito do Consumidor, São Paulo, v. 13, n. 52, p. 267-318, out./dez. 2004. p. 278.

957 AGOGLIA, María Martha; BORAGINA, Juan Carlos; MEZA, Jorge Alfredo. Responsabilidad por incumplimiento contractual. Buenos Aires: Hammurabi, 2003. p. 74. O que desemboca, segundo os autores, "em uma concepção positivista e amoral da culpa, cuja essência consistiria na mera desconformidade do ato com as regras de conduta." Vide ainda: QUEIROGA, Antônio Elias de. Responsabilidade civil e o novo 
recepção dessa corrente teórica ${ }^{958}$, saliente-se que tal construção deve ser rechaçada, pois, consoante denuncia Alvino Lima, aceitar a existência da culpa despida de culpabilidade não passa de mero disfarce a acobertar sua derrocada ${ }^{959}$, crítica que certamente é apta a demolir as compreensões normativistas do fenômeno sob análise.

É preciso aceitar - repita-se - que afirmar culpado todo aquele que não cumpre um dever de prestar pré-existente ${ }^{960}$ esvazia completamente a noção de culpa. Perspectivas nesse sentido implicam a manutenção da culpa como uma figura meramente decorativa, encobrindo o verdadeiro fator de atribuição do dever de reparar os danos contratuais. ${ }^{961}$

Afirmar culpado quem não cumpre um dever previamente assumido é o mesmo que dizer que outra foi a causa que desencadeou o evento lesivo. ${ }^{962}$ Por isso, reafirme-se, que, ao se visualizar a culpa como "violação da lei"963, se promove exatamente o que seus cultores não desejam: a objetivação do dever de reparar.

código civil. 2 ed. Rio de Janeiro: Renovar, 2003. p. 193.0 autor encampa corrente doutrinária bastante semelhante que denomina o fenômeno como "culpa contra a legalidade."

${ }^{958}$ BUERES, Alberto Jesus. Derecho de daños. Buenos Aires: Hammurabi, 2001. p. 328-333.

${ }^{959}$ LIMA, Alvino. Situação atual, no direito civil moderno, das teorias da culpa e do risco, Revista Forense, Rio de Janeiro, v. 37, n. 83, p. 385-389, set. 1940. p. 387-388.

${ }^{960}$ São nesse sentido as lições de: FRANÇA, Rubens Limongi. Raízes e dogmática da cláusula penal. Tese (Concurso Professor Titular) - Faculdade de Direito da USP, São Paulo, 1987. p. 194. WILSON, Carlos Pizarro. La culpa como elemento constitutivo del incumplimiento en las obligaciones de medio o de diligencia, Revista de Derecho de la Pontificia Universidad Católica de Valparaíso, Valparaíso, n. 31, p. 255-265, jul./dez. 2008. p. 263. "En materia de responsabilidad contractual, el incumplimiento constituye culpa, siendo imposible disociar ambos elementos en atención a la noción de incumplimiento de aquellas obligaciones que involucrar exigencia de diligencia para la satisfacción del acreedor."

${ }^{961}$ PICASSO, Sebastián. El incumplimiento en las obligaciones contractuales: el problema de la ausencia de culpa y de la imposibilidad sobrevenida de la prestación - obligaciones de medios y de resultado. In: GESUALDI, Dora Mariana (Coord.). Derecho privado. Buenos Aires: Hammurabi, 2001. p. 1116. "En verdad, estos intentos de preservar la culpa a todo precio reposan en la idea de que la responsabilidad por culpa es "moralizante". Hay en el fondo una presuposición cuasi intuitiva, según la cual sólo debe sancionarse a quien actúa "mal", a quien realmente "merece" ser erigido en sujeto pasivo del deber de responder. Se trata, sin embargo, de una ilusión -derivada en parte, seguramente, de la incorrecta traslación al campo técnico-jurídico del sentido que cotidianamente se asigna a la palabra "culpa" cuando es empleada en expresiones tales como "tener la culpa"-, que no sólo desconoce los modernos fundamentos del Derecho de danos, sino que tampoco cae en la cuenta de que la culpa como categoría jurídica no tiene hoy nada de moralizante ni ejemplificador. No se juega aquí una cuestión ética; se juega, simplemente, un criterio más de imputación de un daño a un responsable."

962 CORSARO, Luigi. Colpa e responsabilità civile, Rassegna di Diritto Civile, Napoli, n. 2, p. 270-310, 2000. p. 308.

${ }^{963}$ GOMES, Orlando. Responsabilidade civil do fabricante, Revista de Direito Civil, Imobiliário, Agrário e Empresarial, São Paulo, v. 9, n. 32, p. 12-21, abr./jun. 1985. p. 18. Saliente-se que o texto não destaca quais os autores que trabalham nessa perspectiva, embora o autor assevere sua existência. 
A inserção da culpa em bitolas, mediante a criação de parâmetros abstratos em sua identificação, objetivou o dever de reparar ao desprezar as características daquele que causa o dano ${ }^{964}$ e das intersubjetividades inerentes ao caso concreto.

E, no universo contratual, esse processo - de objetivação da culpa - acaba por redundar na identificação do elemento subjetivo com o não cumprimento imputável da prestação pelo devedor, tornando-a absolutamente desnecessária na caracterização do dever de reparar, afirmação que se sustenta desde as primeiras linhas desta tese, embora sob outros argumentos.

É possível inferir, assim, que os principais responsáveis pela derrocada da culpa são exatamente aqueles que não se permitiram vislumbrar a necessidade de substituíla por outros balizamentos, fantasiando, não raras vezes, soluções dogmaticamente supérfluas e/ou incoerentes.

Quando se confunde a culpa com o desrespeito a um dever contratual ${ }^{965}$, retirase qualquer utilidade daquela na configuração do dever de reparar os danos contratuais. A conclusão é inafastável.

Ao encerrar esse exercício de imaginação - essa viagem a momentos prováveis, mas raramente comprováveis -, é oportuno resgatar que, muito embora, por longa data, à culpa tenha se reservado papel de destaque ${ }^{966}$ na arquitetura da responsabilidade contratual, ela nunca mereceu realmente tamanha importância.

A culpa foi - e ainda o é - um instrumento de dominação nas mãos daqueles que, ao longo dos séculos, concentraram, em suas mãos, o poder e o capital - primeiro, a Igreja, depois, a classe burguesa ${ }^{967}$, hoje metamorfoseada, mas ainda no poder. E precioso, especialmente, por conta da função de filtro que lhe é inerente.

\footnotetext{
${ }^{964}$ GOMES, Orlando. Culpa x risco, Revista Forense, Rio de Janeiro, v. 37, n. 83, p. 378-384, set. 1940. p. 383.

965 Como se percebe em: TJDFT. Ap. Cív. 2008.01.1.036124-8. Rel. Des. Waldir Leôncio Lopes Júnior. j. 23.06.2010. “[...] 1. Não demonstrada a ocorrência de caso fortuito ou de força maior, que excluem a responsabilidade pelo descumprimento da obrigação (CCB, art. 393), prepondera a presunção de culpa lato sensu. $O$ dever de indenizar decorre da obrigação contratual violada. [...]"

966 COELHO, Fábio Ulhoa. Curso de direito civil. São Paulo: Saraiva, 2004, v. 2. p. 264. "Em razão do extremo apego ao princípio da culpa - e ao valor que a alicerça, caríssimo ao capitalismo, da vontade como fonte última de todas as obrigações -, à discussão e elaboração dos fundamentos a partir dos quais se justifica imputar responsabilidade a quem agira licitamente corresponde uma trajetória não linear."

967 A questão foi explorada pormenorizadamente no item 1.1 deste trabalho.
} 
Ao lado de ideologias veladas, vale lembrar, enfim, a repetição acrítica de lições buscadas no passado e uma postura acentuadamente conservadora - propagada, especialmente, ao longo dos últimos cem anos - cooperaram para a criação de um mito - e de um monstro - que hodiernamente não possui relevância alguma na configuração jurídica do dever de reparar os danos oriundos da violação de um dever contratual.

\subsection{Do equívoco existente na distinção entre culpa aquiliana e culpa contratual}

A dicotomia entre responsabilidade contratual e aquiliana desenvolveu-se nos meandros da oposição que, por longa data, visualizava direito público e privado como dimensões antagônicas e distantes. ${ }^{968}$ Com efeito, nessa lógica, passam a coexistir duas culpas distintas. Em linhas gerais, sustenta-se - no caso, a partir de uma percepção normativa - que a culpa extracontratual consiste na ofensa a um dever genérico de não causar dano a outrem, e a contratual se configura na violação de um dever pré-determinado por uma relação obrigacional com gênese em um contrato. ${ }^{969}$

A dicotomia acima exposta é defendida no Brasil, dentre outros ${ }^{970}$, por Agostinho Oli Koppe Pereira ${ }^{971}$, Álvaro Villaça Azevedo ${ }^{972}$, Arnaldo Rizzardo ${ }^{973}$, Carlos Roberto Gonçalves $^{974}$, José Carlos Moreira Alves ${ }^{975}$, Maria Helena Diniz ${ }^{976}$, Miguel Maria

${ }^{968}$ LEONARDO, Rodrigo Xavier. Responsabilidade civil contratual e extracontratual: primeiras anotações em face do novo código civil brasileiro, Revista de Direito Privado, São Paulo, v. 5, n. 19, p. 260-269, jul./set. 2004. p. 263.

969 GONÇALVES, Carlos Roberto. Direito civil brasileiro: responsabilidade civil. 3 ed. São Paulo: Saraiva, 2008 , v. 4. p. 301. "A culpa será contratual ou extracontratual conforme a natureza do dever violado. Se tal dever se fundar em uma relação jurídica obrigacional preexistente, ter-se-á culpa contratual [situação em que] o credor deverá comprovar a mora [ou o inadimplemento] do devedor, mas não precisará demonstrar a sua culpa, porque em princípio todo inadimplemento se presume culposo."

${ }^{970}$ GAGLIANO, Pablo Stolze; PAMPLONA FILHO, Rodolfo. Novo curso de direito civil: obrigações. 8 ed. São Paulo: Saraiva, 2007, v. 2. p. 268-269. IPPÓLITO, Rita Maria. Culpa e risco: fundamentos ou critérios de responsabilização?, Revista da Escola de Direito, Pelotas, v. 3, n. 1, p. 77-103, jan./dez. 2002. p. 84-86.

971 PEREIRA, Agostinho Oli Koppe. A culpa e a responsabilidade civil no direito brasileiro, Revista da Faculdade de Direito, Caxias do Sul, n. 6, p. 116-132, mar. 1997. p. 124-130.

972 AZEVEDO, Álvaro Villaça. Teoria geral das obrigações. 10 ed. São Paulo: Atlas, 2004. p. 223.

${ }^{973}$ RIZZARDO, Arnaldo. Parte geral do código civil. 2 ed. Rio de Janeiro: Forense, 2003. p. 547-548.

974 GONÇALVES, Carlos Roberto. Comentários ao código civil: parte especial do direito das obrigações responsabilidade subjetiva, responsabilidade objetiva, responsabilidade por fato de outrem, responsabilidade profissional, etc; preferências e privilégios creditórios. São Paulo: Saraiva, 2003, v. 11. p. 301.

975 MOREIRA ALVES, José Carlos. Direito romano: instituições de direito romano. 6 ed. Rio de Janeiro: Forense, 2000, v. 2. p. 36. Haverá “culpa em sentido restrito quando [a violação de dever jurídico] decorre de 
de Serpa Lopes ${ }^{977}$, Ney da Fontoura Boccanera ${ }^{978}$, Numa do Valle ${ }^{979}$ e Orlando Gomes. ${ }^{980}$ No direito estrangeiro, a distinção pode ser detectada nas obras de Christian Larroumet $^{981}$, Colin e Capitant ${ }^{982}$, Inocêncio Galvão Telles ${ }^{983}$, Lorenzo de la Maza Rivadeneira ${ }^{984}$ e Roberto de Ruggiero. ${ }^{985}$

De um modo geral, esses autores frisam que, além de as culpas se manifestarem em universos distintos - nas searas aquiliana e contratual -, a dicotomia não só existe como é importante.

falta negligência; é a falta voluntária do cuidado necessário para que se evite o inadimplemento de uma obrigação pré-existente (e, nesse caso, se diz culpa contratual) ou a lesão de direito real ou pessoal [...]."

${ }^{976}$ DINIZ, Maria Helena. Curso de direito civil brasileiro: teoria geral do direito civil. 25 ed. São Paulo: Saraiva, 2008, v. 1. p. 552-553. Defende a autora que a culpa pode ser classificada em função da natureza do dever jurídico violado e deste modo "se tal dever se fundar num contrato, tem-se a culpa contratual [...] e se oriundo do preceito geral de direito, que manda sejam respeitadas a pessoa e os bens alheios, a culpa é extracontratual ou aquiliana."

977 SERPA LOPES, Miguel Maria de. Curso de direito civil: obrigações em geral. Atual. José Serpa Santa Maria. Rio de Janeiro: Freitas Bastos, 1989, v. 2. p. 329-331.

978 BOCCANERA, Ney da Fontoura. Culpa aquiliana, Revista de Direito Civil, Imobiliário, Agrário e Empresarial, São Paulo, v. 7, n. 24, p. 106-108, abr./jun. 1983. p. 107.

979 VALLE, Numa P. do. Do caso fortuito e de força maior: da distinção nítida entre um e outro importância prática e jurídica da distinção, Revista dos Tribunais, São Paulo, v. 30, n. 129, p. 439-449, jan. 1941. p. 440.

${ }^{980}$ GOMES, Orlando. Introdução ao direito civil. 11 ed. Atual. Humberto Theodoro Junior. Rio de Janeiro: Forense, 1995. p. 489.

${ }^{981}$ LARROUMET, Christian. La defensa de la responsabilidad contractual en derecho frances, Revista Trimestral de Direito Civil, Rio de Janeiro, n. 8, p. 151-163, out./dez. 2001. p. 156. O autor, no texto citado, limita-se a destacar que culpa contratual e extracontratual são distintas, entretanto, sem explicar o que o leva a tal conclusão.

982 COLIN, Ambrosio; CAPITANT, Henry. Curso elemental de derecho civil: teoría general de las obligaciones. 2 ed. Trad. Demofilo de Buen. Madrid: Instituto Editorial Reus, 1943, t. 3. p. 827-828.

983 TELLES, Inocêncio Galvão. Direito das obrigações. 6 ed. Coimbra: Coimbra, 1989. p. 198-200. Utilizando as expressões responsabilidade obrigacional e extra-obrigacional em vez de contratual e extracontratual, vez que, nem sempre, no primeiro caso, a obrigação deriva do incumprimento de um contrato.

984 RIVADENEIRA, Lorenzo de la Maza. Responsabilidad contractual, Revista Chilena de Derecho, Santiago, v. 16, n. 3, p. 619-634, set./dez. 1989. p. 620-628. Argumenta o autor que, enquanto, na responsabilidade extracontratual, a gravidade da culpa é irrelevante; na contratual, o devedor pode exonerarse demonstrando ter agido consoante a diligência exigida para a hipótese.

${ }^{985}$ RUGGIERO, Roberto de. Instituições de direito civil: direito das obrigações, direito hereditário. Trad. Paolo Capitanio. Campinas: Bookseller, 1999, v. 3. p. 166-167. Ao tratar do tema, salienta o autor que se origina "tanto uma como outra uma obrigação ao id quod interest entre o autor e a vítima do dano; mas ao passo que na contratual o pressuposto é uma relação à qual o id quod interest se substitui ou se acrescenta, na aquiliana falta esse pressuposto e a indenização aparece como o objeto primário e originário da obrigação [destacando-se ainda que] diferenças profundas também existem quanto à medida do dano a indenizar, à forma e à graduação da culpa." 
Na primeira das hipóteses, o parâmetro que baliza a compreensão do fenômeno é de ordem psíquica, o que não ocorre na última, na qual a culpa há de ser aferida de modo objetivo. $^{986}$

Curiosamente e em sentido diametralmente oposto, defende-se que a culpa contratual seria menos severa com quem deixa de observá-la, quando comparada à aquiliana ${ }^{987}$, e isso porque "as partes livremente se escolheram e livremente contrataram, isto é, entraram voluntariamente em relações à que não eram obrigadas"988, reflexão que parece derivar da classificação da culpa em graus - grave, leve e levíssima -, afastando, do universo contratual, a culpa levíssima.

Tais teses perderam sua razão de ser.

Afastada, aqui, a discussão sobre o ambiente em que se manifesta o fenômeno - por nada acrescentar ao debate - percebe-se que, na primeira das justificativas, se exige a utilização de modelos distintos. Nesse contexto, recorre-se ao modelo subjetivo - cuja aferição é formulada em concreto ou em abstrato ${ }^{989}$, consoante a vertente doutrinária eleita - na seara aquiliana e, ao objetivo-abstrato, como quadro conveniente à solução dos problemas na esfera contratual. Em princípio, perceba-se que a distinção, hodiernamente, parece afrontar a isonomia constitucional.

Também é difícil compreender como a culpa contratual pode ser menos prejudicial ao devedor. O modelo objetivo de aferição de culpa é mais rigoroso quando comparado ao subjetivo - este último é mais maleável aos argumentos daquele a quem se atribuiu a culpa. Desse modo, não é aceitável que o devedor se sinta mais (ou menos) confortável no universo contratual do que na seara extracontratual, quando se cogita acerca da arquitetura do dever de reparar. E, independentemente do problema apontado, fato é que, em um e em outro caso, o viés de análise, uma vez mais, despreza a diretriz constitucional da isonomia.

\footnotetext{
986 VISINTINI, Giovanna. Tratado de la responsabilidad civil: la culpa como criterio de imputación de la responsabilidad. Trad. Aída Kemelmajer de Carlucci. Buenos Aires: Astrea, 1999, v. 1. p. 227-241.

${ }^{987}$ AMÉZAGA, Juan José. Culpa aquiliana: leciones del curso de derecho civil. Montevideo: s/e, 1914. p. 57.

${ }^{988}$ COELHO, José Gabriel Pinto. A responsabilidade civil baseada no conceito da culpa. Coimbra: Imprensa da Universidade, 1906. p. 224-225.

${ }^{989}$ Esse viés foi aparentemente afastado, contemporaneamente, pelo recurso a noção de culpa normativa.
} 
Outro problema acarretado pelo viés teórico segundo o qual a culpa contratual é mais benevolente que a aquiliana - e perceba-se aqui o equívoco existente, fundado na necessidade de penalização do causador do dano - aloca-se na dificuldade de qualificação da culpa em graus e na duvidosa recepção dessa classificação pelo direito brasileiro. Retiradas suas escoras, a construção vem a baixo.

A dicotomia parece também estar ligada a dois equívocos conceituais: (a) a visualização da culpa como ausência de cumprimento na seara contratual e (b) a atribuição dos ônus probatórios. ${ }^{990}$

Como aquele será tratado logo à frente, destaque-se, aqui, que o último dos problemas denunciados não pode ser tratado como um aspecto suficiente na formulação de um quadro classificatório próprio. A diferença no regime probatório - que, diga-se de passagem, não é absoluta -, ainda que seja patente, se apresenta como precária para legitimar qualquer classificação estrutural, limitando-se a atuar como uma peculiaridade em um ou outro caso.

Retomando o primeiro dos pontos, releva destacar que são vários os autores que desenvolvem seus estudos a partir da perspectiva que identifica a culpa com o não cumprimento de uma prestação nascida de um contrato. Dentre eles, Jacques Dupichot defende que a culpa contratual "se define diretamente como a inexecução de compromissos livremente assumidos, pois, para o 'bom contratante', inexecução significa culpa."991

Seguindo essa trilha, sustenta-se que a culpa, "nas relações contratuais, consiste no inadimplemento de obrigação anteriormente assumida." 992 Percorrendo caminho semelhante, assevera-se que o inadimplemento constitui, "ao mesmo tempo, a realização do dano e a demonstração da culpa." "993 Enfim, salienta-se que, uma vez

\footnotetext{
990 DINIZ, Maria Helena. Curso de direito civil brasileiro: teoria geral do direito civil. 25 ed. São Paulo: Saraiva, 2008, v. 1. p. 553. "Quem pedir indenização pela culpa contratual não precisa prová-la, basta constituir o devedor em mora; se, contudo, pretender indenização pela culpa aquiliana, é necessário provála."

${ }^{991}$ DUPICHOT, Jacques. Derecho de las obligaciones. Trad. Rosangela Calle. Bogotá: Temis, 1984. p. 65.

992 MARQUES, Henrique Paulo Azevedo. Da responsabilidade civil em face dos acidentes de trânsito, Revista dos Tribunais, São Paulo, v. 38, n. 181, p. 510-517, set. 1949. p. 513.

993 CAMPISTA FILHO, David. Responsabilidade civil e a ação liberatória do seguro, Revista dos Tribunais, São Paulo, v. 31, n. 137, p. 16-25, mai. 1942. p. 20.
} 
prometido um resultado, será "suficiente constatar a inexecução", para que se caracterize "a culpa contratual." 994

O equívoco dessas construções pode ser facilmente demonstrado. ${ }^{995}$ É inaceitável que se confunda a violação de dever contratual - em quaisquer de suas modalidades - com a culpa.

Mais que isso. Ao promover-se tal sinonímia, como outrora observado, afastase a exigência - ou necessidade - da culpa na imposição do dever de reparar e, quase sem querer, também a partir desses argumentos, os autores comprovam a tese defendida neste trabalho - ou seja, que a culpa não tem serventia alguma na conformação da responsabilidade contratual -, atirando em seus próprios pés.

É fácil perceber por que a classificação dicotômica da culpa não só é desnecessária, como também é completamente despida de fundamentos sólidos, e isso, mesmo em perspectiva dogmática. A culpa é uma só, consoante ensinam Aguiar Dias ${ }^{996}$, Alfredo Colmo ${ }^{997}$ e Chironi ${ }^{998}$, e não há argumentos válidos que legitimem as tentativas de bipartição do tema.

No Brasil, aliás, além do autor destacado, esse é o pensamento de Caio Mário da Silva Pereira ${ }^{999}$, Marcelo Junqueira Calixto ${ }^{1000}$ e Sílvio de Salvo Venosa ${ }^{1001}$ e, no direito

${ }^{994}$ WALD, Arnoldo. Da responsabilidade civil contratual e delitual, Revista Forense, Rio de Janeiro, v. 72, n. 256, p. 107-123, out./dez. 1976. p. 117.

995 GAMARRA, Jorge. Incidencia del problema de la carga de la prueba en la fundamentación de la responsabilidad civil, Revista de la Facultad de Derecho y Ciencias Sociales, Montevideo, v. 2, n. 3, p. 639665 , 1951. p. 655. Consoante o autor, o não cumprimento da obrigação não é sinônimo de culpa já que há necessidade de qualificá-lo como imprudente ou negligente. Vai além, ao frisar que "pensar o contrário seria intolerável perante o conceito subjetivo de culpa."

${ }^{996}$ AGUIAR DIAS, José de. Da responsabilidade civil. 10 ed. Rio de Janeiro: Forense, 1995, v. 1. p. 129.

${ }^{997}$ COLMO, Alfredo. De las obligaciones en general. Buenos Aires: Jesus Menendez, 1920. p. 84-92.

${ }^{998}$ CHIRONI, Giampietro. La colpa nel diritto civile odierno: colpa contrattuale. 2 ed. Torino: Fratelli Bocca Editori, 1897. p. 19-24.

${ }^{999}$ PEREIRA, Caio Mário da Silva. Responsabilidade civil: de acordo com a constituição federal de 1988. 8 ed. Rio de Janeiro: Forense, 1997. p. 70. Do mesmo autor: PEREIRA, Caio Mário da Silva. Instituições de direito civil: teoria geral das obrigações. 20 ed. Atual. Luis Roldão de Freitas Gomes. Rio de Janeiro: Forense, 2004, v. 2. p. 331. "A culpa contratual e a aquiliana partem da mesma idéia ética e induzem para o responsável a mesma conseqüência. Nesse ponto, a concepção tradicional choca-se com a noção moderna, já que aquela as diferençava, enquanto que esta as aproxima e identifica, com toda razão."

${ }^{1000}$ CALIXTO, Marcelo Junqueira. A culpa na responsabilidade civil: estrutura e função. Rio de Janeiro: Renovar, 2008. p. 361.

${ }^{1001}$ VENOSA, Sílvio de Salvo. Direito civil: responsabilidade civil. 3 ed. São Paulo: Atlas, 2003, v. 4. p. 2526. 
estrangeiro, outra não é a posição sustentada por Amézaga ${ }^{1002}$, Carlos Alberto Ghersi ${ }^{1003}$, Félix Alberto Trigo Represas ${ }^{1004}$, José Gabriel Pinto Coelho ${ }^{1005}$, Pietro Rescigno ${ }^{1006}$ e Ramón Domínguez Águila. ${ }^{1007}$

É imperioso concluir pela unidade conceitual da culpa, ainda que, em pontos secundários, haja diferenças. A culpa é uma só, reafirme-se, mesmo diante da possibilidade de existência de diversidade de regimes ${ }^{1008}$ na caracterização do dever de reparar. Não há como pensar de modo distinto, até porque o quadro filosófico no qual a dicotomia foi concebida resta completamente superado.

Por isso, a independência sustentada entre responsabilidade contratual e aquiliana - figuras cuja origem remonta à noção de violação de dever pré-existente ${ }^{1009}-$, como se percebe, apesar da distinção de regimes normativos ${ }^{1010}$ no tratamento do dever de reparar, não se sustenta.

1002 AMÉZAGA, Juan José. Responsabilidade por culpa: unidade genérica e diferenças específicas, Revista Forense, Rio de Janeiro, v. 35, n. 75, p. 67-73, jul./set. 1938. p. 69-73. Do mesmo autor: AMÉZAGA, Juan José. Culpa aquiliana: leciones del curso de derecho civil. Montevideo: s/e, 1914. p. 3-11. Embora, reconhece o autor, possa ser aferida em graus distintos, consoante se trate de hipótese com gênese no incumprimento de obrigação pré-existente ou no universo aquiliano.

${ }^{1003}$ GHERSI, Carlos Alberto. De Velez a Borda un cambio ideológico trascendente, que no se complementó en el rápido acceso a la justicia. In: GHERSI, Carlos Alberto (Dir.). Responsabilidad: problemática moderna. Mendoza: Ediciones Jurídicas Cuyo, 1996. p. 23.

${ }^{1004}$ REPRESAS, Félix Alberto Trigo. La buena fe y su relación con la responsabilidad civil. In: CÓRDOBA, Marcos (Dir.). Tratado de la buena fe en el derecho: doctrina nacional. Buenos Aires: La Ley, 2004, v. 1. p. 213.

1005 COELHO, José Gabriel Pinto. A responsabilidade civil baseada no conceito da culpa. Coimbra: Imprensa da Universidade, 1906. p. 9-12.

${ }^{1006}$ RESCIGNO, Pietro. Danno ingiusto e ruolo della colpa: un profilo storico, Rivista de Diritto Civile, Padova, anno 36, n. 2, p. 133-155, mar./abr. 1990. p. 147. Afirmando o autor, que a culpa é uma só, embora possam ter características que levem a distinções em razão de sua origem e gradação.

${ }^{1007}$ ÁGUILA, Ramón Domínguez. La culpa en el derecho civil chileno - aspectos generales, Revista Anales Derecho UC, Santiago, v. 3, p. 107-138, mar. 2008. p. 118.

${ }^{1008}$ GHERSI, Carlos Alberto. Teoría general de la reparación de daños. Buenos Aires: Astrea, 1997. p. 112114.

${ }^{1009}$ MARTINS-COSTA, Judith. Comentários ao novo código civil: do inadimplemento das obrigações. Rio de Janeiro: Forense, 2003, v. 5, t. 2. p. 97.

${ }^{1010}$ ALPA, Guido. Responsabilità civile e danno: lineamenti e questioni. Imola: Il Mulino, 1991. p. 17-18. Veja ainda: LEONARDO, Rodrigo Xavier. Responsabilidade civil contratual e extracontratual: primeiras anotações em face do novo código civil brasileiro, Revista de Direito Privado, São Paulo, v. 5, n. 19, p. 260269, jul./set. 2004. p. 260-269. O autor demonstra a existência de diferenças no que tange ao início da fluência dos juros de mora, ao regime probatório, ao foro competente para a solução dos litígios e que o prazo prescricional da pretensão à reparação de danos sofridos na seara extracontratual é trienal, enquanto, na contratual, seria decenal. 
A existência de diferenças sutis, como dito, não afasta a possibilidade de tratamento unificado do dever de reparar - e, muito menos, a cisão da culpa -, especialmente porque aquele, independentemente da origem, recorre à idêntica técnica sancionatória. ${ }^{1011}$ Assevere-se, entretanto, no que tange a esse último ponto, que a questão não é pacífica ${ }^{1012}$ - existindo teses monistas, dualistas e híbridas -, tema que, por extrapolar os limites deste trabalho, é aqui apenas referenciado.

\subsection{A equiparação entre as obrigações de meio, de resultado e de garantia ${ }^{1013}$}

A classificação binária das obrigações ${ }^{1014}$ foi construída - e isso raramente é dito - com o escopo de ampliar as possibilidades de exclusão do dever de reparar. O modelo teórico visava a atenuar o rigor do objetivismo vigente ${ }^{1015}$, e não, como pode parecer ao leitor, ampliar as hipóteses de reparação dos danos suportados injustamente pelo credor.

E, embora a dicotomia tenha sido erigida em uma época na qual os efeitos colaterais do avanço da técnica cresciam de forma avassaladora, aparentemente, tal realidade foi desprezada na formatação das obrigações de meio e de resultado.

1011 MENEZES CORDEIRO, Antônio Manuel da Rocha e. Direito das obrigações. Lisboa: Associação Acadêmica da Faculdade de Direito de Lisboa, 1986, v. 2. p. 275.

1012 COSTA, Mário Júlio de Almeida. Estudos de direito civil brasileiro e português: I jornada luso-brasileira de direito civil. São Paulo: RT, 1980. p. 95. "Escuso salientar o transcendente relevo desta área do direito das obrigações. É sabido que no sistema anglo-americano a responsabilidade ou ilícito civil constitui mesmo um universo contraposto ao dos contratos. Pode dizer-se, realmente, que nos sistemas comom law não existe um domínio jurídico unificado que corresponda ao direito das obrigações dos sistemas romano-germânicos em que nos integramos. A respectiva matéria encontra-se organizada em torno desses dois temas básicos: o dos contratos (contracts, law of contracts), e o dos atos ilícitos (torts). Trata-se de duas esferas autônomas que se bastam a si próprias, sem convergirem na categoria global do direito das obrigações."

1013 Informe-se que, sem prejuízo da possibilidade teórica de que as discussões sobre esse tema sejam desenvolvidas também na ambiência da responsabilidade aquiliana, as ideias e reflexões aqui apresentadas restringem-se ao universo das relações contratuais.

${ }^{1014}$ Que surge merecendo, dentre outras, a crítica de desprezar a existência das obrigações de garantia.

${ }^{1015}$ VITA NETO, José Virgílio. A atribuição da responsabilidade contratual. Tese (Doutorado) - Faculdade de Direito da USP, São Paulo, 2007. p. 28-30. No mesmo sentido: RUIZ, Roberto Martinez. Obligaciones de medio y de resultado. La Ley, Buenos Aires, t. 90, p. 756-760, abr./jun. 1958. p. 756-757. Segundo o autor, a classificação surge para atenuar o rigor do objetivismo na caracterização da impossibilidade exonetatória invertendo os ônus probatórios em desfavor da vítima. 
Deveras importante resgatar que o modelo binário - batizado por René Demogue e aperfeiçoado por Henry Mazeaud ${ }^{1016}$-, em sua formulação originária, longe de expurgar a culpa de uma das molduras por ele criadas - no caso, do regime inerente às obrigações de resultado -, continua a exigi-la na caracterização do dever de reparar.

No caso, trabalha com a redistribuição dos ônus probatórios ${ }^{1017}$ e, desse modo, nas obrigações de meio, a culpa deverá ser provada pelo credor lesado, enquanto, nas de resultado, será presumida, cabendo ao devedor o ônus de desconstituí-la.

Registre-se, ainda, que a influência exercida pelo enquadramento dicotômico da obrigação - em verdade, da prestação - continua angariando seguidores ${ }^{1018}$, apesar de conter um oceano de celeumas. Aliás, os inconvenientes e contradições existentes na classificação binária têm merecido rara atenção da doutrina pátria que, em regra, tem aquela como ponto de partida para suas reflexões.

Abandonando, aqui, a passividade que permeia as mentes de muitos daqueles que convivem diuturnamente com o Direito ${ }^{1019}$, é preciso apontar que, em linhas gerais, a dicotomia está ancorada em múltiplos critérios. Funda-se, assim, certas vezes, (a) no grau de determinação da prestação; em outras ocasiões, (b) na maior ou menor aleatoriedade do resultado prometido; e, enfim, (c) na intensidade da participação do credor na execução da prestação. ${ }^{1020}$

${ }^{1016}$ CÁRDENAS, Betty Mercedes Martínez. La adaptación de la teoría de las obligaciones de medios y las obligaciones de resultados en el derecho colombiano. In: ESPINOSA, Fabricio Mantilla; BARRIOS, Francisco Ternera (Dir.). Los contratos en el derecho privado. Bogotá: Legis, 2007. p. 900. Consoante a autora, diante da dificuldade de conciliar o conteúdo dos artigos 1137 e 1147 do Código Civil francês, o autor citado promoveu estudos visando à equalização da questão. Em síntese, a culpa nas obrigações de resultado era presumida a partir da exegese do artigo 1147 e nas obrigações de meio deveria ser provada pelo credor.

1017 BUERES, Alberto Jesus. Derecho de daños. Buenos Aires: Hammurabi, 2001. p. 23-27. O autor relata que a Demogue é atribuída indevidamente a paternidade da classificação, embora reconheça que o autor francês foi o primeiro a utilizar a terminologia que impera até os dias de hoje.

${ }^{1018}$ LOPEZ, Teresa Ancona. $O$ dano estético: responsabilidade civil. 3 ed. São Paulo: RT, 2004. p. 70. Segundo a autora, nas obrigações de meio, a prova da culpa do devedor pertence ao credor lesado, e nas de resultado, há inversão dos ônus probatórios. Daí que, na última hipótese, o devedor se liberta do dever de reparar provando ausência de culpa. No mesmo sentido, COMPARATO, Fábio Konder. Ensaios e pareceres de direito empresarial. Rio de Janeiro: Forense, 1978. p. 528. Consoante o autor, a dicotomia escora-se em acertada lógica e possui explícita utilidade prática. Veja ainda: STOCO, Rui. A teoria do resultado à luz do código de defesa do consumidor, Revista de Direito do Consumidor, São Paulo, n. 26, p. 200-220, abr./jun. 1998. p. 202.

${ }^{1019}$ Sobre o tema, é essencial a leitura de: GROSSI, Paolo. A formação do jurista e a exigência de um hodierno "repensamento" epistemológico, Revista da Faculdade de Direito da UFPR, Curitiba, v. 40, p. 525, 2004. p. 5-25.

${ }^{1020}$ BERDAGUER, Jaime. Las obligaciones de resultado: situación actual y perspectivas futuras. In: FERNÁNDEZ, Carlos López; CAUMONT, Arturo; CAFFERA, Gerardo (Coord.). Estudios de derecho civil en homenaje al profesor Jorge Gamarra. Montevideo: FCU, 2001. p. 37-38. 
O leitor, certamente, percebeu que a ausência de um critério transparente legitimando a classificação binária ${ }^{1021}$ é um problema a ser enfrentado. As múltiplas possibilidades de enquadramento - álea de obtenção do resultado, atividade ou passividade do credor, maior ou menor precisão da prestação, assunção dos riscos do negócio etc impossibilitam a sustentação de um quadro classificatório autônomo.

E o impedem porque, consoante o referencial utilizado para classificar a prestação, essa poderá ser alocada em uma ou outra cercania, o que não parece aceitável em qualquer quadro que se afirme científico.

Além disso, cada proposta destacada possui defeitos que tornam sua utilização deveras complexa, mormente diante da ausência de fronteiras claras no interior de cada molde abstratamente construído.

Não bastassem esses problemas, a dicotomia não suportou as vertiginosas mudanças sociais provocadas pelo caminhar do tempo, restando eclipsada diante da hodierna compreensão da complexidade que habita o espaço contratual. ${ }^{1022}$

A ausência de critérios precisos para delinear a natureza dos deveres assumidos e a utilização de marcos universais, sem a investigação das intersubjetividades inerentes ao processo obrigacional concretamente estabelecido, são ofensas ululantes - ao menos em potência - ao princípio constitucional da isonomia e, por que não, à segurança jurídica.

Uma vez percebidos as incongruências denunciadas, defende-se que a rígida distinção das obrigações de meio e resultado, mediante a fixação de critérios abstratos, não pode persistir, sendo necessária a análise de cada hipótese.

E, se, de um lado, a perspectiva é acertada, pois o estudo do tema não pode fugir da leitura da relação obrigacional concretamente estipulada, tendo como foco o negócio existente entre as partes ${ }^{1023}$, por outro, carrega consigo as patologias denunciadas outrora.

${ }^{1021}$ CÁRDENAS, Betty Mercedes Martínez. La adaptación de la teoría de las obligaciones de medios y las obligaciones de resultados en el derecho colombiano. In: ESPINOSA, Fabricio Mantilla; BARRIOS, Francisco Ternera (Dir.). Los contratos en el derecho privado. Bogotá: Legis, 2007. p. 901-903.

1022 LÓPEZ, Andrés Mariño. Los fundamentos de la responsabilidad contractual. Montevideo: Carlos Alvarez, 2005. p. 29-31 e 174-183.

1023 SCHREIBER, Anderson. A tríplice transformação do adimplemento: adimplemento substancial, inadimplemento antecipado e outras figuras, Revista Trimestral de Direito Civil, Rio de Janeiro, n. 32, p. 327, out./dez. 2007. p. 26. 
É oportuno lembrar que a dificuldade na identificação da natureza da obrigação assumida - como de meio ou de resultado -, muitas vezes, serve de divisor de águas na imposição (ou não) do dever de reparar danos injustamente suportados pela vítima ${ }^{1024}$, o que ocorre em razão dos distintos regimes adotados na imputação do aludido dever. Novamente se afere, com transparência incomum, o manifesto desrespeito à principiologia constitucional.

Resta inegável que a construção dicotômica há de ser afastada. Seus problemas teóricos conduzem à inutilidade do modelo na praxis. ${ }^{1025}$ Mas, apesar das censuras apontadas, surgem subclassificações. Adjetivam-se as obrigações de meio (atenuada, ordinária e agravada ou reforçada) e as de resultado (atenuadas, ordinárias, agravadas e absolutas). ${ }^{1026}$

Verifique-se, ainda, que novas críticas devem ser somadas às anteriores. Primeiro, por ser inafastável a conclusão de que as obrigações de meio agravada se identificam com as classificadas como sendo de resultado atenuada.

Ademais, o problema atado à ausência de um marco claro no sistema binário amplia-se na fragmentação proposta. Insta destacar, ainda, o equívoco explícito no tratamento dos deveres inerentes à conservação da coisa, os quais, ao menos na perspectiva do presente trabalho, não são concebidos como deveres de prestação, mas como deveres gerais de conduta.

Colaborando com a multiplicação das incertezas que permeiam a temática explorada, há também quem defenda a relativização da dicotomia da classificação enfocada.

\footnotetext{
${ }^{1024}$ NOGUEIRA, Lavyne Lima. Responsabilidade civil do profissional liberal perante o código de defesa do consumidor, Revista de Direito do Consumidor, São Paulo, v. 10, n. 40, p. 199-226, out./dez. 2001. p. 215217.

1025 PADILLA, Rodrigo. La responsabilidad civil del abogado y las obligaciones de medio y resultado, Revista de Responsabilidad Civil y Seguros, Buenos Aires, n. 4, p. 80-106, abr. 2006. p. 92-100.

1026 LÓPEZ, Andrés Mariño. Los fundamentos de la responsabilidad contractual. Montevideo: Carlos Alvarez, 2005. p. 163-169. Segundo a aludida construção teórica, as (a) obrigações de meio atenuadas exigiriam do devedor diligência mínima; as (b) ordinárias, diligência média; e as (c) agravadas importariam a presunção de culpa em desfavor do devedor. Por sua vez, nas (d) obrigações de resultado atenuadas, permitese que o devedor se liberte do dever de reparar demonstrando ausência de culpa; nas (e) ordinárias, imperam as ideias clássicas acerca do tema; nas (f) agravadas, só será possível invocar algumas excludentes autorizadas previamente; e nas ( $\mathrm{g}$ ) obrigações de resultado absolutas impera o risco integral, não sendo possível sequer a prova de ausência de nexo causal. São exemplos do autor: (a) a obrigação do depositário no contrato gratuito; (b) as prestações inerentes aos serviços médicos; (c) o dever do comodatário ou do depositário de conservar a coisa a ser restituída; (e) a responsabilidade do arrendatário; (f) a responsabilidade dos hoteleiros e por danos nucleares; e (g) as prestações genéricas.
} 
A partir da perspectiva da responsabilidade profissional, sustenta-se que o risco deve atuar como fator de imputabilidade nas situações em que é manifesto o despreparo do causador do dano. ${ }^{1027}$ Apesar de a ideia aparentemente estimular o aperfeiçoamento profissional - e, portanto, ampliar a tutela dos vulneráveis -, não resiste a uma análise minudente. Seu primeiro vício é o reducionismo.

Alie-se a essa questão o fato de promover o tratamento diferenciado de profissionais que tenham mais (ou melhor) acesso à informação do que outros, em razão de sua situação econômica, seu âmbito geográfico de atuação etc.

Além disso, persistem os mesmos ranços quanto às dificuldades de enquadramento. Apenas para estimular a memória e demonstrar a pertinência das críticas formuladas, vale lembrar que, ainda hoje, pairam dúvidas sobre como classificar as obrigações assumidas pelos profissionais liberais, dentre eles podendo ser lembrados os médicos ${ }^{1028}$ e os advogados.

Mas as discussões não param por aqui. Tendo por lastro a percepção dos defeitos da classificação binária, defende-se que a dicotomia deve ser afastada em prol da recepção da teoria do risco. Nessa esteira e paradoxalmente, Lavyne Lima Nogueira afirma que isso não traria problema algum, pois bastaria à parte provar que não agiu com culpa para se eximir do dever de reparar os danos a ela imputados pelo lesado. ${ }^{1029}$

${ }^{1027}$ VASCONCELOS, Fernando Antônio de. A responsabilidade do advogado à luz do código de defesa do consumidor, Revista de Direito do Consumidor, São Paulo, n. 30, p. 89-96, abr./jun. 1999. p. 95-96.

${ }^{1028}$ O que pode ser demonstrado: STJ. REsp 1.180.815/MG. 3. T. Rel. Min. Nancy Andrighi. j. 19/8/2010. "Trata-se, na origem, de ação de indenização por danos morais e estéticos, ajuizada pela ora recorrente contra o recorrido, na qual alega que foi submetida a uma cirurgia estética (mamoplastia de aumento e lipoaspiração), que resultou em grandes lesões proliferativas - formadas por tecidos de cicatrização - nos locais em que ocorreram os cortes da operação. Ora, o fato de a obrigação ser de resultado, como o caso de cirurgia plástica de cunho exclusivamente embelezador, não torna objetiva a responsabilidade do médico, ao contrário do que alega a recorrente. Permanece subjetiva a responsabilidade do profissional de Medicina, mas se transfere para o médico o ônus de demonstrar que os eventos danosos decorreram de fatores alheios à sua atuação durante a cirurgia. Assim, conforme o acórdão recorrido, o laudo pericial é suficientemente seguro para afirmar a ausência de qualquer negligência do cirurgião. Ele não poderia prever ou evitar as intercorrências registradas no processo de cicatrização da recorrente. Assim, não é possível pretender imputar ao recorrido a responsabilidade pelo surgimento de um evento absolutamente casual, para o qual não contribuiu. A formação do chamado queloide decorreu de característica pessoal da recorrente, e não da má atuação do recorrido. Ademais, ao obter da recorrente, por escrito, o termo de consentimento, no qual explica todo o procedimento, informando-lhe sobre os possíveis riscos e complicações pós-cirúrgicos, o recorrido agiu com honestidade, cautela e segurança. Logo, a Turma negou provimento ao recurso."

${ }^{1029}$ NOGUEIRA, Lavyne Lima. Responsabilidade civil do profissional liberal perante o código de defesa do consumidor, Revista de Direito do Consumidor, São Paulo, v. 10, n. 40, p. 199-226, out./dez. 2001. p. 217 219. 
Apesar de a objetivação do dever de reparar os danos contratuais ser o cerne deste estudo, não existe a mínima possibilidade de defesa da reflexão formulada acima. $\mathrm{O}$ equívoco é gigantesco. As construções teóricas que utilizam fatores de imputabilidade objetivos não admitem a ingerência da culpa em seu campo de atuação, apesar, diga-se de passagem, do fato de que, a confusão detectada acima ser bastante comum. ${ }^{1030}$ Aponta-se, aqui, outra razão respeitável justificando a segregação da culpa da arquitetura da responsabilidade contratual.

Indo além, é possível verificar, ainda, que, sequer no interior de cada um dos moldes imaginados por Demogue, as peças que os compõem deixaram de se mover e, portanto, de criar problemas. Muitos desses artefatos foram mudados de lugar ou substituídos por elementos com formas e tonalidades - mais ou menos - distintas das primitivas.

${ }^{1030}$ Prova da assertiva encontra-se no seguinte julgado: STJ. REsp 1.007.692-RS. 3. T. Rel. Min. Nancy Andrighi. j. 17/8/2010. "De acordo com o TJ, a empresa realizou quatro operações bancárias de aplicação financeira: duas mediante cheques TB (transferência bancária de valores) e duas mediante cheques administrativos, mas depois não pôde resgatar as aplicações. Os prejuízos suportados pela recorrida foram expressamente mencionados no acórdão recorrido a partir das provas dos autos, totalizando o desfalque no valor de $\mathrm{R} \$ 1.500 .000$ desviados pelos bancos recorrentes para a conta de terceiro. A subtração deu-se em endossos apostos nos cheques, sacados em dois dos bancos envolvidos e depositados em um terceiro banco, tendo sido devidamente compensados. [...] Assim, a responsabilidade objetiva prevista no art. 14 do CDC é perfeitamente aplicável à hipótese dos autos. Também é indiscutível que o desvio de valores envolveu a prestação defeituosa de serviços bancários, obrigando os fornecedores a responder, independentemente da existência de culpa, pela reparação dos danos causados ao consumidor. Logo, a responsabilidade deve ser apurada a partir da existência de atos comissivos ou omissivos legítimos das partes que tenham concorrido, ainda que indiretamente, para o desfalque, nos termos do art. 159 do CC/1916. Destarte, o endosso dos cheques que deram suporte ao desvio dos valores não pode ser tido como ato legítimo da recorrida. Nesse aspecto, o tribunal a quo registrou o cuidado adotado pela recorrida para que os cheques por ela emitidos fossem subscritos por duas pessoas, o que foi informado aos bancos recorrentes. No entanto, eles não demonstraram igual cautela, tendo conferido a seus prepostos poderes suficientes para praticar atos que resultaram em prejuízo para sua correntista. Dessa forma, não se pode cogitar a ilegitimidade nos atos praticados pelos bancos, por intermédio de seus prepostos, visto que eles agiram dentro dos limites dos poderes que lhes foram outorgados, caracterizando, na realidade, culpa por fato de terceiro, prevista no art. 1.521 do CC/1916, que consagra as culpas in eligendo e in vigilando. Em razão de a recorrida confiar o depósito de dinheiro aos cuidados desses bancos, formalizaram-se contratos equiparados aos de mútuo, nos quais, de acordo com o art. 1.257 do CC/1916, transfere-se o domínio da coisa emprestada ao mutuário, por cuja conta correm todos os riscos desde a tradição. Daí decorre a concorrência de culpas, que na verdade consubstancia concorrência de causas para o evento danoso, mas que só deve ser admitida em casos excepcionais. Quanto aos cheques TB, eles não admitem endosso, de modo que somente podiam ser depositados em conta bancária de titularidade do próprio emitente, no caso a recorrida. Já quanto à verificação dos endossos, o entendimento consolidado neste Superior Tribunal é que o banco apresentante do cheque à câmara de compensação tem o dever de verificar a regularidade da sucessão dos endossos. Deve, pois, tomar a cautela de exigir provas da legitimidade do endossante, como, por exemplo, cópia do contrato social da empresa, quando o título for nominal à pessoa jurídica. Dessarte, ainda que pelos atos culposos, os três bancos recorrentes deverão responder solidariamente pela indenização, nos termos da lei. Diante do exposto, a Turma negou provimento ao recurso. [...]" 
Originalmente, nas obrigações de meio - também conhecidas como obrigações de diligência e prudência ${ }^{1031}$-, o compromisso assumido pelo devedor lhe impõe seguir um plano prestacional que, mesmo sendo projetado visando à satisfação dos interesses do credor, não é afiançado pelo primeiro. ${ }^{1032} \mathrm{O}$ desempenho da prestação prometida exige, assim, apenas o empenho para vencer as vicissitudes surgidas e, portanto, o devedor estará liberado ao demonstrar que buscou, da melhor forma possível, o adimplemento. ${ }^{1033}$

Nesse quadro, o ônus de promover a prova da culpa do devedor - quando houver a violação de dever no curso do processo obrigacional - pertence ao credor lesado. ${ }^{1034}$ Incumbe a ele, portanto, demonstrar que o nível de diligência adotado pelo devedor se desviou do exigido pelas circunstâncias ${ }^{1035}$ que informam o caso concreto. Ausente essa prova, além de não receber a prestação a ele prometida, o credor não poderá postular reparação alguma.

A pesquisa permitiu identificar que não são poucos os autores que pensam desse modo. As premissas contidas na tese clássica são defendidas - mesmo que alguns autores, sem quaisquer justificativas ou explicações, aludam à expressão "em regra" - por Hildegard Giostri ${ }^{1036}$, Joana Graeff-Martins ${ }^{1037}$, Lucíola Nerilo ${ }^{1038}$, Oscar Ivan Prux ${ }^{1039}$,

${ }^{1031}$ KUMMEROW, Gert. Esquema del daño contractual resarcible según el sistema normativo venezolano. Caracas: Universidad Central de Venezuela, 1964. p. 32-33.

1032 PICASSO, Sebastián. La culpa y el incumplimiento en las obligaciones de medios. In: FERNÁNDEZ, Carlos López; CAUMONT, Arturo; CAFFERA, Gerardo (Coord.). Estudios de derecho civil en homenaje al profesor Jorge Gamarra. Montevideo: FCU, 2001. p. 347. Veja ainda: FERNANDÉZ, Carlos López. Obligaciones de medios y de resultado, Revista de la Facultad de Derecho, Montevideo, n. 18, p. 97-132, jul./dez. 2000. p. 98-102. GAMARRA, Jorge. Incidencia del problema de la carga de la prueba en la fundamentación de la responsabilidad civil, Revista de la Facultad de Derecho y Ciencias Sociales, Montevideo, v. 2, n. 3, p. 639-665, 1951. p. 641. LIRA, Ricardo Pereira. Obrigação de meios e obrigação de resultado a pretexto da responsabilidade médica: análise dogmática, Revista de Direito Renovar, Rio de Janeiro, n. 6, p. 75-82, set./dez. 1996. p. 77-78.

${ }^{1033}$ LÔBO, Paulo Luiz Netto. Responsabilidade civil do advogado, Revista de Direito Privado, São Paulo, v. 3, n. 10, p. 211-220, abr./jun. 2002. p. 218. "Como regra geral a doutrina dominante diz que o profissional liberal assume obrigação de meios, sendo excepcionais as obrigações de resultado. Na obrigação de meios, a contrariedade ao direito reside na falta de diligência que se impõe ao profissional, considerado o estado-daarte da técnica e da ciência, no momento da prestação do serviço."

${ }^{1034}$ MAZEAUD, Henri; MAZEAUD, Léon; TUNC, André. Tratado teórico y práctico de la responsabilidad civil delictual y contractual. Trad. Luis Alcalá Zamora y Castillo. Buenos Aires: Ediciones Jurídicas EuropaAmérica, 1962, v. 2, t. 1. p. 451. Isso ocorre nas obrigações que os autores classificam como de diligência.

${ }^{1035}$ DUPICHOT, Jacques. Derecho de las obligaciones. Trad. Rosangela Calle. Bogotá: Temis, 1984. p. 6. No mesmo sentido: WEBER, Márcia Regina Lusa Cadore. Responsabilidade civil do médico, Revista da PGE, Porto Alegre, v. 27, n. 57, p. 185-204, 2004. p. 191.

1036 GIOSTRI, Hildegard Taggesel. Algumas reflexões sobre as obrigações de meio e de resultado na avaliação da responsabilidade médica, Revista Trimestral de Direito Civil, Rio de Janeiro, n. 5, p. 101-116, jan./mar. 2001. p. 103-105. 
dentre outros. ${ }^{1040}$ Idêntica linha de reflexão é notada, ainda, nos escritos de Cesare Massimo Bianca ${ }^{1041}$, Christian Larroumet ${ }^{1042}$, Gert Kummerow ${ }^{1043}$ e Jorge Gamarra. ${ }^{1044}$

Uma vez observados os inconvenientes contidos na rígida distribuição dos ônus probatórios nas obrigações de meio - e talvez, também, os malefícios causados às incontáveis vítimas de danos injustos -, a construção clássica é criticada. Argumentos dogmáticos e sociológicos conduzem à reconstrução de algumas das escoras de sustentação do tema. ${ }^{1045}$

A exigência de culpa para imposição do dever de reparar persiste, mas, agora, caberá ao devedor demonstrar que agiu de modo diligente para se eximir da sanção reparatória. A prova da ausência de culpa, na realidade que exsurge nesse momento, passa a pertencer ao devedor.

${ }^{1037}$ GRAEFF-MARTINS, Joana. Cirurgia plástica estética: natureza da obrigação do cirurgião, Revista de Direito Privado, São Paulo, v. 10, n. 37, p. 105-129, jan./mar. 2009. p. 111.

${ }^{1038}$ NERILO, Lucíola F. L.. A responsabilidade civil pelo descumprimento da cláusula geral da boa-fé nos contratos, Revista dos Tribunais, São Paulo, v. 96, n. 866, p. 67-98, dez. 2007. p. 89.

${ }^{1039}$ PRUX, Oscar Ivan. Um novo enfoque quanto à responsabilidade civil do profissional liberal, Revista de Direito do Consumidor, São Paulo, n. 19, p. 202-231, jul./set. 1996. p. 205-211.

1040 AGUIAR JUNIOR, Ruy Rosado de. Responsabilidade civil do médico, Revista dos Tribunais, São Paulo, v. 84, n. 718, p. 33-53, ago. 1995. p. 35.

${ }^{1041}$ MASSIMO BIANCA, Cesare. Diritto civile: l'obbligazione. Milano: Giuffrè, 2006, v. 4. p. 74-77. Justifica seu raciocínio frisando que, no desempenho de qualquer prestação, existe uma fase preparatória e uma fase final. Alude que, nas obrigações de resultado, a diligência é exigida na primeira das fases. Assim, nos casos de incumprimento, o devedor exime-se de responsabilidade ao demonstrar que dispendeu a diligência necessária durante os atos preparatórios necessários para o desempenho da prestação.

${ }^{1042}$ LARROUMET, Christian. La causa estraña. In: ESPINOSA, Fabricio Mantilla; BARRIOS, Francisco Ternera (Dir.). Los contratos en el derecho privado. Bogotá: Legis, 2007. p. 294.

${ }^{1043}$ KUMMEROW, Gert. Esquema del daño contractual resarcible según el sistema normativo venezolano. Caracas: Universidad Central de Venezuela, 1964. p. 32-33.

${ }^{1044}$ GAMARRA, Jorge. Incidencia del problema de la carga de la prueba en la fundamentación de la responsabilidad civil, Revista de la Facultad de Derecho y Ciencias Sociales, Montevideo, v. 2, n. 3, p. 639665, 1951. p. 652.

${ }^{1045}$ CÁRDENAS, Betty Mercedes Martínez. La adaptación de la teoría de las obligaciones de medios y las obligaciones de resultados en el derecho colombiano. In: ESPINOSA, Fabricio Mantilla; BARRIOS, Francisco Ternera (Dir.). Los contratos en el derecho privado. Bogotá: Legis, 2007. p. 908. "A consequiência da inversão da carga probatória [imputando-a ao credor] nas obrigações de meio se traduz no agravamento da situação do credor e ao mesmo tempo na negação do conteúdo obrigacional contido no contrato. Em efeito, o credor, além de não receber a prestação que lhe é devida (ou nos moldes devidos), se vê compelido a provar que o comportamento do devedor desviou-se do exigido pelos estados da ciência, da arte ou da técnica. Ademais, se as obrigações devem ser adimplidas de boa-fé, cumprirá mesmo ao devedor demonstrar o adimplemento pontual da prestação assumida." 
Consoante essa lógica, perceba-se, basta ao credor demonstrar a existência de um contrato, o dano por ele suportado ${ }^{1046}$ e que esse deriva de uma patologia no curso do processo obrigacional.

No Brasil, comungam dessa mesma linha de pensamento Caio Mário da Silva Pereira $^{1047}$, Clóvis Bevilaqua ${ }^{1048}$ e Paulo Lôbo. ${ }^{1049}$ No exterior, Antunes Varela ${ }^{1050}$, Carmen Domínguez Hidalgo ${ }^{1051}$, Édgar Cortés ${ }^{1052}$, Jorge Zago ${ }^{1053}$, Jorge Mosset Iturraspe e Miguel Piedecasas ${ }^{1054}$, defendendo, em termos gerais, ser mais fácil para o devedor demonstrar ter seguido o programa obrigacional, do que atribuir ao credor o ônus de provar que aquele não foi diligente. ${ }^{1055}$

E, apesar de o passo dado ser importante, aqui, aparece o problema de saber como se provará a ausência de culpa. Isso porque, historicamente - e ainda hoje -, o limite da culpa está alocado no advento de uma causa estranha e não imputável ao devedor. ${ }^{1056}$

${ }^{1046}$ A prova do dano é dispensada - ao menos, em princípio - nas hipóteses de ajuste prévio de cláusula penal pelas partes.

${ }^{1047}$ PEREIRA, Caio Mário da Silva. Responsabilidade civil: de acordo com a constituição federal de 1988.8 ed. Rio de Janeiro: Forense, 1997. p. 247.

${ }^{1048}$ BEVILAQUA, Clóvis. Direito das obrigações. 5 ed. Rio de Janeiro: Freitas Bastos, 1940. p. 147.

${ }^{1049}$ LÔBO, Paulo Luiz Netto. Responsabilidade civil dos profissionais liberais e o ônus da prova, Revista de Direito do Consumidor, São Paulo, n. 26, p. 159-165, abr./jun. 1998. p. 164-165. Ao discorrer sobre o tema no universo das relações de consumo, o autor salienta que o ônus da prova da ausência de culpa pertencerá sempre ao devedor, mesmo que seja ele profissional liberal. Parece inegável que, (a) diante da forte aproximação principiológica existente entre o direito do consumidor e o direito civil; (b) da tendência na unificação do dever de reparar; (c) do estado da arte no tratamento do tema na contemporaneidade; e, especialmente, (d) da leitura da temática sob as luzes do princípio constitucional da isonomia, as conclusões alcançadas pelo autor também possam informar os contratos civis.

${ }^{1050}$ ANTUNES VARELA, João de Matos. Direito das obrigações. Rio de Janeiro: Forense, 1978, v. 2. p. 120.

${ }^{1051}$ HIDALGO, Carmen Domínguez. La concepción dualista de la responsabilidad civil en Chile: panorama general, Revista Anales Derecho UC, Santiago, v. 3, p. 73-89, mar. 2008. p. 74.

1052 CORTÉS, Édgar. Breve nota sobre la culpa contractual y la extracontractual en el derecho colombiano, Revista Anales Derecho UC, Santiago, v. 3, p. 93-104, mar. 2008. p. 103.

1053 ZAGO, Jorge. El significado de la culpa. In: GESUALDI, Dora Mariana (Coord.). Derecho privado. Buenos Aires: Hammurabi, 2001. p. 1284.

${ }^{1054}$ ITURRASPE, Jorge Mosset; PIEDECASAS, Miguel. Responsabilidad contractual. Santa Fé: RubinzalCulzoni, 2007. p. 221-225. Consoante os autores, mesmo nas obrigações classificadas como de meio, o ônus da prova do adimplemento pertence ao devedor, até porque sustentar o contrário implica a imposição de grave dificuldade probatória ao lesado.

1055 FERNANDÉZ, Carlos López. Obligaciones de medios y de resultado, Revista de la Facultad de Derecho, Montevideo, n. 18, p. 97-132, jul./dez. 2000. p. 113-117.

${ }^{1056}$ ITURRASPE, Jorge Mosset. La vigencia del distingo entre obligaciones de medio y de resultados en los servicios, desde la perspectiva del consumidor, Revista da Ajuris, Porto Alegre, v. 1, p. 250-252, mar. 1988. p. 250. No mesmo sentido: RUIZ, Roberto Martinez. Obligaciones de medio y de resultado. La Ley, Buenos Aires, t. 90, p. 756-760, abr./jun. 1958. p. 759-760. 
Ora, se a culpa só pode ser afastada com a demonstração da inexistência de nexo causal entre a violação de um dever contratual e a lesão suportada pelo titular de uma posição jurídica criada pelo contrato, não há razão para que se continue a defender a manutenção do elemento subjetivo como fator de atribuição do dever de reparar. ${ }^{1057} \mathrm{~A}$ constatação - e isso parece incontestável - faz ruir quaisquer modelos de apreciação subjetiva da responsabilidade contratual.

Ocorre que, em vez de prevalecer a lógica apontada, surgem teses mirabolantes. Sob o pálio da culpa, defende-se que, havendo o inadimplemento ou a mora - nas obrigações de meio -, o ônus da prova da ausência de culpa é do devedor, mas, caso haja cumprimento inexato, sua prova deve ser promovida pelo credor. ${ }^{1058}$ Tal construção parece destoar do estado da arte no tratamento do dever de reparar - em desfavor da vítima, afrontando um dos pilares fundantes do direito de danos -, ao retomar a discussão sobre a necessidade de prova da culpa do devedor na hipótese apontada. Infira-se, ainda, que a aludida tentativa de conformação teórica do tema afasta a possibilidade de sistematizar, coerentemente, as diferentes hipóteses de violação de dever contratual.

Afirma-se, também, que a culpa é irrelevante - perceba, o atento leitor que ainda está no universo das obrigações de meio - à caracterização da mora e do inadimplemento. ${ }^{1059} \mathrm{~A}$ culpa, nesse contexto, só terá utilidade na apreciação das situações de adimplemento imperfeito, restando afastada das demais patologias. ${ }^{1060}$

O passo dado em direção à objetivação do dever de reparar os danos contratuais é importante, entretanto, ainda não autoriza a uniformização na sistematização da matéria sob análise.

${ }^{1057}$ A questão é analisada ao longo de todo o trabalho.

1058 AGOGLIA, María Martha; BORAGINA, Juan Carlos; MEZA, Jorge Alfredo. Responsabilidad por incumplimiento contractual. Buenos Aires: Hammurabi, 2003. p. 201. O único argumento apresentado pelos autores para justificar a posição assumida cinge-se às regras codificadas pelo direito argentino.

${ }^{1059}$ BUERES, Alberto Jesus. Derecho de daños. Buenos Aires: Hammurabi, 2001. p. 438. Consoante o autor, a culpa só teria papel relevante na apreciação do cumprimento inexato da prestação.

1060 PICASSO, Sebastián. La culpa y el incumplimiento en las obligaciones de medios. In: FERNÁNDEZ, Carlos López; CAUMONT, Arturo; CAFFERA, Gerardo (Coord.). Estudios de derecho civil en homenaje al profesor Jorge Gamarra. Montevideo: FCU, 2001. p. 360-361. Do mesmo autor: PICASSO, Sebastián. El incumplimiento en las obligaciones contractuales: el problema de la ausencia de culpa y de la imposibilidad sobrevenida de la prestación - obligaciones de medios y de resultado. In: GESUALDI, Dora Mariana (Coord.). Derecho privado. Buenos Aires: Hammurabi, 2001. p. 1105-1106. Eis o principal argumento: como o dever de agir com diligência só é relevante na aferição do adimplemento, quando ocorre o não cumprimento (temporal ou não) tal análise é supérflua, já que, para adimplir, "o devedor não só deve agir diligentemente, devendo também executar a prestação prometida." 
De modo mais restritivo, afirma-se que a regra de diligência só terá utilidade quando houver o cumprimento inexato de obrigação de fazer; entretanto, ao contrário da trilha anteriormente seguida, o ônus da prova da culpa do devedor, nesses casos, pertencerá ao credor, retomando o viés clássico de análise do tema ${ }^{1061}$ e, com ele, as críticas outrora formuladas.

É possível perceber, nas linhas delineadas até este momento, a evolução havida no tratamento do tema. Da imposição originária acerca da presença da culpa em ambos os modelos à objetivação do dever de reparar - consoante o estado da arte - na maioria das hipóteses que podem ser imaginadas. Demonstrou-se que a culpa, atualmente, sobrevive em escassas situações.

Nessa metamorfose, salta aos olhos a tendência - ainda que não necessariamente retilínea - para o abrandamento das mazelas oriundas da alocação da culpa como fator de imputabilidade do dever de reparar.

Em termos gerais, pode afirmar-se que, em um primeiro momento, as discussões tentam identificar a quem incumbe provar a culpa. Em uma segunda etapa, quando os ônus probatórios foram transferidos ao devedor, o filtro tornou-se mais poroso. Posteriormente, a culpa deixa de atuar como pressuposto em parte relevante do universo preenchido pela noção de violação de dever contratual.

E, caso não se tenha percebido, até este momento, uma palavra sequer foi destinada à análise das linhas evolutivas no tratamento das obrigações classificadas, consoante a proposta dicotômica, como de resultado. Nessas, a conduta do devedor há de coincidir com a prestação prometida - e esperada - por ocasião do ajuste negocial.

Nas obrigações de resultado, haverá adimplemento se alcançada perfeita consonância - premissa, que, na atualidade, deve ser balizada pela boa-fé objetiva - entre o comportamento desvelado na concretude dos fatos e a projeção derivada das legítimas expectativas do credor. Em outras palavras, haverá adimplemento se o futuro antecipado mentalmente, no momento do contrato, for atingido quando alcançado pelo tempo presente.

${ }^{1061}$ VISINTINI, Giovanna. Tratado de la responsabilidad civil: la culpa como criterio de imputación de la responsabilidad. Trad. Aída Kemelmajer de Carlucci. Buenos Aires: Astrea, 1999, v. 1. p. 202-206. Segundo a autora, a prova da culpa do devedor, nesses casos, pertencerá ao credor lesado pelo desvio de curso no programa obrigacional. 
Originalmente, consoante esse viés do modelo binário, presumia-se culpado o devedor ${ }^{1062}$ que deixasse de adimplir, cabendo a ele, portanto, demonstrar a inexistência do dever de reparar.

E, apesar de existir corrente minoritária defendendo que incumbe ao lesado, também nesses casos, a prova da culpa do devedor ${ }^{1063}$, o modelo prevalente, durante algum tempo, trabalhou com a inversão dos ônus probatórios.

O tempo avança, e o estudo da matéria encontra ambiente propício a alçar novos ares. Afirma-se que a culpa do devedor é irrelevante ${ }^{1064}$ na configuração do dever de reparar, nascido da inobservância de prestações classificadas como de resultado. Em apertada síntese, é possível afirmar que a presunção de culpa, contida na tese clássica, foi abandonada e substituída por um fator objetivo na imputação do aludido dever. ${ }^{1065}$

Com o passar dos anos, a doutrina enxergou que a culpa era um elemento supérfluo ${ }^{1066}$ nesse contexto, totalmente prescindível à configuração do dever de reparar os danos contratuais havidos da violação da prestação qualificada como de resultado. A culpa foi banida - e com acerto - desse universo.

E banida, talvez porque se percebeu que, na seara contratual, presumir a culpa do devedor, quando do não cumprimento das obrigações de resultado, equivale a criar um sistema de responsabilidade objetiva. ${ }^{1067}$

1062 PRUX, Oscar Ivan. Um novo enfoque quanto à responsabilidade civil do profissional liberal, Revista de Direito do Consumidor, São Paulo, n. 19, p. 202-231, jul./set. 1996. p. 205-211.

${ }^{1063}$ Sobre o tema: GAMARRA, Jorge. Incidencia del problema de la carga de la prueba en la fundamentación de la responsabilidad civil, Revista de la Facultad de Derecho y Ciencias Sociales, Montevideo, v. 2, n. 3, p. 639-665, 1951. p. 647-658. No mesmo sentido: LIRA, Ricardo Pereira. Obrigação de meios e obrigação de resultado a pretexto da responsabilidade médica: análise dogmática, Revista de Direito Renovar, Rio de Janeiro, n. 6, p. 75-82, set./dez. 1996. p. 80-81.

${ }^{1064}$ PICASSO, Sebastián. El incumplimiento en las obligaciones contractuales: el problema de la ausencia de culpa y de la imposibilidad sobrevenida de la prestación - obligaciones de medios y de resultado. In: GESUALDI, Dora Mariana (Coord.). Derecho privado. Buenos Aires: Hammurabi, 2001. p. 1105.

${ }^{1065}$ BUERES, Alberto Jesus. Derecho de daños. Buenos Aires: Hammurabi, 2001. p. 36. No mesmo sentido: GAMARRA, Jorge. Responsabilidad contractual objetiva. In: BUERES, Alberto Jesús; DE CARLUCCI, Aída Kemelmajer (Dir.). Responsabilidad por daños en el tercer milenio. Buenos Aires: Abeledo-Perrot, 1997. p. 113.

1066 BUSTAMANTE ALSINA, Jorge. El perfil de la responsabilidad civil al finalizar el siglo XX. In: BUERES, Alberto Jesús; DE CARLUCCI, Aída Kemelmajer (Dir.). Responsabilidad por daños en el tercer milenio. Buenos Aires: Abeledo-Perrot, 1997. p. 20-26.

1067 CÁRDENAS, Betty Mercedes Martínez. La adaptación de la teoría de las obligaciones de medios y las obligaciones de resultados en el derecho colombiano. In: ESPINOSA, Fabricio Mantilla; BARRIOS, Francisco Ternera (Dir.). Los contratos en el derecho privado. Bogotá: Legis, 2007. p. 909. 
Sim, responsabilidade objetiva. Ora, se o devedor deve demonstrar que uma causa estranha, portanto, uma causa a ele não imputável, foi o que impediu o adimplemento, para que possa afastar o dever de reparar, é evidente que a culpa se torna irrelevante nesse processo.

Identifique-se que, no momento em que a doutrina atribui ao devedor o ônus de demonstrar que a violação do dever contratual está atada a uma causa alheia a sua esfera de atuação, embora não perceba, promove a desconexão entre o elemento subjetivo e o dever de reparar, que exsurge do não desempenho da prestação.

A discussão se amplia, quando se apreende que grande parte das prestações, na contemporaneidade, são classificadas como de resultado, assertiva que resta comprovada ao se resgatar que, nessa configuração, estão enquadradas as obrigações de dar ${ }^{1068}$, as de não fazer e, ainda, muitas das classificadas como de fazer. ${ }^{1069}$

Quando se aceita que o dever de reparar os danos oriundos do não cumprimento das obrigações de resultado é imputado objetivamente àquele que o causa, dá-se um passo enorme em direção ao banimento da culpa da arquitetura jurídica da responsabilidade contratual.

É relevante apontar, ainda, que ao elemento subjetivo não foi reservado papel algum em outro momento importante do quadro classificatório. Embora, normalmente desprezadas em boa parte dos trabalhos sobre o assunto, as obrigações de garantia devem ser lembradas. Como possuem traços distintos das anteriores, não há como enquadrá-las nas hipóteses pensadas pelo sistema binário. Por meio delas, garante-se o adimplemento de determinada prestação. ${ }^{1070}$

Tendo por conteúdo "a eliminação de um risco que pesa sobre o credor",1071, mostra-se irrefutável que a violação dessa espécie de prestação - de garantia - há de ser aferida em perspectiva objetiva.

1068 DEVOTO, Luigi. L'imputabilità e le sue forme nel diritto civile. Milano: Giuffrè, 1964. p. 241-245. Consoante o autor, o incumprimento das obrigações de resultado prescinde da culpa para a imposição do dever de reparar.

1069 FERNANDÉZ, Carlos López. Obligaciones de medios y de resultado, Revista de la Facultad de Derecho, Montevideo, n. 18, p. 97-132, jul./dez. 2000. p. 131.

${ }^{1070}$ Enquadram-se aqui o fiador, o avalista e o segurador.

1071 COMPARATO, Fábio Konder. Ensaios e pareceres de direito empresarial. Rio de Janeiro: Forense, 1978. p. 537. 
A trilha aberta até aqui, talvez, tenha induzido a entender que o modelo dicotômico se justifica, mesmo que apenas a partir das soluções que cria para o tratamento das patologias - atadas à violação de dever contratual - detectadas no curso do processo obrigacional. Como exposto, o que diferencia uma e outra - obrigação de meio e de resultado -, na contemporaneidade, é a natureza - subjetiva ou objetiva - do fator de atribuição do dever de reparar os danos contratuais. ${ }^{1072}$

Tal perspectiva, entretanto, não se sustenta. E, isso porque, na primeira das classificações, a culpa sobrevive em raras ocasiões - atuando como fator de imputabilidade nos casos de cumprimento imperfeito das obrigações de fazer -, consoante defende a doutrina de vanguarda.

Ademais, de nada adiante defender a diferença de regimes, enquanto não houver um critério que permita discernir, com um mínimo de tranquilidade, sobre o enquadramento a ser dado a cada hipótese que clame por uma resposta do sistema.

Enfim e a partir da constatação de que o ônus da prova exoneratória do dever de reparar incumbe ao devedor nos dois momentos da classificação binária, surge outra questão. Em um e outro caso, consoante a dogmática codificada, a imposição do dever de reparar somente será afastada se o devedor demonstrar que adimpliu a prestação prometida, ou que isso não se deu em razão de causa alheia a sua esfera de atuação.

Aliás, no tocante ao último dos pontos destacados, é oportuno salientar que a terminologia utilizada - obrigações de meio ou de diligência - é bastante infeliz. E o é, por sugerir que o devedor não precisa atender às legítimas expectativas do credor por ocasião do pagamento. ${ }^{1073}$ Autoriza pensar que basta ao devedor provar que agiu adequadamente.

Ledo engano. Em que pese a possibilidade de demonstrar que a conduta desempenhada foi informada pela diligência exigida nas obrigações de meio, essa não pode ser considerada como causa de exoneração do dever de reparar. Quando muito, a demonstração de que a conduta é irrepreensível servirá como prova do adimplemento. ${ }^{1074}$

1072 AGOGLIA, María Martha; BORAGINA, Juan Carlos; MEZA, Jorge Alfredo. Responsabilidad por incumplimiento contractual. Buenos Aires: Hammurabi, 2003. p. 54-58.

${ }^{1073}$ ITURRASPE, Jorge Mosset. La vigencia del distingo entre obligaciones de medio y de resultados en los servicios, desde la perspectiva del consumidor, Revista da Ajuris, Porto Alegre, v. 1, p. 250-252, mar. 1988. p. 250.

${ }^{1074}$ GONZÁLEZ, Jorge Baraona. Responsabilidad contractual y fatores de imputación de daños: apuntes para una relectura en clave objetiva, Revista Chilena de Derecho, Santiago, v. 24, n. 1, p. 151-177, jan./abr. 1997. p. 166-169. 
É evidente que, se o devedor demonstrar que sua conduta se coaduna ao que era dele esperado, não será obrigado a reparar os danos suportados pelo credor. Isso ocorre, entretanto, reafirme-se, por demonstrar - e, apenas, se o fizer - que adimpliu a prestação prometida. ${ }^{1075} \mathrm{E}$, nesse caso, ele se libera do dever de reparar, não porque não agiu com culpa, mas sim, por ter havido adimplemento, ato-fato jurídico que põe fím ao processo obrigacional. A violação de dever contratual, nesses casos, é meramente aparente. Por isso, a prova a ser promovida pelo devedor está conectada à demonstração da inexistência de desrespeito ao aludido dever, e não, à ausência de culpa.

Apesar da clareza dessas constatações, a questão, longe de encontrar resposta única, vive um momento de efervescência. Defende-se ser possível, nas obrigações de meio, a prova "de la no culpa", bastando ao devedor demonstrar que sua conduta se conformou à diligência exigida para a hipótese. ${ }^{1076}$

Sustenta-se que a ausência de culpa não pode ser confundida com quaisquer das situações de causa estranha e não imputável ao devedor. ${ }^{1077}$ Consoante esse viés, o devedor se libera da culpa - e, portanto, do dever de reparar -, ao provar que fez todo o possível para adimplir, respeitando o programa obrigacional e os corolários que emanam da pontualidade, da indivisibilidade e da boa-fé objetiva.

E, embora essa perspectiva não seja de todo equivocada, parece que os autores que a defendem não percebem, que se o dano foi causado por elemento externo à álea de atuação do devedor, a demonstração, por parte deste, de uma conduta diligente não tem razão de ser, e isso porque a causa daquele se encontra - como se percebe - em outro lugar.

Uma vez resgatadas as críticas pontuais que um e outro momento da classificação binária têm recebido, os distintos problemas estruturais contidos na proposta dicotômica, bem como a impossibilidade de acoplamento do elemento subjetivo em ambas as vertentes analisadas, é hora de apontar outras razões que conduzem à necessidade de superar esse viés teórico.

\footnotetext{
1075 ITURRASPE, Jorge Mosset; PIEDECASAS, Miguel. Responsabilidad contractual. Santa Fé: RubinzalCulzoni, 2007. p. 225-231.

${ }^{1076}$ AGOGLIA, María Martha; BORAGINA, Juan Carlos; MEZA, Jorge Alfredo. Responsabilidad por incumplimiento contractual. Buenos Aires: Hammurabi, 2003. p. 89-94.

${ }^{1077}$ BUERES, Alberto Jesus. Derecho de daños. Buenos Aires: Hammurabi, 2001. p. 46.
} 
Afirma-se que a classificação binária das obrigações é uma falácia, haja vista que, em ambas as hipóteses, o credor espera o desempenho da prestação prometida, ou seja, acredita que irá receber o resultado de um dar, fazer ou não fazer. ${ }^{1078} \mathrm{Em}$ sentido semelhante, defende-se que a distinção entre obrigações de meio e resultado é artificial, pois ambas devem conduzir ao adimplemento ${ }^{1079}$, fim natural e esperado em todo e qualquer processo obrigacional. Defende-se, ainda, que "a passagem pela qualificação das obrigações de meio e das obrigações de resultado constitui efetivamente um desvio inútil e se pode legitimamente almejar o desaparecimento dessa distinção, cuja elaboração é de uma incrível complexidade."1080

A dicotomia não se sustenta com o peso das críticas. Além das anteriormente apontadas, uma atenta reflexão sobre o tema permite inferir que todo e qualquer programa obrigacional tem como finalidade o desempenho de uma conduta que visa à satisfação dos legítimos interesses do credor.

Mesmo nas obrigações classificadas como de meio - conforme antecipado -, incumbe ao devedor demonstrar que desempenhou a prestação prometida ou provar a presença de impossibilidade liberatória ${ }^{1081}$, até porque a dicotomia não pode atentar contra as linhas condutoras da responsabilidade contratual. ${ }^{1082}$

1078 PADILLA, Rodrigo. La responsabilidad civil del abogado y las obligaciones de medio y resultado, Revista de Responsabilidad Civil y Seguros, Buenos Aires, n. 4, p. 80-106, abr. 2006. p. 92-100.

1079 PARODI, Felipe Osterling; FREYRE, Mario Castillo. Tratado de las obligaciones. Lima: Fondo Editorial de la Pontificia Universidad Católica del Perú, 2005, v. 16, t. 1. p. 217. Complementam os autores, afirmando que "nas obrigações de meio se busca um resultado. E nas obrigações de resultado, existe, necessariamente, um meio para cumpri-las."

${ }^{1080}$ SAVAUX, Eric. O fim da responsabilidade contratual?, Revista Justitia, São Paulo, n. 194, p. 130-152, abr./jun. 2001. p. 145-146. "O benefício esperado dessa transformação é evidente. Trata-se de extirpar, de nosso direito das sanções da inexecução, a infernal distinção das obrigações em obrigações de meios e obrigações de resultado. A passagem por esta qualificação das obrigações é um desvio lógico inútil: para determinar se a obrigação é 'de meios' ou 'de resultado', se examina sempre o conteúdo concreto do contrato, o que as partes declararam querer, ou o que diz, em seu lugar, a lei ou o juiz. Basta, pois que se pergunte: 1) o que o devedor devia; 2) se ele fez bem o que devia; a passagem por uma 'qualificação' da obrigação é uma fachada. Toda a questão do 'fato gerador' da responsabilidade contratual se encaminha em verdade à questão do conteúdo exato do contrato [em verdade, da prestação;] é a extensão da obrigação contratual que se deve considerar, e não o aspecto de se saber se 'a obrigação de reparar' supõe ou não a prova de uma culpa do devedor. A passagem pela qualificação das obrigações de meio e das obrigações de resultado constitui efetivamente um desvio inútil, e se pode legitimamente almejar o desaparecimento dessa distinção, cuja elaboração é de uma incrível complexidade.”

${ }^{1081}$ ROCHA, Hernando Tapias. La acción de responsabildad contractual. In: ESPINOSA, Fabricio Mantilla; BARRIOS, Francisco Ternera (Dir.). Los contratos en el derecho privado. Bogotá: Legis, 2007. p. 240.

${ }^{1082}$ ITURRASPE, Jorge Mosset. La vigencia del distingo entre obligaciones de medio y de resultados en los servicios, desde la perspectiva del consumidor, Revista da Ajuris, Porto Alegre, v. 1, p. 250-252, mar. 1988. p. 251-252. 
A única diferença realmente relevante que parece existir entre ambas é que, nas primeiras, o interesse a ser satisfeito insere-se em uma álea maior do que a que delineia as últimas. ${ }^{1083}$ Em um ou outro caso, as contingências inerentes a cada situação serão mais ou menos amplas, apenas isso e nada mais.

Seguindo esses passos, é possível antever que, nas obrigações de garantia - e também nas prestações genéricas -, a álea de situações de exclusão do dever de reparar será ainda menor do que nas situações anteriores. Tais diferenças, entretanto, não parecem ter força suficiente para sustentar um quadro classificatório, o que não implica que devam ser ignoradas no processo de realização do direito.

A dicotomia também não resiste quando a relação obrigacional é pensada em perspectiva funcional. Aquela, aliás, qualquer que seja seu objeto, se desenvolve em busca do adimplemento - que é sua finalidade, o que não quer dizer, saliente-se, que resultado provável se identifique com resultado necessário. ${ }^{1084}$ Por isso, a boa-fé e os deveres que nela têm sua gênese devem ser constantemente revisitados ${ }^{1085}$ e reinventados em busca da satisfação dos anseios de todos os destinatários do Direito.

É importante reafirmar - independentemente da qualificação da obrigação como de meio, de resultado ou de garantia - que a prestação consiste no desvelar de um programa a ser observado pelo devedor, mirando a satisfação dos interesses do credor. ${ }^{1086}$

1083 AGOGLIA, María Martha; BORAGINA, Juan Carlos; MEZA, Jorge Alfredo. Responsabilidad por incumplimiento contractual. Buenos Aires: Hammurabi, 2003. p. 58-65.

${ }^{1084}$ LÔBO, Paulo Luiz Netto. Teoria geral das obrigações. São Paulo: Saraiva, 2005. p. 35-36. "Quem procura um advogado, um engenheiro, um médico não quer a excelência dos meios pelo profissional empregados, quer o resultado, no grau mais elevado de probabilidade. Quanto mais renomado o profissional, mais provável é o resultado pretendido, no senso comum do cliente. [...] Toda obrigação tem por objeto um plano, um projeto, um programa de prestação, em outras palavras, um resultado, ainda que sejam considerados outros fatores aleatórios ou circunstâncias de fato que alteram os melhores propósitos do devedor [...] frustrando o resultado esperado [sem que para isso haja] necessidade de recurso à qualificação da obrigação como de meio."

1085 MIRAGEM, Bruno. Responsabilidade civil médica no direito brasileiro, Revista de Direito do Consumidor, São Paulo, v. 16, n. 63, p. 52-91, jul./set. 2007. p. 60. "Não se deve impor, contudo, uma separação rígida entre obrigações de meio e de resultado. Considerando-se que se trata de distinção com o forte apelo prático de estabelecer o ônus da prova ou a presunção de culpa, nesses limites deve ser colocada a discussão. O amplo reconhecimento e a aplicação do princípio da boa-fé no direito das obrigações passam a exigir que a avaliação do cumprimento ou não da obrigação pelo devedor seja examinado em vista também dos interesses legítimos da outra parte, o que torna mais intensos os deveres das partes na relação obrigacional, mesmo os deveres de diligência e cuidado, assim como o dever de informação e esclarecimento."

${ }^{1086}$ MEZA, Jorge Alfredo. El contrato. In: GESUALDI, Dora Mariana (Coord.). Derecho privado. Buenos Aires: Hammurabi, 2001. p. 792. Nesse sentido: GAMARRA, Jorge. Responsabilidad contractual objetiva. In: BUERES, Alberto Jesús; DE CARLUCCI, Aída Kemelmajer (Dir.). Responsabilidad por daños en el tercer milenio. Buenos Aires: Abeledo-Perrot, 1997. p. 118. 
A prestação, nessa esteira, muito mais que o desempenho da conduta outrora prometida - desempenho esse, normalmente analisado em perspectiva estática e abstrata -, implica a realização das legítimas expectativas do credor, elemento essencial daquelanos níveis estrutural e funcional ${ }^{1087}$, projeções veementemente ignoradas pelo modelo dicotômico ainda hoje tão aplaudido. E, se é perfeitamente aceitável que essas questões tenham sido ignoradas em um passado não tão remoto - considerado, aqui, o contexto em que surge o quadro classificatório, por conta de aspectos de ordem sociocultural -, hodiernamente, os pontos realçados não podem ser desprezados.

É fundamental compreender que toda obrigação visa a um resultado. ${ }^{1088} \mathrm{E}$, nesse condão, é imperioso aceitar que cada pessoa - e cada contratante - deve ser responsável não apenas por seus atos culposos, mas por todas aquelas condutas que possam causar um dano injusto a outrem.

Por mais essa razão, a culpa há de ser definitivamente banida do universo do dever de reparar. ${ }^{1089}$ Para isso, entretanto, é imperioso aceitar que a dicotomia surgida há aproximadamente um século atenta de modo assaz contra os pilares de sustentação do tema na contemporaneidade, dentre eles merecendo destaque, (a) a primazia do interesse do lesado ${ }^{1090}$; (b) a necessidade de tutela dos interesses da coletividade; (c) a importância de constante respeito aos marcos que delineiam o direito de danos; e, por que não, (d) a adequação aos influxos oriundos dos princípios constitucionais da isonomia substancial e da solidariedade social.

Na inobservância do programa obrigacional, “o casus [será] o único limite de responsabilidade para todas as obrigações - de meio e resultado - e, para qualquer tipo de infração" - inadimplemento, mora, cumprimento inexato ou violação de dever geral de conduta.

\footnotetext{
${ }^{1087}$ PIZARRO, Ramón. Objeto de la obligación: su importancia con respecto a la esencia del instituto. In: GESUALDI, Dora Mariana (Coord.). Derecho privado. Buenos Aires: Hammurabi, 2001. p. 805-806.

${ }^{1088}$ LÔBO, Paulo Luiz Netto. Responsabilidade civil do advogado, Revista de Direito Privado, São Paulo, v. 3, n. 10, p. 211-220, abr./jun. 2002. p. 219.

${ }^{1089}$ JOSSERAND, Louis. Evolução da responsabilidade civil, Revista Forense, Rio de Janeiro, n. 86, p. $52-$ 63, jun. 1941. p. 60.

${ }^{1090}$ LÔBO, Paulo Luiz Netto. Teoria geral das obrigações. São Paulo: Saraiva, 2005. p. 34.
} 
A aludida percepção implica a desconstrução da ilusória "relação de causa e efeito"1091 que conduz a acreditar na gênese do dever de reparar e, por consequência, suprime um pressuposto existente tão somente em aparência na situação concretamente estabelecida. Nunca é demais lembrar que a desconfiguração do dever de reparar exige "a demonstração da causa estranha" não imputável à conduta do devedor, e não, simplesmente, a prova de ausência de culpa ${ }^{1092}$, se é que, um dia, isso foi realmente possível, pois, consoante observado, a doutrina equipara esse momento ao casus ${ }^{1093}$, promovendo a fusão de dois contextos que não se tocam nem no tempo, nem no espaço.

E, quando se pensa a relação obrigacional a partir dos ditames constitucionais, quando se aceita que o processo obrigacional deve ser iluminado pela isonomia substancial, é possível alcançar semelhantes conclusões. A culpa cria dificuldades no processo que conduze à reparação dos danos suportados por alguns. ${ }^{1094}$

Enfim, são traçadas aqui, diante das conexões com o tema, algumas letras sobre a teoria da carga dinâmica das provas. Em apertada síntese, o modelo teórico leva a crer que deverá produzir a prova aquele que estiver em melhores condições de fazê-lo. Essa determinação pode ser embasada no profissionalismo, na situação pessoal de cada uma das partes, no conhecimento dos fatos etc. ${ }^{1095}$ Como a aludida teoria atribui a prova àquele que possua melhores condições de efetuá-la ${ }^{1096}$, permite sua inversão em distintas hipóteses. $^{1097}$

1091 BUERES, Alberto Jesus. La buena fe y la imposibilidad de pago en la responsabilidad contractual. In: CÓRDOBA, Marcos (Dir.). Tratado de la buena fe en el derecho: doctrina nacional. Buenos Aires: La Ley, 2004, v. 1. p. 287.

1092 ITURRASPE, Jorge Mosset; PIEDECASAS, Miguel. Responsabilidad contractual. Santa Fé: RubinzalCulzoni, 2007. p. 42.

${ }^{1093}$ MASSIMO BIANCA, Cesare. Supervivencia de la teoría de la culpa. In: BUERES, Alberto Jesús; DE CARLUCCI, Aída Kemelmajer (Dir.). Responsabilidad por daños en el tercer milenio. Buenos Aires: Abeledo-Perrot, 1997. p. 141.

${ }^{1094}$ LÔBO, Paulo Luiz Netto. Teoria geral das obrigações. São Paulo: Saraiva, 2005. p. 34. Consoante o autor, a dicotomia proposta "estabelece uma inaceitável desigualdade na distribuição da carga da prova entre as duas espécies: na obrigação de meio, a vítima não apenas tem de provar os requisitos da responsabilidade civil para a reparação, mas que o meio empregado foi tecnicamente inadequado ou sem a diligência requerida, o que envolve informações especializadas, que o autor do dano dispõe e ela não; na obrigação de resultado, basta a prova dos requisitos [e tal tratamento diferenciado da vítima] conflita com o princípio constitucional da igualdade, que é uma das conquistas modernas da responsabilidade civil."

${ }^{1095}$ ITURRASPE, Jorge Mosset. Contratos. Buenos Aires: Rubinzal-Culzioni, 2007. p. 408.

${ }^{1096}$ GHERSI, Carlos Alberto. Teoría general de la reparación de daños. Buenos Aires: Astrea, 1997. p. 131133.

1097 JUNQUEIRA DE AZEVEDO, Antonio. Estudos e pareceres de direito privado. São Paulo: Saraiva, 2004. p. 18. 
Apesar disso, se é evidente que o passo dado é importante, por permitir que os ônus probatórios sejam atribuídos ao devedor, o modelo teórico em nada colabora para afastar a culpa da seara da responsabilidade contratual, ignorando o estágio alcançado pelo estado da arte.

Nada mais resta a ser feito neste momento, senão concluir que, além dos problemas dogmáticos ligados à artificialidade do modelo dicotômico e às dificuldades inerentes à construção das cercanias que permitam enquadrar as situações fáticas em uma ou outra classificação, o sistema binário ofende as diretrizes constitucionais que hão de informar - em cada situação concreta - o processo de realização do Direito.

\subsection{Da culpa ao dano: a objetivação da responsabilidade contratual}

Apesar de ser recorrente a afirmação de que a culpa é o "único critério regulador da responsabilidade humana" e que o caminho trilhado da responsabilidade sem culpa para o dever de reparar nela lastreado deve ser compreendido como um momento de importância ímpar na História do Direito, por superar concepções forjadas no pensamento primitivo $^{1098}$, as linhas traçadas até este instante permitem enxergar a importância dos fatores objetivos de atribuição do dever de reparar os danos contratuais.

Em verdade, pode ser afirmado que, quando se afasta a culpa do universo da responsabilidade contratual, naturalmente se promove (a) a aproximação do tratamento do dever de reparar os danos contratuais das balizas que informam o direito de danos; (b) a adequação da leitura do tema aos pressupostos teóricos que informam o processo de personalização do direito civil, especialmente, diante da ampliação da tutela da pessoa humana; (c) a primazia da função preventiva responsabilidade civil quando comparada com seu aspecto reparatório; (d) o respeito ao princípio da isonomia, mormente quando constatadas as dificuldades que permeiam a conceituação da culpa e a insegurança daí decorrente; (e) a solidariedade social, ao funcionalizar o exercício de uma série de posições jurídicas à necessidade de olhar para o próximo; (f) o distanciamento do tratamento do tema a partir do binômio crime/castigo, colaborando com a construção do embasamento

1098 DE CUPIS, Adriano. El daño: teoria general de la responsabilidad civil. Trad. Ángel Martínez Sarrión. Barcelona: Bosch, 1975. p. 189-205. Saliente-se, apesar do discurso emotivo, que o autor reconhece a existência de hipóteses de responsabilidade objetiva. 
filosófico no tratamento do assunto; além de, claramente, (g) afastar o equívoco dogmático que historicamente vê o fortuito como limite da culpa e, (h) colaborar com a construção de soluções em conformidade com os anseios inerentes a uma sociedade plural e democraticamente estabelecida.

Observada essa miríade de vantagens e antes de comprovar que as linhas condutoras do tema não vão da culpa ao risco, mas da culpa ao dano, é imperioso corrigir um equívoco comum. Ele consiste na intransigente defesa de que é impossível sustentar a existência do dever de reparar sem culpa.

Assertivas nesse sentido não passam de um mito erigido com o escopo de tutelar os interesses de grupos economicamente privilegiados. A culpa é - e sempre foi desnecessária à gênese do dever de reparar danos oriundos do não cumprimento de obrigações de garantia ou de prestações classificadas como genéricas ${ }^{1099}$, inseridas, aqui, as pecuniárias. Aliás, mesmo o direito codificado, na última das hipóteses, permite inferir a veracidade da afirmação quando incorpora a ideia do genus nunquam perit. ${ }^{100}$

Há mesmo quem afirme, nesse último caso, que a responsabilidade do devedor deve ser vista como "objetiva absoluta" "1101, e isso porque não lhe é dado invocar quaisquer das excludentes de causalidade para afastar o dever de reparar ${ }^{1102}$, nascido do não desempenho da prestação. E, se, ao longo da História, na arquitetura jurídica da responsabilidade contratual, sempre houve situações avessas à culpa, mais recentemente, são incontáveis as hipóteses atadas a um fator de imputação objetivamente aferível.

Podem ser lembradas, aqui, dentre outras, as hipóteses em que o dever de reparar se impõe (a) ao transportador - pelos danos causados aos passageiros e/ou objetos que lhe são entregues -, (b) ao depositário - pelas lesões decorrentes da guarda e/ou conservação da coisa - e (c) ao empreiteiro - pelos danos oriundos da ausência de segurança ou solidez da obra.

${ }^{1099}$ POTHIER, Robert Joseph. Tratado das obrigações. Trad. Adrian Sotero De Witt Batista; Douglas Dias Ferreira. Campinas: Servanda, 2002. p. 585. Nesse sentido: BIRENBAUM, Gustavo. Classificação: obrigações de dar, fazer e não fazer. In: TEPEDINO, Gustavo (Coord.). Obrigações: estudos na perspectiva civil-constitucional. Rio de Janeiro: Renovar, 2005. p. 132-133.

1100 “Art. 246. Antes da escolha, não poderá o devedor alegar perda ou deterioração da coisa, ainda que por força maior ou caso fortuito."

${ }^{1101}$ BERDAGUER, Jaime. Las obligaciones de resultado: situación actual y perspectivas futuras. In: FERNÁNDEZ, Carlos López; CAUMONT, Arturo; CAFFERA, Gerardo (Coord.). Estudios de derecho civil en homenaje al profesor Jorge Gamarra. Montevideo: FCU, 2001. p. 50.

1102 BARRIOS, Francisco Ternera. Introducción. In: ESPINOSA, Fabricio Mantilla; BARRIOS, Francisco Ternera (Dir.). Los contratos en el derecho privado. Bogotá: Legis, 2007. p. 74. 
Ignorando essa lógica, nos últimos duzentos anos, a doutrina tem repetidamente defendido (a) que a utilização da culpa como fator de atribuição do dever de reparar estimula o exercício do livre-arbítrio e da livre-iniciativa ${ }^{1103}$ e (b) que o recurso a fatores objetivos de atribuição do dever de reparar promove a atrofia do homem responsável. ${ }^{104}$ Ao mesmo tempo, vozes gritam que (c) afastar a culpa condenará o homem à inatividade - promovendo a inércia daquele, que se prostrará como uma estátua , e o autor do dano à indigência ${ }^{1105}$ e que (d) abandonar a culpa conduzirá o Direito a um momento pré-cultural da História ${ }^{1106}$, promovendo a ressurreição de teses primitivas ${ }^{1107}$ e a recondução da humanidade à barbárie. ${ }^{1108}$

Ademais, talvez por acreditarem que (e) a culpa, por estar ligada a um sujeito responsável, "corresponde à consciência ética e à refinada sensibilidade jurídica de nosso tempo" 1109 , ouvem-se vozes brandindo que (f) "suprimir a culpa" da responsabilidade civil é o mesmo que suprimir a pessoa do direito civil, para esmagá-la sob a matéria e sob a sociedade." $" 1110$

E, além dos argumentos apontados, é bastante comum identificar quem afirme que afastar a culpa da responsabilidade civil é algo (g) inaceitável, por promover a incidência de regimes distintos na configuração do dever de reparar, (h) repugnante, por ser intolerável que alguém que não seja minimamente responsável pela lesão possa ser compelido a repará-la e (i) contrário à moral inerente às relações humanas. ${ }^{1111}$

${ }^{1103}$ TOURNEAU, Philippe le. La responsabilidad civil. Trad. Javier Tamayo Jaramillo. Bogotá: Legis, 2004. p. 28-31.

${ }^{1104}$ YAGÜEZ, Ricardo de Angel. La responsabilidad civil. 2 ed. Bilbao: Universidad de Deusto, 1989. p. 77.

1105 AZEVEDO, Vicente de Paulo Vicente de. O fundamento da responsabilidade civil extracontratual, Revista de Direito Privado, São Paulo, v. 1, n. 1, p. 151-165, jan./mar. 2000. p. 161-164.

${ }^{1106}$ NONATO, Orosimbo. Aspectos do modernismo jurídico e o elemento moral na culpa objectiva, Revista Forense, Rio de Janeiro, n. 56, p. 5-26, jan./jun. 1931. p. 19-26.

1107 COELHO, José Gabriel Pinto. A responsabilidade civil baseada no conceito da culpa. Coimbra: Imprensa da Universidade, 1906. p. 21 e 207. Interessante destacar que se utilizava a expressão dano objetivo.

1108 AZEVEDO, Vicente de Paulo Vicente de. O fundamento da responsabilidade civil extracontratual, Revista de Direito Privado, São Paulo, v. 1, n. 1, p. 151-165, jan./mar. 2000. p. 161-164.

${ }^{1109}$ LARENZ, Karl. Derecho de obligaciones. Trad. Jaime Santos Briz. Madrid: Editorial Revista de Derecho Privado, 1958, t. 1. p. 283.

1110 MAZEAUD, Léon. H. Capitant e a elaboração da teoria francesa da responsabilidade civil, Revista Forense, Rio de Janeiro, v. 37, n. 83, p. 394-400, set. 1940. p. 396.

1111 COELHO, José Gabriel Pinto. A responsabilidade civil baseada no conceito da culpa. Coimbra: Imprensa da Universidade, 1906. p. 117-121. 
Acrescente-se, aqui, enfim, (j) o interesse do Estado Liberal - e, hodiernamente, da classe detentora do capital - na manutenção da culpa como único fator de atribuição do dever de reparar. O intuito é justificado na absorção e diluição dos danos na sociedade, no mais das vezes, composta por seres humanos que são tratados como vítimas do progresso.

O leitor pode perceber - com alguma facilidade - que os influxos responsáveis pela ascensão da culpa ao Olimpo têm origem em argumentos e justificativas das mais distintas ordens. ${ }^{1112}$

O que parece passar despercebido nessas reflexões é a perpetuação de uma realidade excludente. Ao tratar o dever de reparar como uma dívida, a construção do quadro do subjetivismo foi erigida, dentre outros argumentos, a partir da necessidade de punição do causador do dano.

Por essa razão, era imperiosa a averiguação da origem da lesão e da voluntariedade do ato. Nesse contexto, resta patente porque não havia qualquer lugar reservado às hipóteses de responsabilidade sem culpa. ${ }^{1113}$

Os argumentos colacionados em favor da culpa, entretanto, são ilusórios ${ }^{1114}$, e a defesa do subjetivismo na apreciação do dever de reparar peca, e peca, dentre outros motivos, por ser unilateral.

Teses assim concebidas ignoram a figura do lesado e desprezam o interesse social na reparação do dano. ${ }^{1115}$ Ademais - e esse é um grave problema no maniqueísmo denunciado -, ignoram que a culpa atua como um filtro ${ }^{1116}$ - em desfavor dos lesados -, selecionando as demandas que terão (ou não) seguimento e serão (ou não) eventualmente providas.

\footnotetext{
${ }^{1112}$ Descritos, também, nos itens $1.1,1.3,3.1$ e 3.3 deste trabalho.

${ }^{1113}$ LORENZETTI, Ricardo Luis. El sistema de la responsabilidad civil ¿una deuda de responsabilidad, un crédito de indemnización o una relación jurídica?, Revista da Ajuris, Porto Alegre, n. 63, p. 166-198, mar. 95. p. 168-172.

1114 AZEVEDO, Vicente de Paulo Vicente de. O fundamento da responsabilidade civil extracontratual, Revista de Direito Privado, São Paulo, v. 1, n. 1, p. 151-165, jan./mar. 2000. p. 161-164.

1115 COSTA, Álvaro Ferreira da. Responsabilidade sem culpa, Revista da Faculdade de Direito, Curitiba, v. 4, n. 4, p. 234-250, dez. 1956. p. 238-239.

1116 SCHREIBER, Anderson. Novas tendências da responsabilidade civil brasileira, Revista Trimestral de Direito Civil, Rio de Janeiro, n. 22, p. 45-70, abr./jun. 2005. p. 47.
} 
Mesmo com tantos sacerdotes cultuando-a como um dogma ${ }^{1117}$, nas últimas décadas do século XIX, a questão toma novo rumo. ${ }^{1118}$ A partir de fundamentos de ordem (a) sociológica - o excessivo número das vítimas do maquinismo -, (b) política - as sementes do Estado Social começavam a germinar - e (c) filosófica - o Direito, mesmo que lentamente e com ferrenha oposição, muda o foco de suas preocupações -, a evolução da temática imerge em águas nunca antes navegadas.

Em um primeiro momento, surgem teses pretendendo mitigar os efeitos deletérios da culpa, sem, contudo, retirar seu papel de pressuposto no universo do dever de reparar. Em linhas gerais, essas construções buscavam (a) ampliar a noção de culpa, (b) destacar a importância da utilização do critério abstrato em lugar do concreto em sua apreciação, (c) criar presunções - legais e jurisdicionais ${ }^{1119}$ - que autorizavam visualizar a presença da culpa sem promover sua prova e, ainda, (d) admitir um maior número de hipóteses de responsabilidade contratual. ${ }^{1120}$

É importante destacar, entretanto, que não existe - ao menos, aparentemente uma sequência histórica retilínea que permita visualizar o exato momento de gênese de cada proposta de abrandamento dos efeitos perniciosos da culpa. O aspecto a ser salientado, portanto, cinge-se à existência de um traço comum a todas elas e que consiste na manutenção da culpa como pressuposto do dever de reparar. As aludidas teses, portanto, não visavam à supressão da culpa do universo do dever de reparar, mas sim, à ampliação da porosidade do aludido filtro.

É inquestionável, contudo, que o alargamento do conceito de culpa e a utilização do modelo abstrato para sua aferição ${ }^{1121}$, bem como o surgimento das presunções $^{1122}$, a consequente inversão dos ônus probatórios ${ }^{1123}$ e a ampliação dos

\footnotetext{
${ }^{1117}$ E vale lembrar, aqui, que dogmas não pertencem às ciências.

${ }^{1118}$ BAÍA, Jacinto Américo Guimarães. A evolução da responsabilidade civil e a reparação do dano nuclear, Revista de Direito Civil, Imobiliário, Agrário e Empresarial, São Paulo, v. 2, n. 4, p. 49-68, abr.jun. 1978. p. 52-55.

${ }^{1119}$ GOMES, Orlando. Introdução ao direito civil. 11 ed. Atual. Humberto Theodoro Junior. Rio de Janeiro: Forense, 1995. p. 91.

${ }^{1120}$ RODRIGUES, Silvio. Direito civil: responsabilidade civil. 19 ed. São Paulo: Saraiva, 2002, v. 4. p. 155.

${ }^{1121}$ VENOSA, Sílvio de Salvo. Direito civil: parte geral. 4 ed. São Paulo: Atlas, 2004, v. 1. p. 614.

1122 JOSSERAND, Louis. Evolução da responsabilidade civil, Revista Forense, Rio de Janeiro, n. 86, p. 5263, jun. 1941. p. 58. "Uma presunção é a indução dum fato desconhecido tirada de um fato conhecido; esta indução é, portanto, obra da lei, e a presunção é então legal, e as vezes do juiz, sendo nesse caso presunções do homem."
} 
contornos da responsabilidade contratual ${ }^{124}$ são momentos importantes na escala evolutiva do tratamento dos danos provocados pela violação de dever contratual. Uma visita a cada um desses distintos momentos permite compreender, com maior exatidão, como cada um colaborou com a reconfiguração da arquitetura jurídica da responsabilidade contratual contemporânea.

A primeira das propostas - ao ampliar as possibilidades semânticas contidas no conceito sob análise - despe a culpa do subjetivismo, apresentando-a, agora, como um comportamento lesivo ao interesse de outrem. ${ }^{125}$ As correntes normativas se embasam na incompatibilidade do viés psicológico de aferição da culpa (a) com a proliferação dos danos disparados pela industrialização e (b) com a ampliação das complexidades da vida em sociedade. ${ }^{1126}$ A metamorfose denunciada insere, na noção de culpa, a garantia de que o devedor que promete prestar assegura, implicitamente, possuir aptidão para fazê-lo. ${ }^{1127}$

Em termos gerais, o normativismo defende a existência de culpa sem culpabilidade. Aqui, a aferição da culpa é promovida em perspectiva normativa. ${ }^{1128}$ Nesse contexto, exsurgem figuras esdrúxulas, como a culpa objetiva ${ }^{129}$, tese, aliás, manifestamente contraditória. ${ }^{1130}$ Para evitar enfadonha repetição, reafirme-se, apenas, que, embora não se perceba, o normativismo promove a objetivação do dever de reparar os danos contratuais ao fundir as noções de culpa e de antijuridicidade.

${ }^{1123}$ LÔBO, Paulo Luiz Netto. Responsabilidade civil do advogado, Revista de Direito Privado, São Paulo, v. 3, n. 10, p. 211-220, abr./jun. 2002. p. 213-218.

${ }^{1124}$ Podem ser lembradas aqui hipóteses vislumbrando a tutela de direitos da personalidade nos casos de acidentes de trabalho e em locais de acesso público - como circos e teatros - e o caso do transporte interessado.

${ }^{1125}$ FERNANDES, Adaucto. Das obrigações no direito brasileiro. Rio de Janeiro: A. Coelho Branco Fo Editor, 1951, v. 2. p. 531-532.

${ }^{1126}$ MORAES, Maria Celina Bodin de. Prefácio. In: SCHREIBER, Anderson. Novos paradigmas da responsabilidade civil: da erosão dos filtros da reparação à diluição dos danos. São Paulo: Atlas, 2007. p. XIII.

${ }^{1127}$ LARENZ, Karl. Derecho justo: fundamentos de etica juridica. Trad. Luis Díez-Picazo. Madrid: Civitas, 1993. p. 116.

${ }^{1128}$ CALIXTO, Marcelo Junqueira. A culpa na responsabilidade civil: estrutura e função. Rio de Janeiro: Renovar, 2008. p. 152.

${ }^{1129}$ VASCONCELOS, Ábner de. Responsabilidade civil objetiva, Revista Forense, Rio de Janeiro, v. 53, n. 163, p. 22-33, jan./fev. 1953. p. 27. "[...] é culpa objetiva, de responsabilidade virtual pelos danos de outrem, estabelecer uma fábrica, explorar uma mina, efetuar transportes, andar de automóvel, exercer uma profissão suscetível de causar prejuízos, embora qualquer dessas atividades seja exercida com a melhor das intenções, no interesse do público, da economia nacional, isto é, com o propósito de dar trabalho e criar riqueza."

${ }^{1130}$ LEVI, Giulio. Responsabilità civile e responsabilità oggetiva: diversi modi di introduzione della responsabilità oggetiva e loro influenza sulla legislazione italiana. Milano: Giuffrè, 1986. p. 76. Consoante afirma o autor, "ou existe o elemento subjetivo ou não existe: ou existe o dolo ou a culpa ou não existe." 
Naquilo que diz respeito à segunda perspectiva apontada, tem-se que a mutação sofrida no processo de aferição da culpa - abandonando a análise concreta do desvelar dos acontecimentos, em homenagem a projeções abstratamente formuladas - é outro fator responsável por promover o rompimento dos diques do modelo subjetivo. ${ }^{1131}$

Por sua vez, surgem as presunções. ${ }^{1132}$ É importante lembrar que uma presunção "consiste na inferência que, empiricamente, se extrai do indício, conforme a experiência de vida, a experiência científica ou técnica."1133

Antes de prosseguir e almejando a perfeita compreensão do assunto, é preciso salientar que uma presunção pode ser relativa ou absoluta, e que as últimas, ao contrário das primeiras, não admitem prova em sentido contrário. Aponte-se, desde cedo, que, na seara da responsabilidade contratual, se uma presunção for considerada absoluta, a culpa não passará de um vocábulo inútil. ${ }^{1134}$

Quando se defende que a presunção é relativa, aliás, com o faz a doutrina majoritária ao abordar a questão, afirma-se que o devedor tem o ônus de afastar a presunção de culpa que recai sobre ele. $\mathrm{Na}$ seara contratual, é comum afirmar-se existir presunção de culpa no não cumprimento da prestação.

A questão não é pacífica, existindo autores defendendo que a presunção depende da classificação da obrigação imposta ao devedor. ${ }^{1135}$ Entretanto, consoante parcela representativa da doutrina, a culpa está contida em quaisquer das formas de incumprimento, cabendo ao devedor desconstituir tal presunção. Podem ser lembrados

\footnotetext{
${ }^{1131}$ Acreditamos que a questão tenha sido abordada de modo suficiente no item 3.1, razão pela qual, evitando desnecessária repetição, reportamo-nos ao apontado momento desta tese.

1132 SIMÃO, José Fernando. Responsabilidade civil pelo fato do animal: estudo comparativo dos códigos civis de 1916 e de 2002. In: DELGADO, Mário Luiz; ALVES, Jones Figueirêdo (Coord.). Questões controvertidas: responsabilidade civil. São Paulo: Método, 2006, v. 5. p. 345-346. "A razão da criação da presunção é simples. Representa um importante passo na evolução histórica do dever de indenizar. Não conseguem os juristas romper o sistema milenar baseado na culpa, chegando à responsabilidade objetiva, sem que se trilhe o caminho da presunção."

1133 ALTERINI, Atílio Aníbal. Estudios de derecho civil: conceptos, contratos, consumidor, derecho de daños. Buenos Aires: La Ley, 2007. p. 352.

${ }^{1134}$ Sobre o tema: GOMES, Orlando. Culpa x risco, Revista Forense, Rio de Janeiro, v. 37, n. 83, p. 378-384, set. 1940. p. 380. E, ainda: LIMA, Alvino. Situação atual, no direito civil moderno, das teorias da culpa e do risco, Revista Forense, Rio de Janeiro, v. 37, n. 83, p. 385-389, set. 1940. p. 385.

${ }^{1135}$ LOPEZ, Teresa Ancona. O dano estético: responsabilidade civil. 3 ed. São Paulo: RT, 2004. p. 70.
} 
Carlos Pizarro Wilson ${ }^{1136}$, Fernando Pessoa Jorge ${ }^{1137}$, Hernando Tapias Rocha ${ }^{1138}$ e Pedro Romano Martinez. ${ }^{1139}$

A alusão cada vez mais recorrente às presunções de culpa - apesar da severa e acertada crítica ${ }^{140}$ e dos problemas que derivam de sua inadequada compreensão ${ }^{1141}$ demonstra, ainda que em nível subliminar, o reconhecimento da necessidade de objetivação do dever de reparar. ${ }^{1142}$

As construções teóricas acerca da culpa presumida - mormente quando essa presunção é absoluta ${ }^{1143}$ - não passam de artifícios para encobrir a recepção de um novo paradigma: o da responsabilidade objetiva. ${ }^{1144}$ Verifique-se ser "incongruente uma presunção de culpa que só pode ser afastada com a prova do fortuito."1145

${ }^{1136}$ WILSON, Carlos Pizarro. La responsabildad contractual en el derecho chileno. In: ESPINOSA, Fabricio Mantilla; BARRIOS, Francisco Ternera (Dir.). Los contratos en el derecho privado. Bogotá: Legis, 2007. p. 220.

1137 JORGE, Fernando Pessoa. Ensaio sobre os pressupostos da responsabilidade civil. Coimbra: Almedina, 1999. p. 40. O autor utiliza a expressão responsabilidade obrigacional.

${ }^{1138}$ ROCHA, Hernando Tapias. La acción de responsabildad contractual. In: ESPINOSA, Fabricio Mantilla; BARRIOS, Francisco Ternera (Dir.). Los contratos en el derecho privado. Bogotá: Legis, 2007. p. 233.

1139 MARTINEZ, Pedro Romano. Cumprimento defeituoso: em especial na compra e venda e na empreitada. Almedina: Coimbra, 2001. p. 122.

${ }^{1140}$ RIOS, Arthur. Responsabilidade civil. Os novos conceitos indenizáveis no projeto Reale, Revista da Faculdade de Direito, São Paulo, v. 80, p. 322-339, jan./dez. 1985. p. 323. "A teoria da culpa presumida não nos convence, no campo do direito, pelas mesmas razões que repelimos o "mal presumido", como essência existencial da pessoa humana. A culpa ou ausência de culpa, o mal ou o bem, como fatores de julgamento e juízos, só podem existir, objetivamente, com base em provas e não em presunções, sempre que possível. A posição da culpa presumida também não se sustenta, pois é de irritante conservadorismo e apego a uma idéia já não confortável na fase do direito social do Século XX. Esta encerrada a fase do individualismo em todos os campos da ciência! Foram duas grandes guerras mundiais e uma gama enorme de problemas sociais, que acabaram trazendo benefícios no desenvolvimento do pensamento político, social e jurídico, chegando nas obrigações de reparar danos a uma necessidade de maior atenção, para a questão social do prejuízo individual ou seja dos reflexos comunitários dos danos."

${ }^{1141}$ Um bom exemplo da confusão entre os conceitos de culpa presumida e responsabilidade objetiva pode ser encontrado em: BORGHI, Hélio. Responsabilidade civil: breves reflexões doutrinárias sobre o estado no direito brasileiro. In: Rosa Maria Barreto Borriello de Andrade; DONNINI, Rogério (Coord.). Responsabilidade civil: estudos em homenagem ao professor Rui Geraldo Carmargo Viana. São Paulo: RT, 2009. p. 241.

${ }^{1142}$ AGUIAR DIAS, José de. Da responsabilidade civil. 10 ed. Rio de Janeiro: Forense, 1995, v. 1. p. 84.

1143 MORAES, Maria Celina Bodin de. Risco, solidariedade e responsabilidade objetiva, Revista dos Tribunais, São Paulo, v. 95 , n. 854, p. 11-37, dez. 2006. p. 14. A autora resgata a evolução na leitura da Súmula 341 do STF. Em um primeiro momento, trabalhava-se com presunção relativa de culpa do patrão; compreensão essa alterada posteriormente, em caráter aparentemente contra legem (Art . 1523 CC 1916), mediante a assertiva de que se trata de hipótese de presunção absoluta de culpa - em verdade, objetivação da aferição do dever de reparar - do patrão.

1144 AZEVEDO, Vicente de Paulo Vicente de. O fundamento da responsabilidade civil extracontratual, Revista de Direito Privado, São Paulo, v. 1, n. 1, p. 151-165, jan./mar. 2000. p. 160-161. "No fundo constituem a abolição do elemento moral, a culpa, apenas rotulada com outros nomes. Falta a coragem da 
Outro expediente utilizado na ampliação do universo de tutela das vítimas dos danos injustos consiste na dilatação das hipóteses de responsabilidade contratual. $\mathrm{O}$ enquadramento de situações de responsabilidade aquiliana na seara negocial abranda as dificuldades inerentes à prova da culpa do devedor, e isso porque, nessa seara, consoante o estado da arte, o ônus de provar a ausência de culpa incumbe ao devedor.

A nova moldura impõe que as obrigações de seguridade ${ }^{1146}$ - tratadas neste trabalho como deveres gerais de conduta ${ }^{147}$ - sejam respeitadas. Essa mutação faz com que a responsabilidade contratual ganhe terreno, espalhando-se como plumas ao sabor dos ventos.

É interessante perceber - consoante as linhas tecidas até este instante - como a doutrina se esforçou na elaboração de estratégias que garantissem a tutela das vítimas de danos injustos. Ela dilatou o conceito de culpa e alterou a forma de perqueri-la. Forjou presunções ${ }^{1148}$ e ampliou os contornos da responsabilidade contratual.

Consoante o tempo trilha seu caminho rumo ao desconhecido, o ocaso da culpa $^{1149}$ é percebido. E, para a infelicidade de alguns, quando se entendeu que as pilastras erigidas pelo Code Napoleón para atravessar a eternidade se tornaram incapazes de sustentar as "necessidades do mundo moderno" $" 1150$, já era tarde para salvá-las.

A trilha rumo à objetivação do dever de reparar também parece estar ligada a questionamentos sobre o porquê de impor-se à vítima - enquanto decorrência inexorável

sinceridade. Aferrados às idéias tradicionais, os autores na sua maioria, embora confessando a insuficiência dos sistemas vigentes, não se animam a declará-lo."

${ }^{1145}$ GAMARRA, Jorge. Responsabilidad contractual objetiva. In: BUERES, Alberto Jesús; DE CARLUCCI, Aída Kemelmajer (Dir.). Responsabilidad por daños en el tercer milenio. Buenos Aires: Abeledo-Perrot, 1997. p. 114-115.

1146 PEREIRA, Caio Mário da Silva. Responsabilidade civil: de acordo com a constituição federal de 1988. 8 ed. Rio de Janeiro: Forense, 1997. p. 266.

${ }^{1147}$ Vide capítulo II.

${ }^{1148}$ Para uma análise detalhada desses fenômenos, veja: LIMA, Alvino, Culpa e risco. 2 ed. São Paulo: RT, 1999. p. 70-102.

${ }^{1149}$ PORTO, Mário Moacyr. O ocaso da culpa como fundamento da responsabilidade civil, Revista Forense, Rio de Janeiro, n. 302, p. 45-48, abr./jun. 1988. p. 45-48.

${ }^{1150}$ NERY JUNIOR, Nelson. Aspectos da responsabilidade civil do fornecedor no código de defesa do consumidor, Revista do Advogado, São Paulo, n. 33, p. 76-79, dez. 1990. p. 78. 
da eleição de um fator subjetivo do dever de reparar - o ônus de suportar, sozinha, os danos provocados por outrem. ${ }^{1151}$

Nesse percurso, alude-se ao incômodo causado à alma e ao mal-estar moral provocado por situações em que a vítima suporta danos oriundos de um fato que nada tem a ver com ela. ${ }^{1152}$ Tudo indica que o próximo momento será a explícita aceitação de hipóteses de responsabilidade sem culpa.

É relevante destacar que, durante essa travessia - no conflito que se instaura entre as súplicas almejando a mudança e as objeções e críticas ao modelo objetivo ${ }^{1153}$-, a culpa continua atuando como um filtro na imputação dos danos suportados pelas vítimas.

Não obstante seu poder mítico, chega, enfim, o momento de ser substituída. ${ }^{1154}$ Assim, apesar de, em um primeiro momento, a transição do regime subjetivo para o objetivo ter sido disfarçada, aludindo-se à culpa em situações em que ela é supérflua ${ }^{1155}$, noutro instante, reconhece-se, de modo explícito, a existência de responsabilidade sem culpa.

O surgimento e a proliferação de leis especiais afastando a culpa do processo de conformação do dever de reparar - prova hialina da revolta dos fatos contra os Códigos $^{1156}$ - é um marco deveras importante nessa transformação. No Brasil, salvo melhor juízo, o Decreto $2.681 / 12^{1157}$ foi a primeira lei tratando expressamente do tema.

${ }^{1151}$ PORTO, Mário Moacyr. O ocaso da culpa como fundamento da responsabilidade civil, Revista Forense, Rio de Janeiro, n. 302, p. 45-48, abr./jun. 1988. p. 45.

1152 JOSSERAND, Louis. Evolução da responsabilidade civil, Revista Forense, Rio de Janeiro, n. 86, p. 5263, jun. 1941. p. 54.

1153 SILVA, Wilson Melo da. Responsabilidade sem culpa e socialização do risco. Belo Horizonte: Bernardo Álvares, 1962. p. 173-200.

${ }^{1154}$ PEREIRA, Caio Mário da Silva. Instituições de direito civil: introdução ao direito civil; teoria geral do direito civil. 20 ed. Atual. Maria Celina Bodin de Moraes. Rio de Janeiro: Forense, 2004, v. 1. p. 663. "Em verdade, a culpa, como fundamento da responsabilidade civil, é insuficiente, pois deixa sem reparação danos sofridos por pessoas que não conseguem provar a falta do agente. O que importa é a causalidade entre o mal sofrido e o fato causador, por influxo do princípio segundo o qual toda pessoa que cause a outra um dano está sujeita à sua reparação, sem o problema de se cogitar do problema da imputabilidade do evento à culpa do agente."

1155 HINESTROSA, Fernando. Devenir del derecho de daños, Roma e America: Diritto Romano Comune, Roma, n. 10, p. 17-36, 2000. p. 27. É possível constatar que o recurso à culpa, em diversas decisões, não reflete mais que mero jogo de palavras, revelando um esforço desnecessário na manutenção da incolumidade do espiritualismo e da moral cristã.

1156 GOMES, Orlando. Culpa x risco, Revista Forense, Rio de Janeiro, v. 37, n. 83, p. 378-384, set. 1940. p. 380-384.

1157 AGUIAR JUNIOR, Ruy Rosado de. Os contratos nos códigos civis francês e brasileiro, Revista CEJ, Brasília, v. 9, n. 28, p. 5-14, jan./mar. 2005. p. 9. "Assim, a teoria da responsabilidade subjetiva foi alterada, 
É interessante destacar que a inserção do fator objetivo de imputação do dever de reparar, aparentemente, foi motivada pela necessidade de tutela dos imóveis atravessados pelas ferrovias - e não, dos passageiros transportados ou das cargas despachadas -, por conta dos incêndios causados pelas faíscas expelidas pelos cavalos de ferro movidos a vapor.

E, uma vez rompido o dique, outras tantas leis seguiram idêntico caminho ${ }^{1158}$, podendo ser lembrados o Decreto 24.687/34, reformado pelo Decreto-Lei 7.036/44, o Decreto-Lei 483/38, substituído pela Lei $7565 / 86^{1159}$ e as Leis 6.938/81, 8.078/90 e 8.884/94, instituindo, respectivamente, a lei de política nacional do meio ambiente, o código de defesa do consumidor e lei antitruste. ${ }^{1160}$

A objetivação do dever de reparar está ligada ao processo de transformação da sociedade - e das angústias por ele provocadas - iniciado no século XVIII. Dentre outros motivos, foi disparada (a) pelo reconhecimento das necessidades contemporâneas ${ }^{1161}$ e (b) pela primazia do ressarcimento sobre a análise de aspectos subjetivos na conduta do causador do dano. ${ }^{1162}$

Agora, busca-se a reparação, não mais, a expiação. ${ }^{1163}$ Aquela deixou de ser vista como o resultado da reprovação de uma conduta. ${ }^{1164} \mathrm{E}$, uma vez aceita a objetivação

em parte, e, pela primeira vez, no pioneiro Decreto. n. 2.681, de 7.12.1912, sobre o transporte ferroviário. Depois, essa norma foi aplicada para o transporte em geral, com responsabilidade sempre presumida do transportador. Posteriormente, e ainda na primeira metade do século XX, sobreveio a lei de acidente no trabalho; mais recentemente, e com maior abrangência, o Código de Defesa do Consumidor, publicado em 1990, aplicável na extensa área das relações de consumo, que admitiu a responsabilidade objetiva do fornecedor, por defeito do produto."

${ }^{1158}$ Relatando uma série de leis que aludem à responsabilidade objetiva: LIMA, Alvino, Culpa e risco. 2 ed. São Paulo: RT, 1999. p. 259-277. Veja ainda: PEREIRA, Caio Mário da Silva. Responsabilidade civil: de acordo com a constituição federal de 1988. 8 ed. Rio de Janeiro: Forense, 1997. p. 23-24. TOLOMEI, Carlos Young. A noção de ato ilícito e a teoria do risco na perspectiva do novo código civil. In: TEPEDINO, Gustavo (Coord.). A parte geral do novo código civil: estudos na perspectiva civil-constitucional. Rio de Janeiro: Renovar, 2002. p. 353-354.

${ }^{1159} \mathrm{O}$ primeiro, regrando os acidentes de trabalho, e a segunda, instituindo o código brasileiro da aeronáutica.

1160 Sobre o tema: RODRIGUES, Silvio. Direito civil: responsabilidade civil. 19 ed. São Paulo: Saraiva, 2002, v. 4. p. 157-161.

1161 GOMES, Orlando. Culpa x risco, Revista Forense, Rio de Janeiro, v. 37, n. 83, p. 378-384, set. 1940. p. 379-380.

${ }^{1162}$ PONZANELLI, Giulio. La responsabilità civile: profili di diritto comparato. Bologna: Il Mulino, 1992. p. 67-69.

1163 GIMÉNEZ-CANDELA, Teresa. Una perspectiva historica de la responsabilidad objetiva, Roma $e$ America: Diritto Romano Comune, Roma, n. 8, p. 117-129, 1999. p. 119. 
do dever de reparar, a assunção de um risco - classificado como "risco-proveito" ${ }^{1165}$, risco profissional" $" 1166$ e risco criado ${ }^{1167}$ etc - ocupa o lugar outrora reservado à culpa.

É oportuno salientar, ainda, que, apesar de os estudos sobre a culpa na guarda $^{1168}$ e a preocupação com a tutela dos menos favorecidos terem cooperado com a objetivação do dever de reparar ${ }^{169}$, parece que as ancoragens mais importantes do fenômeno se prendem à (a) mutação social ${ }^{1170}$, (b) ampliação dos deveres dos que exercem atividades perigosas ${ }^{1171} \mathrm{e}$ (c) necessidade de promover os direitos da personalidade. ${ }^{1172}$

${ }^{1164}$ GESUALDI, Dora Mariana. De la antijuridicidad a las causas de justificación. In: BUERES, Alberto Jesús; DE CARLUCCI, Aída Kemelmajer (Dir.). Responsabilidad por daños en el tercer milenio. Buenos Aires: Abeledo-Perrot, 1997. p. 151.

${ }^{1165}$ PEREIRA, Caio Mário da Silva. Responsabilidade civil: de acordo com a constituição federal de 1988. 8 ed. Rio de Janeiro: Forense, 1997. p. 281. A teoria sintetiza-se na "idéia de que é sujeito à reparação aquele que retira um proveito ou vantagem do fato causador do dano." Veja ainda: LIMA, Alvino. Situação atual, no direito civil moderno, das teorias da culpa e do risco, Revista Forense, Rio de Janeiro, v. 37, n. 83, p. 385389, set. 1940. p. 389.

1166 COELHO, José Gabriel Pinto. A responsabilidade civil baseada no conceito da culpa. Coimbra: Imprensa da Universidade, 1906. p. 47-50.

${ }^{1167}$ PEREIRA, Caio Mário da Silva. Responsabilidade civil: de acordo com a constituição federal de 1988. 8 ed. Rio de Janeiro: Forense, 1997. p. 285. O autor parece inclinar-se pela incidência dessa modalidade de risco. Segundo ele, "a teoria do risco criado importa em ampliação do conceito de risco proveito [pois] aumenta os encargos do agente; é, porém, mais equitativa para a vítima, que não tem de provar que o dano resultou de uma vantagem ou de um benefício obtido pelo causador do dano."

${ }^{1168}$ LIMA, Alvino. A reparação civil do dano no anteprojeto do código das obrigações, Revista Forense, Rio de Janeiro, v. 41, n. 97, p. 13-21, jan./mar. 1944. p. 19. Em apertada síntese, lembra o autor, que "o homem é legalmente obrigado à guarda das coisas [e que] a perda desta direção e vigilância, uma vez causado dano pela coisa, importará" a responsabilidade do guardião.

${ }^{1169}$ FIGUEIRA, J. G. de Andrade. A responsabilidade civil e o contrato de seguro no anteprojeto do código das obrigações, Revista Forense, Rio de Janeiro, v. 41, n. 97, p. 38-42, jan./mar. 1944. p. 39. Sustenta o autor, ao indagar-se se não seria o momento de recepcionar a responsabilidade objetiva do que "deixar fixado que o dano pode resultar não só de violação da lei [como de outras fontes] e deixar a porta aberta para o reconhecimento da responsabilidade em todos os casos [tem por foco a preocupação com] "le pieton", o homem da rua, o pária dos novos tempos, aquele sobre quem a ameaça da morte pesa sem cessar cada vez mais, o fraco dos tempos modernos, que precisa ser protegido [...]"

${ }^{1170}$ AMARAL, Francisco. O direito civil na pós-modernidade. In: FIUZA, César; SÁ, Maria de Fátima Freire de; NAVES, Bruno Torquato de Oliveira (Coord.). Direito civil: atualidades. Belo Horizonte: Del Rey, 2003. p. 73. "Particularmente na segunda metade do séc. XX, revoluções na ciência e na tecnologia provocam-lhe sensíveis mudanças. A medicina, com a descoberta de novos fármacos e a realização de transplantes, a biologia, com a novas técnicas de reprodução assistida, controle da hereditariedade e engenharia genética e, principalmente, o advento da tecnologia da informação, com a rapidez na transmissão do conhecimento, tudo isso contribui para mudanças radicais na sociedade contemporânea, e a tornam completamente diversa da anterior. Pode-se, por isso, afirmar que se vive hoje na sociedade pós-moderna ou pós-industrial dominada pelo conhecimento científico e pela riqueza de informações, marcada pelo pluralismo e por elevado grau de complexidade, pela revolução da técnica, pela mundialização da economia e pela massificação dos meios de comunicação. De tudo isso decorre uma natural inadequação das fontes, dos institutos e da metodologia jurídica herdada dos séculos XVIII e XIX, próprias de uma sociedade e de um Estado bastante diversos do contemporâneo, o que leva a falar-se em crise. Mas o que está em crise não é a realidade, que se transforma continuamente", e sim, os modelos que permitem promover sua compreensão.

${ }^{1171}$ LIMA, Alvino. Situação atual, no direito civil moderno, das teorias da culpa e do risco, Revista Forense, Rio de Janeiro, v. 37, n. 83, p. 385-389, set. 1940. p. 386-387. 
Hoje, mais de século após o surgimento dos primeiros estudos sobre o tema, percebe-se que nenhuma das preocupações dos autores subjetivistas tinha fundamento plausível. A tese de que "a adoção da teoria do risco condenaria o homem à inércia" sucumbiu à realidade cotidiana. ${ }^{1173}$ Aferiu-se que, em vez de induzir ao ócio, o recurso a fatores objetivos do dever de reparar estimula a cooperação e a solidariedade.

Identificou-se, ainda, que a perspectiva de análise do tema em perspectiva objetiva, estimula o desenvolvimento de tecnologias menos lesivas. ${ }^{1174}$ Oportuno resgatar que, as vantagens obtidas por aqueles que investem em pesquisa e desenvolvimento são significativas - é evidente, desde que, haja oportunidade de avanço - se comparadas às práticas imitativas. ${ }^{1175}$ Aliás, a inovação tecnológica é, sem dúvida, um importante fator que conduz ao rompimento do "fluxo circular" da economia. ${ }^{1176}$

A seu turno, as economias mantiveram crescimento pujante. A adoção de parâmetros simplificados e de fácil aferição na conformação do dever de reparar estimula a

${ }^{1172}$ VINEY, Geneviève. As tendências atuais do direito da responsabilidade civil. In: TEPEDINO, Gustavo (Org.). Direito civil contemporâneo: novos paradigmas à luz da legalidade constitucional. São Paulo: Atlas, 2008. p. 51.

1173 AGUIAR DIAS, José de. Da responsabilidade civil. 10 ed. Rio de Janeiro: Forense, 1995, v. 1. p. 73.

1174 TRIMARCHI, Pietro. Sul significato economico dei criteri di responsabilità contrattuale, Rivista Trimestrale di Diritto e Procedura Civile, Milano, t. 26, p. 512-531, 1970. p. 523.

1175 SOUSA, Sergio Almeida de. Um modelo evolucionário de busca tecnológica em condições de hipercumulatividade, Revista Brasileira de Economia, Rio de Janeiro, v. 59, n. 3, p. 335-380, jul./set. 2005. p. 375.

${ }^{1176}$ COSTA, Achyles Barcelos da. O desenvolvimento econômico na visão de Joseph Schumpeter, Cadernos IHU Ideias, São Leopoldo, v. 4, n. 47, p. 3-16, 2006. p. 3-8. Na economia do 'fluxo circular', segundo Schumpeter, a vida econômica transcorre monotonamente, em que cada bem produzido encontra o seu mercado, período após período. Isso, contudo, não significa concluir que inexista crescimento econômico. Admitem-se incrementos na produtividade, decorrentes de aperfeiçoamentos no processo de trabalho e de mudanças tecnológicas contínuas na função de produção. Entretanto, essa base tecnológica já é conhecida, incorporada que foi com o tempo na matriz produtiva da economia. Os agentes econômicos apegam-se ao estabelecido, e as adaptações às mudanças ocorrem em ambiente familiar e de trajetória previsível. Nessas circunstâncias, de acordo com Schumpeter, mudanças econômicas substanciais não podem ter origem no fluxo circular, pois a reprodução do sistema está vinculada aos negócios realizados em períodos anteriores. [...] O desenvolvimento dessa idéia leva Schumpeter a procurar estabelecer de onde provêem as inovações, quem as produz e como são inseridas na atividade econômica. Do plano, Schumpeter descarta a hipótese de que elas se originem no âmbito dos desejos e necessidades dos consumidores, embora esses sejam elementos importantes para a adoção e difusão de novas combinações. Todavia, esses atores são passivos em relação à pesquisa e ao desenvolvimento de novos produtos e processos. Apenas os incorporam aos seus hábitos diários. [...] Contudo, esses são ganhos passageiros (windfall gains), que desaparecem assim que as inovações vão se difundindo na sociedade por meio de novos concorrentes (imitadores) que se juntam ao mercado, e à medida que as novas combinações passam à condição de atividade normal. [...] A introdução no mercado de um novo produto ou processo gera lucros extraordinários, o que atrai uma leva de imitadores que buscam aproveitar as oportunidades abertas pela inovação. [...] A interrupção na continuidade da expansão se deve à eliminação dos lucros extraordinários pela queda nos preços, devido ao aumento da oferta. O outro movimento deriva de adaptações que são feitas pelos agentes, oriundas de mudanças causadas pelas inovações. A introdução de uma novidade de produtos ou processos vem alterar as condições competitivas daqueles empreendimentos já estabelecidos." 
composição extrajudicial, reduzindo os custos da contratação em inúmeras hipóteses, ao afastar ou diminuir ${ }^{1177}$, do cálculo, as despesas de eventuais demandas judiciais. A culpa estimula a litigiosidade. ${ }^{1178}$

Além disso, a supressão da culpa implica a diminuição da discricionariedade que permeia o labor judicial ${ }^{1179}$, o que, além de corroborar a assertiva anterior, imprime respeito à isonomia constitucional, especialmente quando são recuperadas as lições sobre os problemas atinentes à caracterização e identificação da culpa em cada situação que o exija.

Em razão dessa segunda metamorfose - a primeira, como visto, se opera dentro do modelo subjetivo -, o dever de reparar é pensado a partir da necessidade de transferir o dano àquele que o causou. ${ }^{1180} \mathrm{E}$, como se busca tutelar a vítima ${ }^{1181}$, a responsabilidade contratual - superando a ideia de sanção em desfavor do causador do dano - passa a ser pensada como garantia em favor do credor. ${ }^{1182}$

${ }^{1177}$ POMAR, Fernando Gómez. Carga de la prueba y responsabilidad objetiva, InDret, Barcelona, n. 1, p. 117, 2001. p. 2. "En la medida en que la regla de responsabilidad objetiva permite a los jueces y tribunales decidir la responsabilidad del demandado sin consideración hacia el nivel de diligencia exigible, y sin detenerse a determinar si el cuidado realmente observado por el demandado se ha atenido a tal nivel, los procedimientos judiciales en la materia serán, en buena lógica, más simples y menos costosos.”

1178 TRIMARCHI, Pietro. Sul significato economico dei criteri di responsabilità contrattuale, Rivista Trimestrale di Diritto e Procedura Civile, Milano, t. 26, p. 512-531, 1970. p. 517-526.

${ }^{1179}$ MORAES, Maria Celina Bodin de. Perspectivas a partir do direito civil-constitucional. In: TEPEDINO, Gustavo (Org.). Direito civil contemporâneo: novos paradigmas à luz da legalidade constitucional. São Paulo: Atlas, 2008. p. 34.

${ }^{1180}$ DE CORES, Carlos. Acerca de las funciones de la responsabilidad civil. In: FERNÁNDEZ, Carlos López; CAUMONT, Arturo; CAFFERA, Gerardo (Coord.). Estudios de derecho civil en homenaje al profesor Jorge Gamarra. Montevideo: FCU, 2001. p. 117.

1181 PASQUALOTTO, Adalberto de Souza. A responsabilidade civil do fabricante e os riscos do desenvolvimento. In: MARQUES, Cláudia Lima (Coord.). A proteção do consumidor no Brasil e no Mercosul. Porto Alegre: Livraria do Advogado, 1994. p. 78. No mesmo sentido: MORAES, Maria Celina Bodin de. A constitucionalização do direito civil e seus efeitos sobre a responsabilidade civil, Direito, Estado e Sociedade, Rio de Janeiro, v. 9, n. 29, p 233-258, jul/dez 2006. p. 245. "A constitucionalização do direito dos danos impôs, como se viu, a releitura da própria função primordial da responsabilidade civil. O foco que tradicionalmente recaía sobre a pessoa do causador do dano, que por seu ato reprovável deveria ser punido, deslocou-se no sentido da tutela especial garantida à vítima do dano injusto, que merece ser reparada. A punição do agente pelo dano causado, preocupação pertinente ao direito penal, perde a importância no âmbito cível para a reparação da vítima pelos danos sofridos." Veja ainda: FACCHINI NETO, Eugênio. Aspectos da responsabilidade civil e o novo código, Revista da PGE, Porto Alegre, v. 27, n. 57, p. 157-184, 2004. p. 162. "O foco atual da responsabilidade civil, pelo que se percebe da sua evolução histórica e tendências doutrinárias, tem sido no sentido de estar centrado cada vez mais no imperativo de reparar um dano, do que na censura do seu responsável. Cabe ao direito penal preocupar-se com o agente causador do dano. Ao direito civil, contrariamente, compete inquietar-se com a vítima."

${ }^{1182}$ GOMES, Orlando. Introdução ao direito civil. 11 ed. Atual. Humberto Theodoro Junior. Rio de Janeiro: Forense, 1995. p. 92. BUSTAMANTE ALSINA, Jorge. El perfil de la responsabilidad civil al finalizar el siglo XX. In: BUERES, Alberto Jesús; DE CARLUCCI, Aída Kemelmajer (Dir.). Responsabilidad por daños en el tercer milenio. Buenos Aires: Abeledo-Perrot, 1997. p. 16. LORENZETTI, Ricardo Luis. El 
Entre outros fatores, essa transformação parece ter sido estimulada pela constatação de que, se, entre as bases fundantes da responsabilidade objetiva, se encontram a equidade e solidariedade social, o agente deve ser visto como responsável por outra pessoa, e não, apenas, por sua esfera de atividades.

Nessa esteira, alude-se à responsabilidade frente ao outro ${ }^{183}$, e não mais, perante a si próprio ou a Deus. A mudança de paradigma ocorrida é evidente e incontestável.

Infira-se, ademais, que a defesa do crédito em nível superior à tutela desmedida do devedor ${ }^{1184}$ promove, sem dúvida, a pessoa humana. Esse aspecto valora a confiança e a necessidade de cumprimento das promessas feitas ao outro, mesmo porque não se olvida que "uma sociedade desconfiada é uma sociedade que não negocia, e, onde não há negociações, não há progresso." ${ }^{1185}$ Tais vantagens não são ignoradas.

Ocorre que, por outro lado, essa forma de conceber o dever de reparar é tão maniqueísta quanto as construções por ela combatidas, é tão unilateral quanto as teses que conduziram à mitificação da culpa. E, como retornar ao modelo subjetivista é algo absolutamente inaceitável, é fundamental buscar uma alternativa. Por isso, o elemento que imanta o dever de reparar deve ser o dano, esse mal que, ao infligir um indivíduo, aflige a sociedade como um todo.

É sobre o dano, e não, sobre a vítima, que a responsabilidade contratual deve ser estruturada. Infira-se que, quando o dever de reparar é pensado a partir do dano, além de facilitar-se o acesso à justiça contratual, se promove, com mais facilidade, (a) a proteção da pessoa humana, (b) a reparação integral - se é que isso é possível em muitas situações dos danos, (c) a função preventiva do Direito ${ }^{1186} \mathrm{e}$, por que não, (d) o próprio bem comum.

sistema de la responsabilidad civil ¿una deuda de responsabilidad, un crédito de indemnización o una relación jurídica?, Revista da Ajuris, Porto Alegre, n. 63, p. 166-198, mar. 95. p. 172-178.

${ }^{1183}$ BARRETTO, Vicente de Paulo. Responsabilidade e teoria da justiça contemporânea. In: SILVA FILHO, José Carlos Moreira da; PEZZELLA, Maria Cristina Cereser (Coord.). Mitos e rupturas no direito civil contemporâneo. Rio de Janeiro: Lumen Juris, 2008. p. 68-71.

${ }^{1184}$ ITURRASPE, Jorge Mosset; PIEDECASAS, Miguel. Responsabilidad contractual. Santa Fé: RubinzalCulzoni, 2007. p. 20-21.

1185 FARO, Frederico Kastrup de. Boa-fé objetiva e dever de cooperação: uma análise sob as óticas do exercício da autonomia privada e da execução do contrato, Revista Trimestral de Direito Civil, Rio de Janeiro, n. 38, p. 3-39, abr./jun. 2009. p. 11.

1186 BARROSO, Lucas Abreu; FROTA, Pablo Malheiros da Cunha. A obrigação de reparar por danos resultantes da liberação do fornecimento e da comercialização de medicamentos. Inédito. 
Eis a terceira transformação - implícita, talvez, em teses defendendo que o dano é o centro gravitacional do processo que almeja sua reparação -, mutação que, por ainda estar em curso, exige especial atenção. A leitura do tema deve, entretanto e necessariamente, ultrapassar a perspectiva individual e egoísta que informou o estudo do direito civil por longa data. ${ }^{1187} \mathrm{O}$ dano há de ser tratado como um mal social ${ }^{1188} \mathrm{e}$, por isso, exige-se que seja não apenas combatido, mas, primordialmente, evitado, reflexão que, aliás, é compartilhada, de algum modo, por autores como Alberto Bueres ${ }^{1189}$, Jorge Meza, Juan Boragina, Martha Agoglia ${ }^{1190}$ e Pietro Barcellona. ${ }^{1191}$

Nunca é demais lembrar que o risco - e o contrato é uma de suas fontes assumiu proporções inimagináveis na contemporaneidade, disseminando-se globalmente. Por isso, qualquer oportunidade de evitá-lo há de ser valorada, mormente quando se aceita que o Direito tem por escopo a promoção da pessoa humana e do bem comum, e não, simplesmente, a solução de conflitos de interesses de natureza puramente patrimonial.

É importante apontar, ainda, que, apesar de uma boa parte dos civilistas não enxergar a apontada transição - e a importância de ver o dano como um mal social -, é possível encontrar autores atribuindo destaque - mesmo que vislumbrem exceções - à objetivação do dever de reparar. ${ }^{1192}$ Ao lecionar sobre o tema, Jorge Gamarra ${ }^{1193}$ afirma que o viés objetivo deve ser tratado como regra, enquanto Sebastián Picasso salienta que a

${ }^{1187}$ No mesmo sentido: NALIN, Paulo. Responsabilidade civil: descumprimento do contrato e dano extrapatrimonial. Curitiba: Juruá, 1996. p. 41-53.

${ }^{1188}$ Nessa perspectiva, veja: SILVA, Wilson Melo da. Responsabilidade sem culpa e socialização do risco. Belo Horizonte: Bernardo Álvares, 1962. p. 263-267.

1189 BUERES, Alberto Jesus. La localización del daño resarcible. In: FERNÁNDEZ, Carlos López; CAUMONT, Arturo; CAFFERA, Gerardo (Coord.). Estudios de derecho civil en homenaje al profesor Jorge Gamarra. Montevideo: FCU, 2001. p. 436.

1190 AGOGLIA, María Martha; BORAGINA, Juan Carlos; MEZA, Jorge Alfredo. Responsabilidad por incumplimiento contractual. Buenos Aires: Hammurabi, 2003. p. 98.

${ }^{1191}$ BARCELLONA, Pietro. Formazione e sviluppo del diritto privato moderno. Napoli: Jovene, s/a. p. 418.

1192 NORONHA, Fernando. Desenvolvimentos contemporâneos da responsabilidade civil, Revista dos Tribunais, São Paulo, n. 761, p. 31-44, mar. 1999. p. 38.

${ }^{1193}$ GAMARRA, Jorge. Incidencia del problema de la carga de la prueba en la fundamentación de la responsabilidad civil, Revista de la Facultad de Derecho y Ciencias Sociales, Montevideo, v. 2, n. 3, p. 639665 , 1951. p. 657. Reconhece o autor que, no universo contratual, predominam obrigações cuja principiologia afasta a culpa em homenagem às exigências da vida econômica e da necessidade de respeito às expectativas do credor. 
culpa não é nem o fundamento exclusivo, nem o predominante no universo da responsabilidade contratual. ${ }^{1194}$

O dever de reparar distanciou-se de suas raízes. Em vez de atuar como instrumento de proteção da propriedade e de promoção de (in)justiça comutativa, ao ser informado pelos influxos que emanam do Estado Democrático de Direito, funcionaliza-se em busca da cidadania e da justiça social. ${ }^{1195}$ Sabe-se que a equalização dos interesses em questão não é tarefa fácil e exige atenção de toda a comunidade científica. É inegável, entretanto, a necessidade de aceitação de que o tema é permeado ${ }^{1196}$ por valores democraticamente apostos no texto constitucional.

A proteção da pessoa humana, a garantia de igualdade material e as opções pautadas na solidariedade devem permear qualquer processo visando à reparação de danos contratuais. Observadas essas premissas, sem dúvida, alcançar-se-á o tão sonhado bem comum. Parece pertinente informar que idêntico caminho - a utilização de fatores objetivos de imputação dos danos contratuais - tem sido trilhado no direito continental europeu $^{1197}$ e no direito anglo-americano, no qual, aliás, a matéria se insere em matriz que determina ser objetiva a responsabilidade do devedor ${ }^{1198}$ que não cumpre pontualmente uma obrigação de caráter negocial. ${ }^{1199}$

${ }^{1194}$ PICASSO, Sebastián. El incumplimiento en las obligaciones contractuales: el problema de la ausencia de culpa y de la imposibilidad sobrevenida de la prestación - obligaciones de medios y de resultado. In: GESUALDI, Dora Mariana (Coord.). Derecho privado. Buenos Aires: Hammurabi, 2001. p. 1115.

1195 BARROSO, Lucas Abreu. Novas fronteiras da obrigação de indenizar e da determinação da responsabilidade civil. In: DELGADO, Mário Luiz; ALVES, Jones Figueiredo (Coord.). Questões controvertidas: responsabilidade civil. São Paulo: Método, 2006, v. 5. p. 363-368.

${ }^{1196}$ Como apontado nos itens 1.2 e 1.3 deste trabalho.

${ }^{1197}$ FUENZALIDA, Carlos Vattier. Notas sobre el incumplimiento y la responsabilidad contractual, Revista Electrónica del Departamento de Derecho de la Universidad de La Rioja, Logroño, n. 3, p. 57-68, dez. 2005. p. 64. "El Derecho anglosajón ha influido también, en una medida variable, en las propuestas que propician la unificación del Derecho de obligaciones y contratos en la Unión Europea. Esta influencia se constata de un modo manifiesto en los Principios de la Comisión Lando, cuyo régimen está muy próximo, por lo demás, al del Contract Code. En efecto, los Principios consagran, aunque no definen, una noción amplia de incumplimiento, del que se responde siempre, a no ser que se deba a un impedimento incontrolado e imprevisto."

1198 LÓPEZ, Andrés Mariño. Los fundamentos de la responsabilidad contractual. Montevideo: Carlos Alvarez, 2005. p. 22.

1199 Advirta-se aqui que temos consciência de que as teses construídas no comom law não podem ser simplesmente pinçadas daquele sistema e inseridas em uma realidade completamente distinta daquela em que foram construídas, mormente porque o Direito deve ser compreendido a partir de suas historicidade. A alusão ao sistema anglo-saxão deve ser lida assim com intuito exclusivamente informativo, na tentativa de demonstrar a tendência notada em nível global. 
E, sem a pretensão de formular, aqui, qualquer estudo profundo do direito comparado - mesmo porque o autor não tem condições de fazê-lo -, intenta, apenas, demonstrar que a objetivação do dever de reparar é uma tendência global que não pode ser desprezada.

As múltiplas evidências demonstrando a crescente objetivação do pensamento jurídico hodierno ${ }^{1200}$ devem ser acrescentadas aos argumentos em favor da morte da culpa. Em termos gerais, a tendência apontada afasta, do cerne das análises, o comportamento do agente, priorizando a investigação da repercussão social que emana da conduta dos diversos atores sociais.

Provas desse fenômeno são (a) a inserção de um sem-número de cláusulas gerais na codificação vigente - como as da boa-fé objetiva e da função social dos contratos -, (b) a emenda constitucional do divórcio, que aparentemente sepultou a culpa no direito de família, (c) os estudos sobre o exercício inadmissível de posições jurídicas e, ainda, (d) a compreensão da empresa como atividade econômica.

É oportuno apontar, ademais, que afastar a culpa do interior da moldura de atribuição dos danos contratuais produzirá efeitos bastante positivos, dentre eles, (a) a redução dos casos de ofensa à isonomia substancial, provocados, normalmente, pelo recurso a noções distintas de culpa, (b) a superação de raciocínios medievais que buscam punir os pecadores, em vez de, homenagear a pessoa humana, (c) o abandono de reflexões lastreadas em uma lógica patrimonial-individualista, pautada exclusivamente no anseio por acumulação de capital - e (ou) de poder, (d) a compreensão do dano como uma patologia social - e não como um problema meramente individual -, (e) a diminuição da confusão existente - e bastante comum - entre os fenômenos da responsabilidade subjetiva e objetiva. $^{1201}$

\footnotetext{
${ }^{1200}$ HIRONAKA, Giselda Maria Fernandes Novaes. Tendências do direito civil no século XXI. In: FIUZA, César; SÁ, Maria de Fátima Freire de; NAVES, Bruno Torquato de Oliveira (Coord.). Direito civil: atualidades. Belo Horizonte: Del Rey, 2003. p. 112-113. "Esta é a interessante visão da boa-fé pela sua angulação subjetiva; contudo, enquanto princípio informador da validade e eficácia contratual, a principiologia deve orientar-se pelo viés objetivo do conceito de boa-fé, pois visa [sic] garantir a estabilidade e a segurança dos negócios jurídicos, tutelando a justa expectativa do contraente que acredita e espera que a outra parte aja em conformidade com o avençado, cumprindo as obrigações assumidas. Trata-se de um parâmetro de caráter genérico, objetivo, em consonância com as tendências do direito contratual contemporâneo, e que significa bem mais que simplesmente a alegação da ausência de má-fé, ou da ausência da intenção de prejudicar, mas que significa, antes, uma verdadeira ostentação de lealdade contratual, comportamento comum ao homem médio, o padrão jurídico standard."

${ }^{1201}$ Prova disso são os julgados listados abaixo, nos quais se utiliza a expressão culpa objetiva: STJ. REsp 47346/PR. 1. T. Rel. Min. Cesar Asfor Rocha. j. 16.05.94. DJ 01.08.94. p. 18595; STJ. EDcl no AgRg no
} 
Além disso, se promoverá (f) a construção de um sistema dogmático coerente, pois, como demonstrado, o fortuito não é o limite da culpa, $(\mathrm{g})$ a redução do número de julgados teratológicos ${ }^{1202} \mathrm{e}$, talvez, (h) o incentivo à contratação de seguros - como os já existentes no campo do crédito à exportação ${ }^{1203}$-, garantindo a reparação dos danos suportados pelos lesados e estimulando esse campo da economia.

Enfim, (i) quando a comunidade jurídica compreender, com a clareza necessária, o fato de que é o dano, e não, seu causador que está no foco das atenções do Direito, acredita-se que, sem dúvida, haverá uma miríade de estudos repensando a temática, salientando não só a necessidade de ressarcimento, mas, especialmente, a prevenção dos danos.

REsp 135368/PR. 1. T. Rel. Min. Francisco Falcão. j. 20.03.03. DJ 26.05.03. p. 258; TJPR. Ap. Cív. 0571633-4. 8. CCív. Rel. Des. João Domingos Kuster Puppi. j. 09.07.09. Vide ainda: TJPR. Ap. Cív. 0460525-8. 10. CCív. Rel. Des. Marcos de Luca Fanchin. j. 26.06.08. Eis um trecho do acórdão que demonstra o problema detectado: "O parágrafo $4 .^{\circ}$ do artigo 14 do Código de Defesa do Consumidor, ao mandar apurar a culpa subjetiva em relação à responsabilidade pessoal dos profissionais liberais, apenas criou uma exceção à regra genérica da culpa objetiva, mas não excluiu a submissão desses profissionais ao referido Código, naquilo que diz respeito aos serviços prestados aos pacientes."

${ }^{1202}$ Como se percebe em: TJRS. Ap. Cív. 70027024074. 10. CCív. Rel. Des. Jorge Alberto Schreiner Pestana. j. 27.11.08. DJRS 01.01.09. Valendo destacar o trecho do voto que dita que, "de pronto, cabe registrar que em outras demandas onde agentes financeiros formalizaram contratos com terceiros que apresentaram documentos adulterados, de regra perdidos ou furtados, tem esta Câmara reconhecido a responsabilidade dos Bancos sempre que as falsificações eram passíveis de constatação ou não tenha a entidade bancária tomado mínimas precauções ao contratar com os estelionatários. [...] Destarte, em que pese o episódio traduzir prejuízo à demandante, inexiste o pressuposto da culpa atribuível à instituicão ora demandada, rompido o nexo de causalidade em vista de a ação ser de responsabilidade exclusiva de terceiro, situação prevista no art. $14, \S 3^{\circ}$, inc. II, da Lei n. ${ }^{\circ} 8.078 / 90$, não incorrendo o réu em falha nas providências que lhe eram exigíveis."

${ }^{1203}$ Sobre o tema: BRITO, Andréia Carvalho de. Contrato de seguro de crédito à exportação. In: PAMPLONA FILHO, Rodolfo; PEDROSA, Lauricio Alves Carvalho. Novas figuras contratuais: homenagem ao professor Washington Luiz da Trindade. São Paulo: LTr, 2010. p. 15-29. 


\section{FUNDAMENTOS DO DEVER DE REPARAR OS DANOS CONTRATUAIS NA CIVILÍSTICA CONTEMPORÂNEA}

\subsection{Críticas à dogmática ${ }^{1204}$ codificada em matéria de responsabilidade contratual}

O Direito é fato social e está presente nos momentos de fundo cultural, histórico e sociológico ${ }^{1205}$ que permeiam as relações humanas. Aceita essa premissa, facilmente se percebe porque a positividade possui caráter acessório ${ }^{1206}$ e, consequentemente, porque aquele há de ser concebido como um constante vir a ser que tem por principais pautas a promoção da pessoa e a busca do bem comum. É essencial "olhar além do direito formal, [...] não se contentar [apenas com os momentos consagrados nas leis e] buscar aquelas raízes que, sempre, quer se queira quer não, atingem o estrato escondido dos valores." 1207

Compreender o Direito "como instrumento de transformação social" e de promoção do ser - premissa longínqua dos paradigmas individualistas ${ }^{1208} \mathrm{e}$ patrimonialistas sobre os quais a dogmática está fundada - conduz à implosão das bases de sustentação de uma postura que venera posturas de culto à lei e que despreza os avanços da hermenêutica e das ciências da linguagem. ${ }^{1209}$

${ }^{1204}$ COING, Helmut. Historia de derecho y dogmática jurídica, Revista Chilena de Derecho, Santiago, v. 9, n. 2, p. 245-257, mai./ago. 1982. p. 245. Por dogmática, há de se compreender a ciência que promove a investigação da conexão entre princípios e regras contidas em um direito positivo vigente. Cabe a ela, ademais, pôr em relevo princípios que se chocam e delimitar seu universo de aplicação. Age de modo a preparar a aplicação dos preceitos codificados aos casos submetidos ao intérprete e ainda facilitar a apresentação do direito por ocasião do ensino jurídico.

${ }^{1205}$ FACHIN, Luiz Edson. Teoria crítica do direito civil. Rio de Janeiro: Renovar, 2000. p. 65.

1206 PERILLO, Emanuel Augusto. A positividade como expressão do direito, Revista da Faculdade de Direito, Curitiba, v. 4, n. 4, p. 105-109, dez. 1956. p. 106-109.

1207 GROSSI, Paolo. A formação do jurista e a exigência de um hodierno "repensamento" epistemológico, Revista da Faculdade de Direito da UFPR, Curitiba, v. 40, p. 5-25, 2004. p. 22.

${ }^{1208}$ STRECK, Lenio Luiz. O estado democrático de direito e a necessária constitucionalização do direito: a crise dos 10 anos da constituição cidadã, Revista da Faculdade de Direito de Cruz Alta, Cruz Alta, v. 4, n. 4, p. 23-41, jan./jul. 1999. p. 28-29.

1209 COFRÉ, Juan. Racionalidad en el derecho: una aproximación filosófica a la hermenéutica jurídica, Revista Chilena de Derecho, Santiago, v. 22, n. 1, p. 41-59, jan./abr. 1995. p. 57. 
E, apesar de o Direito configurar um espaço de libertação ${ }^{1210}$ do ser, em algum momento do tempo, a preocupação com o método - a fiel observância a uma metodologia previamente eleita era um dos principais paradigmas vigentes nos séculos XIX e XX - foi, sem dúvida, uma das maiores responsáveis pelo afastamento entre as respostas dadas pelo Direito e a experiência concreta das relações humanas. A valorização da dogmática ${ }^{1211}$ criou problemas como a universalização dos conceitos e a compressão do ser.

Mesmo que hoje se reconheça que o discurso retórico da ordem social dominante foi utilizado para sustentar uma estrutura ilegítima ${ }^{1212}$ - disparando ou incitando, por exemplo, o processo de exclusão social -, não faltam vozes para aplaudi$\mathrm{la}^{1213}$, mesmo depois de comprovado que a equação Direito é igual à lei ${ }^{1214}$ - por tanto tempo cultuada ${ }^{1215}$ - afastou aquele da realidade dos fatos e permitiu o aprisionamento de cada momento da existência humana. ${ }^{1216}$ Em vez de buscar soluções para os problemas da vida em sociedade - especialmente pelos transtornos provocados por um direito dos proprietários, dos contratantes, dos pais de família etc -, dedicavam-se longos tratados à sistematização do conjunto de regras alocadas nesse ou naquele código.

${ }^{1210}$ COELHO, Luiz Fernando. Teoria crítica do direito. 3 ed. Belo Horizonte: Del Rey, 2003. p. 575.

1211 SALDANHA, Nelson. Da teologia à metodologia: secularização e crise do pensamento jurídico. Belo Horizonte, Del Rey, 2005. p. 110-111. Destaca o autor que, ao se considerar "que o conceito de ordenamento foi tomado pelos formalistas e puristas como uma noção puramente formal, constituída por um "sistema de normas", a exclusão dos aspectos não-formais do problema acarretou e implicou a redução do objeto "Direito" à condição de um ente abstrato, [negando que] o Direito, em sua objetividade e sua positividade, representa uma ordem entre outras, dentro da dimensão geral de politicidade que corresponde ao plano institucional da vida dos homens. Representa igualmente uma ordem concreta e efetiva, composta de relações e decisões, além de normas e de princípios. A concentração sobre problemas metodológicos desvia o pensamento jusfilosófico do sentido real de ordem, que possui o Direito. Desvia-o, também, da dimensão hermenêutica que existe na experiência jurídica. $\mathrm{O}$ cientificismo subjacente ao metodologismo mantém a problemática da teoria jurídica na ante-sala das questões concretas, isto é, mantém-na na temática que alguns chamam metateórica. As exigências lógicas que se acham dentro do metodologismo, e com elas o prazer lúdico que se lhes refere, prendem o questionamento em uma série de indagações formais que não afetam a realidade."

1212 WARAT, Luis Alberto. Introdução geral ao direito: a epistemologia jurídica da modernidade. Porto Alegre: SAFE, 2002, v. 2. p. 42.

1213 PEÑA, Carlos. El derecho desde el derecho, Persona y Sociedad, Santiago, v. 18, n. 2, p. 23-32, ago. 2004. p. 24-25. Consoante o autor, uma das características mais marcantes da dogmática é a indissolúvel unidade que guarda com seu objeto, pois, ao contrário do que ocorre em outras ciências, o direito não se limita a descrevê-lo, existindo mesmo, ante o papel do jurista, constante reconfiguração visando a sua otimização.

${ }^{1214}$ Cujas constantes eram a cientificidade e a neutralidade.

1215 JUNQUEIRA DE AZEVEDO, Antonio. O direito pós-moderno e a codificação, Revista da Faculdade de Direito, São Paulo, v. 94, p. 3-12, jan./dez. 1999. p. 6-7.

${ }^{1216}$ FACHIN, Luiz Edson. Teoria crítica do direito civil. Rio de Janeiro: Renovar, 2000. p. 55. 
Os efeitos da valorização da dogmática podem ser percebidos nos códigos civis. As primeiras codificações, aliás, acabam por refletir (a) a racionalização - ao permitirem abandonar os particularismos existentes -, (b) o progresso econômico e individual, (c) o avanço pedagógico - todos têm como conhecer a lei - e, enfim, (d) um aspecto utópico, pois teriam sido erigidas para a eternidade. ${ }^{1217}$

Entretanto, uma vez construídas para solucionar os problemas que esse ramo do direito se propõe a resolver ${ }^{1218}$, desprezam, no mais das vezes, (a) o fato de que o Direito está presente em outras nascentes, e não, apenas neles, (b) as particularidades de cada situação concretamente estabelecida, (c) a existência de menos favorecidos e de vulneráveis, (d) a fantasia contida na suposição de que todos conhecem a lei e, ainda, dentre outros aspectos e, (e) as mutações sociais e mudanças dos paradigmas vigentes.

Ademais, além dos problemas atados ao excessivo apego à tradição - apego que, se não impede, dificulta a evolução do pensamento científico e a transformação da realidade social -, é importante perceber, como apontado, que codificar implica renegar o particularismo jurídico, pois, na medida em que impõe a utilização das mesmas regras na solução de casos díspares ${ }^{1219}$, afasta as possibilidades de recurso às intersubjetividades inerentes à cada hipótese concretamente estabelecida.

Se é certo que um código se distingue por seu conteúdo e papel - contendo as regras inerentes a uma dada matéria, com a expectativa de dirigir o regime jurídico de um ou mais setores da vida em sociedade ${ }^{1220}$-, ao mesmo tempo, pode-se identificar que o Direito assim concebido envelhece precocemente ${ }^{1221}$, processo que flui mais rapidamente nos sistemas fechados.

${ }^{1217}$ DIEZ-PICAZO, Luis. Codificación, descodificación y recodificación, Anuario de Derecho Civil, Madrid, v. 45 , n. 2, p. $473-484$, abr./jun. 1992. p. 474-478.

${ }^{1218}$ A ideia se aclara ainda mais, quando se lembra o teor do art. $4^{\circ}$ da LICC e o papel subsidiário e hierárquico por ela reservado à analogia, aos costumes e, enfim, aos princípios. Demonstrando a superação do caminho eleito pelo legislador: BARROSO, Lucas Abreu. Situação atual do art. $4^{\circ}$ da lei de introdução ao código civil, Revista Brasileira de Direito Constitucional, São Paulo, n. 5, p. 236-242, 2005. p. 236-242.

${ }^{1219}$ SACCO, Rodolfo. Codificare: modo superato di legiferare?, Rivista di Diritto Civile, Padova, anno 29, n. 2, p. 117-135, mar./abr. 1983. p. 119.

${ }^{1220}$ ASCENSÃO, José de Oliveira. $O$ direito: introdução e teoria geral - uma perspectiva luso-brasileira. 2 ed. Rio de Janeiro: Renovar, 2001. p. 376.

${ }^{1221}$ MAGALHÃES, Joseli Lima. Da recodificação do direito civil brasileiro. Rio de Janeiro: Lumen Juris, 2006. p. 212. "A codificação das leis civis, apesar de sistematizar o Direito, tornando-o mais claro, menos formal, mais conhecido e preciso, não tem sido capaz de manter-se atual em face das novas transformações pelas quais o mundo moderno tem passado." 
É impossível a qualquer código monopolizar as regras inerentes à solução de todas as celeumas em sua área de atuação ${ }^{1222}$, conclusão que se aclara quando se tem em conta o momento vivido pela humanidade. As mudanças sociais propagadas em velocidade avassaladora impedem o reconhecimento prévio e formal de um sem número de situações.

Apontados alguns dos problemas pelos quais a valorização da dogmática parece ser a principal responsável - os quais são sentidos até hoje -, é preciso ir além e assinalar problemas pontuais - que mais de perto interessam a esta tese - existentes na codificação civil brasileira.

Assim e sem mais delongas, é essencial resgatar que o código revogado, desde sua gênese, esteve afastado da realidade social então vigente. Pior. Talvez, sequer possa ser considerado como um conjunto de regras dotado de legitimidade material ${ }^{1223}$, vez que elaborado visando a atender os reclames dos detentores do poder na transição entre os séculos XIX e XX.

Não por acaso, "a história das verdades sociais é a história de uma ilusão coletiva marcada pelo poder." ${ }^{1224}$ Vale lembrar que o código Beviláqua foi elaborado para atender ao interesse dos fazendeiros que desejavam a manutenção da propriedade e dos contratos de trabalho como ajustados. ${ }^{1225}$

${ }^{1222}$ FARO, Frederico Kastrup de. Boa-fé objetiva e dever de cooperação: uma análise sob as óticas do exercício da autonomia privada e da execução do contrato, Revista Trimestral de Direito Civil, Rio de Janeiro, n. 38, p. 3-39, abr./jun. 2009. p. 4.

${ }^{1223}$ ITAGIBA, Ivair Nogueira. Justiça comutativa e justiça institucional, Revista da Ordem dos Advogados do Brasil, Rio de Janeiro, v. 4, n. 11, p. 447-457, set./dez. 1973. p. 449. "Apesar de redigido no mais puro ouro do vernáculo, o Código civil já era velho e revelho para a época em que foi dado à estampa. Estruturado no individualismo estreito de um mundo agonizante, referto de arcaicas instituições sacadas às Ordenações portuguesas, cunhado de princípios obsoletos do Direito romano [...] suas disposições [...] destinavam-se não ao povo, senão a uma aristocracia, a coronéis da Guarda Nacional que, na primeira República, sucederam aos barões do Império. Esse, alterado em alguns pontos, o Direito positivo que rege a sociedade civil."

${ }^{1224}$ WARAT, Luis Alberto. Introdução geral ao direito: a epistemologia jurídica da modernidade. Porto Alegre: SAFE, 2002, v. 2. p. 68.

1225 GOMES, Orlando. Raízes históricas e sociológicas do código civil brasileiro. São Paulo: Martins Fontes, 2003. p. 24-31. Veja ainda: BARROSO, Lucas Abreu. A realização do direito civil. Curitiba: Juruá, 2011. (No prelo). “Apresentado ao Congresso Nacional em 1900, o primeiro código civil do país demonstrava avanços e retrocessos, respectivamente, se comparado com a realidade nacional e com as perspectivas desenvolvimentistas. Isso porque era bastante evoluído em relação aos ideários do Brasil do século XIX, porém despreparado para enfrentar os acontecimentos impactantes que decorreram do romper do século XX. Tal codificação havia sido pautada nas aspirações políticas e econômicas da classe dominante (agrária e liberal) da época, com vistas a assegurar por meio do individualismo e do patrimonialismo a integral proteção de seu mais autêntico interesse, resumido na propriedade privada. Do ponto de vista metodológico, consequentemente, exigia uma visão restrita do intérprete e configurava um sistema jurídico fechado (ou de autorreferência absoluto)." 
Hoje, é possível afirmar - com tranquilidade e pesar - que o código revogado serviu - e foi servil - aos interesses de um pequeno grupo de brasileiros, deixando, à margem de suas preocupações, a grande massa populacional. ${ }^{1226}$ Abandonou, portanto, um imenso contingente de pessoas à própria sorte.

A percepção de tais problemas - ainda na vigência daquele - produziu severa crítica ao conservadorismo e ao apego à tradição ${ }^{1227}$ e, a partir daí, soam vozes destacando que a solução para os problemas cotidianos não pode ser encontrada em regras codificadas buscando respostas para os problemas de um mundo há muito inexistente. ${ }^{1228}$

A codificação havia parado no tempo. ${ }^{1229}$

Ao mesmo tempo, entremeio ao processo de descodificação denunciado por Natalino Irti ${ }^{1230}$, alude-se à "agonia do código civil" - melhor seria, dos códigos civis -, processo disparado pela perda de espaço e sentido daquele conjunto de regras fundadas sob a suposta existência de coerência sistêmica e visando a solução de todos os problemas existentes na esfera das relações interprivadas. De modo cada vez mais frequente, é possível identificar, (a) a proliferação de leis esparsas - também em nível supranacional e o conflito dessas com as regras, figuras e institutos existentes na codificação, (b) a migração, para os textos constitucionais, dos vetores mais importantes do direito privado, e, enfim, (c) o distanciamento entre as regras codificadas e a função promocional que há de ser incorporada pelo Direito. ${ }^{1231}$

${ }^{1226}$ MAGALHÃES, Joseli Lima. Da recodificação do direito civil brasileiro. Rio de Janeiro: Lumen Juris, 2006. p. 72.

${ }^{1227}$ CUNHA, Abelmar Ribeiro da. Tendência socializadora do direito civil, Revista Forense, Rio de Janeiro, v. 48, n. 134, p. 21-39, mar./abr. 1951. p. 28.

${ }^{1228}$ GOMES, Orlando. Introdução ao direito civil. 11 ed. Atual. Humberto Theodoro Junior. Rio de Janeiro: Forense, 1995. p. 70.

${ }^{1229}$ COSTA, Álvaro Ferreira da. Responsabilidade sem culpa, Revista da Faculdade de Direito, Curitiba, v. 4, n. 4, p. 234-250, dez. 1956. p. 246-247. "Nosso Código Civil é obra que parou no tempo e apoiada em uma realidade diferente da atual: os dados em que se apoiou, os fatores que a determinaram, as idéias que lhe serviram de inspiração e os sentimentos que a estimularam estão certamente superados pelos acontecimentos. A um estágio puramente agrícola, que é o do Código, corresponde, agora, uma época industrial; a uma civilização de caráter ruralista sucedeu a convivência urbana; a uma convivência patriarcal sucede um sistema de vida democrático [...] A realidade cresce e modifica-se e o Código, inerte, é incapaz de atender às exuberâncias de novos tempos e novas idéias."

${ }^{1230}$ IRTI, Natalino. L'età della decodificazione, Revista de Direito Civil, Imobiliário, Agrário e Empresarial, São Paulo, v. 3, n. 10, p. 15-33, out./dez. 1979. p. 15-33.

${ }^{1231}$ GOMES, Orlando. A agonia do código civil, Revista de Direito Comparado Luso-Brasileiro, Rio de Janeiro, v. 4, n. 7, p. 1-9, jul. 1985. p. 1-9. 
Apesar das fragilidades e dos problemas contidos e criados pelo direito codificado, é possível aferir o ressurgimento dessa vertente no processo de recodificação do direito civil - do qual o código brasileiro vigente é fruto -, processo que só faria sentido se esse tivesse sido elaborado em perspectiva principiológica - para servir como vértice agregador e conformador do direito privado -, e não, como uma teia normativa abstrata.

É nessa contextualização que no Brasil - no entrechoque de críticas dos mais distintos matizes - surge um "novo" código civil no resplandecer do século XXI. Esse código, entretanto, tem pouco de novo. É inegável que o código vigente desde janeiro de 2003 se alicerça nas regras contidas no diploma revogado e que, embora haja uma nova codificação, não há um código renovado. ${ }^{1232} \mathrm{E}$, em que pese abandonar o caráter individualista da codificação de 1916 - inerente ao Estado Liberal -, segue a compreensão axiológica atada ao Estado Social, desprezando "o ideal de democracia social e o respeito às minorias, característicos do Estado Democrático de Direito."1233

E, ao se construir algo que se pretendia novo, a partir das bases fundantes do modelo anterior, perdeu-se uma oportunidade histórica de enfrentar as profundas mudanças disseminadas na realidade contemporânea e de criar mecanismos hábeis para solucionar os problemas inerentes à realidade social contemporânea. ${ }^{1234}$

O legislador ignorou - ou propositalmente desprezou - o fato de que "a repetição do passado impede receber os sinais do novo", sendo responsável - hoje, mais do que ontem - pela "morte do pensamento, do sentimento e da ação", até porque "repetir o passado é uma forma de esgotar o presente, de desestimar sua força criativa, de introduzir uma pulsão destrutiva.",1235

1232 PEREIRA, Caio Mário da Silva. Instituições de direito civil: introdução ao direito civil; teoria geral do direito civil. 20 ed. Atual. Maria Celina Bodin de Moraes. Rio de Janeiro: Forense, 2004, v. 1. p. 93.

${ }^{1233}$ SOARES, Mário Lúcio Quintão; BARROSO, Lucas Abreu. A dimensão dialética do novo código civil em uma perspectiva principiológica. In: BARROSO, Lucas Abreu (Org.). Introdução crítica ao código civil. Rio de Janeiro: Forense, 2006. p. 2. Mais à frente discorrem os autores que: "Pode-se afirmar que a exclusão social está introjetada no novo Código Civil, ao privilegiar apenas os status e o senso comum reconhecidos por toda a sociedade. Os institutos e a sistematização, consubstanciados no novo Código Civil, não conseguiram, pois, se libertar do estigma da exclusão social. Ou seja, condicionados por fatores ideológicos e econômicos, os instrumentos concernentes à igualdade, incorporados à nova legislação civil, demonstram-se incapazes de conferir a cada um o que lhe é devido consoante uma sociedade mais justa e igualitária, que estabelece os pilares da cidadania plena e coletiva." Ibid. p. 12-13.

${ }^{1234}$ TARREGA, Maria Cristina Vidotte Blanco; ARAÚJO, Ionnara Vieira de. O código civil de 2002 - uma opção metodológica, Revista da Faculdade de Direito da UFG, Goiânia, v. 31, p. 123-137, jan./jun. 2007. p. 130-132.

${ }^{1235}$ WARAT, Luis Alberto. Introdução geral ao direito: o direito não estudado pela teoria jurídica moderna. Porto Alegre: SAFE, 1997, v. 3. p. 138. 
E, como o código vigente está muito mais para uma reforma do que para uma construção, é fácil perceber por que vários problemas detectados no modelo que se propôs a substituir ainda persistem, dentre eles, (a) a influência da classe dominante no processo de codificação ${ }^{1236}$, (b) os paradigmas ultrapassados em que se embasa, (c) a manifesta desatualização $^{1237}$ de seu conteúdo e forma e (d) a repetição acrítica de estruturas dogmáticas incoerentes.

Aliás, a opção culturalista, embora inove e promova melhorias quando se compara seu resultado aos da codificação revogada, se esquece dos menos favorecidos. ${ }^{1238}$ O código peca por ignorar a realidade aceita pelo Direito vigente - em especial, diante da carga axiológica inerente à principiologia constitucional - e por tentar proteger-se sob o manto da neutralidade axiológica, ignorando, dentre outros vetores, a experiência constitucional brasileira. ${ }^{1239}$

Daí que qualquer análise um pouco mais acurada do direito codificado recentemente no Brasil permite, sem maiores percalços, identificar que a racionalidade que o permeia continua a ter por paradigma um sujeito abstrato, que ele busca tutelar por meio da proteção patrimonial ${ }^{1240}$, em um claro exemplo da manutenção dos influxos colhidos no Estado Liberal.

${ }^{1236}$ VERDÚ, Pablo Lucas. O sentimento constitucional: aproximação ao estudo do sentir constitucional como modo de integração política. Trad. Agassiz Almeida Filho. Rio de Janeiro: Forense, 2004. p. 120. "Toda dogmática está influenciada ideologicamente; é interesseira, uma vez que recolhe e protege uns determinados interesses socioeconômicos, explicando-os e aplicando-os, tendendo a formalizar-se conceitualmente, mascarando-se com as vestes abstratas da juridicidade."

${ }^{1237}$ PEREIRA, Caio Mário da Silva. Instituições de direito civil: introdução ao direito civil; teoria geral do direito civil. 20 ed. Atual. Maria Celina Bodin de Moraes. Rio de Janeiro: Forense, 2004, v. 1. p. 86. Acenando o autor acerca de que "é certo que a demora de sua votação, a resistência de elementos tradicionalistas e uma certa timidez na aceitação de idéias novas atuaram negativamente; daí resultou que o diploma de 1916 já nasceu desatualizado, exigindo reformas."

${ }^{1238}$ COELHO, Luiz Fernando. Teoria crítica do direito. 3 ed. Belo Horizonte: Del Rey, 2003. p. 6. “Aos teóricos do movimento culturalista escapou que a ciência do direito não descreve uma ordem imanente, objetivamente pressuposta, mas a constrói ideologicamente."

1239 TEPEDINO, Gustavo. O código civil, os chamados microssistemas e a constituição: premissas para uma reforma legislativa. In: TEPEDINO, Gustavo (Coord.). Problemas de direito civil-constitucional. Rio de Janeiro: Renovar, 2000. p. 5-9.

${ }^{1240}$ FACHIN, Luiz Edson. Aspectos da racionalidade histórico-cultural do arquétipo inserido no código civil brasileiro de 2002, Revista do Advogado, São Paulo, n. 98, p. 143-150, jul. 2008. p. 145. No mesmo sentido: TEPEDINO, Gustavo. Normas constitucionais e direito civil, Revista da Faculdade de Direito de Campos, Campos dos Goitacases, v. 4/5, n. 4/5, p. 167-175, 2003/2004. p. 169-175. O autor denuncia o caráter patrimonial do Código vigente enquanto meramente projetado, embora reconheça existir a possibilidade de sua releitura a partir dos princípios constitucionais. 
Ademais, por ser concebido - enquanto projeto - em um momento no qual ainda imperava o Estado Social, desconhece os reais objetivos do Estado Democrático de Direito $^{1241}$, isso quando não afronta preceitos constitucionalmente consagrados. ${ }^{1242} \mathrm{E}$ a prova de que está ancorado em paradigmas superados ${ }^{1243}$ autoriza afirmar que, além de ser retrógrado - por ter nascido velho -, é demagógico. ${ }^{1244}$

Talvez seja oportuno realçar, ainda, que a incipiência de debates por ocasião da tramitação do projeto do qual se origina lhe rende a qualificação de antidemocrático. ${ }^{1245}$ Essa leitura, contudo, não é pacífica, havendo autores que não se cansam de aplaudir a codificação vigente. ${ }^{1246}$

Tal otimismo, entretanto, é raro. Aliás, mesmo aqueles que aclamam a codificação não ignoram a necessidade de reflexão sobre uma nova perspectiva

${ }^{1241}$ SOARES, Mário Lúcio Quintão; BARROSO, Lucas Abreu. A dimensão dialética do novo código civil em uma perspectiva principiológica. In: BARROSO, Lucas Abreu (Org.). Introdução crítica ao código civil. Rio de Janeiro: Forense, 2006. p. 2-12. Isso ocorre especialmente por conta do desprezo à democracia social e do desrespeito às minorias.

${ }^{1242}$ Podendo aqui ser lembradas, dentre outras, as seguintes hipóteses: (a) a imposição do regime da separação obrigatória de bens para as pessoas com mais de setenta anos à data do casamento; (b) a exigência do dever de coabitação entre os cônjuges; (c) a vedação da possibilidade de transação entre segurado e vítima sem participação do segurador; e (d) o tratamento diferenciado do cônjuge e do companheiro no direito sucessório.

${ }^{1243}$ JUNQUEIRA DE AZEVEDO, Antonio. O direito pós-moderno e a codificação, Revista da Faculdade de Direito, São Paulo, v. 94, p. 3-12, jan./dez. 1999. p. 10. Entre as principais críticas formuladas pelo autor, estão as que versam sobre a sobrecarga do Judiciário (quando os problemas poderiam ser resolvidos sem necessidade de intervenção judicial); o excesso de noções vagas (que dificulta a manutenção da unidade conceitual do direito privado).

${ }^{1244}$ TEPEDINO, Gustavo. A constitucionalização do direito civil: perspectivas interpretativas diante do novo código. In: FIUZA, César; SÁ, Maria de Fátima Freire de; NAVES, Bruno Torquato de Oliveira (Coord.). Direito civil: atualidades. Belo Horizonte: Del Rey, 2003. p. 128. "Daí o desajuste maior do novo Código: ele é retrógrado e demagógico. Não tanto por deixar de regular os novos direitos, as relações de consumo, as questões da bioética, da engenharia genética e da cibernética que estão na ordem do dia e que dizem respeito ao direito privado. E não apenas por ter como paradigma os códigos civis do passado (da Alemanha, de 1896, da Itália, de 1942, de Portugal, de 1966), em vez de buscar apoio em recentes e bem-sucedidas experiências (como os Códigos Civis de Quebéc e da Holanda, promulgados nos anos 90). O novo Código nasce velho principalmente por não levar em conta a história constitucional brasileira e a corajosa experiência jurisprudencial, que protegem a personalidade humana mais do que a propriedade, o ser mais do que o ter, os valores existenciais mais do que os patrimoniais. E é demagógico porque, engenheiro de obras feitas, pretende consagrar direitos que, na verdade, estão tutelados em nossa cultura jurídica pelo menos desde o pacto político de outubro de 1988. Ressalte-se ainda que, também do ponto de vista técnico, o Código já surge obsoleto."

1245 JUNQUEIRA DE AZEVEDO, Antonio. Estudos e pareceres de direito privado. São Paulo: Saraiva, 2004. p. 62-63. O autor justifica sua reflexão, com a qual se concorda integralmente, diante da ausência de debate aberto sobre os mais de 2000 artigos que compõem a codificação vigente.

1246 SEGALLA, Conrado Rodrigues. O novo código civil já nasceu velho? (ser ou não inovador, eis a questão?). In: HIRONAKA, Giselda Maria Fernandes Novaes (Coord.). Novo código civil: interfaces no ordenamento jurídico brasileiro. Belo Horizonte: Del Rey, 2004. p. 31. 
metodológica no processo de realização do Direito. ${ }^{1247} \mathrm{E}$ isso, por ser essencial, dentre outras razões, para mitigar aquele que talvez seja o principal efeito colateral produzido por mais esse código: o processo de exclusão social. ${ }^{1248}$

Mesmo que ele esteja embasado em paradigmas metodológicos, axiológicos e éticos distintos dos que orientaram a elaboração do revogado, tais balizas não solucionarão o problema denunciado. E, se é certo que, mesmo ignorando o estado da arte, evolui quando comparado ao modelo que se foi, também parece inegável que as críticas que pendem sobre ele são merecidas.

A inserção no texto codificado de incontáveis cláusulas gerais e o reconhecimento do viés social do direito civil ratificam a primeira parte da assertiva formulada. ${ }^{1249}$ A opção pelo sistema aberto - quando comparado à estrutura precedente -, se, de um lado, perde em previsibilidade, de outro, ganha em legitimidade e utilidade para a sociedade. ${ }^{1250}$ Tais pontos são positivos, não se olvida.

As cláusulas gerais, aliás, entremeio a aplausos ${ }^{1251}$ e críticas ${ }^{1252}$ que vão desde (a) a instabilidade que trazem ao sistema por conta de sua vagueza ${ }^{1253}$, passando (b) pelas

${ }^{1247}$ MARTINS-COSTA, Judith. Os direitos fundamentais e a opção culturalista do novo código civil. In: SARLET, Ingo Wolfgang (Org.). Constituição, direitos fundamentais e direito privado. 2 ed. Porto Alegre: LAEL, 2006. p. 84. Ao discorrer sobre o tema, destaca a autora que "[...] se pode perceber que o novo Código Civil brasileiro está a requerer, de seus intérpretes, a compreensão da nova metodologia que enseja, embasada em uma diversa pré-compreensão do fenômeno jurídico [que] não é dada só por dados fáticos mas por critérios de valor que direcionam o exame do fato segundo a "ética da situação."

${ }^{1248}$ FACHIN, Luiz Edson; RUZYK, Carlos Eduardo Pianovski. Direitos fundamentais, dignidade da pessoa humana e o novo código civil: uma análise crítica. In: SARLET, Ingo Wolfgang (Org.). Constituição, direitos fundamentais e direito privado. 2 ed. Porto Alegre: LAEL, 2006. p. 97.

${ }^{1249}$ VELLOSO, Andrei Pitten. Mutações paradigmáticas da codificação: do código civil de 1916 ao código civil de 2002, Revista da PGE, Porto Alegre, v. 27, n. 57, p. 9-52, 2004. p. 42-47.

${ }^{1250}$ BARCELLONA, Pietro. Formazione e sviluppo del diritto privato moderno. Napoli: Jovene, s/a. p. 9.

${ }^{1251}$ MARTINS-COSTA, Judith. O direito privado como um "sistema em construção": as cláusulas gerais no projeto do código civil brasileiro, Revista de Informação Legislativa, Brasília, v. 35, n. 139, p. 5-22, jul./set. 1998. p. 17. Consoante a autora, é imprescindível "a necessidade de um Código que, estruturado como um sistema aberto, alie aos modelos cerrados [...] janelas representadas pelas cláusulas gerais [as quais] permitirão a permanente atualização do Código, evitando um envelhecimento que, na sociedade globalizada e tecnológica, avizinha-se sempre e cada vez mais rápido [enquanto ao] mesmo tempo, viabilizarão o desenvolvimento de um direito privado pluralista como a sociedade que lhe dá origem e justificação, porém harmônico e compreensível, já que não necessariamente pulverizado em centenas de pequenos mundos normativos tecnicamente díspares, valorativamente autônomos e em si mesmos fechados e conclusos."

1252 JUNQUEIRA DE AZEVEDO, Antônio. O direito pós-moderno e a codificação, Revista de Direito do Consumidor, São Paulo, v. 9, n. 33, p. 123-129, jan./mar. 2000. p. 128-129.

${ }^{1253}$ KATAOKA, Eduardo Takemi. Segurança jurídica como direito fundamental e as cláusulas gerais do novo código civil brasileiro. In: SARMENTO, Daniel; GALDINO, Flávio (Org.). Direitos fundamentais: estudos em homenagem ao professor Ricardo Lobo Torres. Rio de Janeiro: Renovar, 2006. p. 363-373. Argumenta o autor que as cláusulas gerais (em razão do modelo utilizado para sua inserção na codificação 
preocupações com seu uso adequado ${ }^{1254}$, até alcançarem (c) as denúncias de sua desatualização ${ }^{1255}$, possuem, ao menos, duas vantagens indeléveis: oxigenar a codificação - embora não a ponto de libertar completamente o Direito dos grilhões impostos pela dogmática - e permitir a realização dos objetivos constitucionais ao viabilizar a incidência dos princípios e valores consagrados na Constituição, ainda que, diante da força normativa dos princípios, essa última vantagem possa ser refutada.

Tais aspectos positivos não impedem, entretanto, a visualização de que as construções teóricas existentes, salvo rara exceção, são oriundas de um Direito pensado para uma sociedade agrária e liberal.

As estruturas erigidas pela codificação vigente desconhecem não só a substituição da realidade que a envolve pela que vigorou no modelo industrial, como também o declínio desse arquétipo e a ascensão de outro, cujos contornos ainda estão sendo delineados. ${ }^{1256}$

Por tudo isso, para que algo do código possa ser realmente aproveitado, é imperiosa sua releitura. Primeiro, aceitando que um código não se restringe às letras outrora promulgadas, incorporando as construções e reconstruções erigidas no seu entorno. ${ }^{1257}$ Depois, que as soluções buscadas no direito codificado sempre deverão ser informadas pelos princípios e valores espelhados no texto constitucional e a partir da percepção que um signo pode ter diversos significados. É importante lembrar aqui, uma vez mais, que o Direito rompeu o invólucro conceitual que o aprisionava. ${ }^{1258}$

vigente - muito aberto e sem balizas que permitam soluções previsíveis) são fonte de insegurança jurídica e, por consequência, de aumento dos custos das negociações.

${ }^{1254}$ MAZZEI, Rodrigo. Código civil de 2002 e o judiciário: apontamentos na aplicação das cláusulas gerais. In: DIDIER JUNIOR, Fredie; MAZZEI, Rodrigo (Coord.). Reflexos do novo código civil no direito processual. Salvador: Juspodivm, 2006. p. 23-57.

1255 JUNQUEIRA DE AZEVEDO, Antonio. O princípio da boa-fé nos contratos, Revista CEJ, Brasília, v. 3, n. 9, p. 40-45, dez. 1999. p. 41-44. O autor destaca que as cláusulas gerais surgem como paradigma no início do século XX e se alocam sobre a ideia de segurança na lei. Salienta ainda que, há algum tempo, aquele paradigma fora substituído pela análise do "caso concreto e da Constituição."

${ }^{1256} \mathrm{O}$ paradigma a que se alude e as características que permitem sua identificação são demarcados de modo bastante claro em: BECK, Ulrich. La sociedad del riesgo: hacia una nueva modernidad. Trad. Jorge Navarro. Barcelona: Paidós, 1998. p. 25-289.

${ }^{1257}$ DIEZ-PICAZO, Luis. Codificación, descodificación y recodificación, Anuario de Derecho Civil, Madrid, v. 45, n. 2, p. 473-484, abr./jun. 1992. p. 479.

${ }^{1258}$ STRECK, Lenio Luiz. O que é isto - decido conforme minha consciência?. Porto Alegre: LAEL, 2010. p. 107. "As tentativas de "aprisionar" o direito no interior de conceitos fracassaram de forma retumbante. Definitivamente, a razão teórica não tem "vida autônoma", separada / cindida do modo como lidamos com o mundo, nossas escolhas, etc (razão prática). Autoritarismos, duas grandes guerras e ditaduras: esses foram os 
Assim, muito embora o direito civil atual - e, na mesma trilha, a codificação em vigor - esteja mais próximo da realidade socioeconômica vigente ${ }^{1259}$, não é possível ignorar que o Direito - repita-se uma vez mais - é algo a ser diuturnamente construído a partir dos anseios sociais, e não, apenas tendo por escopo a satisfação dos interesses da classe dominante. E, para aqueles que pensam que o Direito está em crise, expressão compreendida aqui como "perda de fundamentos"1260, é oportuno resgatar que, exatamente nas crises, é que estão as oportunidades. ${ }^{1261}$ Por isso, em vez de lamentar, é essencial assumir uma postura crítica e construtiva.

É imperioso recuperar, neste momento do trabalho, como antes destacado, que a codificação vigente - ao repetir boa parte das passagens contidas na revogada - se aproxima muito mais de uma reforma do que de algo que possa ser denominado novo. ${ }^{1262}$

A comparação das regras contidas em um e outro código - entre aquele que se diz novo e aquele tratado como velho - permite, com tranquilidade, aferir a veracidade da assertiva, ponto essencial no desvelar das futuras reflexões.

E, embora tenha havido evolução em termos de organização topológica no tratamento dado, por exemplo, ao direito das obrigações - tema que interessa de perto às linhas deste trabalho -, em essência, foram mantidos os mesmos preceitos contidos na codificação de 1916.

Daí que, para que se possa definitivamente afastar a culpa da arquitetura jurídica da responsabilidade contratual, é preciso desmistificar, no mínimo, três graves problemas não só assentados na codificação revogada, como também transplantados acriticamente para o código civil vigente.

resultados da "pureza do direito". Conceitos sem mundo prático: definitivamente o positivismo fracassou, embora continue dominando o imaginário dos juristas."

${ }^{1259}$ GIORGIANNI, Michele. O direito privado e suas atuais fronteiras, Revista dos Tribunais, São Paulo, v. 87 , n. 747, p. 35-55, jan. 1998. p. 46-55.

${ }^{1260}$ LÔBO, Paulo Luiz Netto. O contrato: exigências e concepções atuais. São Paulo: Saraiva, 1986. p. 6.

1261 FAGÚNDEZ, Paulo Roney Ávila. O significado da modernidade. In: LEITE, José Rubens Morato; BELlO FILHO, Ney de Barros (Coord.). Direito ambiental contemporâneo. Barueri: Manole, 2004. p. 217. "A crise é uma expressão que traz em si uma idéia de dificuldade, de empecilho, de embaraço para se atingir um determinado objetivo. Mas a crise é algo natural, é um aspecto negativo da vida e que pode ser transmutado em positivo. A crise é dificuldade e, ao mesmo tempo, é uma oportunidade de mudança. Sem crise não se muda de rumo. Sem dificuldade não se valoriza a conquista."

1262 GAMA, Ricardo Rodrigues. Algumas considerações sobre o novo código civil brasileiro, Revista de Direito Privado, São Paulo, v. 3, n. 9, p. 18-35, jan./mar. 2002. p. 31. 
O primeiro deles encontra-se no equívoco do tratamento dado por parte substancial da doutrina à culpa ${ }^{1263}$ - essa palavra que, às vezes, parece surgir de "um vínculo mágico" que ata lei e ciência e que cativa mais do que "a voz digna da majestade" 1264 -, erro comprovado pela confusão promovida entre a noção daquela e a de inadimplemento. $^{1265}$

Perceba-se que, ao se promover essa fusão, toda violação de dever - que não derive de causa estranha e não imputável - será necessariamente culposa, o que é incorreto, porque, quando não decorrer do acaso ou do exercício de uma posição defensiva juridicamente consagrada, a violação de dever contratual será necessariamente imputável a uma das partes, embora nem sempre culposa.

Como o segundo dos problemas foi suficientemente explorado ${ }^{1266}$, só será aqui referido. A lógica que informa a dogmática codificada exige a culpa na configuração do dever de reparar os danos contratuais, premissa incorreta diante da existência de situações que, em nenhum momento da História, a exigiram na atribuição do aludido dever. A culpa, como provado, não é pressuposto da responsabilidade contratual. ${ }^{1267}$

Mais grave é o fato de a doutrina brasileira - repetindo o pensamento clássico europeu - tratar o fortuito como limite da culpa ${ }^{1268}$, quando, em verdade, essas duas figuras são como retas paralelas. Tal problema, aliás, não é recente, remontando ao direito romano, que trabalhava os conceitos de dolo, culpa e fortuito como "vizinhos", nessa mesma e exata ordem. $^{1269}$

1263 COLIN, Ambrosio; CAPITANT, Henry. Curso elemental de derecho civil: teoria general de las obligaciones. 2 ed. Trad. Demofilo de Buen. Madrid: Instituto Editorial Reus, 1943, t. 3. p. 827-828. O equívoco dos autores encontra-se na premissa que embasa suas reflexões, haja vista que entendem a culpa como o incumprimento de obrigação (culpa contratual) ou como a lesão que é causada a outrem em razão de um comportamento doloso ou negligente (culpa extracontratual).

${ }^{1264}$ WARAT, Luis Alberto. Introdução geral ao direito: a epistemologia jurídica da modernidade. Porto Alegre: SAFE, 2002, v. 2. p. 77.

${ }^{1265}$ Nesse sentido: MESSA, Gian Carlo. L'obbligazione degli interessi e le sue fonti. Milano: Società Editrice Libraria, 1911. p. 163-166. VON THUR, Andreas. Tratado de las obrigaciones. Trad. W. Roces. Madrid: Reus, 1934, t. 1. p. 57. VIVES, Álvaro Pérez. Teoría general de las obligaciones: de las fuentes de las obligaciones. 2 ed. Bogotá: Temis, 1954, v. 2, t. 1. p. 16.

${ }^{1266}$ No item 3.3.

${ }^{1267}$ MENGONI, Luigi. Obbligazioni "di risultato" e obbligazioni "di mezzi" (studio critico), Rivista del Diritto Commerciale, Milano, anno 52, n. 5-10, parte 1, p. 3-90, 1954. p. 39-49.

${ }^{1268}$ TADEU, Silney Alves. Responsabilidade civil: nexo causal, causas de exoneração, culpa da vítima, força maior e concorrência de culpas, Revista de Direito do Consumidor, São Paulo, v. 16, n. 64, p. 134-165, out./dez. 2007. p. 154.

${ }^{1269}$ BIONDI, Biondo. Istituzioni di diritto romano. 2 ed. Milano: Giuffrè, 1952. p. 335-337. 
A repetição acrítica da afirmação "onde cessa a culpa, começa o fortuito",1270, através dos séculos, criou uma aura de pureza científica ao redor do tema, escondendo um grave equívoco dogmático no tratamento da responsabilidade contratual. No Brasil, a aleatoriedade das fontes levou a identificar essa lógica informando o raciocínio de Alvino Lima $^{1271}$, Arnoldo Wald ${ }^{1272}$, Baptista de Mello ${ }^{1273}$, Caio Mário da Silva Pereira ${ }^{1274}$, Carlos Alberto Bittar ${ }^{1275}$, Cibele Pinheiro Marçal Tucci ${ }^{1276}$, Darcy Arruda Miranda ${ }^{1277}$, Eduardo e Graziela Righi $^{1278}$, Everaldo Cambler ${ }^{1279}$, Inácio de Carvalho Neto ${ }^{1280}$, João Franzen de Lima $^{1281}$, Numa do Valle ${ }^{1282}$, Orlando Gomes ${ }^{1283}$ e Sílvio Venosa. ${ }^{1284}$

${ }^{1270}$ ESPINOLA, Eduardo. Systema do direito civil brasileiro: theoria geral das relações jurídicas de obrigação. Rio de Janeiro: Porto, 1912, v. 2, t. 1. p. 361.

${ }^{1271}$ LIMA, Alvino. Da responsabilidade do depositário no caso fortuito ou de força maior, Revista dos Tribunais, São Paulo, v. 34, n. 154, p. 3-6, mar. 1945. p. 5. "O caso fortuito significa exclusão da culpa."

1272 WALD, Arnoldo. Da responsabilidade civil contratual e delitual, Revista Forense, Rio de Janeiro, v. 72, n. 256, p. 107-123, out./dez. 1976. p. 116.

${ }^{1273}$ MELLO, Baptista de. Do caso fortuito e da força maior nos contractos civis, Revista dos Tribunais, São Paulo, v. 25, n. 101, p. 15-28, mai. 1936. p. 17-21. "Ao lado da culpa contractual, e para eximi-la, encontramse o caso fortuito e a força maior."

${ }^{1274}$ PEREIRA, Caio Mário da Silva. Instituições de direito civil: teoria geral das obrigações. 20 ed. Atual. Luis Roldão de Freitas Gomes. Rio de Janeiro: Forense, 2004, v. 2. p. 308-333. Sustenta o autor, mais à frente, que, "consagrando o nosso Direito o princípio da exoneração pela inimputabilidade, enuncia-se em tese a irresponsabilidade do devedor pelos prejuízos, quando resultam de caso fortuito ou de força maior." Ibid. p. 346.

1275 BITTAR, Carlos Alberto. Direito das obrigações. 2 ed. Rio de Janeiro: Forense Universitária, 2004. p. 148-153. Entendendo ser necessária a culpa para a caracterização da responsabilidade contratual em quaisquer das modalidades de incumprimento, o autor frisa que causas excludentes de responsabilidade exoneram o devedor da obrigação.

${ }^{1276}$ TUCCI, Cibele Pinheiro Marçal. Responsabilidade civil no código de defesa do consumidor, Revista da Faculdade de Direito de São Bernardo do Campo, São Bernardo do Campo, v. 9, n. 11, p. 67-83, 2005. p. 79.

${ }^{1277}$ MIRANDA, Darcy Arruda. Anotações ao código civil brasileiro. São Paulo: Saraiva, 1987, v. 3. p. 129131.

${ }^{1278}$ RIGHI, Eduardo; RIGHI, Graziela Boabaid. A complexidade obrigacional e a violação positiva do contrato no ordenamento jurídico brasileiro, Revista Brasileira de Direito Civil Constitucional e Relações de Consumo, Santo Amaro, n. 1, p. 33-107, jan./mar. 2009. p. 60-67.

${ }^{1279}$ CAMBLER, Everaldo. Curso avançado de direito civil: direito das obrigações. São Paulo: RT, 2001. p. 211-218.

${ }^{1280}$ CARVALHO NETO, Inácio de. Curso de direito civil brasileiro: teoria geral das obrigações. Curitiba: Juruá, 2009, v. 2. p. 372.

${ }^{1281}$ LIMA, João Franzen de. Curso de direito civil brasileiro: direito das obrigações. 3 ed. Rio de Janeiro: Forense, 1979, v. 2. p. 282. Frisando que embora a culpa seja a base da responsabilidade decorrente da inexecução da prestação, essa pode ser afastada mediante prova do casus.

1282 VALLE, Numa P. do. Do caso fortuito e de força maior: da distinção nítida entre um e outro importância prática e jurídica da distinção, Revista dos Tribunais, São Paulo, v. 30, n. 129, p. 439-449, jan. 1941. p. 439. A "culpa contratual é, sempre, presumida contra o inadimplente do contrato, cumprindo a este, portanto, o ônus da prova de que a sua omissão ou inexecução das obrigações que assumiu, foi motivada por um caso fortuito, ou devida a um caso de força maior." 
No exterior, o mesmo problema é percebido nas pesquisas de Alfonso de Cossio Corral ${ }^{1285}$, Álvaro Pérez Vives ${ }^{1286}$, Amézaga ${ }^{1287}$, Antunes Varela ${ }^{1288}$, Arias Bustamante $^{1289}$, Biagio Brugi ${ }^{1290}$, Chironi ${ }^{1291}$, Colin e Capitant ${ }^{1292}$, Enneccerus ${ }^{1293}$, Georges Ripert e Jean Boulanger ${ }^{1294}$, Guilherme Alves Moreira ${ }^{1295}$, Henri, Léon Mazeaud e André Tunc $^{1296}$, Inocêncio Galvão Telles ${ }^{1297}$, João Calvão da Silva ${ }^{1298}$, Louis Josserand ${ }^{1299}$, Mario

${ }^{1283}$ GOMES, Orlando. Obrigações. 9 ed. Atual. Humberto Theodoro Junior. Rio de Janeiro: Forense, 1994. p. 143-149. Defendendo que haverá inexecução culposa toda vez que a prestação não venha a ser desempenhada por fato imputável ao devedor, ou seja, quando o incumprimento não seja oriundo de caso fortuito ou força maior. Posteriormente, salienta o autor que se passou "a considerar fortuito todo inadimplemento não imputável ao devedor", exprimindo seu pensamento com a assertiva de que "o fortuito começa onde cessa a culpa."

${ }^{1284}$ VENOSA, Sílvio de Salvo. Direito civil: teoria geral das obrigações e teoria geral dos contratos. 2 ed. São Paulo: Atlas, 2002, v. 2. p. 254.

${ }^{1285}$ CORRAL, Alfonso de Cossio y. Instituciones de derecho civil: parte general, obligaciones y contratos. 2 ed. Madrid: Civitas, 1991, t. 1. p. 401-402

${ }^{1286}$ VIVES, Álvaro Pérez. Teoría general de las obligaciones: de las fuentes de las obligaciones. 2 ed. Bogotá: Temis, 1954, v. 2, t. 1. p. 22-23. Prova-se a ausência de culpa, demonstrando o caso fortuito ou que se portou como deveria.

${ }^{1287}$ AMÉZAGA, Juan José. Culpa aquiliana: leciones del curso de derecho civil. Montevideo: s/e, 1914. p. 145-149. Afirmando, em síntese, que do devedor sempre se exige comportamento culposo, o qual, para se ver liberado da sanção ressarcitória, deverá demonstrar a presença de causa estranha e não imputável.

${ }^{1288}$ ANTUNES VARELA, João de Matos. Das obrigações em geral. 7 ed. Coimbra: Almedina, 1997, v. 2. p. 94-101.

${ }^{1289}$ BUSTAMANTE, Lino Rodriguez-Arias. Derecho de obligaciones. Madrid: Editorial Revista de Derecho Privado, 1965. p. 194-195.

${ }^{1290}$ BRUGI, Biagio. Instituciones de derecho civil. Trad. Jaime Simo Bofarull. Cidade do México: UTEHA, 1946. p. 378-383. Lecionando que o incumprimento da obrigação deverá ser culposo para produzir o dever de reparar perdas e danos, mas o devedor somente se libera se demonstrar caso fortuito.

${ }^{1291}$ CHIRONI, Giampietro. La colpa nel diritto civile odierno: colpa contrattuale. 2 ed. Torino: Fratelli Bocca Editori, 1897. p. 653-654.

${ }^{1292}$ COLIN, Ambrosio; CAPITANT, Henry. Curso elemental de derecho civil: teoria general de las obligaciones. 2 ed. Trad. Demofilo de Buen. Madrid: Instituto Editorial Reus, 1943, t. 3. p. 24-25. "O devedor incorre em culpa e, por conseguinte, é responsável pelo prejuízo causado ao credor, desde o momento em que a obrigação não seja cumprida por obra sua. Por outro lado, o devedor não incorre em culpa e está liberado de toda responsabilidade, quando o incumprimento da obrigação é imputável a uma causa que lhe seja estranha."

${ }^{1293}$ ENNECCERUS, Ludwig. Derecho de obligaciones: doctrina general. Trad. Blas Pérez Gonzales; José Alguer. Barcelona: Bosch, 1944, v. 1. p. 253-256. Para quem a prova de ausência de culpa se faz com a demonstração, pelo devedor, de força maior.

${ }^{1294}$ RIPERT, Georges; BOULANGER, Jean. Tratado de derecho civil: las obligaciones. Trad. Delia García Daireaux. Buenos Aires: La Ley, 1964, v. 1, t. 4. p. 476-486. Consoante o autor, apesar de ser necessária a culpa, que está presente no não cumprimento da obrigação, para isentar-se de responsabilidade, o devedor deverá provar que não adimpliu em razão de caso fortuito ou força maior.

${ }^{1295}$ MOREIRA, Guilherme Alves. Instituições do direito civil português: das obrigações. Coimbra: Coimbra, 1925, v. 2. p. 115.

${ }^{1296}$ MAZEAUD, Henri; MAZEAUD, Léon; TUNC, André. Tratado teórico y práctico de la responsabilidad civil delictual y contractual. Trad. Luis Alcalá Zamora y Castillo. Buenos Aires: Ediciones Jurídicas Europa- 
Talamanca $^{1300}$, Menezes Leitão ${ }^{1301}$, Pothier $^{1302}$, Rafael Duran Trujillo ${ }^{1303}$, Roberto de Ruggiero $^{1304}$ e Von Thur. ${ }^{1305}$ Saliente-se existir, ainda, quem defenda que o caso fortuito exclui a culpa e que a força maior rompe o dever de reparar nas hipóteses em que o fator de atribuição de responsabilidade é o risco ${ }^{1306}$, tese que perde sentido diante da sinonímia entre as expressões.

Retomando a discussão, é possível deduzir que tais construções têm um ponto em comum. Todas elas comungam o entendimento de que a culpa termina com o advento de causa estranha à esfera de atuação do parceiro contratual. E, assim, relevante parte da doutrina, mesmo sem se atentar para esse fato, sustenta que a caracterização da

América, 1962, v. 2, t. 1. p. 450-451. Prova-se ausência de culpa, destaca o autor, com a demonstração do caso fortuito.

1297 TELLES, Inocêncio Galvão. Direito das obrigações. 6 ed. Coimbra: Coimbra, 1989. p. 294-295. Confundindo a imputação com a culpa, o autor afirma que, se o evento não é imputável ao devedor, isto é, não provém de culpa sua, derivando de fato do credor, de caso fortuito ou força maior, não incidirá aquele em responsabilidade.

${ }^{1298}$ SILVA, João Calvão da. Não cumprimento das obrigações. In: Comemorações dos 35 anos do código civil e dos 25 anos da reforma de 1977. Coimbra: Coimbra, 2007. p. 485-494. Na visão do autor, ao devedor cabe provar no atual estágio do direito que não agiu com culpa por ocasião do incumprimento do contrato. Tal prova é realizada com a demonstração da incidência de caso fortuito.

1299 JOSSERAND, Louis. Evolução da responsabilidade civil, Revista Forense, Rio de Janeiro, n. 86, p. 5263, jun. 1941. p. 61. Nas linhas do autor francês, são percebidos os dois problemas denunciados, quando, ao discorrer sobre a responsabilidade contratual, destaca que, em razão da inversão dos ônus probatórios, "a só inexecução do contrato constitui uma falta pela qual o devedor deve reparação, salvo se provar o caso de força maior."

${ }^{1300}$ TALAMANCA, Mario. Colpa. In: Enciclopedia del diritto. Milano: Giuffrè, 1960, v. 7. p. 518. O caso fortuito "constitui-se sempre o limite da culpa."

${ }^{1301}$ LEITÃO, Luís Manuel Teles de Menezes. Direito das obrigações: transmissão e extinção das obrigações, não cumprimento e garantias do crédito. 3 ed. Coimbra: Almedina, 2005, v. 2. p. 243-250. Entendendo que a responsabilidade contratual deriva da culpa, e que essa é excluída com a demonstração, a cargo do devedor, de caso fortuito, força maior, fato do credor ou de terceiro.

${ }^{1302}$ POTHIER, Robert Joseph. Tratado das obrigações. Trad. Adrian Sotero De Witt Batista; Douglas Dias Ferreira. Campinas: Servanda, 2002. p. 128-132.

${ }^{1303}$ TRUJILLO, Rafael Durán. Nociones de responsabilidad civil: contractual y delictuosa. Bogotá: Temis, 1957. p. 67-68. A culpa é afastada, consoante a lição do autor, pelo advento de causa externa não imputável ao devedor.

${ }^{1304}$ RUGGIERO, Roberto de. Instituições de direito civil: direito das obrigações, direito hereditário. Trad. Paolo Capitanio. Campinas: Bookseller, 1999, v. 3. p. 173.

${ }^{1305}$ VON THUR, Andreas. Tratado de las obrigaciones. Trad. W. Roces. Madrid: Reus, 1934, t. 2. p. 100. Para quem a impossibilidade não culposa de desempenho da prestação convencionalmente se denomina caso fortuito.

${ }^{1306}$ CAMBLER, Everaldo; GONÇALVES, Carlos Roberto; MAIA, Mairan. Comentários ao código civil brasileiro: do direito das obrigações. Rio de Janeiro: Forense, 2003, v. 3. p. 34-35. 
responsabilidade contratual prescinde da culpa ${ }^{1307}$ enquanto fator de imputação do dever de reparar.

Isso porque, ao se exigir do devedor - ou do credor, quando do desrespeito a um dever geral de conduta - a demonstração de que a impossibilidade decorreu de causa estranha à sua esfera de atuação ${ }^{1308}$, recorre-se às premissas que informam a responsabilidade objetiva, segundo as quais, salvo rara exceção, o dever de reparar será afastado mediante a prova da inexistência de nexo causal.

O que impede a gênese do dever de reparar na proposta dogmática incorporada à codificação vigente é o advento de evento alheio à conduta do causador do dano, e não, a simples ausência de culpa.

Dogmaticamente, exige-se a culpa para a configuração da responsabilidade contratual, mas a demonstração de que sua conduta foi pautada pela mais extrema diligência não será suficiente para eximir o devedor - ou o credor - do dever de reparar se não provar o advento de causa estranha não imputável.

O conflito apontado é manifesto.

O paradoxo se instaura e somente é superado quando se aceita que o fator de atribuição do dever de reparar - como outrora apontado - será identificado objetivamente $^{1309}$ quando do desrespeito ao programa obrigacional concretamente estabelecido. Não há como negar: a culpa está morta.

Apesar disso - como ocorre com os mitos -, continua a ser idolatrada, atrapalhando - muitas vezes - a compreensão adequada da violação de dever contratual. A configuração dogmática da responsabilidade contratual transformou a culpa em um "conceito puramente formal" quando deixou de alocar as soluções que propõe nos

\footnotetext{
${ }^{1307}$ SERPA LOPES, Miguel Maria de. Curso de direito civil: obrigações em geral. Atual. José Serpa Santa Maria. Rio de Janeiro: Freitas Bastos, 1989, v. 2. p. 338-339. Consoante as palavras do autor, "o simples fato de o devedor não realizar a obrigação contratual no tempo e forma devidas cria para ele um estado de culpa, em razão do que, demandado sob tal fundamento, cabe-lhe o ônus da prova de uma daquelas situações em que a lei considera afastada a responsabilidade [e desta forma] o credor, para estabelecer seu direito, deve provar o contrato: porém uma vez demonstrada a dívida, o devedor que afirme tê-la cumprido ou ter estado impedido de o fazer, por força maior, deve provar essa alegação."

${ }^{1308}$ MALUF, Carlos Alberto Dabus. Do caso fortuito e da força maior: excludentes de culpabilidade, Revista do Advogado, São Paulo, n. 44, p. 28-37, out. 1994. p. 35-36.

${ }^{1309}$ ITURRASPE, Jorge Mosset; PIEDECASAS, Miguel. Responsabilidad contractual. Santa Fé: RubinzalCulzoni, 2007. p. 21.
} 
fundamentos do dever de reparar, transferindo-as para os critérios de exclusão desse dever. A culpa, hoje, é preservada "apenas à força da tradição." ${ }^{1310}$ É um ente inútil.

E, embora se reconheça - não sem refutação ${ }^{1311}$ - que a ausência de culpa e o caso fortuito - expressão aqui utilizada para representar a categoria jurídica na qual se inclui - sejam situações bastante distintas, como se verifica nos trabalhos de Carlos Alberto Dabus Maluf ${ }^{1312}$, Flávio Augusto Monteiro de Barros ${ }^{1313}$, Maria Helena Diniz ${ }^{1314}$, Scavone Junior ${ }^{1315}$ e Silvio Rodrigues ${ }^{1316}$, ou ainda, nas pesquisas de Alfredo Colmo ${ }^{1317}$, Christian Larroumet ${ }^{1318}$, Édgar Cortés ${ }^{1319}$, Pessoa Jorge ${ }^{1320}$ e Ricardo Lorenzetti ${ }^{1321}$, é

${ }^{1310}$ VITA NETO, José Virgílio. A atribuição da responsabilidade contratual. Tese (Doutorado) - Faculdade de Direito da USP, São Paulo, 2007. p. 49-50.

${ }^{1311}$ Além das referências transcritas há pouco, veja ainda: MASSIMO BIANCA, Cesare. La colpa come elemento costitutivo della fatispecie dell'illecito, Roma e America: Diritto Romano Comune, Roma, n. 3, p. 201-204, 1997. p. 204. "La scoperta della zona grigia tra colpa e caso fortuito è un altro articioso tentativo di debellare il principio della colpa, un altro episodio di una contestazione dottrinaria, la quale dimentica che il principio della colpa non è un mero criterio di responsabilità, ma è un principio di civiltà giuridica, che consente de tutelare un'essenziale esigenza dell'uomo: quella di realizare liberadamente la sua personalità e le sue scelte de vita nella realtà sociale. A fronte di questa esigenza vi è l'altra esigenza, quella di tenere indenni coloro che dalla nostra attività possono risentire un danno."

${ }^{1312}$ MALUF, Carlos Alberto Dabus. Do caso fortuito e da força maior: excludentes de culpabilidade, Revista do Advogado, São Paulo, n. 44, p. 28-37, out. 1994. p. 30-35.

1313 BARROS, Flávio Augusto Monteiro. Manual de direito civil: direito das obrigações e contratos. São Paulo: Método, 2005, v. 2. p. 163.

1314 DINIZ, Maria Helena. Curso de direito civil brasileiro: teoria geral das obrigações. 23 ed. São Paulo: Saraiva, 2008, v. 2. p. 381. Sustentando que, na seara contratual, "o devedor terá o ônus de provar que não agiu culposamente ou que houve ocorrência de força maior ou caso fortuito."

${ }^{1315}$ SCAVONE JUNIOR, Luiz Antonio. Causas e cláusulas de exclusão de responsabilidade civil, Revista de Direito Privado, São Paulo, v. 2, n. 8, p. 53-119, out./dez. 2001. p. 93-94. Do mesmo autor e no mesmo sentido: SCAVONE JUNIOR, Luiz Antonio. Do descumprimento das obrigações: consequiências à luz do princípio da restituição integral: interpretação sistemática e teleológica. São Paulo: Juarez de Oliveira, 2007. p. 231-232.

${ }^{1316}$ RODRIGUES, Silvio. Direito civil: parte geral das obrigações. 30 ed. São Paulo: Saraiva, 2002, v. 2. p. 236-237.

${ }^{1317}$ COLMO, Alfredo. De las obligaciones en general. Buenos Aires: Jesus Menendez, 1920. p. 95-99. Demonstrando conhecer a distinção apontada, está entre os autores que defendem que a prova da ausência de culpa é suficiente para liberar o devedor das consequências do incumprimento da obrigação, salientando ser desnecessária, assim, a prova de ter ocorrido caso fortuito ou força maior.

${ }^{1318}$ LARROUMET, Christian. La defensa de la responsabilidad contractual en derecho frances, Revista Trimestral de Direito Civil, Rio de Janeiro, n. 8, p. 151-163, out./dez. 2001. p. 154.

${ }^{1319}$ CORTÉS, Édgar. Breve nota sobre la culpa contractual y la extracontractual en el derecho colombiano, Revista Anales Derecho UC, Santiago, v. 3, p. 93-104, mar. 2008. p. 104.

1320 JORGE, Fernando Pessoa. Ensaio sobre os pressupostos da responsabilidade civil. Coimbra: Almedina, 1999. p. 131. Não se pode dizer que o caso fortuito começa onde termina a culpa.

${ }^{1321}$ LORENZETTI, Ricardo Luis. Tratado de los contratos: parte general. Buenos Aires: Rubinzal Culzoni, 2004. p. 612-615. 
imperioso informar que não é essa a lógica que informa a codificação vigente em solo pátrio.

Os preceitos contidos na codificação apregoam haver culpa na ausência de pagamento $^{1322}$ e são construídos considerando que aquela - por ser presumida no incumprimento - somente será afastada diante do fortuito, consagrando, portanto, a gênese do dever de reparar a partir de uma perspectiva objetiva, atada à conduta, sim, mas não necessariamente à culpa daquele que violou um dever contratual.

Ora, se a parte a quem se pretende imputar o dever de reparar deve demonstrar a superveniência e inevitabilidade do evento que impossibilitou a observância de um específico dever contratual ${ }^{1323}$, ainda que comumente se aluda à exclusão de culpa, em verdade, o processo se desenvolve em outro plano, nesse caso, o da causalidade.

Ademais, é evidente que à culpa não se reserva mais espaço algum na sociedade contemporânea - pelo menos, não na solução das celeumas que atingem o processo obrigacional. A culpa, além dos incontáveis problemas denunciados, foi afastada de seu embasamento sociológico no momento em que deixou de impedir o advento dos danos. No plano filosófico, sua justificativa desaparece com o advento do racionalismo. E, em termos dogmáticos, além de anacrônica ${ }^{1324}$, é uma figura inútil.

Aliás, nesse contexto, caso se pretenda aproveitar algo da codificação - no que tange ao tema investigado -, é imprescindível compreender que, quando aquela utiliza a expressão "sem culpa"1325, quer dizer "sem responsabilidade"1326 e, na mesma esteira, ao

1322 BARBERO, Domenico. Sistema del derecho privado: obligaciones. Trad. Santiago Sentis Melendo. Buenos Aires: EJEA, 1967, v. 3. p. 75-120. Consoante o autor, o não cumprimento da prestação deverá ser considerado fonte de responsabilidade do devedor pelos danos suportados pelo credor a não ser que aquele demonstre a presença de impossibilidade (absoluta ou temporal) de desempenho e que tal evento não pode ser imputável a ele. Apesar de fazer alusão à necessidade de culpa, destaca que ao devedor se atribui o ônus de salientar a existência de caso fortuito ou situações similares. É exatamente essa a lógica que informa os artigos 389, 393, 394 e 395 do CC.

1323 TRABUCCHI, Alberto. Istituzioni di diritto civile. 37 ed. Padova: Cedam, 1997. p. 545-550.

1324 NORONHA, Fernando. Desenvolvimentos contemporâneos da responsabilidade civil, Revista dos Tribunais, São Paulo, n. 761, p. 31-44, mar. 1999. p. 33. Ao discorrer sobre o papel da culpa, o autor destaca que, "se o Código Civil condensou uma evolução multimilenar, consagrando soluções que ao tempo eram consideradas as mais perfeitas, a verdade é que atualmente elas já não atendem às necessidades sociais. As concepções novecentistas estão sendo atropeladas pelo processo histórico."

${ }^{1325}$ Como nos artigos 234 (primeira parte), 235, 238, 240 (primeira parte), 248 (primeira parte), 250, 256, $458,459,567,612,613,718$ e $769 \S 1^{\circ}$, todos do código civil.

${ }^{1326}$ BUERES, Alberto Jesus. Derecho de daños. Buenos Aires: Hammurabi, 2001. p. 63-66. 
utilizar a expressão "por culpa" ${ }^{1327}$, em verdade, alude à consequência imputável à conduta do devedor.

Uma análise panorâmica dos dispositivos inseridos na codificação permite ratificar as assertivas formuladas. Em um primeiro momento, como exposto outrora ${ }^{1328}$, em todas as obrigações de dar, o dever de reparar será objetivamente aferido, pois, consoante a lógica que informa a codificação, a ausência de culpa depende da prova da causa estranha e não imputável - compreensão que se apresenta, com clareza incomum, na conjugação dos artigos 389 e 393 do CC. Em síntese, deles se extrai que o não desempenho da prestação importa em perdas e danos, salvo quando decorrente de caso fortuito ou de força maior. Aqui se inserem as hipóteses: (a) de perecimento e deterioração das obrigações de dar e/ou restituir, bem como de intelecção (b) das regras sobre o tema nos contratos aleatórios, na locação, na empreitada e no contrato de depósito, (c) da impossibilidade de desempenho de uma ou mais prestações nas obrigações alternativas, (d) e mesmo o tratamento dado genericamente ao incumprimento no processo obrigacional, pois, se, de um lado, a codificação destaca que, "nos contratos benéficos, responde por simples culpa o

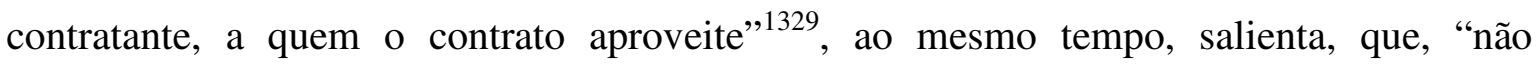
havendo fato ou omissão imputável ao devedor, não incorre este em mora."1330

Noutro mote, estão as hipóteses (e) de desrespeito à obrigação de fazer, mesmo porque a codificação versa apenas acerca da impossibilidade de desempenho da prestação - como visto outrora, consoante o estado da arte, a culpa não ocupa lugar algum na configuração das situações de mora e inadimplemento de prestações dessa natureza - e (f) de desrespeito às obrigações de não fazer, pois, nesse último caso, só a prova - a ser promovida pelo devedor - da existência de um motivo legítimo que justifique o desrespeito ao dever de abstenção impedirá a configuração do dever de reparar.

A seu turno, (g) nas situações em que há pluralidade de partes - como no caso do tratamento dado às obrigações indivisíveis e à solidariedade passiva -, percebe-se claramente que não é a culpa que importa na atribuição do dever de reparar a esse ou

\footnotetext{
${ }^{1327}$ Como nos artigos 234 (in fine), 236, 239, 240 (in fine), 248 (in fine), 251, 254, 255, $263 \S \S 1^{\circ}$ e $2^{\circ}, 279$, 280, 392, 414, 600, 625 I, 640 parágrafo único, 667, 676, 678 e 697, todos do código civil.

${ }^{1328}$ Mais precisamente, no item 3.3.

${ }^{1329}$ Art. 392 do CC.

${ }^{1330}$ Art. 396 do CC.
} 
àquele devedor, mas o fato de o perecimento ou de a impossibilidade de desempenho da prestação estarem conectadas à conduta de um ou vários devedores.

Enfim, nas situações em que a culpa é pensada buscando solucionar problemas causados em razão (h) de cessão de posição contratual - como previsto no regramento de contratos como os de depósito, mandato e comissão - e nos (i) contratos ajustados tendo por foco a gestão de interesse do parceiro negocial - com ou sem poder de representação -, ela pode ser facilmente afastada quando se percebe que é aquele que transmite sua posição no contrato - ou age em nome de outrem - o responsável pelo risco suportado pelo outro contratante e que, por isso, deve, em princípio, assumi-lo.

Diante de todo o exposto, é impossível não concluir que a responsabilidade contratual está fundada "no princípio da palavra dada."1331 No processo de apuração do dever de reparar os danos contratuais, a culpa não passa de um estereótipo ${ }^{1332}$, apesar de ainda ser pensada como um ente mitológico. ${ }^{1333}$

Não restam dúvidas de que o fator de imputação do dever de reparar os danos contratuais é objetivo, estando atado aos riscos da contratação. ${ }^{1334}$ As muralhas que protegem a culpa devem ser postas abaixo, também porque "o emparedamento das possibilidades desvirtua o potencial humano ao mesmo tempo em que obstrui a revelação de seu blefe."1335

Resta, agora, a missão de identificar o que a irá substituir.

1331 JUNQUEIRA DE AZEVEDO, Antonio. A boa-fé na formação dos contratos, Revista da Faculdade de Direito, São Paulo, v. 87, p. 79-90, jan./dez. 1992. p. 89-90. Interessante destacar o posicionamento do autor ao discorrer sobre o dever de reparar os danos surgidos no universo da formação dos contratos ao sustentar que tal dever estaria fundado na solidariedade social.

${ }^{1332}$ WARAT, Luis Alberto. O direito e sua linguagem. 2 versão. 2 ed. Porto Alegre: SAFE, 1995. p. 70-72. "Os estereótipos são palavras que apresentam uma carga conotativa provocadora de associações tão fortes que a simples evocação de seus significantes motiva comportamentos ou determina opiniões. [...] Um estereótipo é uma expressão ou uma palavra que pretende gerar adesões valorativas, comportamentos ou opiniões a partir de um processo de significação, no qual o receptor da mensagem a aceita de modo acrítico, baseado em solidariedades significantes epidérmicas."

${ }^{1333}$ WARAT, Luis Alberto. Introdução geral ao direito: interpretação da lei: temas para uma reformulação. Porto Alegre: SAFE, 1994, v. 1. p. 104-105. "Seria um mito um discurso cuja função é esvaziar o real e pacificar as consciências, fazendo com que os homens se conformem com a situação que lhes foi imposta socialmente, e que não só aceitem, como veneram [sic] as formas de poder que engendram essa situação."

${ }^{1334}$ ITURRASPE, Jorge Mosset; PIEDECASAS, Miguel. Responsabilidad contractual. Santa Fé: RubinzalCulzoni, 2007. p. 245.

${ }^{1335}$ BAUMAN, Zygmunt. Modernidade líquida. Trad. Plínio Dentzien. Rio de Janeiro: Zahar, 2001. p. 70232. 


\subsection{A confiança como fator de imputação do dever de reparar os danos contratuais}

Da constatação de que o processo obrigacional deve ser compreendido como uma relação de cooperação, e não, como um quadro de submissão do devedor aos interesses do credor, emana energia suficiente para implodir mais um pilar de sustentação da culpa.

Uma vez aceitas como premissas a cooperação imposta aos parceiros negociais ${ }^{1336}$ e as questões atadas à funcionalização no exercício de posições jurídicas, desaparece a necessidade de proteção de um devedor que outrora poderia ser obrigado a sujeitar-se aos caprichos do titular do direito à prestação.

É indubitável também que o principal escopo da relação obrigacional seja a satisfação dos legítimos interesses do credor. ${ }^{1337}$ "O adimplemento atrai e polariza" o processo obrigacional. ${ }^{1338}$ Nesse universo, visando à consagração desse momento, a confiança ganha destaque, devendo ser respeitada por todas as pessoas vinculadas à relação obrigacional.

A fluidez e complexidade do processo obrigacional - no transcorrer do qual, exige-se, cada vez mais, que decisões sejam tomadas ${ }^{1339}$ em velocidade estonteante exigem a valorização da confiança, elevada aqui à fonte normativa. ${ }^{1340}$ Confiança que, orientando originalmente a construção de teorias como as do erro e da aparência ${ }^{1341}$ - ao impor o respeito às expectativas legítimas provocadas no titular de certa posição jurídica -, expande seu universo de atuação, tornando-se uma preocupação constante do Direito.

\footnotetext{
${ }^{1336}$ MONTEIRO, Washington de Barros; MALUF, Carlos Alberto Dabus; SILVA, Regina Beatriz Tavares da. Curso de direito civil: direito das obrigações. 37 ed. São Paulo: Saraiva, 2010, v. 5. p. 25.

${ }^{1337}$ GOMES, Orlando. Obrigações. 9 ed. Atual. Humberto Theodoro Junior. Rio de Janeiro: Forense, 1994. p. 10.

${ }^{1338}$ COUTO E SILVA, Clóvis Veríssimo do. A obrigação como processo. São Paulo: Bushatsky, 1976. p. 5.

${ }^{1339}$ LUHMANN, Niklas. Confianza. Trad. Amada Flores. Barcelona: Anthropos, 2005. p. 40. Como "en la que el daño resultante de una ruptura de la confianza pude ser mas grande que el beneficio que se gana de la prueba de la confianza asegurada."

1340 MARQUES, Cláudia Lima. Novos temas na teoria dos contratos: confiança e o conjunto contratual, Revista da Ajuris, Porto Alegre, v. 32, n. 100, p. 73-97, dez. 2005. p. 86.

${ }^{1341}$ LARENZ, Karl. Derecho justo: fundamentos de etica juridica. Trad. Luis Díez-Picazo. Madrid: Civitas, 1993. p. 90-95.
} 
Infira-se que, enquanto valor essencial ao tráfego negocial, a confiança faz atuar, permitindo abandonar a inércia ${ }^{1342}$, quadro que se reforça na realidade contemporânea, no interior da qual, paradoxalmente, as relações se multiplicam ao mesmo tempo - e talvez na mesma proporção - em que as pessoas se distanciam. ${ }^{1343}$

É possível imaginar que a supressão da confiança dessa moldura seria trágica: o volume dos negócios sofreria redução, e o custo das negociações aumentaria ${ }^{1344}$, até porque valorizar a confiança alheia implica a redução dos custos da atividade. ${ }^{1345}$

Confiar é condição básica de convivência pacífica na vida em sociedade ${ }^{1346}$, valor que, muito antes de lastrear-se em pilares de ordem ética ou moral, se apresenta como uma necessidade social. ${ }^{1347}$

Por isso, exige conformação jurídica, pois, apesar de ser incapaz de eliminálos, sem dúvida, reduz os riscos do contrato. É relevante destacar, também que, apesar de a figura sob análise, historicamente, formatar-se a partir da análise de estados pessoais, na atualidade, não há como fugir de sua objetivação. ${ }^{1348}$

1342 MARQUES, Cláudia Lima. Novos temas na teoria dos contratos: confiança e o conjunto contratual, Revista da Ajuris, Porto Alegre, v. 32, n. 100, p. 73-97, dez. 2005. p. 77. A confiança é fonte autônoma de responsabilidade.

${ }^{1343}$ MARTINS-COSTA, Judith. A proteção da legítima confiança nas relações obrigacionais entre a administração e os particulares, Revista da Faculdade de Direito da UFRGS, Porto Alegre, v. 22, p. 228-255, set. 2002. p. 232-233.

${ }^{1344}$ Vale lembrar quão catastróficos foram os efeitos da crise mundial - uma crise essencialmente de falta de confiança no cumprimento dos pactos - disparada no fim do ano de 2008.

${ }^{1345}$ LORENZETTI, Ricardo Luis. Teoria da decisão judicial: fundamentos do direito. Trad. Bruno Miragem. São Paulo: RT, 2009. p. 95. Tanto em termos de estratégias de marketing como ao evitar demandas judiciais.

${ }^{1346}$ NORONHA, Fernando. O direito dos contratos e seus princípios fundamentais: autonomia privada, boafé e justiça contratual. São Paulo: Saraiva, 1994. p. 82. Veja ainda: MACHADO, João Baptista. Obra dispersa. Braga: Scientia Iurídica, 1991, v. 1. p. 352. "Mais ainda: esse poder confiar é logo condição básica da própria possibilidade da comunicação dirigida ao entendimento, ao consenso e à cooperação (logo, da paz jurídica). Note-se que, independentemente do preceito ético, pensado como regra geral de conduta, a não correspondência sistemática à confiança inspirada tornaria insegura, ou paralisaria mesmo, a interaç̧ão humana." Veja ainda: MALINOWSKI, Bronislaw. Crimen y costumbre en la sociedad salvaje. Trad. J. y M. T. Alier. Barcelona: Planeta-Agostini, 1985. p. 70-74.

${ }^{1347}$ MARTINS, Raphael Manhães. Inadimplemento antecipado: perspectiva para sua aplicação no direito brasileiro, Revista de Direito Privado, São Paulo, v. 8, n. 30, p. 199-238, abr./jun. 2007. p. 219. "Afinal, num mundo onde as variáveis e os riscos são inúmeros, como nossa sociedade de consumo ou da informação, o ser humano precisa eliminar algumas destas possibilidades, de forma a reduzir a complexidade social e ganhar tempo, permitindo atuação e intervenção mais ampla no espaço social.”

${ }^{1348}$ LUHMANN, Niklas. Confianza. Trad. Amada Flores. Barcelona: Anthropos, 2005. p. 46. "La relación de la confianza con un objeto es independiente de los intereses específicos individuales e de los contextos de experiencia y ocurre sin considerar el estado particular de las cosas para las que llega a ser relevante." 
Torna-se imperioso enxergar que a confiança não está fundada em subjetivismos ou sentimentalismos ${ }^{1349}$, apesar das severas críticas direcionadas a essa reflexão sob o argumento da necessidade de valorização da vontade externada pelos parceiros negociais ${ }^{1350}$, censuras que, aliás, não terminam aqui, afirmando-se que a confiança, sozinha, não teria valor algum, podendo ser equiparada a "um cego a guiar outro cego." 1351

Tais críticas, entretanto, parecem desconhecer o declínio do voluntarismo e a necessidade de tutela de uma infinidade de vulnerabilidades a permear toda a pluralidade das relações sociais e a realidade de cada programa obrigacional concretamente estabelecido.

Assim, se por um lado, é possível perceber que se contrata visando à satisfação de necessidades das mais distintas ordens - e não, ao menos em regra, dando vazão a uma vontade, no mais das vezes inexistente - e, por que alguém acreditou nas promessas do outro, de outro, infere-se que as pessoas não são iguais, mas, longe disso, bastante distintas, e isso também em perspectiva sociocultural. Por isso, desvalorizar a confiança, nessa órbita, é desrespeitar o próprio Direito. ${ }^{1352}$

1349 BARRETO, Ricardo Menna; ROCHA, Leonel Severo. Confiança nos contratos eletrônicos: uma observação sistêmica, Revista Jurídica Cesumar, v. 7, n. 2, p. 409-425, jul./dez. 2007. p. 414. Aferida em nível sistêmico, atua como mecanismo de redução de complexidades, possibilitando, assim, a construção do social.

${ }^{1350}$ ASCENSÃO, José de Oliveira. Alteração das circunstâncias e justiça contratual no novo código civil, Revista Trimestral de Direito Civil, Rio de Janeiro, n. 25, p. 93-118, jan./mar. 2006. p. 96.

1351 ASCENSÃO, José de Oliveira. Cláusulas contratuais gerais, cláusulas abusivas e boa-fé, Revista de Direito Privado, São Paulo, v. 1, n. 4, p. 9-25, out./dez. 2000. p. 21-22.

${ }^{1352}$ LUHMANN, Niklas. Confianza. Trad. Amada Flores. Barcelona: Anthropos, 2005. p. 162-163. "Si el efecto de estos diversos mecanismos va a ser aumentado, su combinación debe asegurarse independientemente de las estructuras motivadoras personales y de la inclinación al riesgo. Esto puede hacerse solamente a través de la organización, que pone en juego motivos nuevos, impersonales, para la acción. A este grado, además, una diferenciación del sistema para que goce de confianza es un requisito necesario para la especificación interna. La organización en ninguna forma hace superfluas a la confianza y desconfianza, sino que despersonaliza estos mecanismos. La persona que confía ya no lo hace tanto a su propio riesgo, sino el riesgo del sistema; todo lo que tiene que hacer es tener cuidado aun de que ninguno de los errores perceptibles se deslicen su propia confianza. La persona que desconfía ya no lo hace volviendo a los modos personales de reducción, tal como la animosidad personal, la hostilidad, o las precauciones de seguridad, sino que lo hace de una manera semejante a la potencia del sistema, que ya ha programado anticipadamente el modo de conducta para los casos de desilusión y pone en guardia al que desconfía contra cualquier exceso. [...] Agotado todo, la teoría de sistemas efectúa más que la ética por cuanto hace comprensible los mecanismos de especificación del sistema. Asimismo, en el análisis final, no puede decir al actor cómo debería actuar y si debería confiar o no. Sin embargo, posee la posibilidad de mostrar claramente cómo pueden establecerse los sistemas en los cuales, a pesar de la alta complejidad, puede dejarse al actor decidir si confía o no. Los sistemas son racionales al grado de que pueden abarcar y reducir la complejidad, y esto sólo pueden hacerlo si poseen el entendimiento de cómo hacer uso de la confianza y la desconfianza sin 
Hoje "a rua grita", exigindo, talvez, maior respeito à confiança em detrimento da manutenção das vantagens de uma segurança jurídica que nunca conheceu. ${ }^{1353}$ Aliás, atualmente, parece mais fácil sustentar que o contrato é fonte de deveres das mais distintas ordens porque alguém confiou no compromisso assumido pelo outro do que, como outrora, defender ter havido uma mítica fusão de vontades almejando obrigar os atores sociais ${ }^{1354}$, contratualmente vinculados, a desempenharem a prestação prometida.

Infira-se que, ao comprometer a palavra perante alguém, o outro - que nela acredita - legitimamente passar a contar com a conduta prometida, de modo que o eu, para ele, se transforma em alguém de quem se pode exigir a prestação de contas dos seus atos. $^{1355}$

A assertiva é ratificada quando se recorda a origem canônica das pacta sunt servanda. ${ }^{1356}$ Apesar da existência de censura na alocação da confiança como fundamento da obrigatoriedade do contrato ${ }^{1357}$, é bem mais aceitável atribuir-lhe esse papel do que continuar a defender que o aludido princípio mantém seu fundamento filosófico no pensamento medieval que atava o incumprimento das obrigações à mentira, essa ao pecado ${ }^{1358}$, e esse, enfim, a sanções eternas de ordem metafísica. ${ }^{1359}$ Fato inconteste, por longa data, afirmou-se que quem não honrasse a palavra dada queimaria no fogo do inferno!

colocar exigencias demasiado pesadas en la persona que finalmente otorga confianza y desconfianza: el individuo."

${ }^{1353}$ WARAT, Luis Alberto. A rua grita dionísio: direitos humanos da alteridade, surrealismo e cartografia. Trad. e Org. Vivian Alves de Assis; Júlio Cesar Marcellino Junior; Alexandre Morais da Rosa. Rio de Janeiro: Lumen Juris, 2010. p. 53. Na lição do autor, "os pensamentos precisam oxigenar-se, não se arrogar em abstrações ou em visões unívocas. O racionalismo oculta o sol e priva a sensibilidade de seu oxigênio. Teremos que reaprender a escutar a rua enquanto produtora do novo. A inovação como diferença que nos permite escapar das zonas cristalizadas de nossa cultura, dos lugares comuns que aprisionam em seu vazio."

${ }^{1354}$ DE LORENZO, Miguel Federico. El péndulo de la autonomía de la voluntad. In: GESUALDI, Dora Mariana (Coord.). Derecho privado. Buenos Aires: Hammurabi, 2001. p. 456.

1355 OST, François. Tiempo y contrato: crítica del pacto fáustico, Doxa, Alicante, n. 25, p. 597-626, 2002. p. 600 .

1356 AMARAL, Francisco. Historicidade e racionalidade na construção do direito brasileiro, Revista Brasileira de Direito Comparado, Rio de Janeiro, n. 20, p. 29-87, jan./jun. 2001. p. 44.

${ }^{1357}$ DÍEZ-PICAZO, Luiz. Fundamentos del derecho civil patrimonial: introduccion, teoria del contrato. 5 ed. Madrid: Civitas, 1996, v. 1. p. 125. Segundo o autor, "os contratos não obrigam apenas por respeito à palavra, mas por serem mecanismos institucionais de realização de fins e interesses."

${ }^{1358}$ DUPICHOT, Jacques. Derecho de las obligaciones. Trad. Rosangela Calle. Bogotá: Temis, 1984. p. 16.

1359 Outros fundamentos utilizados pela doutrina para justificar a obrigatoriedade do cumprimento dos contratos podem ser encontrados em: ANDRADE, Darcy Bessone de Oliveira. Aspectos da evolução da teoria dos contratos. São Paulo: Saraiva, 1949. p. 93-100. 
É evidente, entretanto, que a relação obrigacional não está fundada na suposta soberania da vontade reconhecida por regras codificadas (ou não), muito menos, na moral cristã, que, por longa data, informou a temática. Em verdade, ela se encontra ancorada na "aura de confiança" que deriva da comunicação social ${ }^{1360}$, essencial à vida em sociedade e, por isso, ao Direito cabe garantir que essa confiança não seja frustrada. ${ }^{1361}$

Superada essa questão, é importante explorar a origem e extensão do valor ora radiografado. Afirma-se que a confiança teria gênese na boa-fé ${ }^{1362}$, reflexão encontrada nos estudos de Eduardo Gouvêa ${ }^{1363}$, Jorge Cesa Ferreira da Silva ${ }^{1364}$, José Carlos Moreira da Silva Filho ${ }^{1365}$ e Judith Martins-Costa ${ }^{1366}$, muito embora pareça que tal lógica deva ser invertida, até porque, historicamente, a fides surge antes da bona fides. ${ }^{1367}$

É preciso aclarar, também, que, embora possam se complementar, confiança e boa-fé não se confundem. ${ }^{1368}$ Enquanto a última alude ao "modo" pelo qual a cooperação deve instrumentalizar-se no processo obrigacional - dentre outras funções a ela

${ }^{1360}$ DUTRA, Jeferson Luiz Dellavalle. Princípios contratuais e reflexividade sistêmica: boa-fé, equilíbrio econômico e função social do contrato. In: SILVA FILHO, José Carlos Moreira da; PEZZELLA, Maria Cristina Cereser (Coord.). Mitos e rupturas no direito civil contemporâneo. Rio de Janeiro: Lumen Juris, 2008. p. 153-157.

${ }^{1361}$ HESPANHA, António Manuel. O caleidoscópio do direito: o direito e a justiça nos dias e no mundo de hoje. Coimbra: Almedina, 2007. p. 186.

1362 SCHAEFER, Fernanda. Princípio da confiança e procedimentos médicos realizados à distância. In: NALIN, Paulo (Org.). Contrato \& sociedade. Curitiba: Juruá, 2004, v. 1. p. 17-23. Na visão da autora, a confiança apresenta-se como uma forma de materialização da boa-fé, coibindo lesões diante da lealdade reciprocamente imposta às partes.

1363 GOUVÊA, Eduardo de Oliveira. Boa-fé objetiva e responsabilidade civil contratual: principais inovações, Revista Forense, Rio de Janeiro, n. 369, p. 73-88, set./out. 2003. p. 81. Segundo o autor, a "boa-fé contratual está abrangida em tudo e por tudo pela boa-fé objetiva [podendo traduzir-se] no dever de cada parte agir de forma a não lesar a confiança da outra.

${ }^{1364}$ SILVA, Jorge Cesa Ferreira da. A boa-fé e a violação positiva do contrato. Rio de Janeiro: Renovar, 2007. p. 35-55.

1365 SILVA FILHO, José Carlos Moreira da. Pessoa humana e boa-fé objetiva nas relações contratuais: a alteridade que emerge da ipseidade. In: SILVA FILHO, José Carlos Moreira da; PEZZELLA, Maria Cristina Cereser (Coord.). Mitos e rupturas no direito civil contemporâneo. Rio de Janeiro: Lumen Juris, 2008. p. 318.

1366 MARTINS-COSTA, Judith. A boa-fé como modelo (notas para a compreensão da boa-fé obrigacional como modelo doutrinário e jurisprudencial no direito brasileiro), Roma e America: Diritto Romano Comune, Roma, n. 13, p. 71-97, 2002. p. 93. A autora trabalha a boa-fé como "norma reitora da proteção da confiança."

${ }^{1367}$ MENEZES CORDEIRO, Antônio Manuel da Rocha e. Da boa fé no direito civil. Coimbra: Almedina, 1984, v. 1, p. 53-70.

${ }^{1368}$ MARTINS, Raphael Manhães. O princípio da confiança legítima no direito brasileiro: uma discussão em torno do enunciado n. 362, da IV jornada de direito civil, Revista da Ajuris, Porto Alegre, v. 35, n. 112, p. 257-271, dez. 2008. p. 267-271. 
consagradas $^{1369}$-, a confiança diz respeito fundamentalmente à proteção da legítima expectativa criada no alter em razão da interação negocial. ${ }^{1370}$

Ademais, as leituras que vinculam, aos influxos da boa-fé, a proteção da confiança surgida no outro $^{1371}$, muito embora não sejam de todo incorretas, dão primazia à primeira, criando uma aparente relação de subserviência da confiança àquela. Por isso, é fundamental ir além, desatrelando essa ligação, pois, em verdade, sob as lentes do microscópio, não existe liame de dependência entre essas figuras.

É relevante perceber que, enquanto a boa-fé projeta os comportamentos daquele a quem se impõe o exercício de determinadas posições jurídicas - selecionando o que deve ser feito (ou não) em favor do outro -, a confiança alimenta as expectativas legitimamente despertadas diretamente no outro, independentemente de quem seja ou dos comportamentos exteriorizados por aquele em quem se acredita.

A confiança se apresenta, portanto, como um ser sem olhos e, desse modo, é a principal responsável pela sensação prévia de sucesso do projeto obrigacional que induz a contratar. Tamanha a independência entre as figuras, que é possível antever um quadro no qual a conduta de uma das partes se despiu da boa-fé exigida pelo Direito e, ainda assim, não foi capaz de frustrar a confiança que permeia a relação negocial.

E, antes que surja a discussão, é essencial informar que a confiança aqui tratada não é aquela que surge em cada indivíduo isoladamente considerado a partir da identificação de seus estados anímicos. ${ }^{1372}$

Pensar desse modo implica substituir um critério subjetivo por outro, solução inadmissível diante (a) das múltiplas faces do contrato na contemporaneidade, (b) das premissas que informam o Estado Democrático de Direito e, ainda, (c) da tendência de objetivação dos raciocínios jurídicos.

${ }^{1369}$ Sobre o tema, no Brasil, por todos: MARTINS-COSTA, Judith. A boa-fé no direito privado. São Paulo: RT, 2000. p. 381-472.

${ }^{1370}$ MARTINS-COSTA, Judith. Princípio da confiança legítima e principio da boa-fé objetiva. termo de compromisso de cessação (tcc) ajustado com o cade. critérios de interpretação contratual: os "sistemas de referência extracontratuais" ("circunstâncias do caso") e sua função no quadro semântico da conduta devida. princípio da unidade ou coerência hermenêutica e "usos do tráfego". adimplemento contratual, Revista dos Tribunais, São Paulo, v. 95, n. 852, p. 87-126, out. 2006. p. 94-99.

${ }^{1371}$ LARENZ, Karl. Derecho justo: fundamentos de etica juridica. Trad. Luis Díez-Picazo. Madrid: Civitas, 1993. p. 95-96.

1372 MARTINS, Raphael Manhães. Inadimplemento antecipado: perspectiva para sua aplicação no direito brasileiro, Revista de Direito Privado, São Paulo, v. 8, n. 30, p. 199-238, abr./jun. 2007. p. 221. 
Longe disso - a partir das condições de vida estabelecidas pela sociedade -, a confiança ultrapassa o nível pessoal, e seu principal lastro está no fato de que os outros também confiam. ${ }^{1373}$ Ao transcender os interesses das partes - bem como, por óbvio, as percepções individuais -, ela atua como um instrumento vital à equalização dos negócios pactuados cotidianamente em sociedade. ${ }^{1374}$

Por isso - e esse ponto é fundamental -, a relevância de compreender o valor sob análise a partir de uma percepção de ordem sistêmica ${ }^{1375}$ - e, portanto, objetiva -, que permita identificá-la em perspectiva social, e não, a partir da investigação dos anseios do indivíduo, de suas idiossincrasias e de suas angústias pessoais.

Nesse mote, a confiança haverá de ser identificada a partir de um procedimento que ultrapasse a perquirição das subjetividades inerentes às titularidades concretamente identificáveis ${ }^{1376}$, devendo ser ancorada em nível social ou sistêmico.

Em outras palavras, será apreendida objetivamente ${ }^{1377}$, especialmente por se apresentar como um valor essencial à redução das contingências contidas no futuro ${ }^{1378}$,

${ }^{1373}$ LUHMANN, Niklas. Confianza. Trad. Amada Flores. Barcelona: Anthropos, 2005. p. 118-121.

1374 MIRANDA, José Gustavo Souza. A proteção da confiança nas relações obrigacionais, Revista de Informação Legislativa, Brasília, v. 38, n. 153, p. 131-149, jan./mar. 2002. p. 132. "O ponto a destacar, que é de vital importância, é o aspecto da proteção que o Direito reconhece à "confiança". Não se trata de proteger o destinatário, mas sim a segurança do tráfico."

1375 WEINGARTEN, Celia. El valor economico de la confianza para empresas y consumidores, Revista de Direito do Consumidor, São Paulo, v. 9, n. 33, p. 33-50, jan./mar. 2000. p. 36. "Esse tipo de confiança se estrutura além dos motivos individuais da pessoa que confia (feição subjetiva), e só é possível em um consenso social estruturado sobre pautas culturais e valores morais transmissíveis de uma geração a outra em um âmbito de normalidade ou de indução.” Veja ainda: GIDDENS, Anthony; BECK, Ulrich; LASH, Scott. Modernização reflexiva: política, tradição e estética na ordem social moderna. Trad. Magda Lopes. São Paulo: Unesp, 1997. p. 111. “A natureza problemática da confiança nas condições sociais modernas é especialmente significativa quando consideramos os próprios sistemas abstratos, em vez de apenas seus "representantes". Em uma multiplicidade de sistemas abstratos, a confiança é uma parte necessária da vida cotidiana da atualidade, quer isto seja ou não conscientemente reconhecido pelos indivíduos em questão. Os sistemas de confiança tradicionais eram quase sempre baseados no "trabalho visível"; por ter acesso especial às qualidades esotéricas da tradição, o guardião era a tradição em forma de pessoa. As características desincorporadas dos sistemas abstratos significam uma constante interação com os "outros ausentes" pessoas que nunca vimos ou encontramos, mas cujas ações afetam diretamente características da nossa própria vida. Dado o caráter dividido e contestado da especialização, a criação de sistemas abstratos estáveis é uma tentativa que vale a pena. Alguns tipos de sistema abstrato tornaram-se tão pertinentes às vidas das pessoas que, em um determinado momento do tempo, parecem ter uma solidez de pedra, semelhante à tradição estabelecida; mas são vulneráveis ao colapso da confiança generalizada."

1376 CARNEIRO DA FRADA, Manuel António de Castro Portugal. Teoria da confiança e responsabilidade civil. Coimbra: Almedina, 2007. p. 372.

${ }^{1377}$ BOTH, Laura Garbini; PINHEIRO, Rosalice Fidalgo. As “fórmulas mágicas” da boa-fé na jurisprudência brasileira: um cenário de transferência de culturas. In: CORTIANO JUNIOR, Eroulths et all (Coord.). Apontamentos críticos para o direito civil brasileiro contemporâneo. Curitiba: Juruá, 2009. p. 220. "O resultado desse empenho teórico em relação à compreensão do processo de aculturação ou da transferência de elementos culturais entre diferentes sociedades fundamenta de forma inquestionável a afirmação de que 
mitigando, consequentemente, as complexidades da vida em sociedade ${ }^{1379}$, o que parece ser realmente possível, mormente quando se vislumbra que o risco - aqui inserido, sem dúvida, o risco de contratar - permeia a contemporaneidade com intensidade e extensão jamais imaginadas.

Essa confiança sem rosto ${ }^{1380}$ permite construir pontes com um horizonte que paradoxalmente nunca será alcançado ${ }^{1381}$, até porque é exatamente essa constante e eterna viagem ao desconhecido que promove a renovação do valor explorado.

E por estar lastreada na experiência comprovada de funcionamento dos sistemas, a confiança substitui a racionalidade que informava as sociedades do passado, respaldando a manutenção de ilhas de segurança social ${ }^{1382}$ durante o fluxo descontínuo e inseguro do ir e vir de seus membros.

Ao dar suporte à vida em sociedade, mantém hibernados os instintos mais primitivos do homem. Esse valor social permite ultrapassar barreiras individuais meramente psíquicas e/ou voluntaristas, estabilizando as relações cotidianas ao diminuir as variáveis que influenciam a tomada de decisões, permitindo antecipar o futuro. ${ }^{1383}$

não existe acaso na organização da sociedade e da sua expressão cultural, as culturas são estruturadas de forma lógica, e isto as torna passíveis de busca e enunciação de leis gerais."

${ }^{1378}$ LUHMANN, Niklas. Confianza. Trad. Amada Flores. Barcelona: Anthropos, 2005. p. 26.

${ }^{1379}$ MARQUES, Cláudia Lima. A chamada nova crise do contrato e o modelo de direito privado brasileiro: crise de confiança ou de crescimento do contrato?. In: MARQUES, Cláudia Lima (Coord.). A nova crise do contrato: estudos sobre a nova teoria contratual. São Paulo: RT, 2007. p. 32. "O indivíduo decide se aquela atividade, oferta ou contexto de consumo [e não apenas nessa órbita, pensamos nós] merece sua confiança. Efetivamente, se confiamos no parceiro contratual atuamos de forma mais simples e direta. Neste caso, muitas coisas podem não ser ditas, ficam pressupostas, compartilhadas pela nossa cultura e base social comum, em silêncio. [...] Se não confiamos, temos que tudo prever e tudo evitar."

${ }^{1380}$ GIDDENS, Anthony. As conseqüências da modernidade. Trad. Raul Fiker. São Paulo: Unesp, 1991. p. 87-91. Ainda que seja inegável que os pontos de acesso possam facilitar ou dificultar esse processo. Consoante o autor, "pontos de acesso são pontos de conexão entre indivíduos ou coletividades leigos e os representantes de sistemas abstratos [...] lugares de vulnerabilidade para os sistemas abstratos, mas também junções nas quais a confiança pode ser mantida ou reforçada." Entendemos que se faz necessário ir além, compreendendo, como pontos de acesso, os momentos de contato existentes entre as partes na relação negocial, eis que, nem sempre, um dos contratantes representará um sistema perito. Ademais, parte-se do pressuposto de que os contratantes estão contidos no sistema social.

${ }^{1381}$ PRICE, Jorge E. Douglas. El puente de macedonio, Revista da Faculdade Mineira de Direito, Belo Horizonte, v. 10, n. 19, p. 51-69, jan./jun. 2007. p. 56-57.

1382 BRANCO, Gerson Luiz Carlos. A proteção das expectativas legítimas derivadas das situações de confiança: elementos formadores do princípio da confiança e seus efeitos, Revista de Direito Privado, São Paulo, v. 3, n. 12, p. 167-225, out./dez. 2002. p. 175-176. Ao discorrer sobre o tema, o autor destaca que a confiança decorre de um "consentimento social que não é baseado na declaração de vontade, mas na elaboração e na aceitação de regras que levem em conta o ponto de vista do outro."

${ }^{1383}$ LUHMANN, Niklas. Confianza. Trad. Amada Flores. Barcelona: Anthropos, 2005. p. 5-25 e 33. "Los elementos esenciales de la experiencia deben representarse en la historia, ya que la historia es la forma más 
É, com lastro na confiança, que cada pessoa projeta sua atuação excluindo aquilo em que acredita (ou não) que irá ocorrer, reduzindo, sensivelmente, as incertezas contidas no porvir. ${ }^{1384}$ Essa mesma confiança - a ser respeitada e constantemente perseguida -, ao mesmo tempo em que projeta o ingresso do elemento ético no cerne das relações negociais, atua como fonte de deveres que auxiliam, em razão das expectativas surgidas, o processo de superação das incertezas cotidianas. ${ }^{1385}$

E, se é inegável que a existência de uma estrutura de autoridade formal e a explicitação dos deveres impostos aos contratantes são mecanismos importantes na redução das contingências contidas no programa contratual concretamente estabelecido, é imprescindível que a essas premissas seja acrescentada a confiança, fonte normativa que intensifica a cooperação exigida dos contratantes e impõe a aceitação da ampliação dos riscos que acompanham a hodierna conformação da relação obrigacional. ${ }^{1386}$

Assim, aquele que desrespeita a confiança legitimamente depositada em si pelo outro, contraria, sem dúvida alguma, as exigências impostas pelo Direito. ${ }^{1387}$ Consequentemente, uma vez violada, produzirá efeitos e responsabilidades ${ }^{1388}-$ sem que haja necessidade de atravessar o caminho nebuloso do subjetivismo.

importante de reducir la complejidad. Por este medio, la dimensión temporal con respecto a 10 que es pasado, resuelve un problema que pertenece estrictamente hablando a la dimensión social: la exclusión de la acción inesperada. La naturaleza socialmente contingente del mundo es con ello oscurecida, de modo que en el mundo familiar la construcción social inevitable del sentido permanece anónima. Comparado con esto, la confianza se orienta al futuro. Por supuesto que la confianza solamente es posible en un mundo familiar; necesita a la historia como trasfondo confiable. No se puede dar confianza sin esta base esencial y sin todas las experiencias previas. Pero aparte de ser sólo una inferencia del pasado, la confianza va más allá de la información que recibe del pasado y se arriesga definiendo el futuro. La complejidad del mundo futuro se reduce por medio del acto de la confianza. Al confiar, uno se compromete con la acción como si hubiera sólo ciertas posibilidades en el futuro. El actor une su futuro en el presente con su presente en el futuro. De esta manera ofrece a otras personas un futuro determinado, un futuro común, que no emerge directamente del pasado que ellas tienen en común, sino que contiene algo relativamente nuevo."

${ }^{1384}$ SILVA, Jorge Cesa Ferreira da. A boa-fé e a violação positiva do contrato. Rio de Janeiro: Renovar, 2007. p. 49.

1385 WEINGARTEN, Celia. El valor economico de la confianza para empresas y consumidores, Revista de Direito do Consumidor, São Paulo, v. 9, n. 33, p. 33-50, jan./mar. 2000. p. 34-35. Em sentido semelhante, MARTINS-COSTA, Judith. A proteção da legítima confiança nas relações obrigacionais entre a administração e os particulares, Revista da Faculdade de Direito da UFRGS, Porto Alegre, v. 22, p. 228-255, set. 2002. p. 233.

${ }^{1386}$ BELLEY, Jean-Guy. Uma filosofia da aspiração jurídica: a arte de bem se obrigar, Revista Trimestral de Direito Civil, Rio de Janeiro, n. 23, p. 17-37, jul./set. 2005. p. 27.

${ }^{1387}$ CASTILHA, Gustavo Ordoqui. Buena fe contractual. Montevideo: Del Foro, 2005. p. 21.

${ }^{1388}$ MARQUES, Cláudia Lima. A chamada nova crise do contrato e o modelo de direito privado brasileiro: crise de confiança ou de crescimento do contrato?. In: MARQUES, Cláudia Lima (Coord.). A nova crise do contrato: estudos sobre a nova teoria contratual. São Paulo: RT, 2007. p. 45. 
Na qualidade de instrumento de salvaguarda das expectativas surgidas naqueles que contratam $^{1389}$, deve assumir o papel de fator de imputação do dever de reparar os danos contratuais, embora se defenda, sem razão, que um sistema fundado na confiança não se coaduna com a estrutura do dever de reparar, embasado na violação de dever, por faltar, no último caso, o investimento de confiança. ${ }^{1390} \mathrm{E}$, sem razão, porque, dentre outros motivos, ao lastrear-se em perspectiva exclusivamente dogmática, aprisiona a realidade social.

Nesse quadro, a confiança deixa de servir apenas à teoria dos vícios do consentimento e a outras questões pontuais exploradas pela doutrina, projetando seus efeitos de modo a tutelar as legítimas expectativas daquele que confia na conduta prometida pelo outro. ${ }^{1391}$

Ademais, sendo inegável que a confiança atua na fase que antecede a formação do contrato - justificando a imposição do dever de reparar os danos pré-contratuais -, é impossível refutar a constatação de que esse valor permeia também toda e todas as relações negociais.

Ora, se com lastro na confiança, é possível extrair efeitos de negócios ou de cláusulas que sequer existem ${ }^{1392}$ e exigir a reparação de danos causados na fase précontratual, seria contraditório, como observado, não admitir que esse valor deva assumir o papel de protagonista na fundamentação do dever de reparar os danos oriundos da violação de dever contratual.

1389 NALIN, Paulo. Do contrato: conceito pós-moderno em busca de sua formulação na perspectiva civilconstitucional. Curitiba: Juruá, 2001. p. 154.

${ }^{1390}$ CARNEIRO DA FRADA, Manuel António de Castro Portugal. Teoria da confiança e responsabilidade civil. Coimbra: Almedina, 2007. p. 584-602.

${ }^{1391}$ D’AZEVEDO, Ana Rispoli. Os novos deveres dos contratantes na perspectiva do código civil de 2002 e do código de defesa do consumidor. In: MARQUES, Cláudia Lima (Coord.). A nova crise do contrato: estudos sobre a nova teoria contratual. São Paulo: RT, 2007. p. 293. Em sentido semelhante: VITA NETO, José Virgílio. A atribuição da responsabilidade contratual. Tese (Doutorado) - Faculdade de Direito da USP, São Paulo, 2007. p. 81-82. Afere-se assim que o dever de reparar não se submete "ao princípio da autonomia privada, mas sim a uma das diversas concretizações do princípio da confiança. Constituem conteúdo que se adiciona à relação contratual, uma vez que haja um comportamento em desacordo com as expectativas existentes. A defraudação da confiança depositada deve ser repelida pelo ordenamento jurídico; e suas conseqüências, desfeitas. Os instrumentos dogmáticos para tanto dispostos pelo ordenamento jurídico se concretizam nos deveres de indenização e nas pretensões e ações a ele correspondentes. Esses se funcionalizam a reparar os danos pela não realização das expectativas existentes, bem como a reafirmar a confiança defraudada."

${ }^{1392}$ Uma análise detalhada dessa e de outras questões inerentes às conexões possíveis entre o direito e confiança são feitas com maestria em: MARQUES, Cláudia Lima. Contratos no código de defesa do consumidor: o novo regime das relações contratuais. 5 ed. São Paulo: RT, 2006. p. 187-210 e 280-288. 
O argumento se reforça quando se infere ser inegável que, na seara das relações de consumo, aquele que induz o surgimento de confiança alheia responderá objetivamente por seu desrespeito. ${ }^{1393} \mathrm{E}$ ganha força, especialmente diante da possibilidade de sua utilização nos contratos civis, diante da aproximação principiológica existente entre esses e os contratos de consumo. ${ }^{1394}$

É possível concluir, nesse momento, que é, na confiança, que a sociedade contemporânea deposita a garantia de que as obrigações serão adimplidas. ${ }^{1395}$ "Respeite à palavra dada" e "honre o nome que lhe foi legado" são expressões que denotam a necessidade de consideração ao próximo, mormente porque um evento pretérito - o contrato e as expectativas por ele produzidas - é diretamente responsável por ter semeado a confiança no outro.

Enfim, diante da percepção de que (a) a hodierna concepção do contrato impõe respeitar e "responder pela confiança que o outro nele depositou ao contratar"1396 e de que (b) as expectativas produzidas pela confiança podem ser consideradas como fonte autônoma no direito obrigacional - a infração desse valor importa a responsabilização do causador do dano ${ }^{1397}$-, não há como negar o papel central dessa figura na gênese do dever de reparar os danos contratuais. Percebe-se, assim, por que

"os conceitos se substituem antes mesmo de se modificarem as leis. A estrutura dogmática do Direito desagrega-se sob o peso de intrusões, que não respeitam o isolacionismo a que a submeteram os conceitualistas,

${ }^{1393}$ ALTERINI, Atilio Aníbal. Responsabilidad objetiva derivada de la generación de confianza, Revista de Direito Civil, Imobiliário, Agrário e Empresarial, São Paulo, v. 19, n. 73, p. 5-16, jul./set. 1995. p. 7-11.

${ }^{1394}$ Nesse sentido, o enunciado 167, aprovado na III Jornada de Estudos de Direito Civil sob a coordenação do Conselho da Justiça Federal, dispondo que, "com o advento do Código Civil de 2002, houve forte aproximação principiológica entre esse Código e o Código de Defesa do Consumidor, no que respeita à regulação contratual, uma vez que ambos são incorporadores de uma nova teoria geral dos contratos."

${ }^{1395}$ LEWICKI, Bruno. Panorama da boa-fé objetiva. In: TEPEDINO, Gustavo (Coord.). Problemas de direito civil-constitucional. Rio de Janeiro: Renovar, 2000. p. 58. "Há implicações de ordem religiosa, ética e moral; ora a fides é uma deusa (cuja mão direita era um símbolo de entrega e de lealdade) cultuada pelos romanos; ora emprega-se a fides como uma ligação, uma garantia de cumprimento dos pactos, associando alguns autores esta idéia a uma planta que era utilizada para atar; numa linha aproximada, outros autores enxergam na fides a representação em palavras do aperto de mão que selava os tratos. Há ainda juristas que identificam como fides a qualidade que provocava a confiança entre os cidadãos romanos, calcada na honradez, moralidade, integridade, virilidade que seriam inerentes a estas pessoas. Sem embargo destas e de outras especulações, aponta-se ainda a fides, internamente, como expressão do poder jurídico dos patrões sobre os escravos, e, externamente, como expressão da dominação que Roma exercia sobre outros povos."

${ }^{1396}$ MARQUES, Cláudia Lima. Contratos no código de defesa do consumidor: o novo regime das relações contratuais. 5 ed. São Paulo: RT, 2006. p. 212-213.

${ }^{1397}$ WEINGARTEN, Celia. El valor economico de la confianza para empresas y consumidores, Revista de Direito do Consumidor, São Paulo, v. 9, n. 33, p. 33-50, jan./mar. 2000. p. 47. A quebra de confiança, consoante discorre, com razão, a autora, será aferida objetivamente. 
dominados por preocupações puristas. Brechas, cada vez mais largas, fendem o sistema lógico, de circuito fechado, a que se reduziram a ciência e a prática do Direito Privado." 1398

É claro que as expectativas tuteladas, em algumas hipóteses, precisarão ser justificadas. Cada questão deverá ser contextualizada, afastando-se os reducionismos inerentes às análises atomísticas. O despertar ou não de confiança há de ser aferido a partir da valoração da integralidade do comportamento do alter $^{1399}$ e da inserção desse no meio em que atua. Nesse contexto, palavras e ações devem ser levadas a sério quando, e apenas quando, possam efetivamente despertar a confiança daqueles a quem se dirigem. ${ }^{1400}$

Eis mais um pilar na sustentação deste trabalho. A confiança - na verdade, sua violação - assume o papel de fator de imputação do dever de reparar no curso do processo obrigacional. Ela é protagonista nesse processo, e sua violação impõe, salvo escusa legítima, o dever de reparar. À culpa - antagonista nessa realidade -, por mais esse motivo, não se reserva espaço na responsabilidade contratual. ${ }^{1401}$ Nada mais pode ser feito por ela.

\subsection{O dever de reparar e a efetivação da justiça contratual}

Até este momento foi possível identificar que os critérios utilizados pela doutrina clássica não só não explicam, satisfatoriamente, a responsabilidade contratual em nível dogmático, como também são insuficientes para dirimir os problemas atados ao

1398 GOMES, Orlando. A função renovadora do direito, Revista da Faculdade de Direito da Universidade Federal do Paraná, Curitiba, n. 12, p. 39-47, 1969. p. 42.

${ }^{1399}$ MARTINS-COSTA, Judith. A ilicitude derivada do exercício contraditório de um direito: o renascer do venire contra factum proprium, Revista da Ajuris, Porto Alegre, v. 32, n. 97, p. 143-169, mar. 2005. p. 167168. Embora, como o próprio título demonstre, a reflexão exarada pela autora tenha sido construída a partir da análise de uma figura bastante pontual (o venire), parece perfeitamente plausível que tenha maior abrangência.

1400 MARTINS-COSTA, Judith. A proteção da legítima confiança nas relações obrigacionais entre a administração e os particulares, Revista da Faculdade de Direito da UFRGS, Porto Alegre, v. 22, p. 228-255, set. 2002. p. 231. Embora o texto se dirija à análise de relações jurídicas entre o Estado e particulares, como demonstra a autora, não há óbice algum em transplantar as reflexões formuladas às relações ajustadas entre os particulares.

${ }^{1401}$ É importante resgatar, nesse momento, o já destacado enunciado 363, aprovado na IV Jornada de Estudos de Direito Civil sob a coordenação do Conselho da Justiça Federal, dispondo que "os princípios da probidade e da confiança são de ordem pública, estando a parte lesada somente obrigada a demonstrar a existência da violação." 
desenvolvimento tecnológico e à proliferação dos danos na sociedade contemporânea. ${ }^{1402}$ As mesmas reflexões autorizam afirmar que o subjetivismo que informa o pensamento de parte da doutrina pátria atenta contra o interesse social de restabelecimento do equilíbrio desfeito pelo dano. ${ }^{1403}$

É relevante ressaltar, uma vez mais, que a reparação dos danos - e, no que interessa ao presente estudo, dos danos contratuais -, na atual quadra da História, longe de buscar a crucificação de hereges, está fundada na necessidade de reparar a lesão injustamente causada e/ou suportada por uma pessoa que, por confiar no(s) outro(s), não esperava se encontrar nesse estado deletério.

A necessidade de afastar o subjetivismo do processo de realização do Direito que visa à imputação, ao causador do dano, do dever de repará-lo - ao menos, em regra baliza-se, ademais, na constatação de que os riscos do contrato pesam - quase todos sobre o credor. Aclare-se que não se alude aqui à perda do objeto da prestação, mas acerca da frustração da expectativa do credor provocada pela violação de um dever contratual. Daí que, salvo incomum distribuição distinta dos riscos ${ }^{1404}$, a impossibilidade de desempenho da prestação não imputável ao devedor privará o credor da prestação por ele esperada. E será o credor - uma vez mais, em regra - que suportará a frustração causada pela morte em especial nas obrigações de fazer ${ }^{1405}$-, bancarrota ou mesmo a decorrente do desaparecimento do devedor.

Por isso, ao se distribuírem, de modo mais adequado, os riscos do contrato afastando a culpa do processo de imputação do dever de reparar -, em princípio, acreditase que as cargas e tensões no processo obrigacional serão mais bem equilibradas. E, embora nessa seara, mecanismos como a concorrência, o dever de informar e as condições gerais de contratação ${ }^{1406}$ atuem, em maior ou menor medida, em favor do equilíbrio do

1402 GUTIÉRREZ, Graciela Messina de Estrella. Un aspecto de la teoría del riesgo. In: GESUALDI, Dora Mariana (Coord.). Derecho privado. Buenos Aires: Hammurabi, 2001. p. 1297.

${ }^{1403}$ COSTA, Álvaro Ferreira da. Responsabilidade sem culpa, Revista da Faculdade de Direito, Curitiba, v. 4, n. 4, p. 234-250, dez. 1956. p. 235.

${ }^{1404}$ DUARTE, Ronnie. Responsabilidade civil e o novo código: contributo para uma revisitação conceitual, Revista dos Tribunais, São Paulo, v. 95, n. 850, p. 57-88, ago. 2006. p. 81.

1405 DELGADO, Mário Luiz. Da intransmissibilidade, causa mortis, das obrigações de prestação de fato. In: DELGADO, Mário Luiz; ALVES, Jones Figueirêdo (Coord.). Questões controvertidas: no direito das obrigações e dos contratos. São Paulo: Método, 2005, v. 4. p. 95-123.

1406 CANARIS, Claus-Wilhelm. A liberdade e a justiça contratual na "sociedade de direito privado". In: MONTEIRO, António Pinto (Coord.). Contratos: actualidade e evolução. Porto: Universidade Católica Portuguesa, 1997. p. 61-63. 
contrato, não se pode ignorar que não dão conta de uma infinidade de situações surgidas na multifacetária realidade das relações negociais.

Infira-se que a leitura proposta redunda, ainda, no melhor aproveitamento da carga eficacial contida em potência no princípio da isonomia. E isso porque, se a realização da justiça pressupõe tratamento igualitário de pessoas na mesma situação ${ }^{1407}$, justo será distribuir os riscos do contrato equitativamente entre as partes. Sobre o credor, penderão aqueles que são inerentes à eventualidade do não (ou do mau) cumprimento da prestação que lhe é devida e, sobre o devedor, os de ressarcir os danos causados pela inobservância do programa obrigacional ${ }^{1408}$ quando não conseguir demonstrar que uma causa estranha e não imputável - ou o exercício de uma posição defensiva - provocou a violação do dever contratual.

Também é oportuno resgatar que a principiologia na seara contratual trabalha a partir de parâmetros objetivos - probidade, lealdade, boa-fé. ${ }^{1409}$ Tais valores exigem respeito à crença depositada pelo credor no desempenho da prestação prometida e à assentada na convicção de ambas as partes de que o "contrato" não lhes causará danos injustos, o que se coaduna com as exigências da vida hodierna. ${ }^{1410}$

Na complexidade da realidade contemporânea, não há mais como sustentar a manutenção da culpa como fator de atribuição do dever de reparar os danos contratuais. Exigir uma conduta culposa como pressuposto da responsabilidade contratual implica, em última análise, a negação do acesso à justiça, por produzir manifesto desequilíbrio no negócio entabulado entre as partes.

\footnotetext{
${ }^{1407}$ LOPES, José Reinaldo de Lima. Voltar à teoria da justiça?, Revista de Direito Alternativo, São Paulo, n. 1, p. 71-76, 1992. p. 71-72.

${ }^{1408}$ ITURRASPE, Jorge Mosset; PIEDECASAS, Miguel. Responsabilidad contractual. Santa Fé: RubinzalCulzoni, 2007. p. 237.

${ }^{1409}$ Prova da assertiva formulada pode ser encontrada no enunciado 363, aprovado na IV Jornada de Estudos de Direito Civil do Conselho da Justiça Federal.

1410 GAMARRA, Jorge. Incidencia del problema de la carga de la prueba en la fundamentación de la responsabilidad civil, Revista de la Facultad de Derecho y Ciencias Sociales, Montevideo, v. 2, n. 3, p. 639665, 1951. p. 657-658. Apesar de entender que, em algumas poucas hipóteses, as obrigações contratuais possam ser classificadas como de meio, afirma que duas razões justificam a afirmação de que a culpa seja o único fundamento da responsabilidade contratual: a) "o fetichismo da unidade conceitual" e a excessiva abstração que dele deriva; b) o receio de abrir-se uma brecha no sistema que permitisse o ingresso da teoria do risco.
} 
A conclusão se embasa em multifacetados fatores, dentre eles, podendo ser lembrados, (a) a fluidez das relações na "sociedade líquido-moderna"1411 , (b) a expansão dos danos indenizáveis, (c) a invisibilidade dos danos, (d) a necessidade de leitura das vicissitudes surgidas no curso do processo obrigacional, por meio das lentes constitucionais da isonomia, solidariedade social, dignidade da pessoa humana e dos princípios contratuais sociais, (e) as incoerências sistêmicas promovidas pela mitificação da culpa e, enfim, (f) a força normativa atribuída à confiança na qualidade de fator de imputação do dever de reparar os danos contratuais.

É passada a hora de a culpa - esse filtro histórico na conformação do dever de reparar - ser removida do discurso jurídico. Além das incontáveis vantagens suscitadas ao longo desta pesquisa, a objetivação do dever de reparar é capaz de ampliar o nível de preocupação com o próximo antes da tomada de decisões, amplificando as responsabilidades durante todo o processo obrigacional. ${ }^{1412}$

É evidente, por outro lado, que, quando se busca a imposição do dever de reparar, não se pode ignorar uma premissa importante. É imperioso que haja preocupação constante com a justiça contratual, aferida aqui, não por meio de marcos fixados pelas correntes voluntaristas, mas a partir da aferição do equilíbrio do contrato - genético e funcional - e da cooperação exigida dos parceiros contratuais no desvelar da relação obrigacional. $^{1413}$

E, ao compreender que "equilíbrio é o ponto de meio, ponto de encontro, aquele que permite a realização das expectativas legítimas de ambos os parceiros"1414, percebe-se que a exigência não almeja tutelar uma ou outra parte na relação obrigacional,

${ }^{1411}$ BAUMAN, Zygmunt. Vida líquida. Trad. Carlos Alberto Medeiros. Rio de Janeiro: Zahar, 2007. p. 7. "Líquido-moderna é uma sociedade em que as condições sob as quais agem seus membros mudam num tempo mais curto do que aquele necessário para a consolidação, em hábitos e rotinas, das formas de agir. A liquidez da vida e a da sociedade se alimentam e se revigoram mutuamente. A vida líquida, assim como a sociedade líquido-moderna, não podem manter a forma ou permanecer em seu curso por muito tempo."

${ }^{1412}$ BAÍA, Jacinto Américo Guimarães. A evolução da responsabilidade civil e a reparação do dano nuclear, Revista de Direito Civil, Imobiliário, Agrário e Empresarial, São Paulo, v. 2, n. 4, p. 49-68, abr./jun. 1978. p. 57.

1413 CUNHA, Wladimir Alcibíades Marinho Falcão. A equivalência material dos contratos e a revisão contratual fundada na lesão no código civil de 2002. In: BARROSO, Lucas Abreu (Org.). Introdução crítica ao código civil. Rio de Janeiro: Forense, 2006. p. 32.

1414 MARQUES, Cláudia Lima. Direitos básicos do consumidor na sociedade pós-moderna de serviços: o aparecimento de um sujeito novo e a realização de seus direitos, Revista de Direito do Consumidor, São Paulo, v. 9, n. 35, p. 61-96, jul./set. 2000. p. 62. 
mas sim, a relação jurídica considerada em toda sua complexidade e, consequentemente, a vida em sociedade.

Por isso, o equilíbrio deve permear cada momento do processo obrigacional. $^{1415}$ Seus efeitos devem se projetar não só sob o vértice econômico, mas também visando à equalização do viés jurídico, ou seja, da carga de direitos e deveres distribuídos entre as partes. Tanto é verdade que, mesmo de modo incipiente, o direito brasileiro consagra diversos dispositivos destinados à manutenção dos pactos. ${ }^{1416}$

A efetivação da justiça contratual exige, assim, que o respeito à força obrigatória se sujeite a um pressuposto prévio: a presença e (ou) a manutenção da equivalência entre as prestações reciprocamente consideradas ${ }^{1417}$ em perspectiva genética e funcional. É evidente que esse cálculo não será promovido em perspectiva milimétrica ${ }^{1418}$, até porque, antes de buscar soluções pautadas no perfeito equilíbrio, é essencial "impedir a eficácia de estipulações clamorosa e intoleravelmente injustas."1419

Apesar da clareza da constatação, propostas que destoam da ideia de intangibilidade contratual nem sempre são aceitas com tranquilidade, havendo vozes que se opõem, veementemente, à possibilidade de revisão do contrato. ${ }^{1420}$

1415 DONNINI, Rogério. Revisão contratual sem imprevisão, Revista Brasileira de Direito Civil Constitucional e Relações de Consumo, Santo Amaro, n. 1, p. 245-259, jan./mar. 2009. p. 251. Ao discorrer sobre o princípio da força obrigatória dos contratos, o autor destaca que tal "princípio foi elevado a um patamar tal (intangibilidade contratual) em nosso País, que mesmo relações iníquas, desiguais, injustas, foram convalidadas, sob o argumento de que os pactos deveriam ser cumpridos (pacta sunt servanda) [pois a] idéia de contrato, antes da Constituição Federal de 1988 e, em especial, do Código de Defesa do Consumidor, tinha como pontos principais, enaltecidos pela doutrina e jurisprudência dominantes, apenas os princípios da autonomia da vontade e o da força obrigatória dos pactos [...] de forma até mesmo desmedida, olvidando-se da própria noção de contrato, fundamentada na idéia de comutatividade, que é ínsita a qualquer contrato e consiste no equilíbrio nas prestações assumidas pelas partes."

${ }^{1416}$ Dentre outros os artigos 156, 157, 317, 478 e 620 do código civil e artigo 6, inciso V do código de defesa do consumidor.

1417 ALTERINI, Atílio Aníbal. Teoría de la imprevisión y cláusula de hardship. In: GESUALDI, Dora Mariana (Coord.). Derecho privado. Buenos Aires: Hammurabi, 2001. p. 990-992.

${ }^{1418}$ PERLINGIERI, Pietro. O direito civil na legalidade constitucional. Trad. Maria Cristina De Cicco. Rio de Janeiro: Renovar, 2008. p. 376-377. O autor, realça que "esta ilação lesa o princípio da autonomia e não considera as peculiaridades de casos como aquele de quem, desejando adquirir um apartamento confinante para ampliar o próprio, esteja disposto a pagar um surplus em relação ao valor de mercado. [...] Proporcionalidade não significa equivalência entre prestações nem correspectividade restrita, mas equilíbrio, proporção no regulamento."

${ }^{1419}$ RIBEIRO, Joaquim de Souza. Direito dos contratos: estudos. Coimbra: Coimbra, 2007. p. 55.

${ }^{1420}$ CARVAlHo, Afrânio de. O futuro código civil, Revista de Direito Civil, Imobiliário, Agrário e Empresarial, São Paulo, v. 9, n. 34, p. 7-28, out./dez. 1985. p. 20-22. Criticando a inserção de figuras como a lesão e a resolução/revisão do contrato por excessiva onerosidade superveniente porque atraem "irresistivelmente todos os intrujões e vigaristas." O autor destaca que, "conquanto inspiradas em ideal de justiça, as iniciativas que acabam de ser referidas excedem [...] o mínimo ético a que o direito deve ater-se 
Em termos gerais, sustentam que (a) a reorganização do ajuste negocial desrespeita a segurança jurídica por desprezar a certeza quanto ao cumprimento da palavra dada $^{1421}$ e que o intervencionismo "contribui para a perda da força do Direito como instrumento de pacificação social [e que] enquanto a segurança conduz à paz, a justiça induz à guerra" ${ }^{, 1422}$, censura que ultrapassa os limites da razão. Noutros momentos, quando timidamente admitem a possibilidade de intervenção, propõem que, em vez de conceder ao juiz o poder de interpretar um contrato cuja realidade interna e externa normalmente desconhece, melhor seria subordinar sua decisão a rígidos limites. ${ }^{1423}$ Teses desse talante, entretanto, não se sustentam.

A ideia de segurança jurídica, no Estado Democrático de Direito, deve ser repensada $^{1424}$, sendo inaceitável que continue escorada nos pilares do Estado Liberal, período no qual a manutenção das regras do jogo visava à perpetuação dos interesses da classe dominante. $^{1425}$

Em apertada síntese, a segurança jurídica, no Estado Liberal, pode ser descrita como uma interpretação bem elaborada de uma das premissas mais importantes no pensamento do Príncipe. ${ }^{1426}$

[...] acabam se tornando embaraçosas [...] pela possibilidade de gerarem o oposto daquilo que visam: [abalam] a fé dos contratos."

${ }^{1421}$ THEODORO JUNIOR, Humberto. A onda reformista do direito positivo e suas implicações com o princípio da segurança jurídica, Revista da Escola Nacional da Magistratura, Brasília, v. 1, n. 1, p. 92-120, abr. 2006. p. 116.

${ }^{1422}$ Ibid. p. 113. Consoante leciona o autor, considerando-se que "o valor absoluto da justiça está fora do alcance da obra normativa do homem, o Direito se contenta em implantar a ordem, a segurança, dentro de um norte inspirado em certos padrões extraídos de alguns valores éticos que o anseio de justiça da sociedade consegue ressaltar [e deste modo] o mundo do Direito [...] não é o da Justiça [mas] o da segurança [vez que] sem justiça alguma o Direito - é verdade - encontrará dificuldades para manter seu projeto de pacificação social [mas sem segurança] simplesmente não existe."

${ }^{1423}$ DUPICHOT, Jacques. Derecho de las obligaciones. Trad. Rosangela Calle. Bogotá: Temis, 1984. p. 41.

${ }^{1424}$ NALIN, Paulo. A função social do contrato no futuro código civil brasileiro, Revista de Direito Privado, São Paulo, v. 3, n. 12, p. 50-60, out./dez. 2002. p. 60. Afirma o autor que, da mesma forma que o paradigma para aferir o que seja justiça contratual migrou do voluntarismo para a solidariedade social, o conteúdo da segurança jurídica também sofreu alteração. Mas qual seria ele? "Para cumprir o valor constitucional da solidariedade, isto é, para se alcançar o contrato funcionalizado, são inadmissíveis efeitos contratuais que aniquilem uma das partes do contrato, que vulnerem um setor da cadeia de consumo, que distanciem as posições econômicas envolvidas."

${ }^{1425}$ IRTI, Natalino. L'età della decodificazione, Revista de Direito Civil, Imobiliário, Agrário e Empresarial, São Paulo, v. 3, n. 10, p. 15-33, out./dez. 1979. p. 15-17.

${ }^{1426}$ MAQUIAVEL, Nicolau. O príncipe: com notas de Napoleão Bonaparte. 2 ed. Trad. José Cretella Junior; Agnes Cretella. RT: São Paulo, 1997. p. 114. "Esforce-se então, o príncipe, para vencer e manter o poder; os meios serão sempre considerados honrosos e louvados por todos." 
Essa forma de pensar, entretanto, foi substituída por uma preocupação maior com a realização dos conteúdos substanciais do direito material. Apenas desse modo, conduzirá a decisões pautadas na justiça e na equidade. ${ }^{1427}$ A segurança, sem dúvida, ao lado da justiça e do bem comum, é um valor importante na contemporaneidade. Esse valor deve, entretanto, ser compreendido como segurança no Direito, e não, enquanto segurança do direito. ${ }^{1428}$ Não se trata de simples jogo de palavras. A mudança é visível, por exemplo, na força obrigatória do contrato, que deixa de estar escorada na liberdade negocial e só se mantém enquanto se mantiver o equilíbrio intrínseco no processo obrigacional. ${ }^{1429}$

As censuras também são afastadas quando se compreende que a recepção de uma postura conservadora ignora que o código vigente - e antes dele, a Constituição confere ao juiz o poder de resolver, a partir de parâmetros éticos, os problemas que lhe sejam apresentados. ${ }^{1430}$ Ao se destruir "o fetiche da segurança, [abandona-se a identificação do] justo com o legal", permitindo que o Direito resplandeça como um mecanismo de transformação social. ${ }^{1431}$

Em verdade, não há por que temer a intervenção nos contratos, mesmo porque a fundamentação do ato decisório não se restringe a remeter a solução do problema a uma ou outra cláusula geral contida na codificação. É essencial encontrar - e assim fundamentar a decisão judicial - os "matizes sociais" que autorizam a concluir que um dado comportamento é (ou não) conforme o Direito. ${ }^{1432}$

A seu turno, a necessidade de criação de limites normativos facilmente é refutada quando se aceita que os princípios exercem esse papel - de cercanias -, aliás, de forma bem melhor que regras inflexíveis, em razão de sua porosidade e maleabilidade, portanto, de sua capacidade de adaptação à concretude da realidade fática.

${ }^{1427}$ MEDINA, Diego Eduardo López. Teoría impura del derecho: la transformación de la cultura jurídica latinoamericana. Bogotá: Legis, 2005. p. 432.

1428 BARROSO, Lucas Abreu. Novas fronteiras da obrigação de indenizar e da determinação da responsabilidade civil. In: DELGADO, Mário Luiz; ALVES, Jones Figueiredo (Coord.). Questões controvertidas: responsabilidade civil. São Paulo: Método, 2006, v. 5. p. 363-366.

1429 CAFFERA, Gerardo. Autonomía privada: los cambios y las tensiones del presente. In: FERNÁNDEZ, Carlos López; CAUMONT, Arturo; CAFFERA, Gerardo (Coord.). Estudios de derecho civil en homenaje al profesor Jorge Gamarra. Montevideo: FCU, 2001. p. 91.

${ }^{1430}$ REALE, Miguel. O projeto do novo código civil. 2 ed. São Paulo: Saraiva, 1999. p. 8.

${ }^{1431}$ WARAT, Luis Alberto. Introdução geral ao direito: interpretação da lei: temas para uma reformulação. Porto Alegre: SAFE, 1994, v. 1. p. 59.

${ }^{1432}$ NALIN, Paulo. Cláusula geral e segurança jurídica no código civil, Revista da Faculdade de Direito da Universidade Federal do Paraná, Curitiba, n. 41, p. 85-98, 2004. p. 95. 
Saliente-se, ademais, nesse contexto, que a forma sufoca a substância quando continente e conteúdo não dialogam, transformando o meio em fim. ${ }^{1433}$ Além disso, entre os fenômenos no processo de descodificação, encontra-se a tendência de abandono do rigor metodológico em busca de decisões intuitivamente justas, vez que a justiça é o principal fim do Direito. ${ }^{1434}$ Hodiernamente, aceita-se, com alguma naturalidade, que as decisões judiciais não precisam ser ancoradas nos textos $\operatorname{codificados}^{1435}$, o que não significa, é evidente - e que fique claro -, a legitimação de idiossincrasias.

Enfim, refutando as censuras existentes, observe-se que, ao contrário de produzir o caos, a revisão do contrato tem forte caráter social, refletindo os anseios do Estado Democrático de Direito. Tal possibilidade se apresenta, contemporaneamente, como via hábil a conduzir ao bem comum e à promoção de justiça social ${ }^{1436}$, essa última, aliás, que, por estar atrelada a uma leitura antropocêntrica do direito, se encontra mais preparada que a justiça comutativa para a solução dos problemas do ser humano concebido a partir de suas individualidades. ${ }^{1437}$

Soa inadmissível, portanto, especialmente após ponderar sobre os argumentos apresentados, obrigar o devedor a cumprir a prestação prometida se a equação custobenefício nunca existiu ou sofreu acentuada mudança. E, quando se alude à promoção de justiça contratual, não se pretende, em momento algum, afastar o clausulado contratual. Se esse estipular prestações equilibradas, deverá ser respeitado.

\footnotetext{
${ }^{1433}$ FACHIN, Luiz Edson. Teoria crítica do direito civil. Rio de Janeiro: Renovar, 2000. p. 119.

${ }^{1434}$ VERDÚ, Pablo Lucas. O sentimento constitucional: aproximação ao estudo do sentir constitucional como modo de integração política. Trad. Agassiz Almeida Filho. Rio de Janeiro: Forense, 2004. p. 178-179. "O fim do Direito não é a determinação e a calculabilidade racional-formal de uma regulação, senão a justiça, isto é, uma simetria sem privilégio nem prejuízo para o indivíduo quando de sua aplicação."

${ }^{1435}$ DIEZ-PICAZO, Luis. Codificación, descodificación y recodificación, Anuario de Derecho Civil, Madrid, v. 45, n. 2, p. 473-484, abr./jun. 1992. p. 480.

${ }^{1436}$ LÔBO, Paulo Luiz Netto. Prefácio. In: CUNHA, Wladimir Alcibíades Marinho Falcão. Revisão judicial dos contratos: do código de defesa do consumidor ao código civil de 2002. São Paulo: Método, 2007. p. 910. Sustenta o autor, que esta "não se confunde com os modelos aristotélicos tradicionais de justiça comutativa ou de justiça distributiva, pois dá a cada um o que é seu na medida da promoção da mudança social e da contemplação das desigualdades reais dos figurantes." Uma outra perspectiva do tema é esboçada em: ITAGIBA, Ivair Nogueira. Justiça comutativa e justiça institucional, Revista da Ordem dos Advogados do Brasil, Rio de Janeiro, v. 4, n. 11, p. 447-457, set./dez. 1973. p. 447-448. "Há de haver Direito, de cunho eminentemente sociológico, a ordenar providências que evitem abusos contra os economicamente mais fracos. A norma jurídica, então, não visa a uma determinada classe, porque busca o bem comum. É a Justiça institucional, a Justiça social, a reger tudo que é devido à comunidade, aos membros integrantes da sociedade civil. O preceito legal atende, nesse caso, às necessidades inatas, adquiridas ou variáveis dos indivíduos, segundo suas condições sociais."
}

1437 BARROSO, Lucas Abreu. A obrigação de indenizar e a determinação da responsabilidade civil por dano ambiental. Rio de Janeiro: Forense, 2006. p. 118-119. 
Caso contrário, impõe-se a equalização dos interesses das partes durante o processo obrigacional. ${ }^{1438} \mathrm{E}$, isso porque o contrato que obriga é o contrato justo ${ }^{1439}$, constatação que, apesar de divergências ${ }^{1440}$, é encontrada não só em textos filosóficos, mas também nas reflexões dogmáticas formuladas por Francisco Sales Costa ${ }^{1441}$, Onofre Mendes Junior ${ }^{1442}$, Paulo Lôbo ${ }^{1443}$, Rosa Maria de Andrade Nery ${ }^{1444}$, Ruy Rosado de Aguiar Junior ${ }^{1445}$ e, em leis e códigos. ${ }^{1446}$

1438 MEJÍA, Juan Pablo Cárdenas. Justicia y abuso contractual. In: ESPINOSA, Fabricio Mantilla; BARRIOS, Francisco Ternera (Dir.). Los contratos en el derecho privado. Bogotá: Legis, 2007. p. 714-715.

1439 BORGES, Roxana Cardoso Brasileiro. Contrato: do clássico ao contemporâneo - a reconstrução do conceito, Revista do Programa de Pós-Graduação em Direito da Universidade Federal da Bahia, Salvador, v. 13, p. 29-50, 2006. p. 36-38. Veja ainda: GLITZ, Frederico Eduardo Zenedin. Favor contractus: alguns apontamentos sobre o princípio da conservação do contrato no direito positivo brasileiro e no direito comparado. In: CONRADO, Marcelo; PINHEIRO, Rosalice Fidalgo (Coord.). Direito privado $e$ constituição: ensaios para uma recomposição valorativa da pessoa e do patrimônio. Curitiba: Juruá, 2009. p. 244. E mais: PERLINGIERI, Pietro. O direito civil na legalidade constitucional. Trad. Maria Cristina De Cicco. Rio de Janeiro: Renovar, 2008. p. 371. "O ato negocial é válido não tanto porque desejado, mas se, e apenas se, destinado a realizar, segundo um ordenamento [sic] fundado no personalismo e no solidarismo, um interesse merecedor de tutela."

${ }^{1440}$ CRISTOFARO, Pedro Paulo. A força obrigatória do contrato e o novo código civil. In: TEPEDINO, Gustavo; FACHIN, Luiz Edson (Coord.). O direito e o tempo: embates jurídicos e utopias contemporâneas. Rio de Janeiro: Renovar, 2008. p. 477-494.

${ }^{1441}$ COSTA, Francisco Ricardo Sales. A segurança das relações jurídicas instrumentalizadas através do contrato. In: ROSSI, Alexandre Luiz Bernardi; MESQUITA, Gil Ferreira (Org.). Maioridade constitucional: estudo em comemoração aos 18 anos da Constituição Federal. São Paulo: Lemos \& Cruz, 2008. p. 152-155.

${ }^{1442}$ MENDES JUNIOR, Onofre. A proteção do fraco no direito moderno, Revista da Faculdade de Direito, Belo Horizonte, n. 7, p. 79-90, 1955. p. 86. "As idéias solidaristas fizeram sentir sua influência no próprio campo do direito privado, vencendo as resistências dos civilistas ortodoxos, quebrando-se o escudo da intangibilidade das convenções [...] de modo a evitar que as alterações de situação sobrevindas à época do contrato transformem a obrigatoriedade do adimplemento em instrumento de opressão.

${ }^{1443}$ LÔBO, Paulo Luiz Netto. Constitucionalização do direito civil, Revista de Informação Legislativa, Brasília, v. 36, n. 141, p. 99-109, jan./mar. 1999. p. 108. "Talvez uma das maiores características do contrato, na atualidade, seja o crescimento do princípio da equivalência material das prestações, que perpassa todos os fundamentos constitucionais a ele aplicáveis. Esse princípio preserva a equação e o justo equilíbrio contratual, seja para manter a proporcionalidade inicial dos direitos e obrigações, seja para corrigir os desequilíbrios supervenientes, pouco importando que as mudanças de circunstâncias pudessem ser previsíveis. O que interessa não é mais a exigência cega de cumprimento do contrato, da forma como foi assinado ou celebrado, mas se sua execução não acarreta vantagem excessiva para uma das partes e desvantagem excessiva para outra, aferível objetivamente, segundo as regras da experiência ordinária.”

1444 NERY, Rosa Maria Barreto Borriello de Andrade. Vínculo obrigacional: relação jurídica de razão (técnica e ciência de proporção). Tese (Livre-Docência) - Faculdade de Direito da PUC/SP, São Paulo, 2004. p. 233. "Veja-se: quando se fala, na justiça comutativa, em equilíbrio entre as prestações devidas, de outra coisa não se fala que de proporção; quando se diz, em justiça distributiva, sobre distribuição de encargos, segundo o que o sujeito pode suportar, de outra coisa não se fala que de proporção; quando se diz, em justiça social, que é necessário buscar o bem comum, de outra coisa não se fala, senão em justiça para todos."

${ }^{1445}$ AGUIAR JUNIOR, Ruy Rosado de. O poder judiciário e a concretização das cláusulas gerais: limites e responsabilidade, Revista de Direito Renovar, Rio de Janeiro, n. 18, p. 11-19, set./dez. 2000. p. 12.

${ }^{1446}$ Como exemplo, o Uniform Comercial Code $\S 2-302$. "Unconscionable contract or Term. (1) If the court as a matter of law finds the contract or any term of the contract to have been unconscionable at the time it was made the court may refuse to enforce the contract, or it may enforce the remainder of the contract without the unconscionable term, or it may so limit the application of any unconscionable term as to avoid any 
Aliás, por justo deve ser compreendido, em um primeiro momento, o contrato equilibrado. ${ }^{1447} \mathrm{~A}$ justiça contratual na contemporaneidade, longe de estar centrada na intocável conjunção de declarações livremente externadas, deve ser aferida a partir de parâmetros impostos por uma ordem constitucional que valoriza o ser humano ${ }^{1448} \mathrm{em}$ sua essência, em razão de suas necessidades pessoais e a partir do contexto em que o negócio jurídico se estabelece.

A força obrigatória do contrato não pode imperar quando houver desequilíbrio manifesto entre os múltiplos direitos e deveres que se contrapõem concretamente. ${ }^{1449}$ Por conta disso, a manutenção da equalização entre direitos que exsurgem multifacetariamente nas distintas posições jurídicas havidas na travessia de um processo obrigacional que busca a satisfação de interesses legítimos ${ }^{1450}$ deve ser uma preocupação constante ${ }^{1451}$, até porque liberdade com justiça é uma reclamação social candente conclamada há tempos. ${ }^{1452}$

E, apesar de sustentar-se que a tutela do vulnerável prejudica a sociedade, pois os contratos não são nada mais que instrumentos para circulação de riqueza - sendo essa sua verdadeira função social ${ }^{1453}$-, é necessário resgatar a multiplicidade de funções atribuídas ao contrato. ${ }^{1454}$

unconscionable result. (2) If it is claimed or appears to the court that the contract or any term thereof may be unconscionable the parties shall be afforded a reasonable opportunity to present evidence as to its commercial setting, purpose, and effect to aid the court in making the determination."

${ }^{1447}$ NEGREIROS, Teresa. Teoria do contrato: novos paradigmas. Rio de Janeiro: Renovar, 2002. p. 166.

1448 CUNHA, Daniel Sica da. A nova força obrigatória dos contratos. In: MARQUES, Cláudia Lima (Coord.). A nova crise do contrato: estudos sobre a nova teoria contratual. São Paulo: RT, 2007. p. 258-266.

${ }^{1449}$ ALVIM, Decio Ferraz. Da cláusula "rebus sic stantibus", Revista dos Tribunais, São Paulo, v. 23, n. 90, p. 13-20, mai. 1934. p. 20.

1450 NERY, Rosa Maria Barreto Borriello de Andrade. Vínculo obrigacional: relação jurídica de razão (técnica e ciência de proporção). Tese (Livre-Docência) - Faculdade de Direito da PUC/SP, São Paulo, 2004. p. 121-173.

${ }^{1451}$ CUNHA, Wladimir Alcibíades Marinho Falcão. Revisão judicial dos contratos: do código de defesa do consumidor ao código civil de 2002. São Paulo: Método, 2007. p. 97-100. Como destaca o autor, a justiça contratual deve permear todo o processo obrigacional.

1452 ALTERINI, Atílio Aníbal. Estudios de derecho civil: conceptos, contratos, consumidor, derecho de daños. Buenos Aires: La Ley, 2007. p. 444.

1453 TIMM, Luciano Benetti. A função social do direito contratual no código civil brasileiro: justiça distributiva vs eficiência econômica, Revista dos Tribunais, São Paulo, v. 97, n. 876, p. 11-43, out. 2008. p. 21-43.

${ }^{1454}$ BARROSO, Lucas Abreu et all. Direito dos contratos. São Paulo: RT, 2008. p. 40-48. 
A ascensão da ideologia neoliberal faz com que a culpa retome seu poder persuasivo, transferindo, como demonstrado outrora, os riscos do negócio para a sociedade. ${ }^{1455}$

O problema se agrava porque nem todos enxergam - alguns não conseguem, outros não querem - que o processo econômico perdeu sua capacidade de satisfazer as necessidades básicas de subsistência do ser humano, transformando-se em fonte de violência social e de aumento das desigualdades. ${ }^{1456}$

É preciso ter cuidado: a análise econômica do Direito tem frágeis premissas, é reducionista ${ }^{1457}$ e provoca exclusão social. ${ }^{1458}$ Em síntese, não existe uma "economia da salvação." ${ }^{1459}$ Ademais, é primordial ter em conta que a promoção da pessoa humana - e não a proteção do patrimônio - é a finalidade precípua do direito ${ }^{1460}$, premissa que parece ser ignorada pela economia quando almeja a máxima eficiência diante da escassez de recursos.

${ }^{1455}$ LÔBO, Paulo Luiz Netto. Responsabilidade civil dos profissionais liberais e o ônus da prova, Revista de Direito do Consumidor, São Paulo, n. 26, p. 159-165, abr./jun. 1998. p. 161. "A culpa esteve sempre no centro da construção doutrinária liberal da responsabilidade civil, como projeção do princípio da autonomia da pessoa. Hoje, com a ideologia do neoliberalismo, a culpa retoma sua força persuasiva como instrumento poderoso dos interesses empresariais de facilitação ao lucro, ainda que ao preço da transferência dos riscos para a sociedade. $\mathrm{O}$ argumento falacioso, tantas vezes manejado no passado, de que a irresponsabilidade do fornecedor pelos produtos que produzia ou distribuía era necessária para redução dos preços ao consumidor, e para não inibir o desenvolvimento tecnológico, não mais convence como a experiência demonstrou: os produtos mais seguros, com mais qualidade e avanço tecnológico, ao lado da legislação de proteção do consumidor, estão ficando cada vez mais baratos."

${ }^{1456}$ GHERSI, Carlos Alberto. Teoría general de la reparación de daños. Buenos Aires: Astrea, 1997. p. 10.

${ }^{1457}$ PERLINGIERI, Pietro. O direito civil na legalidade constitucional. Trad. Maria Cristina De Cicco. Rio de Janeiro: Renovar, 2008. p. 105-109. A essência e principais críticas a essa escola do pensamento podem ser encontradas em: LORENZETTI, Ricardo Luis. Teoria da decisão judicial: fundamentos do direito. Trad. Bruno Miragem. São Paulo: RT, 2009. p. 186-208.

${ }^{1458}$ ROSA, Alexandre Morais da. O giro econômico do direito ou o novo e sofisticado caminho da servidão: para uma nova gramática do direito democrático no século XXI. In: AVELÃS NUNES, António José; COUTINHO, Jacinto Nelson Miranda (Coord.). O direito e o futuro: o futuro do direito. Almedina: Coimbra, 2008. p. 223-234.

1459 D’ORS, Alvaro. Premissas morales para un nuevo planteamiento de la economía, Revista Chilena de Derecho, Santiago, v. 17, n. 3, p. 439-448, set./dez. 1990. p. 440. Continua o autor, ao destacar que "esse domínio da economia é um claro sintoma da corrupção do ser e da idolatria do ter."

${ }^{1460}$ RUZYK, Carlos Eduardo Pianovski. A responsabilidade civil por danos produzidos no curso de atividade econômica e a tutela da dignidade da pessoa humana: o critério do dano ineficiente. In: RAMOS, Carmem Lucia Silveira et all (Org.). Diálogos sobre direito civil: construindo a racionalidade contemporânea. Rio de Janeiro: Renovar, 2002. p. 136-140. 
A análise econômica despreza, ainda, a carga axiológica contida no Direito e a necessidade de promoção de justiça social. ${ }^{1461}$ É claro que não se pretende afastar os elementos econômicos da análise de cada situação concreta. Ao contrário, a necessidade de equacionar o direito obrigacional com as diretrizes da ciência econômica ${ }^{1462}$ é uma premissa inafastável, desde que - e apenas nesse contexto - essa atue como um instrumento em favor da sociedade ${ }^{1463}$ e permita, portanto, que outros valores possam sobrepor-se à frieza dos números. ${ }^{1464}$

É sempre valioso resgatar que o direito contratual hodierno "não se limita a revestir passivamente a operação econômica de um véu legal de per si não significativo", atuando, ao revés, de modo a orientá-la consoante um objetivo político. ${ }^{1465}$ Dentre eles, sem dúvida alguma, a erradicação da pobreza e a redução das desigualdades sociais.

Também não se ignora que "é essencial à responsabilidade civil que haja um sistema econômico que a sustente." ${ }^{1466}$ Mais uma vez, entretanto, saliente-se que o vértice da análise deve ser a pessoa humana, e não, as relações econômicas, e isso porque o cerne das preocupações deve estar centrado no homem, e não, no processo de acumulação de riqueza. $^{1467}$

${ }^{1461}$ ALTERINI, Atílio Aníbal. Estudios de derecho civil: conceptos, contratos, consumidor, derecho de daños. Buenos Aires: La Ley, 2007. p. 10. "Cuando se enfoca la relación entre los reclamos culturales personalistas, la Economía y el Derecho, hay que tener en cuenta, por la pronto, que la interpretación jurídica está precisada a aplicar el modelo ético y de justicia, y no debe limitarse a una mera captación de los hechos; y que, por consiguiente, el análisis económico del Derecho debe ser sometido por el jurista a la crítica axiológica, partiendo de los valores fundamentales humanidad y dignidad, y atendiendo a la justicia, equidad, seguridad, orden y paz social."

1462 BAPTISTA, Sílvio Neves. A crise do contrato, Revista de Direito Civil, Imobiliário, Agrário e Empresarial, São Paulo, v. 9, n. 32, p. 22-35, abr./jun. 1985. p. 22-24.

${ }^{1463}$ MARTÍNEZ, Pedro Soares. O homem e a economia, Revista da Faculdade de Direito da Universidade de Lisboa, Coimbra, v. 38, n. 1, p. 101-111, 1997. p. 109. "A economia não pode debruçar-se sobre um homem abstrato: nem sobre um homem universal, que também corresponderia, do ponto de vista económico, a uma nova abstração. A economia tem de adotar por objeto de análise um homem institucional, isto é, integrado em determinado meio social, condicionado por esse meio e pelas respectivas instituições. [...] Essa institucionalização do objeto da análise económica rejeita a idéia de que o progresso material encontre justificação em si mesmo; nega o primado da economia; situa-a num plano instrumental, subordinada a outros valores que a transcendem.”

${ }^{1464}$ PIMENTA, Eduardo Goulart. Direito, economia e relações patrimoniais privadas, Revista de Informação Legislativa, Brasília, v. 43, n. 170, p. 159-173, abr./jun. 2006. p. 159-172.

${ }^{1465}$ ROPPO, Enzo. O contrato. Trad. Ana Coimbra; M. Januário C. Gomes. Coimbra: Almedina, 2009. p. 23.

${ }^{1466}$ LORENZETTI, Ricardo Luis. El sistema de la responsabilidad civil ¿una deuda de responsabilidad, un crédito de indemnización o una relación jurídica?, Revista da Ajuris, Porto Alegre, n. 63, p. 166-198, mar. 95. p. 180.

${ }^{1467}$ GHERSI, Carlos Alberto. De Velez a Borda un cambio ideológico trascendente, que no se complementó en el rápido acceso a la justicia. In: GHERSI, Carlos Alberto (Dir.). Responsabilidad: problemática moderna. Mendoza: Ediciones Jurídicas Cuyo, 1996. p. 27. "A simbiosis que enunciamos do sistema jurídico com o 
Aliás, é possível identificar mais um problema na análise econômica do Direito. Ele consiste na possibilidade - ao menos, esse é o viés preponderante no direito anglo-saxônico - de permitir-se ao devedor optar pelo adimplemento (ou não) da prestação, com o pagamento das perdas e danos caso escolha não cumprir o contrato $^{1468}$, comportamento inaceitável - também - por violar o dever de cooperação e frustrar a justa expectativa depositada no pacto.

Tal leitura nega, em última análise, o acesso à ordem jurídica justa, já que a justiça contratual também é encontrada na imposição do dever de reparar. Se o dano é uma realidade social inquestionável, a necessidade de sua reparação também o é. Somente assim, haverá adequada distribuição de justiça social, justiça que brota da experiência vivida $^{1469}$, e não, como consequência do respeito a condutas permitidas pelo legislador. ${ }^{1470}$

A reflexão tecida - a objetivação do dever de reparar os danos contratuais como fonte de promoção de justiça social - implica, concomitantemente, benefícios para o indivíduo e à sociedade, que se desintegrará se não houver controle do processo de proliferação dos danos. ${ }^{1471}$

econômico só pode ter como vértice a pessoa humana. A partir dela, será possível a convivência pacífica. Somente assim, a produção de riqueza terá sentido, pois, ao contrário, o sistema será colocado antes do homem e a riqueza só servirá para consolidar o poder, a desigualdade, a discriminação, a fome. Neste quadro, o conflito, cedo ou tarde, aparecerá e, a cada momento, será necessária mais violência para silenciá-lo."

${ }^{1468}$ VISINTINI, Giovanna. Tratado de la responsabilidad civil: la culpa como criterio de imputación de la responsabilidad. Trad. Aída Kemelmajer de Carlucci. Buenos Aires: Astrea, 1999, v. 1. p. 221.

${ }^{1469}$ COELHO, Luiz Fernando. Saudade do futuro. 2 ed. Curitiba: Juruá, 2007. p. 78. "Quanto à justiça, não importando o conceito que dela se faça, integra nossa concepção acerca do direito e das leis e está intimamente ligada ao princípio da legitimidade, de tal sorte que o senso comum internalizou a concepção de que uma ordem jurídica ilegítima é essencialmente injusta e vice-versa. O momento culminante dessa integração vem a consolidar-se nas teses do culturalismo fenomenológico, que, contra todo reducionismo analítico ou empírico-sociológico, leva a que o direito, enquanto experiência vivida, não possa separar-se de seus valores fundamentais, dos quais o mais alto é a justiça, a qual deve corresponder o bem e a verdade." Mais à frente, destaca o autor: "A justiça não é algo que possa ser reduzido a uma manifestação setorial do humano: ela não pode ser reduzida a um conceito, uma virtude, uma norma, um valor, um critério. Ela é um sentimento, uma emoção, uma paixão, algo que as pessoas vivenciam e que permeia tudo isso. A justiça é uma vivência ao mesmo tempo subjetiva e intersubjetiva que adquire sentido numa comunidade. Se existe uma finalidade da justiça, ela se resume no binômio dignidade/solidariedade, o que vale tanto para o homem comum, o cidadão que sente a injustiça na própria carne, quanto para aqueles a quem a sociedade delegou a tarefa de distribuir a justiça, o que importa torná-la efetiva em todos os setores da vida humana individual e coletiva." Ibid. p. 190.

${ }^{1470}$ LIMA, Bruno de Mendonça. Justiça: um critério para o legislador, Revista da Faculdade de Direito de Porto Alegre, v. 3, n. 1, p. 930-957, 1951. p. 933-935.

${ }^{1471}$ GHERSI, Carlos Alberto. El ser humano y la dañosidad como inevitable contingencia social. In: GHERSI, Carlos Alberto (Dir.). Responsabilidad: problemática moderna. Mendoza: Ediciones Jurídicas Cuyo, 1996. p. 30-31. 
Além do mais, parece não haver dúvida quanto ao fato de que é preciso encarar a responsabilidade civil - e o dever de reparar a ela afeito - como um problema de ordem social que se amplia diuturnamente. ${ }^{1472}$ Isso porque, cada dano promove desequilíbrio nas esferas individual e social e, desse modo, sua reparação é imprescindível para restaurar a harmonia - nessas duas searas - outrora existente. ${ }^{1473}$ E como se percebe, a culpa não tem a habilidade necessária para realizar essa missão.

Almejando apaziguar, aqui, eventuais preocupações dirigidas a questionar o aparente rigor da imposição do dever de reparar com base em pautas objetivas, são necessárias mais algumas palavras. De início, é importante resgatar o fato de que a moldura que delimita o que seja impossibilidade liberatória, hodiernamente, não se restringe a enquadrar as situações em que houve a impossibilidade objetiva. ${ }^{1474}$ Nesse contexto, a impossibilidade econômica, o excessivo sobrecusto ou cláusulas iníquas ${ }^{1475}$ poderão - ou, como parece mais apropriado, deverão - ser considerados no processo que visa à apuração - e à depuração - do dever de reparar.

Também é necessário ponderar que, contemporaneamente, nem sempre, a imposição do dever de reparar poderá se adequar, com perfeição, aos contornos doutrinariamente elaborados pela dogmática e que tinham por premissa a reparação integral do prejuízo. Isso se dá em razão de diversas causas, que vão desde a concorrência de condutas na conformação do dano, até a incidência dos vetores constitucionais na realidade concreta do caso.

\footnotetext{
${ }^{1472}$ PORTO, Mário Moacyr. O ocaso da culpa como fundamento da responsabilidade civil, Revista Forense, Rio de Janeiro, n. 302, p. 45-48, abr./jun. 1988. p. 45. 'Sucede que o 'mandamento jurídico', a 'regra moral', por mais prestigiosos que se apresentam, jamais alcançam a imutabilidade de um advérbio, face as incontornáveis variações do tempo e do espaço. Vivemos hoje a época da crescente mecanização dos nossos hábitos de conviver, da "robotização" das atividades fabris, do tráfego alucinante das megalópoles, das agressões ao meio ambiente pelos grandes complexos industriais, dos "vazamentos" catastróficos das usinas nucleares, enfim, da despersonalização do homem, das vicissitudes da luta de Galatéia contra Pigmaleão."

${ }^{1473}$ BAÍA, Jacinto Américo Guimarães. A evolução da responsabilidade civil e a reparação do dano nuclear, Revista de Direito Civil, Imobiliário, Agrário e Empresarial, São Paulo, v. 2, n. 4, p. 49-68, abr.jun. 1978. p. 56.

${ }^{1474}$ A matéria foi tratada ao longo deste trabalho, nos itens $2.1,2.2$ e 2.3 .

1475 Como exemplo: STJ. AgRg no REsp 749736/RS. 4. T. Rel. Aldir Passarinho Junior. j. 18.08.05. DJU 26.09.05. p. 403. "Tendo sido extinta a ação de reintegração de posse em razão da transformação do contrato de arrendamento mercantil em compra e venda, ante o pagamento do valor residual garantido, e ainda por ausência da mora debendi em face da excessiva onerosidade, abusividade e ilegalidades contratuais, restando este último fundamento inatacado no recurso especial interposto, incide na espécie a Súmula n. 283 da Corte Suprema. II. [...]" (grifos nossos).
} 
Nesse quadro, a preocupação com a tutela do patrimônio mínimo ${ }^{1476}$ ou com a proteção do mínimo social ${ }^{1477}$ - teses aparentemente desconhecidas entre os autores clássicos $^{1478}$ - se apresenta como um interessante mecanismo de equalização do valor devido, além de denotar, efetivamente, “o caráter instrumental da esfera patrimonial em relação à pessoa.",1479

Enfim e em apertada síntese, qualquer leitura que se proponha a analisar o dever de reparar os danos oriundos da violação de um dever contratual não se pode descuidar do efeito cascata produzido socialmente pelos contratos. Desse modo, da mesma forma como um negócio equilibrado irradia efeitos benéficos, um ajuste que penda excessivamente em favor de uma das partes poderá produzir malefícios de múltiplas ordens. ${ }^{1480}$ Por tudo isso, o sentimento de justiça deve permear cada instante do processo obrigacional concretamente estabelecido, resgatando, a todo momento, a necessidade de preocupação com o próximo ${ }^{1481}$, corolário do princípio constitucional da solidariedade social.

${ }^{1476}$ FACHIN, Luiz Edson. Estatuto jurídico do patrimônio mínimo. Rio de Janeiro: Renovar, 2001. p. 303311. Veja ainda: NERY, Rosa Maria Barreto Borriello de Andrade. Vínculo obrigacional: relação jurídica de razão (técnica e ciência de proporção). Tese (Livre-Docência) - Faculdade de Direito da PUC/SP, São Paulo, 2004. p. 256-267.

${ }^{1477}$ LORENZETTI, Ricardo Luis. Teoria da decisão judicial: fundamentos do direito. Trad. Bruno Miragem. São Paulo: RT, 2009. p. 133.

1478 ESPINOLA, Eduardo. Systema do direito civil brasileiro: theoria geral das relações jurídicas de obrigação. Rio de Janeiro: Porto, 1912, v. 2, t. 1. p. 271. Discorre o autor que, em princípio, é indiferente o estado a que ficará reduzido o patrimônio do devedor em razão da satisfação da prestação.

${ }^{1479}$ FACHIN, Luiz Edson. Estatuto jurídico do patrimônio mínimo. Rio de Janeiro: Renovar, 2001. p. 176184. Por consequência, "não se pode olvidar a possibilidade de ocorrência de sacrifício de interesses, especialmente de credores. Daí por que a migração proposta: entre a garantia creditícia e a dignidade pessoal, opta-se por esta que deve propiciar a manutenção dos meios indispensáveis à sobrevivência"; e, por que não, dos recursos necessários à vida com dignidade o que implica, pelo menos, a possibilidade de acesso aos direitos e garantias fundamentais de primeira e segunda dimensões consagrados na $\mathrm{CF} / 88$.

1480 SANTOS, Eduardo Sens dos. O novo código civil e as cláusulas gerais: exame da função social do contrato, Revista de Direito Privado, São Paulo, v. 3, n. 10, p. 9-37, abr./jun. 2002. p. 24-25. “Cláusulas abusivas num [sic] financiamento rural, por exemplo, afetam imediatamente o agricultor e, indiretamente toda a comunidade na qual ele está inserido: a família perde renda; o dono do armazém não vende mais a mesma quantidade de produtos e também deixa de lucrar; sem lucro, passa a economizar combustível, e o dono do posto perde da mesma forma."

1481 DONNINI, Rogério. Revisão contratual sem imprevisão, Revista Brasileira de Direito Civil Constitucional e Relações de Consumo, Santo Amaro, n. 1, p. 245-259, jan./mar. 2009. p. 254. "Note-se que é um aspecto ético que liga um indivíduo às responsabilidades e interesses sociais, um verdadeiro comportamento centrado na ética, com a finalidade de beneficiar as demais pessoas numa dada sociedade." 


\subsection{A hermenêutica contratual hoje: o caso concreto como ponto de partida}

Quando o olhar se volta ao passado, avulta a impressão de que as codificações oitocentistas - e muitas das que as sucederam - foram concebidas a partir de uma racionalidade focada na antecipação das soluções para os problemas inerentes ao Direito. Alicerçadas sobre pilares como a segurança jurídica ${ }^{1482}$ e a completude, podem ser equiparadas a grandiosos palacetes - com as portas cerradas ${ }^{1483}$-, que prometiam proteção àqueles que conseguissem pagar pelo acesso.

A vida nesse castelo permitia ignorar a existência de um incomensurável número de excluídos que batiam as suas portas. Tais códigos - e boa parte das escolas que pretendiam orientar sua atuação - propagavam um universo fantasioso, isolado da realidade. Esse mundo de sonhos foi erigido tendo por pautas (a) o legocentrismo, (b) o apego à letra da lei, (c) a completude do direito, (d) a coerência da ordem jurídica, (e) a coercibilidade e, enfim, (d) a neutralidade axiológica ${ }^{1484}$ das regras de conduta.

Tal lógica aprisionou o Direito, que se distanciou, dia após dia, da realidade social à qual deveria estar indissociavelmente atado. Impedido de ultrapassar a literalidade do conteúdo simbólico, representativo de preceitos normativos dogmaticamente préconcebidos - consequência da lógica formal e letárgica ${ }^{1485}$, que, por algum tempo,

\footnotetext{
${ }^{1482}$ Para um olhar crítico sobre o assunto: WARAT, Luis Alberto. A rua grita dionísio: direitos humanos da alteridade, surrealismo e cartografia. Trad. e Org. Vivian Alves de Assis; Júlio Cesar Marcellino Junior; Alexandre Morais da Rosa. Rio de Janeiro: Lumen Juris, 2010. p. 51. Consoante o autor, "a partir de algumas interpretações psicanalíticas poderíamos dizer que essa busca de segurança responde às necessidades psíquicas do homem de se encontrar ou se reencontrar com o grande Outro ou de responder aos impulsos derivados das nostalgias da primeira mamada; ambas as interpretações falam da necessidade psicológica do homem de se reencontrar com uma sensação de segurança derivada do momento mítico de sua imbricação simbiótica com a mãe. Recuperar o efeito simbólico dessa simbiose força o homem à busca e à construção de crenças substitutivas que na modernidade são encontradas na razão e na sensação de segurança que o Direito lhe empresta."

${ }^{1483}$ FACHIN, Luiz Edson. Direito e futuro: um passivo a descoberto. Estado de direito. Porto Alegre, p. 8, fev./mar. 2008.

${ }^{1484}$ MEDINA, Diego Eduardo López. Teoría impura del derecho: la transformación de la cultura jurídica latinoamericana. Bogotá: Legis, 2005. p. 377-378.

1485 GROSSI, Paolo. A formação do jurista e a exigência de um hodierno "repensamento" epistemológico, Revista da Faculdade de Direito da UFPR, Curitiba, v. 40, p. 5-25, 2004. p. 8. "O pior - ainda de modo mais grave - é que essa passividade psicológica, essa posição renunciante, não se verifica apenas no jurista do século XIX embebido do triunfalismo pós-revolucionário e ressurgimental, mas se a constata quase intacta no espírito do jurista hodierno, o qual - vítima de um plágio de dois séculos - persiste em não tirar as lentes deformantes que lhe foram postas sobre o nariz há duzentos anos e em tomar por conquistas inalienáveis aquilo que era um fruto de uma indébita expropriação."
} 
informou o raciocínio jurídico -, o Direito não pôde cumprir a "tarefa hermenêutica" a ele inerente. $^{1486}$

É razoável apontar, nesse contexto, que o formalismo tecnicista ${ }^{1487}$, que orientou o processo de interpretação/aplicação do Direito nos últimos séculos - dentre outros problemas -, legitimou a repetição de soluções totalmente desvinculadas da realidade social. ${ }^{1488}$

Intencionalmente ou não, essa forma - cartesiana e, portanto, bem pouco maleável - de pensar o Direito - essa "ciência" prenhe de segredos e de vozes abafadas, com seus rituais míticos e "de efeitos mágicos" - transformou-o em um mecanismo de alienação. $^{1489}$

Ao desprezar que aquele "é a realização intrínseca de uma idéia de justiça","1490, impossibilitou a procura de respostas que - para além de perspectivas exclusivamente dogmáticas - deveriam ser perpassadas por fundamentos sociológicos e filosóficos e tendo por pauta as necessidades reais de cada cidadão.

${ }^{1486}$ FLACH, Norberto. O formalismo jurídico oitocentista: doença infantil do positivismo, Revista da Faculdade de Direito Ritter dos Reis, Porto Alegre, v. 3, p. 131-180, mar./jul. 2000. p. 169.

${ }^{1487}$ Críticas contundentes a essa escola de pensamento podem ser encontradas em: WARAT, Luis Alberto. Introdução geral ao direito: interpretação da lei: temas para uma reformulação. Porto Alegre: SAFE, 1994, v. 1. p. 51-101. Veja ainda: WARAT, Luis Alberto. O direito e sua linguagem. 2 versão. 2 ed. Porto Alegre: SAFE, 1995. p. 99-100. "Em relação às teorias analíticas da linguagem, importa sublinhar que elas caíram na armadilha de pressupor as regras da linguagem como dados normativos, isto é, afirmaram a existência de uma ética gramatical e de uma ética semântica que deveriam ser assumidas como um dado normativo. Através desta lingüística, se recuperou, no interior de sua problemática, o princípio do egocentrismo textual vigente no senso comum lingüístico dos juristas. Importa ainda lembrar que a teoria analítica, em sua pretensão epistêmica, provocou um deslocamento ideológico complementar, criando o tópico da linguagem axiomatizada e estereotipando a imagem de uma ciência jurídica alheia às funções da lei na sociedade. Com referência às análises pragmáticas das linguagens jurídicas, comprova-se uma certa insuficiência analítica nas questões vinculadas à relação das enunciações jurídicas com as práticas políticas e ideológicas da sociedade, assim, como de suas próprias dimensões políticas. As abordagens pragmáticas ficam presas ainda a uma tarefa de desmistificação, de denúncia do valor persuasivo dos discursos do direito, que é, em muitos aspectos, insatisfatória, em virtude da sua persistência em tratar exclusivamente em termos linguísticos os discursos."

${ }^{1488}$ STRECK, Lenio Luiz. Quinze anos de constituição - análise crítica da jurisdição constitucional e das possibilidades hermenêuticas de concretização dos direitos fundamentais-sociais, Revista da Ajuris, Porto Alegre, v. 30, n. 92, p. 205-234, dez. 2003. p. 210-211.

${ }^{1489}$ WARAT, Luis Alberto. Introdução geral ao direito: a epistemologia jurídica da modernidade. Porto Alegre: SAFE, 2002, v. 2. p. 57.

${ }^{1490}$ LEGAZ Y LACAMBRA, Luís. Direito e política, Revista Forense, Rio de Janeiro, v. 48, n. 136, p. 5-17, jul./ago. 1951.p. 11. 
E, uma vez observados os seus inconvenientes, o classicismo - marcado pelo caráter analítico - entra em crise. ${ }^{1491}$ Quando os problemas contidos na absorção do Direito pela lei ${ }^{1492}$ foram identificados, o legocentrismo acaba por ser afastado, diante da exigência de decisões que promovam a justiça no caso concreto, soluções que não poderiam ser alcançadas em leis - e na forma de pensá-las - concebidas no "paleolítico jurídico."1493

Em termos gerais, é possível apontar que reflexões e debates versando sobre (a) a pluralidade - essa marca indelével da contemporaneidade -, (b) a falta de legitimidade material no processo legislativo, (c) a deturpação da justiça na construção da norma jurídica ${ }^{1494}$ e (d) a compreensão do Direito como fenômeno histórico e social, conduziram à percepção de que muitas das respostas dogmaticamente construídas careciam de fundamento adequado.

Os problemas denunciados podem ser identificados, igualmente, quando se afere que muitos dos conceitos que sustentavam análises pautadas unicamente no pensamento dogmático não se acoplavam às impressões trazidas do mundo concreto. ${ }^{1495}$ Sob outro prisma, os defeitos do pensamento clássico também pululam quando se lembra ao contrário do apregoado por jusnaturalistas e juspositivistas - que o Direito não é algo dado, mas um constante vir a ser, portanto, algo a ser construído.

A compreensão do Direito em sua historicidade - e, não mais, como uma ordem lógica pautada na manutenção de valores imutáveis, consoante afirmado pelo racionalismo ${ }^{1496}$ - permite aproximá-lo da realidade social. ${ }^{1497}$

${ }^{1491}$ SALDANHA, Nelson. Sobre o "direito civil constitucional" (notas sobre a crise do classicismo jurídico), Revista da Faculdade de Direito, Curitiba, v. 36, p. 87-92, 2001. p. 88-91.

1492 GROSSI, Paolo. Mitología jurídica de la modernidad. Trad. Manuel Martínez Neira. Madrid: Trotta, 2003. p. 36.

${ }^{1493}$ GROSSI, Paolo. A formação do jurista e a exigência de um hodierno "repensamento" epistemológico, Revista da Faculdade de Direito da UFPR, Curitiba, v. 40, p. 5-25, 2004. p. 9. "A rígida visão potestativa do direto, indiscutível para os nossos pais, está visivelmente se desmanchando, particularmente no campo do direito privado, em que as mudanças sociais e econômicas, mas ainda mais as mirabolantes novidades da técnica em contínuo arranque, freqüentemente relegam a um paleolítico jurídico as previsões contidas em tão respeitados quanto inutilizáveis textos legislativos."

${ }^{1494}$ CASTANHEIRA NEVES. Antonio. Digesta: escritos acerca do direito, do pensamento jurídico, da sua metodologia e outros. Coimbra: Coimbra, 1995, v. 2. p. 373. Por realização do direito, compreenda-se "a realização da intenção axiológico-normativa do direito enquanto tal, em termos normativamente adequados ao problema jurídico concreto."

${ }^{1495}$ GORDILHO, Heron José de Santana. Por uma dogmática pós-moderna, Revista do Programa de PósGraduação em Direito da Universidade Federal da Bahia, Salvador, v. 16, p. 47-61, 2008. p. 59.

${ }^{1496}$ RAMOS, Carmem Lucia Silveira. Os princípios gerais do direito civil, Revista da Faculdade de Direito, Curitiba, v. 22, n. 22, p. 272-284, 1985. p. 279. 
Em outras palavras, enquanto fato inconteste, "o vento forte e demolidor pôde ser eliminado, ou, ao menos, grandemente atenuado, [quando se teve] o bom senso de olhar além do direito formal, de não se contentar com a sua manifestação [geral e abstrata], de buscar aquelas raízes que, sempre, quer se queira, quer não, atingem o estrato escondido dos valores"1498 que informam uma dada sociedade.

Tudo isso quer significar que o jurista não pode pensar o Direito a partir de um viés científico focado apenas na estruturação sistêmica de seus elementos constitutivos. Ao contrário, deve verificar também - e especialmente -, dentre outros aspectos, o resultado econômico e a repercussão social que cada norma construída provocará. ${ }^{1499}$ Com isso, quer-se dizer que, além dos raciocínios meramente dogmáticos, tantos outros reducionismos - tão caros ao positivismo ${ }^{1500}$ - devem ser evitados e/ou afastados.

Ora, se "o Direito consiste na solução que se busca", parece inconcebível compreendê-lo como um mero conjunto de regras responsáveis pela formatação de respostas prévias para problemas cotidianos inerentes à vida em sociedade. ${ }^{1501} \mathrm{Em}$ verdade, consoante sustentado por Luiz Edson Fachin, somente a assunção de posturas hermenêuticas emancipatórias poderão efetivamente conduzir o Direito a mares ainda não navegados. ${ }^{1502}$

${ }^{1497}$ LÔBO, Paulo Luiz Netto. O contrato: exigências e concepções atuais. São Paulo: Saraiva, 1986. p. 3. “A tarefa que se apresenta é a de compreender o significado desse "direito novo", servindo para demonstrar o desacordo entre um "corpo de doutrina" (direito dos juristas) e uma realidade social a ele alheia; realidade que vai sendo absorvida pelo ordenamento jurídico, mas que não se encontra totalmente assimilada no plano da dogmática ou da teoria jurídica, onde muitas vezes é energicamente repelida."

1498 GROSSI, Paolo. A formação do jurista e a exigência de um hodierno "repensamento" epistemológico, Revista da Faculdade de Direito da UFPR, Curitiba, v. 40, p. 5-25, 2004. p. 22.

${ }^{1499}$ BARROSO, Lucas Abreu. A função ambiental do contrato. In: DELGADO, Mário Luiz; ALVES, Jones Figueirêdo (Coord.). Questões controvertidas: no direito das obrigações e dos contratos. São Paulo: Método, 2005, v. 4. p. 286.

${ }^{1500}$ WARAT, Luis Alberto. O direito e sua linguagem. 2 versão. 2 ed. Porto Alegre: SAFE, 1995. p. 15. "O Positivismo Lógico identifica a ciência com a linguagem a partir de uma atitude reducionista, que pensa a linguagem como uma atitude textual auto-suficiente, encontrando a significação o interior do próprio sistema criado e esquecendo as outras cenas significativas, como a produção social dos sentidos que, na verdade, é anterior ao próprio significado textual."

${ }^{1501}$ Nesse sentido: BOBBIO, Norberto. Da estrutura à função: novos estudos de teoria do direito. Trad. Daniela Beccaccia Versiani. Barueri: Manole, 2007. p. 40. Daí que "a atividade principal do jurista não é mais a interpretação de um direito já construído, mas a pesquisa de um direito a ser construído, in fieri, não tanto a convalidação, com base em uma análise das fontes formais do direito que é, mas a legitimação, com base em princípios materiais de justiça, do direito que deve ser."

${ }^{1502}$ FACHIN, Luiz Edson. A "reconstitucionalização" do direito civil brasileiro: lei nova e velhos problemas à luz de dez desafios. In: SILVA FILHO, José Carlos Moreira da; PEZZELLA, Maria Cristina Cereser (Coord.). Mitos e rupturas no direito civil contemporâneo. Rio de Janeiro: Lumen Juris, 2008. p. 4-5. 
É passada a hora de dar um basta às formas arcaicas de pensar o Direito, contornos que mais fazem lembrar o brincar de lego. No processo hermenêutico, parece não haver lugar para momentos lúdicos, ainda que seu resultado deva, paradoxalmente, promover a satisfação de todos os agentes sociais envolvidos em cada questão. Urge, portanto, superar o viés clássico, segundo o qual interpretação e aplicação da lei são operações distintas. ${ }^{1503}$

É imprescindível aceitar que "interpretar é dar sentido a cada momento"1504 e que a norma jurídica é o resultado - e não o fundamento - de um processo que deve ter em conta múltiplas variáveis. Compreender que interpretar é aplicar ${ }^{1505}$ - a cisão desses momentos é algo inconcebível ${ }^{1506}$ - permite a fuga do "exílio do exercício lógico contido no silogismo de memória iluminista" ao mesmo tempo em que proclama o "coenvolvimento e [da] cocriação no complexo procedimento normativo."1507

Agora, em vez de repetir discursos construídos abstratamente para regrar hipóteses imaginárias - entre as quais, incontáveis situações, há muito, não são identificadas na complexidade das relações sociais -, "o magistrado deve ser o artista que dá vida e movimento ao mármore esplêndido em que trabalha." 1508

${ }^{1503}$ ASCENSÃO, José de Oliveira. $O$ direito: introdução e teoria geral - uma perspectiva luso-brasileira. 2 ed. Rio de Janeiro: Renovar, 2001. p. 642-643. "Abstratamente, a distinção das operações é clara. A interpretação é logicamente prévia à aplicação: só depois de conhecer a regra poderemos valorar juridicamente o caso singular. Dá-se então a incidência do sistema, caracterizado pela sua generalidade, sobre o caso, que é singular. [...] A primeira parte é a tarefa de interpretação. Mas não se pode supor, mesmo que essa tenha sido realizada perfeitamente, que tudo está terminado quando se apuram as regras sobre a matéria. É ainda necessário demonstrar que se aplicam ao caso figurado."

${ }^{1504}$ STRECK, Lenio Luiz. O estado democrático de direito e a necessária constitucionalização do direito: a crise dos 10 anos da constituição cidadã, Revista da Faculdade de Direito de Cruz Alta, Cruz Alta, v. 4, n. 4, p. 23-41, jan./jul. 1999. p. 40.

${ }^{1505}$ STRECK, Lenio Luiz. Quinze anos de constituição - análise crítica da jurisdição constitucional e das possibilidades hermenêuticas de concretização dos direitos fundamentais-sociais, Revista da Ajuris, Porto Alegre, v. 30, n. 92, p. 205-234, dez. 2003. p. 206.

${ }^{1506}$ Em sentido contrário, entendendo que são operações distintas, veja BITTAR, Carlos Alberto; BITTAR FILHO, Carlos Alberto. Direito civil constitucional. 3 ed. São Paulo: RT, 2003. p. 33-34.

${ }^{1507}$ GROSSI, Paolo. Il diritto tra norma e applicazione: il ruolo del giurista nell'attuale società italiana. Prolusione del Prof. Paolo Grossi, ordinario di Storia del Diritto Italiano nella Facoltà di Giurisprudenza dell'Università di Firenze, tenuta nella cerimonia inaugurale della Scuola di Specializzazione per le professioni legali. Capturado em 17/07/09 em http://www.estig.ipbeja.pt/ ac_direito/prolusione.pdf.

${ }^{1508}$ MELLO, Baptista de. Interpretação e humanização da lei, Revista dos Tribunais, São Paulo, v. 24, n. 95, p. 308-313, mai. 1935. p. 309-310. Mesmo alcançando conclusões que nesta quadra histórica são consideradas ultrapassadas pela hermenêutica hodierna, não se pode deixar de destacar as letras poéticas do autor, transcritas aqui no original em que pese a grafia já superada: "Nos dias que correm, já se não navega mais no mar revolto da natureza só com a sciencia de ordenar; é mister colher no amago do direito a idéia de humanidade, para com ella fecundar o texto rígido da lei, para applical-a liberalmente e imprimir realidade à sua dureza, para sentil-a com a consciencia e com a razão, para arrancal-a dos codigos e espagir sobre o seu 
E, se essa metodologia implica a edificação de um "Direito concreto", a partir de regras - sua importância não é negada -, princípios e valores construídos democraticamente, não se pode esquecer de que ela se deve permitir influenciar pelo sentido material de justiça ${ }^{1509}$, almejado pela comunidade em que a questão que clama por solução se encontra inserida.

Por isso, muito mais que simplesmente rechaçar a utilização de brocardos como o in claris cessat interpretatio ${ }^{1510}$ - e tantas outras propostas similares -, a atividade hermenêutica tem início na premissa de que o Direito não é algo pronto, mas sim, um constante exsurgir. ${ }^{1511}$ Assim, longe de trabalhar com respostas prontas, ele deve ser pensado - e construído - a partir das intersubjetividades inerentes às hipóteses que lhe são apresentadas ${ }^{1512}$, o que não quer dizer, frise-se, que quaisquer ativismos mereçam aplausos.

conteudo a agua lustral da vida, eis que ella é um phenomeno humano, por isso mesmo imperfeita e transitoria. $\mathrm{O}$ magistrado tem de ser um criador do direito e não um executor passivo da lei [atualizando] os rigores da ordem social, sentindo, porém, as palpitações universaes de angustia com que todos procuram desencantar a formula vivificativa de seu equilibrio na existencia."

1509 CASTANHEIRA NEVES, Antonio. O actual problema metodológico da interpretação jurídica. Coimbra: Coimbra, 2003, v. 1. p. 42-43.

${ }^{1510}$ DINIZ, Maria Helena. Interpretação literal: uma leitura dos leigos, Revista do Advogado, São Paulo, n. 67, p. 94-98, ago. 2002. p. 94. Alude a autora que a citada parêmia "não tem qualquer aplicabilidade, pois tanto as leis claras como as ambíguas comportam interpretação."

${ }^{1511}$ AMARAL, Francisco. Direito civil: introdução. 7 ed. Rio de Janeiro: Renovar, 2008. p. 6-40.

1512 BARROSO, Lucas Abreu. Desmistificando as relações de família no novo direito civil. In: ALBUQUERQUE, Fabíola Santos; EHRHARDT JUNIOR, Marcos; OLIVEIRA, Catarina Almeida de (Coord.). Famílias no direito contemporâneo: estudos em homenagem a Paulo Luiz Netto Lôbo. Salvador: Podivm, 2009. p. 122. Veja ainda: MARÇAL, Antonio Cota. O inferencialismo de Brandom e a argumentação jurídica. In: GALUPPO, Marcelo Campos (Org.). O Brasil que queremos: reflexões sobre o estado democrático de direito. Belo Horizonte: PUC Minas, 2006. p. 115. "Na ordem da explicação, o Direito não pode equacionar uma demanda pelo reconhecimento de um direito subjetivo recorrendo a uma fórmula ou equação matematicamente construída ou formalmente correta. No Direito, o conteúdo conceitual é função dos indivíduos envolvidos, da cultura em que se movem os destinatários do direito, dos fatos, estados mentais, intenções, circunstâncias e consequiências, em que ocorrem as ações e escolhas dos jurisdicionados. A avaliação acerca da correção de uma ação não pode levar em conta apenas a norma positivada. Nem tão só e abstratamente os princípios do direito. A liberdade do indivíduo; a capacidade discursiva, que cria, discute e modifica o direito como convenção normatizada; interesses e valores, desejos e crenças, ideologias e teorias, que se sucedem, se corrigem e freqüentemente se contradizem; necessidades, carências, patologias e distorções resultantes da condição biofisiológica do indivíduo humano ou da própria convivência social são certamente apenas alguns dos fatores que deverão ser considerados na argumentação jurídica. Em uma palavra, a argumentação jurídica é simultaneamente teórica e prática. Como argumentação teórica tem que se pautar pela discursividade lógica e inferencial relativamente já bem delimitadas. Como argumentação prática - aquela voltada para a ação a ser escolhida como "meio" adequado para se obter determinado fim ou como um "fim" a se realizar - a argumentação jurídica tem, sempre e a cada vez, que continuar procurando se constituir. Primeiro porque não foi ainda suficientemente elaborada e teorizada como já o foi razoavelmente a argumentação teórica de outros segmentos científicos. Segundo porque deverá estar sempre em construção, uma vez que alguns de seus elementos constitutivos, tais como a intenção do agente, a especificidade do fato por ele produzido, as circunstâncias e as consequiências individualizadoras das ações não são variáveis completamente determináveis a priori." 
Para tanto, é imperioso superar mitos como (a) a crença monista, segundo a qual todo Direito emana do Estado, (b) a exegese - e técnicas similares - como método interpretativo/aplicativo e (c) a "significação monolítica" dos institutos - e figuras fundantes da radiografia das relações sociais. ${ }^{1513}$

E, sendo possível constatar que (a) um discurso monológico ${ }^{1514}$ - essa "ficção simplificadora" ${ }^{\text {1515 }}$ - torna-se inaceitável frente aos distintos pluralismos ${ }^{1516}$ existentes na contemporaneidade $^{1517}$, (b) as interpretações fundadas na letra da lei destoam, de modo gritante, do pensamento jurídico de vanguarda e, enfim, (c) é essencial explorar os limites semânticos das regras jurídicas, torna-se factível conceber que o terreno necessário para sustentar nova(s) forma(s) de pensar o Direito se encontra preparado.

Além da percepção dos momentos destacados, em termos gerais, é necessário aceitar (a) a importância de saber quais são as questões realmente relevantes para a sociedade e (b) que o juiz deve se permitir influenciar pelo papel emancipatório do Direito. $^{1518}$

${ }^{1513}$ FACHIN, Luiz Edson. Questões do direito civil brasileiro contemporâneo. Rio de Janeiro: Renovar, 2008. p. 14-15.

${ }^{1514}$ WARAT, Luis Alberto. Introdução geral ao direito: a epistemologia jurídica da modernidade. Porto Alegre: SAFE, 2002, v. 2. p. 363. Sobre o assunto, veja ainda: CARRION, Eduardo Kroeff Machado. O poder judiciário, o juiz e a lei, Revista de Direito Alternativo, São Paulo, n. 1, p. 65-70, 1992. p. 66-67. No mesmo sentido: AGUIAR, Roberto. O imaginário dos juristas, Revista de Direito Alternativo, São Paulo, $\mathrm{n}$. 2, p. 18-27, 1993. p. 20-21. JUNQUEIRA DE AZEVEDO, Antônio. O direito pós-moderno e a codificação, Revista de Direito do Consumidor, São Paulo, v. 9, n. 33, p. 123-129, jan./mar. 2000. p. 123.

${ }^{1515}$ HESPANHA, António Manuel. O caleidoscópio do direito: o direito e a justiça nos dias e no mundo de hoje. Coimbra: Almedina, 2007. p. 56.

${ }^{1516}$ SILVA, José Afonso da. O estado democrático de direito, Revista dos Tribunais, São Paulo, v. 77, n. 635, p. 7-13, set. 1988. p. 11. "A Democracia que o Estado Democrático de Direito realiza há de ser um processo de convivência social numa sociedade livre, justa e solidária, em que o poder emana do povo [...]; participativa, porque envolve a participação crescente do povo no processo decisório e na formação dos atos de governo; pluralista, porque respeita a pluralidade de idéias, culturas e etnias e pressupõe, assim, o diálogo entre opiniões e pensamentos divergentes e a possibilidade de convivência de organização e interesses diferentes na sociedade; há de ser um processo de liberação da pessoa humana das formas de opressão, que não depende apenas do reconhecimento formal de certos direitos individuais, políticos e sociais, mas, especialmente, da vigência de condições econômicas suscetíveis de favorecer o seu pleno exercício." Veja ainda: SOUZA SANTOS, Boaventura de. O estado e o direito na transição pós-moderna: para um novo senso comum sobre o poder e o direito, Revista Crítica de Ciências Sociais, Coimbra, v. 30, p. 13-43, jun. 1990. p. 34-38. Ressalta o autor a essencialidade do pluralismo nos momentos de produção do direito - e da interpenetração de cada um desses momentos - na realização da cidadania material.

${ }^{1517}$ Ainda que isso não seja aceito pacificamente.

${ }^{1518}$ MAIA, Antonio Cavalcanti. O direito constitucional do limiar do século XXI: princípios jurídicos e póspositivismo. In: MORAES, Guilherme Peña de. Readequação constitucional do estado moderno. Rio de Janeiro: Lumen Juris, 2006. p. XXXVI-XLVIII. 
Apenas um Direito assim pautado - portanto, constantemente preocupado com a realização e a promoção de justiça social $^{1519}$ - pode auxiliar na transformação da sociedade, atendendo a esse inafastável e impostergável comando constitucional.

É oportuno apontar, ainda, que, quando se aceita que interpretar, muito além de entender, é intuir ${ }^{1520}$, se vislumbra por que é impossível antever qual deva ser a resposta a ser dada pelo Direito para um dado problema, sem que antes se identifique, com clareza, qual o traço peculiar na realidade concreta a ser enfrentada. ${ }^{1521} \mathrm{E}$, embora - e como antecipado, a realização do Direito não se possa pautar pela subjetividade do intérprete por conta de problemas como os ligados ao solipsismo e ao deficit democrático ${ }^{1522}$-, ainda assim, a proposta se apresenta como opção viável.

Em verdade, por mais que seja evidente que uma "decisão jurídica não se apresenta como um processo de escolha do julgador [entre as] diversas possibilidades de solução da demanda" ${ }^{\text {1523 }}$, nem por isso, uma conformação hermenêutica construtiva - que tenha início no caso concreto e seja balizada por valores e princípios democraticamente erigidos - deve ser afastada.

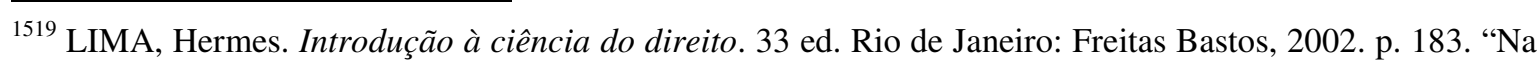
face social da justiça são os problemas organizatórios de fundo - econômicos, políticos, humanos - que surgem pondo em causa não apenas as soluções legais, mas a própria estrutura da sociedade ou aspectos dessa estrutura. Aí então a justiça não se limita a resolver conflitos de conduta ou de interesses no plano da lei positiva. Aí a justiça é instrumento de mudança e de transformação. Aí a justiça é captadora de anseios e reivindicações. Aí a justiça o que propugna são causas, e não apenas sentenças. A justiça aí pensa na humanidade e não no caso particular. A justiça social atua como o sal da terra e move o espírito de liderança que conduz os acontecimentos."

1520 JUNQUEIRA DE AZEVEDO, Antônio. O direito pós-moderno e a codificação, Revista de Direito do Consumidor, São Paulo, v. 9, n. 33, p. 123-129, jan./mar. 2000. p. 129.

${ }^{1521}$ STRECK, Lenio Luiz. O que é isto - decido conforme minha consciência?. Porto Alegre: LAEL, 2010. p. 64. Noutras palavras, "antes da manifestação do caso a ser decidido."

${ }^{1522}$ Como exemplo: STJ. AgRg nos EREsp 319997/SC. 1. S. Rel. - para o acórdão - Humberto Gomes de Barros. j. 14.08.02. DJU 07.04.03. p. 216. "Não me importa o que pensam os doutrinadores. Enquanto for Ministro do Superior Tribunal de Justiça, assumo a autoridade da minha jurisdição. O pensamento daqueles que não são Ministros deste Tribunal importa como orientação. A eles, porém, não me submeto. Interessa conhecer a doutrina de Barbosa Moreira ou Athos Carneiro. Decido, porém, conforme minha consciência. Precisamos estabelecer nossa autonomia intelectual, para que este Tribunal seja respeitado. É preciso consolidar o entendimento de que os Srs. Ministros Francisco Peçanha Martins e Humberto Gomes de Barros decidem assim, porque pensam assim. E o STJ decide assim, porque a maioria de seus integrantes pensa como esses Ministros. Esse é o pensamento do Superior Tribunal de Justiça, e a doutrina que se amolde a ele. É fundamental expressarmos o que somos. Ninguém nos dá lições. Não somos aprendizes de ninguém. Quando viemos para este Tribunal, corajosamente assumimos a declaração de que temos notável saber jurídico - uma imposição da Constituição Federal. Pode não ser verdade. Em relação a mim, certamente, não é, mas, para efeitos constitucionais, minha investidura obriga-me a pensar que assim seja." (grifos nossos).

${ }^{1523}$ STRECK, Lenio Luiz. O que é isto - decido conforme minha consciência?. Porto Alegre: LAEL, 2010. p. 96-98. Informe-se que o itálico é do original. 
E, se, de um lado, a preocupação com a indevida utilização da liberdade - que é apenas ilusória - por parte daqueles que são investidos na função decisória é digna de nota, por outro - e salvo momentos de rara lucidez ${ }^{1524}-$, grande parte das reflexões nesse sentido estão ancoradas em premissas incorretas.

Isso porque (a) estão atadas à "racionalidade calculadora" do positivismo e às preocupações com a tutela dos "projetos da burguesia daquela época" - cujo sucesso dependia da "exigência de previsibilidade e segurança jurídica" problemas na formação daqueles a quem se atribui o poder jurisdicional. ${ }^{1526} \mathrm{Em}$ ambos os casos, as mazelas antevistas podem ser superadas com investimento na formação profissional e/ou com o adequado exercício da jurisdição constitucional.

Atribuir poder de criação aos juízes, portanto, não legitima solipsismos. Cada decisão - nesse universo de liberdade aparente - precisa conformar-se aos preceitos constitucionais, aos princípios e aos valores que informam o Estado Democrático de Direito. ${ }^{1527}$ A obediência a essas premissas afasta o "déficit de democracia", contido nos ativismos e evita que o protagonista identifique sua leitura do direito com o Direito. ${ }^{1528}$

Aliás e como antecipado, hodiernamente, parece não existir outro caminho senão o que conduz à ratificação da ideia de que os momentos pré-normativos nada mais são do que um conjunto de significantes a exigir adequada compreensão - portanto, atribuição de significado - da gênese da norma jurídica a ser concretamente exarada em cada situação que o exija.

\footnotetext{
${ }^{1524}$ Sobre o tema: FARIA, José Eduardo. As transformações do judiciário em face de suas responsabilidades sociais, Revista de Direito Alternativo, São Paulo, n. 2, p. 33-46, 1993. p. 36-38. STRECK, Lenio Luiz. O que é isto - decido conforme minha consciência?. Porto Alegre: LAEL, 2010. p. 20-84. ALBESA, Joaquín Rams. La moral en la disciplina general de los contratos. In: GESUALDI, Dora Mariana (Coord.). Derecho privado. Buenos Aires: Hammurabi, 2001. p. 31-39.

${ }^{1525}$ Como denuncia, por exemplo: PINHEIRO, Rosalice Fidalgo. Contrato e direitos fundamentais. Curitiba: Juruá, 2009. p. 72.

${ }^{1526}$ FROTA, Pablo Malheiros da Cunha. Reflexões sobre a eficácia dos direitos fundamentais nas relações entre particulares e a constitucionalização do direito civil, Que Direito É Este?, Brasília, v. 1, n. 1, p. 119153, ago./dez. 2010. p. 121-127.

${ }^{1527}$ MAGALHÃES, Joseli Lima. Da recodificação do direito civil brasileiro. Rio de Janeiro: Lumen Juris, 2006. p. 19.

${ }^{1528}$ STRECK, Lenio Luiz. Decisionismo e discricionariedade judicial em tempos pós-positivistas: o solipsismo hermenêutico e os obstáculos à concretização da constituição no Brasil. In: AVELÃS NUNES, António José; COUTINHO, Jacinto Nelson Miranda (Coord.). O direito e o futuro: o futuro do direito. Almedina: Coimbra, 2008. p. 107-111. "A explicitação da resposta de cada caso deverá estar sustentada em consistente justificação, contendo a reconstrução do direito, doutrinária e jurisprudencialmente, confrontando tradições, enfim, colocando à lume a fundamentação jurídica que, ao fim e ao cabo, legitimará a decisão no plano do que se entende por responsabilidade política do intérprete no paradigma do Estado Democrático de Direito."
} 
É relevante apontar, também, que a formatação das soluções para as preocupações denunciadas exige a eleição de um método. Nessa busca, é preciso ter cuidado com visões maniqueístas - dentre elas, as fórmulas concebidas pela análise econômica do Direito e pela teoria da imputação objetiva ${ }^{1529}$-, até porque cada perspectiva relativista normalmente impõe sua utilidade em vez de oferecê-la. ${ }^{1530}$

A missão - escolha de um método - é deveras complexa, fato que não se nega. É evidente que, na contemporaneidade, a expansão dos textos normativos dificulta o processo de conciliação racional de incomensuráveis momentos pré-normativos compostos por regras e princípios ${ }^{1531}$, mormente, quando se identifica que, abstratamente, os sentidos contidos nos signos, no mais das vezes, são polifônicos. ${ }^{1532}$

Combater ou fugir? Aparentemente, não há alternativa, embora parte considerável da doutrina - no Brasil e fora dele - não consiga enxergar a necessidade de assunção de uma postura combativa, o que ocorre, talvez, por acreditarem que "há mortos que morrem devagar" ${ }^{\prime 1533}$, como se isso fosse realmente possível.

Sem a pretensão de encontrar, aqui, uma resposta universal que possa embasar a solução dos problemas inerentes às relações sociais na contemporaneidade - até porque, além de ser pretensiosa, a missão ultrapassaria, em muito, os objetivos desta tese -, talvez seja possível identificar alguns critérios que possam informar uma decisão jurídica ${ }^{1534}$ na contemporaneidade.

\footnotetext{
${ }^{1529}$ Sobre o tema: MONTIJANO, Martín García-Ripoll. Imputación objetiva, causa próxima y alcance de los daños indenizables. Granada: Comares, 2008. p. 205-222. Acredita-se que a incidência da teoria da imputação objetiva, apesar de útil em algumas situações, não pode ser pensada como a única ou a melhor solução para os problemas na seara do incumprimento contratual. A reflexão tem gênese ao menos em três distintas razões: (a) a necessidade da delimitação das condutas que sejam permitidas e não proibidas; (b) as dificuldades em se aferir de quem seria a legitimidade para promover tais opções; e (c) por aparentemente diminuir as hipóteses em que haverá a imputação do dever de reparar.
}

${ }^{1530}$ SOUZA SANTOS, Boaventura de. A filosofia à venda, a douta ignorância e a aposta de Pascal, Revista Crítica de Ciências Sociais, Coimbra, v. 80, p. 11-43, mar. 2008. p. 12.

${ }^{1531}$ LORENZETTI, Ricardo Luis. A era da desordem e o fenômeno da descodificação, Revista de Direito do Consumidor, São Paulo, v. 17, n. 68, p. 212-241, out./dez. 2008. p. 217.

${ }^{1532}$ STRECK, Lenio Luiz. O que é isto - decido conforme minha consciência?. Porto Alegre: LAEL, 2010. p. 68.

${ }^{1533}$ CASTANHEIRA NEVES, Antonio. Entre o legislador, a sociedade e o juiz ou entre sistema, função e problema - os modelos actualmente alternativos da realização jurisdicional do direito, Boletim da Faculdade de Direito, Coimbra, v. 74, p. 1-44, 1998. p. 19-23.

1534 CASTANHEIRA NEVES, Antonio. O actual problema metodológico da interpretação jurídica. Coimbra: Coimbra, 2003, v. 1. p. 28. " O que a faz imprescindível é o acto normativo da utilização metodológica (metodológico-normativa) de um critério jurídico - que, aliás, não tem de ser necessariamente oferecido num texto prescritivo, num texto-norma legal, pois pode decerto provir de uma prática 
Tais critérios podem ser encontrados no pensamento jurisprudencialista ${ }^{1535}$, mesmo porque parece inegável que o paradigma deixou de ser a lei. ${ }^{1536}$ Atualmente, as luzes estão focadas nos juízes ${ }^{1537}$ e na sua law in action. ${ }^{1538}$

A adequada realização do Direito hodierno reclama o que Canotilho denomina "principialização da jurisprudência, ou seja, a mediação judicativo-decisória dos princípios jurídicos relevantes para a solução materialmente justa" dos casos que demandam uma resposta. $^{1539}$

consuetudinária, de uma decisão-precedente, etc - no juízo decisório de um concreto problema normativojurídico: a referência desse critério ao mérito deste problema, ou a compreensão-assimilação intencionalmente normativa daquele critério justamente como critério normativo da concreta solução do problema jurídico, é o que, essencialmente, exige e constitui a interpretação jurídica."

${ }^{1535}$ CASTANHEIRA NEVES, Antonio. Entre o legislador, a sociedade e o juiz ou entre sistema, função e problema - os modelos actualmente alternativos da realização jurisdicional do direito, Boletim da Faculdade de Direito, Coimbra, v. 74, p. 1-44, 1998. p. 18. "O que dá sentido ao jurisprudencialismo é uma outra perspectiva bem diferente. Designamo-la por perspectiva do homem (do homem-pessoa), í. é, aquela perspectiva em que o direito, com urna sua normatividade axiologicamente fundada, é assumida por, e está directamente ao serviço de uma prática pessoalmente titulada e historicamente concreta, prática dinamizada pelas controvérsias também prático-concretas, mas cuja intencionalidade capital é a realização nessa prática e através dela, como básica condição mediadora, do homem-pessoa convivente e assim do homem no eu direito e no seu dever ou na sua responsabilidade. Não já a perspectiva macroscópica ou da globalização socialmente contextual em que a pressão do todo tende a indiferenciar a especificidade de tudo, numa confusão das dimensões - caso em que o todo não é só o integrante holístico, é antes o dissolvente das essências -, e por isso o direito perde nele a sua autonomia, já que, funcionalizado aí à estruturação, organização e regulação global da sociedade, vê-se ele intencionado também funcionalmente ab extra por urna estratégia que não é sua, que de todo lhe é heterónoma. Não já essa perspectiva macroscópica, mas uma perspectiva que se poderá dizer de imanência microscópica, porquanto o direito é; diferentemente, convocado, e nessa convocação problematizado, pelo homem concreto que vive e comunitariamente convive os acontecimentos práticos (volvidos em casos ou problemas práticos) da inter-acção histórico-social. O que se denuncia desde logo na diferenciação que atinge o normativo nuclear: naquela primeira perspectiva, o judicativamente sobretudo relevante é a lex, seja como norma, seja como imperativo, seja como regra - pelas possibilidades, à parte decerto os implicados compromissos políticos, de racionalização e de programada assimilação que permitirá aos objectivos e às exigências contextuais -; nesta outra perspectiva, o importante é, pelo contrário, a axiológica normatividade de uma validade como ius que intenciona uma sua realização histórico-concreta mediante o juízo prático sobre a inter-acção pessoalmente titulada e comunitariamente responsável - e quaisquer que sejam os elementos normativo-jurídicos (fundamentos, critérios) a que se vincule e em que se haja de apoiar esse juízo, traduz-se sempre ele numa mediação normativajudicativamente constitutiva que esses elementos não reduzem."

1536 Daí que o recurso às cláusulas gerais, embora louvável quando comparado às técnicas legislativas gestadas no passado, não deixa de ser uma vertente superada

1537 JUNQUEIRA DE AZEVEDO, Antônio. O direito pós-moderno e a codificação, Revista de Direito do Consumidor, São Paulo, v. 9, n. 33, p. 123-129, jan./mar. 2000. p. 126. "Introduziram-se, assim, nos textos normativos, os conceitos jurídicos indeterminados, a serem concretizados pelo julgador no caso a decidir, e as cláusulas gerais, como a de boa-fé."

${ }^{1538}$ CANARIS, Claus-Wilhelm. Direitos fundamentais e direito privado. Trad. Ingo Wolfgang Sarlet; Paulo Moto Pinto. Coimbra: Almedina, 2003. p. 40-41.

1539 CANOTILHO, José Joaquim Gomes. A "principialização" da jurisprudência através da constituição, Revista de Processo, São Paulo, v. 25, n. 98, p. 83-89, abr./jun. 2000. p. 83. 
E, sendo evidente que a perspectiva aplicativa - centrada nas regras e instrumentalizada pela técnica da subsunção ${ }^{1540}$ - se encontra superada, parece possível afirmar que seu lugar foi ocupado pela atuação judicial e pela atenção ao caso, aos princípios e à razão prática. ${ }^{1541}$

O raciocínio jurídico, portanto, deverá ser orientado por lógica distinta daquela que informou o pensamento clássico. ${ }^{1542} \mathrm{E}$, em princípio, parece não haver outra alternativa senão a que leva a aceitar que, na contemporaneidade, o pensamento jurídico deve ser (a) problemático, (b) comprometido com as questões práticas a serem solucionadas pelo Direito $^{1543}$, (c) permeado por vetores axiológicos e, enfim, (d) construído com o auxílio da argumentação. ${ }^{1544}$

Essas quatro balizas metodológicas, quando conjugadas, ratificam as assertivas anteriores. A atividade hermenêutica vai muito além da mera busca pela regra aplicável ao caso sub judice.

\footnotetext{
${ }^{1540}$ Para um olhar crítico: ROSA, Alexandre Morais da. Prefácio. In: WARAT, Luis Alberto. A rua grita dionísio: direitos humanos da alteridade, surrealismo e cartografia. Trad. e Org. Vivian Alves de Assis; Júlio Cesar Marcellino Junior; Alexandre Morais da Rosa. Rio de Janeiro: Lumen Juris. 2010. p. XIII. "No Direito o discurso masculino, viril, do uso e abuso da força e da coerção desfila como protagonista de um normativismo que acredita que todos os problemas do mundo estariam resolvidos pela subsunção perfeita entre texto normativo e mundo da vida, não se dando conta, claro, que o mundo é inapreensível, e que aceitar essa impotência é condição de possibilidade para o se abrir para a alteridade."
}

1541 AMARAL, Francisco. Uma carta de princípios para um direito como ordem prática: In: TEPEDINO, Gustavo; FACHIN, Luiz Edson (Coord.). O direito e o tempo: embates jurídicos e utopias contemporâneas. Rio de Janeiro: Renovar, 2008. p. 132.

${ }^{1542}$ COELHO, Luiz Fernando. Saudade do futuro. 2 ed. Curitiba: Juruá, 2007. p. 106-107. "Não que a lógica analítica tenha deixado de cumprir o seu papel a realização da justiça; não que a lógica formal esteja ultrapassada como processo de raciocínio para o jurista, mas sim que, em face da necessidade de voltar a práxis judicial para a concreção da vida social, desenvolveu-se novo logos mais adequado à compreensão da realidade do direito; lógica do razoável, lógica material, teoria da argumentação, pensamento tópico-retórico, lógica jurídica concreta, são algumas das denominações que têm servido para rotular as elaborações e conquistas atinentes à construção da nova metodologia que leva em conta o contingente, o movimento, o tempo, a realidade e a concreção, dados esses reunidos na compreensão do direito como experiência.

${ }^{1543}$ Nesse sentido: PERELMAN, Chaïm. Lógica jurídica. Trad. Verginia Pupi. São Paulo: Martins Fontes, 2000. p. 238. Veja ainda: CAMARGO, Margarida Maria Lacombe. Hermenêutica e argumentação: uma contribuição ao estudo do direito. 3 ed. Rio de Janeiro: Renovar, 2003. p. 178. "Podemos definir o pensamento prático como aquele que se compromete diretamente com problemas, uma vez que é chamado a resolvê-los. E com isso abandonamos a idéia de direito como simples aplicação de normas [...] em prol da idéia de que o direito se constitui num verdadeiro ato de criação normativa que se dá a cada caso concreto."

${ }^{1544}$ MARÇAL, Antonio Cota. O inferencialismo de Brandom e a argumentação jurídica. In: GALUPPO, Marcelo Campos (Org.). O Brasil que queremos: reflexões sobre o estado democrático de direito. Belo Horizonte: PUC Minas, 2006. p. 114. "Em razão de sua especificidade prático-social a argumentação jurídica se pauta por: a) princípios do direito; b) normas legais gerais e específicas, substantivas e processuais; c) regras e procedimentos de fundamentação jurídica, que ponderem elementos como julgados judiciais, crenças e constructos racionais elaborados pela teoria jurídica (dita comumente doutrina); d) informações fáticas relativas ao agente, ao evento ou à ação objeto de apreciação, bem como suas circunstâncias e consequiências jurídicas; e) teorias e resultados científicos especializados acerca da matéria sob avaliação." 
Em verdade, não são poucos os autores afirmando que o paradigma judicativodecisório $^{1545}$ ocupou o lugar da subsunção ${ }^{1546}$, razão pela qual é possível afirmar que, hodiernamente, o Direito, em cada hipótese que o exija, deve ser sentido. ${ }^{1547}$

Seguindo na trilha aberta há pouco, ressalte-se que o processo de realização do Direito tem, como ponto de partida, o caso concreto. ${ }^{1548}$ A partir dele, os princípios, regras e valores jurídicos fundamentarão cada reflexão. E, se o problema é o ponto de partida ${ }^{1549}$ - se a centralidade do caso é o eixo hermenêutico ${ }^{1550}$-, a análise das condições daqueles

1545 AMARAL, Francisco. O código civil brasileiro e o problema metodológico de sua realização. In: TARTUCE, Flávio; CASTILHO, Ricardo (Coord.). Direito civil: direito patrimonial, direito existencial. São Paulo: Método, 2006. p. 14. "O mundo tem mudado, aliás, mudado em velocidade vertiginosa, e neste contexto, o estágio hodierno das relações sociais, analisadas em sua máxima complexidade, impõe uma maior atenção dos responsáveis pela solução dos conflitos que nela eclodem, e conseqüentemente, uma enfática atuação dos agentes estatais na tutela dos jurisdicionados, missão esta cada vez mais difícil, por conta da proliferação das celeumas no cotidiano social e da ampliação de preceitos jurídicos construídos com o escopo de apresentar saídas à apontada crise." Saliente-se que também é imperioso observar-se o pluralismo das fontes legislativas no processo de realização do Direito.

${ }^{1546}$ Entendemos que o conceito de norma jurídica serve para descrever uma norma concreta, ou seja, aquela construída pelo juiz em cada caso que lhe é apresentado e que resulta do processo de realização do Direito. Os textos contidos nas leis e codificações devem ser tratados como preceitos normativos.

${ }^{1547}$ VERDÚ, Pablo Lucas. O sentimento constitucional: aproximação ao estudo do sentir constitucional como modo de integração política. Trad. Agassiz Almeida Filho. Rio de Janeiro: Forense, 2004. p. 49-50. "Qual o ponto característico do sentimento do Direito e como conhecemos? Aquilo que é afirmado por uma decisão do poder basta como simples designação do Direito? Se assim fosse, qualquer pretexto com base na autoridade seria Direito. Então, poder + ignorância = Direito. Porém, tampouco é Direito o que é reconhecido como tal. Em tal caso, a manutenção de uma ordem estaria determinada pelo capricho dos que querem vincular-se a ela. Calibramos nosso juízo acerca de se uma determinada criação é artística, conforme medidas objetivas, e não segundo a opinião de quem produz tal obra de arte ou com base na opinião de um público mais ou menos amplo que o tenha aceitado. O mesmo acontece com o Direito. Mantemos na base de sua atitude, maturidade e educação uma medida para o que é a verdadeira arte e o verdadeiro Direito.”

1548 NERY, Rosa Maria Barreto Borriello de Andrade. Vínculo obrigacional: relação jurídica de razão (técnica e ciência de proporção). Tese (Livre-Docência) - Faculdade de Direito da PUC/SP, São Paulo, 2004. p. 304-307. Veja ainda: STRECK, Lenio Luiz. Da interpretação de textos à concretização de direitos: a incindibilidade, entre interpretar e aplicar - contributo a partir da hermenêutica filosófica, Revista da Faculdade de Direito da Universidade de Lisboa, Coimbra, v. 46, n. 2, p. 911-954, 2005. p. 938-939. “O caso concreto de que tratam as posturas positivistas não é o caso concreto que emerge na era do póspositivismo. No positivismo o assim denominado "caso" é uma ficção, apontável entre várias alternativas, a partir de um processo subsuntivo/dedutivo, que tem na regra a pretensão de abarcar as diversas hipóteses de aplicação desde conceitos abstratos-universalizantes. Já no paradigma pós-metafísico o "caso" é produto de uma análise conteudistica que se constrói no interior de uma intersubjetividade [...] a partir da faticidade (mundo prático)."

1549 CASTANHEIRA NEVES. Antonio. Digesta: escritos acerca do direito, do pensamento jurídico, da sua metodologia e outros. Coimbra: Coimbra, 1995, v. 1. p. 47-49. "Diremos que a concreta decisão jurídica deixou de poder pensar-se segundo o esquema de um processo lógico, tendo apenas no conteúdo significativo-conceitual da norma positiva o seu fundamento e o seu ponto de partida metódico, para ir necessariamente entendida como um autonomo juízo normativo (uma decisão e avaliação normativas) que tem o seu ponto de partida num caso concreto, tomado na sua unidade material de relevância, e que encontra seu fundamento num princípio jurídico-normativo, quer este tenha já encontrado expressão numa norma [sic, regra] ou não."

1550 JUNQUEIRA DE AZEVEDO, Antônio. O direito pós-moderno e a codificação, Revista de Direito do Consumidor, São Paulo, v. 9, n. 33, p. 123-129, jan./mar. 2000. p. 127. 
que compõem a relação jurídica - as intersubjetividades inerentes à questão concretamente situada - se torna um fator deveras relevante nesse processo ${ }^{1551}$, o que não quer necessariamente dizer que a decisão a ser tomada deva pautar-se pelos interesses de um, de outro, ou mesmo de ambos, nem que possa estar fundada em quaisquer espécies de arbitrariedades.

A análise das intersubjetividades havidas na relação concretamente estabelecida ganha em importância, ainda, quando se compreende que o contrato deve ser lido a partir da historicidade ${ }^{1552}$ que lhe é inerente, bem como, das funções que deve observar.

Adquire realce, também, quando se identifica o processo de fragmentação que o atingiu. ${ }^{1553}$ Sobre esse ponto, aliás, parece oportuno resgatar que, hodiernamente, "o contrato são os contratos", pois, sob um mesmo signo, são designadas situações bastante distintas, dentre as quais, encontram-se (a) negócios individuais e paritários, cujos termos são detalhadamente discutidos pelas partes, (b) contratos pactuados por adesão às condições gerais de contratação, permitindo certo grau de interação do aderente, com a alteração, ainda que mínima, do clausulado predisposto, (c) contratos formulados em razão de ações metaindividuais, sem qualquer consideração acerca da situação subjetiva dos destinatários, (d) negócios que somente são justificáveis em nível comunitário ou global ${ }^{1554}$ etc.

${ }^{1551}$ MARTINS-COSTA, Judith; BRANCO, Gerson Luis Carlos. Diretrizes teóricas do novo código civil brasileiro. São Paulo: Saraiva, 2002. p. 123. Ao versar sobre a "ética da situação", a autora leciona que "esta expressão rica em significados indica, primariamente, que a noção de sujeito de direitos deve ser percebida em sua essencial pluralidade, englobando o rico e o pobre, o empresário e o desempregado, a grande corporação econômica e os menores de rua, o contratante forte e o contratante débil, o latifundiário e o semterra, o consumidor e o fornecedor, enfim, o ser humano e(m) suas circunstâncias, sempre urgentes e concretas [devendo-se] considerar, ainda mais, que um mesmo sujeito pode desempenhar e desempenha, concomitantemente, vários papéis sociais." Daí, segundo a autora, "o apelo, tantas vezes feito na nova Lei Civil, aos "usos do lugar" às "circunstâncias do caso", à "natureza da situação" para permitir ao aplicador do Direito descer do plano das abstrações ao terreno por vezes áspero do concreto."

1552 Sobre o tema: ROPPO, Enzo. O contrato. Trad. Ana Coimbra; M. Januário C. Gomes. Coimbra: Almedina, 2009. p. 24-26.

${ }^{1553}$ Para melhor compreensão do tema: ZANETTI; Cristiano de Souza. Direito contratual contemporâneo: a liberdade contratual e sua fragmentação. São Paulo: Método, 2008. p. 191-278.

${ }^{1554}$ MARTINS-COSTA, Judith. O método da concreção e a interpretação dos contratos: primeiras notas de uma leitura suscitada pelo código civil. In: DELGADO, Mário Luiz; ALVES, Jones Figueiredo (Coord.). Questôes controvertidas: no direito das obrigações e dos contratos. São Paulo: Método, 2005, v. 4. p. 133. 
Por sua vez, o pensamento jurídico, construído a partir de uma razão prática, buscará uma solução criativa para cada problema. ${ }^{1555}$ Isso não equivale a dizer que o conteúdo dos textos normativos possa ser ignorado, embora queira se frisar que deve sujeitar-se a constante controle de constitucionalidade ${ }^{1556} \mathrm{e}$ às peculiaridades do caso.

Adequar essa percepção à realidade da codificação impõe compreender, antes, que qualquer código nada mais é do que um retrato de opções ideológicas e culturais. E, também por isso, as regras codificadas devem passar por constante releitura, tendo por moldura os princípios e valores consagrados pelo Direito ${ }^{1557}$ e a realidade concreta que clama por uma resposta.

Aliás, aparentemente, não é há como ignorar que mesmo a codificação vigente permite uma atuação como a proposta neste trabalho, bastando que se visualize a importância - e a extensão - dos pilares da operabilidade ${ }^{1558}$, da eticidade $^{1559}$ e da sociabilidade.

1555 AMARAL, Francisco. A interpretação jurídica segundo o código civil, Revista Brasileira de Direito Comparado, Rio de Janeiro, n. 29, p. 19-41, jul./dez. 2005. p. 36-37.

${ }^{1556}$ LÔBO, Paulo Luiz Netto. A constitucionalização do direito civil brasileiro, Revista Brasileira de Direito Civil Constitucional e Relações de Consumo, Santo Amaro, n. 1, p. 197-210, jan./mar. 2009. p. 204. "Não há como promover a cisão entre os dois hemisférios normativos, que estão inseparavelmente interligados, seja o Código velho ou novo. Ao contrário, a aplicação do Código é exigente de cuidado, para que o núcleo normativo da Constituição sobre direito civil se expresse com vigor. Cabe ao intérprete assegurar a compatibilidade de cada decisão, fundada em norma do Código Civil, com os princípios constitucionais, ainda que a estes não se refira explicitamente. Cada interpretação é um microcosmo da imensa tarefa de realização de uma sociedade livre, justa e solidária. O Código Civil cumprirá sua vocação de pacificação social se for efetivamente iluminado pelos valores maiores que foram projetados nas normas constitucionais, notadamente nos princípios. Somente assim será acolhido como lei de todos os brasileiros e não apenas dos mais afortunados. A certeza da permanente constitucionalização, com a revitalização de sentido de suas normas, assegurar-lhe-á durabilidade pela pertinência com as mutações sociais."

${ }^{1557}$ FACHIN, Luiz Edson. Questões do direito civil brasileiro contemporâneo. Rio de Janeiro: Renovar, 2008. p. 12.

1558 AMARAL, Francisco. A eqüidade no código civil brasileiro, Revista CEJ, Brasília, n. 25, p. 16-23, abr./jun. 2004. p. 17. "Entre os princípios introduzidos no Código Civil de 2002, que orientam comportamentos e a própria realização do Direito sistematizado pelo legislador, cientista e filósofo, destacase o princípio da operabilidade ou da concretude, essencialmente um princípio de hermenêutica filosófica e jurídica que leva o intérprete não à função limitadora de aplicar o Direito, mas à de construir a norma jurídica adequada ao caso concreto e específico."

1559 AMARAL, Francisco. Os princípios jurídicos na relação obrigatória, Revista da Ajuris, Porto Alegre, v. 32, n. 99, p. 133-143, set. 2005. p. 136. Para quem, a eticidade entra em cena quando, no processo de realização do Direito, se atribuiu maior valor a parâmetros ético-jurídicos que aos lógico-formais. Veja ainda, do mesmo autor: AMARAL, Francisco. Historicidade e racionalidade na construção do direito brasileiro, Revista Brasileira de Direito Comparado, Rio de Janeiro, n. 20, p. 29-87, jan./jun. 2001. p. 85. "O princípio da eticidade reconhece o caráter problemático e conjectural do direito, afastando a sua prática do pensamento, lógico-formal e positivista que tem marcado os trabalhos exegéticos da civilistica brasileira, e defendendo o recurso a critérios ético-jurídicos [...]." 
Fica fácil aceitar que o pensamento jurídico será balizado pela prática social quando se visualiza que "o suum cuique tribuere variará conforme o tempo, o lugar e as circunstâncias" ${ }^{\prime 560}$ em que as personagens estão situadas, ou seja, dependerá do palco em que os atores sociais, cotidianamente, representam os mais distintos momentos da vida.

Razão prática e racionalidade material são convocadas a atuar. ${ }^{1561} \mathrm{O}$ viés pragmático - nos parece que nunca, na História recente do homem, se esteve tão perto de Roma - é de extrema valia nesse processo por levar a respostas aceitáveis ideológica e socialmente justas. ${ }^{1562}$ Assim, nessa esteira, a racionalidade que conduzirá esse processo deve perpassar as informações às quais o intérprete teve acesso - ou pôde ter, por ser um dos protagonistas nesse processo - e as circunstâncias temporais e espaciais que envolvem o problema a ser enfrentado.

Longe de haver uma verdade absoluta, o que existe é uma verdade construída pela razão crítica. ${ }^{1563} \mathrm{E}$, almejando calar os críticos, uma sentença parece ser bem mais imparcial e democrática do que regras previamente codificadas. ${ }^{1564}$ Além disso, não há como negar que o Direito é contextual e que, assim, tanto suas "espacialidades são potencialmente infinitas", como incomensuráveis são suas temporalidades. ${ }^{1565}$

Ademais, quando se identifica que (a) a atividade se alocou no lugar dos atos, (b) a confiança tomou o lugar da liberdade de contratar, (c) o contrato transformou-se nos contratos, (d) o surgimento das redes contratuais ocorreu ${ }^{1566}$, (e) à solidariedade se atribui

${ }^{1560}$ DINIZ, Maria Helena. Interpretação literal: uma leitura dos leigos, Revista do Advogado, São Paulo, n. 67, p. 94-98, ago. 2002. p. 97.

${ }^{1561}$ AMARAL, Francisco. O direito civil na pós-modernidade. In: FIUZA, César; SÁ, Maria de Fátima Freire de; NAVES, Bruno Torquato de Oliveira (Coord.). Direito civil: atualidades. Belo Horizonte: Del Rey, 2003. p. 65-69. A razão prática lastreia-se no seguinte questionamento: "Que devo fazer?" A seu turno, a segunda das ideias pauta-se no agir a partir de determinados valores sociais.

1562 AMARAL, Francisco. Direito civil: introdução. 7 ed. Rio de Janeiro: Renovar, 2008. p. 60.

1563 COFRÉ, Juan. Racionalidad en el derecho: una aproximación filosófica a la hermenéutica jurídica, Revista Chilena de Derecho, Santiago, v. 22, n. 1, p. 41-59, jan./abr. 1995. p. 55-59.

${ }^{1564}$ MENAUT, António Carlos Pereira. Judicialismo. In: CUNHA, Paulo Ferreira da (Org.). Instituições de direito: filosofia e metodologia do direito. Coimbra: Almedina, 1998, v. 1. p. 433.

1565 SOUZA SANTOS, Boaventura de. O estado e o direito na transição pós-moderna: para um novo senso comum sobre o poder e o direito, Revista Crítica de Ciências Sociais, Coimbra, v. 30, p. 13-43, jun. 1990. p. $31-32$.

${ }^{1566}$ MARQUES, Cláudia Lima. Três tipos de diálogos entre o código de defesa do consumidor e o código civil de 2002: superação das antinomias pelo "diálogo das fontes". In: PFEIFFER, Roberto Augusto Castellanos; PASQUALOTTO, Adalberto (Coord.). Código de defesa do consumidor e o código civil de 2002: convergências e assimetrias. São Paulo: RT, 2005. p. 42-43. 
valor jurídico, (f) a relação obrigacional deve ser compreendida como um processo e, enfim, (g) o dano é um mal social, verifica-se quão importante é o pensamento pragmático.

Tendo, ainda, como premissa, a hipercomplexidade - enquanto característica marcante do momento vivido pela humanidade -, parece razoável apontar que, em uma sociedade plural - e todos os relativismos que pertencem a ela -, a importância da análise da questão a partir do caso se agiganta.

Nesse contexto extremamente complexo, as soluções somente serão alcançadas mediante recurso a um processo dialógico e argumentativo ${ }^{1567}$, processo prenhe de democracia em razão da necessidade de ouvir, e atentamente, todos os lados. ${ }^{1568}$

E, apesar do coro entoado em sentido contrário - como não poderia ser diferente, a questão não é pacífica -, havendo quem sustente que a maior garantia de liberdade do indivíduo está na lei ${ }^{1569}$, reafirme-se que cada decisão deve brotar de um processo de reflexão e de argumentação pautado nos interesses de sujeitos historicamente situados e nos valores sociais vigentes.

Oportuno destacar que a incorporação da poiésis no discurso jurídico ${ }^{1570}$ desponta como uma alternativa interessante, especialmente porque faz com que a equidade - esse importante fator de equilíbrio ${ }^{1571}$ - ganhe destaque no processo de realização do Direito.

${ }^{1567}$ NUNES, Dierle José Coelho. Alguns fundamentos de revisionismo contratual ... acerca do direito obrigacional e contratual numa perspectiva democrática, Revista da Faculdade Mineira de Direito, Belo Horizonte, v. 8, n. 15, p. 60-81, jan./jun. 2005. p. 60-66.

${ }^{1568}$ LORENZETTI, Ricardo Luis. Teoria da decisão judicial: fundamentos do direito. Trad. Bruno Miragem. São Paulo: RT, 2009. p. 26. "O pluralismo e a diversidade constituem um fato incontrastável, e por essa razão é necessário assumir critérios compreensivos das diferentes posições para que seja alcançado um consenso entrecruzado."

1569 THEODORO JUNIOR, Humberto. A onda reformista do direito positivo e suas implicações com o princípio da segurança jurídica, Revista da Escola Nacional da Magistratura, Brasília, v. 1, n. 1, p. 92-120, abr. 2006. p. 93-94.

${ }^{1570}$ CARNEIRO, Maria Francisca. Sobre la presencia de elementos estéticos en la teoría civilista. In: GESUALDI, Dora Mariana (Coord.). Derecho privado. Buenos Aires: Hammurabi, 2001. p. 29. "A poiésis, no caso, pode ser entendida, na concepção aristotélica do termo, como um conjunto de referenciais - que no caso do Direito podem ser o equilíbrio, a simetria e as proporções - que balizam ações ou criações humanas."

${ }^{1571}$ LOPES, Mônica Sette. Os sujeitos jurídicos: concepções tangenciadoras do novo código civil, Revista da Faculdade de Direito, Belo Horizonte, v. 42, p. 191-217, 2002/2003. p. 203. "A eqüidade não constitui um instrumento para a desestabilização das forças sociais, mas, ao contrário, a busca interminável de acertamentos e de proporcionalidades que estabeleçam um equilíbrio possível entre as pessoas que se situam no amplo exercício de sua condição de sujeitos de direitos e deveres." 
Vale lembrar que a aludida baliza se encontra apta a conduzir à realização de justiça material ${ }^{1572}$, notadamente por conta de sua função individualizadora ${ }^{1573}$, salientando-se que o recurso à equidade não se restringe às hipóteses legal ou contratualmente previstas. $^{1574}$

A perspectiva assumida neste trabalho exige, ainda, como frisado outrora, a admissão da existência de diferenças entre o texto e o sentido desse texto, ou seja, aquilo que o texto não "carrega." ${ }^{, 1575}$ Em seu momento de atuação, princípios, valores e regras hão de moldar-se à individualização do caso, postura que certamente - dentre outras vantagens - conduzirá à humanização da decisão. ${ }^{1576}$

Atualmente, em vez de procurar, em vão, respostas verdadeiras ou falsas, buscam-se soluções definíveis e aceitáveis dialeticamente. ${ }^{1577} \mathrm{E}$, longe de repetir o monólogo de outrora - contido, por exemplo, no silogismo e na universalização dos

1572 AMARAL, Francisco. A eqüidade no código civil brasileiro, Revista CEJ, Brasília, n. 25, p. 16-23, abr./jun. 2004. p. 22. "Quanto à sua própria natureza, a equiidade é um princípio ético, um modelo ideal de justiça, um princípio inspirador do Direito, que visa à realização da perfeita igualdade material, transformando-se em modelo jurídico quando aplicado pelo órgão jurisdicional a um conflito de interesses específico. Não é uma instância menor do Direito; ao contrário, constitui-se em um arquétipo axiológico que orienta a aplicação do Direito de modo a evitar eventual injustiça ou desigualdade, decorrente da rigidez da sua fórmula geral."

${ }^{1573}$ KFOURI NETO, Miguel. Graus de culpa e redução equitativa da indenização, Revista dos Tribunais, São Paulo, v. 94, n. 839, p. 47-68, set. 2005. p. 50-52.

1574 AMARAL, Francisco. Os princípios jurídicos na relação obrigatória, Revista da Ajuris, Porto Alegre, v. 32, n. 99, p. 133-143, set. 2005. p. 142.

1575 STRECK, Lenio Luiz. Da interpretação de textos à concretização de direitos: a incindibilidade, entre interpretar e aplicar - contributo a partir da hermenêutica filosófica, Revista da Faculdade de Direito da Universidade de Lisboa, Coimbra, v. 46, n. 2, p. 911-954, 2005. p. 919. Mais à frente, discorre o autor: "uma coisa é "deduzir" de um topos ou de uma lei o caso concreto; outra é entender o direito como aplicação de índole hermenêutica [mais que isso, de] hermenêutica filosófica, exatamente porque a hermenêutica jurídica deixa de ser uma "questão de método" e passa a ser filosofia [e, portanto como a] filosofia não é lógica, a hermenêutica jurídica não pode ser apenas uma ferramenta para a organização do pensamento." Ibid. p. 921923.

1576 PERLINGIERI, Pietro. Scuole civilistiche e dibattito ideologico: introduzione allo studio del diritto privato in italia, Rivista di Diritto Civile, Padova, anno 24, n. 4, p. 405-441, jul./ago. 1978. p. 436.

1577 WARAT, Luis Alberto. O direito e sua linguagem. 2 versão. 2 ed. Porto Alegre: SAFE, 1995. p. 94-96. "Para a obtenção dos efeitos de verdade dos raciocínios fundados no método tópico, apela-se, fundamentalmente, aos tópicos, isto é, crenças e metáforas legitimadas pelo senso comum. Os tópicos são diretrizes retóricas, lugares comuns revelados pela experiência e aptos a resolver questões vinculadas a círculos problemáticos concretos. Os tópicos operam como fio condutor de natureza retórica para toda a sequiência de argumentos que determinam o efeito de verossimilhança da conclusão. Os argumentos que o raciocínio fundado em tópicos apresenta, [sic] podem ser contraditórios, opostos, mas se são compatíveis com os tópicos, a contradição se devanece [sic] na enunciação e não se manifesta no raciocínio. Assim, os tópicos compatibilizam as oposições e contradições. A referência aos tópicos, como denominador comum do raciocínio não demonstrativo, permite que argumentos ambíguos ou contraditórios concorram para a sustentação da conclusão." 
conceitos -, a solução será dialogicamente construída, balizando-se na multiplicidade de valores em pauta e nas experiências dos diversos atores sociais. ${ }^{1578}$

Quando se pensa o Direito como uma prática social discursiva, (a) aproveitamse as regras existentes, sem hipertrofiar seu papel, (b) viabiliza-se a adoção de posturas criativas, sem o risco da discricionariedade e, enfim, (c) acoplam-se as dimensões sociais aos contornos jurídicos ${ }^{1579}$ balizadores da solução de cada problema.

Por isso, o Direito há de ser erigido a partir do diálogo forjado em uma racionalidade fundada na força do melhor argumento e desenvolvido com base em três vertentes: (a) respeito à verdade factual, (b) coerência com os ditames oriundos dos princípios sociais e (c) valoração das convicções doutrinárias. ${ }^{1580}$

Enfim - e acoplando as reflexões tecidas até este instante aos principais objetivos deste trabalho -, é oportuno apontar que, uma vez mais, resta claro por que a análise externa e meramente descritiva da relação obrigacional tem pouca utilidade na contemporaneidade.

Nesse prisma, muito embora a análise de cada situação de violação de dever contratual exija a compreensão de diversos aspectos, a identificação de eventual conduta culposa do devedor é dispensável, o que não afasta a perquirição das intersubjetividades na relação negocial concretamente estabelecida.

Aparentemente, é relevante resgatar, ainda, que o contrato não pode ser descrito como uma foto - que permite a quem se põe diante dela recordar um passado distante -, devendo ser pensando como um filme, no qual a valorização da confiança e das expectativas de cada personagem é premissa inafastável.

E, em cada um desses roteiros, ao se considerar que a manutenção do equilíbrio na relação contratual atua como base ética do direito obrigacional ${ }^{1581}$, quaisquer distorções

1578 GORDILHO, Heron José de Santana. Por uma dogmática pós-moderna, Revista do Programa de PósGraduação em Direito da Universidade Federal da Bahia, Salvador, v. 16, p. 47-61, 2008. p. 60.

1579 CÁRCOVA, Carlos María. ¿Que hacen los jueces cuando juzgan?. In: GESUALDI, Dora Mariana (Coord.). Derecho privado. Buenos Aires: Hammurabi, 2001. p. 13.

1580 FARIA, José Eduardo. As transformações do judiciário em face de suas responsabilidades sociais, Revista de Direito Alternativo, São Paulo, n. 2, p. 33-46, 1993. p. 46.

1581 AMARAL, Francisco. A interpretação jurídica segundo o código civil, Revista Brasileira de Direito Comparado, Rio de Janeiro, n. 29, p. 19-41, jul./dez. 2005. p. 30. 
hão de ser corrigidas - antes da análise da violação de dever contratual - de modo a manter o contrato ${ }^{1582}$, mas sem agravar a situação do parceiro negocial.

Assim, se, de um lado, a atribuição dos efeitos da violação de dever contratual deve ser promovida objetivamente e a partir da apreciação de cada relação negocial concretamente estabelecida ${ }^{1583}$, por outro e antes disso, será imperioso aferir se existe e/ou se a equivalência entre as prestações mantém-se intacta.

O diálogo que deve se estabelecer na construção da norma jurídica há de considerar diversas variáveis. Em um mundo em que os inventos e a pressa atuam como êmbolos a exigir a modificação do direito constituído, a objetivação do dever de reparar efetivamente reflete o aperfeiçoamento do espírito democrático, ao permitir, ao mesmo tempo, que a sociedade se afaste do individualismo nefasto e propicie a cada pessoa uma vida mais serena e segura. ${ }^{1584}$

A aparente severidade contida em um sistema objetivo pode ser atenuada com a adequada leitura do conteúdo de uma (a) causa estranha e não imputável, (b) do princípio da boa-fé, (c) da teoria da inexibilidade da prestação ${ }^{1585}$ e, ainda, do princípio da reparação integral. ${ }^{1586}$ É possível ponderar, ainda, que, na maioria dos casos, se fosse dado a uma das partes - mormente se contratantes eventuais - a opção de escolher pagar menor ou maior

${ }^{1582}$ BUSSATTA, Eduardo Luiz. Princípio da conservação dos contratos. In: HIRONAKA, Giselda Maria Fernandes Novaes; TARTUCE, Flávio (Coord.). Direito contratual: temas atuais. São Paulo: Método, 2008. p. 147-167.

${ }^{1583}$ BARCELLONA, Pietro. Formazione e sviluppo del diritto privato moderno. Napoli: Jovene, s/a. p. 387 391.

${ }^{1584}$ RIOS, Arthur Edmundo Souza. Responsabilidade civil pelo risco profissional, Revista da Faculdade de Direito da UFG, Goiânia, v. 4, n. 1, p. 37-50, jan./jun. 1980. p. 40-49.

${ }^{1585}$ GAMARRA, Jorge. Responsabilidad contractual objetiva. In: BUERES, Alberto Jesús; DE CARLUCCI, Aída Kemelmajer (Dir.). Responsabilidad por daños en el tercer milenio. Buenos Aires: Abeledo-Perrot, 1997. p. 119.

1586 GOMES, José Jairo. Responsabilidade civil na pós-modernidade: influência da solidariedade e da cooperação, Revista de Direito Privado, São Paulo, v. 6, n. 23, p. 227-233, jul./set. 2005. p. 233. "Ocorrendo situação causadora de dano, o equilíbrio derivado da solidariedade e da cooperação deve ser restabelecido. A atenção que se deve devotar aos valores e princípios superiores que orientam o sistema jurídico deixa claro que tal restabelecimento não implica sempre e necessariamente a busca incessante da exata recomposição patrimonial, porquanto a vida social impõe a todos a assunção de certos prejuízos e a exposição a certos riscos." No mesmo sentido: ZANCHIM, Kleber Luiz. Redução da indenização na responsabilidade objetiva, Revista de Direito Privado, São Paulo, v. 9, n. 33, p. 201-214, jan./mar. 2008. p. 213. "Na sociedade de risco pós-moderna é difícil falar em reparação integral de danos. Em nome do desenvolvimento, o sacrifício de direitos torna-se natural.." 
preço em razão da assunção pelo parceiro negocial de responsabilidade subjetiva ou objetiva, aquela optaria pela segunda das opções. ${ }^{1587}$

Nesse diálogo - que só pode ser promovido a partir dos marcos que informam o paradigma judicativo-decisório - há de se considerar que, em nível dogmático, sociológico e filosófico, a culpa não tem mais razão de ser e que, o fator de imputabilidade na atribuição do dever de reparar os danos contratuais é a confiança. Por hora, não há outra alternativa plausível. Deve ter em conta, ainda e enfim, a partir da intersubjetividade inerente à relação concretamente estabelecida, que a análise da imputação (ou não) do dever de reparar deve gravitar em torno da identificação de um dano injustamente causado - e/ou suportado - por alguém e do solidarismo que informa qualquer análise do tema.

1587 TRIMARCHI, Pietro. Sul significato economico dei criteri di responsabilità contrattuale, Rivista Trimestrale di Diritto e Procedura Civile, Milano, t. 26, p. 512-531, 1970. p. 529. 


\section{CONCLUSÃO}

É preciso, agora, antes que o tempo dificulte a apreensão dos sentidos contidos nas páginas que precedem este momento - transformando-os em ecos que se distanciam com o transcorrer dos dias -, tecer conclusões acerca de aspectos que, a nosso ver, despontam no universo explorado.

A tarefa assumida, sem ignorar, aqui, seu caráter irrefutavelmente provisório, tem, por principal escopo, atestar a inutilidade da culpa na arquitetura jurídica da responsabilidade contratual no direito brasileiro contemporâneo, bem como a importância da admissão dessa constatação pela comunidade jurídica.

Aceitar a principal conclusão alcançada neste trabalho exige, entretanto, a apreensão de pré-conceitos. Assim e nesse contexto, assevere-se ser de fundamental importância perceber que o direito civil fundado na Modernidade não possui aptidão para solucionar os problemas que permeiam a vida na realidade contemporânea, momento indelevelmente marcado pela complexidade, contingência, reflexividade, tecnocentrismo e pluralismos das mais distintas ordens.

É relevante compreender que, à medida que a insegurança toma conta de cada instante da vida, e o fluir do tempo impede antever as consequências contidas em cada conduta prometida a outrem, a culpa, gradativamente, perdeu espaço na formatação do dever de reparar. Quando se admite que a contingência é uma das características mais expressivas da contemporaneidade e quando se percebe que ela atua impedindo a formulação de juízos de previsibilidade, resplandece a conclusão de que o fundamento sociológico de sustentação da culpa foi a pique.

Entender o processo que conduziu à morte da culpa impõe, também, identificar que a racionalidade jurídica hodierna tem, como cerne, o texto constitucional. Nele estão afixados os holofotes que conduzirão às respostas adequadas em cada conflito de interesses detectado na concretude da vida. Assim, como as soluções para as patologias que afetam o desvelar natural do processo obrigacional só poderão ser erigidas a partir dos princípios constitucionais - acoplados, é evidente, à esfera contratual -, mostra-se, de fundamental importância, ultrapassar os simplismos criados pelo tratamento dogmático do tema. 
Infira-se, portanto, que a solidariedade social, a igualdade material e a dignidade da pessoa humana - dentre outras balizas - orientarão todo e qualquer processo almejando a conformação do dever de reparar os danos provocados pela violação de um dever contratual, banindo, definitivamente, do pensamento jurídico hodierno, quaisquer influxos com natureza exclusivamente individualista e, com eles, obviamente, a culpa.

Outro passo importante para a fixação dos sentidos contidos no texto é a percepção de que o dever de reparar os danos contratuais tem natureza autônoma e que ele será disparado diante da constatação de existência de disparidade(s) relevante(s) entre a conduta desvelada e as promessas contidas no programa obrigacional concretamente ajustado entre as partes.

Ratifique-se que o aludido dever tem por pressupostos (a) a existência de um contrato, (b) a lesão a interesse legítimo de uma das partes -, (c) a antijuridicidade, compreendida, neste momento, como comportamento contrário ao Direito - e, enfim, (d) um nexo de causalidade atando a conduta - antijurídica - à lesão a um interesse juridicamente protegido.

Aceitando, ou não, o leitor a morte da culpa na responsabilidade contratual, parece ser irrefutável que essa não tem como ser validamente qualificada como elemento indispensável ao processo de conformação do dever de reparar.

Noutro mote, a importância da noção de violação de dever - no interior da qual se encontram (a) o inadimplemento, (b) a mora, (c) o cumprimento inexato da prestação e (d) a violação de deveres gerais de conduta - merece ser realçada. Isso porque, além de (a) facilitar o tratamento sistêmico das distintas patologias que podem se manifestar no desvelar de cada processo obrigacional, (b) comprovam a validade de assertivas atestando que esse último deve ser compreendido tendo em conta toda sua complexidade, visão que, aliás, afasta perspectivas meramente descritivas do fenômeno obrigacional e facilita a apreensão de uma análise com viés funcionalizado.

O passeio realizado através do tempo em busca da reconstrução de momentos importantes na História - é evidente, naquilo que interessa, mais de perto, a este estudo tornou factível aceitar que a culpa, durante longa data, favoreceu a expansão do capitalismo e que ideologias veladas, a repetição acrítica do conhecimento e o conservadorismo dos juristas estão entre os principais responsáveis por sua mitificação. 
Aliás, essa mesma tentativa de recuperação de momentos, às vezes, esquecidos, mostrou por que a culpa deve ser concebida em perspectiva subjetiva, mesmo que, ao ser assim pensada, não se torne adequada à solução dos problemas existentes na contemporaneidade. É oportuno repisar que as teorias normativistas, ao promoverem a fusão das noções de culpa e de antijuridicidade, em verdade, ratificam a tese contida no título dessa pesquisa, transformando a culpa em um adorno sem utilidade alguma.

É oportuno apontar que, como o fortuito ${ }^{1588}$ não é limite da culpa, ao se exigir a demonstração de que a violação de um dever tem origem em causa estranha e não imputável - como prática hábil à desconstituição da presunção de culpa contida naquela -, se exige, de fato, a prova de inexistência de nexo causal. Resta demonstrado, portanto, que, em termos dogmáticos, além de ultrapassada, a culpa é uma figura completamente prescindível à configuração do dever de reparar os danos contratuais na contemporaneidade.

$\mathrm{O}$ retorno ao passado permitiu, enfim, inferir que, a partir de fundamentos (a) sociológicos - as vítimas do maquinismo -, (b) políticos - o Estado Social começava a germinar - e (c) filosóficos - o personalismo -, construíram, em um primeiro momento, teses, com o intuito de mitigar os efeitos deletérios da culpa e, em um segundo instante, com o propósito de banir, de uma vez por todas, a culpa de, pelo menos, alguns dos moldes conformadores do dever de reparar.

Em linhas gerais, o primeiro grupo de teses - referidas, acima - buscou (a) alargar as possibilidades semânticas contidas na culpa, (b) realçar o critério abstrato na apreciação daquela, (c) formatar presunções que substituíssem sua prova e (d) aumentar as hipóteses abarcadas pela responsabilidade contratual. E, uma vez demonstrado o ocaso da culpa, operou-se uma segunda metamorfose que, tendo por pauta a necessidade de transferir o dano àquele que o causou, e não mais punir quem o provocou, gradativamente, fez com que mais e mais questões passassem a ser solucionadas a partir de fatores objetivos de imputação do dever de reparar.

É oportuno apontar, ainda, que, filosoficamente, o fundamento metafísico sobre o qual se fundou a culpa perdeu sua razão de ser na contemporaneidade, podendo ser substituído, mais que adequadamente, pela confiança, compreendida, aqui, em perspectiva sistêmica.

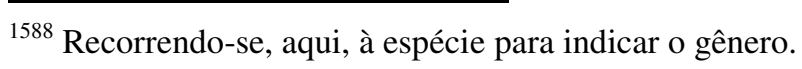


Aliás, do conflito que potencialmente se instaura entre a estrutura binária de atuação da culpa - pecado e punição - e a lógica de promoção de respeito ao próximo, contida na valorização e respeito à confiança, aparentemente, não há como não se optar pela última.

É de suma importância, entretanto, identificar que a lesão a um interesse juridicamente protegido - que pode ser tranquilamente lida como dano, desde que esse assim seja compreendido - é o cerne ao redor do qual a responsabilidade contratual há de ser estruturada e pensada.

Aceitar que o dano se revela como um mal de ordem social implica a extirpação da culpa do campo operativo da responsabilidade contratual, favorecendo, no mínimo, (a) o respeito à isonomia, (b) a superação de teses de cunho patrimonialindividualistas, (c) a construção de um sistema dogmático coerente, (d) a redução do número de julgados incorretos, (e) a aproximação da responsabilidade contratual do direito de danos, (f) a conformação da temática sob análise aos pressupostos que informam a personalização do direito civil, (g) a promoção da função preventiva da responsabilidade civil, (h) a solidariedade social, (i) o distanciamento da leitura da matéria a partir do sistema binário crime/castigo, (j) a definitiva superação das construções que veem o fortuito como limite da culpa e, por que não, (k) a construção de soluções em conformidade com os anseios de uma sociedade plural e democraticamente estabelecida.

E, como o contrato que obriga é o que se mantém equilibrado - tanto no viés econômico, como no jurídico -, em cada um dos seus momentos - em verdade, dos momentos do processo obrigacional -, não se pode olvidar que a imposição do dever de reparar se subordina à existência e à manutenção do balanceamento entre as prestações reciprocamente consideradas.

Resta, enfim, a esperança de que, cada vez que Hermes seja conclamado a distribuir justiça, ele possa incorporar no seu discurso a consideração de que cada pessoa, longe de ser tratada como sujeito do Direito, deve ser vista, não apenas como sujeito de direitos, mas, especialmente, como titular de responsabilidades, banindo, assim, definitivamente, a culpa do processo de conformação jurídica da responsabilidade contratual. 


\section{REFERÊNCIAS}

AFONSO, Elza Maria Miranda. Prefácio. In: MATA-MACHADO, Edgar de Godoi. Contribuição ao personalismo jurídico. Belo Horizonte: Del Rey, 2000.

AGOGLIA, María Martha. ¿Es la antijuridicidad un presupuesto de la responsabilidad civil?. In: GESUALDI, Dora Mariana (Coord.). Derecho privado. Buenos Aires: Hammurabi, 2001.

AGOGLIA, María Martha; BORAGINA, Juan Carlos; MEZA, Jorge Alfredo. Responsabilidad por incumplimiento contractual. Buenos Aires: Hammurabi, 2003.

AGOGLIA, María Martha; BORAGINA, Juan Carlos; MEZA, Jorge Alfredo. La buena fe y la obligación de seguridad. In: CÓRDOBA, Marcos (Dir.). Tratado de la buena fe en el derecho: doctrina nacional. Buenos Aires: La Ley, 2004, v. 1.

AGUIAR DIAS, José de. Da responsabilidade civil, Revista do Advogado, São Paulo, n. 19, p. 33 39, out. 1985.

AGUIAR DIAS, José de. Da responsabilidade civil. 10 ed. Rio de Janeiro: Forense, 1995, v. 1.

AGUIAR JUNIOR, Ruy Rosado de. O poder judiciário e a concretização das cláusulas gerais: limites e responsabilidade, Revista de Direito Renovar, Rio de Janeiro, n. 18, p. 11-19, set./dez. 2000.

AGUIAR JUNIOR, Ruy Rosado de. Os contratos nos códigos civis francês e brasileiro, Revista CEJ, Brasília, v. 9, n. 28, p. 5-14, jan./mar. 2005.

AGUIAR JUNIOR, Ruy Rosado de. Projeto do código civil: as obrigações e os contratos, Revista de Direito Renovar, Rio de Janeiro, n. 15, p. 19-35, set./dez. 1999.

AGUIAR JUNIOR, Ruy Rosado de. Responsabilidade civil do médico, Revista dos Tribunais, São Paulo, v. 84, n. 718, p. 33-53, ago. 1995.

AGUIAR JUNIOR, Ruy Rosado. O princípio da igualdade e o direito das obrigações. In: TEPEDINO, Gustavo; FACHIN, Luiz Edson (Coord.). $O$ direito e o tempo: embates jurídicos e utopias contemporâneas. Rio de Janeiro: Renovar, 2008.

AGUIAR, Roberto. O imaginário dos juristas, Revista de Direito Alternativo, São Paulo, n. 2, p. 18-27, 1993.

ÁGUILA, Ramón Domínguez. La culpa en el derecho civil chileno - aspectos generales, Revista Anales Derecho UC, Santiago, v. 3, p. 107-138, mar. 2008.

ALBESA, Joaquín Rams. La moral en la disciplina general de los contratos. In: GESUALDI, Dora Mariana (Coord.). Derecho privado. Buenos Aires: Hammurabi, 2001.

ALBUQUERQUE, Fabíola Santos. O princípio da informação à luz do código civil e do código de defesa do consumidor. In: BARROSO, Lucas Abreu (Org.). Introdução crítica ao código civil. Rio de Janeiro: Forense, 2006.

ALPA, Guido. Responsabilità civile e danno: lineamenti e questioni. Imola: Il Mulino, 1991. 
ALTERINI, Atílio Aníbal. Estudios de derecho civil: conceptos, contratos, consumidor, derecho de daños. Buenos Aires: La Ley, 2007.

ALTERINI, Atilio Aníbal. Responsabilidad objetiva derivada de la generación de confianza, Revista de Direito Civil, Imobiliário, Agrário e Empresarial, São Paulo, v. 19, n. 73, p. 5-16, jul./set. 1995.

ALTERINI, Atílio Aníbal. Teoría de la imprevisión y cláusula de hardship. In: GESUALDI, Dora Mariana (Coord.). Derecho privado. Buenos Aires: Hammurabi, 2001.

ALTHEIM, Roberto. Direito de danos: pressupostos contemporâneos do dever de indenizar. Curitiba: Juruá, 2008.

ALVES, Alaôr Caffé. A função ideológica do direito, Revista da Faculdade de Direito de São Bernardo do Campo, São Bernardo do Campo, v. 6, n. 8, p. 1-11, 2002.

ALVES, Alaôr Caffé. Estado e direito: estrutura, formas e ilusões da sociedade real, Revista da Ordem dos Advogados do Brasil, São Paulo, v. 18, n. 43/48, p. 57-74, 1988.

ALVIM, Agostinho. Da eqüidade, Revista dos Tribunais, São Paulo, v. 30, n. 132, p. 3-8, jul. 1941.

ALVIM, Agostinho. Da inexecução das obrigações e suas conseqüências. 4 ed. São Paulo: Saraiva, 1972.

ALVIM, Agostinho. Do enriquecimento sem causa, Revista dos Tribunais, São Paulo, n. 259, p. 3 36, 1957.

ALVIM, Arruda. A função social dos contratos no novo código civil, Revista dos Tribunais, São Paulo, v. 92, n. 815, p. 11-31, set. 2003.

ALVIM, Decio Ferraz. Da cláusula "rebus sic stantibus", Revista dos Tribunais, São Paulo, v. 23, n. 90, p. 13-20, mai. 1934.

AMARAL, Francisco. A eqüidade no código civil brasileiro, Revista CEJ, Brasília, n. 25, p. 16-23, abr./jun. 2004.

AMARAL, Francisco. A evolução do direito civil brasileiro, Revista da PGE, Porto Alegre, v. 13, n. 38 , p. $65-83,1983$.

AMARAL, Francisco. A interpretação jurídica segundo o código civil, Revista Brasileira de Direito Comparado, Rio de Janeiro, n. 29, p. 19-41, jul./dez. 2005.

AMARAL, Francisco. Direito civil: introdução. 7 ed. Rio de Janeiro: Renovar, 2008.

AMARAL, Francisco. Historicidade e racionalidade na construção do direito brasileiro, Revista Brasileira de Direito Comparado, Rio de Janeiro, n. 20, p. 29-87, jan./jun. 2001.

AMARAL, Francisco. Individualismo e universalismo no direito civil brasileiro: permanência ou superação de paradigmas romanos?, Revista Brasileira de Direito Comparado, Rio de Janeiro, n. 13, p. 64-95, jul./dez. 1992.

AMARAL, Francisco. Individualismo e universalismo no direito civil brasileiro: permanência ou superação de paradigmas romanos?, Revista de Direito Civil, Imobiliário, Agrário e Empresarial, São Paulo, v. 19, n. 71, p. 69-86, jan./mar. 1995. 
AMARAL, Francisco. O código civil brasileiro e o problema metodológico de sua realização. In: TARTUCE, Flávio; CASTILHO, Ricardo (Coord.). Direito civil: direito patrimonial, direito existencial. São Paulo: Método, 2006.

AMARAL, Francisco. O direito civil na pós-modernidade. In: FIUZA, César; SÁ, Maria de Fátima Freire de; NAVES, Bruno Torquato de Oliveira (Coord.). Direito civil: atualidades. Belo Horizonte: Del Rey, 2003.

AMARAL, Francisco. O projeto de código civil, Revista Brasileira de Direito Comparado, Rio de Janeiro, n. 16, p. 23-47, jan./jun. 1999.

AMARAL, Francisco. Os princípios jurídicos na relação obrigatória, Revista da Ajuris, Porto Alegre, v. 32, n. 99, p. 133-143, set. 2005.

AMARAL, Francisco. Uma carta de princípios para um direito como ordem prática. In: TEPEDINO, Gustavo; FACHIN, Luiz Edson (Coord.). O direito e o tempo: embates jurídicos e utopias contemporâneas. Rio de Janeiro: Renovar, 2008.

AMÉZAGA, Juan José. Culpa aquiliana: leciones del curso de derecho civil. Montevideo: s/e, 1914.

AMÉZAGA, Juan José. Responsabilidade por culpa: unidade genérica e diferenças específicas, Revista Forense, Rio de Janeiro, v. 35, n. 75, p. 67-73, jul./set. 1938.

ANDRADE, Darcy Bessone de Oliveira. Aspectos da evolução da teoria dos contratos. São Paulo: Saraiva, 1949.

ANTUNES VARELA, João de Matos. Das obrigações em geral. 7 ed. Coimbra: Almedina, 1997, v. 2.

ANTUNES VARELA, João de Matos. Direito das obrigações. Rio de Janeiro: Forense, 1978, v. 2.

ANTUNES VARELA, João de Matos. Direito das obrigações: conceito, estrutura e função da relação obrigacional, fontes das obrigações, modalidades das obrigações. Rio de Janeiro: Forense, 1977, v. 1.

ASCENSÃO, José de Oliveira. Alteração das circunstâncias e justiça contratual no novo código civil, Revista Trimestral de Direito Civil, Rio de Janeiro, n. 25, p. 93-118, jan./mar. 2006.

ASCENSÃO, José de Oliveira. Cláusulas contratuais gerais, cláusulas abusivas e o novo código civil, Revista da Faculdade de Direito da Universidade Federal do Paraná, Porto Alegre, n. 39, p. 5-22, 2003.

ASCENSÃO, José de Oliveira. Cláusulas contratuais gerais, cláusulas abusivas e boa-fé, Revista de Direito Privado, São Paulo, v. 1, n. 4, p. 9-25, out./dez. 2000.

ASCENSÃO, José de Oliveira. $O$ direito: introdução e teoria geral - uma perspectiva lusobrasileira. 2 ed. Rio de Janeiro: Renovar, 2001.

ASSIS, Araken de. Resolução do contrato por inadimplemento. 3 ed. São Paulo: RT, 1999.

ÁVILA, Humberto. Teoria dos princípios: da definição à aplicação dos princípios jurídicos. 4 ed. São Paulo: Malheiros, 2004. 
AZEVEDO JUNIOR, José Osório de. Breves anotações sobre o pagamento e o ato jurídico não negocial. In: NANNI, Giovanni Ettore (Coord.). Temas relevantes do direito civil contemporâneo: reflexões sobre os cinco anos do código civil. São Paulo: Atlas, 2008.

AZEVEDO, Álvaro Villaça. Inexecução culposa e cláusula penal compensatória, Revista dos Tribunais, São Paulo, n. 791, p. 121-132, set. 2001.

AZEVEDO, Álvaro Villaça. Teoria geral das obrigações. 10 ed. São Paulo: Atlas, 2004.

AZEVEDO, Vicente de Paulo Vicente de. O fundamento da responsabilidade civil extracontratual, Revista de Direito Privado, São Paulo, v. 1, n. 1, p. 151-165, jan./mar. 2000.

BAÍA, Jacinto Américo Guimarães. A evolução da responsabilidade civil e a reparação do dano nuclear, Revista de Direito Civil, Imobiliário, Agrário e Empresarial, São Paulo, v. 2, n. 4, p. 4968, abr./jun. 1978.

BALLESTEROS, Jorge Santos. La responsabilidad civil contractual aplicada a la actividad del empresario. In: ESPINOSA, Fabricio Mantilla; BARRIOS, Francisco Ternera (Dir.). Los contratos en el derecho privado. Bogotá: Legis, 2007.

BAPTISTA, Sílvio Neves. A crise do contrato, Revista de Direito Civil, Imobiliário, Agrário e Empresarial, São Paulo, v. 9, n. 32, p. 22-35, abr./jun. 1985.

BARASI, Lodovico. La teoria generale delle obbligazioni: l'attuazione. Milano: Giuffrè, 1946, v. 3.

BARBERO, Domenico. Sistema del derecho privado: obligaciones. Trad. Santiago Sentis Melendo. Buenos Aires: EJEA, 1967, v. 3.

BARBOSA, Mafalda Miranda. Liberdade vs. responsabilidade: a precaução como fundamento da imputação delitual?. Coimbra: Almedina, 2006.

BARCELLONA, Pietro. Formazione e sviluppo del diritto privato moderno. Napoli: Jovene, s/a.

BARRETO, Cunha. O dirigismo na vida dos contratos, Revista dos Tribunais, São Paulo, v. 28, n. 117, p. 455-462, jan. 1939.

BARRETO, Ricardo Menna; ROCHA, Leonel Severo. Confiança nos contratos eletrônicos: uma observação sistêmica, Revista Jurídica Cesumar, v. 7, n. 2, p. 409-425, jul./dez. 2007.

BARRETTO, Vicente de Paulo. Responsabilidade e teoria da justiça contemporânea. In: SILVA FILHO, José Carlos Moreira da; PEZZELLA, Maria Cristina Cereser (Coord.). Mitos e rupturas no direito civil contemporâneo. Rio de Janeiro: Lumen Juris, 2008.

BARRIOS, Francisco Ternera. Introducción. In: ESPINOSA, Fabricio Mantilla; BARRIOS, Francisco Ternera (Dir.). Los contratos en el derecho privado. Bogotá: Legis, 2007.

BARRIOS, Luis. El conflicto de la celulosa. Estado de derecho. Montevideo, dez. 2007.

BARROS, Flávio Augusto Monteiro. Manual de direito civil: direito das obrigações e contratos. São Paulo: Método, 2005, v. 2.

BARROS, Raimundo Gomes de. Relação de causalidade e o dever de indenizar, Revista de Direito do Consumidor, São Paulo, n. 27, p. 32-41, jul./set. 1998.

BARROSO, Lucas Abreu et all. Direito dos contratos. São Paulo: RT, 2008. 
BARROSO, Lucas Abreu. A função ambiental do contrato. In: DELGADO, Mário Luiz; ALVES, Jones Figueirêdo (Coord.). Questões controvertidas: no direito das obrigações e dos contratos. São Paulo: Método, 2005, v. 4.

BARROSO, Lucas Abreu. A obrigação de indenizar e a determinação da responsabilidade civil por dano ambiental. Rio de Janeiro: Forense, 2006.

BARROSO, Lucas Abreu. A realização do direito civil. Curitiba: Juruá, 2011. (No prelo).

BARROSO, Lucas Abreu. Desmistificando as relações de família no novo direito civil. In: ALBUQUERQUE, Fabíola Santos; EHRHARDT JUNIOR, Marcos; OLIVEIRA, Catarina Almeida de (Coord.). Famílias no direito contemporâneo: estudos em homenagem a Paulo Luiz Netto Lôbo. Salvador: Podivm, 2009.

BARROSO, Lucas Abreu. Novas fronteiras da obrigação de indenizar e da determinação da responsabilidade civil. In: DELGADO, Mário Luiz; ALVES, Jones Figueiredo (Coord.). Questões controvertidas: responsabilidade civil. São Paulo: Método, 2006, v. 5.

BARROSO, Lucas Abreu. Situação atual do art. $4^{\circ}$ da lei de introdução ao código civil, Revista Brasileira de Direito Constitucional, São Paulo, n. 5, p. 236-242, 2005.

BARROSO, Lucas Abreu; FROTA, Pablo Malheiros da Cunha. A obrigação de reparar por danos resultantes da liberação do fornecimento e da comercialização de medicamentos. Inédito.

BARZOTTO, Luis Fernando. Os direitos humanos como direitos subjetivos: da dogmática jurídica à ética, Revista da PGE, Porto Alegre, v. 28, n. 59, p. 137-175, jun. 2004.

BAUMAN, Zygmunt. Medo líquido. Trad. Carlos Alberto Medeiros. Rio de Janeiro: Zahar, 2008.

BAUMAN, Zygmunt. Modernidade e ambivalência. Trad. Marcus Penchel. Rio de Janeiro: Zahar, 1999.

BAUMAN, Zygmunt. Modernidade líquida. Trad. Plínio Dentzien. Rio de Janeiro: Zahar, 2001.

BAUMAN, Zygmunt. Vida líquida. Trad. Carlos Alberto Medeiros. Rio de Janeiro: Zahar, 2007.

BAUMAN, Zygmunt. Vida para o consumo: a transformação das pessoas em mercadorias. Trad. Carlos Alberto Medeiros. Rio de Janeiro: Zahar, 2008.

BECK, Ulrich. La sociedad del riesgo: hacia una nueva modernidad. Trad. Jorge Navarro. Barcelona: Paidós, 1998.

BECK, Ulrich. Viviendo en la sociedad del riesgo mundial. Trad. María Ángeles Sabiote González; Yago Mellado López. Barcelona: CIDOB, 2007.

BECKER, Anelise. Elementos para uma teoria unitária da responsabilidade civil, Revista de Direito do Consumidor, São Paulo, n. 13, p. 42-55, jan./mar. 1995.

BELLEY, Jean-Guy. Uma filosofia da aspiração jurídica: a arte de bem se obrigar, Revista Trimestral de Direito Civil, Rio de Janeiro, n. 23, p. 17-37, jul./set. 2005.

BENÍTEZ, Elsa. La revolución industrial y el derecho de daños: sus consecuencias. In: GHERSI, Carlos Alberto (Dir.). Responsabilidad objetiva: el artículo 1113 y la ley 24.999. Mendoza: Ediciones Jurídicas Cuyo, 1999. 
BENJAMIN, Antônio Herman de Vasconcellos e; MARQUES, Cláudia Lima; BESSA, Leonardo Roscoe. Manual de direito do consumidor. São Paulo: RT, 2007.

BERDAGUER, Jaime. Las obligaciones de resultado: situación actual y perspectivas futuras. In: FERNÁNDEZ, Carlos López; CAUMONT, Arturo; CAFFERA, Gerardo (Coord.). Estudios de derecho civil en homenaje al profesor Jorge Gamarra. Montevideo: FCU, 2001.

BERGEL, Salvador Darío. Introducción del principio precautorio en la responsabilidad civil. In: GESUALDI, Dora Mariana (Coord.). Derecho privado. Buenos Aires: Hammurabi, 2001.

BERMAN, Harold. Direito e revolução: a formação da tradição jurídica ocidental. Trad. Eduardo Takemi Kataoka. São Leopoldo: Unisinos, 2006.

BERTI, Silma Mendes. Considerações sobre a responsabilidade civil do médico, Revista de Direito Comparado, Belo Horizonte, v. 2, n. 2, p. 121-129, mar. 1998.

BETTI, Emílio. Teoria generale delle obbligazioni: prolegomeni: funzione economico-sociale dei rapporti d'obbligazione. Milano: Giuffrè, 1953, v. 1.

BEVILAQUA, Clóvis. Direito das obrigações. 5 ed. Rio de Janeiro: Freitas Bastos, 1940.

BIONDI, Biondo. Istituzioni di diritto romano. 2 ed. Milano: Giuffrè, 1952.

BIRENBAUM, Gustavo. Classificação: obrigações de dar, fazer e não fazer. In: TEPEDINO, Gustavo (Coord.). Obrigações: estudos na perspectiva civil-constitucional. Rio de Janeiro: Renovar, 2005.

BITTAR, Carlos Alberto. Direito das obrigações. 2 ed. Rio de Janeiro: Forense Universitária, 2004.

BITTAR, Carlos Alberto; BITTAR FILHO, Carlos Alberto. Direito civil constitucional. 3 ed. São Paulo: RT, 2003.

BOBBIO, Norberto. Da estrutura à função: novos estudos de teoria do direito. Trad. Daniela Beccaccia Versiani. Barueri: Manole, 2007.

BOBBIO, Norberto. O positivismo jurídico: lições de filosofia do direito. Trad. Márcio Pugliesi; Edson Bini; Carlos Rodrigues. São Paulo: Ícone, 1995.

BOCCANERA, Ney da Fontoura. Culpa aquiliana, Revista de Direito Civil, Imobiliário, Agrário e Empresarial, São Paulo, v. 7, n. 24, p. 106-108, abr./jun. 1983.

BOLOGNA, Pablo Salvat. ¿Debe el derecho ser justo?, Persona y Sociedad, Santiago, v. 18, n. 2, p. 33-62, ago. 2004.

BONAVIDES, Paulo. Curso de direito constitucional. 9 ed. São Paulo: Malheiros, 2000.

BONFIM, Vinícius Silva. A responsabilidade de ter "olhos": o direito na perspectiva do imaginário literário, Revista CEJ, Brasília, v. 14, n. 48, p. 101-109, jan./mar. 2010.

BORAGINA, Juan Carlos. El daño. In: GESUALDI, Dora Mariana (Coord.). Derecho privado. Buenos Aires: Hammurabi, 2001.

BORGES, Nelson. A teoria da imprevisão no direito civil e no processo civil. São Paulo: Malheiros, 2002. 
BORGES, Roxana Cardoso Brasileiro. Contrato: do clássico ao contemporâneo - a reconstrução do conceito, Revista do Programa de Pós-Graduação em Direito da Universidade Federal da Bahia, Salvador, v. 13, p. 29-50, 2006.

BORGES, Roxana Cardoso Brasileiro. Direitos da personalidade e dignidade: da responsabilidade civil para a responsabilidade constitucional. In: DELGADO, Mário Luiz; ALVES, Jones Figueiredo (Coord.). Questões controvertidas: responsabilidade civil. São Paulo: Método, 2006, v. 5.

BORGES, Roxana Cardoso Brasileiro. Reconstrução do conceito de contrato: do clássico ao atual. In: HIRONAKA, Giselda Maria Fernandes Novaes; TARTUCE, Flávio (Coord.). Direito contratual: temas atuais. São Paulo: Método, 2008.

BORGHI, Hélio. Responsabilidade civil: breves reflexões doutrinárias sobre o estado no direito brasileiro. In: NERY, Rosa Maria Barreto Borriello de Andrade; DONNINI, Rogério (Coord.). Responsabilidade civil: estudos em homenagem ao professor Rui Geraldo Carmargo Viana. São Paulo: RT, 2009.

BOTH, Laura Garbini; PINHEIRO, Rosalice Fidalgo. As "fórmulas mágicas" da boa-fé na jurisprudência brasileira: um cenário de transferência de culturas. In: CORTIANO JUNIOR, Eroulths et all (Coord.). Apontamentos críticos para o direito civil brasileiro contemporâneo. Curitiba: Juruá, 2009.

BRAGA NETTO, Felipe Peixoto. Teoria dos ilícitos civis. Belo Horizonte: Del Rey, 2003.

BRANCO, Gerson Luiz Carlos. A proteção das expectativas legítimas derivadas das situações de confiança: elementos formadores do princípio da confiança e seus efeitos, Revista de Direito Privado, São Paulo, v. 3, n. 12, p. 167-225, out./dez. 2002.

BRAVO, Adolfo. O conceito de responsabilidade no código civil portuguez, Revista dos Tribunais, São Paulo, v. 25, n. 104, p. 361-376, nov. 1936.

BREBBIA, Roberto H. La equidad en el derecho de daños. In: BUERES, Alberto Jesús; DE CARLUCCI, Aída Kemelmajer (Dir.). Responsabilidad por daños en el tercer milenio. Buenos Aires: Abeledo-Perrot, 1997.

BRITO, Alejandro Guzmán. La penetración del derecho romano en américa, Revista Chilena de Derecho, Santiago, v. 18, n. 2, p. 203-211, mai./ago. 1991.

BRITO, Andréia Carvalho de. Contrato de seguro de crédito à exportação. In: PAMPLONA FILHO, Rodolfo; PEDROSA, Lauricio Alves Carvalho. Novas figuras contratuais: homenagem ao professor Washington Luiz da Trindade. São Paulo: LTr, 2010.

BRUGI, Biagio. Instituciones de derecho civil. Trad. Jaime Simo Bofarull. Cidade do México: UTEHA, 1946.

BUERES, Alberto Jesus. Derecho de daños. Buenos Aires: Hammurabi, 2001.

BUERES, Alberto Jesus. La buena fe y la imposibilidad de pago en la responsabilidad contractual. In: CÓRDOBA, Marcos (Dir.). Tratado de la buena fe en el derecho: doctrina nacional. Buenos Aires: La Ley, 2004, v. 1.

BUERES, Alberto Jesus. La localización del daño resarcible. In: FERNÁNDEZ, Carlos López; CAUMONT, Arturo; CAFFERA, Gerardo (Coord.). Estudios de derecho civil en homenaje al profesor Jorge Gamarra. Montevideo: FCU, 2001. 
BUSNELLI, Francesco Donato. L'illecito civile nella stagione europea delle riforme del diritto delle obbligazioni, Rivista de Diritto Civile, Padova, anno 52, n. 6, p. 439-457, nov./dez. 2006.

BUSSANI, Mauro. As peculiaridades da noção de culpa: um estudo de direito comparado. Trad. Helena Saldanha. Porto Alegre: LAEL, 2000.

BUSSATTA, Eduardo Luiz. Princípio da conservação dos contratos. In: HIRONAKA, Giselda Maria Fernandes Novaes; TARTUCE, Flávio (Coord.). Direito contratual: temas atuais. São Paulo: Método, 2008.

BUSSATTA, Eduardo Luiz. Resolução dos contratos e teoria do adimplemento substancial. São Paulo: Saraiva, 2007.

BUSTAMANTE ALSINA, Jorge. El perfil de la responsabilidad civil al finalizar el siglo XX. In: BUERES, Alberto Jesús; DE CARLUCCI, Aída Kemelmajer (Dir.). Responsabilidad por daños en el tercer milenio. Buenos Aires: Abeledo-Perrot, 1997.

BUSTAMANTE ALSINA, Jorge. Teoria general de la responsabilidad civil. 3 ed. Buenos Aires: Abeledo-Perrot, 1980.

BUSTAMANTE, Lino Rodriguez-Arias. Derecho de obligaciones. Madrid: Editorial Revista de Derecho Privado, 1965.

CAENEGEM, Raoul C. van. Uma introdução histórica ao direito privado. Trad. Carlos Eduardo Lima Machado. São Paulo: Martins Fontes, 2000.

CAFFERA, Gerardo. Autonomía privada: los cambios y las tensiones del presente. In: FERNÁNDEZ, Carlos López; CAUMONT, Arturo; CAFFERA, Gerardo (Coord.). Estudios de derecho civil en homenaje al profesor Jorge Gamarra. Montevideo: FCU, 2001.

CALDANI, Miguel Angel Ciuro. Aspectos filosóficos de la buena fe. In: CÓRDOBA, Marcos (Dir.). Tratado de la buena fe en el derecho: doctrina nacional. Buenos Aires: La Ley, 2004, v. 1.

CALIXTO, Marcelo Junqueira. A culpa na responsabilidade civil: estrutura e função. Rio de Janeiro: Renovar, 2008.

CALIXTO, Marcelo Junqueira. Reflexões em torno do conceito de obrigação, seus elementos e fontes. In: TEPEDINO, Gustavo (Coord.). Obrigações: estudos na perspectiva civil-constitucional. Rio de Janeiro: Renovar, 2005.

CAMARGO, Margarida Maria Lacombe. Hermenêutica e argumentação: uma contribuição ao estudo do direito. 3 ed. Rio de Janeiro: Renovar, 2003.

CAMBLER, Everaldo. Curso avançado de direito civil: direito das obrigações. São Paulo: RT, 2001.

CAMBLER, Everaldo; GONÇALVES, Carlos Roberto; MAIA, Mairan. Comentários ao código civil brasileiro: do direito das obrigações. Rio de Janeiro: Forense, 2003, v. 3.

CAMPISTA FILHO, David. Responsabilidade civil e a ação liberatória do seguro, Revista dos Tribunais, São Paulo, v. 31, n. 137, p. 16-25, mai. 1942.

CANARIS, Claus-Wilhelm. A liberdade e a justiça contratual na "sociedade de direito privado". In: MONTEIRO, António Pinto (Coord.). Contratos: actualidade e evolução. Porto: Universidade Católica Portuguesa, 1997. 
CANARIS, Claus-Wilhelm. Direitos fundamentais e direito privado. Trad. Ingo Wolfgang Sarlet; Paulo Moto Pinto. Coimbra: Almedina, 2003.

CANARIS, Claus-Wilhelm. La riforma del diritto tedesco delle obbligazioni: contenuti fondamentali e profili sistematici del Gesetz zur Modernisierung des Schuldrechts. Trad. Marcello Farneti; Sonja Haberl. Padova: CEDAM, 2003.

CANARIS, Claus-Wilhelm. O novo direito das obrigações na alemanha, Revista Brasileira de Direito Comparado, Rio de Janeiro, n. 25, p. 3-26, jul./dez. 2003.

CANARIS, Claus-Wilhelm. Pensamento sistemático e conceito de sistema na ciência do direito. 3 ed. Trad. Antônio Manuel da Rocha e Menezes Cordeiro. Lisboa: Fundação Calouste Gulbenkian, 2002.

CANCINO, Emilssen González de. La protección del deudor en la tradición romanística: una búsqueda de soluciones, Revista Brasileira de Direito Comparado, Rio de Janeiro, n. 10, p. 120141, jan./jun. 1991.

CANOTILHO, José Joaquim Gomes. A "principialização" da jurisprudência através da constituição, Revista de Processo, São Paulo, v. 25, n. 98, p. 83-89, abr./jun. 2000.

CANOTILHO, José Joaquim Gomes. Direito constitucional e teoria da constituição. 7 ed. Coimbra: Almedina, 2003.

CANOTILHO, José Joaquim Gomes. Estudos sobre direitos fundamentais. Coimbra: Coimbra, 2004.

CAORSI, Juan Benítez. Reflexiones en torno a la noción de ilicitud, Revista de Direito Privado, São Paulo, n. 21, p. 287-294, jan./mar. 2005.

CAPRA, Fritjof. $O$ ponto de mutação: a ciência, a sociedade e a cultura emergente. São Paulo: Cultrix, 1997.

CÁRCOVA, Carlos María. ¿Que hacen los jueces cuando juzgan?. In: GESUALDI, Dora Mariana (Coord.). Derecho privado. Buenos Aires: Hammurabi, 2001.

CÁRCOVA, Carlos María. Las teorias jurídicas post positivistas. 2. ed. Buenos Aires: Abeledo Perrot, 2009.

CÁRDENAS, Betty Mercedes Martínez. La adaptación de la teoría de las obligaciones de medios y las obligaciones de resultados en el derecho colombiano. In: ESPINOSA, Fabricio Mantilla; BARRIOS, Francisco Ternera (Dir.). Los contratos en el derecho privado. Bogotá: Legis, 2007.

CARLUCCI, Aída Kemelmajer de. Los dilemas de la responsabilidad civil, Revista Chilena de Derecho, Santiago, v. 28, n. 4, p. 671-679, out./dez. 2001.

CARNEIRO DA FRADA, Manuel António de Castro Portugal. Teoria da confiança e responsabilidade civil. Coimbra: Almedina, 2007.

CARNEIRO, Maria Francisca. Sobre la presencia de elementos estéticos en la teoría civilista. In: GESUALDI, Dora Mariana (Coord.). Derecho privado. Buenos Aires: Hammurabi, 2001.

CARPENA, Heloisa. A disciplina das obrigações de fazer no código civil de 2002: uma interpretação sistemática de sua execução à luz da efetividade consagrada no código do consumidor. In: PFEIFFER, Roberto Augusto Castellanos; PASQUALOTTO, Adalberto (Coord.). 
Código de defesa do consumidor e o código civil de 2002: convergências e assimetrias. São Paulo: RT, 2005.

CARRILHO, Cristiano. Manual de história dos sistemas jurídicos. Rio de Janeiro: Elsevier, 2009.

CARRION, Eduardo Kroeff Machado. O poder judiciário, o juiz e a lei, Revista de Direito Alternativo, São Paulo, n. 1, p. 65-70, 1992.

CARVALHO NETO, Inácio de. Curso de direito civil brasileiro: teoria geral das obrigações. Curitiba: Juruá, 2009, v. 2.

CARVALHO, Afrânio de. O futuro código civil, Revista de Direito Civil, Imobiliário, Agrário e Empresarial, São Paulo, v. 9, n. 34, p. 7-28, out./dez. 1985.

CARVALHO, Délton Winter de. Dano ambiental futuro: a responsabilização pelo risco ambiental. Rio de Janeiro: Forense Universitária, 2008.

CASIELLO, Juan José. El pago: concepto y esencia jurídica. In: GESUALDI, Dora Mariana (Coord.). Derecho privado. Buenos Aires: Hammurabi, 2001.

CASSETTARI, Christiano. Multa contratual: teoria e prática. São Paulo: RT, 2009.

CASTANHEIRA NEVES, Antonio. Entre o legislador, a sociedade e o juiz ou entre sistema, função e problema - os modelos actualmente alternativos da realização jurisdicional do direito, Boletim da Faculdade de Direito, Coimbra, v. 74, p. 1-44, 1998.

CASTANHEIRA NEVES, Antonio. O actual problema metodológico da interpretação jurídica. Coimbra: Coimbra, 2003, v. 1.

CASTANHEIRA NEVES. Antonio. Digesta: escritos acerca do direito, do pensamento jurídico, da sua metodologia e outros. Coimbra: Coimbra, 1995, v. 2.

CASTANHEIRA NEVES. Antonio. Digesta: escritos acerca do direito, do pensamento jurídico, da sua metodologia e outros. Coimbra: Coimbra, 1995, v. 1.

CASTILHA, Gustavo Ordoqui. Buena fe contractual. Montevideo: Del Foro, 2005.

CASTILLA, Gustavo Ordoqui. Diez reglas para la avaluación del daño contractual, Revista de Derecho de la Universidad Católica del Uruguay, Montevideo, v. 2, p. 75-125, 2001.

CASTRO, Torquato. Causalidade jurídica no direito romano: o título na linguagem jurídica dos romanos, Revista de Direito Civil, Imobiliário, Agrário e Empresarial, São Paulo, v. 8, n. 27, p. 747, jan./mar. 1984.

CATALAN, Marcos Jorge. Descumprimento contratual: modalidades, conseqüências e hipóteses de exclusão do dever de indenizar. Curitiba: Juruá, 2005.

CAUBET, Christian Guy. O escopo do risco no mundo real e no mundo jurídico. In: VARELLA, Marcelo Dias (Org.). Governo dos riscos: rede latino-americana-européia sobre governo dos riscos. Brasília: Pallotti, 2005.

CHINELATO, Silmara Juny. Tendências da responsabilidade civil no direito contemporâneo: reflexos no código de 2002. In: DELGADO, Mário Luiz; ALVES, Jones Figueiredo (Coord.). Questões controvertidas: responsabilidade civil. São Paulo: Método, 2006, v. 5. 
CHIRONI, Giampietro. La colpa nel diritto civile odierno: colpa contrattuale. 2 ed. Torino: Fratelli Bocca Editori, 1897.

CIMBALI, Enrico. La nuova fase del diritto civile: nei rapporti economici e sociali. 4 ed. Torino: UTET, 1907.

COELHO, Fábio Ulhoa. Curso de direito civil. São Paulo: Saraiva, 2004, v. 2.

COELHO, José Gabriel Pinto. A responsabilidade civil baseada no conceito da culpa. Coimbra: Imprensa da Universidade, 1906.

COELHO, Luiz Fernando. Saudade do futuro. 2 ed. Curitiba: Juruá, 2007.

COELHO, Luiz Fernando. Teoria crítica do direito. 3 ed. Belo Horizonte: Del Rey, 2003.

COFRÉ, Juan. Racionalidad en el derecho: una aproximación filosófica a la hermenéutica jurídica, Revista Chilena de Derecho, Santiago, v. 22, n. 1, p. 41-59, jan./abr. 1995.

COING, Helmut. Historia de derecho y dogmática jurídica, Revista Chilena de Derecho, Santiago, v. 9 , n. 2, p. 245-257, mai./ago. 1982.

COLIN, Ambrosio; CAPITANT, Henry. Curso elemental de derecho civil: teoria general de las obligaciones. 2 ed. Trad. Demofilo de Buen. Madrid: Instituto Editorial Reus, 1943, t. 3.

COLLURA, Giorgio. Importanza dell inadempimento e teoria del contratto. Milano: Giuffrè, 1992.

COLMO, Alfredo. De las obligaciones en general. Buenos Aires: Jesus Menendez, 1920.

COMPARATO, Fábio Konder. Ensaios e pareceres de direito empresarial. Rio de Janeiro: Forense, 1978.

COMPARATO, Fábio Konder. Os problemas fundamentais da sociedade brasileira e os direitos humanos, Revista da Ordem dos Advogados do Brasil, São Paulo, v. 19, n. 51, p. 7-18, 1989.

CORDEIRO, Eros Belin de Moura. A constituição da república de 1988 e as transformações na teoria contratual. In: CONRADO, Marcelo; PINHEIRO, Rosalice Fidalgo (Coord.). Direito privado e constituição: ensaios para uma recomposição valorativa da pessoa e do patrimônio. Curitiba: Juruá, 2009.

CORRAL, Alfonso de Cossio y. Instituciones de derecho civil: parte general, obligaciones y contratos. 2 ed. Madrid: Civitas, 1991, t. 1.

CORRAL, Alfonso de Cossio y. Instituciones de derecho civil: parte general, obligaciones y contratos. 2 ed. Madrid: Civitas, 1991, t. 1.

CORSARO, Luigi. Colpa e responsabilità civile, Rassegna di Diritto Civile, Napoli, n. 2, p. 270$310,2000$.

CORTÉS, Édgar. Breve nota sobre la culpa contractual y la extracontractual en el derecho colombiano, Revista Anales Derecho UC, Santiago, v. 3, p. 93-104, mar. 2008.

CORTIANO JUNIOR, Eroulths. As quatro fundações do direito civil: ensaio preliminar, Revista da Faculdade de Direito, Curitiba, v. 45, p. 99-102, 2006. 
CORTIANO JUNIOR, Eroulths. O discurso jurídico da propriedade e suas rupturas: uma análise do ensino do direito de propriedade. Rio de Janeiro: Renovar, 2002.

CORTIANO JUNIOR, Eroulths. Para além das coisas (breve ensaio sobre o direito, a pessoa e o patrimônio mínimo). In: RAMOS, Carmem Lucia Silveira et all (Org.). Diálogos sobre direito civil: construindo a racionalidade contemporânea. Rio de Janeiro: Renovar, 2002.

CORTIANO JUNIOR, Eroulths; MEIRELLES, Jussara Maria Leal de; PAULINI, Umberto. Um estudo sobre o ofuscamento jurídico da realidade: a impossibilidade de proteção de novos valores e fatos a partir de velhos institutos. In: CORTIANO JUNIOR, Eroulths; MEIRELLES, Jussara Maria Leal de; FACHIN, Luiz Edson; NALIN, Paulo (Coord.). Apontamentos críticos para o direito civil brasileiro contemporâneo. Curitiba: Juruá, 2007.

COSTA JUNIOR, Olímpio. A relação jurídica obrigacional: situação, relação e obrigação em direito. São Paulo: Saraiva, 1994.

COSTA, Achyles Barcelos da. O desenvolvimento econômico na visão de Joseph Schumpeter, Cadernos IHU Ideias, São Leopoldo, v. 4, n. 47, p. 3-16, 2006.

COSTA, Álvaro Ferreira da. Responsabilidade sem culpa, Revista da Faculdade de Direito, Curitiba, v. 4, n. 4, p. 234-250, dez. 1956.

COSTA, Francisco Ricardo Sales. A segurança das relações jurídicas instrumentalizadas através do contrato. In: ROSSI, Alexandre Luiz Bernardi; MESQUITA, Gil Ferreira (Org.). Maioridade constitucional: estudo em comemoração aos 18 anos da Constituição Federal. São Paulo: Lemos \& Cruz, 2008.

COSTA, Mário Júlio de Almeida. Direito das obrigações. 6 ed. Coimbra: Almedina, 1994.

COSTA, Mário Júlio de Almeida. Estudos de direito civil brasileiro e português: I jornada lusobrasileira de direito civil. São Paulo: RT, 1980.

COSTA, Mário Júlio de Almeida. La buena fe en los contratos según el derecho portugués. In: GESUALDI, Dora Mariana (Coord.). Derecho privado. Buenos Aires: Hammurabi, 2001.

COSTA, Pedro Oliveira da. Apontamentos para uma visão abrangente da função social dos contratos. In: TEPEDINO, Gustavo (Coord.). Obrigações: estudos na perspectiva civilconstitucional. Rio de Janeiro: Renovar, 2005.

COUTO E SILVA, Clóvis Veríssimo do. A obrigação como processo. São Paulo: Bushatsky, 1976.

CRISTOFARO, Pedro Paulo. A força obrigatória do contrato e o novo código civil. In: TEPEDINO, Gustavo; FACHIN, Luiz Edson (Coord.). O direito e o tempo: embates jurídicos e utopias contemporâneas. Rio de Janeiro: Renovar, 2008.

CRUZ, Gaston Fernandez. Los supuestos dogmaticos de la responsabilidad contractual: la division de sistemas y la previsibilidad, Revista de Direito Privado, São Paulo, v. 5, n. 19, p. 289-318, jul./set. 2004.

CRUZ, Gisela Sampaio da. O problema do nexo causal na responsabilidade civil. Rio de Janeiro: Renovar, 2005.

CUNHA DE SÁ, Fernando Augusto. Direito ao cumprimento e direito a cumprir. Coimbra: Almedina, 1997. 
CUNHA, Abelmar Ribeiro da. Tendência socializadora do direito civil, Revista Forense, Rio de Janeiro, v. 48, n. 134, p. 21-39, mar./abr. 1951.

CUNHA, Alexandre dos Santos. A teoria das pessoas de Teixeira de Freitas: entre individualismo e humanismo, Revista da Faculdade de Direito da UFRGS, Porto Alegre, v. 18, p. 15-23, 2000.

CUNHA, Daniel Sica da. A nova força obrigatória dos contratos. In: MARQUES, Cláudia Lima (Coord.). A nova crise do contrato: estudos sobre a nova teoria contratual. São Paulo: RT, 2007.

CUNHA, Wladimir Alcibíades Marinho Falcão. A equivalência material dos contratos e a revisão contratual fundada na lesão no código civil de 2002. In: BARROSO, Lucas Abreu (Org.). Introdução crítica ao código civil. Rio de Janeiro: Forense, 2006.

CUNHA, Wladimir Alcibíades Marinho Falcão. Revisão judicial dos contratos: do código de defesa do consumidor ao código civil de 2002. São Paulo: Método, 2007.

D’AZEVEDO, Ana Rispoli. Os novos deveres dos contratantes na perspectiva do código civil de 2002 e do código de defesa do consumidor. In: MARQUES, Cláudia Lima (Coord.). A nova crise do contrato: estudos sobre a nova teoria contratual. São Paulo: RT, 2007.

D’ALMEIDA, Luiz Duarte. A culpa em Roma e o direito penal: notas de reflexão para uma oral de melhoria de direito romano, Revista da Faculdade de Direito da Universidade de Lisboa, Coimbra, v. 40, n. $1 / 2$, p. 317-321, 1999.

D'ORS, Alvaro. Premissas morales para un nuevo planteamiento de la economía, Revista Chilena de Derecho, Santiago, v. 17, n. 3, p. 439-448, set./dez. 1990.

DE CARLUCCI, Aída Kemelmajer. El sistema dualista de responsabilidad contractual y extracontractual en Argentina. Reflexiones sobre la inconveniencia de su supervivencia, Revista Anales Derecho UC, Santiago, v. 3, p. 29-69, mar. 2008.

DE CORES, Carlos. Acerca de las funciones de la responsabilidad civil. In: FERNÁNDEZ, Carlos López; CAUMONT, Arturo; CAFFERA, Gerardo (Coord.). Estudios de derecho civil en homenaje al profesor Jorge Gamarra. Montevideo: FCU, 2001.

DE CUPIS, Adriano. El daño: teoria general de la responsabilidad civil. Trad. Ángel Martínez Sarrión. Barcelona: Bosch, 1975.

DE LORENZO, Miguel Federico. El péndulo de la autonomía de la voluntad. In: GESUALDI, Dora Mariana (Coord.). Derecho privado. Buenos Aires: Hammurabi, 2001.

DELGADO, Mário Luiz. Da intransmissibilidade, causa mortis, das obrigações de prestação de fato. In: DELGADO, Mário Luiz; ALVES, Jones Figueirêdo (Coord.). Questões controvertidas: no direito das obrigações e dos contratos. São Paulo: Método, 2005, v. 4.

DEVOTO, Luigi. L'imputabilità e le sue forme nel diritto civile. Milano: Giuffrè, 1964.

DIEZ-PICAZO, Luis. Codificación, descodificación y recodificación, Anuario de Derecho Civil, Madrid, v. 45, n. 2, p. 473-484, abr./jun. 1992.

DIEZ-PICAZO, Luis. Fundamentos del derecho civil patrimonial: las relaciones obligatorias. 5 ed. Madrid: Civitas, 1996, v. 2.

DÍEZ-PICAZO, Luiz. Fundamentos del derecho civil patrimonial: introduccion, teoria del contrato. 5 ed. Madrid: Civitas, 1996, v. 1. 
DIFINI, Luiz Felipe Silveira. Princípio do estado constitucional democrático de direito, Revista da Ajuris, Porto Alegre, v. 31, n. 95, p. 161-184, set. 2004.

DINIZ, Arthur José Almeida. Humanismo de tecnologia, Revista da Faculdade de Direito, Belo Horizonte, n. 31, p. 121-136, 1987/1988.

DINIZ, Maria Helena. Curso de direito civil brasileiro: responsabilidade civil. 22 ed. São Paulo: Saraiva, 2008, v. 7.

DINIZ, Maria Helena. Curso de direito civil brasileiro: teoria geral do direito civil. 25 ed. São Paulo: Saraiva, 2008, v. 1.

DINIZ, Maria Helena. Curso de direito civil brasileiro: teoria geral das obrigações. 23 ed. São Paulo: Saraiva, 2008, v. 2.

DINIZ, Maria Helena. Interpretação literal: uma leitura dos leigos, Revista do Advogado, São Paulo, n. 67, p. 94-98, ago. 2002.

DOHRMANN, Klaus Jochen Albiez. Um nuevo derecho de obligaciones. la reforma 2002 del bgb, Anuario de Derecho Civil, Madrid, v. 55, n. 3, p. 1133-1227, jul./set. 2002.

DONNINI, Rogério. Revisão contratual sem imprevisão, Revista Brasileira de Direito Civil Constitucional e Relações de Consumo, Santo Amaro, n. 1, p. 245-259, jan./mar. 2009.

DUARTE, Ronnie. Responsabilidade civil e o novo código: contributo para uma revisitação conceitual, Revista dos Tribunais, São Paulo, v. 95, n. 850, p. 57-88, ago. 2006.

DUPICHOT, Jacques. Derecho de las obligaciones. Trad. Rosangela Calle. Bogotá: Temis, 1984.

DUTRA, Jeferson Luiz Dellavalle. Princípios contratuais e reflexividade sistêmica: boa-fé, equilíbrio econômico e função social do contrato. In: SILVA FILHO, José Carlos Moreira da; PEZZELLA, Maria Cristina Cereser (Coord.). Mitos e rupturas no direito civil contemporâneo. Rio de Janeiro: Lumen Juris, 2008.

ENGELMANN, Wilson. Os direitos humanos e as nanotecnologias: em busca de marcos regulatórios, Cadernos IHU Idéias, São Leopoldo, v. 7, n. 123, p. 3-24, 2009.

ENNECCERUS, Ludwig. Derecho de obligaciones: doctrina general. Trad. Blas Pérez Gonzales; José Alguer. Barcelona: Bosch, 1944, v. 1.

ESMEIN, Paul. La faute et sa place dans responsabilité civile, Revue Trimestrielle de Droit Civil, Paris, n. 47, p. 481-490, 1949.

ESPINOLA, Eduardo. Systema do direito civil brasileiro: theoria geral das relações jurídicas de obrigação. Rio de Janeiro: Porto, 1912, v. 2, t. 1.

ESPINOSA, Fabricio Mantilla; BARRIOS, Francisco Ternera. La resolución. In: ESPINOSA, Fabricio Mantilla; BARRIOS, Francisco Ternera (Dir.). Los contratos en el derecho privado. Bogotá: Legis, 2007.

FACCHINI NETO, Eugênio. Aspectos da responsabilidade civil e o novo código, Revista da PGE, Porto Alegre, v. 27, n. 57, p. 157-184, 2004.

FACCHINI NETO, Eugênio. Prefácio. In: VAZ, Caroline. Funções da responsabilidade civil: da reparação à punição ou dissuasão: os punitive damages no direito comparado e brasileiro. Porto Alegre: LAEL, 2009. 
FACCHINI NETO, Eugênio. Reflexões histórico-evolutivas sobre a constitucionalização do direito privado. In: SARLET, Ingo Wolfgang (Org.). Constituição, direitos fundamentais e direito privado. 2 ed. Porto Alegre: LAEL, 2006.

FACHIN, Luiz Edson. A "reconstitucionalização" do direito civil brasileiro: lei nova e velhos problemas à luz de dez desafios. In: SILVA FILHO, José Carlos Moreira da; PEZZELLA, Maria Cristina Cereser (Coord.). Mitos e rupturas no direito civil contemporâneo. Rio de Janeiro: Lumen Juris, 2008.

FACHIN, Luiz Edson. A construção do direito privado contemporâneo na experiência críticodoutrinária brasileira a partir do catálogo mínimo para o direito civil-constitucional no Brasil. In: TEPEDINO, Gustavo (Org.). Direito civil contemporâneo: novos paradigmas à luz da legalidade constitucional. São Paulo: Atlas, 2008.

FACHIN, Luiz Edson. A reforma no direito brasileiro: novas notas sobre um velho debate no direito civil, Revista Brasileira de Direito Comparado, Rio de Janeiro, n. 16, p. 147-156, jan./jun. 1999.

FACHIN, Luiz Edson. Aspectos da racionalidade histórico-cultural do arquétipo inserido no código civil brasileiro de 2002, Revista do Advogado, São Paulo, n. 98, p. 143-150, jul. 2008.

FACHIN, Luiz Edson. Contratos na ordem pública do direito contemporâneo. In: TEPEDINO, Gustavo; FACHIN, Luiz Edson (Coord.). $O$ direito e o tempo: embates jurídicos e utopias contemporâneas. Rio de Janeiro: Renovar, 2008.

FACHIN, Luiz Edson. Direito e futuro: um passivo a descoberto. Estado de direito. Porto Alegre, fev./mar. 2008.

FACHIN, Luiz Edson. Estatuto jurídico do patrimônio mínimo. Rio de Janeiro: Renovar, 2001.

FACHIN, Luiz Edson. Limites e possibilidades da nova teoria geral do direito civil, Revista da Faculdade de Direito, Curitiba, v. 27, n. 27, p. 49-60, 1992-1993.

FACHIN, Luiz Edson. Parecer sobre o projeto de código civil, Revista da Faculdade de Direito de Campos, Campos dos Goitacases, v. 2/3, n. 2/3, p. 161-191, 2001/2002.

FACHIN, Luiz Edson. Questões do direito civil brasileiro contemporâneo. Rio de Janeiro: Renovar, 2008.

FACHIN, Luiz Edson. Responsabilidade por dano de cumprimento diante do desaproveitamento da função social do contrato. In: NERY, Rosa Maria Barreto Borriello de Andrade; DONNINI, Rogério (Coord.). Responsabilidade civil: estudos em homenagem ao professor Rui Geraldo Camargo Viana. São Paulo: RT, 2009.

FACHIN, Luiz Edson. Teoria crítica do direito civil. Rio de Janeiro: Renovar, 2000.

FACHIN, Luiz Edson; RUZYK, Carlos Eduardo Pianovski. Direitos fundamentais, dignidade da pessoa humana e o novo código civil: uma análise crítica. In: SARLET, Ingo Wolfgang (Org.). Constituição, direitos fundamentais e direito privado. 2 ed. Porto Alegre: LAEL, 2006.

FACHIN, Melina Girardi; PAULINI, Umberto. Problematizando a eficácia dos direitos fundamentais nas relações entre particulares: ainda e sempre sobre a constitucionalização do direito civil. In: TEPEDINO, Gustavo; FACHIN, Luiz Edson (Org.). Diálogos sobre direito civil. Rio de Janeiro: Renovar, 2008, v. 2. 
FAGÚNDEZ, Paulo Roney Ávila. O significado da modernidade. In: LEITE, José Rubens Morato; BELLO FILHO, Ney de Barros (Coord.). Direito ambiental contemporâneo. Barueri: Manole, 2004.

FARIA, Jorge Leite Areias Ribeiro de. Direito das obrigações. Coimbra: Almedina, 1990, v. 2.

FARIA, José Eduardo. A justiça e a formação da magistratura, Nomos, Fortaleza, v. 7/8, n. 2, p. 6575, jan./dez. 1988/1989.

FARIA, José Eduardo. As transformações do judiciário em face de suas responsabilidades sociais, Revista de Direito Alternativo, São Paulo, n. 2, p. 33-46, 1993.

FARIA, José Eduardo. Globalização econômica e reforma constitucional, Revista dos Tribunais, São Paulo, v. 86, n. 736, p. 11-19, fev. 1997.

FARO, Frederico Kastrup de. Boa-fé objetiva e dever de cooperação: uma análise sob as óticas do exercício da autonomia privada e da execução do contrato, Revista Trimestral de Direito Civil, Rio de Janeiro, n. 38, p. 3-39, abr./jun. 2009.

FERNANDES, Adaucto. Das obrigações no direito brasileiro. Rio de Janeiro: A. Coelho Branco $\mathrm{F}^{\mathrm{o}}$ Editor, 1951, v. 2.

FERNANDÉZ, Carlos López. Obligaciones de medios y de resultado, Revista de la Facultad de Derecho, Montevideo, n. 18, p. 97-132, jul./dez. 2000.

FERREYRA, Roberto Antonio Vázquez. El acto ilícito: significado, estrutura y evolución. In: GESUALDI, Dora Mariana (Coord.). Derecho privado. Buenos Aires: Hammurabi, 2001.

FIGUEIRA, J. G. de Andrade. A ação direta da vítima contra a companhia seguradora de responsabilidade civil, Revista dos Tribunais, São Paulo, v. 30 [sic 31], n. 139, p. 440-445, set. 1942.

FIGUEIRA, J. G. de Andrade. A garantia das vítimas e a responsabilidade civil, Revista dos Tribunais, São Paulo, v. 39, n. 184, p. 17-22, mar. 1950.

FIGUEIRA, J. G. de Andrade. A responsabilidade civil e o contrato de seguro no anteprojeto do código das obrigações, Revista Forense, Rio de Janeiro, v. 41, n. 97, p. 38-42, jan./mar. 1944.

FIUZA, César. Direito civil: curso completo. 11 ed. Belo Horizonte: Del Rey, 2008.

FIUZA, César. Para uma releitura da teoria geral da responsabilidade civil, Revista da Faculdade Mineira de Direito, Belo Horizonte, v. 7, n. 13/14, p. 9-15, 2004.

FIUZA, César. Por uma nova teoria do ilícito civil, Revista da Faculdade Mineira de Direito, Belo Horizonte, v. 6, n. 11/12, p. 29-48, 2003.

FIUZA, César. Por uma redefinição da contratualidade, Revista da Faculdade Mineira de Direito, Belo Horizonte, v. 9, n. 18, p. 33-41, jul./dez. 2006.

FLACH, Norberto. O formalismo jurídico oitocentista: doença infantil do positivismo, Revista da Faculdade de Direito Ritter dos Reis, Porto Alegre, v. 3, p. 131-180, mar./jul. 2000.

FLAH, Lily; SMAYEVSKY, Miriam. El llamado valor de la vida humana. In: GESUALDI, Dora Mariana (Coord.). Derecho privado. Buenos Aires: Hammurabi, 2001. 
FONSECA, Arnoldo Medeiros da. Caso fortuito e teoria da imprevisão. 3 ed. Rio de Janeiro: Revista Forense, 1958.

FONTES, André. Os fatores de atribuição na responsabilidade por danos, Revista Brasileira de Direito Comparado, Rio de Janeiro, n. 16, p. 177-189, jan./jun. 1999.

FRADERA, Véra Maria Jacob de. A boa-fé objetiva, uma noção presente no conceito alemão, brasileiro e japonês de contrato, Revista Brasileira de Direito Comparado, Rio de Janeiro, n. 24, p. 127-157, jan./jun. 2003.

FRADERA, Véra Maria Jacob de. Conceito de culpa, Revista dos Tribunais, São Paulo, n. 770, p. 117-122, dez. 1999.

FRANÇA, Rubens Limongi. Raízes e dogmática da cláusula penal. Tese (Concurso Professor Titular) - Faculdade de Direito da USP, São Paulo, 1987.

FRANÇA, Rubens Limongi. Recepção do direito romano no direito brasileiro, Revista de Direito Civil, Imobiliário, Agrário e Empresarial, São Paulo, v. 3, n. 7, p. 181-196, jan./mar. 1979.

FRANÇA, Rubens Limongi. Responsabilidade civil e abuso de direito, Revista do Advogado, São Paulo, n. 19, p. 40-45, out. 1985.

FRANCO, Vera Helena de Mello. A responsabilidade do fabricante no direito brasileiro futuro (confronto com o direito comparado), Revista de Direito Mercantil, industrial, econômico e financeiro, São Paulo, v. 28, n. 73, p. 80-99, jan./mar. 1989.

FREIRE, Ricardo Maurício. Tendências do pensamento jurídico contemporâneo. Salvador: Podivm, 2007.

FRIED, Charles. Contrato como promessa: uma teoria da obrigação contratual. Trad. Sérgio Duarte. Rio de Janeiro: Elsevier, 2008.

FROTA, Pablo Malheiros da Cunha. Danos morais e a pessoa jurídica. São Paulo: Método, 2008.

FROTA, Pablo Malheiros da Cunha. Os deveres contratuais gerais nas relações civis e de consumo. Dissertação (Mestrado) - Faculdade Autônoma de Direito de São Paulo, São Paulo, 2008.

FUENZALIDA, Carlos Vattier. Notas sobre el incumplimiento y la responsabilidad contractual, Revista Electrónica del Departamento de Derecho de la Universidad de La Rioja, Logroño, n. 3, p. 57-68, dez. 2005.

GAGLIANO, Pablo Stolze; PAMPLONA FILHO, Rodolfo. Novo curso de direito civil: obrigações. 8 ed. São Paulo: Saraiva, 2007, v. 2.

GAGLIANO, Pablo Stolze; PAMPLONA FILHO, Rodolfo. Novo curso de direito civil: responsabilidade civil. 5 ed. São Paulo: Saraiva, 2007, v. 3.

GALDOS, Jorge Mario. El principio favor debilis en materia contractual, Derecho del consumidor, Rosario, n. 8, p. 37-47, 1997.

GALUPPO, Marcelo Campos; BASILE, Rafael Faria. O princípio jurídico da igualdade e a ação afirmativa étnico-racial no estado democrático de direito: o problema das cotas, Revista de Informação Legislativa, Brasília, v. 43, n. 171, p. 99-108, out./dez. 2006. 
GAMA, Ricardo Rodrigues. Algumas considerações sobre o novo código civil brasileiro, Revista de Direito Privado, São Paulo, v. 3, n. 9, p. 18-35, jan./mar. 2002.

GAMARRA, Jorge. Incidencia del problema de la carga de la prueba en la fundamentación de la responsabilidad civil, Revista de la Facultad de Derecho y Ciencias Sociales, Montevideo, v. 2, n. 3, p. 639-665, 1951.

GAMARRA, Jorge. Responsabilidad contractual objetiva. In: BUERES, Alberto Jesús; DE CARLUCCI, Aída Kemelmajer (Dir.). Responsabilidad por daños en el tercer milenio. Buenos Aires: Abeledo-Perrot, 1997.

GAMARRA, Jorge. Responsabilidad contractual: el incumplimiento. Montevideo: FCU, 2004.

GAMARRA, Jorge. Tratado de derecho civil uruguayo. 2 ed. Montevideo: FCU, 2003, v. 2, t. 20.

GAUDEMET, Eugene. Teoría general de las obligaciones. Trad. Pablo Macedo. México: Editorial Porúa, 1974.

GAZALLE, Gustavo Kratz. O conceito de mora no código civil de 2002. Porto Alegre: SAFE, 2008.

GESUALDI, Dora Mariana. De la antijuridicidad a las causas de justificación. In: BUERES, Alberto Jesús; DE CARLUCCI, Aída Kemelmajer (Dir.). Responsabilidad por daños en el tercer milenio. Buenos Aires: Abeledo-Perrot, 1997.

GHERSI, Carlos Alberto. De Velez a Borda un cambio ideológico transcendente, que no se complementó en el rápido acceso a la justicia. In: GHERSI, Carlos Alberto (Dir.). Responsabilidad: problemática moderna. Mendoza: Ediciones Jurídicas Cuyo, 1996.

GHERSI, Carlos Alberto. El ser humano y la dañosidad como inevitable contingencia social. In: GHERSI, Carlos Alberto (Dir.). Responsabilidad: problemática moderna. Mendoza: Ediciones Jurídicas Cuyo, 1996.

GHERSI, Carlos Alberto. La independencia de poderes y el acceso a la reparación de daños. In: GHERSI, Carlos Alberto (Dir.). Responsabilidad: problemática moderna. Mendoza: Ediciones Jurídicas Cuyo, 1996.

GHERSI, Carlos Alberto. La pobreza jurídica y el ejercicio de los derechos fundamentales: el valor de las libertades negativas, Revista de Direito do Consumidor, São Paulo, v. 11, n. 43, p. 11-20, jul./set. 2002.

GHERSI, Carlos Alberto. Teoría general de la reparación de daños. Buenos Aires: Astrea, 1997.

GIDDENS, Anthony. As conseqüências da modernidade. Trad. Raul Fiker. São Paulo: Unesp, 1991.

GIDDENS, Anthony; BECK, Ulrich; LASH, Scott. Modernização reflexiva: política, tradição e estética na ordem social moderna. Trad. Magda Lopes. São Paulo: Unesp, 1997.

GIMÉNEZ-CANDELA, Teresa. Una perspectiva historica de la responsabilidad objetiva, Roma e America: Diritto Romano Comune, Roma, n. 8, p. 117-129, 1999.

GIORGI, Jorge. Teoria de las obligaciones en el derecho moderno. Madrid: Reus, 1977, v. 2.

GIORGIANNI, Michele. L`inadempimento. Milano: Giuffrè, 1975. 
GIORGIANNI, Michele. L'obbligazione: la parte generale delle obbligazioni. Milano: Giuffrè, 1968, v. 1.

GIORGIANNI, Michele. O direito privado e suas atuais fronteiras, Revista dos Tribunais, São Paulo, v. 87, n. 747, p. 35-55, jan. 1998.

GIOSTRI, Hildegard Taggesel. Algumas reflexões sobre as obrigações de meio e de resultado na avaliação da responsabilidade médica, Revista Trimestral de Direito Civil, Rio de Janeiro, n. 5, p. 101-116, jan./mar. 2001.

GLITZ, Frederico Eduardo Zenedin. Favor contractus: alguns apontamentos sobre o princípio da conservação do contrato no direito positivo brasileiro e no direito comparado. In: CONRADO, Marcelo; PINHEIRO, Rosalice Fidalgo (Coord.). Direito privado e constituição: ensaios para uma recomposição valorativa da pessoa e do patrimônio. Curitiba: Juruá, 2009.

GOMES, José Jairo. Responsabilidade civil na pós-modernidade: influência da solidariedade e da cooperação, Revista de Direito Privado, São Paulo, v. 6, n. 23, p. 227-233, jul./set. 2005.

GOMES, Orlando. A agonia do código civil, Revista de Direito Comparado Luso-Brasileiro, Rio de Janeiro, v. 4, n. 7, p. 1-9, jul. 1985.

GOMES, Orlando. A função renovadora do direito, Revista da Faculdade de Direito da Universidade Federal do Paraná, Curitiba, n. 12, p. 39-47, 1969.

GOMES, Orlando. Culpa x risco, Revista Forense, Rio de Janeiro, v. 37, n. 83, p. 378-384, set. 1940.

GOMES, Orlando. Introdução ao direito civil. 11 ed. Atual. Humberto Theodoro Junior. Rio de Janeiro: Forense, 1995.

GOMES, Orlando. Obrigações. 9 ed. Atual. Humberto Theodoro Junior. Rio de Janeiro: Forense, 1994.

GOMES, Orlando. Questões de direito civil. São Paulo: Saraiva, 1976.

GOMES, Orlando. Raízes históricas e sociológicas do código civil brasileiro. São Paulo: Martins Fontes, 2003.

GOMES, Orlando. Responsabilidade civil do fabricante, Revista de Direito Civil, Imobiliário, Agrário e Empresarial, São Paulo, v. 9, n. 32, p. 12-21, abr./jun. 1985.

GOMES, Orlando. Tendências modernas na teoria da responsabilidade civil. In: DI FRANCESCO, José Roberto. Estudos em homenagem ao professor Silvio Rodrigues. São Paulo: Saraiva, 1989.

GOMES, Orlando. Transformações gerais do direito das obrigações. São Paulo: RT, 1967.

GONÇALVES, Carlos Roberto. Comentários ao código civil: parte especial do direito das obrigações - responsabilidade subjetiva, responsabilidade objetiva, responsabilidade por fato de outrem, responsabilidade profissional, etc.; preferências e privilégios creditórios. São Paulo: Saraiva, 2003, v. 11.

GONÇALVES, Carlos Roberto. Direito civil brasileiro: responsabilidade civil. 3 ed. São Paulo: Saraiva, 2008, v. 4.

GONZÁLEZ, Jorge Baraona. El retraso en el cumplimiento de las obligaciones. Madrid: Dykinson S. L., 1998. 
GONZÁLEZ, Jorge Baraona. Responsabilidad contractual y fatores de imputación de daños: apuntes para una relectura en clave objetiva, Revista Chilena de Derecho, Santiago, v. 24, n. 1, p. 151-177, jan./abr. 1997.

GONZÁLEZ, Sérgio Pérez. El derecho en la sociedad global del riesgo, Revista Electrónica del Departamento de Derecho de la Universidad de La Rioja, Logroño, n. 6, p. 95-107, dez. 2008.

GORDILHO, Heron José de Santana. Por uma dogmática pós-moderna, Revista do Programa de Pós-Graduação em Direito da Universidade Federal da Bahia, Salvador, v. 16, p. 47-61, 2008.

GOUVÊA, Eduardo de Oliveira. Boa-fé objetiva e responsabilidade civil contratual: principais inovações, Revista Forense, Rio de Janeiro, n. 369, p. 73-88, set./out. 2003.

GRAEFF-MARTINS, Joana. Cirurgia plástica estética: natureza da obrigação do cirurgião, Revista de Direito Privado, São Paulo, v. 10, n. 37, p. 105-129, jan./mar. 2009.

GRAMSTRUP, Erik Frederico. Responsabilidade objetiva na cláusula geral codificada e nos microssistemas. In: DELGADO, Mário Luiz; ALVES, Jones Figueirêdo (Coord.). Questões controvertidas: responsabilidade civil. São Paulo: Método, 2006, v. 5.

GRAU, Eros Roberto. O futuro do direito. In: AVELÃS NUNES, António José; COUTINHO, Jacinto Nelson Miranda (Coord.). $O$ direito e o futuro: o futuro do direito. Almedina: Coimbra, 2008.

GRAU, Eros Roberto. Pareceres, juristas e apedeutas, Revista da Faculdade de Direito da UFRGS, Porto Alegre, v. 18, p. 93-96, 2000.

GRAU, Eros Roberto. Técnica legislativa e hermenêutica contemporânea. In: TEPEDINO, Gustavo (Org.). Direito civil contemporâneo: novos paradigmas à luz da legalidade constitucional. São Paulo: Atlas, 2008.

GROENINGA, Giselle Câmara. Sem mais desculpas - é tempo de responsabilidade. In: DIAS, Maria Berenice (Org.). Direito das famílias: contributo do ibdfam em homenagem a Rodrigo da Cunha Pereira. São Paulo: RT, 2009.

GROENINGA, Giselle Câmara. Uma análise interdisciplinar da (in)operabilidade do conceito de culpa no direito de família. Dissertação (Mestrado) - Faculdade de Direito da USP, São Paulo, 2007.

GROSSI, Paolo. A formação do jurista e a exigência de um hodierno "repensamento" epistemológico, Revista da Faculdade de Direito da UFPR, Curitiba, v. 40, p. 5-25, 2004.

GROSSI, Paolo. Il diritto tra norma e applicazione: il ruolo del giurista nell'attuale società italiana. Prolusione del Prof. Paolo Grossi, ordinario di Storia del Diritto Italiano nella Facoltà di Giurisprudenza dell'Università di Firenze, tenuta nella cerimonia inaugurale della Scuola di Specializzazione per le professioni legali. Capturado em 17/07/09 em http://www.estig.ipbeja.pt/ ac direito/prolusione.pdf

GROSSI, Paolo. Mitología jurídica de la modernidad. Trad. Manuel Martínez Neira. Madrid: Trotta, 2003.

GUEDES, Paulo Sergio Rosa; WALZ, Julio Cesar. O sentimento de culpa. 2 ed. Porto Alegre: ed. do autor, 2009.

GUERRA FILHO, Willis Santiago. Pós-modernismo, pós-positivismo e a filosofia do direito, Nomos, Fortaleza, v. 15, n. 1/2, p. 13-17, jan./dez. 1996. 
GUIMARÃES, Paulo Jorge Scartezzini. Vícios do produto e do serviço por qualidade, quantidade e insegurança: cumprimento imperfeito do contrato. São Paulo: RT, 2004.

GUTIÉRREZ, Graciela Messina de Estrella. Un aspecto de la teoría del riesgo. In: GESUALDI, Dora Mariana (Coord.). Derecho privado. Buenos Aires: Hammurabi, 2001.

HAMMERSCHMIDT, Denise. O risco na sociedade contemporânea e o princípio da precaução no direito ambiental, Revista Seqüência, Florianópolis, n. 45, p. 97-122, dez. de 2002.

HELLERN, Victor; NOTAKER, Henry; GAARDER, Jostein. O livro das religiões. Trad. Isa Mara Lando. São Paulo: Companhia das Letras, 2000.

HERKENHOFF, Henrique Geaquinto. Responsabilidade pressuposta. In: TARTUCE, Flávio; CASTILHO, Ricardo (Coord.). Direito civil: direito patrimonial, direito existencial. São Paulo: Método, 2006.

HESPANHA, António Manuel. O caleidoscópio do direito: o direito e a justiça nos dias e no mundo de hoje. Coimbra: Almedina, 2007.

HIDALGO, Carmen Domínguez. La concepción dualista de la responsabilidad civil en Chile: panorama general, Revista Anales Derecho UC, Santiago, v. 3, p. 73-89, mar. 2008.

HINESTROSA, Fernando. Devenir del derecho de daños, Roma e America: Diritto Romano Comune, Roma, n. 10, p. 17-36, 2000.

HINESTROSA, Fernando. Notas sobre la responsabilidad por incumplimiento de las obligaciones. In: GESUALDI, Dora Mariana (Coord.). Derecho privado. Buenos Aires: Hammurabi, 2001.

HIRONAKA, Giselda Maria Fernandes Novaes Direito civil: estudos. Belo Horizonte: Del Rey, 2000.

HIRONAKA, Giselda Maria Fernandes Novaes. A função social do contrato, Revista de Direito Civil, Imobiliário, Agrário e Empresarial, São Paulo, v. 12, n. 45, p. 141-152, jul./set. 1988.

HIRONAKA, Giselda Maria Fernandes Novaes. Contrato: estrutura milenar de fundação do direito privado - superando a crise e renovando princípios, no início do vigésimo primeiro século, ao tempo da transição legislativa brasileira. In: BARROSO, Lucas Abreu (Org.). Introdução crítica ao código civil. Rio de Janeiro: Forense, 2006.

HIRONAKA, Giselda Maria Fernandes Novaes. Direito das obrigações: o caráter de permanência de seus institutos, as alterações produzidas pela lei civil brasileira de 2002 e a tutela das gerações futuras. In: HIRONAKA, Giselda Maria Fernandes Novaes (Coord.). Novo código civil: interfaces no ordenamento jurídico brasileiro. Belo Horizonte: Del Rey, 2004.

HIRONAKA, Giselda Maria Fernandes Novaes. Responsabilidade pressuposta. Belo Horizonte: Del Rey, 2005.

HIRONAKA, Giselda Maria Fernandes Novaes. Responsabilidade pressuposta: evolução de fundamentos e de paradigmas na responsabilidade civil na contemporaneidade, Revista da Faculdade de Direito da UFG, Goiânia, v. 31, p. 33-59, jan./jun. 2007.

HIRONAKA, Giselda Maria Fernandes Novaes. Tendências do direito civil no século XXI. In: FIUZA, César; SÁ, Maria de Fátima Freire de; NAVES, Bruno Torquato de Oliveira (Coord.). Direito civil: atualidades. Belo Horizonte: Del Rey, 2003. 
HIRONAKA. Giselda Maria Fernandes Novaes. Tendências atuais da responsabilidade civil: marcos teóricos para o direito do século XXI, Revista Brasileira de Direito Comparado, Rio de Janeiro, n. 19, p. 189-206, jul./dez. 2000.

HOLMES, Oliver Wendell. O caminho do direito, Revista da PGE, Porto Alegre, v. 13, n. 36, p. 13-31, 1983.

HORBACH, Carlos Bastide. A nova roupa do direito constitucional: neo-constitucionalismo, póspositivismo e outros modismos, Revista dos Tribunais, São Paulo, n. 859, p. 81-91, mai. 2007.

HUXLEY, Aldous. Admirável mundo novo. Trad. Lino Vallandro; Vidal Serrano. Rio de Janeiro: Globo, 2009.

IPPÓLITO, Rita Maria. Culpa e risco: fundamentos ou critérios de responsabilização?, Revista da Escola de Direito, Pelotas, v. 3, n. 1, p. 77-103, jan./dez. 2002.

IRTI, Natalino. L'età della decodificazione, Revista de Direito Civil, Imobiliário, Agrário e Empresarial, São Paulo, v. 3, n. 10, p. 15-33, out./dez. 1979.

ITAGIBA, Ivair Nogueira. Justiça comutativa e justiça institucional, Revista da Ordem dos Advogados do Brasil, Rio de Janeiro, v. 4, n. 11, p. 447-457, set./dez. 1973.

ITURRASPE, Jorge Mosset. Contratos. Buenos Aires: Rubinzal-Culzioni, 2007.

ITURRASPE, Jorge Mosset. La vigencia del distingo entre obligaciones de medio y de resultados en los servicios, desde la perspectiva del consumidor, Revista da Ajuris, Porto Alegre, v. 1, p. 250252, mar. 1988.

ITURRASPE, Jorge Mosset; PIEDECASAS, Miguel. Responsabilidad contractual. Santa Fé: Rubinzal-Culzoni, 2007.

JORGE, Fernando Pessoa. Ensaio sobre os pressupostos da responsabilidade civil. Coimbra: Almedina, 1999.

JOSSERAND, Louis. Derecho civil: teoría general de las obligaciones. Trad. Santiago Cunchillos y Manterola. Buenos Aires: Bosch Editores, 1950, v. 1, t. 2.

JOSSERAND, Louis. Evolução da responsabilidade civil, Revista Forense, Rio de Janeiro, n. 86, p. 52-63, jun. 1941.

JUNQUEIRA DE AZEVEDO, Antonio. A boa-fé na formação dos contratos, Revista de Direito do Consumidor, São Paulo, n. 3, p. 78-87, set./dez. 1992.

JUNQUEIRA DE AZEVEDO, Antonio. A boa-fé na formação dos contratos, Revista da Faculdade de Direito, São Paulo, v. 87, p. 79-90, jan./dez. 1992.

JUNQUEIRA DE AZEVEDO, Antonio. Caracterização jurídica da dignidade da pessoa humana, Revista dos Tribunais, São Paulo, v. 91, n. 797, p. 11-26, mar. 2002.

JUNQUEIRA DE AZEVEDO, Antonio. Estudos e pareceres de direito privado. São Paulo: Saraiva, 2004.

JUNQUEIRA DE AZEVEDO, Antonio. Insuficiências, deficiências e desatualização do projeto de código civil na questão da boa-fé objetiva nos contratos, Revista dos Tribunais, São Paulo, v. 89, n. 775, p. 11-17, mai. 2000. 
JUNQUEIRA DE AZEVEDO, Antonio. Novos estudos e pareceres de direito privado. São Paulo: Saraiva, 2009.

JUNQUEIRA DE AZEVEDO, Antonio. O direito pós-moderno e a codificação, Revista da Faculdade de Direito, São Paulo, v. 94, p. 3-12, jan./dez. 1999.

JUNQUEIRA DE AZEVEDO, Antônio. O direito pós-moderno e a codificação, Revista de Direito do Consumidor, São Paulo, v. 9, n. 33, p. 123-129, jan./mar. 2000.

JUNQUEIRA DE AZEVEDO, Antonio. O princípio da boa-fé nos contratos, Revista CEJ, Brasília, v. 3, n. 9, p. 40-45, dez. 1999.

JUNQUEIRA DE AZEVEDO, Antonio. Por uma nova categoria de dano na responsabilidade civil: o dano social. In: FILOMENO, José Geraldo Brito; WAGNER JUNIOR, Luiz Guilherme da Costa; GONÇALVES, Renato Afonso (Coord.). O código civil e sua interdisciplinaridade: os reflexos do código civil nos demais ramos do direito. Belo Horizonte: Del Rey, 2004.

JUSTO, Antônio Santos. Direito privado romano: direito das obrigações. 2 ed. Coimbra: Coimbra, 2006, v. 2.

KASER, Max. Direito privado romano. Trad. Samuel Rodrigues; Ferdinand Hämmerle. Lisboa: Fundação Calouste Gulbenkian, 1999.

KATAOKA, Eduardo Takemi. Segurança jurídica como direito fundamental e as cláusulas gerais do novo código civil brasileiro. In: SARMENTO, Daniel; GALDINO, Flávio (Org.). Direitos fundamentais: estudos em homenagem ao professor Ricardo Lobo Torres. Rio de Janeiro: Renovar, 2006.

KFOURI NETO, Miguel. Graus de culpa e redução equitativa da indenização, Revista dos Tribunais, São Paulo, v. 94, n. 839, p. 47-68, set. 2005.

KONDER, Carlos Nelson; RENTERÍA, Pablo. A funcionalização das relações obrigacionais: interesse do credor e patrimonialidade da prestação. In: TEPEDINO, Gustavo; FACHIN, Luiz Edson. Diálogos sobre direito civil. Rio de Janeiro: Renovar, 2008, v. 2.

KUMMEROW, Gert. Esquema del daño contractual resarcible segun el sistema normativo venezolano. Caracas: Universidad Central de Venezuela, 1964.

LA TORRE, Antonio. Genesi e metamorfosi della responsabilità civile, Roma e America: Diritto Romano Comune, Roma, n. 8, p. 61-115, 1999.

LA TORRE, Antonio. I criterio d'imputazione della responsabilità civile, Roma e America: Diritto Romano Comune, Roma, n. 10, p. 96-114, 2000.

LAMBOIS, Susuna Elena. La obligación de seguridad. In: GESUALDI, Dora Mariana (Coord.). Derecho privado. Buenos Aires: Hammurabi, 2001.

LANFREDI, Geraldo Ferreira. Política ambiental: busca de efetividade de seus instrumentos. São Paulo: RT, 2002.

LARENZ, Karl. Derecho de obligaciones. Trad. Jaime Santos Briz. Madrid: Editorial Revista de Derecho Privado, 1958, t. 1.

LARENZ, Karl. Derecho justo: fundamentos de etica juridica. Trad. Luis Díez-Picazo. Madrid: Civitas, 1993. 
LARROUMET, Christian. La causa estraña. In: ESPINOSA, Fabricio Mantilla; BARRIOS, Francisco Ternera (Dir.). Los contratos en el derecho privado. Bogotá: Legis, 2007.

LARROUMET, Christian. La defensa de la responsabilidad contractual en derecho frances, Revista Trimestral de Direito Civil, Rio de Janeiro, n. 8, p. 151-163, out./dez. 2001.

LEGAZ Y LACAMBRA, Luís. Direito e política, Revista Forense, Rio de Janeiro, v. 48, n. 136, p. 5-17, jul./ago. 1951.

LEITÃO, Luís Manuel Teles de Menezes. Direito das obrigações: transmissão e extinção das obrigações, não cumprimento e garantias do crédito. 3 ed. Coimbra: Almedina, 2005, v. 2.

LEONARDO, Rodrigo Xavier. A teoria das redes contratuais e a função social dos contratos: reflexões a partir de uma recente decisão do superior tribunal de justiça, Revista dos Tribunais, São Paulo, v. 94, n. 832, p. 100-111, fev. 2005.

LEONARDO, Rodrigo Xavier. Direito das obrigações: em busca de elementos caracterizadores para compreensão do livro I da parte especial do código civil. In: CANEZIN, Claudete Carvalho. Arte jurídica: biblioteca científica do programa de pós-graduação em direito civil e processo civil da universidade estadual de londrina. Curitiba: Juruá, 2005, v. 1.

LEONARDO, Rodrigo Xavier. Responsabilidade civil contratual e extracontratual: primeiras anotações em face do novo código civil brasileiro, Revista de Direito Privado, São Paulo, v. 5, n. 19, p. 260-269, jul./set. 2004.

LEVI, Giulio. Responsabilità civile e responsabilità oggetiva: diversi modi di introduzione della responsabilità oggetiva e loro influenza sulla legislazione italiana. Milano: Giuffrè, 1986.

LEWICKI, Bruno. Panorama da boa-fé objetiva. In: TEPEDINO, Gustavo (Coord.). Problemas de direito civil-constitucional. Rio de Janeiro: Renovar, 2000.

LIMA NETO, Francisco Vieira. Ato antijurídico e responsabilidade civil aquiliana - crítica à luz do novo código civil. In: BARROSO, Lucas Abreu (Org.). Introdução crítica ao código civil. Rio de Janeiro: Forense, 2006.

LIMA, Alvino, Culpa e risco. 2 ed. São Paulo: RT, 1999.

LIMA, Alvino. A reparação civil do dano no anteprojeto do código das obrigações, Revista Forense, Rio de Janeiro, v. 41, n. 97, p. 13-21, jan./mar. 1944.

LIMA, Alvino. Da influência, no direito civil, do movimento socializador do direito, Revista Forense, Rio de Janeiro, v. 36, n. 80, p. 19-27, out./dez. 1939.

LIMA, Alvino. Da responsabilidade do depositário no caso fortuito ou de força maior, Revista dos Tribunais, São Paulo, v. 34, n. 154, p. 3-6, mar. 1945.

LIMA, Alvino. Situação atual, no direito civil moderno, das teorias da culpa e do risco, Revista Forense, Rio de Janeiro, v. 37, n. 83, p. 385-389, set. 1940.

LIMA, Bruno de Mendonça. Justiça: um critério para o legislador, Revista da Faculdade de Direito de Porto Alegre, v. 3, n. 1, p. 930-957, 1951.

LIMA, Hermes. Introdução à ciência do direito. 33 ed. Rio de Janeiro: Freitas Bastos, 2002.

LIMA, João Franzen de. Curso de direito civil brasileiro: direito das obrigações. 3 ed. Rio de Janeiro: Forense, 1979, v. 2. 
LIMA, Ruy Cirne. O sujeito de direitos no código civil, Revista da Faculdade de Direito de Porto Alegre, v. 5, n. 1, p. 13-17, 1971.

LIRA, Ricardo Pereira. Obrigação de meios e obrigação de resultado a pretexto da responsabilidade médica: análise dogmática, Revista de Direito Renovar, Rio de Janeiro, n. 6, p. 75-82, set./dez. 1996.

LISBOA, Wladimir Barreto. O direito, a moral e os limites da justiça: algumas dificuldades legadas pelos modernos. In: COPETTI, André; STRECK, Lenio Luiz; ROCHA, Leonel Severo (Org.). Constituição, sistemas sociais e hermenêutica: programa de pós-graduação em direito da unisinos. Porto Alegre: LAEL, 2006, v. 2.

LLAMBÍAS, Jorge Joaquín. Estudio sobre la mora en las obligaciones. Buenos Aires: Perrot, 1965.

LÔBO, Paulo Luiz Neto. O contrato: exigências e concepções atuais. São Paulo: Saraiva, 1986.

LÔBO, Paulo Luiz Netto. A constitucionalização do direito civil brasileiro, Revista Brasileira de Direito Civil Constitucional e Relações de Consumo, Santo Amaro, n. 1, p. 197-210, jan./mar. 2009.

LÔBO, Paulo Luiz Netto. Constitucionalização do direito civil, Revista de Informação Legislativa, Brasília, v. 36, n. 141, p. 99-109, jan./mar. 1999.

LÔBO, Paulo Luiz Netto. Deveres gerais de conduta nas obrigações civis. In: DELGADO, Mário Luiz; ALVES, Jones Figueirêdo (Coord.). Questões controvertidas: no direito das obrigações e dos contratos. São Paulo: Método, 2005, v. 4.

LÔBO, Paulo Luiz Netto. Direito civil: parte geral. São Paulo: Saraiva, 2009.

LÔBO, Paulo Luiz Netto. Prefácio. In: CUNHA, Wladimir Alcibíades Marinho Falcão. Revisão judicial dos contratos: do código de defesa do consumidor ao código civil de 2002. São Paulo: Método, 2007.

LÔBO, Paulo Luiz Netto. Responsabilidade civil do advogado, Revista de Direito Privado, São Paulo, v. 3, n. 10, p. 211-220, abr./jun. 2002.

LÔBO, Paulo Luiz Netto. Responsabilidade civil dos profissionais liberais e o ônus da prova, Revista de Direito do Consumidor, São Paulo, n. 26, p. 159-165, abr./jun. 1998.

LÔBO, Paulo Luiz Netto. Teoria geral das obrigações. São Paulo: Saraiva, 2005.

LÔBO, Paulo Luiz Netto. Transformações gerais do contrato, Revista Trimestral de Direito Civil, Rio de Janeiro, n. 16, p. 103-113, out./dez. 2003.

LOPES, José Reinaldo de Lima. Responsabilidade civil do fabricante e a defesa do consumidor. São Paulo: RT, 1992.

LOPES, José Reinaldo de Lima. Voltar à teoria da justiça?, Revista de Direito Alternativo, São Paulo, n. 1, p. 71-76, 1992.

LOPES, Mônica Sette. Os sujeitos jurídicos: concepções tangenciadoras do novo código civil, Revista da Faculdade de Direito, Belo Horizonte, v. 42, p. 191-217, 2002/2003.

LÓPEZ, Andrés Mariño. Los fundamentos de la responsabilidad contractual. Montevideo: Carlos Alvarez, 2005. 
LOPEZ, Teresa Ancona. O dano estético: responsabilidade civil. 3 ed. São Paulo: RT, 2004.

LORENZETTI, Ricardo Luis. A era da desordem e o fenômeno da descodificação, Revista de Direito do Consumidor, São Paulo, v. 17, n. 68, p. 212-241, out./dez. 2008.

LORENZETTI, Ricardo Luis. El sistema de la responsabilidad civil ¿una deuda de responsabilidad, un crédito de indemnización o una relación jurídica?, Revista da Ajuris, Porto Alegre, n. 63, p. 166198, mar. 95.

LORENZETTI, Ricardo Luis. Esquema de una teoría sistémica del contrato, Revista de Direito do Consumidor, São Paulo, v. 9, n. 33, p. 51-77, jan./mar. 2000.

LORENZETTI, Ricardo Luis. Esquema de una teoría sistémica del contrato. In: FERNÁNDEZ, Carlos López; CAUMONT, Arturo; CAFFERA, Gerardo (Coord.). Estudios de derecho civil en homenaje al profesor Jorge Gamarra. Montevideo: FCU, 2001.

LORENZETTI, Ricardo Luis. La oferta como apariencia y la aceptación basada en la confianza, Revista de Direito do Consumidor, São Paulo, v. 9, n. 35, p. 9-38, jul./set. 2000.

LORENZETTI, Ricardo Luis. Teoria da decisão judicial: fundamentos do direito. Trad. Bruno Miragem. São Paulo: RT, 2009.

LORENZETTI, Ricardo Luis. Tratado de los contratos: parte general. Buenos Aires: Rubinzal Culzoni, 2004.

LOTUFO, Renan. Da oportunidade da codificação civil, Revista do Advogado, São Paulo, n. 68, p. 19-30, dez. 2002.

LOVECE, Graciela. El riesgo de la víctima y la eximición de responsabilidad, Revista de Responsabilidad Civil y Seguros, Buenos Aires, n. 6 extra, p. 1-6, jun. 2007.

LUHMANN, Niklas. Confianza. Trad. Amada Flores. Barcelona: Anthropos, 2005.

LUHMANN, Niklas. Observaciones de la modernidad: racionalidad y contingencia en la sociedad moderna. Trad. Carlos Fortea Gil. Barcelona: Paidós, 1997.

MACHADO, João Baptista. Obra dispersa. Braga: Scientia Iurídica, 1991, v. 1.

MADEIRA, Hélcio Maciel França. À história do direito, Revista da Faculdade de Direito de São Bernardo do Campo, São Bernardo do Campo, v. 8, n. 10, p. 149-154, 2004.

MAGALHÃES, Joseli Lima. Da recodificação do direito civil brasileiro. Rio de Janeiro: Lumen Juris, 2006.

MAIA, Antonio Cavalcanti. O direito constitucional do limiar do século XXI: princípios jurídicos e pós-positivismo. In: MORAES, Guilherme Peña de. Readequação constitucional do estado moderno. Rio de Janeiro: Lumen Juris, 2006.

MALINOWSKI, Bronislaw. Crimen y costumbre en la sociedad salvaje. Trad. J. y M. T. Alier. Barcelona: Planeta-Agostini, 1985.

MALUF, Carlos Alberto Dabus. Do caso fortuito e da força maior excludentes de culpabilidade no código civil de 2002. In: DELGADO, Mário Luiz; ALVES, Jones Figueiredo (Coord.). Questões controvertidas: responsabilidade civil. São Paulo: Método, 2006, v. 5. 
MALUF, Carlos Alberto Dabus. Do caso fortuito e da força maior: excludentes de culpabilidade, Revista do Advogado, São Paulo, n. 44, p. 28-37, out. 1994.

MALUF, Carlos Alberto Dabus. Limitações ao direito de propriedade: de acordo com o código civil de 2002 e com o estatuto da cidade. São Paulo: RT, 2005.

MAQUIAVEL, Nicolau. O príncipe: com notas de Napoleão Bonaparte. 2 ed. Trad. José Cretella Junior; Agnes Cretella. RT: São Paulo, 1997.

MARÇAL, Antonio Cota. O inferencialismo de Brandom e a argumentação jurídica. In: GALUPPO, Marcelo Campos (Org.). O Brasil que queremos: reflexões sobre o estado democrático de direito. Belo Horizonte: PUC Minas, 2006.

MARCHI, Eduardo César Silveira Vita. Dos riscos pela perda fortuita da coisa vendida no direito romano, Revista da Faculdade de Direito, São Paulo, v. 96, p. 45-73, jan./dez. 1996.

MARINONI, Luiz Guilherme. Tutela específica: arts. 461, cpc e 84, cdc. 2 ed. São Paulo: RT, 2001.

MARQUES, Cláudia Lima. A boa-fé nos serviços bancários, financeiros, de crédito e securitários e o código de defesa do consumidor: informação, cooperação e renegociação?, Revista de Direito do Consumidor, São Paulo, v. 11, n. 43, p. 215-257, jul./set. 2002.

MARQUES, Cláudia Lima. A chamada nova crise do contrato e o modelo de direito privado brasileiro: crise de confiança ou de crescimento do contrato?. In: MARQUES, Cláudia Lima (Coord.). A nova crise do contrato: estudos sobre a nova teoria contratual. São Paulo: RT, 2007.

MARQUES, Cláudia Lima. Contratos no código de defesa do consumidor: o novo regime das relações contratuais. 5 ed. São Paulo: RT, 2006.

MARQUES, Cláudia Lima. Direito na pós-modernidade e a teoria de Erik Jayme. In: OLIVEIRA JUNIOR, José Alcebíades (Org.). Faces do multiculturalismo: teoria, política, direito. Santo Ângelo: Ediuri, 2007.

MARQUES, Cláudia Lima. Direitos básicos do consumidor na sociedade pós-moderna de serviços: o aparecimento de um sujeito novo e a realização de seus direitos, Revista de Direito do Consumidor, São Paulo, v. 9, n. 35, p. 61-96, jul./set. 2000.

MARQUES, Cláudia Lima. Novos temas na teoria dos contratos: confiança e o conjunto contratual, Revista da Ajuris, Porto Alegre, v. 32, n. 100, p. 73-97, dez. 2005.

MARQUES, Cláudia Lima. Três tipos de diálogos entre o código de defesa do consumidor e o código civil de 2002: superação das antinomias pelo "diálogo das fontes". In: PFEIFFER, Roberto Augusto Castellanos; PASQUALOTTO, Adalberto (Coord.). Código de defesa do consumidor e o código civil de 2002: convergências e assimetrias. São Paulo: RT, 2005.

MARQUES, Henrique Paulo Azevedo. Da responsabilidade civil em face dos acidentes de trânsito, Revista dos Tribunais, São Paulo, v. 38, n. 181, p. 510-517, set. 1949.

MARQUES, Mário Reis. Grandes linhas de evolução do pensamento e da filosofia jurídicas. In: CUNHA, Paulo Ferreira da (Org.). Instituições de direito: filosofia e metodologia do direito. Coimbra: Almedina, 1998, v. 1.

MARTINEZ, Pedro Romano. Cumprimento defeituoso: em especial na compra e venda e na empreitada. Almedina: Coimbra, 2001. 
MARTÍNEZ, Pedro Soares. O homem e a economia, Revista da Faculdade de Direito da Universidade de Lisboa, Coimbra, v. 38, n. 1, p. 101-111, 1997.

MARTINS, Raphael Manhães. Análise paradigmática do direito das obrigações: boa-fé, deveres laterais e violações positivas do contrato, Revista Jurídica Empresarial, Porto Alegre, v. 8, p. 137 160, mai.jun. 2009.

MARTINS, Raphael Manhães. Inadimplemento antecipado: perspectiva para sua aplicação no direito brasileiro, Revista de Direito Privado, São Paulo, v. 8, n. 30, p. 199-238, abr./jun. 2007.

MARTINS, Raphael Manhães. O princípio da confiança legítima no direito brasileiro: uma discussão em torno do enunciado n. 362, da IV jornada de direito civil, Revista da Ajuris, Porto Alegre, v. 35, n. 112, p. 257-271, dez. 2008.

MARTINS-COSTA, Judith. A boa-fé como modelo (notas para a compreensão da boa-fé obrigacional como modelo doutrinário e jurisprudencial no direito brasileiro), Roma e America: Diritto Romano Comune, Roma, n. 13, p. 71-97, 2002.

MARTINS-COSTA, Judith. A boa-fé no direito privado. São Paulo: RT, 2000.

MARTINS-COSTA, Judith. A boa-fé objetiva e o adimplemento das obrigações, Revista Brasileira de Direito Comparado, Rio de Janeiro, n. 25, p. 229-282, jul./dez. 2003.

MARTINS-COSTA, Judith. A ilicitude derivada do exercício contraditório de um direito: o renascer do venire contra factum proprium, Revista da Ajuris, Porto Alegre, v. 32, n. 97, p. $143-$ 169, mar. 2005.

MARTINS-COSTA, Judith. A proteção da legítima confiança nas relações obrigacionais entre a administração e os particulares, Revista da Faculdade de Direito da UFRGS, Porto Alegre, v. 22, p. 228-255, set. 2002.

MARTINS-COSTA, Judith. Adimplemento e inadimplemento. In: EMERJ DEBATE O NOVO CÓDIGO CIVIL. Rio de Janeiro: EMERJ, 2002, parte 01.

MARTINS-COSTA, Judith. Comentários ao novo código civil: do direito das obrigações - do adimplemento e da extinção das obrigações. Rio de Janeiro: Forense, 2005, v. 5, t. 1.

MARTINS-COSTA, Judith. Comentários ao novo código civil: do inadimplemento das obrigações. Rio de Janeiro: Forense, 2003, v. 5, t. 2.

MARTINS-COSTA, Judith. O direito privado como um "sistema em construção": as cláusulas gerais no projeto do código civil brasileiro, Revista de Informação Legislativa, Brasília, v. 35, n. 139, p. 5-22, jul./set. 1998.

MARTINS-COSTA, Judith. O método da concreção e a interpretação dos contratos: primeiras notas de uma leitura suscitada pelo código civil. In: DELGADO, Mário Luiz; ALVES, Jones Figueiredo (Coord.). Questões controvertidas: no direito das obrigações e dos contratos. São Paulo: Método, 2005, v. 4.

MARTINS-COSTA, Judith. Os avatares do abuso de direito e o rumo indicado pela boa-fé. In: TEPEDINO, Gustavo (Org.). Direito civil contemporâneo: novos paradigmas à luz da legalidade constitucional. São Paulo: Atlas, 2008.

MARTINS-COSTA, Judith. Os danos à pessoa no direito brasileiro e a natureza de sua reparação. In: MARTINS-COSTA, Judith (Org.). A reconstrução do direito privado. São Paulo: RT, 2002. 
MARTINS-COSTA, Judith. Os danos à pessoa no direito brasileiro e a natureza da sua reparação, Revista dos Tribunais, São Paulo, v. 90, n. 789, p. 21-47, jul. 2001.

MARTINS-COSTA, Judith. Os direitos fundamentais e a opção culturalista do novo código civil. In: SARLET, Ingo Wolfgang (Org.). Constituição, direitos fundamentais e direito privado. 2 ed. Porto Alegre: LAEL, 2006.

MARTINS-COSTA, Judith. Princípio da confiança legítima e principio da boa-fé objetiva. termo de compromisso de cessação (tcc) ajustado com o cade. critérios de interpretação contratual: os "sistemas de referência extracontratuais" ("circunstâncias do caso") e sua função no quadro semântico da conduta devida. princípio da unidade ou coerência hermenêutica e "usos do tráfego". adimplemento contratual, Revista dos Tribunais, São Paulo, v. 95, n. 852, p. 87-126, out. 2006.

MARTINS-COSTA, Judith. Reflexões sobre o princípio da função social dos contratos, Revista Brasileira de Direito Comparado, Rio de Janeiro, n. 29, p. 65-102, jul./dez. 2005.

MARTINS-COSTA, Judith. Um aspecto na obrigação de indenizar: notas para uma sistematização dos deveres pré-negociais de proteção no direito civil brasileiro, Revista dos Tribunais, São Paulo, v. 97, n. 867 , p. 11-51, jan. 2008.

MARTINS-COSTA, Judith; BRANCO, Gerson Luis Carlos. Diretrizes teóricas do novo código civil brasileiro. São Paulo: Saraiva, 2002.

MASI, Domenico de. A sociedade pós-industrial. In: MASI, Domenico de. A sociedade pósindustrial. 4 ed. Trad. Anna Maria Capovilla et all. São Paulo: Senac, 2003.

MASSIMO BIANCA, Cesare. Diritto civile: 1’obbligazione. Milano: Giuffrè, 2006, v. 4.

MASSIMO BIANCA, Cesare. La colpa come elemento costitutivo della fatispecie dell'illecito, Roma e America: Diritto Romano Comune, Roma, n. 3, p. 201-204, 1997.

MASSIMO BIANCA, Cesare. La nozione di buona fede quale regola di comportamento contrattuale, Rivista di Diritto Civile, Padova, anno 29, n. 3, p. 205-216, mai./jun. 1983.

MASSIMO BIANCA, Cesare. Supervivencia de la teoría de la culpa. In: BUERES, Alberto Jesús; DE CARLUCCI, Aída Kemelmajer (Dir.). Responsabilidad por daños en el tercer milenio. Buenos Aires: Abeledo-Perrot, 1997.

MATA-MACHADO, Edgar de Godoi. Contribuição ao personalismo jurídico. Belo Horizonte: Del Rey, 2000.

MAURER, Béatrice. Notas sobre o respeito da dignidade da pessoa humana ... ou uma pequena fuga incompleta em torno de um tema central. In: SARLET, Ingo Wolfgang (Org.). Dimensões da dignidade: ensaios de filosofia do direito e do direito constitucional. 2 ed. Porto Alegre: LAEL, 2009.

MAYO, Jorge. El ámbito de la culpa en el derecho de las obligaciones. In: GESUALDI, Dora Mariana (Coord.). Derecho privado. Buenos Aires: Hammurabi, 2001.

MAZEAUD, Denis. Responsabilidad contractual y responsabilidad extracontractual: el futuro de la distinción en el derecho francés, Revista Anales Derecho UC, Santiago, v. 3, p. 13-25, mar. 2008.

MAZEAUD, Henri; MAZEAUD, Léon; TUNC, André. Tratado teórico y práctico de la responsabilidad civil delictual y contractual. Trad. Luis Alcalá Zamora y Castillo. Buenos Aires: Ediciones Jurídicas Europa-América, 1962, v. 2, t. 1. 
MAZEAUD, Léon. H. Capitant e a elaboração da teoria francesa da responsabilidade civil, Revista Forense, Rio de Janeiro, v. 37, n. 83, p. 394-400, set. 1940.

MAZZEI, Rodrigo. Código civil de 2002 e o judiciário: apontamentos na aplicação das cláusulas gerais. In: DIDIER JUNIOR, Fredie; MAZZEI, Rodrigo (Coord.). Reflexos do novo código civil no direito processual. Salvador: Juspodivm, 2006.

MEDINA, Diego Eduardo López. Teoría impura del derecho: la transformación de la cultura jurídica latinoamericana. Bogotá: Legis, 2005.

MEIRELLES, Jussara Maria Leal de. Repersonalização, transindividualidade, relativização: a subjetividade revista em prol de um desenvolvimento juridicamente sustentável. In: CONRADO, Marcelo; PINHEIRO, Rosalice Fidalgo (Coord.). Direito privado e constituição: ensaios para uma recomposição valorativa da pessoa e do patrimônio. Curitiba: Juruá, 2009.

MEJÍA, Juan Pablo Cárdenas. Justicia y abuso contractual. In: ESPINOSA, Fabricio Mantilla; BARRIOS, Francisco Ternera (Dir.). Los contratos en el derecho privado. Bogotá: Legis, 2007.

MELLO, Baptista de. Do caso fortuito e da força maior nos contractos civis, Revista dos Tribunais, São Paulo, v. 25, n. 101, p. 15-28, mai. 1936.

MELLO, Baptista de. Interpretação e humanização da lei, Revista dos Tribunais, São Paulo, v. 24, n. 95 , p. 308-313, mai. 1935.

MELO, Albertino Daniel de. Novo código civil: linhas ideológicas e confrontação tópica, Revista da Faculdade de Direito, Belo Horizonte, v. 42, p. 59-79, 2002/2003.

MENAUT, António Carlos Pereira. Judicialismo. In: CUNHA, Paulo Ferreira da (Org.). Instituições de direito: filosofia e metodologia do direito. Coimbra: Almedina, 1998, v. 1.

MENDES JUNIOR, Onofre. A proteção do fraco no direito moderno, Revista da Faculdade de Direito, Belo Horizonte, n. 7, p. 79-90, 1955.

MENDES, Felismina. Risco: um conceito do passado que colonizou o presente, Revista Portuguesa de Saúde Pública, Lisboa, v. 20, n. 2, p. 53-62, jul./dez. 2002.

MENEZES CORDEIRO, Antônio Manuel da Rocha e. Da boa fé no direito civil. Coimbra: Almedina, 1984, v. 1.

MENEZES CORDEIRO, António Manuel da Rocha e. Da modernização do direito civil: aspectos gerais. Coimbra: Almedina, 2004, v. 1.

MENEZES CORDEIRO, António Manuel da Rocha e. Direito das obrigações. Lisboa: Associação Acadêmica da Faculdade de Direito de Lisboa, 1986, v. 2.

MENEZES CORDEIRO, António Manuel da Rocha e. Direito das obrigações. Lisboa: Associação Acadêmica da Faculdade de Direito de Lisboa, 1986, v. 1.

MENGONI, Luigi. Obbligazioni "di risultato" e obbligazioni "di mezzi" (studio critico), Rivista del Diritto Commerciale, Milano, anno 52, n. 5-10, parte 1, p. 3-90, 1954.

MESSA, Gian Carlo. L'obbligazione degli interessi e le sue fonti. Milano: Società Editrice Libraria, 1911.

MEZA, Jorge Alfredo. El contrato. In: GESUALDI, Dora Mariana (Coord.). Derecho privado. Buenos Aires: Hammurabi, 2001. 
MIRAGEM, Bruno. Abuso de direito: ilicitude objetiva no direito privado brasileiro, Revista dos Tribunais, São Paulo, v. 94, n. 842, p. 11-44, dez. 2005.

MIRAGEM, Bruno. Responsabilidade civil médica no direito brasileiro, Revista de Direito do Consumidor, São Paulo, v. 16, n. 63, p. 52-91, jul./set. 2007.

MIRANDA, Custódio da Piedade Ubaldino. A responsabilidade civil no âmbito do código de defesa do consumidor, Revista do Advogado, São Paulo, n. 33, p. 49-56, dez. 1990.

MIRANDA, Darcy Arruda. Anotações ao código civil brasileiro. São Paulo: Saraiva, 1987, v. 3.

MIRANDA, José Gustavo Souza. A proteção da confiança nas relações obrigacionais, Revista de Informação Legislativa, Brasília, v. 38, n. 153, p. 131-149, jan./mar. 2002.

MOISÁ, Benjamin. La culpa como unico fundamento de la responsabilidad civil, Revista de Responsabilidad Civil y Seguros, Buenos Aires, n. 12, p. 349-358, dez. 2006.

MONREAL, Eduardo Novoa. O direito como obstáculo à transformação social. Trad. Gérson Pereira dos Santos. Porto Alegre: SAFE, 1988.

MONTEIRO, Washington de Barros. Curso de direito civil: direito das obrigações. Atual. Carlos Alberto Dabus Maluf. São Paulo: Saraiva, 2003, v. 4.

MONTEIRO, Washington de Barros; MALUF, Carlos Alberto Dabus. Curso de direito civil: direito das obrigações. 35 ed. São Paulo: Saraiva, 2010, v. 4.

MONTEIRO, Washington de Barros; MALUF, Carlos Alberto Dabus; SILVA, Regina Beatriz Tavares da. Curso de direito civil: direito das obrigações. 37 ed. São Paulo: Saraiva, 2010, v. 5.

MONTIJANO, Martín García-Ripoll. Imputación objetiva, causa próxima y alcance de los daños indenizables. Granada: Comares, 2008.

MORAES, Maria Celina Bodin de. A caminho de um direito civil constitucional, Revista de Direito Civil Imobiliário, Agrário e Empresarial, São Paulo, v. 17, n. 65, p. 21-32, jul./set. 1993.

MORAES, Maria Celina Bodin de. A constitucionalização do direito civil e seus efeitos sobre a responsabilidade civil, Direito, Estado e Sociedade, Rio de Janeiro, v. 9, n. 29, p 233-258, jul/dez 2006.

MORAES, Maria Celina Bodin de. Constituição e direito civil: tendências, Revista dos Tribunais, São Paulo, v. 89, n. 779, p. 47-63, set. 2000.

MORAES, Maria Celina Bodin de. Danos à pessoa humana: uma leitura civil-constitucional dos danos morais. Rio de Janeiro: Renovar, 2003.

MORAES, Maria Celina Bodin de. O conceito de dignidade humana: substrato axiológico e conteúdo normativo. In: SARLET, Ingo Wolfgang (Org.). Constituição, direitos fundamentais $e$ direito privado. 2 ed. Porto Alegre: LAEL, 2006.

MORAES, Maria Celina Bodin de. Perspectivas a partir do direito civil-constitucional. In: TEPEDINO, Gustavo (Org.). Direito civil contemporâneo: novos paradigmas à luz da legalidade constitucional. São Paulo: Atlas, 2008.

MORAES, Maria Celina Bodin de. Prefácio. In: SCHREIBER, Anderson. Novos paradigmas da responsabilidade civil: da erosão dos filtros da reparação à diluição dos danos. São Paulo: Atlas, 2007. 
MORAES, Maria Celina Bodin de. Risco, solidariedade e responsabilidade objetiva, Revista dos Tribunais, São Paulo, v. 95, n. 854, p. 11-37, dez. 2006.

MOREIRA ALVES, José Carlos. Direito romano: instituições de direito romano. 6 ed. Rio de Janeiro: Forense, 2000, v. 2.

MOREIRA NETO, Diogo de Figueiredo. Direitos humanos, legitimidade e constitucionalismo. In: SARMENTO, Daniel; GALDINO, Flávio (Org.). Direitos fundamentais: estudos em homenagem ao professor Ricardo Lobo Torres. Rio de Janeiro: Renovar, 2006.

MOREIRA, Guilherme Alves. Instituições do direito civil português: das obrigações. Coimbra: Coimbra, 1925, v. 2.

MOREIRA, Lenice Silveira. Ciência jurídica e complexidade: reflexões sobre as mudanças epistemiológicas [sic] necessárias à compreensão do direito no século XXI, Revista da FARN, Natal, v. 5, n. 1/2, p. 27-50, 2006.

MORELLO, Augusto Mario. El principio de la buena fe en la sociedad del riesgo. In: CÓRDOBA, Marcos (Dir.). Tratado de la buena fe en el derecho: doctrina nacional. Buenos Aires: La Ley, 2004, v. 1.

MOZOS, Jose Luis de los. Metodologia y ciencia en el derecho privado moderno. Madrid: Editoriales de Derecho Reunidas, 1977.

MULHOLLAND, Caitlin Sampaio. A responsabilidade civil por presunção de causalidade. Rio de Janeiro: GZ, 2009.

NALIN, Paulo. A função social do contrato no futuro código civil brasileiro, Revista de Direito Privado, São Paulo, v. 3, n. 12, p. 50-60, out./dez. 2002.

NALIN, Paulo. Cláusula geral e segurança jurídica no código civil, Revista da Faculdade de Direito da Universidade Federal do Paraná, Curitiba, n. 41, p. 85-98, 2004.

NALIN, Paulo. Do contrato: conceito pós-moderno em busca de sua formulação na perspectiva civil-constitucional. Curitiba: Juruá, 2001.

NALIN, Paulo. Responsabilidade civil: descumprimento do contrato e dano extrapatrimonial. Curitiba: Juruá, 1996.

NALIN, Paulo; XAVIER, Luciana Pedroso; XAVIER, Marília Pedroso. A obrigação como processo: breve releitura trinta anos após. In: TEPEDINO, Gustavo; FACHIN, Luiz Edson. Diálogos sobre direito civil. Rio de Janeiro: Renovar, 2008, v. 2.

NANNI, Giovanni Ettore. O dever de cooperação nas relações obrigacionais à luz do princípio constitucional da solidariedade. In: NANNI, Giovanni Ettore (Coord.). Temas relevantes do direito civil contemporâneo: reflexões sobre os cinco anos do código civil. São Paulo: Atlas, 2008.

NEGREIROS, Teresa. O princípio da boa-fé contratual. In: MORAES, Maria Celina Bodin de (Coord.). Princípios do direito civil contemporâneo. Rio de Janeiro: Renovar, 2006.

NEGREIROS, Teresa. Teoria do contrato: novos paradigmas. Rio de Janeiro: Renovar, 2002.

NERILO, Lucíola F. L.. A responsabilidade civil pelo descumprimento da cláusula geral da boa-fé nos contratos, Revista dos Tribunais, São Paulo, v. 96, n. 866, p. 67-98, dez. 2007. 
NERY JUNIOR, Nelson. Aspectos da responsabilidade civil do fornecedor no código de defesa do consumidor, Revista do Advogado, São Paulo, n. 33, p. 76-79, dez. 1990.

NERY, Rosa Maria Barreto Borriello de Andrade. Introdução ao pensamento jurídico e à teoria geral do direito privado. São Paulo: RT, 2008.

NERY, Rosa Maria Barreto Borriello de Andrade. Vínculo obrigacional: relação jurídica de razão (técnica e ciência de proporção). Tese (Livre-Docência) - Faculdade de Direito da PUC/SP, São Paulo, 2004.

NOBILI, Chiara. Le obbligazioni. Milano: Giuffrè, 2001.

NOGUEIRA, J. A.. As novas directrizes do direito, Revista dos Tribunais, São Paulo, v. 20, n. 78, p. 3-21, mai. 1931.

NOGUEIRA, Lavyne Lima. Responsabilidade civil do profissional liberal perante o código de defesa do consumidor, Revista de Direito do Consumidor, São Paulo, v. 10, n. 40, p. 199-226, out./dez. 2001.

NONATO, Orosimbo. Aspectos do modernismo jurídico e o elemento moral na culpa objectiva, Revista Forense, Rio de Janeiro, n. 56, p. 5-26, jan./jun. 1931.

NORDMEIER, Carl Friedrich. O novo direito das obrigações no código civil alemão - a reforma de 2002. In: MARQUES, Cláudia Lima (Coord.). A nova crise do contrato: estudos sobre a nova teoria contratual. São Paulo: RT, 2007.

NORONHA, Fernando. Desenvolvimentos contemporâneos da responsabilidade civil, Revista dos Tribunais, São Paulo, n. 761, p. 31-44, mar. 1999.

NORONHA, Fernando. Direito das obrigações. São Paulo: Saraiva, 2004, v. 1.

NORONHA, Fernando. O ato ilícito nos contratos e fora deles, Revista de Direito Civil, Imobiliário, Agrário e Empresarial, São Paulo, v. 9, n. 34, p. 34-35, out./dez. 1985.

NORONHA, Fernando. O direito dos contratos e seus princípios fundamentais: autonomia privada, boa-fé e justiça contratual. São Paulo: Saraiva, 1994.

NUNES, Dierle José Coelho. Alguns fundamentos de revisionismo contratual ... acerca do direito obrigacional e contratual numa perspectiva democrática, Revista da Faculdade Mineira de Direito, Belo Horizonte, v. 8, n. 15, p. 60-81, jan./jun. 2005.

OLIVARES, Álvaro Vidal. Cumplimiento e incumplimiento contractual en el codigo civil: una perspectiva más realista, Revista Chilena de Derecho, Santiago, v. 34, n. 1, p. 41-59, jan./abr. 2007.

OLIVEIRA, A. Gonçalves de. Ato ilícito e responsabilidade civil, Revista dos Tribunais, São Paulo, v. 27, n. 115, p. 23-31, set. 1938.

OLIVEIRA, Ubirajara Mach de. A harmonização formal do direito da venda internacional de mercadorias no âmbito da Convenção de Viena de 1980 e o standard da boa-fé, Revista da Faculdade de Direito Ritter dos Reis, Porto Alegre, v. 4, p. 97-124, mar./jul. 2001.

OLIVEIRA, Ubirajara Mach de. Quebra positiva do contrato, Revista de Direito do Consumidor, São Paulo, n. 25, p. 39-56, jan./mar. 1998.

OST, François. Júpiter, Hércules, Hermes: tres modelos de juez, Doxa, Alicante, n. 14, p. 169-194, 1993. 
OST, François. Tiempo y contrato: crítica del pacto fáustico, Doxa, Alicante, n. 25, p. 597-626, 2002.

OSTI, Giuseppe. Revisione critica della teoria sulla impossibilità della prestazione (continuazione), Rivista di Diritto Civile, Milano, v. 10, n. 4, p. 313-360, jul./ago. 1918.

OSTI, Giuseppe. Revisione critica della teoria sulla impossibilità della prestazione, Rivista di Diritto Civile, Milano, v. 10, n. 3, p. 209-249, mai./jun. 1918.

PACCHIONI, Giovanni. Obbligazioni e contratti: succinto commento al libro quarto del codice civile. Padova: CEDAM, 1950.

PADILLA, Rodrigo. La responsabilidad civil del abogado y las obligaciones de medio y resultado, Revista de Responsabilidad Civil y Seguros, Buenos Aires, n. 4, p. 80-106, abr. 2006.

PAPAYANNIS, Diego Martín. En torno de la teoría del derecho de daños, Revista de Responsabilidad Civil y Seguros, Buenos Aires, n. 8, p. 23-34, ago. 2007.

PARDO, José Esteve. El derecho del medio ambiente como derecho de decisión y gestión de riesgos, Revista Electrónica del Departamento de Derecho de la Universidad de La Rioja, Logroño, n. 4, p. 7-16, dez. 2006.

PARODI, Felipe Osterling; FREYRE, Mario Castillo. Tratado de las obligaciones. Lima: Fondo Editorial de la Pontificia Universidad Católica del Perú, 2005, v. 16, t. 1.

PASQUALOTTO, Adalberto de Souza. A responsabilidade civil do fabricante e os riscos do desenvolvimento. In: MARQUES, Cláudia Lima (Coord.). A proteção do consumidor no Brasil e no Mercosul. Porto Alegre: LAEL, 1994.

PEÑA, Carlos. El derecho desde el derecho, Persona y Sociedad, Santiago, v. 18, n. 2, p. 23-32, ago. 2004.

PENTEADO, Luciano de Camargo. Abuso do poder econômico-contratual e boa-fé, Revista de Direito Privado, São Paulo, v. 3, n. 11, p. 138-153, jul./set. 2002.

PENTEADO, Luciano de Camargo. Efeitos contratuais perante terceiros. São Paulo: Quarter Latin, 2006.

PEREIRA, Agostinho Oli Koppe. A culpa e a responsabilidade civil no direito brasileiro, Revista da Faculdade de Direito, Caxias do Sul, n. 6, p. 116-132, mar. 1997.

PEREIRA, Alexandre Pimenta Batista. Os confins da responsabilidade objetiva nos horizontes da sociologia do risco: almejando a permanente certeza na contingência das improbabilidades, Revista de Informação Legislativa, Brasília, v. 43, n. 170, p. 181-189, abr./jun. 2006.

PEREIRA, Caio Mário da Silva. Instituições de direito civil: introdução ao direito civil; teoria geral do direito civil. 20 ed. Atual. Maria Celina Bodin de Moraes. Rio de Janeiro: Forense, 2004, v. 1.

PEREIRA, Caio Mário da Silva. Instituições de direito civil: teoria geral das obrigações. 20 ed. Atual. Luis Roldão de Freitas Gomes. Rio de Janeiro: Forense, 2004, v. 2.

PEREIRA, Caio Mário da Silva. Responsabilidade civil: de acordo com a constituição federal de 1988. 8 ed. Rio de Janeiro: Forense, 1997.

PERELMAN, Chaïm. Lógica jurídica. Trad. Verginia Pupi. São Paulo: Martins Fontes, 2000. 
PERILLO, Emanuel Augusto. A positividade como expressão do direito, Revista da Faculdade de Direito, Curitiba, v. 4, n. 4, p. 105-109, dez. 1956.

PERLINGIERI, Pietro. A doutrina do direito civil na legalidade constitucional. In: TEPEDINO, Gustavo (Org.). Direito civil contemporâneo: novos paradigmas à luz da legalidade constitucional. São Paulo: Atlas, 2008.

PERLINGIERI, Pietro. Normas constitucionais nas relações privadas, Revista da Faculdade de Direito, Rio de Janeiro, n. 6-7, p. 63-77, 1999.

PERLINGIERI, Pietro. O direito civil na legalidade constitucional. Trad. Maria Cristina De Cicco. Rio de Janeiro: Renovar, 2008.

PERLINGIERI, Pietro. Perfis do direito civil: introdução ao direito civil constitucional. 2 ed. Trad. Maria Cristina De Cicco. Rio de Janeiro: Renovar, 2002.

PERLINGIERI, Pietro. Scuole civilistiche e dibattito ideologico: introduzione allo studio del diritto privato in italia, Rivista di Diritto Civile, Padova, anno 24, n. 4, p. 405-441, jul./ago. 1978.

PEZZELLA, Maria Cristina Cereser. Código civil em perspectiva histórica. In: SARLET, Ingo Wolfgang (Org.). O novo código civil e a constituição. 2 ed. Porto Alegre: LAEL, 2006.

PICASSO, Sebastián. El incumplimiento en las obligaciones contractuales: el problema de la ausencia de culpa y de la imposibilidad sobrevenida de la prestación - obligaciones de medios y de resultado. In: GESUALDI, Dora Mariana (Coord.). Derecho privado. Buenos Aires: Hammurabi, 2001.

PICASSO, Sebastián. La culpa y el incumplimiento en las obligaciones de medios. In: FERNÁNDEZ, Carlos López; CAUMONT, Arturo; CAFFERA, Gerardo (Coord.). Estudios de derecho civil en homenaje al profesor Jorge Gamarra. Montevideo: FCU, 2001.

PIMENTA, Eduardo Goulart. Direito, economia e relações patrimoniais privadas, Revista de Informação Legislativa, Brasília, v. 43, n. 170, p. 159-173, abr./jun. 2006.

PINHEIRO PEDRO. Antônio Fernando. Aspectos ideológicos do meio ambiente. In: SILVA, Bruno Campos (Org.). Direito ambiental: enfoques variados. São Paulo: Lemos \& Cruz, 2004.

PINHEIRO, Rosalice Fidalgo. Contrato e direitos fundamentais. Curitiba: Juruá, 2009.

PIZARRO, Ramón. Objeto de la obligación: su importancia con respecto a la esencia del instituto. In: GESUALDI, Dora Mariana (Coord.). Derecho privado. Buenos Aires: Hammurabi, 2001.

POMAR, Fernando Gómez. Carga de la prueba y responsabilidad objetiva, InDret, Barcelona, n. 1, p. 1-17, 2001.

PONDÉ, Lafayette. Responsabilidade civil dos médicos, Revista Forense, Rio de Janeiro, v. 57, n. 191, p. 30-36, set./out. 1960.

PONTES DE MIRANDA, Francisco Cavalcanti. Tratado de direito privado: parte especial. 2 ed. Rio de Janeiro: Borsoi, 1958, t. 23.

PONTES DE MIRANDA, Francisco Cavalcanti. Tratado de direito privado: parte especial. Rio de Janeiro: Borsoi, 1959, t. 26.

PONZANELLI, Giulio. La responsabilità civile: profili di diritto comparato. Bologna: Il Mulino, 1992. 
POPP, Carlyle. Liberdade negocial e dignidade da pessoa humana: aspectos relevantes. In: NALIN, Paulo; VIANNA, Guilherme Borba (Coord.). Direito em movimento. Curitiba: Juruá, 2007.

PORTO, Mário Moacyr. O ocaso da culpa como fundamento da responsabilidade civil, Revista Forense, Rio de Janeiro, n. 302, p. 45-48, abr./jun. 1988.

POTHIER, Robert Joseph. Tratado das obrigações. Trad. Adrian Sotero De Witt Batista; Douglas Dias Ferreira. Campinas: Servanda, 2002.

PRADA, Maria González de; WAYAR, Ernesto. La mora, la demora y la crisis de la culpa. In: BUERES, Alberto Jesús (Dir.). Responsabilidad por daños. Buenos Aires: Abeledo-Perrot, 1997.

PRATA, Ana. A tutela constitucional da autonomia privada. Coimbra: Almedina, 1982.

PRICE, Jorge E. Douglas. El puente de macedonio, Revista da Faculdade Mineira de Direito, Belo Horizonte, v. 10, n. 19, p. 51-69, jan./jun. 2007.

PROUDHON, Pierre Joseph. A propriedade é um roubo e outros escritos anarquistas. Trad. Suely Bastos. Porto Alegre: L\&PM, 1998.

PRUX, Oscar Ivan. Um novo enfoque quanto à responsabilidade civil do profissional liberal, Revista de Direito do Consumidor, São Paulo, n. 19, p. 202-231, jul./set. 1996.

QUEIROGA, Antônio Elias de. Responsabilidade civil e o novo código civil. 2 ed. Rio de Janeiro: Renovar, 2003.

RAIZER, Ludwig. O futuro do direito privado, Revista da PGE, Porto Alegre, v. 9, n. 25, p. 11-30, 1979.

RAMOS, Carmem Lucia Silveira. Os princípios gerais do direito civil, Revista da Faculdade de Direito, Curitiba, v. 22, n. 22, p. 272-284, 1985.

REALE, Miguel. Diretrizes da reforma do código civil, Revista do Advogado, São Paulo, n. 19, p. 5-12, out. 1985.

REALE, Miguel. O projeto do novo código civil. 2 ed. São Paulo: Saraiva, 1999.

REALE, Miguel. Visão geral do novo código civil, Revista de Direito Privado, São Paulo, v. 3, n. 9, p. 9-17, jan./mar. 2002.

REIS, Clayton. El daño a la persona en el derecho brasileño. In: GESUALDI, Dora Mariana (Coord.). Derecho privado. Buenos Aires: Hammurabi, 2001.

RENN, Ortwin; STIRLING Andrew; MÜLLER-HEROLD, Ulrich. The precautionary principle: a new paradigm for risk management and participation, Idées pour le Débat, Paris, n. 3, p. 1-19, 2004.

REPRESAS, Félix Alberto Trigo. La buena fe y su relación con la responsabilidad civil. In: CÓRDOBA, Marcos (Dir.). Tratado de la buena fe en el derecho: doctrina nacional. Buenos Aires: La Ley, 2004, v. 1.

RESCIGNO, Pietro. Danno ingiusto e ruolo della colpa: un profilo storico, Rivista de Diritto Civile, Padova, anno 36, n. 2, p. 133-155, mar./abr. 1990.

RIBEIRO, Darci Guimarães. Da tutela jurisdicional às formas de tutela. Porto Alegre: LAEL, 2010. 
RIBEIRO, Joaquim de Souza. Direito dos contratos: estudos. Coimbra: Coimbra, 2007.

RIBEIRO, Renato. Sujeito de direito, Revista de Direito Civil, Imobiliário, Agrário e Empresarial, São Paulo, v. 8, n. 29, p. 113-126, jul./set. 1984.

RIGHI, Eduardo; RIGHI, Graziela Boabaid. A complexidade obrigacional e a violação positiva do contrato no ordenamento jurídico brasileiro, Revista Brasileira de Direito Civil Constitucional e Relações de Consumo, Santo Amaro, n. 1, p. 33-107, jan./mar. 2009.

RINESSI, Antônio. La extensión del resarcimiento y la infracción al deber de seguridad, Revista de Responsabilidad Civil y Seguros, Buenos Aires, n. 2, p. 1-8, fev. 2007.

RIOS, Arthur Edmundo Souza. Responsabilidade civil pelo risco profissional, Revista da Faculdade de Direito da UFG, Goiânia, v. 4, n. 1, p. 37-50, jan./jun. 1980.

RIOS, Arthur Edmundo Souza. Responsabilidade civil: os novos conceitos indenizáveis no projeto Reale, Revista da Faculdade de Direito da UFG, Goiânia, v. 10, n. 1/2, p. 67-85, jan./dez. 1986.

RIPERT, Georges. A regra moral nas obrigações civis. Trad. Osório de Oliveira. Campinas: Bookseller, 2002.

RIPERT, Georges; BOULANGER, Jean. Tratado de derecho civil: las obligaciones. Trad. Delia García Daireaux. Buenos Aires: La Ley, 1964, v. 1, t. 4.

RIVADENEIRA, Lorenzo de la Maza. Responsabilidad contractual, Revista Chilena de Derecho, Santiago, v. 16, n. 3, p. 619-634, set./dez. 1989.

RIZZARDO, Arnaldo. Direito das obrigações. Forense: Rio de Janeiro, 2000.

RIZZARDO, Arnaldo. Parte geral do código civil. 2 ed. Rio de Janeiro: Forense, 2003.

ROCHA, Hernando Tapias. La acción de responsabildad contractual. In: ESPINOSA, Fabricio Mantilla; BARRIOS, Francisco Ternera (Dir.). Los contratos en el derecho privado. Bogotá: Legis, 2007.

ROCHA, Leonel Severo. Interpretação jurídica e racionalidade, Revista da Faculdade de Direito de Cruz Alta, Cruz Alta, v. 4, n. 4, p. 43-54, jan./jul. 1999.

ROCHA, Leonel Severo. Novas perspectivas da teoria do direito, Revista da Ajuris, Porto Alegre, v. 26, n. 77, p. 248-255, mar. 2000.

RODRIGUES, Rafael Garcia. A pessoa e o ser humano no novo código civil. In: TEPEDINO, Gustavo (Coord.). A parte geral do novo código civil: estudos na perspectiva civil-constitucional. Rio de Janeiro: Renovar, 2002.

RODRIGUES, Silvio. Direito civil: parte geral das obrigações. 30 ed. São Paulo: Saraiva, 2002, v. 2 .

RODRIGUES, Silvio. Direito civil: parte geral. 32 ed. São Paulo: Saraiva, 2002, v. 1.

RODRIGUES, Silvio. Direito civil: responsabilidade civil. 19 ed. São Paulo: Saraiva, 2002, v. 4.

ROPPO, Enzo. O contrato. Trad. Ana Coimbra; M. Januário C. Gomes. Coimbra: Almedina, 2009.

ROSA, Alexandre Morais da. O giro econômico do direito ou o novo e sofisticado caminho da servidão: para uma nova gramática do direito democrático no século XXI. In: AVELÃS NUNES, 
António José; COUTINHO, Jacinto Nelson Miranda (Coord.). O direito e o futuro: o futuro do direito. Almedina: Coimbra, 2008.

ROSA, Alexandre Morais da. Prefácio. In: WARAT, Luis Alberto. A rua grita dionísio: direitos humanos da alteridade, surrealismo e cartografia. Trad. e Org. Vivian Alves de Assis; Júlio Cesar Marcellino Junior; Alexandre Morais da Rosa. Rio de Janeiro: Lumen Juris. 2010.

ROSAS, Cristian Patricio. Daños derivados de actividades riesgosas. In: GHERSI, Carlos Alberto (Dir.). Responsabilidad: problemática moderna. Mendoza: Ediciones Jurídicas Cuyo, 1996.

ROSENVALD, Nelson. Dignidade humana e boa-fé no código civil. São Paulo: Saraiva, 2005.

RUGGIERO, Roberto de. Instituições de direito civil: direito das obrigações, direito hereditário. Trad. Paolo Capitanio. Campinas: Bookseller, 1999, v. 3.

RUIZ, Roberto Martinez. Obligaciones de medio y de resultado. La Ley, Buenos Aires, t. 90, p. 756-760, abr./jun. 1958.

RUSCELLO, Francesco. Istituzioni di diritto privato: le obbligazioni. 2 ed. Milano: Giuffrè, 2006, v. 2.

RUZYK, Carlos Eduardo Pianovski. A responsabilidade civil por danos produzidos no curso de atividade econômica e a tutela da dignidade da pessoa humana: o critério do dano ineficiente. In: RAMOS, Carmem Lucia Silveira et all (Org.). Diálogos sobre direito civil: construindo a racionalidade contemporânea. Rio de Janeiro: Renovar, 2002.

SACCO, Rodolfo. Codificare: modo superato di legiferare?, Rivista di Diritto Civile, Padova, anno 29, n. 2, p. 117-135, mar./abr. 1983.

SAGARNA, Fernando Alfredo. La relación de causalidad: ¿es prescindible como presupuesto de la responsabilidad civil?. In: GESUALDI, Dora Mariana (Coord.). Derecho privado. Buenos Aires: Hammurabi, 2001.

SALDANHA, Nelson. Da teologia à metodologia: secularização e crise do pensamento jurídico. Belo Horizonte, Del Rey, 2005.

SALDANHA, Nelson. Sobre o "direito civil constitucional" (notas sobre a crise do classicismo jurídico), Revista da Faculdade de Direito, Curitiba, v. 36, p. 87-92, 2001.

SALLES, Raquel Bellini de Oliveira. A justiça social e a solidariedade como fundamentos éticojurídicos da responsabilidade civil objetiva, Revista Trimestral de Direito Civil, Rio de Janeiro, $\mathrm{n}$. 18, p. 109-133, abr./jun. 2004.

SALVI, Cesare. La responsabilità civile. 2 ed. Milano: Giuffrè, 2005.

SANTOS, Eduardo Sens dos. O novo código civil e as cláusulas gerais: exame da função social do contrato, Revista de Direito Privado, São Paulo, v. 3, n. 10, p. 9-37, abr./jun. 2002.

SANTOS, Rogério Dultra dos. A institucionalização da dogmática jurídico-canônica medieval. In: WOLKMER, Antonio Carlos (Org.). Fundamentos da história do direito. 4 ed. Belo Horizonte: Del Rey, 2007.

SARLET, Ingo Wolfgang. As dimensões da dignidade da pessoa humana: construindo a compreensão jurídico-constitucional necessária e possível. In: SARLET, Ingo Wolfgang (Org.). Dimensões da dignidade: ensaios de filosofia do direito e do direito constitucional. 2 ed. Porto Alegre: LAEL, 2009. 
SARLET, Ingo Wolfgang. Direitos fundamentais sociais e proibição do retrocesso: algumas notas sobre o desafio da sobrevivência dos direitos sociais num contexto de crise, Revista da Ajuris, Porto Alegre, v. 31, n. 95, p. 103-135, set. 2004.

SARMENTO, Daniel. Direitos fundamentais e relações privadas. 2 ed. Rio de Janeiro: Lumen Juris, 2006.

SAVAUX, Eric. O fim da responsabilidade contratual?, Revista Justitia, São Paulo, n. 194, p. 130152, abr./jun. 2001.

SAVI, Sérgio. Inadimplemento das obrigações, mora e perdas e danos. In: TEPEDINO, Gustavo (Coord.). Obrigações: estudos na perspectiva civil-constitucional. Rio de Janeiro: Renovar, 2005.

SCAVONE JUNIOR, Luiz Antonio. Causas e cláusulas de exclusão de responsabilidade civil, Revista de Direito Privado, São Paulo, v. 2, n. 8, p. 53-119, out./dez. 2001.

SCAVONE JUNIOR, Luiz Antonio. Do descumprimento das obrigações: conseqüências à luz do princípio da restituição integral: interpretação sistemática e teleológica. São Paulo: Juarez de Oliveira, 2007.

SCHAEFER, Fernanda. Princípio da confiança e procedimentos médicos realizados à distância. In: NALIN, Paulo (Org.). Contrato \& sociedade. Curitiba: Juruá, 2004, v. 1.

SCHIPANI, Sándro. Análisis de la culpa en Justiniano 4,3. In: BUERES, Alberto Jesús; DE CARLUCCI, Aída Kemelmajer (Dir.). Responsabilidad por daños en el tercer milenio. Buenos Aires: Abeledo-Perrot, 1997.

SCHMITT, Cristiano Heineck. Cláusulas abusivas nas relações de consumo. 2 ed. São Paulo: RT, 2008.

SCHREIBER, Anderson. A tríplice transformação do adimplemento: adimplemento substancial, inadimplemento antecipado e outras figuras, Revista Trimestral de Direito Civil, Rio de Janeiro, $\mathrm{n}$. 32, p. 3-27, out./dez. 2007.

SCHREIBER, Anderson. Novas tendências da responsabilidade civil brasileira, Revista Trimestral de Direito Civil, Rio de Janeiro, n. 22, p. 45-70, abr./jun. 2005.

SCHREIBER, Anderson. Novos paradigmas da responsabilidade civil: da erosão dos filtros da reparação à diluição dos danos. São Paulo: Atlas, 2007.

SEGALLA, Conrado Rodrigues. O novo código civil já nasceu velho? (ser ou não inovador, eis a questão?). In: HIRONAKA, Giselda Maria Fernandes Novaes (Coord.). Novo código civil: interfaces no ordenamento jurídico brasileiro. Belo Horizonte: Del Rey, 2004.

SEGUÍ, Adela Maria. Aspectos relevantes de la responsabilidad civil moderna, Revista de Direito do Consumidor, São Paulo, v. 13, n. 52, p. 267-318, out./dez. 2004.

SERPA LOPES, Miguel Maria de. Curso de direito civil: obrigações em geral. Atual. José Serpa Santa Maria. Rio de Janeiro: Freitas Bastos, 1989, v. 2.

SESSAREGO, Carlos Fernández. ¿Qué es ser "persona" para el derecho?. In: GESUALDI, Dora Mariana (Coord.). Derecho privado. Buenos Aires: Hammurabi, 2001.

SESSAREGO, Carlos Fernández. Protección a la persona humana, Ajuris, Porto Alegre, v. 56, n. 19, p. 87-142, nov. 1992. 
SILVA FILHO, José Carlos Moreira da. Pessoa humana e boa-fé objetiva nas relações contratuais: a alteridade que emerge da ipseidade. In: SILVA FILHO, José Carlos Moreira da; PEZZELLA, Maria Cristina Cereser (Coord.). Mitos e rupturas no direito civil contemporâneo. Rio de Janeiro: Lumen Juris, 2008.

SILVA, Carlos Augusto. A obrigação como totalidade e processo, Revista da Ajuris, Porto Alegre, v. 31 , n. 95 , p. $55-69$, set. 2004.

SILVA, João Calvão da. Não cumprimento das obrigações. In: Comemorações dos 35 anos do código civil e dos 25 anos da reforma de 1977. Coimbra: Coimbra, 2007.

SILVA, Jorge Cesa Ferreira da. A boa-fé e a violação positiva do contrato. Rio de Janeiro: Renovar, 2007.

SILVA, Jorge Cesa Ferreira da. Inadimplemento das obrigações: mora, perdas e danos, juros legais, cláusula penal, arras ou sinal. São Paulo: RT, 2007.

SILVA, Jorge Cesa Ferreira da. O direito das obrigações no novo código civil: apontamentos para a defesa do estado, Revista da PGE, Porto Alegre, v. 27, n. 57, p. 135-156, 2004.

SILVA, José Afonso da. A dignidade da pessoa humana como valor supremo da democracia, Revista de Direito Administrativo, Rio de Janeiro, v. 212, p. 89-94, abr./jun. 1998.

SILVA, José Afonso da. Curso de direito constitucional positivo. 19 ed. São Paulo: Malheiros, 2001.

SILVA, José Afonso da. O estado democrático de direito, Revista dos Tribunais, São Paulo, v. 77, n. 635 , p. 7-13, set. 1988.

SILVA, Rafael Peteffi da. Teoria do adimplemento e modalidade de inadimplemento, atualizado pelo novo código civil, Revista do Advogado, São Paulo, n. 68, p. 135-153, dez. 2002.

SILVA, Virgílio Afonso da. A constitucionalização do direito: os direitos fundamentais nas relações entre particulares. São Paulo: Malheiros, 2008.

SILVA, Wilson Melo da. Responsabilidade sem culpa e socialização do risco. Belo Horizonte: Bernardo Álvares, 1962.

SIMÃO, José Fernando. Responsabilidade civil pelo fato do animal: estudo comparativo dos códigos civis de 1916 e de 2002. In: DELGADO, Mário Luiz; ALVES, Jones Figueirêdo (Coord.). Questões controvertidas: responsabilidade civil. São Paulo: Método, 2006, v. 5.

SOARES, Mário Lúcio Quintão. Teoria do estado: introdução. 2 ed. Belo Horizonte: Del Rey, 2004.

SOARES, Mário Lúcio Quintão; BARROSO, Lucas Abreu. A concretização do devido processo legal pelo Supremo Tribunal Federal. In: ROSSI, Alexandre Luiz Bernardi; MESQUITA, Gil Ferreira (Org.). Maioridade constitucional: estudo em comemoração aos 18 anos da Constituição Federal. São Paulo: Lemos \& Cruz, 2008.

SOARES, Mário Lúcio Quintão; BARROSO, Lucas Abreu. A dimensão dialética do novo código civil em uma perspectiva principiológica. In: BARROSO, Lucas Abreu (Org.). Introdução crítica ao código civil. Rio de Janeiro: Forense, 2006. 
SOUSA, Sergio Almeida de. Um modelo evolucionário de busca tecnológica em condições de hipercumulatividade, Revista Brasileira de Economia, Rio de Janeiro, v. 59, n. 3, p. 335-380, jul./set. 2005.

SOUZA SANTOS, Boaventura de. A filosofia à venda, a douta ignorância e a aposta de Pascal, Revista Crítica de Ciências Sociais, Coimbra, v. 80, p. 11-43, mar. 2008.

SOUZA SANTOS, Boaventura de. O estado e o direito na transição pós-moderna: para um novo senso comum sobre o poder e o direito, Revista Crítica de Ciências Sociais, Coimbra, v. 30, p. 13 43, jun. 1990.

SOUZA SANTOS, Boaventura de. Para além do pensamento abissal: das linhas globais a uma ecologia de saberes, Revista Crítica de Ciências Sociais, Coimbra, v. 78, p. 3-46, out. 2007.

STEINMETZ, Wilson. Direitos fundamentais e função social do (e no) direito, Revista da Ajuris, Porto Alegre, v. 34, n. 107, p. 285-291, set. 2007.

STIGLITZ, Rubén. El principio de buena fe. In: GESUALDI, Dora Mariana (Coord.). Derecho privado. Buenos Aires: Hammurabi, 2001.

STOCO, Rui. A teoria do resultado à luz do código de defesa do consumidor, Revista de Direito do Consumidor, São Paulo, n. 26, p. 200-220, abr./jun. 1998.

STRECK, Lenio Luiz. Da interpretação de textos à concretização de direitos: a incindibilidade, entre interpretar e aplicar - contributo a partir da hermenêutica filosófica, Revista da Faculdade de Direito da Universidade de Lisboa, Coimbra, v. 46, n. 2, p. 911-954, 2005.

STRECK, Lenio Luiz. Decisionismo e discricionariedade judicial em tempos pós-positivistas: o solipsismo hermenêutico e os obstáculos à concretização da constituição no Brasil. In: AVELÃS NUNES, António José; COUTINHO, Jacinto Nelson Miranda (Coord.). O direito e o futuro: o futuro do direito. Almedina: Coimbra, 2008.

STRECK, Lenio Luiz. O estado democrático de direito e a necessária constitucionalização do direito: a crise dos 10 anos da constituição cidadã, Revista da Faculdade de Direito de Cruz Alta, Cruz Alta, v. 4, n. 4, p. 23-41, jan./jul. 1999.

STRECK, Lenio Luiz. O que é isto - decido conforme minha consciência?. Porto Alegre: LAEL, 2010.

STRECK, Lenio Luiz. Quinze anos de constituição - análise crítica da jurisdição constitucional e das possibilidades hermenêuticas de concretização dos direitos fundamentais-sociais, Revista da Ajuris, Porto Alegre, v. 30, n. 92, p. 205-234, dez. 2003.

SURGIK, Aloísio. O cristianismo e a formação do direito medieval, Revista de Direito Civil, Imobiliário, Agrário e Empresarial, São Paulo, v. 7, n. 26, p. 156-167, out./dez. 1983.

SZAFIR, Dora; VENTURINI, Beatriz. Nuevamente sobre el nexo causal en la responsabilidad contractual. In: FERNÁNDEZ, Carlos López; CAUMONT, Arturo; CAFFERA, Gerardo (Coord.). Estudios de derecho civil en homenaje al profesor Jorge Gamarra. Montevideo: FCU, 2001.

TADEU, Silney Alves. Responsabilidade civil: nexo causal, causas de exoneração, culpa da vítima, força maior e concorrência de culpas, Revista de Direito do Consumidor, São Paulo, v. 16, n. 64, p. 134-165, out./dez. 2007.

TALAMANCA, Mario. Colpa. In: Enciclopedia del diritto. Milano: Giuffrè, 1960, v. 7. 
TARREGA, Maria Cristina Vidotte Blanco; ARAÚJO, Ionnara Vieira de. O código civil de 2002 uma opção metodológica, Revista da Faculdade de Direito da UFG, Goiânia, v. 31, p. 123-137, jan./jun. 2007.

TARTUCE, Flávio. Direito civil: direito das obrigações e responsabilidade civil. 2 ed. São Paulo: Método, 2006, v. 2.

TARTUCE, Flávio. Direito civil: lei de introdução e parte geral. 2 ed. São Paulo: Método, 2006, v. 1.

TARTUCE, Flávio. Função social dos contratos: do código de defesa do consumidor ao código civil de 2002. 2.ed. São Paulo: Método, 2007.

TARTUCE, Flávio. Reflexões sobre o dano social, Revista Trimestral de Direito Civil, Rio de Janeiro, v. 34, p. 179-201, abr./jun. 2008.

TELLES JUNIOR, Goffredo. O chamado direito alternativo, Revista da Faculdade de Direito, São Paulo, v. 94, p. 73-80, jan./dez. 1999.

TELLES, Inocêncio Galvão. Direito das obrigações. 6 ed. Coimbra: Coimbra, 1989.

TENENBAUM, Michael. Efficient breach of contract: perspectives from american courts at the dawn of the $21^{\text {st }}$ century. In: ESPINOSA, Fabricio Mantilla; BARRIOS, Francisco Ternera (Dir.). Los contratos en el derecho privado. Bogotá: Legis, 2007.

TEPEDINO, Gustavo. A constitucionalização do direito civil: perspectivas interpretativas diante do novo código. In: FIUZA, César; SÁ, Maria de Fátima Freire de; NAVES, Bruno Torquato de Oliveira (Coord.). Direito civil: atualidades. Belo Horizonte: Del Rey, 2003.

TEPEDINO, Gustavo. Normas constitucionais e direito civil na construção unitária do ordenamento. In: CONRADO, Marcelo; PINHEIRO, Rosalice Fidalgo (Coord.). Direito privado e constituição: ensaios para uma recomposição valorativa da pessoa e do patrimônio. Curitiba: Juruá, 2009.

TEPEDINO, Gustavo. Normas constitucionais e direito civil, Revista da Faculdade de Direito de Campos, Campos dos Goitacases, v. 4/5, n. 4/5, p. 167-175, 2003/2004.

TEPEDINO, Gustavo. O código civil, os chamados microssistemas e a constituição: premissas para uma reforma legislativa. In: TEPEDINO, Gustavo (Coord.). Problemas de direito civilconstitucional. Rio de Janeiro: Renovar, 2000.

TEPEDINO, Gustavo. Temas de direito civil. 3 ed. Rio de Janeiro: Renovar, 2004.

TEPEDINO, Gustavo. Temas de direito civil. Rio de Janeiro: Renovar, 2006, t. 2.

TEPEDINO, Gustavo; BARBOZA, Heloísa Helena; MORAES, Maria Celina Bodin. Código civil interpretado: conforme a constituição da república. Rio de Janeiro: Renovar, 2004, v. 1.

TEPEDINO, Gustavo; SCHREIBER, Anderson. A boa-fé objetiva no código de defesa do consumidor e no novo código civil. In: TEPEDINO, Gustavo (Coord.). Obrigações: estudos na perspectiva civil-constitucional. Rio de Janeiro: Renovar, 2005.

THEODORO JUNIOR, Humberto. A onda reformista do direito positivo e suas implicações com o princípio da segurança jurídica, Revista da Escola Nacional da Magistratura, Brasília, v. 1, n. 1, p. 92-120, abr. 2006. 
TIMM, Luciano Benetti. "Descodificação", constitucionalização e descentralização do direito privado: o código civil ainda é útil?, Revista de Direito Privado, São Paulo, v. 7, n. 27, p. 223-251, jul./set. 2006.

TIMM, Luciano Benetti. A função social do direito contratual no código civil brasileiro: justiça distributiva $v s$ eficiência econômica, Revista dos Tribunais, São Paulo, v. 97, n. 876, p. 11-43, out. 2008.

TOLOMEI, Carlos Young. A noção de ato ilícito e a teoria do risco na perspectiva do novo código civil. In: TEPEDINO, Gustavo (Coord.). A parte geral do novo código civil: estudos na perspectiva civil-constitucional. Rio de Janeiro: Renovar, 2002.

TOMÁS DE AQUINO. A prudência: a virtude da decisão certa. Trad. Jean Lauand. São Paulo: Martins Fontes, 2005.

TOMASETTI JUNIOR, Alcides. As relações de consumo em sentido amplo na dogmática das obrigações e dos contratos, Revista de Direito do Consumidor, São Paulo, n. 13, p. 12-17, jan./mar. 1995.

TOMASETTI JUNIOR, Alcides. Defesa do consumidor, concentração industrial, reserva de mercado: perplexidades de um civilista atento ao noticiário, Revista de Direito do Consumidor, São Paulo, n. 1, p. 16-26, jan./abr. 1992.

TOURAINE, Alain. Um novo paradigma: para compreender o mundo de hoje. 3 ed. Trad. Gentil Avelino Titton. Petrópolis: Vozes, 2007.

TOURNEAU, Philippe le. La responsabilidad civil. Trad. Javier Tamayo Jaramillo. Bogotá: Legis, 2004.

TRABUCCHI, Alberto. Istituzioni di diritto civile. 37 ed. Padova: Cedam, 1997.

TRIMARCHI, Pietro. Istituzioni di diritto privato. 11 ed. Milano: Giuffré, 1996.

TRIMARCHI, Pietro. Sul significato economico dei criteri di responsabilità contrattuale, Rivista Trimestrale di Diritto e Procedura Civile, Milano, t. 26, p. 512-531, 1970.

TRUJILLO, Rafael Durán. Nociones de responsabilidad civil: contractual y delictuosa. Bogotá: Temis, 1957.

TUCCI, Cibele Pinheiro Marçal. Responsabilidade civil no código de defesa do consumidor, Revista da Faculdade de Direito de São Bernardo do Campo, São Bernardo do Campo, v. 9, n. 11, p. 67-83, 2005.

USTÁRROZ, Daniel. Temas atuais de direito contratual: a boa-fé objetiva, a responsabilidade précontratual e o inadimplemento antecipado. Sapucaia do Sul: Notadez, 2010.

VALLE, Numa P. do. Do caso fortuito e de força maior: da distinção nítida entre um e outro importância prática e jurídica da distinção, Revista dos Tribunais, São Paulo, v. 30, n. 129, p. 439449, jan. 1941.

VASCONCELOS, Ábner de. Responsabilidade civil objetiva, Revista Forense, Rio de Janeiro, v. 53, n. 163, p. 22-33, jan./fev. 1953.

VASCONCELOS, Fernando Antônio de. A responsabilidade do advogado à luz do código de defesa do consumidor, Revista de Direito do Consumidor, São Paulo, n. 30, p. 89-96, abr./jun. 1999. 
VAZ, Caroline. Funções da responsabilidade civil: da reparação à punição ou dissuasão: os punitive damages no direito comparado e brasileiro. Porto Alegre: LAEL, 2009.

VELASCO, Ignácio M. Poveda. Da lei injusta, Revista de Direito Civil, Imobiliário, Agrário e Empresarial, São Paulo, v. 12, n. 44, p. 125-143, abr./jun. 1988.

VELASCO, Ignácio Maria Poveda. História externa e interna do direito romano, Revista de Direito Civil, Imobiliário, Agrário e Empresarial, São Paulo, v. 13, n. 49, p. 74-89, jul./set. 1989.

VELLOSO, Andrei Pitten. Mutações paradigmáticas da codificação: do código civil de 1916 ao código civil de 2002, Revista da PGE, Porto Alegre, v. 27, n. 57, p. 9-52, 2004.

VENOSA, Sílvio de Salvo. A cláusula de "melhores esforços" nos contratos. In: HIRONAKA, Giselda Maria Fernandes Novaes (Coord.). Novo código civil: interfaces no ordenamento jurídico brasileiro. Belo Horizonte: Del Rey, 2004.

VENOSA, Sílvio de Salvo. Direito civil: parte geral. 4 ed. São Paulo: Atlas, 2004, v. 1.

VENOSA, Sílvio de Salvo. Direito civil: responsabilidade civil. 3 ed. São Paulo: Atlas, 2003, v. 4.

VENOSA, Sílvio de Salvo. Direito civil: teoria geral das obrigações e teoria geral dos contratos. 2 ed. São Paulo: Atlas, 2002, v. 2.

VERDÚ, Pablo Lucas. O sentimento constitucional: aproximação ao estudo do sentir constitucional como modo de integração política. Trad. Agassiz Almeida Filho. Rio de Janeiro: Forense, 2004.

VETTORI, Giuseppe. Autonomía privada y contrato justo. In: GESUALDI, Dora Mariana (Coord.). Derecho privado. Buenos Aires: Hammurabi, 2001.

VILLEGAS, Juan Jacobo Calderón. La constitucionalización de las controversias contractuales. In: ESPINOSA, Fabricio Mantilla; BARRIOS, Francisco Ternera (Dir.). Los contratos en el derecho privado. Bogotá: Legis, 2007.

VILLELA, João Baptista. Por uma nova teoria dos contratos, Revista Forense, Rio de Janeiro, v. 74, n. 261, p. 27-35, jan./mar. 1978.

VILLEY, Michel. A formação do pensamento jurídico moderno. Trad. Claudia Berliner. São Paulo: Martins Fontes, 2005.

VINEY, Geneviève. As tendências atuais do direito da responsabilidade civil. In: TEPEDINO, Gustavo (Org.). Direito civil contemporâneo: novos paradigmas à luz da legalidade constitucional. São Paulo: Atlas, 2008.

VISINTINI, Giovanna. Il codice civile: commentario. inadempimento e mora del debitore. 2 ed. Milano: Giuffrè, 2006.

VISINTINI, Giovanna. Tratado de la responsabilidad civil: el daño, otros criterios de imputación. Trad. Aída Kemelmajer de Carlucci. Buenos Aires: Astrea, 1999, v. 2.

VISINTINI, Giovanna. Tratado de la responsabilidad civil: la culpa como criterio de imputación de la responsabilidad. Trad. Aída Kemelmajer de Carlucci. Buenos Aires: Astrea, 1999, v. 1.

VITA NETO, José Virgílio. A atribuição da responsabilidade contratual. Tese (Doutorado) Faculdade de Direito da USP, São Paulo, 2007. 
VIVES, Álvaro Pérez. Teoría general de las obligaciones: de las fuentes de las obligaciones. 2 ed. Bogotá: Temis, 1954, v. 2, t. 1.

VON THUR, Andreas. Tratado de las obligaciones. Trad. W. Roces. Madrid: Reus, 1934, t. 2.

VON THUR, Andreas. Tratado de las obrigaciones. Trad. W. Roces. Madrid: Reus, 1934, t. 1.

WALD, Arnoldo. Curso de direito civil brasileiro: obrigações e contratos. 14 ed. São Paulo: RT, 2000, v. 2.

WALD, Arnoldo. Da responsabilidade civil contratual e delitual, Revista Forense, Rio de Janeiro, v. 72, n. 256, p. 107-123, out./dez. 1976.

WARAT, Luis Alberto. A rua grita dionísio: direitos humanos da alteridade, surrealismo e cartografia. Trad. e Org. Vivian Alves de Assis; Júlio Cesar Marcellino Junior; Alexandre Morais da Rosa. Rio de Janeiro: Lumen Juris, 2010.

WARAT, Luis Alberto. Introdução geral ao direito: a epistemologia jurídica da modernidade. Porto Alegre: SAFE, 2002, v. 2.

WARAT, Luis Alberto. Introdução geral ao direito: interpretação da lei: temas para uma reformulação. Porto Alegre: SAFE, 1994, v. 1.

WARAT, Luis Alberto. Introdução geral ao direito: o direito não estudado pela teoria jurídica moderna. Porto Alegre: SAFE, 1997, v. 3.

WARAT, Luis Alberto. O direito e sua linguagem. 2 versão. 2 ed. Porto Alegre: SAFE, 1995.

WEBER, Márcia Regina Lusa Cadore. Responsabilidade civil do médico, Revista da PGE, Porto Alegre, v. 27, n. 57, p. 185-204, 2004.

WEINGARTEN, Celia. El valor economico de la confianza para empresas y consumidores, Revista de Direito do Consumidor, São Paulo, v. 9, n. 33, p. 33-50, jan./mar. 2000.

WEINGARTEN, Celia. La equidad como principio de seguridad económica para los contratantes, Revista de Direito do Consumidor, São Paulo, v. 10, n. 39, p. 32-40, jul./set. 2001.

WESTERMANN, Harm Peter. Código civil alemão: direito das obrigações - parte geral. Trad. Armindo Edgar Laux. Porto Alegre: SAFE, 1983.

WIEACKER, Franz. História do direito privado moderno. 3 ed. Trad. António Manuel Botelho Hespanha. Lisboa: Fundação Calouste Gulbenkian, 2004.

WILSON, Carlos Pizarro. La culpa como elemento constitutivo del incumplimiento en las obligaciones de medio o de diligencia, Revista de Derecho de la Pontificia Universidad Católica de Valparaíso, Valparaíso, n. 31, p. 255-265, jul./dez. 2008.

WILSON, Carlos Pizarro. La responsabildad contractual en el derecho chileno. In: ESPINOSA, Fabricio Mantilla; BARRIOS, Francisco Ternera (Dir.). Los contratos en el derecho privado. Bogotá: Legis, 2007.

YAGÜEZ, Ricardo de Angel. La responsabilidad civil. 2 ed. Bilbao: Universidad de Deusto, 1989.

ZAGO, Jorge. El significado de la culpa. In: GESUALDI, Dora Mariana (Coord.). Derecho privado. Buenos Aires: Hammurabi, 2001. 
ZANCHIM, Kleber Luiz. Redução da indenização na responsabilidade objetiva, Revista de Direito Privado, São Paulo, v. 9, n. 33, p. 201-214, jan./mar. 2008.

ZANETTI; Cristiano de Souza. Direito contratual contemporâneo: a liberdade contratual e sua fragmentação. São Paulo: Método, 2008. 